\title{
THE POLITICS OF DISSENT
}

Pacifism in France, 1919-1939.

\author{
by \\ Norman Ingram.
}

Ph.D.

University of Edinburgh

1988

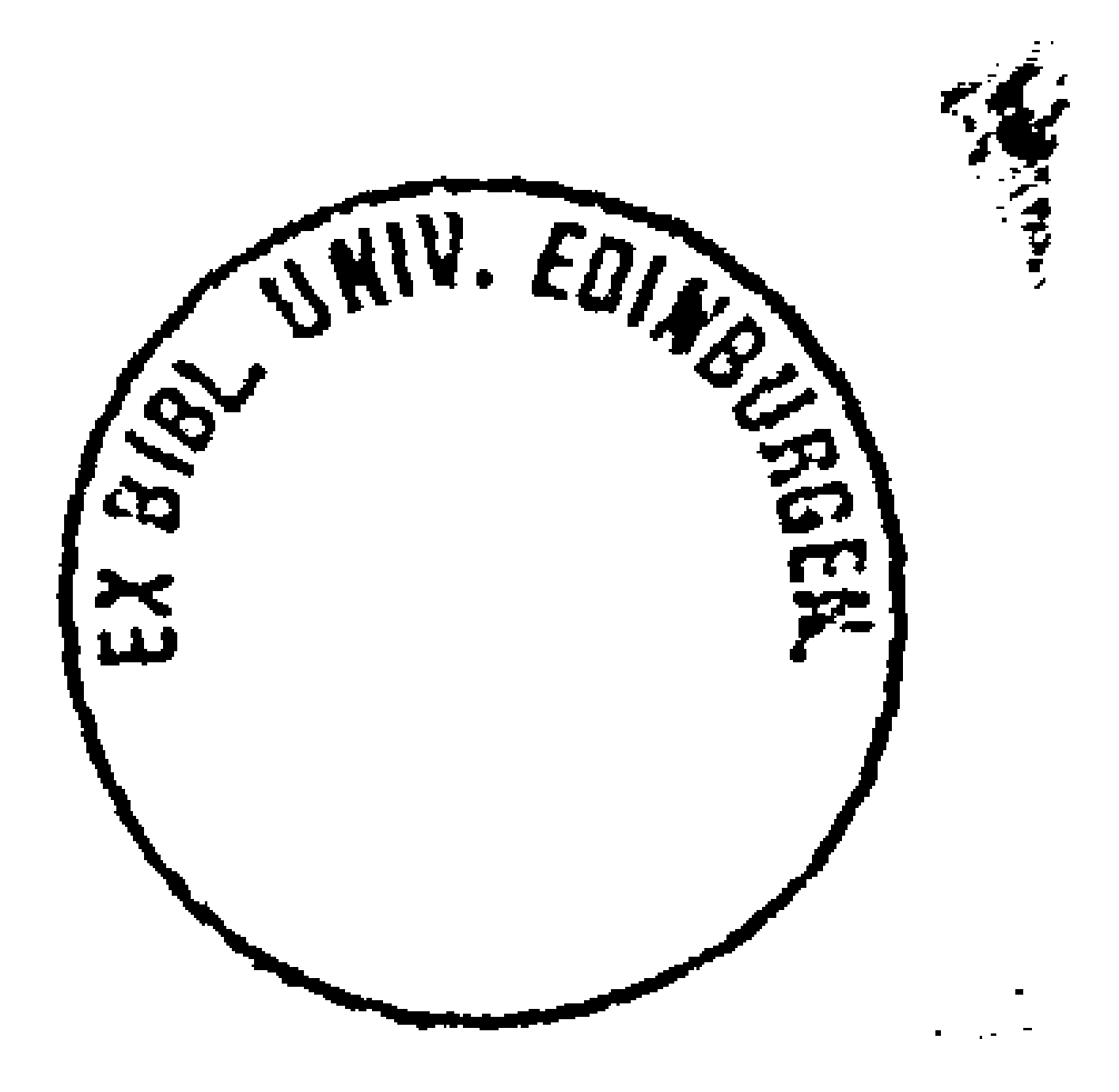


This thesis has been composed by me and the work contained herein is my own. 
To my parents. 
I should greatly encourage young people looking for a thesis topic in history to study the origins and development of conscientious objectors.

Romain Rolland to Pierre Cêrésole, October 1923.

Nous roulons, en apparence, l'éternel rocher de Sisyphe. Constatation amère, et qui découragerait d'aucuns. Mais nous sommes de ceux qui ne désespèrent jamais. Aussi bien trouvonsnous, jusque dans l'aveu de notre déception, des raisons positives d'envisager l'avenir avec une confiance réfléchie.

La Paix par le Droit.

Appel-Programme, 1920. 


\section{Table of Contents}

Abstract

\section{PART I}

Pacifisme Ancien Style, ou le pacifisme des professeurs.

1. Introduction

2. The Paradigm Defined

3. A Decade of Optimism (1919-1929)

4. The APD and French Political Society

5. Cracks in the Paradigm (1928-1933)

6. The Rise of Pessimism (1933-1938)

7 The Paradigm Reaffirmed

8. Conclusions

\section{PART II}

Pacifisme Nouveau Style, or the Politics of Dissent.

1. The Origins of the New Pacifism

2. Years of Growth (1930-1933)

3. Challenges to Intégralité (1934-1938)

4. Munich and all that (1938-1939). 
Thèmes et Variations, or feminism and pacifism in interwar France.

1. Introduction $\quad 219$

2. Aims, Political Orientation, and the Führerprinzip 228

3. Realism and Politics: the French contribution to international action $\quad 244$

4. Inside the French Section. 253

5. Conclusions 282

Conclusions.

Appendices:

I. The Circulaire Chautemps, 1933: The Third Republic Discovers Conscientious Objection.

II. Romain Rolland, Interwar Pacifism and the Problem of Peace. 


\section{Acknowledgements}

Many people and organisations have helped me enormously during my six years of postgraduate study. First and foremost, I must thank the Commonwealth Scholarship Commission in the United Kingdom for the provision of the Scholarship which enabled me to come to Edinburgh in the first place. I am grateful to the Social Sciences and Humanities Research Council of Canada for providing me with the Doctoral Fellowship which enabled me to spend two delightful years in Paris doing research. Finally, I should like to record my thanks to Professor John C. Cairns, Dr. Martin Alexander, Dr. Peter van den Dungen, and my supervisor Professor Maurice Larkin.

I have made use of many libraries and archives during the past five years. My thanks go to the staffs of the following institutions: the Service Historique de l'Armée de Terre (Château de Vincennes), the Archives Nationales (Paris), the Bibliotheqque du Protestantisme Français (Paris), the Library of Congress (Washington), the National Archives of the United States of America (Washington), the Swarthmore College Peace Collection (Swarthmore, Pennsylvania), the Bibliothèque Nationale (Paris), Edinburgh University Library and the National Library of Scotland (Edinburgh). Specifically, I should like to thank Mlle Odile Patrois and Mme Thérèse Muller of the Bibliothèque de Documentation Internationale Contemporaine at Nanterre, and Ms Myrtle Solomon who kindly gave me access to the un-sorted and un-catalogued archives of the War Resisters' International which were at that point stored in her Chelsea garage before finally being transferred to the International Institute for Social History in Amsterdam.

Last, but by no means least, I am profoundly grateful to my family for the support they have given me through six years of post-graduate study. Above all, I should like to thank my parents, to whom this thesis is dedicated, for providing me with the loving home, stimulating environment and so very much more that I shall probably never really fully understand. 


\section{Abstract}

This thesis breaks new ground in examining for the first time the history of pacifism in interwar France. It attempts to define the contours of the French peace movement, to describe it organisationally and in terms of its intellectual content, and finally to place interwar pacifism in the broader context of French political culture. The study is based on several years of primary research in Paris, London, Washington, and Philadelphia, and makes extensive use of hitherto unused archival sources and printed primary material. Of especial interest is the wealth of information gleaned from the Fonds Gabrielle Duchene, the-Romain Rolland papers (which are still being catalogued), the André Trocmé papers, and others.

The first section of the thesis, on pacifisme ancien style, analyses the interwar development of traditional 'ideological' or 'collaborative' French pacifism with roots which go back into the nineteenth century. In the twenties this type of pacifism followed an ascending curve in terms of pacifist commitment, but was never able to embrace the absolute claims of the more radical pacifism which was developing within and around it. There then emerged from this first paradigm the paradigm of pacifisme nouveau style which is the subject of the second section. This resulted from the slow convergence of three complementary strands of dissent from political society: historical dissent over the origins of the Great War and the thesis of unique German war guilt; political dissent over the nature of contemporary French political society; and finally, a dissenting belief that another war would spell the end of western civilisation. The third section deals with feminist pacifism. Its evolution was in opposition to the prevailing trend already elaborated, moving from a position of integral pacifism in the early twenties to an increasingly 'collaborative' stance in the thirties which had close links with Soviet inspired peace and antifascist movements in France.

One of the principal themes of this thesis is the essentially political nature of French pacifism as opposed to the primarily ethical or religious (especially non-conformist Protestant) thinking infusing much of Anglo-American pacifism. It also considers, among much else, the extent to which violence was considered an acceptable tactic by some parts of French pacifism, especially in response to the threat of incipient fascism. The thesis concludes with two Appendices, the first examining the French government's response to the perceived problem of conscientious objection in 1933, and the second examining the political trajectory of Romain Rolland on the problem of peace in the interwar era. 


\section{Abbreviations}

$\begin{array}{ll}\text { APD } & \text { Association de la Paix par le Droit } \\ \text { PD } & \text { La Paix par le Droit } \\ \text { VdP } & \text { La Volonté de Paix (when italicised this } \\ & \text { is the newspaper of the same group) } \\ \text { DFG } & \text { Deutsche Friedensgesellschaft } \\ \text { PH } & \text { La Patrie Humaine } \\ \text { AN } & \text { Archives Nationales } \\ \text { BN } & \text { Bibliothèque Nationale } \\ \text { SHAT } & \text { Service Historique de l'Armée de Terre } \\ \text { BDIC } & \text { Bibliothèque de Documentation Internationale } \\ & \text { Contemporaine } \\ \text { DD } & \text { Dossiers Duchêne } \\ \text { SCPC } & \text { Swarthmore College Peace Collection } \\ \text { WRI } & \text { War Resisters' International } \\ \text { LIFPL } & \text { Ligue International des Femmes pour la } \\ & \text { Paix et la Liberté } \\ \text { IEC/CEI } & \text { International Executive Committee/Comité } \\ & \text { Executif International } \\ \text { LICP } & \text { Ligue Internationale des Combattants de la Paix } \\ \text { AGM } & \text { Annual General Meeting } \\ \text { RUP } & \text { Rassemblement Universel pour la Paix } \\ \text { WILPF } & \text { Womens' International League for Peace and } \\ & \text { Freedom (the English name of the LIFPL) } \\ & \end{array}$


INTRODUCTION 
In response to a 1934 survey on the 'crisis of pacifism', Marcel Déat wrote that it has often been said that the nations do not have the same sociological age, that the same institutions do not have same meaning everywhere'. ${ }^{1}$ His comment is particularly apposite with regard to the history of pacifism and peace movements in France. While there is a large body of historical writing on pacifism in America, Britain, and Germany, the dearth of historical writing on the French peace movement of this century is almost complete.

What are the reasons for this strange lapse? Was France immune to the political phenomena which affected the rest of the interwar world? In fact, quite the opposite was true. The France of the twenties and thirties was alive with a plethora of pacifist groups of various inspirations and orientations. A large compendium of information about FrancoGerman peace groups published in 1932 under the patronage of André Tardieu listed fifty 'pacifist organisations' in France and a further seventeen groups which 'sympathised' with pacifism. ${ }^{2}$ Four years later, the Centre International de Documentation Antiguerrière in Paris published a peace yearbook for France which contained over two hundred organisations described as 'pacifist'. 3 On the surface, then, it would seem that the French peace movement was a hale and hearty creature enjoying large support within the French body politic. To some extent, this was true. Certainly until about 1933, large sections of French political society sought to portray themselves as 'pacifist'. There was tremendous support for Briand4, and as will become clear in Part I of this thesis, important figures of the French intellectual and political elite had close connections with what is described here as pacifisme ancien style.

1 Marcel Déat, 'Réponse à l'Enquête sur la Crise du Pacifisme', PD 44, 2 (February 1934),p.78.

2 See 'Les Organisations Pacifistes Françaises' and 'Les Groupements Sympathisants Français' in Nous roulons la Paix (Paris: SRIP, 1932), pp. 27-110.

3 Annuaire de la Paix, (Paris: Centre International de Documentation Antiguerrière, 1936).

4 The old-style pacifists supported Briand most energetically. His conception of peace was closely allied to their 'ideological' or 'collaborative' stance. The support for Briand within the new pacifism was more nuanced and tended to recall the socialist Briand of the turn of the century. The LICP refused to be represented officially at Briand's funeral, underlining its sectarian attitude to French political society, even in the case of a man whom in other respects it admired. See for example, Robert Tourly, 'Sur une tombe', PH 106 (9 March 1934), p.l.; see also the announcement that unlike some pacifist groups, the LICP would not participate in the State funeral, in PH 15 (12-18 March 1932), P.1; see also Victor Méric, 'Le véritable Briand', PH 17 (26 March - 2 April 1932). 
But it is important to underline that in contradistinction to the British or the German experience, there was no large, all-encompassing pacifist organisation in France. There is no French equivalent - in numbers at least - either to the Peace Pledge Union or to the German Peace Cartel. The French peace movement of the interwar period was a lively and probably numerically significant force, but it was also a balkanised, splintered movement, divided very much unto itself. Indeed, one of the theses of this study is that the predominantly political (as opposed to ethical) nature of French pacifism is one of the features which differentiates it from Anglo-Saxon pacifism. This emphasis on the political produced a shotgun effect in terms of its practical impact on the world of French politics. As the editors of the 1936 Annuaire commented

May we be permitted to draw one conclusion from the work here presented: it is the number of Organisations, even those genuinely pacifist, and the extraordnary dispersion of efforts for peace, among people who have the best will in the world. And we can add without fear of contradiction that these Organisations are often almost totally ignorant of one another's work. 5

The editors noted the warm reception they had received from all groups in compiling the Annuaire but remarked that in such a time of international tension, one had to wonder whether such dispersed efforts for peace would be effective. ${ }^{6}$

The first point, then, to bear in mind in approaching a study of French interwar pacifism is the tremendous diversity of men, women and organisations struggling, often in almost complete isolation, for peace. There were many groups which appear to have consisted of chiefs, but few Indians; it is equally the case that many of the groups listed in the two works cited above, would not in the normal scheme of things be considered as 'pacifist'. For example, both works list the Trait d'Union, a naturist group, as one of the pacifist associations in France. There are also many instances in both compendiums of Masonic groups and positivist associations as well as the more main-stream groups supporting the League of Nations. The Carnegie Endowment for International Peace and the Inter-Parliamentary Union are also mentioned. Groups promoting cultural or student exchanges with Germany figure prominently, as indeed do the veterans' organisations and the political parties most likely to be friendly to peace ideas. The impression, therefore, is one of some semantic confusion about what was understood by the word 'pacifist', in addition to organisational effervescence. No doubt many of the groups listed in these prospectuses would be more at home classified merely as 'internationalist', or as something else entirely. For many, it is clear that peace was not their primary reason for being.

\footnotetext{
5 Op.cit. Annuaire, pp. 11-12.

6 Ibid, p.12.
} 
Having said that, it seems clear that great portions of the French public in the interwar years considered themselves to be 'pacifists', whatever that word may mean. While there are indications that the word had begun to take on pejorative tinges during the Great War, it was nevertheless a fairly common thing to hear a politician proclaim himself a pacifist. One has only to think of Briand, and the great urge to peace which he incarnated, to see the truth of that. There are other examples, too. Herriot, for example, in a speech on 1 February 1925 at the Trocadéro to raise money for a monument to peace, seemed to divide French society into the pacifist and nationalist camps when he cried, 'It is we pacifists who are the most true to the teachings of the war. ${ }^{7}$ The year previously, Charles Richet had written that the French soul was 'profoundly pacifist' and in 1932 he stated that France was the 'most pacific of all peoples'; he went so far as to argue that even the extreme right in France held 'no idea more dearly than that of peace'. 8 Even as late as 1937, in the face of a clearly worsening international situation, Théodore Ruyssen, the President of the Association de la Paix par le Droit, could state quite confidently that since the formation of the APD pacifism had made 'tremendous conquests'. 'It is not an exogeration to say that today pacifism is everywhere'. 9 But in fact, this very success - or apparent success - for the pacifist idea had become one its weaknesses. Ruyssen underlined that there were now so many types of pacifism that the movement had become 'frankly strangely incoherent'. If the end desired remained the same, the methods for reaching it, and the social and political analyses which underpinned them, had become almost irreconcilably different. ${ }^{10}$

This leads quite naturally to the problem of definition when discussing French pacifism. If pacifism is often equated with Communism by the man in the street in France, the reality was certainly different in the interwar years. As a quick glance at the tergiversations of the PCF during the twenties and thirties on the question of peace will show, French Communism in the interwar period was intermittently and opportunistically antimilitarist and internationalist, but hardly pacifist. Indeed, it is one of the basic premisses of this thesis that none of the political parties in interwar France can justifiably be considered 'pacifist'. Being multi-interest political groupings, the parties all had other concerns which, with the pressure of political events on a multitude of fronts, caused peace and pacifism to wax and wane in importance as the political seasons changed. Because the

7 Cited in Jules Prudhommeaux, 'La Propagande. Le Monument de la Réconciliation; une Manifestation émouvante au Trocadéro', PD 35, 2 (February 1925), p.83

8 See Charles Richet, 'Soyons tous les Enfants de la Paix!', PD 34, 3 (March 1924), pp. 105-107; Charles Richet, 'La vraie Figure de la France', PD 42, 7/8 (July-August 1932), PP. 321-323; and Charles Richet, 'La vraie Figure de la France', PD 43, 3 (March 1933), p. 97. See also Part I of this thesis, especially Chapter 4, for a discussion of how old-style French pacifism viewed French political society and its place in it.

9 See Théodore Ruyssen, 'Le Cinquantenaire de la Paix par le Droit, PD 47, 2 (February 1937), pp. 49-51.

10 Ibid. 
line has to be drawn somewhere, this study will therefore not be about the position of the French political parties on the question of peace. Other writers have examined this aspect of interwar history - indeed, it is probably true to say that what little has been written about peace in any connection in French history has been done from this angle. ${ }^{11}$ Others, such as Antoine Prost, have dealt with 'pacifism' as a function of a larger whole, as one aspect of the experience of another group. 12 The few works which do attempt to treat the question of French pacifism proper, usually do so less than dispassionately and are often derisory in their superficiality. ${ }^{13}$ The end result leaves one with the impression that perhaps, after all, the French are different and that they were spared the agonising debates over the problem of peace between the wars which beset the rest of the western world.

But such a supposition is, of course, false. It ignores the fact that one of Europe's best known pacifists in the interwar period was a Frenchman - Romain Rolland - and that in fact

11 See for example, Michel Bilis, Socialistes et Pacifistes, 1933-1939..L'intenable dilemme des socialistes français. (Paris: Syros, 1979); Philippe Robrieux, Histoire Intérieure du parti communiste 1920-1945. (Paris: Fayard, 1980). See also Richard Gombin, 'Socialisme et Pacifisme', in René Rémond and Janine Bourdin, eds., La France et les Français en 1938-1939 (Paris: Presses de la FNSP, 1978), pp. 245-260.

12 See Antoine Prost, Les Anciens Combattants et la Société Française. 3 vols. (Paris: Presses de la FNSP, 1977), esp. III Mentalités et Idélogies, pp.77-119. A study which goes beyond the confines of this thesis and is also an example of a work which discusses pacifism as a function of other concerns (in this case admittedly closely allied to many of the concerns of interwar French pacifists) is Jean-Claude Delbreil, Les catholiques français et les tentatives de rapprochement francoallemand (1920-1933). (Metz: Centre de Recherches Relations Internationales, 1972). See also Barnett Singer, 'From Patriots to Pacifists: The French Primary School Teachers, 1880-1940', Jourmal of Contemporary History 12 (1977), Pp. 413-434. See also Isabel Boussard, 'Le pacifisme paysan' in René Rémond and Janine Bourdin, eds., La France et les Français en 1938-1939 (Paris: Presses de la FNSP, 1978), pp. 59-75. See also Jean-François Sirinelli, 'Khâgneux et normaliens aux années vingt' Thèse de Doctorat d'Etat, Université de Paris-X, Nanterre, 1986, 5 vols., which contains some interesting material on the extent to which this rather specialised milieu of French society became impregnated with pacifist ideas. Mr Yves Santamaria is currently preparing a doctoral thesis on 'Le PCF dans la lutte pour la Paix, 1932-1936' under the direction of Annie Kriegel. For several years Jean-Marie Mayeur has run a joint research seminar at the Sorbonne and the Institut d'Etudes Politiques on 'Les églises chrétienh devant la Guerre et la Paix', but so far nothing has emerged in published form that I am aware of.

13 Perhaps the most glaring example in the latter category is J.B. Barbier, Le Pacifisme dans l'Histoire de France (De l'An Mille à Nos Jours). (Paris: La Librairie Française, 1966). See also Jean Defrasne, Le Pacifisme Collection 'Que sais-je? (Paris: Presses Universitaires de France, 1983). See also Jean-Pierre Cattelain, L'Objection de Conscience. Collection 'Que sais-je?' (Paris: Presses Universitaires de France, 1973). See also Marcel Merle, Pacifisme et Internationalisme XVIle - XXe sizcles. (Paris: Armand Colin, 1966), which is a useful collection of texts from a variety of authors, not all of them by any means French, with rather little in the way of analysis. Two other works which deserve mention are Nicolas Faucier, Pacifisme et Antimilitarisme dans l'entre-deux-guerres (Paris: Spartacus, 1983) and Michel Auvray, Objecteurs, insoumis, déserteurs. Histoire des refractaires en France (Paris: Stock/2, 1983). The first is a personal memoir by the companion of Louis Lecoin and is useful for details about one aspect of interwar French pacifism. Auvray's book is by a present-day militant and conscientious objector and is also useful for detail, although at times rather polemical in approach. Finally, see J.B. Duroselle, 'Les précédents historiques: pacifisme des années 30 et neutralisme des années 50' in Pacifisme et dissuasion. Travaux et recherches de l'Institut Français de Relations Internationales sous la direction de Pierre Lelouche (Paris: IFRI, 1983), pp. 241-252. 
the very word 'pacifism' is French in origin. ${ }^{14}$ How has this state of affairs come to pass? No doubt one reason is the legacy of the Second World War in France with all that that event conjures up in the historical imagination: Vichy, collaborationism, defeatism, the épuration and so on. As one French commentator has written:

In denying the virtue of war, rendered sacrosanct by tradition, pacifism shakes established ideas. It is lumped together with defeatism, with cowardice, with treason.

Pacifism has, therefore, often taken on a pejorative connotation. It is perversion. It is to peace what formalism is to form, simplism to simplicity, sentimentality to sentiment. ${ }^{15}$

He goes on to say that 'pacifism played its role in the birth of the Vichy régime'.16 Thus, in the French mind, the notion of pacifism occasions distressing memories of a particularly difficult time in recent history.

Clearly the usage of the word 'pacifism' contained several shades of meaning in the interwar years, and the same is true today. The historian is thus faced initially with a definitional problem in beginning an examination of interwar French pacifism. One of the most important recent contributions to the historiography of the modern peace movement is Martin Ceadel's book on interwar British pacifism, which despite its Anglo-centricity is an important work for two reasons. Firstly, Ceadel attempts to define what is meant by pacifism, to delineate the boundaries between pacifism and what he calls pacificism, following A.J.P.Taylor's unfortunate usage. The former he defines as the belief that all war is always wrong and should never be resorted to', and the second as the 'assumption that war, though sometimes necessary, is always an irrational and inhumane way to solve disputes, and that its prevention should always be an over-riding political priority'. ${ }^{17}$ The problem with this definition is that it is arguably artificial. As Ceadel himself admits, both of the above positions were described as 'pacifist' during the interwar period in Britain. The same is even more the case in France where the word pacifisme described the whole spectrum of pacifist activity. It was only in the late twenties that French pacifists began to feel the need to distinguish between ordinary pacifism which had a long history in

14 On the place of Romain Rolland within French and European pacifism, see Appendix II of this thesis. On the origins of the word 'pacifism' which was first used at the Universal Peace Congress in Glasgow in 1901, see Roger Chickering, Imperial Germany and a World without War. The Peace Modement and German Society, 1892-1914. (Princeton: Princeton University Press, 1975), PP. 14-15.

15 Defrasne, op. cit. , p.3.

16 Ibid., p.111.

17 Martin Ceadel, Pacifism in Britain 1914-1945. The Defining of a Faith (Oxford: Clarendon Press, 1980), p. 3. Taylor's derivation may be found in A.J.P. Taylor, The Troublemakers: Dissent over Foreign Policy, 1792-1939 (London: Hamish Hamilton, 1957), p.51, n.5. 
France and the arrival of a new and more radical pacifism which was christened pacifisme intégral.

To separate the different strands of pacifism from one another like this in the case of France would leave us with only half the story of the interwar French pacifist experience. As Roger Chickering justly remarks in his study of the pre-war German peace movement, to do so would be to exclude 'from the category of pacifist the very people who invented the term as a self-designation'. 18 Instead, he defines as a pacifist anyone 'who holds war to be wrong and has made a personal commitment to pursuing the kinds of activities he believes will lead to its systematic elimination from international affairs'.19 Chickering's definitional approach has much to commend it. 20

The basic limitation of this thesis will be that of definition. We shall define as pacifist those men, women and organisations in interwar France for whom peace was a primary, consistent, and over-riding concern and goal. This may seem a rather fluid definition, but it has the advantage of limiting the field of endeavour almost immediately. This is not, therefore, a study of political parties in interwar France. Whilst undoubtedly many of the parties, especially the Socialists, Communists, and Radicals, in varying ways and at different times, did express pacifist concerns, their primary purpose was never the achievement of peace as a goal in itself. In like manner, it would be interesting, but beside the point here, to consider in great detail the contribution made by such organisations as the Ligue des Droits de l'Homme, or the veterans' groups, to the struggle for peace. Both of these organisations had other, and more dominant, concerns and are therefore beyond the scope of this study.

Two further types of organisation or thinking which were sometimes confused with pacifism in France must also be excluded. The first is the series of groups which grew out of the Amsterdam Congress against Imperialist War in 1932 and the congress held against Fascism the following year at the Salle Pleyel in Paris. Aside from the fact that this movement, which became known as Amsterdam-Pleyel, has already attracted its own chroniclers $^{21}$, it is clear that it, too, had limitations on its attitudes towards what types of international wars might be resisted. Having said that, Amsterdam-Pleyel lurks at times

18 Chickering, p.16.

19 Ibid.

20 The American-European Consultation on Peace Research in History, held from 24-29 August 1986 at Stadtschlaining, Austria, tended in its majority to follow something like the Chickering definition, referring to 'peace advocacy' rather than pacifism per se.

21 See for example Rosemarie Schumann, Amsterdam 1932. Der Weltkongreß gegen den imperialistischen Krieg (East Berlin: Dietz Verlag, 1985). See also the doctoral thesis by Yves Santamaria cited above. A group which seems to have evolved in the opposite direction to the Amsterdam-Pleyel movement was the Comite de Vigilance des Intellectuels Antifascistes. See Nicole Racine-Furlaud, 'Le Comité de vigilance des intellectuels antifascistes (1934-1939). Antifascisme et pacifisme', Le Mouvement social 101 (October-December 1977), pp. 87-113. 
like an éminence grise behind large parts of this study. Although international in scope and directed in some measure by the needs of Soviet foreign policy, its leading lights and greatest organisational successes were undoubtedly French. Amsterdam-Pleyel began as a protest against one sort of war - imperialist war - and ended up largely as the cover for an antifascist movement which accepted the idea of war as a potential necessity in an ideological crusade to protect the revolution and its home in the Soviet Motherland.

Secondly, at the end of the thirties there is the thorny question of the position of the extreme Right in France on the question of war and peace. There is little doubt that for many partisans of the Right, the political situation in Europe had undergone a complete reversal with the Nazi seizure of power in 1933. As Jospeh Folliet pointed out in his perceptive essay Pacifisme de droite? Bellicisme de gauche?, the traditional poles within French political society seemed to have been reversed by the time of the Munich crisis of 1938. 22 Whereas sections of the Left were now clamouring for action against Hitler, parts of the extreme Right seemed to some contemporary pacifists to be supporting many of the traditional theses of pacifism. This today may seem bizarre. It is clear that the pacifisme des munichois, or at least of those among them who were normally on the political Right, was completely opportunistic in inspiration and had nothing to do with pacifism as it is here defined or was normally understood at the time. As will become evident in Part II of this thesis, the political sea-changes occurring in France in the late thirties did provide French pacifists with a tremendous dilemma - to collaborate or not with these strange political bedfellows? Most pacifists refused to have anything to do with such a marriage of convenience; some, however, succumbed to the temptations of the hic et nunc and in so doing compromised their cause. ${ }^{23}$

Moving beyond the problem of definition to that of typology, one is confronted with several recent and competing conceptual approaches to the history of pacifism. Reinhold Lütgemeier-Davin, for example, divides the peace movement up into two broad categories: what he calls 'organisational pacifism' and 'radical pacifism'. In the former are subsumed the categories of 'scientific', juridical and democratic pacifism, as well as an idealistic ethical-humanitarian pacifism. Radical pacifism he divides into non-violent and revolutionary tendencies. Overlapping between the two are the religious pacifists and a 'pedagogical' pacifism. 24 This division has much to commend it in an analysis of the French example. Following this schema, what is denoted in this thesis as pacifisme ancien style would represent an example of 'organisational' pacifism, while pacifisme nouveau

22 See Joseph Folliet, Pacifisme de droite? Bellicisme de gauche? (Paris: Editions du Cerf, 1938).

23 See especially Part II, Chapter 4 ('Munich and all that') for a discussion of this problem.

24 Reinhold Lütgemeier-Davin, Pazifismus zwischen Kooperation und Konfrontation. Das Deutsche Friedenskartell in der Weimarer Republik. (Köln: Pahl-Rugenstein Verlag, 1982), PP. 13-17. 
style would be a clear case of 'radical' pacifism, incorporating both non-violent and revolutionary elements.

Undoubtedly one of the most significant contributions made recently to the historiography of pacifism is that by Ceadel. His definitional approach is arguably unhelpful in the French or European context, and his analytical structure, taken largely from Weber and the sociology of religion, has some limitations in its applicability to the French case. The very sub-title of his work, 'The Defining of a Faith', indicates the extent to which the religious analysis underpins his argument. Nevertheless, there is much in his study that is suggestive for a history of the French peace movement of the same era.

Ceadel distinguishes between what he calls the 'inspirations' for pacifism and its 'orientations'. The former can be divided up into three further sub-categories: religious, political (ie. socialist or anarchist), and humanitarian. The humanitarian inspiration was, according to Ceadel, the one major philosophical advance made by interwar pacifism, because it attempted to derive a value-neutral, utilitarian justification for pacifism. Pacifism can moreover have three orientations according to Ceadel: sectarian, collaborative, and non-violent. Depending on the political climate of the day, pacifism therefore either retreats into a sectarian stance which condemns completely the society around it and withdraws into purity; or else, it is tempted out of its shell into collaborative arrangements The third possible orientation he defines as non-violence which 'presupposes exceptionally favourable circumstances', is the 'most optimistic' of the three, and 'assumes that pacifism can be applied as an immediately effective policy in the world as it is'.25 Somewhat paradoxically, Ceadel writes that 'the most confident and impressive pacifism has resulted where pacifists have been driven, by disagreement with a society convinced of the inevitability of war, into a sectarian orientation'.26

The use of the term 'non-violent' presents problems for the student of French pacifism as Part II of this thesis makes clear. For many French integral pacifists of the thirties, pacifism did not mean non-violence at all. They envisaged the application of violence to situations on an individual or civic level with surprising equanimity. Nevertheless, it will be apparent that the Ceadel model can be applied to the French example with some degree of success. The old-style pacifists would therefore represent the collaborative orientation, and the new-style pacifists a sectarian stance. The feminist pacifists present a problem, however. They were at the same time both collaborative and sectarian in their orientation, although increasingly collaborative as the thirties progressed. In the immediate post-war period, however, the Ligue Internationale des Femmes pour la Paix et la Liberté, represented in France both an absolute rejection of war and the society which

25 Ceadel, Pacifism in Britain, pp. 15-16.

26 Ibid., pp. 16-17. 
engendered it, and paradoxically also a collaborative position of involvement with political society in an attempt to prevent its recurrence.

It is clear, then, that despite the major contribution made by Ceadel to the typology of pacifism, there remain problems of interpretation. A further criticism one might raise is the extent to which the sociology of religion approach is applicable to the far more secular French example. Admittedly, one is speaking here merely of an analytical tool, which in many ways has much to commend it, but in studying the French case, one cannot help but be struck by the essentially political and secular nature of much of French pacifism.

Roger Chickering's approach to the typology of pacifism is similar in some respects to Ceadel's, although he does not follow the strict definition of pacifism employed by the latter. Chickering's model is based upon Karl Mannheim's work on the sociology of knowledge. He distinguishes between what he calls a 'utopian' pacifism which 'conceives of war as an inseparable aspect of a social and political order that is utterly corrupt and beyond rehabilitation', and on the other hand an 'ideological' pacifism which 'rejects war because of the threat it poses to a social and political order that is basically sound and praiseworthy'.27 Thus, in Chickering's model, utopian pacifism is largely a 'sectarian and chiliastic phenomenon', the province of 'marginal sectors of society'. The difference between the two types of pacifism is reduced to the following: 'Whereas utopian pacifism anticipates a radical personal or collective solution to the problem, ideological pacifism calls for moderate, constructive reform within the framework of political society'.28 Finally, Chickering stresses that neither type of pacifism necessarily precludes what he terms 'the instrumental use of violence'. For the ideological pacifist, 'both wars of national defence and the use of collective sanctions by international agencies' are quite permissible. The utopian pacifist 'fluctuates between extreme passivity and extreme, often violent activism'.29

It seems clear that the Chickering model is the most easily applicable to the interwar French case. The pacifists discussed in Part I are readily assimilated into the category of ideological pacifism, as indeed those of Part II quite easily fit the category of utopian pacifism. The feminists, once again, present a special case which is discussed in Part III. They vacillate between a utopian and an ideological pacifism, gradually moving more in the direction of the latter as the interwar period progresses.

There are conceptual similarities between the Chickering and Ceadel approaches. Ceadel goes one step further than Chickering in differentiating explicitly between inspirations and orientations, but his inclusion of nonviolence as an orientation seems out of

\footnotetext{
27 Chickering, p.19.

28 Ibid., pp. 19-20.

29 Ibid., p.21.
} 
place in a description of European, or at least French, pacifism. There were many pacifists within the Ligue Internationale des Combattants de la Paix, for example, who espoused a violent, civil response to the threat of war. The use of nonviolence as a criterion for establishing orientation thus seems irrelevant in the French context, the imposition perhaps of an Anglo-centric conception of what rightly constitutes pacifism on the European situation. In this sense, Chickering comes much closer to the mark in his acceptance of revolutionary violence as one of the potential methods of pacifism.

The problem with both the Ceadel and the Chickering models is the lack of any sense of evolution over time. Both models do, of course, permit the possibility of change but in a manner a little reminiscent of the Sekundenstil. At any given moment the orientation of a pacifist group can thus be ascertained, but there is little sense of movement or change. And yet, one of the theses of the work here presented, is that there was a great deal of movement and change over time. In order to make sense of this it seems appropriate to employ the idea of paradigmatic change. As will become clear in the body of the thesis, French pacifism evolved remarkably over the period in question. In 1919, what is called pacifisme ancien style defined the paradigm in French pacifism to which all subsequent developments must refer. Gradually, over the course of the twenties, with the rise of pessimism, fears of another war, and the growing feeling that little had fundamentally changed in the European situation since 1918, a gradual realisation that a more radical pacifism was needed overcame some pacifists. This is not to say that this radical response to war was entirely new; it was not. There had been 'integral' pacifists before 1930 , but what is new at the end of the twenties is the fact that these isolated instances of absolute, 'integral' pacifism began to coalesce into a proper movement with its own ideas, leaders and publications. In so doing, it emerged into the body politic and became a force in French politics.

These then, are the two fundamental dichotomies in this study: that between old-style pacifism which was, to use Chickering's model, largely ideological in orientation; and the new-style pacifism, which was more utopian. A variation on this theme is to be found in the feminist pacifism of the Ligue Internationale des Femmes pour la Paix et la Liberté which is discussed in Part III. Feminist pacifism followed a trajectory in opposition to the development from old to new-style pacifism. As Part III makes clear, the feminists of the LIFPL were pacifistes nouveau style before the distinction even existed. But they were never entirely utopian or sectarian in their orientation; they maintained close links with political society despite their espousal of an absolute pacifism. As the interwar years progressed, this orientation became increasingly 'collaborative' or 'ideological', in opposition to the evolution occurring from old to new-style pacifism. Even within old-style pacifism, the situation was hardly static. In the age of Briand and the optimism of the 
twenties, the old-style pacifism followed an ascending curve bringing it close on several issues to the emerging new-style pacifism. But the rise to power of Hitler across the Rhine rapidly brought this to an end, and old-style pacifism reverted to its former ideological prescriptions for peace.

Some final comments are in order before we proceed to the main body of the thesis. It is important to emphasise that one is dealing here with the politics of the margins. Perhaps by its very nature the politics of dissent was always, even in its collaborative, ideological forms, somewhat beyond the pale of French political society. This marginality varied from group to group, orientation to orientation, and over time. The Association de la Paix par le Droit, for example, seems to have had fairly close contacts with mainstream French political life. The same cannot really be said about the new-style pacifism which because of its dissenting attitude on a variety of issues seems to have maintained a fairly strict posture of sectarianism or utopianism. The point to be made is that the historian of marginality is somewhat like the medievalist, forever digging for clues to what the pacifists of the interwar period really thought. In some cases, he is successful. But in many instances, he must content himself with published primary material because pacifist archives simply do not exist. This is certainly the case in this study of French pacifism. The Gabrielle Duchêne bequest at the Bibliotheque de Documentation Internationale Contemporaine at Nanterre is rich in otherwise untraceable tracts, pamphlets and books, but in terms of correspondence with other pacifists it is primarily useful for the history of feminist pacifism. Part III of this thesis is therefore heavily based on this sort of archival material. The Romain Rolland Papers in the Bibliotheque Nationale were also consulted, but they are unfortunately still in the process of being sorted and catalogued, and were therefore of limited use in this thesis. The author also consulted the André Trocmé papers in the Swarthmore College Peace Collection in America; this too was only of limited use because of Trocmé's tangential connection with this study. The Archives Nationales and the Service Historique de l'Armée de Terre were used primarily for Appendix I on the government's reaction to a perceived conscientious objection problem in 1933 . The papers of the Ligue Internationale des Combattants de la Paix and the Association de la Paix par le Droit do not seem to exist; were they to be found, they would be of central interest to future scholars of French pacifism. Additional archival collections were also consulted, but the material gathered therein forms only a small part of the material contained in this thesis.

A second point is that the reader will perhaps look in vain for detailed practical prescriptions for achieving lasting peace, or conversely specific tactical instructions for responding to a war situation. There are a number of reasons for this. For the pacifists of the thirties especially, all energies were directed to avoiding a recurrence of war. As Victor Méric often wrote, when the next war arrived, it would all be too late. For most 
pacifists, the task at hand was thus largely an educative one, informing people of the dangers of war and leaving them to draw their own conclusions. It is also extremely important to realise that there was a limit to how specific even the most committed pacifist orator could be in advising or exhorting an audience to pick up the pacifist cross. As Part II and Appendix I make clear, it was only too easy to fall foul of the Third Republic's laws prohibiting propaganda against the army, for example. Pacifist orators had to be content with drawing a picture and allowing their audiences to take whatever interpretation they chose from it.

One final criticism might well be that little mention is made of the impact of pacifists on French political society. In one sense, it could be argued that it was negligible because it is clear that the pacifist voice was not heard. But in another sense, as Appendix I makes clear, the government was certainly worried in 1933 about the spread of integral pacifist ideas in France. Our purpose in this thesis, though, has not been primarily to examine the extent to which pacifism became a governmental issue in interwar France, but rather to describe the evolution and the political development of an as yet unexamined, but important, peace movement. In so doing, we move into the nebulous and marginal realm of the politics of dissent. 
PART I

.PACIFISME ANCIEN STYLE, OU LE PACIFISME DES PROFESSEURS 


\section{I.l. Introduction}

Pacifism was not born in France in the aftermath of the Great War. Despite the apparent aversion of modern French historiography to the treatment of the subject, pacifism has a long and respectable history in the annals of nineteenth and twentieth century France. Groups which claimed the achievement of peace as their primary goal are to be found well back into the early years of the last century. The earliest French peace society on record, according to Roger Chickering, was the Société de morale chrétienne which was founded in Paris in 1821 by the Duc de la Rochefoucauld-Liancourt and included such luminaries as Guizot, Lamartine and Benjamin Constant in its membership. ${ }^{1}$ Later in the century, under the Second Empire, Victor Hugo was arguably the most renowned pacifist in Europe. But it is above all the period following the initial consolidation of the Third Republic which saw a notable explosion in the number of French peace societies. Between 1898 and 1902 alone, according to Chickering, twenty-seven new peace societies were formed, and the years from 1899 to 1906 represented 'the period of the peace movement's greatest influence in France'. 2

In 1902 the French societies began holding regular national peace congresses. By 1900 the Bureau français de la paix, which had been founded in 1896 by Gaston Moch, a former artillery captain, and which was to become the Délégation permanente des sociétés françaises de la paix in 1902, already claimed some 400 member organisations, most of them admittedly not societies whose primary concern was the achievement of peace. ${ }^{3}$ However, by the time of the outbreak of the First World War, 'the French peace movement was, organisationally at least, an impressive phenomenon. It included in 1913 twenty-eight different societies devoted to popularising arms limitation and arbitration'. 4 In Chickering's view, the rise of the peace societies in late nineteenth century France is

1 Roger Chickering, Imperial Germany and a World Without War. The Peace Movement and German Society, 1892-1914. (Princeton: Princeton University Press, 1975), p.331.

2 Ibid., p.339.

3 Ibid., see also Obituary on Gaston Moch in PD 45, 9 (September 1935), pp.377-378; see also Sandi Cooper, 'Gaston Moch' in Josephson, et al, Biographical Dictionary of Modern Peace Leaders, pp. 645-647.

4 Chickering, pp.339-340. 
directly attributable to the crisis of the Dreyfus affair and the growing influence of Radical republicanism. This process brought the peace movement in from the cold, as it were. The politics of the margins moved much closer to the centre of French political life. As Chickering says

\begin{abstract}
Radicalism and pacifism were closely related phenomena. Like the peace movement, Radicals advocated the rigorous application of democratic principles, distrusted soldiers, renounced all but defensive wars and called for arms limitation and arbitration of international disputes. 5
\end{abstract}

Of the many pre-war French peace societies, probably the most important and influential ${ }^{6}$ was the Association de la Paix par le Droit, which was formed in 1887 by six lycéens in Nîmes, and which had an unbroken existence spanning more than half a century until it finally dissolved in the aftermath of the Second World War. ${ }^{7}$ The Association de la Paix par le Droit represents better than any other competing organisation the pacifisme ancien style which is the paradigm to which all subsequent developments within French pacifism must refer. The APD typifies the bourgeois, liberal, internationalist tradition within French pacifism which believed in the inexorable march of humanity towards a better future in which war would be banished under the aegis of arbitration and conciliation between mutually enlightened powers who would voluntarily disarm and pool their coercive forces into a single army under international command. The APD exemplifies all that was best in the French 'scientific' approach to peace, in its continuing search for what it termed a 'positive' peace which had to be constructed slowly and patiently over time.

This section of the thesis will therefore largely be about the evolution of the Association de la Paix par le Droit over the course of the interwar period. Other organisations could have been chosen to represent this paradigm, but none so clearly epitomises the spirit and methods of traditional French pacifism as the APD. There are other reasons, too, for concentrating our attentions on the APD. As an organisation, it swallowed up several of the more important pre-war groups and thus established a sort of

5 Ibid., p.338.

6 This view is shared by Chickering, p. 337.

7 On the origins of the Association de la Paix par le Droit see ibid., pp.337-338; see also J. Prudhommeaux, 'L'Origine, le Développement et le fonctionnement de l'Association de la Paix par le Droit', $P D, 38,12$ (December 1928), pp.513-518; Henry Babut, 'Les origines de la Paix par le Droit', PD 38, 4/5 (April-May 1928), Pp.169-175; Ernest Roussel, 'Les Origines de la Paix par le Droit', PD 38, 1 (January 1928), pp.10-15; Jacques Dumas, 'Les origines de la Paix par le Droit', PD 38, 3(March 1928), Pp.105-112; see also: Henry Babut, 'Notes brèves sur nos Origines', PD 48, 6/7/8 (May-June-July 1938), pp. 254-256; J. Prudhommeaux, 'Un demi-siècle d'activité de la Revue "La Paix par le Droit"', PD 48, 6/7/8 (May-June-July 1938), pp.269-277. 
hegemony over French pacifism in the immediate post-war period. For example, one of the oldest French peace societies, the Ligue internationale et permanente de la paix which had been founded in 1867 by Frédéric Passy and others, became the Société française des amis de la paix and finally in 1888 under the influence of the Englishman Hodgson Pratt, the Société française pour l'arbitrage entre nations. ${ }^{8}$ When the young lycéens of Nîmes formed their association in 1887, it was to Passy that they looked for an honorary president. However, by the immediate post-war years, the Association de la Paix par le Droit had overtaken the Société française in importance and in 1922 the two associations merged, retaining the name of the APD and its organ. ${ }^{9}$

So much for the organisational legacy of the prewar years. But what about the postwar era? Did the Paix par le Droit retain its position of pre-eminence in the interwar period? The answer is almost certainly affirmative within the parameters of the old style pacifism with which we are concerned in this section. The victory of the Allied powers in 1918, Wilson's fourteen points, and more especially the founding of the League of Nations created an explosion of societies in France whose raison d'être was to support the work of the League. In many ways, these societies, of which there were many, were logical offshoots of the pre-war work of the Paix par le Droit. They represented the culmination of all that the APD wished to achieve in international life. And they were not surprisingly closely connected with the APD in terms of shared membership, shared ideals, and in the case of some, shared organs. For example, Théodore Ruyssen, the long serving President of the APD, was also the Secretary General of the Union Internationale des Associations pour la Société des Nations. ${ }^{10}$ Jules Prudhommeaux, one of the founding six from Nîmes, was the Secretary General not only of the APD, but also of the Association Française pour la Société des Nations. Jules-L. Puech was the editorial secretary of the Association's review, also entitled La Paix par le Droit; and his wife was the president of the Union Féminine pour la Société des Nations and also vice-president of the APD. In 1931 the APD announced that in light of a recent friendly agreement, its review would be open to news and announcements from the Association Française pour la Société des Nations, the Comité Français de Coopération Européenne, the Union Féminine pour la Société des Nations and the Fédération Française des Associations pour la SDN. ${ }^{11}$ The APD was thus the nexus

8 Chickering, pp.334-337.

9 On the fusion of the two societies, see Charles Richet and Theodore. Ruyssen, 'Fusion de la Société Française pour l'Arbitrage et de l'Association de la Paix par le Droit', PD 32, 2(February 1922), Pp.57-58. For a short account of the links between the two organisations see Jacques Dumas, 'La société Française pour l'Arbitrage entre Nations', PD 32, 2 (February 1922), Pp.59-65.

10 Mention is made of Ruyssen's election to this position in Edmond Duméril and J. Prudhommeaux, 'L'Assemblée Générale de l'Association de la Paix par le Droit', (Poitiers, 31 October to 1 November 1921) in PD 31, 12 (December 1921), p.404.

11 See the 'Avis' printed on the inside cover of PD 41, 2 (February 1931). 
between the pre-war societies which had worked for the creation of something like the League of Nations, and the plethora of post-war groups which sprang up to nurture and defend the fledgling Geneva institution. In terms of membership, leadership, intellectual content and the pooling of printed resources the Association de la Paix par le Droit thus stands out as the most important and influential of the French peace societies which collectively make up what we have denoted here as the paradigm of pacifisme ancien style. The theme of interpenetration of the French peace societies is one to which we shall return later in this section, together with its antithesis, the balkanisation of French pacifist efforts.

For the moment, though, it would be useful to take a brief look at the thorny question of membership and circulation figures in order to gain some sort of appreciation of the size of the APD. Thorny, because in the history of marginality, even in the case of relatively mainstream groups such as the APD, the historian feels very much like the medievalist dealing with the imponderables of quantification. Nevertheless, it seems clear that after the quite natural slump in membership figures occasioned by the Great War, the APD quickly began to climb out of the trough towards a membership which varied between roughly 5,000 and 7,000 members for most of the interwar period. Two non-dated reports from the interwar period, written in English, apparently for the Society of Friends, and contained in the Swarthmore College Peace Collection, put the membership of the APD variously at 8,000 and $20,000.12$ The latter figure is certainly too high and the former might be slightly inflated as well. Combing through the various reports presented over twenty years of Annual General Meetings the following figures for membership can be gleaned: 6,000 members in 1929, rising to around 7,000 in 1935 and falling to 6,000 again in 1938.13 This compares with pre-war figures of 1200 in 1902 and about 4000 in 1912.14 The pre-eminence of the APD within old-style French pacifism is further illustrated by a list of the membership charges exacted on the French members of the Bureau International de la Paix which had its headquarters in Geneva. Le Mouvement Pacifiste reported that in 1926 the total contribution of French peace societies to the work of the Bureau, by reason of five centimes per member, was just over 151 Swiss Francs. Of this sum, ninety-eight francs came from the APD, and a further 5.65 francs from its Paris section directly. Following this line of reasoning, the APD claimed (or at least paid for!) only some 2000 members in 1926. Whatever the accuracy of the global figures, the APD's contribution to the BIP was four

12 'Pacifist Organisations in France' (1928?) and 'France', both in SCPC, CDG-B (France), Box 2.

13 An obituary on Séverine mentions 6,000 members. PD 39, 6 (June 1929), p.251; J. Prudhommeaux, 'L'Assemblée Générale de la Paix par le Droit' (Marseille, 27 December 1935), PD 46, 2 (February 1936), p.68; J. Prudhommeaux and J. Lahargue, 'L'Assemblée Générale et le Congrès du Cinquantenaire', (Nìmes, 19-21 April 1938), PD 48, 6/7/8 (May-June-July 1938), p.249.

14 Chickering, pp.337 and 344. 
times higher than the next largest French contributor. That said, the French total pales into insignificance beside the 956 Swiss francs paid by the German peace societies and the 808 francs paid by the various British groups. 15

There seems to have been a fairly high turnover in the Association's membership, too. August Laune, the Association's indefatigable treasurer (and a founding member) complained at the 1938 Annual General Meeting of 2,500 memberships or subscriptions to the Review which had not been renewed over the preceding five years. Clearly the worsening international situation, coupled with the effects of the financial crisis which had finally reached France (in 1932), were probably much to blame for this state of affairs, but nevertheless it seems that it represented a continuing problem for the APD. In this same financial report, Laune noted that over the course of its fifty-year existence the Association had lost a total of 30,000 members or subscribers. 16

Turning to circulation figures for the APD's organs, the situation is broadly similar. Not all subscribers to the Review, La Paix par le Droit or to the more popular broadsheet Les Peuples Unis created following the 1924 annual general meeting, were necessarily members of the Association. That said, the subscription rate for La Paix par le Droit was a close mirror of membership figures in the Association. In 1920 the review had a print run of about 5,000 copies. This compared with 8,000 copies printed in the first seven months of 1914 and 6,000 in the last five. 17 By 1924 the circulation figures had risen to 8,000 again, falling to 5,500 in 1927 , and only 5,300 in 1935 , despite a rise to 7,000 in $1931 .{ }^{18}$

The above figures give us a rough quantitative idea of the nature of the APD, but they tell us very little about the sort of person who was likely to be found in the ranks of this association. Unfortunately little information is available which would provide a precise and objective analysis of the sort of 'pacifist' likely to join the APD. Still, it is possible to paint an impressionistic picture of the APD which will give us at least an approximation of the sort of membership it had.

The first point to be made is that one could almost call the old-style pacifism under discussion in this section the pacifisme des professeurs, such is the level of activity of teachers of all grades within the APD. Barnett Singer has written of the extent to which the instituteurs of the late Third Republic became imbued with pacifist ideas, and Jean-

15 'Tableau des Cotisations versées en 1926 au Bureau International de la Paix.' Le Mouvement Pacifiste (October 1927), pp. 146-147.

16 Laune in Prudhommeaux, Lahargue 'L'Assemblée Générale et le Congrès du Cinquantenaire' PD 48, 6/7/8 (May-June-July 1938), p. 249.

17. Jules-L. Puech, 'Notre revue', PD 30, 11/12 (November-December 1920), p.367.

18 See: J. Prudhommeaux and Georges Cadier, 'L'Assemblée Générale de la Paix par le Droit', PD 34, 7/8 (July-August 1924), p.273; J. Prudhommeaux and J.-L. Puech, 'L'Assemblée Générale et les Fêtes du XLème Anniversaire', $P D$ 37, 12 (December 1927), p.443; J. Prudhommeaux, 'Notre Assemblée Générale', PD 41, 12 (December 1931), p.577; J. Prudhommeaux, 'L'Assemblée Générale de la Paix par le Droit', PD 46, 2(February 1936), p.62. 
François Sirinelli in his recent massive doctorat-d'Etat paints a picture of khâgneux and normaliens in the twenties affected by much the same system of ideas. ${ }^{19}$ The APD was the creation and preserve of academics. A 1932 list of almost sixty local groups of the APD provides the following breakdown by occupation of the group presidents or secretaries: 13 professors, directors of schools and faculties or inspectors of education, one instituteur, two pastors, six medical doctors, one industrialist, three present or sometime mayors, one premier adjoint (to the Mayor of Nìmes), one conseiller-général, one conseiller-municipal, one retired military officer, one newspaper director and one court clerk, for a total of 32 local group presidents for whom the occupation is given or can be deduced. Another 27 groups provide no information as to the occupation of their presidents. ${ }^{20}$ If one examines the APD's executive committee and Conseil de Direction the predominance of the professorial element is even more noticeable. Taking 1932 once again as the point of reference, in that year the executive committee was composed of people who represented the cream of the French intellectual elite. The President, Théodore Ruyssen, was a professor at the University of Brussels, having previously taught at the University of Bordeaux. As Vice-Presidents in 1932 were Jacques Dumas, a doctor of laws and barrister at the Cour de Cassation in Paris, and Mme M.-L. Puech who was President of the Union Féminine pour la Société des Nations. The Secretary General was Professor Jules Prudhommeaux, the secretary in charge of propaganda was Edmond Duméril who was a professeur agregé at the lycée in Nantes, and who was to receive his doctorate in German Literature in 1934, and finally the secretary in charge of the reviews was Jules-L. Puech who held doctorates in law and letters, and in 1934 was to be honoured with the ribbon of the Legion of Honour. The Treasurer of the association was August Laune, a businessman. Of the three members at large in the Executive committee one finds Georges Scelle, professor of international law at the University of Geneva, Célestin Bougle, at that time assistant director of the Ecole Normale Supérieure but who was to finish his career as director in the rue d'Ulm, and Georges Cadier, director of a newspaper in Nantes. This rather long list goes some way to showing the extent to which the APD was very much the creation and preserve of part of the French liberal, educated elite. The Honorary President of the ssociation was Charles Richet, professor at the Faculty of Medicine of the University of Paris and Member of the Institute. Other names of some renown are to be

19 See Barnett Singer, 'From Patriots to Pacifists: The French Primary School Teachers, 18801940', Joumal of Contemporary History 12 (1977), pp.413-434; J.-F. Sirinelli, 'Khâgneux et normaliens aux anneses vingt'. These de Doctorat d'Etat, University of Paris - X, 1986, 5 Vols.

20 See 'Association de la Paix par le Droit' in Nous Voulons la Paix, (Paris, SRIP, 1932), pp.28-31. 
found in the list of members of the Conseil de Direction; one example is that of Justin Godart, senator for the Rhône. And the list could go on. ${ }^{21}$

In terms of the type of pacifist attracted to the APD in the interwar period, more could be said about the links between the Association and Ligue des Droits de l'Homme, Freemasonry, the Radical party, and the extent to which the APD reflected Protestant ideals within a Roman Catholic tradition. More will be said about all of these themes in the course of this section, but in ending this introduction to pacifisme ancien style, one should point out the intimate relations between it and the official world of French politics, in short its central place in an important part of French political culture especially during the twenties. With men like Painleve, Paul-Boncour, Godart, and Pierre Cot - to name but four - interested in the work of the APD, it is perhaps not surprising to find that in 1929 the Association was given the official accolade of being reconnue d'utilité publique.

21 For a list of the members of the Conseil de Direction and the Comite Executif of the APD, see the inside cover of $P D$ 42,6 (June 1932). Additional information on Puech and Duméril can be found in PD 44, 7-8 (July-August 1934), pp. 304-305. 


\section{I.2. The Paradigm Defined.}

It is interesting to note that despite its later 'scientific' or juridical pacifism, the Association de la Paix par le Droit began its existence very much as the result of an ethical and moral rejection of war. The writers of the monthly news column in the PD referred in 1926 to the department of the Gard as the 'cradle of our association'. ${ }^{22}$ As has been mentioned above, the APD was formed in the spring of 1887 by six lycéens in Nîmes, the capital of the Gard, and like a pebble dropped into a still pond the ideas of the APD spread out from Nìmes across France, following in many cases the careers of the original six and their converts to the cause. It is probably no accident that this association was formed in one of the areas of France most imbued with Protestant ideas. ${ }^{23}$ The connection between the APD and Protestantism was to remain strong over the course of its entire life. Several members of the APD's committee were clergymen in the Reformed Church of France. In fact, one of the founding six, Henri Babut was the son of a pastor and went on to study Protestant theology in Montauban before being ordained himself. We have also noted the influence of Protestant ideas coming from England in the formation of the APD. These ideas seem to have been transmitted to the young lycéens of Nimes as a result of a voyage undertaken by the oldest of the founding six, L.-A. Barnier who became the first president of the fledgling association, then called simply the Jeunes Amis de la Paix. As Jules Prudhommeaux wrote in 1928, Barnier 'had brought back from a trip to England which had placed him in contact with several members of the Society of Friends (Quakers) who were committed to ideas of peace and arbitration, the new faith which he hastened to share with his comrades'.24 Ernest Roussel, writing of the origins of the APD, said that it grew out of an adolescent discussion group called 'La Gerbe'. For him the pervasive influence of Protestant ideas was self-evident:

22 Charles Rousseau and Jules Prudhommeaux, 'Dans le Gard: à Caveirac', PD 36, 5 (May 1926), p. 234.

23 See Brian Fitzpatrick, Catholic Royalism in the Department of the Gard, 1814-1852 (Cambridge: at the University Press, 1983), pp.15-17.

${ }^{24}$ Jules Prudhommeaux, 'L'Origine, le Développement et le Fonctionnement de l'Association de la Paix par le Droit', PD 38, 12 (December 1928), p.513. 
The Gerbe was Protestant in spirit, for we were in majority of Huguenot origin, which was only natural in Nimes. We represented different nuances of religious belief. To tell the truth, I think that only one of us had a real faith; he has become a pastor and an admirable one. But we were all sons of the Reformation, through our critical spirit and faith in the value of the things of the mind and of the conscience. ${ }^{25}$

The initial programme of the Jeunes Amis de la Paix was comprised of two points: 1. 'Suppression of permanent armies - creation of national militias to guarantee the internal police'; and 2. 'Creation of a tribunal of international arbitration endowed with a special code'. ${ }^{26}$ Following the suggestion of Frédéric Passy, the order of the two points in the programme was inverted, the suppression of armies being a result of the creation of international tribunals according to him. ${ }^{27}$ The name La Paix par le Droit was suggested by Pasteur Charles Babut who gave the young association 'in three words, a principle, a programme and a hope in a better Future: ${ }^{28}$ Despite the early influence of Quaker individualism on the nascent association, it quickly affirmed a measure of conformity with Third Republic military demands. After one of its early members became a conscientious objector, the APD included an article in its statutes which read that 'Active and ordinary [adhérents] members engage themselves morally to submit to the military laws of their country, if they have not yet satisfied them'.29 Thus, without labouring the point, it is clear that what began in an élan of individualistic moral or religious conviction was quickly transmuted into an essentially political and juridical programme no less fervently espoused for all that. This very early change is important and is one to which we shall return, especially in the debates on conscientious objection within the APD in the late twenties and early thirties, but it is important to note that almost from the outset the paradigm of pacifisme ancien style in France is one which has a social and juridical epicentre rather than a religious or primarily ethical one. The insistence on justice or 'right' in the Association's rather epigrammatic title is one which was to provide both strengths and weaknesses in its approach to the problem of peace in interwar Europe; strength no doubt in its perspicacious analysis of the dangers posed by Hitlerian Germany, but weakness also in its blurred vision of the world of the 1920s created at Versailles.

One further point needs to be made in this pre-war introduction to the nature of the APD's pacifism, that is to say, its relations with the organised working class. As early as 1904-1905 the association had become aware of the need to develop some sort of position on

\footnotetext{
25 Ernest Roussel, 'Les origines de la Paix par le Droit', PD 38, 1 January 1928), p.12.

26 See 'Facsimilé' of the original programme in PD 37, 12 (December 1927), p. 428.

27 Prudhommeaux, 'L'Origine...', PD 38, 12 (December 1928), pp.513-514.

28 Roussel, 'Les origines...', PD 38, 1 (January 1928), p.13.

29 Prudhommeaux, 'L'Origine...', PD 38, 12 (December 1928), p.515.
} 
the pacifism or antimilitarism of large swaths of French syndicalism. Within the pre-war French working class the fight against war had overtly mechanistic dimensions with little in the way of ethical nuance. The argument was quite simple: rid society of the capitalist class and wars would disappear forever. The violence of the syndicalist analysis of war and how to prevent it seemed to be peculiarly French. As Prudhommeaux said in a speech on the relations between pacifism and the working class delivered at the fourteenth international peace congress in Lucerne in September 1905:

For very diverse political and social reasons (absence of obligatory military service, etc), American federationism and English trade unionism have not adopted the violent attitude of French syndicalism with regard to militarism and capitalism..$^{30}$

German trades unions, he noted, contained substantial conservative and Catholic elements. It was precisely the existence of more conservative elements within the trade union movement which dictated the course of action pacifists must follow.

If we know how to go to these moderates and speak a language which is appropriate to their needs and preoccupations, we will stop them on the slope which is leading them to extreme positions. 31

For Prudhommeaux, what was important was to search out a common ground. The end was the same for both groups - the bourgeois and working-class pacifists alike - what differed was the method or means to achieve that end. For the pacifists of the APD and the international congresses it was international arbitration and conciliation, in short the growth of a positive international order. For the working class, it was the overthrow of capitalism. The answer lay in what Prudhommeaux called 'a voyage of reciprocal exploration' ${ }^{32}$ Thus, from almost its earliest days, the APD and its leading thinkers were aware of the existence and ideas of the other main protagonist of peace in the pre-war and later in the interwar period.

With twenty-seven years of pacifist activity behind it in 1914, the APD was already an association of middle-aged men by the time of the Great War. What was its position during the cataclysm? And perhaps more importantly, did the experience of the Great War produce a dramatic paradigmatic change in the Association's pacifist thinking?

30 J. Prudhommeaux, 'Les Rapports du Pacifisme et du Mouvement Ouvrier', PD 15, 11 (November 1905), p.430.

31 Ibid.

32 Ibid., p.433. 
The answer to the above questions is that in fact very little changed in the APD's approach to peace as a result of the Great War. Despite the attacks of the censor's scissors, the review continued to appear regularly, albeit in somewhat truncated format. Meetings continued to be held, and the men and women of the APD simply waited out the war while continuing to publish their prescriptions for a better world. This is not to say that the oldstyle pacifists did not feel the tragedy of the situation. They most certainly did and were greatly moved by it. But, like so many other thinking men and women in those bloody years, they believed that the war was being fought for a higher ideal and that the world which would emerge from the mud of northern France would be a better one. As Charles Richet and Théodore Ruyssen put it in an appeal for 'Peace through Justice' published in January 1918:

Our readers know what our propaganda has been. But it is useful in these troubled and passionate times to recall it one more time. It can be summed up in one word: we have from the very first day of the war and without ceasing advocated the policy which has finally brought North America and two-thirds of South America to the side of the Allies. Let us dare to say without boasting, because it is the simple truth, that we were Wilsonians, not before $\mathrm{Mr}$ Wilson, but before the President of the United States had proclaimed to the universe the doctrine which was to lead to the intervention of the New World in the European war. We have thought, written and repeated untiringly since the tragic days doubly tragic for pacifists - of July 1914, that the aggression of force against justice must be opposed by force without flinching, even at the price of the worst sacrifices - but that this force must spring from a desire for peace, a just peace, organised, durable, as tenacious, as irreducible as the desire for war itself.

In judging moreover this war of defence and liberation necessary, we have abandoned none of our convictions of old. We continue to think, for reasons which we have developed a hundred times, that between civilised men war is a monstrous anachronism and an avoidable evil. Just because it is imposed, we do not believe it holy, nor beautiful, nor salutary; we fulfil with firmness, but with sadness, a cruel duty, and we preserve intact our desire to struggle against the international anarchy from which this war was born. ${ }^{33}$

This long citation defines clearly the APD's position during the Great War. With the benefit of hindsight there was certainly nothing subversive about it, although to the bellicists of the day (a species we no longer are familiar with) there was no doubt much about it that caused concern. The APD was thus thoroughly patriotic during the war. Its members did their duty. Ruyssen, though too old for active service worked for a time as a sort of volunteer nurse, looking after the wounded in a hospital in Nantes. Félicien

33 Charles Richet and Théodore Ruyssen, 'Pour "La Paix par le Droit"', PD 28, 1 /2 (January 1918), p.2. 
Challaye, who was a committee member in the twenties, and of whom much more will be heard, served as a simple sergeant in the territorial army, and so on. 34

If the trauma of the Great War did little to change the APD's basic Weltanschauung, it did, however, force it to define its position with regard to other pacifists who drew different lessons from the wartime experience, and also with regard to the erroneous, but tenacious and damaging conclusions reached by public opinion about the nature of pacifism. Taking the latter point first, several writers in the PD were at pains to distinguish between pacifism and defeatism on the one hand, and on the other hand to emphasise that the APD's programme of positive prescriptions for peace in no way affected its view of what it considered to be a just war. In a short article published before the war had ended, Gustave Belot protested at the insinuation by the judge in the Hélène Brion trial that there was something subversive about pacifism:

Whether it pleases him or not, Pacifism in the proper sense of the word is exactly the same thing in time of war as in time of peace. What do we have to do in order to make people understand that the true idea of Pacifism is that of a regime of international law an idea which the state of war cannot annul?

Pacifism is decidedly not Bolshevism. It has never consisted in compromising or obstructing the defence of the nation...This perpetual caricature that is made of pacifism is an intolerable calumny.... 35

The war experience and public opinion seem to have taken their toll on some readers of the $P D$ however. F. Lepine, an inspecteur de l'enseignement primaire in Reims wrote a long open letter to Ruyssen published in the review in which he raised the question of pacifism and defeatism. Lepine distinguished between the pacifism of a Passy which had 'nothing in common with anarchism or antimilitarism', and a certain 'equivocal pacifism' which 'cohabits happily with the class war, with doctrines of hatred and civil war' and ends up 'lowering itself to antinational and antisocial heresies.' As a prime example of this he cited Barbusse who in his view preached violence and did not distinguish between anarchism, antimilitarism and pacifism. This attitude could only lead to a situation like that in Russia under the Soviets. Ruyssen's response was clearly in favour of pacifism as opposed to defeatism. He defended Barbusse by arguing that his characters in Le Feu 'curse war, but they fight it", and he said that he was still looking for the European pacifists of

34 Félicien Challaye, 'Pour la Paix sans aucune réserve', PD 42, 4 (April 1932), p.149; J.-L. Puech, 'A propos des Articles Challaye-Ruyssen', PD 42, 4 (April 1932), pp.153-154.

35 Gustave Belot, 'Encore le mot "pacifisme"', PD 28, 7/8 (April 1918), p.109. 
whom Lepine wrote 'who fail to recognise the necessity of resisting savage violence by force.' Such pacifists were not to be found in the ranks of the APD in any case. 36

In October 1918 when the Axis demand for an armistice became known, Ruyssen wrote a public letter to Clemenceau asking that the war be ended as soon as possible within the bounds of what was just. But he underlined the dangers for France contained in what he called the 'phobia of peace' which certain public personages seemed to be experiencing - $a$. phobia which saw anyone envisaging peace as either pusillanimous or a traitor. It is perhaps indicative of the extent to which the APD was itself sensitive to these charges that he underlined to Clemenceau that 'we are pacifists, we are not defeatists', reminding the Tiger that in 1916 he had written to Ruyssen that he 'liked' the APD's 'pacifism'. 37

Richet and Ruyssen saluted the end of a war which they believed ought never to have occurred, but for which they believed there were some direct and crushing responsibilities as well as other more imponderable, indirect ones. They celebrated the return of AlsaceLorraine, but even more perhaps the remaking of the map of Europe on revolutionary principles which the end of the war seemed to promise. Let there be no doubt: Richet and Ruyssen did not have a social experiment on Marxist lines in mind. They were referring to the revolutionary principles of the early French revolution, the spirit of '92:

Yes, this war is revolutionary. It achieves the work of our ancestors of '92, compromised by Napoleon. In all of central Europe crowns are falling in cascades: stunned, the sovereigns are fleeing the popular wrath... 38

La guerre $d u$ droit thus assumed at its climax almost mythical proportions for the republicans of the APD. It represented the culmination of a revolutionary struggle begun and then derailed almost 130 years previously.

The euphoria brought on by the end of the war died away rather quickly however as it became apparent that the peace which was emerging from the ashes was not a perfect one. The APD's pronouncements on the state of international affairs, the Versailles treaty and the tasks facing post-war pacifism are a mixture of optimism and despair. On the one hand the men of the APD saw tremendous hope for progress in the post-Versailles world, but equally they could not help but be disturbed by the incompleteness of the post-war system.

36 F. Lepine, 'Pacifisme ou défaitisme?', (letter of 1 January 1918 with response by Ruyssen), $P D$ 28, 3/4/5/6 (February-March 1918), Pp.49-55. For favourable comment on Barbusse, see $P D 28,1 / 2$ January 1918), pp.41-43.

37 . A M. Georges Clemenceau (Lettre adressé à M. Clémenceau au lendemain de la demande d'armistice formulée par les Empires centraux par le Comité Directeur de "l'Association de la Paix par le Droit", Bordeaux, 8 Octobre 1918)', PD 28, 21/22 (November 1918), Pp.332-333.

38 Charles Richet and Theodore Ruyssen, 'La Fin de la Guerre', PD 28, 21/22 (November 1918), p.330. 
In a Appel-Programme published at the beginning of 1920 for example, the APD spoke of the horrors of the war which was finally over, but registered disappointment that what had been fought as the war to end all wars already seemed to have given birth to a bastard peace:
Alas! from this grandiose dream to present reality, what a fall! Granted, the League of Nations has seen the day: it cries in the straw in the stable of the new Bethlehem. It is a triumph of Right. But how pale and imperfect this new constitution still is! The solemn pact which created it does not even dare to pronounce, in the name of organised humanity, a definitive and absolute interdiction of war; it admits the possibility of new bloody conflicts in the future. The Peace Conference in Paris has succeeded neither in imposing an obligatory solution on all disputes by means of law, nor in constituting an international police force. Tomorrow, almost as much as yesterday, war remains possible in an anarchistic world. ${ }^{39}$

But however imperfect the post-war world might be, it had to be lived in and the APD saw the League of Nations as the indirect creation of pacifist hands. Never before had they felt so much that they were moving in the same direction as the march of History; their 'lifeboat was lifted up by the rising tide'. 40 Whereas before the war the APD's task had been the promotion of international arbitration and warning against the coming catastrophe, during the war it had been the fulfillment of its patriotic duty, and after the war its horizons had to be broadened to go beyond its old formulæ to demanding the creation of a League of Nations endowed with real powers of international organisation including that of an international police force. As Ruyssen reiterated later in the year following the APD's first post-war annual general meeting, public opinion was in complete disarray because it seemed that the promises made during the war were not to be fulfilled, and that two years after the armistice the most the French government could offer was a reduction of the length of military service from two years to eighteen months. Added to this was the defection of the Americans from the Geneva experiment and the sniping attacks of some socialists who persisted in seeing the League as but the tool of imperialist oppressors. The pre-war challenge thus remained the same for the APD, although amplified and extended by the creation of the League:

...there is no need to look for a new orientation, nor above all to renounce [anything]. Doubtless, the creation of the League of Nations obliges us not to revise, but to complete the motto of the ancien pacifisme. It is no longer enough to-day to demand 'arbitration' and 'conciliation'. But the League of Nations is too

39 'Pour la Paix par le Droit. Appel Programme', PD 30, 1/2 (Jan-Feb 1920), p.2.

40 Ibid., p.3. 
young, too infirm, too contested not to have need of being defended.

It lacks the assent of the popular masses... ${ }^{41}$

Thus, despite the admitted problems inherent in the new order born of Versailles, the APD saw its mission clearly as the support and extension of an international system based upon a desire for peace achieved through respect for law. Within the APD however there continued to be some dissension as to the nature the Association's post-war pacifism ought to have. Some members thought the Association was going too far in its reconciliation with the former enemy; others thought quite the contrary and saw in the APD's reticences an unwillingness to move forward in the fight for peace and reconciliation. In 1920 for example the review had carried an article about relief to famine-struck areas of Europe, especially with regard to saving the lives of young children. Some readers took great exception to the fact that the appeal was destined towards saving the lives of German children too! Ruyssen replied by saying that he pleaded guilty: 'We admit our pity for the starving child, even if his father is guilty, because it is a double misery to be hungry and also the son of an assassin or thief'. 42 A year later, however, R. Périé, an inspecteur $d^{\prime}$ Academie honoraire, took fundamental issue with the review over its attitude with regard to Germany. Périé argued for more mutual tolerance and forgiveness. The problem with the Versailles Treaty was that it was the judgement of men who were prosecutors and judges in their own court. The argument over whether or not reparations constituted a war indemnity or not was pedantic. Périé accepted the principle of restitution, but argued that in order for it to be valid, and deemed to be valid by the offending party, it had to be the result of a judgement handed down by a competent tribunal - 'that of a universal, ecumenical League of Nations'. The fundamental issue though was one of attitude towards Germany and the reconciliation necessary for the rebuilding of Europe; echoing an Englishman who was in no way a Germanophile, Périé wrote that the Germans 'were not born with a double dose of original sin: 43

The mild dissent of a Périé was certainly not matched by many readers of the $P D$. Jules Puech, the review's secretary, complained in a 1924 article that 'many readers think that the only truth worth repeating is the governmental truth which is disseminated by certain more or less official newspapers'.44 This was fine during the war, although even then the $P D$ was not prepared to become a bourreur de cranes. But Puech argued that the time for such mindless and uncritical conformity had long since passed. The APD and its members had to regain their critical faculties and to praise and condemn public policy where

41 T. Ruyssen, 'Au Travail', PD 30, 11/12 (Nov-Dec 1920), Pp.354-355.

42 T. Ruyssen, 'Réponse à Quelques Objections', PD 30, 5 (May 1920), p.134.

43 R. Périé, 'Scrupules Pacifistes' (letter to Ruyssen), PD 31, 7 (July 1921), pp.237-240.

44 Jules-L. Puech, 'Notre "Sainte Cause"', PD 34, 4/5 (April-May 1924), p.165. 
necessary. The apparent lack of the dissenting spirit amongst the rank-and-file of the APD, if Puech's comments are to be given any credence, reflects the views of wider French society on pacifism. One contributor writing in the review in 1922, said that pacifism frightened people. During the war it somehow became synonymous with 'defeatism', and since the victory, although everyone was in favour of peace, no one wanted to be called a pacifist. But a pacifist was merely someone who was a 'partisan of peace', and thus all men who earnestly desired peace must be pacifist. On this basis, France and Germany could both be divided politically into parties of war and parties of peace. 45 Seven years later the problem remained much the same as Ruyssen exasperatedly attacked the misconceptions of the popular press about the nature of pacifism. His ire had been raised by Louis Lafon - 'this pastor, doctor without charity of a religion of love' - who had defined pacifism as a utopian belief held basically by fools. ${ }^{46}$ And yet again Ruyssen defined to his uncomprehending detractors the pacifisme ancien style of the APD:

Is it necessary to say yet again that pacifism is anything but this march to the stars, and that it is an attempt to organise peace not according to a chimerical plan, but in inspiring itself from a real and secular experience, that of civil life?.... Where is the chimera in this?...In 1914, it was not pacifist idealism which was listened to, but the desperate pessimism of the believers in force, for the greatest benefit of the canon founders of all countries. 47

Ruyssen's pacifism, this pacifism of the APD, showed little sign of self-doubt about the rectitude of its position in the twenties. It was a pacifism based on justice, and Ruyssen and his fellow pacifists believed they knew what that entailed. It meant condemning those who deserted justice and Right for opportunistic reasons. 48 It meant condemning the veterans organisations for their equivocal stand on national defence which made the whole question one of individual conscience. 49 It meant a rapid end to the honeymoon with Barbusse once the latter's conception of peace became evident. Louis Bosse described Barbusse's prescriptions for peace as a 'project for a mechanical paradise'. 50 The problem with Barbusse's thinking was that it reduced peace to an 'all or nothing' concept. Bosse

45 René Lauret, 'Pourquoi le Pacifisme est Décrié', PD 32, 2 (Feb. 1922), pp.72-3.

46 T. Ruyssen, 'Polémiques', PD 39, 10 (Oct 1929), p.357. Lafon was director of La Vie Nouvelle and also contributed to Le Temps.

47 Ibid., p.358.

48. Une idée ... turque: Lénine, laureat du Prix Nobel', PD 28, 1/2 (Jan 1918) p.43. Criticism of Lenin's nomination by the University of Constantinople for the Peace Prize on the grounds cited.

49 T. Ruyssen, 'L'Internationale des Ancien combattants', PD 30, 6/7 (June-July 1920), p. 204. Ruyssen's comments are actually just an introduction to a report on the Geneva Conference by $F$. Couttenoire de Toury which follows.

50 Louis Bosse, 'Quelques Réflexions sur un projet du paradis mécanique', PD 31, 1 (Jan 1921), Pp.36. 
argued instead for the necessity and value of partial steps; Barbusse's method was the panacea of a lazy mind. What made such an argument even more strange in Bosse's view was that the teleology was the same; Ruyssen and Barbusse differed only on means. Barbusse was proposing a 'messianic mysticism' in which 'in the final analysis [he] wants to create peace out of peace. There will be no more war when we have done away with all causes for war... 51 With regard to the question of the class struggle and civil war, Ruyssen wrote that all members of the APD's committee detested the latter but that at the social level, there was no defined doctrine held by members of the APD. 52 Notwithstanding these divergences with some of the tenants of the as yet unself-conscious and undefined pacifisme nouveau style, Ruyssen in 1925 was still affirming that the old style pacifism was capable of working with the disparate elements within the pacifism of the twenties because the end for all was still the same. ${ }^{53}$ As will become clear, it was to take until the early thirties before the incompatibilities of new and old-style pacifism became so marked as finally to force a rupture. But that is to jump ahead somewhat. Pacifism was beginning to change but the men and women of the APD could not at this point begin to guess the degree. Edmond Vermeil saw the beginnings of this divergence at the 1924 international peace congress in Berlin where the pacifist camp seemed to be divided between 'moderates' and 'intransigents'. The differences became particularly obvious in the debates on disarmament, which led Vermeil to conclude

...it is clear that in present-day pacifism there is a tendency towards absolutism, towards ideology, towards peremptory and definitive declarations which arrange everything in the abstract, but solve nothing within the order of present reality - the immediate and quasi-tragic realities in which we move, hither and thither, today...Peace needs not only to be decreed, but to be 'organised'... 54

Kurt Hiller, one of the German 'intransigents' said to Vermeil at the congress in a private conversation that the two strands of pacifism must continue to co-exist within the bosom of

51 Ibid., p.5.

52 T. Ruyssen, 'Réponse a quelques Objections', p.135.

53 T. Ruyssen, 'Le XXIV Congrès Internationale de la Paix', $P D$ 35, 10 (Oct 1925), pp.362-363. On the growing sense of divergence felt by representatives of the 'other side' in the pacifist movement see the letter sent by Henry van Etten of the Society of Friends on behalf of himself and Marianne Rauze (a left-wing pacifist) to G. Duchêne asking for her cooperation in an attempt to prevent the bourgeois pacifists from taking over the XXIVth Peace Congress in Paris as they apparently had done the year before in Berlin (BDIC, DD, FARés 273/19/129).

54 Edmond Vermeil, 'Le XXIIIème Congrès International de la Paix de Berlin', PD 34, 12 (Dec 1924), pp.453-54. 
the same movement, but this was to become an increasingly unattainable, and indeed undesirable, ideal by the end of the decade. 55

Pierre Cot summed up the differences between what he called the 'French' conception of peace and the 'Anglo-Saxon' idea of peace in an important article at the end of the decade. The Kellogg-Briand pact attempted to dispense with war simply by condemning it; what shocked the French mind in his view was that this simple condemnation of war did nothing actively to organise peace:

For France the heart of the problem is less to pronounce a solemn and platonic anathema against war so much as to work towards the organisation of peace. The land of Descartes and of Voltaire prefers techniques to canticles...The Anglo-Saxon, it has been said, tours the world with his Bible and the Frenchmen with his Code. Let us not be embarrassed by this natural and national penchant. We have a conception of peace which is more juridical than mystical. But justice, too, supposes an ideal. 56

The end of the war had seen these two conceptions of peace confront one another in the creation of the League of Nations. The French had held to a belief in a system of positive international law in which recourse to international violence would be forbidden and nations obliged through a system of sanctions, including that of an armed international force, to conform to the new international order. Cot believed that for the Anglo-Saxon nations, on the other hand, the question of sanctions assumed an entirely secondary importance behind a merely moral condemnation of unjust wars by international public opinion, which would express itself through two agencies: a moratorium on wars and a public debate on the causes of the conflict. In his view, the Anglo-Saxon conception carried the day. There was thus according to Cot a fundamental dichotomy of views within the former Allied camp as to the method of achieving peace. 57

55 Ibid., p.454. See also Karl Holl, 'Kurt Hiller', in Helmut Donat and Hijl Holl, eds, Die Friedensbewegung (Hermes Handlexikon), (Dusseldorf: ECON Taschenbuch Verlag, 1983), pp.186188; see also Lewis D. Wurgart, The Actioists. Kurt Hiller and the Politics of Action on the German Left, 1917-1933 (Philadelphia: Transactions of the American Philosophical Society, 1977). The same observations on the Berlin congress were also made by another observer from the APD - see $L$. Léontin, 'Après le Congrès de la Paix de Berlin', PD 34, 12 (Dec 1924), pp.457-458.

56 Pierre Cot, 'La Conception Française de la Lutte contre la Guerre', PD 39, 4/5 (April-May 1929), p.164.

57 Ibid., pp. 164-170. There was, of course, dissent over the nature of French pacifism even within the pages of the PD. See, for example, A. Vulliod, 'La Valeur du Pacte Kellogg-Briand', PD 39, 6 (June 1929), pp. 214-221, in which the author (a professor at the University of Nancy) argued for the moral versus the juridical approach to peace: 'A mon sens, cette constatation nous amène a reconnaître que l'oeuvre de la paix constructive est essentiellement une oeuvre pédagogique et morale. Il existe sans doute (suivant une façon de dire qui est en faveur) une technique de la paix; mais les organes de cette technique sont commandés par l'énergique volonté de paix qui se trouve actuellement vivante dans un grand nombre d'âmes, sur tous les points du globe...' (p.220). 
This conception of pacifism was clearly inimical to that increasingly espoused in the Anglo-Saxon world and by the more avant-garde German pacifists. But it was also increasingly at variance with the movement of ideas within French pacifism itself. As we shall see later in this section, the challenges of the new pacifism caused momentary cracks to appear in the paradigm of the APD's pacifisme ancien style, but by the end of the thirties the international crisis had caused the wagons to be pulled into a circle and the paradigm to be reaffirmed. What is clear however is that though the decade of the twenties represents a period of relative hegemony for the APD and its ideas within French pacifism, there were already signs that the pot was beginning to boil. Not for much longer would the struggle for the same goal suffice; the question of means and the definition of what sort of peace was being fought for gradually assumed paramount importance. 


\section{I.3. A Decade of Optimism (1919-1929).}

The decade from 1919 to 1929 was largely one of guarded optimism for the tenants of the old-style pacifism. There was no ignoring the tremendous upheaval European society had to face, but the overall picture was one of an international order which was slowly, however imperfectly, rising above anarchy to a state inspired by reason and law. There continued to be wars, but the rule of law was increasingly to be seen in action at Geneva and elsewhere. We shall examine in this section the nature of the APD's optimism, its reaction to the international developments of the twenties, and its position on the question of Franco-German rapprochement in the light of the debate over war guilt.

Underlying the events of the whole decade was the fundamental question of FrancoGerman reconciliation and all of the tangential issues which this topic conjured up. The APD was clearly in favour, in theory at least, of a fundamental reconciliation between the two former enemy nations, but it will be argued here that precious opportunities for such a reconciliation were lost because of the Association's fixation with what it in all good faith considered to be the question of justice and 'Right' in France's relations with Germany. Blinded by this conception of Right and convinced of the entire rec titude of France's cause, the APD was guilty of not providing all the support it could have done to the feeble liberal, democratic and pacifist elements within the struggling Weimar experiment.

As we have noted above, the APD believed implicitly in the rightness of France's role in the Great War, a war which had been forced upon it. The question of war origins and responsibilities is one which the review continued to comment on during the twenties. For example in a 1920 number, Ruyssen debated the question of responsibilities with Louis Guétant of the Clarté group. While recognising that the Central Powers did not bear exclusive responsibility for the conflict, Ruyssen nevertheless argued that they bore primary responsibility. 58 He continued to hold to this line the following year in a review of Les origines de la Guerre published by the Société d'Etudes Documentaires et Critiques sur la Guerre, in which while accepting that the brochure of Morhardt, Demartial, et al

58 Louis Guétant and Théodore Ruyssen, 'Les Responsabilités de la Guerre I et II', PD 30, 10 (October 1920) pp. 328-333. 
was in places 'troubling', he argued nonetheless that the Russian mobilisation was not war, and that one could not logically construe war guilt from a simple order of mobilisation.59 Commenting in 1922 on a polemic which had broken out in the German press between representatives of different strands of German pacifism on the question of war guilt, Ruyssen came round to admitting that Article 231 of the Versailles Treaty bothered him, not because it was an inaccurate representation of what he believed to be the case, but simply because Germany had been forced to 'recognise' its war guilt. 'The moral error, which is serious, is of having forced Germany to declare that it recognised that which in fact, aside from a clear-sighted minority, it had in no way recognised. In short, a lie was extracted from it. ${ }^{60}$ When Victor Margueritte published his Appel aux Consciences in 1925, Ruyssen exasperatedly attacked it for its vanity and naivety. He did not believe that the treaties could or would be revised. He did not deny that Article 231 was wrong, but argued that in that case Germany ought never to have signed the Treaty. What appeared to shock him greatly was that the Appel was signed not only by the usual names of the Société d'Etudes (Georges Demartial, Charles Gide, Gouttenoire de Toury and Mathias Morhardt), but also by more mainstream pacifists such as Victor Basch, Gaston Moch, and Marc Sangnier. In his view the continued talk of treaty revision was an unnecessary troubling of the waters:

In my opinion, it is too late, or too early to stir up these memories. Too late if one wants to return to texts legally signed and for which no procedure for revision which is at once practical and peaceful is conceivable; too early if one claims to be able to deliver a definitive judgement on Articles 227 to $231 \ldots$ It is surprising that the pacifists or ultra-pacifists who composed or signed the Appel aux Consciences do not realise the danger that their campaign is causing to the present peace; imperfect peace no doubt, unjust peace even on more than one point, but real peace, and just peace on many points of primary importance....61

As an address to German pacifists voted at the APD's annual general meeting in Poitiers in 1921 put it, the APD 'registered with great satisfaction the assurance it had received that numerous were the democrats in Germany and Austria who were resolved to execute the treaties insofar as was possible. ${ }^{62}$

59 Theodore Ruyssen, Review of Les Origines de la Guerre published by the Société d'Etudes Documentaires et Critiques sur la Guerre, in PD 31, 7 (July 1921), p.267.

60 Théodore Ruyssen, 'De quelques polémiques allemandes sur les responsabilités de la guerre', PD 32, 3 /4 (March-April 1922), p.113.

61 Thédore Ruyssen, 'Encore l'Article 231!', PD 35, 5(May 1925), p.203.

62 Edmond Duméril and Jules Prudhommeaux, 'L'Assemblée Générale de la Paix par le Droit' (Poitiers, 31 October to 1 November 1921), PD 31, 12 (December 1921), p.408. 
The equation of liberal, democratic and pacifist Germany with the worst of Wilhelmine Germany was an unfortunate and short-sighted position taken by the APD and other French and international pacifist bodies immediately after the War. It is a difficult historical judgement to make, but it seems clear in retrospect that for the future good of Europe the French pacifists ought perhaps to have 'gone the extra mile' in their first postwar contacts with the Germans. In an article in January 1919, however, Ruyssen replied negatively to the suggestion of $\mathrm{M}$ de Jong van Beek en Donk, secretary of a group called the Organisation pour une Paix Durable, that a conference of pacifists, including the Germans, should be held as soon as possible. He was not willing to forgive and forget. He wrote that 'an attempt at an entente which postulated forgetting or this abstention would be vitiated in its very principle. 63 There were certain facts which could not simply be forgotten: the invasion of Belgium, the official theory of the 'scrap of paper', submarine warfare, inhumane warfare, the destruction of civilian property, etc. 'My first act,' he wrote, 'in an assembly in which I might meet German or Austrian pacifists would be to ask them if they totally repudiate all of these acts. ${ }^{64}$ Rapprochement and reconciliation should be left for a time to allow passions to cool; the time had not yet come for it. The German pacifists, liberals and democrats had enough to contend with internally, he thought, and so did the French trying to ensure that the domestic chauvinists did not get out of hand.65

A manifesto of the Deutsche Friedensgesellschaft which came to the APD by means of an English translation, thus escaping the censor, was treated to the same rejection. The German manifesto asked that the new Germany not be treated like the old and insisted that something new was happening in the country. The APD, while claiming not to want to see unjust measures applied against the former enemy, noted that 1 . the German pacifists had never, to their knowledge, protested against the declaration of war against France, or against the invasion of Belgium; 2. that they had never protested against the 'excesses' of the German armies, or more specifically against submarine warfare; 3 . that they had only protested against certain clauses of the treaty of Brest-Litovsk; and finally, 4. that they had never, neither before nor during the war, recognised that the Alsace-Lorraine question was a valid one.66 The French attacks centred largely on Ludwig Quidde and Alfred Hermann Fried whose attitudes during and since the war were deemed by the French pacifists to have been equivocal if not duplicitous. 67

63 Théodore Ruyssen, 'Le Mouvement pacifiste. Pour et contre la reprise des relations pacifistes internationales', PD 29, 1 (January 1919), p.48.

64 Ibid.

65 Ibid., p.49.

66 'Un manifeste de la Société Allemande de la Paix', PD 29, 1 (January 1919), pp.54-56.

67 For attacks on Quidde see 'Les responsabilités de la guerre et le professeur Quidde' in $P D 29$, 1 (January 1919), p.56; for the Fried controversy, see Gaston Moch, 'Un réquisitoire nécessaire. Alfred Hermann Fried', PD 29, 4 (April 1919), pp.155-168; see also 'Le Journal de Guerre d'Alfred H. 
In these early months of 1919 it seemed that for the French pacifists no good thing could come out of Germany. Edmond Duméril acerbically attacked Mathias Erzberger as a convert of la dernière heure when the latter proposed a 'German project for the League of Nations' (the emphasis is Duméril's), and commented caustically that 'it took four years of atrocious war in order for the first project for a League of Nations to be formed in German political circles. How can one believe in the sincerity of a conversion the stages of which have been the same as those of the defeat?' 68 The Erzberger project also provided Duméril with another occasion to wax cynical over the motives behind Erzberger's July 1917 resolution in the Reichstag calling for a peace without annexations. 69

Sooner or later, however, French and German pacifists had to meet one another. The executive committee of the Bureau International de la Paix which was largely controlled by Frenchmen or Belgians, underlined to the German pacifists in late April 1919 that before any meaningful reconciliation could occur the German pacifists would have to recognise Germany's preponderant responsibility for the outbreak of the war, and also its present responsibility to ensure that full reparation was made for the ensuing damages. ${ }^{70}$ When French and German pacifists finally did meet together in Berne under the auspices of the BIP for the first time in four and a half years in late August 1919, the meeting occasioned some sharp and frank exchanges of views. A resolution proposed by Ruyssen concerning Germany's primary responsibility for the outbreak of war was however passed by the Council. ${ }^{71}$

The German pacifist camp was divided on the question of war guilt and reparations. There were those like Dr Fritz Röttcher, a principal contributor to the Völkerfriede (the organ of the German Peace Society) who argued for acceptance of the Versailles Treaty. Others, such as Fried, who directed the Friedenswarte, attacked the treaty. Fried wrote that 'I regret that the victory of democracy has not resulted in a democratic peace... the

Fried' (comprising two letters, one from Fried to Ruyssen and a response by Gaston Moch) in PD 29, 7/8 (July-August 1919), pp.312-325; a final response by Fried may be seen in Alfred H. Fried, 'Un dernier mot', PD 29, 9/10 (Sept-Oct 1919), Pp.401-402. See also Puech's negative comments on the 8th German Peace congress in J.-L. Puech, 'Le 8ème Congrès Allemand de la Paix', PD 29, 7/8 JulyAugust 1919), pp.362-364.

68 Edmond Duméril, 'L'Allemagne et la Société des Nations. Le Projet de Mathias Erzberger', PD 29, 2/3 (February - March 1919), p.65.

69 Ibid.

70 Correspondence between the BIP and the Sociéte Allemande de la Paix about the reopening of relations between international pacifism and German pacifism can be found in 'La Propagande. Le Bureau Internationale de la Paix', PD 29, 7/8 (July-August 1919), p.357-359.

71 See Ruyssen's account of this meeting in Theodore Ruyssen, 'Le renouveau du Pacifisme et le Bureau International de la Paix', PD 29, 9/10/11(Sept - Oct 1919), Pp.403-416. This meeting also discussed in broad terms the problems created for old-style pacifism by the continued disaffection of the working class, the suspicion since the war held by middle classes for pacifism, and the difficulties posed by the new doctrines of non-resistance which were especially to be felt in England. 
treaty is radically antipacifist.... ${ }^{72}$ In February 1921, the DFG over the signatures of $\mathrm{H}$. von Gerlach, Dr L Quidde and Dr H Stöcker, appealed to the BIP about the dangers for future peace posed by Versailles and especially by the reparations question. They claimed that Germany was unable to pay the reparations and that the treaties did not constitute a genuine and lasting peace, '... the decisions of the Paris conference do not guarantee peace, they compromise it. They will be the source of struggles without end. ${ }^{73}$ In the DFG's view, the treaty would have as its only result a rise in the activity of Bolshevism and extreme right-wing circles in Germany. ${ }^{74}$ Even the warnings of a German pacifist such as Hermann Fernau, respected by the APD, seem to have fallen on deaf ears. In a 1921 article published in the review, Fernau argued essentially the same case as the other German pacifists, making the point that without a peace of reconciliation founded on much mutual indulgence, the only winners would be the political reactionaries and the German communists. He accused France of resorting to the same methods and ideas as Imperial Germany in its attempts to have the treaties respected at all costs:

\begin{abstract}
Speaking too often as a conqueror to the conquered, or as a judge to the accused, threatening Germany too often with reprisals, but renouncing all the same the things which it demanded yesterday (extradition of the guilty parties, Diesel motors, milking cattle, etc), French policy not only is in contradiction with the noble promises of the French Revolution, but what is worse, is playing the game of those in Germany who are the sworn enemies of France. ${ }^{75}$
\end{abstract}

Fernau saw Germany being pushed into the arms of Bolshevism because it was being cut off from its occidental heritage. French policy was having as its only effect the discrediting of the Versailles Treaty along with nascent German democracy. He called for the creation of a dike to stop the rising tide of folly which threatened to overthrow democratic civilisation in Germany and he proclaimed that 'Franco-German rapprochement is this dike'.76

The view taken of the German revolution was also less than warm. M. L. Puech writing in 1924 said that 'There has not been a German Revolution; it has still to be accomplished.

72 Cited in 'Chronique. La révision du traité de Versailles - La Paix par le Droit et la guerre - La paix avec la Russie' (letters from A. H. Fried, A. A. Warden and Louis Guétant, with comments by Ruyssen), PD 30, 3/4 (March-A pril 1920) p.90; see also Thédore Ruyssen, 'Les pacifistes Allemands et le Traité de Versailles', PD 30, 1/2 (Jan-Feb 1920) , pp.32-38.

73 .Message adressé au Bureau International de la Paix par la Société Allemande de la Paix au sujet des décisions de la Conférence de Paris', (with response by Ruyssen), in PD 31, 3/4 (MarchApril 1921), p.119.

74 Ibid.

75 Hermann Fernau, 'De la nécessité d'un rapprochement Franco-Allemand', PD 31, 2 (Feb. 1921), p.55.

76 Ibid., p.57. 
Even more, a large part of the [German] nation does not even hate its republic, it is ashamed of it'.77 This, she said, was in contrast to the French revolution which 'glorified the victory of the French people over a régime and a caste'. ${ }^{78}$

Thus, to recapitulate the argument so far, the first few years of the interwar period were ones of intransigence for the men of the APD vis-à-vis Germany. This intransigence expressed itself not only with regard to the political nation, but also unfortunately in equal measure with regard to those very elements in Germany which were trying to create something new out of the defeat. The APD, at least until 1922, failed to take note of these attempts and of the danger to be incurred in not supporting them wholeheartedly. The APD's shortsightedness can perhaps be forgiven; the hatred engendered by a disaster of the magnitude of the Great War must surely take years to die down. Jules Puech writing in 1920 said that three options were open to French pacifists: one was to have nothing whatsoever to do with the former enemy; the second was to rush at the Germans with arms open in reconciliation; and the third was to have as little as possible to do with them, while letting time take its healing course. It was the latter he recommended. 'That is all; I shall not suddenly, on command, love en bloc a people whom I regret not having better killed when I was a soldier...:.$^{79}$

1922 seemed to be a watershed year in terms of the APD's, or at least Ruyssen's, views on rapprochement with Germany. It also marked the return of a healthy scepticism about French government policy towards the former enemy. Ruyssen participated in 1922 in the first post-war visit to Germany by an offical delegation of the Ligue des Droits de l'Homme. The group visited Berlin, Essen, Dortmund and Bochum, speaking before bourgeois and working-class audiences. Generally they were very well received and Ruyssen came back with some favourable impressions. Frenchmen living in Germany believed that Germany had disarmed almost to the zero point, and Ruyssen seemed convinced that German youth was searching for new paths and was in no way reactionary. For all that, the economic difficulties spelled trouble for the Weimar Republic, and he reckoned that ninety per cent of Germans did not accept the war guilt clause, and even amongst those that did there was great doubt about Germany's ability to pay its reparations. All of this led to a net impression of pessimism for Ruyssen. Perhaps as a result of this pessimism, the voyage to Germany seemed to produce a sort of 'road to Damascus' experience in him. He continued to affirm Germany's guilt, but blamed France for not being more indulgent and farsighted in its treatment of its neighbour, a position in

77 M.-L. Puech, 'De l'Allemagne', PD 34, 9(Sept 1924), p.333.

78 Ibid.

79 Jules-L. Puech, 'Chronique - La Paix avec l'Allemagne', PD 30, 1/2 (Jan-Feb 1920), p.27. 
sharp contrast to the polemics in which he had previously engaged with German pacifists over the question of reparations for example:

...our country, hated but secretly admired, could conduct a magnificent campaign of clarity and conciliation (in Germany), if we finally practised with regard to our vanquished neighbour a policy different from the detestable methods which we have abused for four years... while England tries clearly to deal gently with Germany, we continue to talk of 'sanctions' which could very well mean a new occupation should Germany fail to fulfill its latest promises. That these measures are justified by Germany's failure to keep a good number of promises, one can easily agree. But what is certain is that they have ulcerated the German people to the core without it having any idea of the sacrifices we have consented to on our side... What does it profit us to be right in the essence of our demands, if we succeed neither in forcing Germany to pay, nor in reconciling her to us $?^{80}$

By 1923 and the Ruhr Crisis, the APD was thus far less dogmatic in its support of French policy and condemnation of Germany. The Ruhr occupation and the larger question of reparations payments which it represented became the focus of criticism on the part of the APD. At the Association's annual general meeting in Nantes in February 1923, the Ruhr question was debated. Ruyssen both condemned the occupation and upheld the principle of reparations at one and the same time:

...Germany rises up against this occupation; we must bring German opinion round to the belief that the present situation is all the same motivated by its attitude. The task is a difficult one certainly. Will one succeed by the means currently being used? Ruyssen does not think so. 81 .

The Assembly adopted a resolution which, while noting that the French interpretation of the Treaty was correct, conceded that the French view was not shared by many former allies, nor by the Germans. Consequently, it asked that this interpretation be submitted to

80 Théodore Ruyssen, 'La Ligue Française des Droits de l'Homme en Allemagne', PD 32, 7/8 (July-Aug 1922), pp.286 and 291; Théodore Ruyssen, 'Pour le rapprochement Franco-Allemand: La Ligue des Droits de l'Homme et le Bund Neues Vaterland', PD 32, 2 (Feb 1922), pp.90-91 describes the visit of a delegation from the Bund Neues Vaterland comprised of von Gerlach, Nicolai, and Lehmann-Russbuldt to Paris.

81 Ruyssen cited in Jules L. Puech, 'Assemblée Générale de la Paix par le Droit, Nantes, 10 et 11 Février 1923', PD 33, 4 (April 1923), p. 142; the Executive committee of the APD had already condemned methods of coercion and military occupation in anticipation of the Ruhr occupation at its meeting on 18 December 1922, as inefficacious, upsetting to French allies, and damaging to the work of German democrats. The committee continued to affirm nevertheless the rectitude of France's claims to reparations, and asked the French government to seek redress through the League of Nations, and a restructuring of the world economic situation. See: 'La Politique Internationale. Deux ordres du jour sur les réparations: la Paix par le Droit et la Ligue de la République', PD 33, 1 (January 1923), Pp.29-31. 
the International Court of Justice for arbitration. On the heart of the matter - reparations the Assembly agreed that the methods used up until 1923 had been largely sterile in their success in getting the Germans to pay up, and that the Ruhr occupation was costing more than it was bringing in. The assembly demanded that the Allies give up these ineffective methods which were only leading to the danger of renewed war, and that the problem be submitted to the League for resolution along the lines of its work in Austria and Upper Silesia. ${ }^{82}$ Jules Prudhommeaux, writing in March 1923, was even more pessimistic about the effects of the Ruhr occupation. He attacked the popular press for brazenly misrepresenting the state of French public opinion; there was no unity behind the Government's action in the Ruhr.

The labouring masses in their rough common sense have understood since the first day of the military intervention which at the present hour is developing over there like the unstoppable flood let loose by the sorceror's apprentice, that it would not fail to be economically useless, politically dangerous and morally discredited. ${ }^{83}$

Far from being a popular move, Prudhommeaux saw nothing but negative results flowing out of the Ruhr decision: re-institution of censorship on news coming out of the Ruhr basin, France divided against itself to the point were civil war was spoken of, and international opinion turned completely against it. He called for pacifists of all nations to join together in a united front and to avoid sterile polemics with one another over the French action. 84

The two events of the 1920s which mark the apogee of the APD's burgeoning optimistic faith in the new order created at Versailles were undoubtedly the Locarno Pact of 1925 and the Kellogg-Briand Pact of 1928. Prudhommeaux, writing in the October 1925 number of the $P D$, declared that the Locarno accords opened the way towards the realisation of the dream of a United States of Europe held by Mazzini and Victor Hugo. Locarno also restored France to its proper, generous place in the European constellation: 'France regains its real face before the world, and Germany, which will be forever honoured in the annals of history for having taken the initiative in its memorandum of 9 February 1925, enters at last into this society of nations where, as Vandenilde said, "there are no more enemies, where there are no more conquerors, nor conquered, but only peoples united under the sign of equality".85 The APD congratulated Briand on a pact which 'opened a new era in the

82 Ibid., pp.143-44.

83 J. Prudhommeaux, 'Le problème des réparations et le pacifisme international', $P D$ 33, 3 (March 1923), p.119.

84 Ibid., p.122.

85 Jules Prudhommeaux, 'Le Pacte Rhénan et la Conférence de Locarno', PD 35, 10 (Oct 1925), p.387. 
relations between France and Germany'. .6 Indeed, Prudhommeaux went so far in his article as to suggest that in return for the generous gesture of the Germans in agreeing to guarantee the Franco-German frontier, the French might consider doing something about the 'unfortunate' article 231 of the Versailles Treaty. 87 Another commentator, writing the following month in the $P D$, stressed the 'capital fact' that the Locarno agreement had transformed 'into a state of law, juridically established and modifiable only by legal procedure, the pure state of fact (état de fait) which the European statute of 1919 cons tituted with regard to Germany'. 88 Locarno was a victory of 'common sense, of international order, of peace founded on the organised forces of justice; a victory, consequently, of Republican France. 89

The Kellogg-Briand Pact produced another élan of optimism in 1928, despite the reserves which Pierre Cot was to express about the conception of peace embodied in it, as we have seen above. Prudhommeaux noted with satisfaction that the Pact had as its consequence the creation of a solidarity between old world and new for the maintenance of universal peace and that it brought the United States in from the cold.90 Georges Scelle wrote that the pact had a juridical importance, and perhaps even more a political and psychological value. But its potential impact lay in the ability of public opinion to support it:

The Kellogg Pact is a new step on the path of war against war. It is certainly not the last. It depends on public opinion and on the development of democratic institutions that the stages which remain to be achieved be crossed more or less rapidly. Or better said, it depends individually on the will of each one of us to hasten the advent of peace. It is entirely a question of civic and moral education. ${ }^{91}$

The APD was not immune from the highly individualistic conclusions drawn by many pacifists as a consequence of the Kellogg-Briand Pact. Francis Delaisi, in a report on the 'Internal Guarantees for Peace as a Consequence of the Kellogg Pact', suggested that pacifists ought not to count upon Parliament which was 'domesticated and abused' to ensure that war remained a crime. Instead he recommended that people attach themselves with

86 Telegram cited in ibid.

87 Ibid., p.386,

88 Edmond Laskine, 'La victoire de Locarno', PD 35, 11 (Nov 1925), p.431.

89 Ibid., p.433.

90 J. Prudhommeaux, 'La Politique Internationale et la SDN. La mise hors la loi de la guerre. L'accord est fait', $P D$ 38, 7/8 (July-Aug 1928), pp.317.

91 Georges Scelle, 'Le Pacte Kellogg (fin)', PD 38, 10 (Oct 1928), p.441. For the first part of this article see PD 38, 9 (Sept 1928), Pp.356-365.

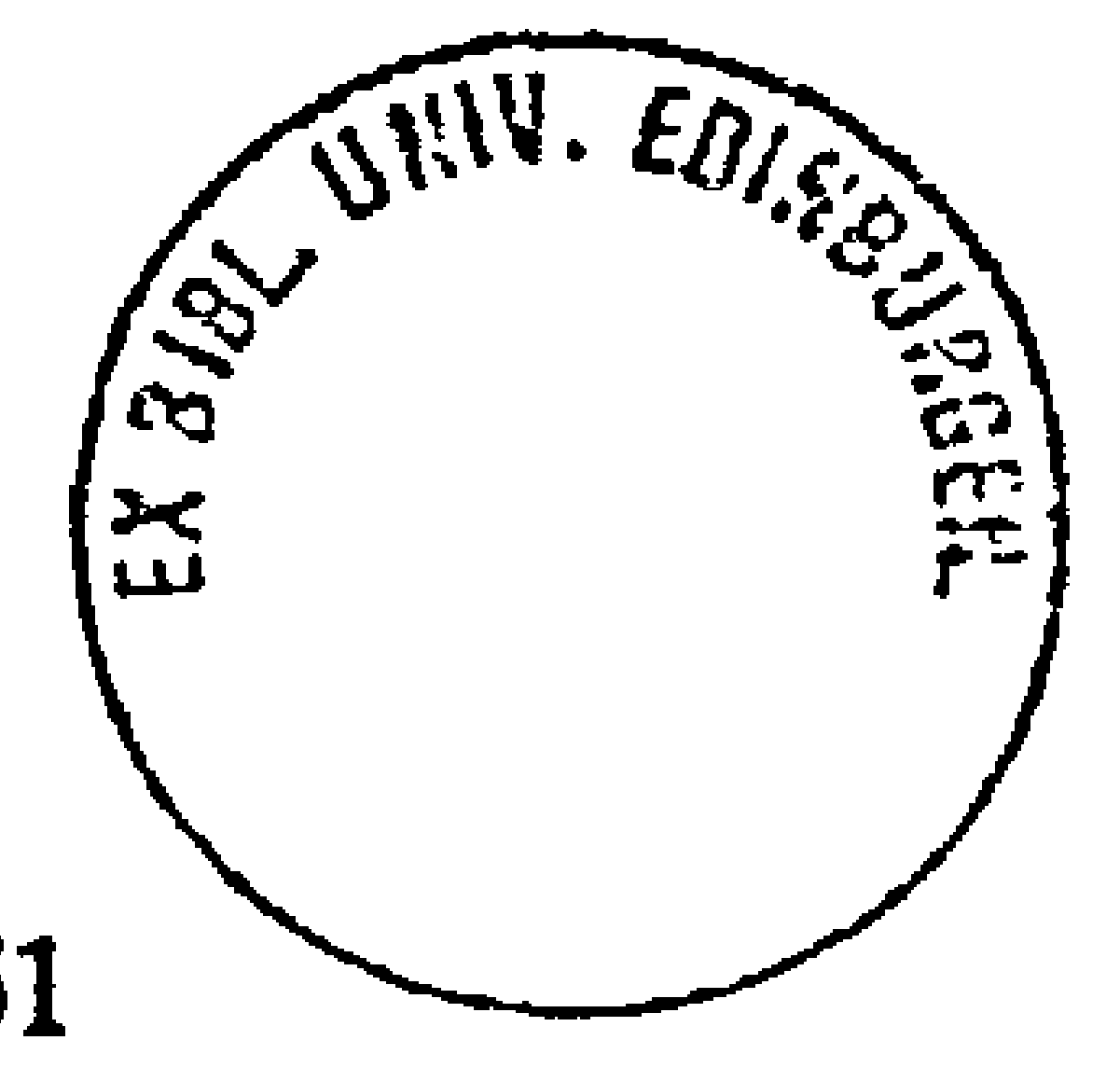


all their strength to the Kellogg Pact in order to oblige governments to take it seriously. And taking this argument to its logical conclusion, Delaisi prọclaimed:

Between my mobilisation papers which tell me to march off to battle with my eyes closed, and the Kellogg Pact which makes war a crime, I choose the Pact - and I also choose the League of Nations. It is it and it only which has the authority to designate the violator of the Pact, the aggressor. If, as such, it denounces my country, I shall abstain from taking arms... The governments thought they were signing a 'scrap of paper': we take them at their word, and we hide behind their signature. We, too, are for conscientious objection, but we transport it from the religious sphere to the juridical. 92

The Kellogg-Briand Pact, by creating what appeared to be a supra-national juridical court of last resort in the case against war, sparked off the pacifisme nouveau style which will be dealt with in Part II of this thesis.

A reaction more in keeping with the APD's usual rather conservative approach to peace was that of Georges Scelle in a report and resolution he presented to the 1928 annual general meeting on how to bring the French constitution into line with the Kellogg Pact and the prescriptions of the League. Scelle's motion, adopted unanimously by the assembly, envisaged the amendment of articles eight and nine of the 1875 constitution such that all future treaties would have to be ratified by the Chamber and the texts deposited with the League, and that any declaration of war would have to be in conformity with the prescriptions of the Kellogg Pact and the Covenant of the League of Nations. ${ }^{93}$

The Kellogg-Briand pact marked in many ways the high-point of the interwar period for French pacifists. In 1928 it seemed as if the international order created at Versailles was finally beginning to function properly. Locarno had shown a new Germany prepared to live in peace with a new France. The legacy of Briand and Stresemann, together with the new-found interest of the United States in the affairs of Europe, augured well for the future. Another five years would pass before it became impossible to ignore the hairline cracks growing and lengthening in the plaster of European peace. In the intervening time the elusive goal of a comprehensive disarmament agreement would dance tantalizingly, but forever out of reach, before French pacifist eyes. But that is to leap ahead somewhat.

92 From Francis Delaisi's report, 'Les Garanties intérieures de la Paix, conséquence du Pacte Kellogg' in J. Prudommeaux, 'L'assemblée Générale de la Paix par le Droit, Bordeaux, 2 et 3 Novembre 1929', in PD, 39, 12 (December 1929), p.458.

93 See the report and resolution of Georges Scelle 'Pourquoi doit-on et comment peut-on mettre la constitution française en accord avec le Pacte Briand-Kellogg et les prescriptions de la Société des nations?', in Jules Prudhommeaux, 'L'Assemblée Générale de Nancy (suite)', PD 39, 1 (January 1929), Pp.7-11. 
Before concluding this examination of the first decade of the interwar period, however, we shall briefly look at the practical measures for peace employed by the APD. In its official publications, the APD listed its means of action as 1 . the organisation of public or private lectures; 2. the creation of local or regional groups for propaganda and discussion; 3. the publication of brochures, tracts and other works destined for propaganda; 4 . the publication of the review La Paix par le Droit and the more popular bulletin Les Peuples Unis alone or in conjunction with other societies; 5. encouraging the composition of works, through competition or otherwise, in connection with its programme; 6. maintaining relations with other groups in France or abroad which were interested in the same goals. ${ }^{94}$ This rather general list of the association's activities makes clear the largely educative and platonic nature of much of the APD's work. This is not to deny its usefulness, merely to point out the obvious, namely that propaganda of this type is very difficult to assess in terms of its efficacy. We are dealing here yet again with the unquantifiable imponderables of recent history. There is no doubt that such activity was of some use in that it contributed towards the creation of a climate of ideas, which by their nature were often very slow in coming to fruition. But come to fruition they did. Many of the ideas and principles of the APD took shape in the interwar years in Geneva; indeed the very idea of Geneva and the League could be said to epitomise the goals of the Association. In the dark hours of 1938, Ruyssen was to look back to an autumn day in 1922 when he and Prudhommeaux stood on the steps of the Salle de la Reformation in Geneva which served as the provisional seat of the League of Nations Assembly. The Comte Clauzel, then Secretary-General of the Ministère des Affaires Etrangères, emerging from the hall, noticed Ruyssen and Prudhommeaux and cried, 'There are the forefathers of the League of Nations'.95

The APD's primary method of propaganda after the publication of its two organs was probably the public lecture. These varied in topic and number from year to year but they were a constant of the Association's activity during the interwar period. In 1928 for example some fifty public lectures were given by members of the APD. 96

Another important aspect of the association's work was its attempt to reach French and European youth with the pacifist message. One of the ways this was done was the publication each year of a brochure entitled La Jeunesse et lia Paix du Monde which was given away to targeted groups around the world. In 1933 the brochure had a French print-

94 See 'Association de la Paix par le Droit' in Nous voulons la Paix, loc cit.

95 Cited in Theodore Ruyssen, 'la Paix par le Droit. Rapport - Documents de l'Assemblée Générale et du Congrès du Cinquantenaire', PD 48, 6/7/8 (May-June-July 1938), p.268.

96 J. Prudhommeaux, 'L'Assemblée Générale de Nancy', PD 39, 1 (Jan 1929), p.4. 
run of 108,000 copies and a further print-run of about 250,000 copies in Dutch, Polish, English, Welsh, Esperanto, Chinese and Malaysian. 97

With many of the members of the APD belonging to the teaching profession at all levels, it is not surprising to find a strong interest in the pedagogy of peace within the association. Throughout the interwar period members of the APD participated in commissions and international conferences on the problems of peace education. There was also much interest in the task of monitoring both French and German school history texts in an attempt to have the bellicist examples removed from school curricula. 98

During the 1928 election campaign members of the APD were encouraged to present motions to election rallies for approval. The 1927 annual general meeting of the association proposed three types of motion: one in favour of the League of Nations in which electoral candidates pledged to work towards an increase in the League's authority, the provision of means whereby the League could effectively fulfill its peace-making role, and the engagement to submit, without exception, all conflicts in which France might find herself to the arbitration of the League. A second motion asked candidates and electoral meetings to vote in favour of continued efforts for 'gradual disarmament'. Finally, a third resolution called for the establishment of 'economic peace' through the lowering of tariff barriers and the creation of a European customs union. 99 Electoral candidates were also to be sent a

97 Cited in Jules Prudhommeaux, 'Notre Assemblée Générale, Paris, 30 et 31 Decembre 1933', PD 44, 2 (February 1934), p.54.

98 For more detailed examinations of this aspect of the association's propaganda which we unfortunately do not have the space to deal with here, please see: Roger Lévy, 'Société des Nations et Coopération Intellectuelle depuis dix ans', PD 40, 6 (June 1930), pp. 218-225; Dr Siegfried Kawerau, 'Les Livres d'Histoire en Allemagne, notamment depuis 1923', PD 37, 3 (March 1926), pp.104-111; Dr. Siegfried Kawerau, 'Où en est l'Allemagne dans l'amélioration de ses Livres d'Histoire?', PD 41, 10 (October 1931), pp.449-452; J. Hadamard, 'Un Nouveau pas à faire dans la Voie de la Paix. Les Manuels Scolaires', PD 40, 1 (January 1930), pp.1-4; Jules Prudhommeaux, 'La Paix par l'Education, l'Histoire a l'Ecole', PD 35, 2 (February 1925), pp.61-68 and 35, 3 (March 1925), pp.99-107; Jules Prudhommeaux, 'Pour la Paix par l'Ecole', PD 38, 7/8 (July-August 1928), pp.293-306; PD, 38, 9 (September 1928), pP.366-375; and PD 38, 10 (October 1928), pp.419-431. On the work of the Comite d'Entente des Associations Françaises pour la Paix par l'Education of which C. Bougle was the president, see the reports on its five national conferences which Ruyssen and Prudhommeaux participated in: PD 41, 3 (March 1931), pp.129-161; PD 42, 5 (May 1932), pp.201-236; PD 43, 4/5 (AprilMay 1933), Pp.125-152; PD 44, 4/5 (A pril-May 1934), pp.145-176; PD 45, 3 (March 1935), pp.116-134 and $P D$ 45, 4 (April 1935), Pp.172-192. On the two international conferences on the teaching of history, see Georges Lapierre, 'La Conférence Internationale pour l'Enseignement de l'Histoire', PD 42, 7/8 (JulyAugust 1932), pp.346-349 and Charles Rousseau and J. Prudhommeaux, 'La Ilème Conférence Internationale pour l'Enseignement de l'Histoire', PD 44, 10 (October 1934), pp.399-400. Finally, for a very thorough set of observations on French and German school history texts which covers the period from the French Revolution onwards and is a rare example of collaboration with Nazi scholars, see 'Les Manuels d'Histoire Allemands et Français. Résolutions adoptées par la commission d'Historiens Allemands et Français, réunis du 25 Novembre au 1er Décembre 1935, pour examen des rectifications qu'il y aurait lieu d'apporter aux Manuels Scolaires des deux Pays', PD 47, 6 June 1937), pp.209-217 and 47, 7 (July 1937), pp.257-271.

99 See Jules Prudhommeaux et J.-L. Puech, 'L'Assemblée Générale et les Fêtes du XLème Anniversiare' (Nîmes, 30-31 October and 1 November 1927), PD 37, 12 (December 1927), PP. 448-449 and 464-465. 
questionnaire asking them if they accepted the APD's programme of support for the League and whether they were a convinced supporter of it. The questionnaire had already been used with some success in the election campaign of 1924.100

The final and perhaps most important aspect of the ADP's external propaganda during the interwar period was its commitment to the idea of Summer Schools in different parts of France and indeed elsewhere in Europe. Taking 1932 as an example, the Association ran Colonies Internationales de Vacances at Saint-Claude, Boulogne-sur-Mer, and for the fifth time at Thonon in the Jura. Sixty-two young girls took part in the summer school at Thonon, down from about 130 in 1930. Additionally, the association's president, Ruyssen, led for many years a course in Geneva sponsored by the Union International des Associations pour la Société des Nations. This course - which became known as the cours Ruyssen - involved 272 students in 1930, of whom 80, including seventeen boursiers, came from France through the good offices of the APD. Numbers began to fall later in the thirties, but the figures given provide some indication of the size and range of these summer schools at which several members of the APD were active contributors. 101

Thus, the APD's position towards the end of the 1920 s can be qualified as one of growing optimism in a new international order which the association believed was partially inspired by its own ideas. The distrust for Germany and especially for German pacifists began to wane by about the time of the Ruhr crisis and diminished further with the signing of the Locarno accords. The Kellogg-Briand Pact capped a decade of achievement for pacifists and internationalists and the future began to look brighter than it had for some time. During this first decade under discussion there was little to challenge the APD's vision of the world and the pacifist's place in it. Germany was clearly wrong, French bellicists were clearly not helping the situation, and after 1925 it was equally clear that international anarchy was gradually being set aside. The fragile edifice was not to stand for long however. Later sections will examine how cracks began to appear in the APD's own vision of what constituted pacifism, as well as in the paradigm of international relations upon which this view was based. But first let us briefly examine the APD's conception of and connection with French political society.

100 Ibid., p.448.

101 See Jules Prudhommeaux, 'Notre Assemblée Générale', PD 44, 2 (February 1934), p.55; see also J. Prudhommeaux, 'L'Assemblée Générale de Boulogne-sur-Mer', PD 41, 1 (January 1931), p.25. The numbers of students attending the international summer school in Geneva had fallen by 1933 to 129 students, albeit from 18 different countries. Madame Prudhommeaux organised the Thonon school and in Geneva Mlle Angles, Mme Thibert, Jacques Dumas, André D. Tolédano, Ruyssen and Prudhommeaux took part. 


\subsection{The APD and French Political Society}

The extent to which the APD upheld in general terms the French case regarding the origins of the War has already been noted, and the way in which this attitude created a barrier initially between them and the pacifist, democratic elements in Germany to which they were naturally attached. The Association quickly regained its critical sense especially following the Ruhr debacle which really marked the definitive rupture with post-war French policy. As Puech pointed out, too, the Association had never allowed its organs to become instruments for the 'bourrage de crânes ' of the war years. ${ }^{102}$ The APD was composed of the best of the liberal, democratic, pacifist, radical elements of Third Republic France. In this brief section we shall examine how the APD saw French political society in the interwar period, and the extent to which it, too, was infected, albeit mildly, with some of the same prejudices as other political groupings in France.

The extent of the APD's anti-German and by extension, pro-French stance during and immediately following the Great War has been noted already. This national hubris extended into the first years of the interwar period as well. For example, in late 1918 a writer in the $P D$ was referring to France's 'mission as the moral prep school teacher of the world' in connection with the formation of the League of Nations. ${ }^{103}$ When it came time to choose an official language for the new League, Alphonse Aulard, in a report on behalf of the Association Française pour la Société des Nations could think of none better than French. He noted that

French has been used up until now in diplomatics as the language of clarity; [Frenchmen] like this custom and this privilege; they are proud of it, they are attached to it as to an adornment of the national patrimony, they do not wish to let the friendship of the peoples forget this secular honour rendered to the language of a nation which is today the victorious champion of humanity.

But if they desire that the future League of Nations should adopt the language of the Rights of Man for speaking to the world, it is

102 See note 44 above.

103 Comment in 'Pour la Société des Nations', PD 17/18/19/20 (September-October 1918), p.298. 
not national pride which motivates them, it is the sentiment of the common good... 104

Before the war had ended, Aulard had also claimed the very idea of a League of Nations as France's. Even a German such as Immanuel Kant became a sort of 'honorary Frenchman' in Aulard's account of the French origins of the League idea:

It was a foreigner, Immanuel Kant, one of the purest disciples of the French Revolution, who most clearly expressed, in terms that were almost French, the idea of a League of Nations in 1795 in his Essay on Perpetual Peace. It is the compatriots of Kant who are today the enemies of a League of Nations, the enemies of the law of peoples, the enemies of the French Revolution. 105

Pride in the French Revolution and republicanism not surprisingly did not extend at all to Napoleon whom Puech called in 1921 on the occasion of the centenary of his death, ' at least as odious as...Wilhelm II'. Puech and the APD were thoroughly republican, but staunchly anti-Bonapartist, and they found the projected ceremonies commemorating Napoleon offensive. The latter's militarism was the negation of everything the good bourgeois republicans of the APD stood for. As René Viviani reminded his audience in a speech in honour of Léon Bourgois cited by Puech, 'the French government has always had, except under the Empire, the cult of Law'.106

But it is to Charles Richet that one must turn for the clearest expression of the duality of old-style pacifism and a sort of cultural or spiritual patriotic imperialism. In a speech delivered at the 1924 Banquet de la Paix, Richet defined his pacifism as one in the long line of illustrious French pacifist writers: Rabelais, Montaigne, La Bruyère, Bossuet, Fénelon, Montesquieu, Voltaire, Lamartine, Victor Hugo and Pasteur. These 'ardent pacifists' incarnated the French pacifist tradition and he threw their names back at those who claimed that he and his colleagues were somehow disloyal to the nation's cultural and political heritage. Waxing lyrical about the French soul and attacking those on the Right who dared to arrogate the Nation to themselves, Richet said

The French soul, infatuated with justice, ideals and pity, is by its very nature, profoundly pacifist. And yet there are energumens, friends of the war and of wars, who dare to entitle their newspaper 'L'Action française'. But we are French action. It is we who are

104 Extract from a report made by A. Aulard to the Association française pour la Societé des Nations cited in 'La langue de la Société des Nations', PD 29, 4 (April 1919), p.192.

105 A. Aulard, 'La Société des Nations et la Révolution française', PD 28, 17/18/19/20 (September-October 1918), p.278.

106 Jules-L. Puech, 'Le centenaire de Napoléon', PD 31, 3/4 (March-A pril 1921), p.110. 
loyal to the French tradition, and in spite of their blasphemies, we shall continue. ${ }^{107}$

Richet went much further, however, in defining his country a priori as an intrinsically pacifist nation in a 1932 article on the 'true face of France'. He was responding to a wave of anti-French feeling in the foreign press, articles provoked no doubt by 'some instinctive jealousy' and which claimed that France was the obstacle to general happiness, a country given over to militarism, imperialism, and hoarding gold in its banks while the rest of the world suffered the effects of the Depression. Richet rejected all of these arguments, claiming that France was the most pacific of nations. Neither peasants, nor workers, nor bourgeois suffered in the slightest from militarism. France had no desire to rule the world, and as for the economic argument, Richet dismissed it by saying that France was still in economic ruins from the effects of the war. He insisted that 'it is evident that there is only one face to France: there are not two Frances, as there are most certainly two Germanys: a generous Germany and a bellicose and hateful Germany'. ${ }^{108}$

Richet's obviously ill-thought-out argument, if it was even that, was challenged by one reader who insisted that the APD had to see its country as it was, without entirely condemning it. France's policies of imperialism and political hegemony in Europe were the result of specific situations but there was no point, according to Robert des Rotours, in denying that they were there. As to the idea that France presented only one face to the world, this was patently absurd given the fundamental opposition of groups like the Action Française and the nationalist leagues both to the democratic nature of France and to its foreign policies. ${ }^{109}$ Richet's rather bizarre response to this was to dig his hole even deeper and argue that 'even those with whom I hardly share an opinion, whether it be M Coty, M Laval or $M$ Tardieu, have no dearer idea than that of peace' ${ }^{110}$

These rather inconsequential articles, written by the Honorary President of the APD are useful, not for their intellectual content and analysis of pacifism's place in French society, of which they contain little, but rather as conduits for a largely indefinable and latent chauvinism on the part of some representatives of old-style pacifism.

107 Charles Richet, 'Soyens tous les Enfants de la Paix', PD 34, 3 (March 1924), p.107. This is the text of Richet's speech to the annual Banquet de la Paix held in Paris on 22 February 1924. The Banquets de la Paix were an event organised by Lucien Le Foyer and which brought together the leading figures of French political life and old-style pacifism.

108 Charles Richet, 'La vraie figure de la France', $P D$ 42, 7/8 (July -August 1932), p.323.

109 Robert des Rotours, 'Sur la "VraikFigure de la France"', PD 43, 2 (February 1933), pp.58-61.

110 Charles Richet, 'La vraie figure de la France', PD 43, 3 (March 1933), p.97. 
Paradoxically, they exist in a review which also published several short pieces announcing the dangers of nascent French fascism. ${ }^{111}$

111 Prudhommeaux announced the arrival of fascism in France in 'A propos du Fascisme français', PD 35, 12 (December 1925), pp.486-489. The following year he commented briefly on the neo-pacifism of Drieu's Jeune Droite in PD 36, 2 (February 1926), Pp.89-90. 


\section{I.5. Cracks in the Paradigm (1928-1933).}

Modris Eksteins has commented on the approximate ten-year time lag between the end of the Great War and the explosion of war literature describing the event. 112 The same slow process of internalisation and subsequent expression can be seen in the development of pacifist ideas in France in the interwar period. Preceding sections have shown how, despite the impression of some tenants of the old-style pacifism that it had changed, the principles espoused by the APD remained relatively constant during the first decade of the interwar years. The APD and its ideas retained the vestiges of their pre-war hegemony in French pacifism at least until 1928 when the approach to the question of peace began noticeably to change as more radical, integral methods of tackling the problem arose. It is not the purpose of this chapter to examine in a systematic way the content of the pacifisme nouveau style which began to appear in significant form from about 1928 onwards - that will be left to Part II of this thesis - but what will be discussed here is the extent to which these questions of methods, principles and goals were discussed within the confines of oldstyle pacifism. Finally, in addition to examining the changing nature of pacifism within the APD, the changes in the international situation will be examined insofar as they impinged upon the world of growing optimism inhabited by the liberal, bourgeois pacifists.

Probably the most important development in the five-year period under discussion here was the 'individualisation' of pacifism. We have noted in preceding chapters of this section that from almost its earliest days the APD was much concerned to avoid 'negative' approaches to peace such as conscientious objection, and instead to concentrate on the development of 'positive' measures for peace, primarily through juridical and educational means. The essential point was that the conquest of peace was a social goal, pursued collectively and not individually as such. The first crack therefore in the paradigm of peace practised by the APD and the old-style pacifists was the increasing attempt after 1928 to make peace a question requiring a response purely on the individual level. In most cases this meant conscientious objection.

112 Modris Eksteins, 'All Quiet on the Western Front and the Fate of a War', Journal of Contemporary History 15, 2 (1980), p.345. 
Of all the pacifist doctrines developed in the interwar period, conscientious objection was probably the 'least French'. As a concept it originated in the Anglo-Saxon world and although it did have its adherents in France, it never became a widely recognised method of resistance to war. The French pacifist preference was always for the creation of large movements (which paradoxically they rarely achieved) with an emphasis on the collective conquest of peace. Nevertheless, it is true to say that conscientious objection did occupy the French mind (and certainly its government) for much of the interwar period. As Ruyssen noted in 1926, the French had been impressed to see that even with the Great War in full swing, the British authorities had not hesitated to admit cases of conscientious objection, and so from a position of intransigent refusal, French opinion was gradually evolving to the point where people were asking 'Why not?'.113 Ruyssen argued for acceptance of objection if it could reasonably be proved that the person in question was sincere in his beliefs and willing to accept a longer, harder, and perhaps personally more dangerous service in place of his military duties. The bottom line for the APD seems to have been to ensure that social duties were performed. Discussing the differences between the Anglo-Saxon and the French, essentially Latin, approach to conscientious objection, Ruyssen wrote that the former sprang 'from a moral and religious individualism' and that its greatest obstacle in France was quite simply that 'the average Frenchman is not tolerant'.114 This together with the nation's long tradition of Catholicism and authoritarian centralism combined to make the acceptance of objection very difficult. Interestingly, Ruyssen recognised that the root of the problem might well be the idea of the 'nation in arms' which constituted a strong and established revolutionary tradition in France. As an indication of Ruyssen's essential conservatism and cautious conformism, he did not however see conscientious objection as a legitimate means of lessening this militaristic hold over the nation's soul. 115

The APD considered the question of conscientious objection for the first time in the postwar period at its annual general meeting in Paris in late December 1925. Paul Allégret, the director of the Ecole de Droit de Limoges, presented the main report on the subject to the assembly along with some ideas about how to resolve the issue to the contentment of all concerned. He gave an historical overview of the question, going back to the 1904 Congrès National de Nimes, at which he had also been charged with presenting a report and motion on the same subject. His main concern then, as now, had been to ensure that there was no 'attack on patriotic sentiment, nor on the dignity of the law, but only the

113 Théodore Ruyssen, 'L'Objection de Conscience', PD 36, 9/10 (September-October 1926), p.331. See also Ruyssen, 'L'Idolâtrie Patriotique', PD 35, 1 (January 1925), pp1-4, in which he likened the plight of COs to that of the Huguenots who went into voluntary exile under Louis XIV.

114 Ibid., p. 332 .

115 Ibid., pp.333-337. 
manifestation of sympathy for those who are guilty only of interpreting to the letter the maxim "Thou shalt not kill". 116 The question of conscientious objection had also been on the agenda of the Congrès Universel pour la Paix held in Paris in September 1925. The Ligue pour la reconnaissance légale de l'Objection de conscience had presented a motion in favour of it, and in the commission charged with preparing a resolution on disarmament, Georges Pioch had managed to have a motion adopted in favour of the abolition of obligatory military service, and the acceptance as an interim measure of the right of objection. When it came time for the full congress to vote on the resolution, however, it was defeated by a vote of 193 to 144 in favour of a substitute resolution proposed by Ferdinand Buisson. 117 With this as a backdrop, Allegret argued in favour of accepting conscientious objection but with severe conditions attached: he could not support a motion such as Pioch's which he thought anarchic. Even the proposal that CO's should serve a period of duty one-third longer than ordinary conscripts appeared too easy to him, too much a temptation for cowards. Instead, he proposed that conscientious objection be recognised on condition that the objectors perform their duties in times of peace either abroad in the colonies, or else in very dangerous work such as the care of people in infectious disease wards of hospitals. In time of war, the objectors would be used as stretcher-bearers in the most dangerous part of the line, in the forward trenches and between the barbed wire in No-Man's Land. Only thus could the state ensure that objection did not become the easy way out for cowards.118 Anticipating the conclusion which many pacifists would draw from the Kellogg-Briand Pact by some three years, Allégret proceeded to add a further distinction to his argument. He believed that there were many young men who were prepared to fight if the cause were just, but who categorically refused to shed their blood in a war of colonial conquest or continental aggression. The concept of a just war was thus of paramount importance. But how to define such a war? The Geneva Protocol of 1924 had declared that all wars of aggression were crimes. Allégret saw this as the first manifestation of the new international republic which the members of the APD had been striving for. It was therefore up to the League of Nations in all future conflicts to pronounce on the rightness of any war. This put the convinced pacifist in the position of having potentially to choose between his minister of War and the League. There was only one choice possible, the League.

It is the lesser evil which must be chosen, and the lesser evil is that of not allowing oneself to become an accomplice of an

116 Paul Allégret, 'Le Devoir Militaire, et le Scrupule de Conscience. Avant et après la Grande Guerre - Une solution. Rapport présenté à l'Assemblée Générale de la "Paix par le Droit"', PD 36, 4 (April 1926), pp.145-146.

117 Ibid., pp.149-153.

118 Ibid., pp.155-156. 
aggressor, it is opposing injustice. One can say that this is a defeatist and antipatriotic teaching. I respond: is it not in reality really defending one's country? Do we conceive it, do we wish it to be anything but an instrument and a force for justice? ${ }^{119}$

At the 1925 AGM Pierre Cérésole, the Swiss engineer behind the creation of the International Civilian Service which sought to send young men to disaster-stricken areas of Europe in a non-military form of active service to society, spoke to the Allégret report. He optimistically foresaw the day when by their sheer number the example of conscientious objectors would have a pacifying effect on the world. The question of objection thus assumed not merely an individual importance, but also a social, collective value in the fight against war. This idea, already present in French pacifism in the mid-twenties, was to find fuller expression in the debates over the efficacy of conscientious objection in the thirties. 120

The traditional French argument against a special regime for those whose conscience forbade them to take arms, was argued 'vehemently' by Célestin Bouglé, who said that it was totally inadmissible for an association which had 'law' at its base to demand recognition for those who flouted it. In Bouglés view, the proposals in favour of objection were

pure anarchy. The League of Nations that we wish to build is founded on respect of the law, a respect that it must guarantee through force: nothing could be more dangerous than to ask it to intervene in favour of those who deny the law in favouring, despite their good faith, cowards and deserters...[franc fileurs] ${ }^{121}$

The discussion became so agitated that the Nancy Group proposed to adjourn it to the following year. It was finally decided however to accept a compromise resolution from Allégret which emphasised the necessity of adopting the principles enshrined in the Geneva Protocol thus permitting general disarmament and in the long run an end to obligatory military service. In the meantime, it asked the League of Nations and the International Court of Justice to define specifically the limited number of cases in which a country could legitimately defend itself so that there could be no equivocation on the subject. ${ }^{122}$

There to all intents and purposes the subject lay for another five years until the full debate on the theory and practice of conscientious objection at the 1930 annual general meeting. In the meantime there was some discussion of the subject in the review. One

119 Ibid., p.156.

120 See J.-L. Puech, 'L'Assemblée Générale de la Paix par le Droit', PD 36, 1 January 1926), p.17.

121 Ibid., p.18.

122 Ibid., pp.18-19. 
reader wrote to ask whether, given his stand as an objector in 1904 and again in 1913, he might legitimately remain a member of the association. Ruyssen replied that he could because although he had refused to carry arms, he had always remained at the disposal of the military authorities and in fact served as a nurse and stretcher-bearer during the Great War. ${ }^{123}$

In the autumn of 1926 the review also ran an enquête on conscientious objection which elicited.far fewer responses than the inquiry earlier in the year on the alleged dangers of toy soldiers to children's growth and development. 124 Four out of the seven responses were in favour of the legal recognition of objection, one was rather confused, and two were completely against the idea. L. Léontin, a regular contributor to the journal, wrote strongly against conscientious objection for the usual French republican reasons, primary amongst them being the fear of a 'pretorian' army which he seemed to think Britain suffered from. 125 The review continued to publish short notices from other pacifist groups about conscientious objection, too. A manifesto sent out by Runham Brown of the War Resisters' International merited simply the comment that the APD did not believe the WRI's approach actually solved the 'grave' problems posed by conscientious objection. ${ }^{126}$ Jules Prudhommeaux and his wife also attended the Bierville congress organised by Marc Sangnier at which two resolutions in favour of sharply delimited conscientious objection were passed. 127

The first of the trials of conscience to receive public attention, that of Georges Cheve in 1927, caused the APD to pause and reflect however. Prudhommeaux, writing in early 1928 after Chevés sentencing in Rouen, saw clearly the potential conscientious objection had if it should ever develop into a 'movement' as such. He pointed out that the verdict solved nothing for the authorities because the question would re-pose itself in six months' time when Chevé left prison.

But how to keep from oneself a troubling thought: if only fifty thousand Chevé's in France stood up one after the other, and as many in the other militarised countries, who cannot see that the governments, moving by degrees from disquiet to terror, would

123 E. Guiton, Théodore Ruyssen, 'A propos de l'objection de conscience', (2 letters), $P D$ 36, 2 (February 1926), pp. 68-69.

124 'Enquête sur l'Objection de Concscience', PD 36, 9/10 (September-October 1926), Pp.337-341 (5 responses); 'PS à l'Enquête sur l'Objection de conscience' (2 responses), PD 36, 12 (December 1926), pp.439-440; for the enquete on toy soldiers see 'Les Jeux de Soldats', PD 36, 5 (May 1926), Pp.193-213; and PD 36, 6 (June 1926), Pp.253-255.

125 Ibid., $P D$ 36, 12 (December 1926), pp.439-440.

126 'Un manifeste pour l'abolition du service militaire obligatoire', $P D$ 36, 12 (December 1926) p.472.

127 'Le Congrès de Bierville', PD 36, 9/10 (September-October 1926), PP.369-372. 
suddenly realise that international disarmament had something good about it? ${ }^{128}$

But the APD contented itself with calling for Cheve to be given the benefit of the 'political' regime in prison, instead of being classed as a common criminal.

Two years later when Eugène Guillot was condemned along with another $\mathrm{CO}$ to a oneyear prison sentence the APD's reaction was much the same. Prudhommeaux criticised the Conseil de Guerre which condemned them as being composed of career officers and a magistrate who by reason of their 'déformation professionelle' were incapable of seeing beyond the letter of the law. It is interesting to note that once again an intelligent man like Prudhommeaux pointed out the logical inconsistency of such a policy on the part of a government which was one of the originators of the Kellogg-Briand Pact. ${ }^{129}$ This demand on the French govern.ment to be consistent with its own proclamations was thus not one used only by other pacifist groups less intellectual than the APD.

A discussion on European political union at the 1929 AGM of the association showed to what extent some French pacifists were confused about the motives behind conscientious objection. Régis de Vibraye suggested that a federated Europe would provide a way out of the moral dilemmas posed by objection because it would allow for the creation of an international police force to take the place of national armies. Each nation would furnish a contingent of its own which would be filled entirely through voluntary subscription. But as a Mr Lowery from the Society of Friends pointed out in the ensuing discussion, it was not the character of the army - be it international or national - that was called into question by objectors but rather the simple fact of being obliged to kill one's fellow man. With either sort of army, the problem remained. 130

The 1930 AGM of the APD saw the question of conscientious objection debated most thoroughly, however. The two rival tendencies in the debate were represented by Pastor Henri Roser, the secretary of the Mouvement International de la Réconciliation (the French branch of the International Fellowship of Reconciliation based in London), and by the president of the Association, Théodore Ruyssen. Roser made an eloquent case for both the 'humanitarian' objectors and those, like him, of the radical Christian persuasion. Ruyssen countered by inviting the audience to 'come back down to earthy reality' and opposed Roser's arguments by saying that one must render to Caesar the things that are Caesar's. However noble the motives of the conscientious objectors might be they constituted a 'disastrous romanticism':

128 J. Prudhommeaux, 'L'Objection de conscience: Georges Chevé', PD 38, 3 (March 1928), p.142. 138.

129 J. Prudhommeaux, 'Guillot et Perrin, objecteurs de conscience', PD 40, 4 (April 1930), pp.137-

130 See J. Prudhommeaux, 'L'Assemblée Générale de la Paix par le Droit, Bordeaux, 2 et 4 novembre 1929', PD 39, 12 (December 1929), pp.451-453. 
We live in a world in which violence still rules: against it Law must prevail. Let us remember the phrase of Pascal: 'Justice is impotent without Force and Force is tyrannical without Justice. Since we cannot make Force just, let us at least make sure that justice is strong: ${ }^{131}$

Ruyssen maintained that the problem of Peace was insoluble from the purely individual point of view and that only a juridical statute regulating the relations of nations would establish peace in the world, thus rendering the question of conscientious objection irrelevant. Three resolutions were presented to the assembly: that of Roser, Ruyssen and also one by René Valfort and Félicien Challaye, which was similar to Roser's. A composite resolution was drawn up which was passed unanimously. Despite Ruyssen's apparent objections to conscientious objection in his speech to the assembly, the final resolution called for an end to universal and obligatory military service which was called 'a heritage of the Napoleonic regime' which could not 'be considered an essentially democratic institution'. The resolution demanded instead the creation as soon as possible of a statute regulating the situation of the conscientious objectors, and as a temporary measure in this direction proposed the creation of a civilian form of service in France. ${ }^{132}$

The assault on obligatory military service continued the following year with another report by Henri Roser, this time on 'The Equivalents of Obligatory Military Service: International Civilian Service and the Volontary Rescue Service'. Roser argued that the resolution proposed by the APD was the logical outcome of the previous year's resolution at Boulogne. Using Pierre Cérésole's International Civilian Service as his example, Roser demonstrated the successes this idea had enjoyed since the war, having helped enormously at the scene of several major natural and human disasters in Europe. ${ }^{133}$ This type of civilian service had its opponents in France, however:

...the anarchists reject it energetically, because for them, a civilian service is still the State domesticating the individual...military service that is ashamed of itself, hidden, camouflaged by the

131 Cited in J. Prudhommeaux, 'L'Assemblée Générale de Boulogne-sur-Mer (suite)', PD 41, 2 (February 1931), p.75.

132 Ibid., p.77. For Roser's resolution see 'Pour notre Assemblée Générale', PD 40, 10 (October 1930), pp.373-375.

133 See Roser's report in Jules Prudhommeaux' 'Notre Assemblée Générale', PD 41, 12 (December 1931), Pp.573-616. Roser listed the areas in which the Service Civil International had provided assistance since the war: 'a Esnes, près de Verdun; aux Ormonts, dans le canton du Vaud, en 1924; à Someo, dans le Tessin, la même année; dans les Grisons, en 1926; dans le Liechtenstein, en 1928, et enfin, pour la plus grande gloire du service civil et le plus grand profit de notre pays, en 1930, à Albefeuille-Lagarde, près de Montauban, au lendemain des terribles inondations dont vous n'avez pas perdu le souvenir. Cétte année même, Cérésole et ses vaillants sont allés à Bryn-Mawr, au secours du Pays de Galles ravagé par le chômage, pour essayer, par la mise en train d'industries nouvelles, de rendre à des malheureux la volonté de vivre. Un autre groupe travaille en Argovie'. 
State which in time of war would quickly transform it without a care for the agreements undertaken. There are others who argue that with modern warfare, the distinction between the two services is an illusion since everything, the road that one rebuilds, the wool one weaves, the tree one cuts down in the forest, immediately finds its wartime use once violence is let loose. Finally, one last objection: Civilian service, affirms $M$ Alexis Danan, has the unfortunate effect of diverting integral pacifists from the only attitude which is logical, that recommended by the great Einstein: total resistance, the categorical refusal to play any role in the drama. ${ }^{134}$

Roser saw, however, two advantages to the institution of a Civilian Service. First, it would give legal sanction to the refusal of military service, thus reconciling it to the law and social order. Personally, he was not entirely convinced by this argument, because in good primitive Christian manner, he believed that a little martyrdom now and again did not hurt the cause. Secondly, though, he argued that if a civilian service were instituted in the manner of Cérésole's project, it would become a beneficial 'school of solidarity', something the obligatory military service was not. In order for it to have this virtue, however, it would have to be voluntarily consented. ${ }^{135}$ He objected to the APD's motion because it proposed that CO's should serve a longer term of civilian service than military service. If CO's themselves had the right to demand this extension, it seemed to him that an external association such as the APD did not. Moreover, the extended service idea was not logical. If one accepted that a civilian service was superior to military service, in terms of dignity and educative value, then logically the association ought to have the courage of its convictions in demanding its institution pure and simple. 136

The discussion on the resolution exposed the equivocal nature of some pacifists' attitudes to conscientious objection. René Valfort argued that incorporating objectors into the nursing and stretcher-bearing corps of the army still made them supporters of war. 'What they demand', he declared, 'is to make war impossible, and not to occupy a place which shelters them from the obligation of killing their fellow man'.137 This is one of the strands of the $\mathrm{CO}$ argument which highlights the contraditions within pacifist theory on it. The point to be made about the APD's discussions of conscientious objection is how disparate the thinking was and how unconscious the APD seemed to be of its internal contradictions. On the one hand there were those who believed that military service was a social obligation but could not see beyond this to a civilian service which would fulfill

134 Ibid., p.599.

135 Ibid., pp.599-600. For a personal analysis of the degradations of military life in the twenties, and a critique of the social utility of this experience and its effects on young men, see André Trocmé, Autobiographie PP. 140ff. in SCPC DG-107 Acc. No. 79A-52.

136 Ibid., pp.600-601.

137 Ibid., p.601. 
the same role. There were those who advocated a civilian service on humanitarian or religious grounds, and wavered between a belief in the necessity of a substitute service for social reasons, and those who took the 'esoteric quasi-pacifist'138 position, close to anarchism, that no demands could be made of certain objectors. There were also those within the APD who argued simply in favour of obligatory military service on grounds of equality before the law, the needs of national security, and the imperative in republican France of avoiding the creation of a 'praetorian' army. Still others, like Ruyssen, seemed prepared to vote in favour of the legal acceptance of conscientious objection out of scruples more at home in the Ligue des Droits de L'Homme. For these pacifists there was no question of objection being a method of fighting war: what they were concerned to do was purely and simply to protect the wounded individual conscience. Finally, there were those like Prudhommeaux who began to see the potential effects an organised campaign of conscientious objection would have on the military system in France and elsewhere, but who lacked the courage or conviction to draw the necessary logical conclusions. Others in this camp, such as René Valfort, did grasp the nettle of collective objection but in so doing objection became a mere method (amorist many presumably) of resisting war, and no longer a matter of individual conscience alone.

The connections were never established in the APD between conscientious objection, moral disarmament and the nascent integral pacifism. The former was accepted to the limited extent that it was perceived to be a question of human conscience and dignity with no direct connection to pacifist theory. When this connection was established by some pacifists, objection was rejected as a method of fighting war. The same can be said of moral disarmament, which was preached throughout the interwar period. The connection between the individual or people who are morally disarmed and a conscientious objection to killing other people in similar circumstances was never fully developed. Finally, in the period up until at least 1933, there seemed to be no inkling on the part of the APD's leadership that both of these positions, taken to their logical conclusions, essentially spelled integral pacifism. Thus, in the same year in which the APD passed resolutions in support of a special statute for conscientious objectors and recognised thit objection was 'respectable' and a method of resisting war, it also categorically rejected the idea of integral pacifism. 139 Conscientious objection was always viewed as an essentially negative approach to peace and therefore of little value. To the extent to which CO's were defended, it was for purely humanitarian reasons.

The failure to draw logical conclusions, to force the issue, to go beyond what might be called the rather anodyne pacifisme des pantouflards can be seen in Prudhommeaux'

138 The typology is Ceadel's, see Pacifism in Britain, p.10.

139 This subject is dealt with fully later in this chapter. 
comments about the recidivism of Eugène Guillot at the end of his first prison sentence for objection. Prudhommeaux wrote that the Kellogg-Briand Pact seemed to have created a new and essential fact in law and in logic with regard to the COs. By making war a crime, it also made the preparation of war a crime. Having taken this step, Prudhommeaux could go no further, however, than to say that the pact had thus created a civic conscientious objection. But

the individual refusal of military service, in France at least and given the present state of things, would not resolve the enormous problem of War and of Peace: this Guillot will never be the shepherd of a flock large enough for one to hope for that... ${ }^{140}$

At the 1932 AGM the topic re-appeared under different guise, this time as a debate on the relative merits of obligatory military service versus a permanent armée de métier. André Lecomte of the Jeune République presented a report in favour of the permanent army, but in the end the assembly pronounced itself incapable of taking an enlightened decision. 141

In 1933 Henri Roser tried to distinguish between conscientious objection per se as a function of conscience, and objection based upon the desire to find a way of combatting war. He was responding to allegations printed in the $P D$ that Pastor Nick in the Côtes-du-Nord was running a sort of 'academy of objection' in which young men were being encouraged and organised to refuse their military service. This allegation was completely untrue according to Roser, who saw in it an occult attempt to make conscientious objection seem a threat to the security of the state. Roser also responded to the stories in the press about the mutilation of a statue of Déroulede in Paris by Gérard Leretour, a sometime objector, and his (and others') use of the hunger strike as a weapon. Roser wrote that though he understood the motives of desperation behind these acts he could not condone them. Most importantly, however, Roser distinguished between what he considered genuine conscientious objection and an ersatz objection which saw itself as merely one tactic among others in the fight against war - an attitude epitomised by the hunger strike:

I understand well that one can say here that attention must be drawn to the extremely grave peril of war and of conscription. But let us recognise that in this case we are no longer concerned with conscientious objection as such. A tactic, a technique of opposition to

140 J. Prudhommeaux, 'Un récidiviste de l'objection de conscience: Eugène Guillot', PD 41, 2 (February 1931), p.108.

141 See 'Notre Assemblée Générale, Pau, 29 octobre - 1er novembre 1932', PD 42, 12 (December 1932), pp.535-536 and 541 . 
war, perhaps, but no longer the unconditional submission of the conscience to an ineluctable truth. This distinction must be made. 142

Whatever the specific motives of most objectors, conscientious objection continued to receive support, not as a method of resisting war so much as a question of pure conscience, until late in the 1930s. In 1936 for example, the review published a petition written by André Philip, then Professor in the Faculty of Law at the University of Lyon, demanding the reform of the law regulating the penalties meted out to convicted COs. Under existing legislation, it was theoretically possible for a convinced objector to spend his entire life from the age of twenty to forty-eight in prison for his beliefs if the law were applied rigourously. Ruyssen signed the petition, and readers of the $P D$ were invited to do the same. The appeal was for signatures from people irrespective of their attitude towards objection as such, and the list of luminaries who signed the petition is impressive. 143

Thus, it can be seen that the APD hardly presented a unanimous face to the world on the question of conscientious objection. Within the association there were several strands of thinking on the subject, all of them at least initially under the delusion that they were talking about the same thing. But it is clear that the conception of objection held by these different strands varied enormously. These differences gradually became more and more apparent. Officially, the APD was in favour of legislation which would attenuate the harsh penalties inflicted upon genuine objectors, but equally it could never bring itself to pronounce in favour of conscientious objection as an efficacious method of war resistance. Having said all that, it is clear that Ruyssen (and perhaps by extension, the APD as a whole) had progressed markedly since his speech in the early twenties to the Congrès

142 Henri Roser, 'L'Objection de Conscience et la Légalité. Lettre ouverte à M. le Rédacteur de "La Paix par le Droit"', PD 44, 1 (January 1934), pp.22-23. The article containing the erroneous allegatons is J. Prudhommeaux, 'La condamnation de "L'objecteur" Philippe Vernier', PD 43, 10 (October 1933), pp.402-403. Roser developed this distinction even further in his response to the 'Enquête sur la Crise du Pacifisme' in PD 44, 2 (February 1934), pp.71-73 in which he argued that the logical conclusion of pacifism was conscientious objection. He differentiated, however, between 'genuine' $\mathrm{CO}$ with its emphasis on the imperatives of the individual conscience, and $\mathrm{CO}$ used merely as a tactic by other pacifists. He underlined forcefully the religious conception he had of pacifism and argued that the spiritual side of the question must be predominant. For Roser no progress ever occurred without a spiritual origin. In this sense Roser comes very close to making pacifism an example of Weber's 'ethic of ultimate ends' - an idea developed further in the case of British pacifism by Martin Ceadel.

143 For the text of the petition, see 'Pour la reforme d'une loi inhumaine', PD 46, 2 (February 1936), pp.97-98. Amongst early signatories of the petition were inter alia: Régis de Vibraye, Paul Langevin, Jacques Maritain, Michel Alexandre, André Gide, Jean Guéhenno, Georges Guy-Grand, E. Mounier, Elie Gounelle, Théodore Ruyssen, André Philip, Wilfred Monod, Paul Rivet, Alain, André Chamson, Joliot-Curie, J.-R. Bloch, Albert Bayet, Jules Isaac, Georges LaPierre, Jean Giono, René Maublanc. 
belge pour le progrès des idées morales, in which he had exalted the moral value of war and attacked those who had shirked their duty in the hecatomb. ${ }^{144}$

The second and more important challenge to the APD's view of pacifism in the early thirties was that of integral pacifism. If conscientious objection constituted a crack in the paradigm, then integral pacifism represented a veritable fissure. The discovery of such irreducible differences of outlook and doctrine within pacifism was even more shocking in that the debate burst upon the APD from within in the form of the Trojan horse, Félicien Challaye, who until 1932 was a member of the Comité Directeur.

The debate on integral pacifism within the APD originated in a discussion between Jacques Hadamard, professor at the College de France, and Challaye in the pages of the Cahiers des Droits de l'Homme in 1928 and 1929.145 The discussion centred on the question of what the Serbian reaction ought to have been to the Austro-Hungarian ultimatum of 23 July 1914. Hadamard argued that the Austro-Hungarian action constituted a refusal of all arbitration and an attack on Serbian independence which had necessarily led to war. Challaye on the other hand argued that while he in no way condoned the Austrian action, the rest of Europe ought to have had the sense to abstain from getting involved in what was to become so catastrophic a generalised war. ${ }^{146}$ This quite naturally evolved into a more theoretical discussion of what Hadamard referred to as the Tolstoyan doctrine of nonresistance to evil. The humanitarian development of this argument in the thirties was that anything was better than a new bloodletting on the scale of the Great War. ${ }^{147}$

Hadamard reduced the 'Tolstoyan' proposition to two arguments. First that anything was preferrable to another war, and secondly, that faced with a nation which refused to defend itself, the aggressor would not dare to execute his crime. It was particularly this latter argument which Hadamard sought to combat. He demonstrated that international, juridical progress founded upon universal and obligatory arbitration of conflicts was fundamentally incompatible with the idea of non-resistance. In a Tolstoyan universe, he argued, arbitration would become a nonsense as the aggressors would simply refuse arbitration in favour of immediate gains. Taking the argument from another angle, he maintained that non-resistance would spell the end of all progress. The adversaries of the

144 See Théodore Ruyssen, 'La Guerre et la morale (Extrait d'un discours prononcé à l'ouverture du Congrès belge pour le progrès des idées morales)', PD 33, 2 (February 1923), pp.49-52, in which Ruyssen said: 'Nous n'aurons garde, quant à nous, de méconnaitre la grandeur morale de certaines heures du temps de guerre. C'est l'honneur du caractère humain de s'élever, sous l'aiguillon de l'épreuve, au-dessus du médiocre niveau de l'humanité moyenne'. Speaking of the duty which all men felt to fight in the Great War, he said '... hélas! il n'est pas vrai que tout le monde ait fait son devoir. Il y a eu, en petit nombre, il est vrai, mais il y a eu quand même en tout les pays des réfractaires, des déserteurs, des lâches et des traitres: il y a eu les mauvais prophètes du défaitisme...'

145 See J. Hadamard, 'Pacifisme Intégral?', PD 41, 2 (February 1931), p.57, notes 1 and 3.

146 Ibid., p.57.

147 Ibid., p.60. Martin Ceadel calls this the 'humanitarian' inspiration for pacifism - in his view the most important intellectual development of interwar pacifism. See Ceadel p.13. 
French Revolution and of liberty still existed, and non-resistance in the civil and international domains meant in the final analysis a return to despotism. But despotism contained within it the seeds of war. Non-resistant pacifists might avoid war in refusing to fight the despot, but they would 'then have the pleasure of fighting for the despot'. History abounded with examples of this. ${ }^{148}$ The progress realised by the Geneva Protocol in determining the aggressor in any conflict would be rendered null and void by the doctrine of non-resistance:

... this so-called avant-garde doctrine would mark a step backwards. This is perhaps our principal reason, sufficient of itself, for repudiating it.

International peace cannot be founded at the same time on the definition of the aggressor and on the theory of non-resistance of the attacked. Between one and the other, one must choose, and our choice is made. One cannot avoid the question of knowing if one wishes to renounce liberty and justice deliberately in favour of peace or if, as we believe, peace, justice and liberty are inseparable things, one not being able to exist without the others. ${ }^{149}$

Challaye responded in the November 1931 issue of the PD with an article in favour of 'peace with no reservations'. ${ }^{150}$ He underlined that he was only concerned with war between peoples, that is to say, nations: civil conflicts were beyond the parameters of his argument and his pacifism. Challaye defined three attitudes possible in the face of international war. The first was the bellicist position, embodied by those who proclaim war to be morally beneficial and socially productive. Secondly, there were those who believed peace to be superior to war, but considered war to be necessary in some cases, and therefore legitimate. These he called the belli-pacifists. Finally, there were those who condemned war in an absolute sense, whatever the circumstances. These demanded peace by any means, these were the pacifists, the tenants of integral pacifism. ${ }^{151}$

Challaye also defined the sources of pacifism. These were two. On the one hand, pacifism could arise from egotism pure and simple, 'an egotism which is in itself legitimate: it is reasonable to safe-guard one's own existence, and to sacrifice it only to a cause which is worth it. ${ }^{152}$ But clearly this egotism could also lead to bellicism or bellipacifism as well. Thus, pacifism arose more from moral ideas than from egotism.

\footnotetext{
148 Ibid., pp.59-61.

149 Ibid., p.67.

150 F. Challaye, 'Pour la Paix sans aucune réserve', PD 41, 11 (November 1931), Pp.489-497.

151 Ibid., p.489.

152 Ibid.
} 
Challaye argued that it represented the application to relations between peoples of the commonplace commandment: 'Thou shalt not kill' and 'Love thy neighbour as thyself. 153

While it was true that integral pacifism sprang from the application of this morale courante, it was absolutely false that it was logically tied to the Tolstoyan conception of non-resistance to evil according to Challaye.

Certainly the Tolstoyan must be an integral pacifist, but the integral pacifist is not necessarily a Tolstoyan. The integral pacifist, he who demands peace at any price between the peoples, can very well accept legitimate familial and individual defence. Legitimate individual or familial defence has nothing but its name in common with the national defence, the so-called national defence. Legitimate individual or familial defence has as its goal, and often with success, the saving of several precious lives; the socalled national defence always has as its consequence the destruction of innumerable precious existences. ${ }^{154}$

Thus, for Challaye, the integral pacifist would not hesitate in using force to defend his mother, his wife or his child. He would run to the aid of someone attacked in the streets. Hefwould defend to the best of his ability Jews atttacked in pogroms, and he would be free to participate in a revolt against an oppressor. 'Civil war, social war are essentially different from foreign war...It is war between peoples, only, which is forbidden by integral pacifism as it is here defined'.155

There were three primary reasons for Challaye's belief in integral pacifism. The first, what he called the decisive reason, was essentially that of Bertrand Russell, namely that the 'evils of war are infinitely greater than any other solution applied to conflicts between peoples.' He claimed that viewed from this angle, integral pacifism was not a 'tissue of abstractions', or a utopia, but rather a living doctrine taken from 'contact with reality, and nourished by experience.' And the experience was that of the last war. Secondly, there was the aspect of suffering which a modern war brought about - an infinity of suffering. Warfare in the twentieth century no longer could limit its effects, horrible that they were, to the combatants. All members of society were now affected by war, and therefore by its terrible sufferings. And finally, the new means of warfare made war the worst of evils, in fact absolute evil. To this absolute evil an absolute remedy needed to be applied and that remedy was integral pacifism, 'peace without the slightest reservation'.156

Challaye foresaw the arguments which the belli-pacifists would marshall against his conception of integral pacifism. The best would be that war can safe-guard national

153 Ibid.

154 Ibid., p.490. Challaye expressed his debt for this idea to his friend, the pacifist René Valfort.

155 Ibid., Pp.490-491.

156 Ibid., pp.491-93. 
independence. To this Challaye replied that armed defence and wars are not necessary or even sufficient for the maintenance of national sovereignty. Examples of this were Andorra, Luxembourg, Switzerland, Denmark, and so forth. Perhaps more important, war in no way guaranteed national independence. Wars could be lost and with them national sovereignty. But even if war could be proved to be one hundred per cent effective in preserving national independence, one had to ask at what price. This led Challaye to his major conclusion that

Rather a foreign occupation than a war - the acceptance of this formula could be the criterion separating the real pacifists from the belli-pacifists... ${ }^{157}$

Challaye believed that modern warfare made the defence of the nation the death of the nation. That did not imply however a total abdication in the face of aggression. If national defence were impossible by means of arms, there were other ways of resisting aggression: passive resistance and non-cooperation such as Gandhi was using in India; the appeal to the conscience of the invading people; the appeal to the conscience of other nations who could then organise an economic and financial boycott against the aggressor, and so on. The integral pacifist was thus called to resist, but not by force of arms. Integral pacifism called therefore for pacifist action on the individual level first - a personal renunciation of war as in the Einstein declaration; and secondly, a social renunciation of war through total and if necessary, unilateral, disarmament. 158

The counter-attack was not long in coming. The editors of the PD wrote in the next number of the review that Challaye's article had caused them no small amount of grief, not only from a very hostile press, but also from many members of the association 'who were far from sharing his views'. ${ }^{159}$ Ruyssen challenged Challaye's pacifism in a clash of the philosophers. The differences between the two men were irreducible. Ruyssen clearly believed that certain things - justice and law, incarnated in the right of peoples to dispose of their own destinies - were most definitely worth fighting for. To Challaye's claim to be speaking from the cold experience of reality, Ruyssen threw back the undeniable facts of recent history: Belgium resisting the Kaiser's army in 1914, the Danes heroically fighting the Prussians in Schleswig in 1864, imposing the plebiscite on Bismark which he was trying to avoid; and he recalled to mind the visceral importance of national identity and selfdetermination, reminding Challaye of 'the little peasants of Posnan who, around 1910, were whipped because they could not recite the catechism in German', to say nothing of the

157 Ibid., p.494.

158 Ibid., pp494-497.

159 'La Paix sans Réserve?', PD 41, 12 (December 1931), p.561. 
old men he had seen sobbing in Colmar, Strasbourg and Mulhouse in 1913, such was the depth of their feeling at being separated from France. 160 Ruyssen charged that Challaye was being illogical in limiting his concept of legitimate defence to the individual or family level; just as at these levels, so the sense of national solidarity led men to defend the social collectivity called the nation. Ruyssen's attack finished on a decidedly ad hominem note. He accused Challaye of reducing the whole problem of war to one of fear, of producing a 'dry theorem', of being a 'prudent bourgeois' who was teaching cowardice, of putting a long and comfortable life above all other values.

In one word, you affirm, you desire, with swagger: 'peace without any reservations', even if it be an unjust peace, a dishonorable peace. We demand, on the contrary, peace in justice and in dignity. We wish to see to it that force, which up until now has been bound up with the law of men only by accident, should be so by rule and without exception, as it is already in a large measure within human communities. 161

Challaye's response to Ruyssen's attack heightened the personal nature of the debate. He accused Ruyssen of cowardice himself for having spent the war as a non-combatant, while he, Challaye, despite his age, served as a sergeant in the territorial infantry and was wounded slightly. This is the classic distinction made during and after the war by those who fought at the front vis-à-vis those who remained behind the lines as noncombatants, or perhaps shirkers. ${ }^{162}$ Challaye affirmed that he was profoundly attached to the idea of national independence, but he still maintained that to fight for this independence given the state of modern warfare would mean the annihilation of the state in any case. There was nothing 'utilitarian' about his argument at all, said Challaye; he made the case for integral pacifism from the moral point of view. True courage was being prepared to sacrifice one's life for a cause that merited it, not in causing the deaths of innocent men and women in a war. He summed up his conception of courage in Bossuet's dictum that one must 'reserve for real service the action of an extraordinary bravery. ${ }^{163}$

The editorial secretary of the review, Jules Puech, intervened at this point in the debate and tried to smooth over the differences between the two men, by arguing that in fact Challaye's conception of pacifism was not that different from Ruyssen's. He did this

160 Théodore Ruyssen, 'La Paix sans réserves? Non!', PD 42, 1 (January 1932), pp.10-12.

161 Ibid., pp.14-15. The attack on Challaye continued the following month with Charles Richet, 'La Paix sans réserve est un rêve!'. PD 42, 2/3 (February-March 1932), pp.70-71.

162 F. Challaye, 'Pour la Paix sans aucune réserve (Réponse à l'article de M. Ruyssen)', PD 42, 4 (April 1932), p.149. On the distinctions drawn by the war veterans between ceux du front and ceux de l'arrière, see Antoine Prost, Les Anciens Combattants et la Société Française, III, Mentalités et Idéologies (Paris: Presses de la FINSP, 1977), pp.78-81.

163 Ibid., Challaye, p.152. 
by quoting from several of Challaye's books on moral philosophy which certainly seemed to lend credence to his argument. He also cited a patriotic lecture which 'Sergeant' Challaye had given to the 109th territorial infantry regiment during the war, expressing in perfect form the patriotic pacifist sentiments of the APD. There is thus little doubt that Challaye's pacifism had changed remarkably since the war, evolving rapidly in the late twenties from one quite similar to that held by the APD to one of intransigent integral pacifism. 164

The sense that a divorce was in the offing remained strong throughout 1932 and 1933. It is hard to escape the impression that French pacifism was indeed traversing a crisis, a fundamental parting of the ways between pacifist forces which until then had been content to rely on the assumption that all pacifists were struggling towards the same peace. But as L. Emery charged in a 1933 article published in the $P D$, there were equivocations within pacifism which needed to be rectified. He wrote that in reading the recent articles of Ruyssen and especially Richet he felt that he no longer understood. 'What they call "pacifism" hardly coincides any longer with what we define by this word'. 165 He defined his conception of pacifism on two levels. First, it was necessary to see that the Europe created by the treaties of 1919 was 'agonising' and that justice had not been done. France

164 Jules-L. Puech, 'A propos des articles Challaye-Ruyssen', PD 42, 4 (April 1932), pp.153-156; see also Challaye's war-time lecture in Félicien Challaye, La Signification Morale de la Guerre actuelle (Conférence faite au Cours d'Instruction Complémentaire pour les sous-officiers du $109 e$ Régiment Territorial d'Infanterie le 29 mars 1916 par le Sergent Felicien Challaye), (Paris: Comité de Propagande Socialiste pour la Defense Nationale, 1916.) Similar sentiments were expressed in a letter to Romain Rolland written in April 1915. Challaye told Rolland that he shared the sentiments expressed by the latter in articles in the Joumal de Genere, but went on to say: 'Je suis en ce moment sur le front, depuis le début d'octobre, et même, maintenant sur la ligne de feu. Ma compagnie territoriale y a tour à tour creusé des tranchés, occupé des tranchés, entretenu une route stratégique; maintenant elle travaille à "l'assainissement du champs de bataille". Je crois avoir fait, et je suis décidé à faire, jusqu'au bout, tout mon devoir militaire; ce n'est point un lâche qui vous écrit. -Mais c'est un soldat que la guerre n'a pas fait renoncer à son idéal de bonté boudhique, chrétienne et socialiste. Si je me bats, si je meurs, ce sera sans aucune haine.

Je crois que nous devons vaincre, à tout prix, pour sauver notre indépendance nationale; pour permettre aux Alsaciens-Lorrains authentiques soit de revenir à la patrie à laquelle ils sont si longtemps fideles, soit d'obtenir une entière autonomie; pour réaliser une Europe où les peuples auront enfin le droit de disposer d'eux-mêmes librement. Mais après la victoire je souhaite et je réclame une paix définitive basée sur la justice international, sur le respect des droits de tous, sur une mutuelle fraternité. Je désire ardemment que ce régime de paix soit réalisé à la fois dans les esprits et les coeurs et dans les institutions internationales que n'écrasent ni n'humilient aucun peuple. Je considère qu'un devoir urgent s'imposera tout de suite après la paix: rétablir le contact entre les peuples divisés par la guerre; entre les savants, entre les chrétiens, entre les socialistes, entre les ouvriers, entre les gens du monde des pays actuellement en lutte. Puis, chez nous, sauver des étroitesses chauvines le droit à une culture vraiment générale, à laquelle ne manquera point l'importante contribution de 'LAllemagne; sauver le droit à Goethe et a Heine, le droit à Kant et à Nietsche, le droit à Beethoven et à Wagner. -Nous aurons de belles luttes à soutenir.

Je me réjouis à l'idée d'y participer, si j'échappe aux petites balles sifflantes et aux éclats des bruyants obus. Nous aurons, pour ce combat aussi, besoin d'un chef: vous serez le nôtre, n'est-ce pas?...' And the letter was signed Félicien Challaye, Sergent au $109 \mathrm{e}$ territoriale, lère compagnie, Secteur portal 140. Letter is in BN MSS Fonds RR, F Challaye to RR, 26 April 1915.

165 L. Emery, 'Les Equivoques du Pacifisme', PD 43, 7 (July 1933), p.239. 
had to be prepared to accept a reduction in her political hegemony and prestige. A pacifism which clung to the treaties was one based upon conservatism and French national advantage, not upon justice:

Thus, we arrive at the first line of division: we refuse categorically to recognise as a pacifist anyone who poses, as a prerequisite condition, respect of the existing international order and the refusal by France of new concessions. We believe on the contrary that the integration of France into a pacified Europe cannot be achieved without the abandonment of its present privileges. A definitive equilibrium is at this price. ${ }^{166}$

The second point of division was over the nature of modern warfare and what this implied for the pacifist case. This had nothing - or at least not necessarily - to do with religious ideas or 'quakerism'. But it had everything to do with the fact that the game had changed:

The idea of placing force at the service of justice, and if need be, of accepting a war of national defence as the ultima ratio was reasonably compatible with a sincere pacifism as long as there existed an acceptable relationship between the ruins caused by war and the values which it could save. Defending a nation was then shedding a tenth of its blood with a view to a superior interest. 167

1914 had changed all this. War was now totally out of proportion to the values which it claimed to be saving. The military defence of a nation had become a verbal relic: 'the expression no longer coincides with the reality'. ${ }^{168}$ This in no way implied the abandonment of the nation, the acceptance of all injustices. What it did imply however was the need to rethink the way in which a nation would defend itself. No doubt many of the substitute methods of national 'defence' were insufficient, but there was no other alternative, argued Emery. The Geneva disarmament conference was a chicanery because it spoke of disarmament and security in the same breath. Pacifism had lost its way according to Emery and in order for it to regain its credit and its strength, it needed to redevelop a programme, and become again an ideal and a moral imperative. ${ }^{169}$

Responding to Emery's article, Richet admitted and defended the idea that he represented a vieux pacifisme in contradistinction to what he called Emery's 'neo-pacifism' which he likened to that of the Nazis in terms of its content. He defended the Versailles Treaty as having finally created a Europe in which minority and national aspirations were

166 Ibid., p.240.

167 Ibid., p.241.

168 Ibid.

169 Ibid., Pp.242-244. 
realised. As far as disarmament was concerned, he believed that Germany was far from disarmed, although he did agree with Emery that any future war would be a disaster for victor and vanquished alike. Richet concluded that there were therefore no equivocations in pacifism. Old pacifists and neo-pacifists alike, he believed, were struggling towards the goal of peace. But he insisted that it was through obligatory arbitration that this peace would be achieved. 170

Ruyssen, too, responded to Emery's article. He declared that the APD's doctrine had not changed in its essential aspects. He was not fanatically attached to the boundaries of Europe as laid down by the Treaties, either, but he did believe that the European situation in 1932 was much more equitable in terms of national identity than certainly had been the case in 1914. To revise the treaties would lead straight to war. This did not mean though that the map of Europe created by the Treaties was perfect in all respects. But the main point of Emery's essay was the same as that argued by Challaye the year before, namely that any future war would be so ruinous, so costly, so dangerous for civilisation that it ought simply not to be fought under any circumstances. Submission rather than destruction was how.he summarised Emery's argument. Ruyssen argued that since Emery was prepared to accept the justice of some wars up until 1914, his neo-pacifism therefore reduced itself in the final analysis simply to a calculation of risks involved in a modern war. The answer Emery arrived at was that these risks were too high and spelled doom. The notion of justice was totally absent from the calculation. Ruyssen invited Emery therefore to spell out in precise terms at what level of destruction a war became immoral, and what measure of 'justice could be sacrificed without remorse'.171 Thus, Ruyssen, despite the definite fact that a future war would be ghastly beyond belief, did not believe that one could confidently extrapolate from it the end of civilisation. Pacifist thinking in this area fell into the realm of hypothesis and conjecture, and not of fact. But beyond this argument on the magnitude of destruction, Ruyssen argued that to declare in advance that one would not defend oneself, far from preventing a war, actually encouraged aggression. The only. sensible path lay in building up the notion of international law and arbitration whilst at the same time seeking to arrive at the highest level of general disarmament possible. ${ }^{172}$

A third crack in the paradigm of optimistic, positive pacifism espoused by the men of the APD was undoubtedly the amazing dispersion of efforts for peace in interwar France, and the apparent immunity of the French peace movement as a whole to any attempt to bring order out of the organisational (and doctrinal) chaos. The problem had existed for

170 Charles Richet, 'Y-a-t-il des Equivoques du Pacifisme?', PD 43, 8/9 (August-September 1933), pp.285-288.

171 Théodore Ruyssen, 'Y-a-t-il des Equivoques du Pacifisme?', PD 43, 8/9 (August-September 1933), pp.288-289.

172 Ibid., pp. $289-290$. 
many years, but the Challaye/Emery controversy likely helped to bring it into focus for the APD. As we have seen earlier in this section, right from the outset of the interwar period, the APD felt crowded by the advent of new groups with the League of Nations as their object. The association felt that many of its members or potential members were being poached away in the early twenties either by the League of Nations associations or sometimes by the Ligue des Droits de l'Homme. ${ }^{173}$ As we have seen, however, the APD was able to establish itself in the early twenties as a kind of bridge between the world of pacifism and the new groups formed in support of the League. Even within the APD the two tendencies existed; Ruyssen described them in 1922 as the tendency in favour of peace and that in favour of the League of Nations. ${ }^{174}$ The problem of balkanisation remained however. Prudhommeaux spoke at the 1924 annual general meeting of a 'crisis of pacifism' engendered by the dangerous and wasteful multiplication of efforts amongst French pacifists. An example of this existed within the APD itself. At the 1922 AGM Lucien Le Foyer and the Paris group he headed were attacked for lethargy; the real reason behind the attempt to unseat Le Foyer from the President's chair in Paris seems to have been the latter's creation of a rival pacifist organisation called the Union Populaire pour la Paix Universelle. 175 No love was lost either between the APD and the Délégation Permanente des Sociétés Françaises de la Paix which was described by Ruyssen as a chief without any Indians. 176

173 See for example, Edmond Duméril, J. Prudhommeaux, and Théodore Ruyssen, 'L'Assemblée Générale de la Paix par le Droit', PD 30, 11/12 (November-December 1920), p.371. Ruyssen spoke of the problem of competition from the League of Nations associations: '...il s'agit avant tout de savoir comment nous pourrons vivre et développer notre Association sans nous heurter à la propagande des groupements nés depuis la guerre et qui poursuivent un but semblable au nôtre sous le pavillon de la Société des Nations.' Georges Cadier for the Poitou group said that '... la concurrence de l'Association française pour la Société des Nations nuit à notre propagande, car notre public ne comprend pas cette dualité. De plus, la Ligue des Droits de l'Homme recueille dans beaucoup de localités les adhésions de personnes favorables à nos idées.' (pp.370-371).

174 Ruyssen cited in Jules Prudhommeaux, 'Conseil Directeur de l'Association de la Paix par le Droit', PD 32, 10 (October 1922), pp.426-427.

175 In his 'Rapport Moral' for the 1924 AGM, Prudhommeaux said that 'Notre mouvement traverse une dangereuse crise de croissance. Aimez-vous le pacifisme? On en a mis partout, et c'est partout la confusion et le désordre. Entre les anciennes sociétés de la Paix et celles qui ont.pour objet la Société des Nations, les divergences persistent. Il y a trop d'oeuvres, trop de sociétés, trop de journaux, et la belle émulation qui enchantait d'abord les optimistes, risque d'aboutir à l'incohérence et à l'impuissance.' - cited in J. Prudhommeaux, and Georges Cadier, 'L'Assemblée Générale de la Paix par le Droit', PD 34, 7/8 (July-August 1924), pp.270-276. For the attack on Le Foyer see Théodore Ruyssen, 'L'Assemblée Générale de l'Association de la Paix par le Droit', PD 32, 6 (June 1922), pp.237-246. A short description of the Union Populaire pour la Paix Universelle can be found in Lucien Le Foyer, 'L'Union Populaire pour la Paix', in Nous woulons la Paix, (Paris: SRIP, 1932), pp.5556.

176 On the Délégation permanente, see Théodore Ruyssen, 'A propos du 9me Congrès national de la Paix', PD 31, 5/6 (May-June 1921), pp.219-220. Ruyssen wrote '...qu'est-ce donc la DP? ...Peu de choses; une façade à laquelle sont accrochés quelques noms biens connus, mais derrière laquelle il n'y a à peu près rien, ni effectifs, ni activité, ni ressources...' 
These fissures and disagreements could only worsen as the twenties flowed into the thirties. The number of groups continued to grow and the doctrines 9 poused by them moved increasingly in the direction of 'intégralité' whether for sentimental or for humanitarian or religious reasons. It is not our purpose here to examine in detail the nature of the pacifism of some of these groups in that they define the paradigm of pacifisme nouveau style which will be discussed fully in the next section. However, insofar as they represented the beginnings of a break with the old-style pacifism typified by the APD, the Ligue International des Combattants de la Paix was condemned for its integral pacifism, the Ligue Internationale des Femmes pour la Paix et la Liberté was criticised for its naive approach to international affairs, and the Volonte de Paix likewise was attacked for its sentimental approach to the problem of peace. 177

The APD's reaction to the Amsterdam Congress against Imperialist War was both positive and negative. Initially Prudhommeaux had taken a very negative line because of the increasingly evident attempts of the Communists to take over the congress for their own ends. ${ }^{178}$ Right up until the eve of the congress his apprehensions about the reception likely to be reserved for 'bourgeois pacifists' grew, but after attending it, he wrote that 'this congress will remain... an important event of the post-war era'. 179 The credit for this success was largely due to Henri Barbusse who had managed to see that the pact of mutual toleration between the multifarious strands of world pacifism was respected. 180 That said, the organisation of the congress was chaotic and in no way designed for constructive work. The unity of tone achieved at Amsterdam was the result of an abdication on the part of many pacifist groups which allowed the Moscow obedience to impose its conceptions on the

177 On the LICP see Ruyssen's comments to Rene Valfort in the debate on the crisis of pacifism at the 1933 AGM in .J. Prudhommeaux, 'Notre Assemblée Générale, Suite et fin', PD 44, 3 (March 1934), p.101. See also Prudhommeaux' comments in J. Prudhommeaux, 'La Ligue des Combattants de la Paix - Le Congrès de Montargis - Les Dissidents', PD 44, 6 (June 1934), pp.244-245, in which Prudhommeaux calls the LICP's propaganda 'ardent and courageous', but reminds readers that the PD has some fundamental reserves about the LICP programme. On the LIFPL, the APD had both positive and negative views. In 1922 Ruyssen condemned the 'empty rhetoric' of the LIFPL international congress at the Hague which sought what he called the 'ardent, at times fanatical, demolition' of the treaties of 1919 but seemed to offer little to put in their place. See Theodore Ruyssen, 'Un Congrès féminin pour la Paix à La Haye', PD 33, 1 (January 1923), pp.34-5. Later in the twenties however the PD applauded the work of the LIFPL in its investigation of the effects of chemical warfare. See Jules Prudhommeaux, 'La guerre chimique et l'opinion: un article de M. de Kérillis', PD 40, 11 (November 1930), pp.451-452. With regard to Madeleine Vernet and the Volonté de Paix, as far back as 1921, Ruyssen had attacked Vernet's 'Appel aux femmes' as 'pathetic' and an appeal only to sentiment. See Thédore Ruyssen, 'Les femmes contre la guerre', PD 31, 3/4 (MarchApril 1921), pp.140-141. In 1928, after the founding of the Volonte de Paix, Prudhommeaux put the readers of the $P D$ on their guard against the 'extremists of peace' to be found in the VP's ranks. See J. Prudhommeaux, 'Pacifisme d'avant-garde', PD 38, 3 (March 1928), pp.137-138.

178 J. Prudhommeaux, 'Un Congrès de la Paix qui s'annonce mal: Genève ou Moscou?', PD 42, 7/8 (July-August 1932), pp.350-351.

179 J. Prudhommeaux, 'Le Congrès Mondial contre la Guerre impérialiste', PD 42, 9 (September 1932), p.405.

180 Ibid., p.406. 
assembly and its resolutions. ${ }^{181}$ Later on in 1932, when local Amsterdam committees began to be formed in France and elsewhere, it became apparent to Prudhommeaux that the movement had been taken over by the Third International. 182 Despite all this, it is surprising to note how measured and friendly Prudhommeaux' reaction to his experiences at the Congress itself actually was.

The APD participated in efforts in the early thirties to remedy this balkanisation of French peace efforts. Jules Prudhommeaux was most actively involved in this work and propagandised tirelessly for the creation of Cartels de la Paix which while not limiting the independence of their constituent members, would provide a force for unity in French pacifism. We have already noted his concerns as early as 1924 at the dispersion and waste of French peace efforts. ${ }^{183}$ By the mid-twenties some cartels had been formed and the movement towards some form of loose unity seemed to gather momentum by the late twenties. 184 The formation of local peace cartels seemed to take off however in 1931, largely under the influence of a tour of France made by a mobile museum on war and peace organised by the Jeune République. Prudhommeaux estimated that during its two-week stay in Bordeaux alone, some 110,000 to 120,000 people saw the museum's display. ${ }^{185}$ The purpose of the mobile museum was to raise the population's consciousness about the problems of war and peace until the time of the Geneva Disarmament conference in February 1932 and the French general elections in May of that year. In provincial France it seems to have had some major successes. In Bordeaux a Cartel Girondin de la Paix was formed which numbered almost 200,000 members within its constituent organisations. The Cartel rouennais de la paix contained thirty-three member organisations on 1 November 1931. Unfortunately, Paris seemed to remain immune to this flurry of cartel formation and Prudhommeaux wrote that the 'dispersion of efforts (in the capital) is a scandal'.186

181 Ibid., pp.408-409.

182 J. Prudhommeaux, 'Les lendemains du Congrès d'Amsterdam', PD 42, 11 (November 1932), pp.494-495. Prudhommeaux formulated many of the same criticisms with regard to the Rassemblement Mondial des Femmes contre la Guerre et le Fascisme which was held in Paris in August 1934. It was an impressive congress - some 1500 delegates were present - but it was over-run by the Communist and Muscovite element and was totally chaotic in terms of organistion with decisions, and more importantly, the final Manifesto imposed from above. In a strange speech for a 'pacifist' to make, Barbusse attacked the religious, non-violent pacifists and called women to the fight, to the Revolution, to violence, if need be. See J. Prudhommeaux, 'Le Rassemblement mondial des Femmes contre la Guerre et le Fascisme', PD 44, 9 (September 1934), Pp.343-347.

183 See note 175 above.

184 On the formation of the Lyon cartel in 1925 see J. Prudhommeaux, 'Le cartel lyonnais pour la Paix et la SDN', PD 36, 1 (January 1926), pp.39-40. See also J. Prudhommeaux, 'Vers l'union des forces pacifistes: Cartels et Semaines de la Paix', PD 39, 11 (November 1929), pp.425-430.

185 J. Prudhommeaux, 'Le Tour de France du Musée "Guerre ou Paix"', PD 41,7 (July 1931), p.320.

186 Ibid., p.318. See also 'Les Cartels de la Paix' in op. cit. Nous voulons la Paix, pp.88-90. See also J. Prudhommeaux, 'Petite histoire des Cartels de la Paix', PD 42, 4 (April 1932), pp.179-182. For a 
Paradoxically, the new-found or at least growing unity of 1932 was to be difficult to maintain in the face of the Amsterdam movement which, too, had claims on being a unifying force in French pacifism. ${ }^{187}$ The inspiration for the creation of peace cartels in France undoubtedly came from across the Channel where the example of the 'powerful' League of Nations Union served to highlight the insufficiencies of the French movement. Despite the very real progress made towards some form of unity in 1931-32, however, French pacifism remained divided unto itself. In 1935, for example, Prudhommeaux engaged in a discussion with Fabien France 188 in which he argued that aside from problems in the French national temperament which produced a splinter effect within the peace movement, there was also another difficulty. This was without doubt the politicisation of the question of peace:

...there exists an extreme right, a right, a centre, a left and an extreme-left in pacifism. M. Herriot is a pacifist just as much as comrade André Marty, the anarchist Sébastien Faure and the objector René Gerin. Le Temps (but yes!) has the pretension of serving peace just as much as Le Barrage, but of serving it better. Hence the rivalries, the incompatibilities, the antagonisms of doctrines, or groups, or persons that make it most difficult to achieve the desired unity within the movement. ${ }^{189}$

Fabien France responded to Prudhommeaux' invitation to show the way forward to unity, by arguing that unity was impossible right across the entire spectrum of French pacifism. Moreover, he believed, the diversity of tendencies was not an obstacle as such. It was clearly impossible to group together in one society nationalists who were not gequinely interested in peace for its own sake, on the one hand, and on the other, the army of 'extremist pacifists, Tolstoyans, conscientious objectors and anarchists of all sorts'. ${ }^{190} \mathrm{He}$ thought that French pacifism could do without people who wanted to preserve peace while preparing for war, and people who thought that individual or collective refusals to fight any war were sufficient. In France's view, there came a time when the divergence on methods signified practically-speaking a divergence on principles. ${ }^{191}$

more general analysis of the need in France for a unification of peace efforts, see Ernest Archdeacon, 'Pour l'unification des Sociétés pacifistes', PD 41, 7 July 1931), pp.313-314.

187 See Part III of this thesis for comments on the trouble caused to local cartels by the machinations of local Amsterdam committees.

188 'Fabien France' was apparently the pseudonym, according to Prudhommeaux, of a 'pacifiste très averti du mouvement d'idées contemporaines, collaborateur apprécié de la Jeune République'. See J. Prudhommeaux, 'La grande pitié du Pacifisme français - Pour l'Unité et la Coordination des Efforts', PD 45, 10 (October 1935), p.391.

189 Ibid., p.393.

190 Fabien France in ibid., p.394.

191 Ibid. 
But that is to jump ahead a couple of years. The point, which ought to be clear, is that French pacifism by the onset of the thirties was experiencing a crisis of growth coupled with a crisis of confidence in the values it proclaimed. In the face of a worsening international situation, French pacifists began to arrive at increasingly radical answers to the problem of peace. Or at least, some did. For the old-style pacifists of the APD, the doctrine and methods remained the same, despite the temptations and hesitations of the years under discussion.

The final crack in the paradigm of pacifisme ancien style was therefore the deteriorating international situation in the early thirties. This situation can be reduced to three main events: the Sino-Japanese conflict in Manchuria and the apparent impotence of the League of Nations to resolve it, the general disappointment caused by the increasing failure of the Geneva Disarmament Conference to reach any substantial agreement on arms reductions, and finally, the rise of Nazism in Germany which riveted French eyes once again on events outre-Rhin.

Disarmament had always been an important plank in the APD's pacifist platform. Ruyssen saw success in disarmament as absolutely necessary if public opinion was to be convinced of the efficacy of the League of Nations. This disarmament would take three forms: moral, economic and military. He believed that moral disarmament was making great progress. Economic disarmament was a slower process, but it would be realised soon that it was necessary because in it lay Europe's future. Military disarmament was the most difficult to achieve, because it was dependent on success in the other two areas, but Ruyssen believed that it, too, would see its hour come.192 Paul Painlevé's new policy of rearmament in 1927 prompted the Comite Directeur of the APD to ask bluntly in a public statement, 'Why these armaments?'193 - especially at a time when Germany was finally beginning to accept the post-war world and had signed the Locarno accords. The Geneva Disarmament conference disappointed pacifists because it was never able to reach beyond the concept of limitation to that of reduction of armaments. In April 1934 Ruyssen rather bitterly attacked its failure. He registered the sense of deception pacifists felt at the German walk-out in October 1933, but sharply criticised the French approach to the whole question of disarmament as well:

The day that France brings to Geneva something other than a juridical dialectic and theoretical plans, the day on which, confident of its present military superiority and of its alliances, it spontaneously offers the sacrifices that it can certainly consent to

192 Théodore Ruyssen, 'Désarmement? ou désarmements?', PD 39, 12 (December 1929), pp.441-442.

193 Le Comité Directeur de la Paix par le Droit, 'Pourquoi ces Armements?' PD 37, 6 (June 1927), pp.185-187. 
without putting its security in danger, that day it will restore the confidence today so lacking, and will recover through the collective solidarity, an ample compensation for the wager that it will have given to the cause of peace. 194

The APD cannot be accused of short-sightedness with regard to its analysis of the situation in Germany preceding the Nazi Machtergreifung. From at least 1930 onwards, the writers of the review were very much aware that something perhaps catastrophic was occurring in Germany, and after the Nazi seizure of power, they lost no time in denouncing the regime to their readers. Our interest is not here in a detailed analysis of the stages of the APD's prise de conscience with regard to Nazism, but merely to indicate that the association could not be accused of political naiveté with regard to Hitler. 195

It is hardly surprising given the length and breadth of some of the cracks in the paradigm of old-style pacifism, that the APD should feel it necessary to institute an enquete on the crisis of pacifism. The review printed responses from a selected group of French pacifists whose views were thought to be fairly representative of the strands within the movement. 196

Fascinating and varied as these responses are, our interest here must be limited to the development of this debate within the association itself, and the decisions it came to with regard to its brand of pacifism. The issue of a crisis in pacifism was thoroughly exposed and debated at the APD's 1933 annual general meeting in Paris. This AGM was really a stock-taking on the part of the association of its activities since the war in the face of a deteriorating national and international situation which caused everyone to ask whether pacifism had failed in its quest. Prudhommeaux' description of the meeting reads like a veritable litany of woes delivered in what he called an 'atmosphere singularly charged

194 Théodore Ruyssen, 'La nouvelle Crise du désarmement', PD 44, 4/5 (April-May 1934), p.186.

195 See Henri Simondet, 'Les Elections Allemandes', PD 40, 10 (October 1930), pp.376-382; Henri Simondet, 'L'Allemagne dans le gâchis', PD 43, 2 (February 1933), pp.62-67; Wilfred Monod, 'L'Antisémitisme et la Notion de Race', PD 43, 6 (June 1933), pp.198-200; Jules Prudhommeaux, 'Les paroles et les actes', PD 43, 6 (June 1933), pp.218-219 (about the divergence between Hitler's words of peace and the treatment being meted out to pacifists within Germany); Jules Prudhommeaux, 'Et si l'Allemagne résiste? - les sanctions économiques', PD 43, 11 (November 1933), pp.458-460 ( in which Prudhommeaux envisaged the use of economic sanctions if Germany should refuse to rejoin the international community). Ruyssen can be forgiven for taking a view shared by many other people in late 1932, namely that the Nazi menace had reached the high tide mark in Germany and would now subside. See the account of Ruyssen's speech at the public meeting held during the association's AGM in Pau at the beginning of November 1932, in 'Notre Assemblée Générale, Pau, 29 Octobre - 1er Novembre 1932', PD 42, 12 (December 1932), pp.518-520.

196 The responses to the enquete were published in $P D$ nos 43,10 to 44,3 (October 1933 to March 1934). The following people submitted responses to the question of what was the definition, the mission, and the very programme of pacifism: C. Bouglé, Léon Brunschvicg, Max Hébert, Georges Michon, Ch. Braibant, Mgr. E. Beaupin, Thomas Barclay, Paul Passy, Georges Guy-Grand, Gaston Richard, Henri La Fontaine, Maxime Leroy, C.-G. Picavet, Charles Rousseau, Mlle M. Angles, Georges Hoog, André D. Tolédano, M. le pasteur Roser, Jacques Bois, Marcel Déat, M. le pasteur Jézequel, Roger Picard, and Charles Rist. 
with bad electricity'.197 The international situation wherever one looked offered nothing but irritation and disquiet. He enumerated the problems as follows: an inability on the part of nations, after the failure of the London Conference, to move beyond the most 'sterile and deceiving of dogmas, that of economic autarchy'; the 'visible decline of the League of Nations attacked not only in its prestige but in its very existence, through treasons and repeated desertions'; the impending failure of the Disarmament Conference which after two years of discussions 'goes from one prorogation to another in order to hide its impotence'; and finally, the repeated failures and defeats of democracy in a Europe which seemed to be 'three quarters submerged by the rising tide of fascism'. 198 The concept of 'peace through justice' seemed at once an old and a still very young slogan to Prudhommeaux. The worst of it all was that the international situation was reflected in extraordinary divisions in the pacifist camp at a time when unity was of paramount importance.

If only in France and in the world pacifists knew how to make a common front against the enemy in order not to be overcome! But never amongst us has the dispersion of efforts been larger in the domain of practical action, and never more profound the divisions in that of doctrine. ${ }^{199}$

Ruyssen presented the main report on the Crisis in Pacifism. He began by outlining the psychological reasons for pacifist confusion. Before the Great War, pacifist goals were modest and timid. The League had not yet been created. Pacifists fought war, according to Ruyssen, with a purely sentimental ideology and they had only one remedy to propose: voluntary arbitrations laid down in purely bilateral pacts. Two experiences completely overturned the world of primordial pacifism: the first was the Great War and the second, flowing out of it, was the creation of the League of Nations. These two events lay at the heart of the present pacifist confusion according to Ruyssen:

From there the opposition which divides pacifists according to whether their thinking is dominated by the one or by the other of these two experiences. For the first, it is the fact of the monstrous war which obsesses them, with its slaughter, its ruins, its abominations which renew every day for us the inexhaustable, ineluctable consequences. And thus, they feel rise in them a horror, a revolt, which obliges them to shout: 'Never again! Peace at any price!'. The others, on the contrary, are attached to the League of Nations, to its promises and its acts. And thence yet another new division in peoples' minds: certain of our members, shocked by the

197 Jules Prudhommeaux, 'Rapport Moral' in Jules Prudhommeaux, 'Notre Assemblée Générale, Paris 30 et 31 décembre 1933', PD 44, 2 (February 1934), pp.53-58, also p.49.

198 lbid., p.49.

199 Ibid. 
impotence and the failures of the Geneva institution, denounce it as a dupery and look elsewhere.- in a return to the state of things before the war or in the 'dictatorship of the proletariat' - the solution to the problem. Others, the 'juridically'-minded, seek to perfect, to complete, to reinforce the LoN, to draw out of it the super-state which will create Humanity. 200

Ruyssen thought that there were three possible objections which could be made to the association's device "la paix par le droit". The first was that there was an equivocation in the very definition of what droit stood for. This argument had been developed in Gaston Richard's response to the Enquête and was one made by Alain.

If you only admit of peace within justice or law, they say to us, you are throwing yourself outside reality, into a complete chimera. Because life is made of injustices...To correct these abuses, you will take the beati possidentes to task - and it will be war, generator of new injustices. When will this eternal flight from justice end? One speaks of the right to looe $e_{2}$ of the right to happiness:. These are but aspirations, as chimerical as the absolute right of peoples to dispose of themselves. Understood thus, the right to peace is a ferment of revolt, of anarchy and of war...201

Thus, for Ruyssen, one had to content oneself with a peace founded upon positive law, always changing, always imperfect, always referring back to rules, to codes, to a sort of unwritten law. There was nothing absolute or metaphysical about this law; it was in constant evolution. And it was necessary in this system of law to have more than a judge. Sanctions were needed, in the first instance moral or economic sanctions, but in the final resort, force had to be there as a deterrent. 'This is,' said Ruyssen, 'my totally realistic conception, in a still barbarous world, of peace through law' ${ }^{202}$

There were two other approaches which could be taken. The first was conscientious objection which he said had been debated thoroughly enough at the Boulogne AGM. The APD's position was essentially that of the Ligue des Droits de l'Homme, namely that the conscience of the objector must be respected, but that conscientious objection as an organised movement was wrong and inefficacious in the struggle against war. ${ }^{203}$

The final approach was the generalised version of a politicised conscientious objection, namely collective non-resistance in the face of aggression, or essentially the ChallayeEmery case discussed above. Ruyssen's argument against this option was simply that the case for this was based purely on opportunistic calculations of the potential risks entailed by a modern war. Challaye and Emery had both fought in the last war apparently

200 Théodore Ruyssen, 'La Crise du Pacifisme', in ibid., pp.62-3.

201 Ibid., p.63.

202 Ibid., p.64.

203 Ibid. 
without any qualms. Ruyssen asked, therefore, whether one was not permitted to wonder if the risks of a modern war were not being exaggerated, and if so, at what level of destruction a war became unfightable. The advocates of non-resistance also made much of the difficulty of knowing who the aggressor was in a modern war, but Ruyssen responded that the League ought to be able to develop some competence in this area, and that nations ought to agree not to pursue any war beyond their own frontiers. But the clinching argument, in his mind, was that by disarming totally and announcing in advance that one would not fight, far from lessening aggression, one was actually encouraging it in a very fallen world. 204

The debate was lively to say the least. There seemed to be a general tendency at this AGM to blame the Treaties of 1919 for all of the problems faced by Europe. Jeanne Mélin came right out and said that Hitler was the result of Versailles. ${ }^{205}$ A-M. Bloch argued that Ruyssen was too willing to accept the insufficiencies of 'positive law', and that what the association must continue to do was proclaim the ideal or 'pure' state of law to which international relations might attain. The hardline minority group was led by Jacques Bois, a professeur agrégé de philosophie, and René Valfort, who argued that it was a nonsense to try to achieve peace through law. Either peace was one's dominant concern, or else the law and justice were the primary values. One could not have it both ways. If justice were predominant in the mind of the APD, then logically one had to admit that the association's device could easily become, in times of international tension, la paix par la guerre or le droit par la guerre. Bois argued in his brilliant, if a little sophistical, response to the enquête on the crisis of pacifism, that the only strictly logical approach for a pacifist was to believe in the achievement of peace through peace. 206

In addition to the polarity which existed between Ruyssen and the tenants of the oldstyle pacifism on the one hand, and the proponents of a more integral pacifism on the other, there was an intermediate position typified by Jules Prudhommeaux who argued that pacifists should lead the way towards the acceptance of the rule of the League of Nations in cases of international aggression. He proposed that the League should constitute a sort of 'mutual assistance society' which by its international authority would pronounce on the rights and wrongs of international conflicts and organise an 'immediate chastisement' against any nation attacking another. He believed that this chastisement could very well

204 Ibid., pp.64-65.

205 Cited in Jules Prudhommeaux, 'Notre Assemblée Générale (Suite)', PD 44, 3 (March 1934), p.99.

206 Ibid., pp.97-99; see also Jacques Bois, 'Enquête sur la Crise du Pacifisme, Réponse de M. Jacques Bois', PD 44, 2 (February 1934), Pp.74-77. 
consist of economic sanctions which if effectively and unanimously applied would bring any nation quickly to its knees. 207

But as one member pointed out, Prudhommeaux proposal did nothing to resolve the problem of how to respond to aggression in the hic et nunc. The organisation he envisaged did not yet exist, or at least only in embryonic form. Georges Cadier remarked that Ruyssen's analysis was completely realistic, but that Prudhommeaux had his eyes turned towards the future and the ideal. And Ruyssen intervened to say that if he and Prudhommeaux appeared to be in opposition, they were in fact in agreement in essentials. It was only in their respective approaches to the present reality that they differed:

\begin{abstract}
On fundamentals we are in agreement. But we approach the problem from different levels of reality. If the great problem of the organisation of peace were resolved, if there existed a universal League of Nations, controlling, in a completely disarmed world, a force which could impose itself on everybody, then, fine, the national defence would be useless. But M. Bloch has said it: the repugnance of the great nations for undertaking agreements of mutual assistance is the sad fact which must be taken into account. There are still - Japan is an example - governments of prey. Aggression is still possible, that is the present; the league of nations, super-state, obeyed by all, that is the future.... 208
\end{abstract}

A composite resolution was hammered out which took into account A.-M. Bloch's arguments about the need to bring existing 'positive' law more into line with the association's vision of an 'ideal' law. The resolution was divided into three sections. The first proclaimed that the Association remained true to its device and its traditional programme. By 'Droit', it understood the 'ensemble of positive international institutions, anabgous to those which assure a relative order within states', comprising 1. 'precise rules governing the relations between states,' 2. 'appropriate procedures for the handling without exception of international differences', and 3. 'an international system of sanctions capable of quelling any attempt made by a state to pursue its national policies by force' ${ }^{209}$

The second section underlined the Association's view of the world and the style of pacifism appropriate to it. Far from considering the present system of international law as the definitive expression of the 'needs of human society', the association recognised that above the present positive law, there existed an ideal state of international law which had yet to be achieved. More particularly, it recognised that the treaties of 1919 were not intangible and that a revision of certain articles thereof was necessary. It believed furthermore that the League of Nations was a partial realisation of the state of ideal law,

207 Ibid., (Assemblée Générale), pp.98-99.

208 Ibid., pp.99-101.

209 Ibid., p.107. 
and it remained resolved to seek its further development and improvement. It noted that the league had been greatly weakened by the failure to resolve the crisis in the Far East, by the indefinite adjournment of the disarmament idea, by the withdrawal of Japan and Germany, and that as a result it found itself in 1933 in a weakened position incapable of guaranteeing respect for law in the world. As a consequence of this it was only natural that the peoples would continue to seek their salvation elsewhere. The continuing inequality in national armaments nevertheless created a system in which no state could be sure of its security. This led states to seek security in offensive alliances and in an arms race which could lead directly to war. The Association saw no possible solution for law or for peace outside a revivified and widened League of Nations, a League which would be capable of constituting a genuine 'mutual Protection Society against War' for its members. For this to be possible, not only moral and economic sanctions, but also an international police force would have to be instituted. 210

Finally, in a third section, the Association declared that while it was the duty of all pacifists to hasten the glad day when the international regime described above would become reality, in the interim it was necessary to support the idea of the national defence, despite the insufficiencies and perils it enshrined, because it 'constituted in a world still subjected to the evil forces of the past, a vital necessity, carrying with it for all citizens the exercise of their duty of national solidarity. 211

The first section of the resolution was passed unanimously minus one vote. The second and third sections were passed by eighty-four votes to eight, although as Prudhommeaux took pains to remark in his account of the Assembly, the vote was taken purely as an indication of feeling within the association and was without binding value. ${ }^{212}$

Thus ended the pivotal period of 1928 to 1933 for the APD. It had faced and dealt with the challenges posed to its conception of the world and the pacifist's place in it by reaffirming in its essentials the doctrine it had nearly always held. There was dissent - of varying degrees - within the association but in terms of its outward programme little had changed. It had encountered, examined and rejected conscientious objection as an acceptable method for pacifism, while at the same time demanding the recognition of the rights of conscience of individual objectors. In this it followed the same course as the ligue des Droits de l'Homme. Closely allied to the problem of objection, but quite distinct in the APD's mind, was the question of integral pacifism. This was rejected outright as a position likely to lead to war rather than prevent it. In the face of an increasingly splintered, balkanised French peace movement, the APD continued to believe strongly in the necessity

210 Ibid., Pp.107-108.

211 Ibid., p.108.

212 Ibid., p.106. 
of union, but it came to see in the period under discussion that differences in method between the various strands of French pacifism necessarily precluded such an arrangement. As we shall see in the next chapter, even within the confines of old-style pacifism, of the pacifism which saw as its reason for existence the support of the League of Nations, there was hesitancy and finally refusal on the part of the APD to consider outright union with other like-minded groups. But more importantly, the period 1928-1933 marked the parting of the ways between the old approach to the problem of peace and the integral pacifism which was creating for itself both a doctrine and a programme in those years. Finally, the period under discussion in this chapter clearly shows the impact the worsening international situation had upon the pacifist optimism of the twenties. The postVersailles world was breathing its last, French hegemony in Europe had passed, and the spectre of Nazi-inspired reoanchisme across the Rhine was beginning to produce a certain degree of Angst in France. We turn now to an examination of the impact of the rise of pessimism on the pacifism of the APD in the period from 1933 to 1938. 


\section{I.6. The Rise of Pessimism (1933-1938).}

If one can speak of changing paradigms within the peace movement in the interwar period, it was even more the case that the Nazi seizure of power represented a sea-change of such proportions that after 1933 it was no longer possible to discuss European politics in the same manner as before. The arrival of Hitler in the German Reichskanzlei is thus an event of conspicuous importance to a study of French pacifism. It changed the nature of the Franco-German political debate and in so doing it fundamentally altered the content and boundaries of the pacifist response to that debate. The tenants of the old-style pacifism were much quicker to realise the importance of the Nazi seizure of power and to adjust to it accordingly than were the proponents of new-style pacifism, as we shall see in the following section. This is not to say that they immediately understood the Nazi menace. They did not. But their political prise de conscience in the post-1933 world of international politics was much quicker than that of some other pacifists. This was undoubtedly a function of the APD's fervent attachment to the cause of justice. The Association, much like the Ligue Internationale des Femmes pour la Paix et la Liberté, was a bicephalous entity. If, during the twenties, this attachment to justice produced a narrowness of spirit and a certain rigidity of approach to the problem of peace, it became in the thirties a source of strength and insight when faced with the dubious proclamations of peace proffered by the Nazis. Running parallel to this clear-sightedness, however, was a tendency for some members of the APD wittingly or unwittingly to allow Fascist Italy and Nazi Germay to set the tone of the political agenda in Europe for the latter half of the interwar period.

Let us begin this section by examining briefly the reaction of the APD to the Nazi seizure of power and the changing evaluation of what Nazism meant for the peace of Europe up until about 1938. It is clear that Ruyssen especially recognised the dangers posed by Hitler very early on, although equally there seemed to be surprise that he had been successful in his bid for power. In his first comment on the Machtergreifung, Ruyssen set the tone for much of his future commentary by arguing for a cautious, careful, but far from pessimistic approach to the new Germany. He believed war to be possible, but not probable given the general economic distress then reigning and the still-fresh memories of the last war on both sides of the Rhine. But equally, it was clear that the peace was in danger. The 
rise of Nazism was largely a function of what Ruyssen now recognised to be the negative aspects of the treaties of 1919 'which have imposed on the vanquished bad borders', together with the economic crisis and the weakness of the democracies. ${ }^{213}$ He remained convinced of the need for Franco-German reconciliation as 'the essential condition of the pacification of Europe'.214 It had to be frankly admitted however, that conciliatory gestures from across the Rhine were few and far between. One could not be a pacifist alone. Peace was a communal effort, and if the desire for peace were not reciprocated across the Rhine then that left the peace-loving countries two alternatives: a war of defence or else peace in servitude. 'Choose who dares', he said! 215 What was needed was a pacifist sangfroid in the face of the challenges of Fascism and Nazism. He believed that general and simultaneous disarmament should continue to figure on the pacifist platform but it could never be a question of unilateral disarmament. Above all, the League of Nations needed to be supported and strengthened. 216

A couple of months later, Ruyssen addressed the issue of whether Hitler could be taken at his word. In his speech to the Reichstag on 17 May 1933 Hitler had made the usual attacks on the Versailles Treaty but had also made some conciliatory statements designed for public consumption outside Germany - assurances that war was unthinkable. Ruyssen thought there were the best reasons in the world to doubt Hitler's sincerity given that but four days previously, von Papen had revealed to the world that the word 'pacifism' had been struck from the German vocabulary. German pacifists were either in prison or else in exile abroad. Thus, for Ruyssen, the olive branch extended by Hitler had to be treated with the utmost caution. It was no longer good enough to maintain that there were two Germany's - one peaceful and the other bellicose. The most that could be said was that within the newly united National Socialist version of Germany, there were two competing tendencies. He thought he saw the tempering hand of the Wilhelmstrasse behind Hitler's speech and that was a good omen. In answer to his question, 'where are we going then?', he replied that 'all depends on the solidity of the moral front which Germany, to its great surprise, has just re-established against herself',217 and he put his faith in the Disarmament Conference.

The APD certainly did not lack for warnings about the situation in Germany from German pacifists. Hellmut von Gerlach, writing in the June 1933 number of the PD, discussed the idea of a preventive war against Hitler which some 'pacifists' apparently were advocating. Von Gerlach rejected such a notion categorically as against the pacifist

213 Théodore Ruyssen, 'Veillons!', PD 43, 3 (March 1933), p.94.

214 Ibid., p.95.

215 Ibid., pp 95-96.

216 Ibid., Pp. 94-95.

217 Thédore Ruyssen, 'Où allons-nous?' PD 43, 6 (June 1933), p.194. 
ideal. He underlined that Hitlerism was a danger to peace, 'but it is not a guaranteed war; this must be the line taken by all pacifists'.218 That said, he warned French pacifists about the dangers posed by weak thinking in opposing Hitler. 'He who preaches the doctrine of Tolstoy today in a country like France would assume a terrible responsibility; to apply it to a Hitler would be an invitation to the use of force'.219

There was a fine line separating calls for Franco-German rapprochement with the eyes wide open, and the calls of some pacifists for a rapprochement with Nazi Germany malgré tout. Ruyssen exemplified the former position with his early insight into the nature of Nazism and his continued hope in a peaceful future for Europe, contained within the parameters of a cautious modus vivendi with the Third Reich. The latter position, however, was typified by Régis de Vibraye at the association's 1933 AGM. De Vibraye presented a report entitled 'Is an entente with Germany impossible?, 220 which by virtu e of its political myopia seemed to open the way to the collaborationism of Vichy. De Vibraye was too willing by far to exculpate Hitler, to the point of claiming that Mein Kampf was an aberration of youth, written in the heat of the Ruhr crisis. ${ }^{221} \mathrm{He}$ warned against accepting the 'unintelligent' and 'nefarious' policies proposed by German émigrés. He qualified Blum's desire to put Germany in quarantine as 'dangerous', and viewed the threat of German expansionism in eastern Europe with equanimity. France, and not Germany, according to Vibraye, had become the anomaly in Europe with its rotten parliamentary institutions. As far as a potenti al Anschluss with Austria was concerned, de Vibraye declared that if 'the Archluss occurred with our participation, it would consolidate the peace. Let us be arbitrators and not adversaries'.222 Small comfort for democratic Austrians.

Von Gerlach attacked de Vibraye's naivete and declared that he could not share his views on Hitler's sincerity. In his view, it was clear that Hitler spoke two messages: one for internal German consumption, and the other for the listening world outside Germany's borders. Between Nazi Germany and democratic France there existed a 'redoubtable moral antagonism'. 223 Wolfgang Hallgarten, another German present at the AGM, took a much softer view, arguing that Hitler should be given time to evolve in the more anodyne direction of a Mussolini. All dictators want to retain power, and in his view this meant that Hitler would gradually become more amenable. ${ }^{224}$ De Vibraye finished the debate by

218 Hellmuth von Gerlach, 'Guerre Préventive?', PD 43, 6 (June 1933), p.197.

219 Ibid.

220 Report and discussion in Jules Prudhommeaux, 'Notre Assemblée Générale (Suite)', PD 44, 3 (March 1934), Pp.110-117.

221 Ibid., p.117.

222 Ibid., pp.111, 113-114.

223 Ibid., p.116.

224 Ibid., p.117. 
calling for France to put 'her reason, her logic, her experience of revolutions' to the service of Hitlerian Germany, and thus work, 'without dangerous illusion but also without a discouraged pessimism, towards a Franco-German rapprochement. 225

There are other examples of this multiplicity of attitudes towards the conditions of Franco-German rapprochement within the APD. They made clear that for some pacifists the betterment of relations between France and Germany had become an end in itself, devoid of moral and political content. Mlle Hélène Lhoumeau, the daughter of Pastor Lhoumeau, president of the Poitou federation of the association, wrote in a letter published in the review that after a prolonged period spent abroad working as an official of the League of Nations, she had the impression on her return to France that the pacifist movement had been 'chloroformed' and 'emptied...of all dynamic force'. 226 The bottom line was Franco-German rapprochement and she believed that it was founded upon a misunderstanding. Instead of trying to understand Germany as it was, France was trying to impose upon it a democratic face which conformed to its own conceptions. She believed, on the contrary, that if a rapprochement with Germany was desired (and she certainly desired it), then it would have to be with Hitlerian Germany, and not with an exiled minority. 227

But German voices continued to be raised against the idea that a rapprochement on Germany's terms was possible or desirable. Friedrich Wilhelm Foerster, the veteran German pacifist, pleaded in an 1935 article published by the review for a 'pacifism without illusions'.228 Foerster warned the French of the dangers they faced in Nazi Germany, predicting with amazing prescience the return of the Polish territories to Germany, the Anschluss, the dismemberment of Czechoslovakia, the colonisation and penetration of Russia, and finally the consolidation of an Eastern Bloc which would turn against the West. ${ }^{229}$ If some of the points of this prophecy were never fulfilled it was surely only providential. Foerster's prescriptions for pacifist action were three-fold; first, stop any thought of treaty revision; secondly, it had to be demonstrated that the Corridor and the other limitations placed upon the German borders by Versailles were just and necessary and designed to repair historical damage from earlier wars; and thirdly, with regard to disarmament, Foerster said that it was an outright lie to say that Germany was

225 Ibid.

226 Hélène Lhoumeau, 'Lettre à M. Ch. Rousseau à propos de "l'Allemagne contre le Droit"', PD 44, 1 (January 1934), p.18.

227 Ibid., p.19.

228 F. W. Foerster, 'Avertissements d'un pacifiste Allemand. Pour un Pacifisme sans Illusions', PD 45, 1 (January 1935), Pp.4-14.

229 Ibid., p.6. 
disarmed - the Allied powers needed to seek some clarifications from Germany and pursue an energetic policy. 230

There was thus much debate within the APD about the proper course to take in dealing with Nazi Germany. On the one hand was the Ruyssen camp which seemed to exhibit remarkably clear-sighted opinions on the nature of Nazism, and on the other hand were the occasional writers, perhaps representing a minority view within the association, who continued to press for a more indulgent approach to the new Germany. It is instructive to consider just how much the entire commentary of the APD in these years - from both tendencies within it - was in fact determined by the pronouncements of Nazi Germany, or to a lesser extent, Fascist Italy. One has very much the impression that the pacifist camp, and other elements of French political society as well, had been reduced to the underdog role of reacting to events across the Rhine rather than determining them.

A further example of this is the way in which Fascist claims of the need for more living space, more markets, more primary materials and so on became part and parcel of the pacifist debate within the APD at the time of the buildup to the Ethiopian War. For example, at the 1935 AGM, two well-meaning reports were presented, one on the division of primary materials in the world, and the second on the problem of over-population in certain countries. In both cases Italy was cited as a prime example of a country which was relatively over-populated and had access to very limited supplies of primary materials. 231 None of the statements made, nor for that matter the conclusions reached, can be reproached in the slightest for illiberality or obvious fascist content as such, but it is surely not coincidental that in a year in which Germany was beginning to flex its muscle, and more importantly, Italy was beginning to embroil itself in Ethiopia for precisely the issues raised in these two reports, the Association should have chosen to discuss them at its annual congress. In a completely unconscious way, the association's political agenda was being subtly set by forces well outside, and antithetical to, the pacifist camp.

Even someone as astute as Ruyssen, however, could be misled by the Nazi propaganda machine. Certainly up until 1935 or 1936, the APD's analysis of Nazism tended to oscillate

230 Ibid., pp.9-13. Foerster's thesis and conclusions were attacked by Louis François in 'Une entente franco-allemande est-elle donc impossible?', PD 45, 3 (March 1935), pp.139-143 and Suite in PD 45, 4 (April 1935), pp.195-204. François' argument is basically that Foerster's thesis leads straight to war, and that if a rapprochement with Fascist ltaly is possible then why not with Nazi Germany. Moreover, many of the 'revisions' which Foerster says that the Nazis want to see in the Europe created at Versailles had been on the cards anyway under the Weimar democrats. He notes the strange conjunction of thought which brings together a German pacifist and the French nationalists. The tone of the article is distinctly lowered by the reversion to the old conspiracy theory: François sees occult links between Blum, the socialists, Jewish finance and the arms manufacturers. He concludes that there is no reason in the world why France should not negotiate with Germany.

231 See the report by M. Maurette, Directeur-adjoint du Bureau International du travail, on 'La Répartition des Matières Premières', and that by Francis Delaisi on 'Le Problème des populations en surnombre' in J. Lahargue, 'Le Congrès de Marseille de la Paix par le Droit (Suite et fin), 28-29 Décembre 1935', PD 46, 4 (April 1936), Pp.170-175. 
from rejection of what Hitler said, to scepticism, through to acceptance. No doubt the desire for peace was so strong that it conditioned to some extent the response the tenants of old-style pacifism made to German peace overtures. In late November 1933, Prudhommeaux could write rather contemptuously of Hitler's pacifisme oratoire, taking a sceptical attitude towards his sincerity but arguing at the same time that France should take Hitler at his word and see how far meaningful discussions could actually proceed. 232 In 1935, to give some measure of the oscillation which beset the APD in these first years of the Third Reich, Ruyssen responded quite warmly to Hitler's speech to the Reichstag of 21 May, declaring that it was a 'categorical affirmation of peace'.233 He took a similar line at the time of the Saar plebiscite. He was disappointed that the vote went in favour of Germany, but declared that it had to be respected. Other problems remained to be sorted out with the Hitler government - the disarmament problem, Austria, Poland and so on - but Ruyssen saw in Hitler's speech after the plebiscite results became known, a declaration of his peaceful intentions:

Assuredly, the declaration made by $\mathrm{M}$. Hitler as soon as the result of the plebiscite was known, constitutes a precious element of appeasement. There is no longer, the Fuehrer affirms, any territorial argument between France and Germany; let us take note of that and let us not push away the hand that reaches out to us. ${ }^{234}$

A. Bloch, the vice-president of the Lorraine group of the APD, wrote an article in 1934 in which he argued that in the world as it was, pacifists would be obliged to work with men who despised and hated the very ideas they stood for. The interwar years had been ones of mistakes: Versailles, the failure to disarm when the opportunity was there in the twenties, and the failure to negotiate more agreements with Weimar Germany which now left France in the position of having to treat with Hitler. Opportunities had been lost and now one had to do business with Hitler. It was a 'mortal folly' to think that this could be done with one's eyes closed, using the ideas of Tolstoyan pacifism. He expressed the desire that

our friends in the minority, our brothers in the ideal, might leave their dream world and rally around us on the basis of our resolution of last December: that of a vigorously non-conformist and revisionist pacifism, energetically set against the injustices, the hypocrisies of the treaties, but no less resolved to resist all

232 Jules Prudhommeaux, 'Le Pacifisme Oratoire d'Hitler et Cie', PD 43, 11 (November 1933), pp.455-458.

233 Théodore Ruyssen, 'Le Discours du Fuehrer', PD 45, 5/6 (May-June 1935), pp.244-249. Cf. Lida Gustava Heyman's letter to Félicien Challaye criticising his attitude to this speech in BDIC DD FA Rés. 208/16, LGH to Félicien Challaye, Zürich, 11 June 1935.

234 Théodore Ruyssen, 'La Sarre a voté', PD 45, 1 (January 1935), Pp.1-2. 
attempts at violence, that is to say of injustice, for violence is unjust in its very principle. ${ }^{235}$

This seems to embody the central point in the APD's response to early Nazism: the necessity of negotiating and working with the Nazi regime in good faith, but without any illusions or false ideas about the sincerity of its statements.

The fervent desire to believe Hitler's words was gradually shattered by his actions. The events of the thirties, far more than the pacific platitudes of Hitler, caused the scales to fall from pacifist eyes. The three crucial events up until 1938 were undoubtedly the remilitarisation of the Rhineland which spelled the end of post-Versailles Locarno Europe, the Abyssinian war which brought international fascism aggressively out of the closet, and finally, the trauma of the Spanish Civil War which became a trial of conscience for many pacifists everywhere.

The growing sense of an impending conflict in Ethiopia preoccupied the APD in mid1935. The review published a number of articles and appeals in connection with what was occurring in Africa. Charles Rousseau in an article examining the juridical side of the conflict concluded that Italy had no business whatsoever in Ethiopia on the basis of the tripartite agreement of 13 December 1906, the bilateral Italo-Abyssinian friendship treaty of 2 August 1928, and more to the point on the basis of the League Covenant and the Kellogg-Briand Pact of which both nations were signatories. 236 The Executive Committee of the Association, in a meeting on 21 July transmitted to Emile Borel, the president of the Fédération Française des Associations pour la Société des Nations, a resolution on the nascent conflict in which it recommended financial, economic and if need be, military, sanctions against Italy. ${ }^{237}$ Likewise, at the end of August, Ruyssen in his capacity as president of the association, sent a message to the Conference for the Defence of the Ethiopian People held in Paris on 3 September. He underlined that the APD gladly associated itself with the efforts of other groups to defend Ethiopian independence against Italian aggression. The association 'categorically condemned the attack against the system of collective security and the League of Nations' by the actions of a member state against another member state before any peaceful means had been sought to resolve the conflict. ${ }^{238}$ But as another indication of how fascist demands cloaked under the guise of imperialist equity were being allowed to set the agenda for the APD, Ruyssen then went on

235 A. Bloch, 'Le Pacifisme a-t-il fait failliite?', PD 44, 3 (March 1934), p.134.

236 Ch. Rousseau, 'Les données Juridiques du Conflit Italo-Ethiopien', PD 45, 9 (September 1935), pp.349-357. Cf. Ch. Rousseau and Jules Prudhommeaux, 'Le Conflit Italo-Ethiopien', PD 45, 7/8 (July-August 1935), pp.307-313.

237 'Projet de Résolution soumis par le Comité Executif de "La Paix par le Droit" à la "Fédération Française des Associations pour la SDN"', PD 45, 9 (September 1935), pp.338-339.

238 'Message à la Conférence tenue à Paris le 3 Septembre 1935 pour la défense du Peuple Ethiopien', PD 45, 9 (September 1935), pp.339-340. 
to weaken his argument by stating that the juridical aspect of the problem was only one side of it. The other aspect which had to be considered was Italy's need for more living room and access to more raw materials and markets for its industry. Thus, while 'categorically' condemning the Italian position, Ruyssen had in a sense justified it. He recommended that the League explore ways of extending the mandate system 'to all territories in which the population is not yet in a state to administer itself according to the principles of civilisation'.239 Similar sentiments were contained in a letter addressed to Pierre Laval on behalf of the association by Ruyssen and Prudhommeaux on 3 September. 240

In October 1935 the APD published the text of an appeal to the French people by the English League of Nations Union in favour of a common front and collective action against Italian aggression in Ethiopia. A French umbrella group, the Comité d'Action pour la SDN responded with a similar text underlining that it was happy to see the British finally won over to the collective security argument which France had been propounding for years. 241 The APD welcomed the British initiative whole-heartedly, but emphasised the dangers for France if it should refuse to go along with the British proposals:

\begin{abstract}
The French must not hide from themselves [the fact] ... that at this truly crucial hour, what is being proposed in reality is the prevention by a timely intimidation of an aggression in Europe or in any other part of the world ....France is at the cross-roads. Which part will she choose? ....For if Great Britain, decided today to serve with all her energy and all her power the cause of peace and of justice, were not to be, as she expects, followed right to the end by our country in this work of communal salvation, for which she has assumed the greatest risks, would it not result from this in a more or less immediate future, a 'withdrawal' of English policy which would have the most serious consequences for France? ${ }^{242}$
\end{abstract}

When war finally did break out, the APD was pleased to see that the sanctions mechanism of the League appeared, at least initially, to work rather well. What was of most concern, however, was the effect the crisis had had on the Entente Cordiale. The British government had seen its position in Africa supported at best only lukewalmy by the French, whom Rousseau reproached for having done what Stresemann had been accused of

239 Ibid., p.340.

240 'Lettre à M. Pierre Laval, président du Conseil, ministre des Affaires Etrangères', PD 45, 9 (September 1935), pp.340-341.

241 Both texts are contained in La Paix par le Droit, 'Un Appel à l'Opinion Française. Que fera la France?', PD 45, 10 (October 1935), pp.386-390. The French were happy to see the British finally accepting the collective security argument. It will be remembered that Pierre Cot had underlined this as one of the fundamental differences between the French and the British conceptions of the organisation of peace. See Pierre Cot, 'La Conception Française de la Lutte contre la Guerre', PD 39, 4/5 (April-May 1929), pp.164-170.

242 Ibid., 'Un Appel...', p.389. 
doing in the past: 'on a finassế. 243 The English had asked for naval support in the Mediterranean, and the French had replied by demanding assurances of support in a future potential conflict with Germany over Austria or Czechoslovakia. This only displaced the problem and irritated the British without resolving it. Rousseau warned that the two essential planks of French foreign policy, the Entente Cordiale and the League of Nations, were in danger of being lost in the Ethiopian affair. ${ }^{244}$ In a retrospective look at the crisis Georges Scelle concurred with this analysis and condemned the Laval government for reneging on the policies of collective security pursued by France for fifteen years at the very moment when Britain seemed to have come round to a French view of this issue. 245 France's moral position as one of 'fidelity to the defence of Justice' had been lost:

Henceforth, it is understood in Geneva that France, in defending for fifteen years the thesis of collective security, has been thinking only of saving herself against the renascent and dreaded power of Germany. ${ }^{246}$

What is interesting in all of these analyses of the Ethiopian conflict is precisely the straight-forward response to Italian aggression by the writers of the APD. In an earlier time, this insistence on 'justice' and the necessity of defending it, if necessary by arms, would have been the province of the Right, and hardly of a 'pacifist' journal of largely Radical inspiration. But times had changed and with them the norms of political behaviour. Rousseau noted the confusion the Ethiopian conflict had caused in the French nationalist camp, where it had been expected that the aggresor to be faced in the thirties would be Germany. Candide had asked, 'Do you want to die for the Negus?'. but as Rousseau pointed out, Frenchmen had not been asked in 1914 if they wanted to die for Sarajevo, and it was now becoming questionable what the attitude of the Right would be if asked to die (potentially) for Memel or Austrian independence tomorrow. 247

The Ethiopian conflict was the subject of a report and resolution presented by Georges Scelle to the Association's Marseille Congress in late December 1935 . Scelle argued for the rigorous application of the Covenant and the defence of justice, which coincided exactly with France's interests in his view. 248 He declared that the situation far surpassed the confines of a purely Italo-Ethiopian conflict; the complete 'organisation of peace was in

243 Ch. Rousseau, 'L'Agression Italienne et les Sanctions', PD 45, 11/12 (November -December 1935), p.451.

244 Ibid., p.452.

245 Georges Scelle, 'Retrospective', PD 46, 1 (January 1936), pp.23-31.

246 Ibid., p.25.

247 Rousseau, 'L'Agression Italienne...', p.452.

248 Scelle cited in J. Lahargue, 'Le Congrès de Marseille de la Paix par le Droit, 28-29 Décembre 1935', PD 46, 3 (March 1936), pp.114-116. 
danger'.249 The 200-odd persons present at the Congress agreed with his analysis. A resolution, 'voted by acclamations', expressed the congress' alarm at the confusion in French public opinion on the Ethiopian war, and went on to demand the firm application of the League Covenant in order that other nations considering aggression might be deterred therefrom. 250

The re-militarisation of the Rhineland and the abrogation of the Locarno accords which it spelled, brought the growing threat of expansionist international fascism closer home to most Frenchmen. It came at a time of deepening ambiguity in the attitude of the French Right to Hitler. Ruyssen noted this growing equivocation in the interview accorded by Hitler to Bertrand de Jouvenel and published in Paris-Midi on 27 February:

An effort at clear-sightedness is all the more necessary since as a result of a reaction as curious as it was spontaneous, the remarks of the Fuehrer were received with marked favour by the same nationalist milieux which a couple of years ago applauded the occupation of the Ruhr and regarded the Weimar Republic with an incurable suspicion. Now, one finds in general nothing but reservations and scepticism in the so-called leftwing papers which for so long regarded Franco-German rapprochement as the surest means of guaranteeing the security of France against the perilous uncertainties of the present. 251

The de Jouvenel interview was remarkable not for what Hitler said, but for the questions which de Jouvenel left unasked and hence unanswered. Ruyssen presciently predicted that on one issue, the future status of the west bank of the Rhine, the Nazis would soon move. They did, even as Ruyssen was writing his article.

Ruyssen condemned the remilitarisation of the Rhineland as completely against international law and as the first step leading to war, in the East if not in the West. He saw clearly that Hitler was trying to neutralise the help France could give to the USSR and its other allies in Eastern Europe, 'in a word, take as many guarantees as possible for the success of the next war, to which the Reich is here and now resolved'.252 It would, of course, also facilitate greatly the Anschluss of Austria. What to do? Simply take Germany at its word and demand that as a proof of its oft-trumpeted desire for peace, it withdraw its troops from the Rhine and then negotiate in good faith a solution to all of the outstanding treaty problems. And if Germany should refuse this proposal, Ruyssen advocated not instituting a system of sanctions against it which would almost surely lead

249 Ibid., p.115.

250 Ibid., p.116.

251 Théodore Ruyssen, 'Le double visage de la politique allemande', PD 46, 3 (March 1936), p.135. Cf. Zeev Sternhell's comments about the importance of this interview in Zeev Sternhell, $\mathrm{Ni}$ droite, ni gauche. L'ideologie fasciste en France (Paris: Editions du Seuil, 1983), p.11.

252 Ibid., p. 140. 
to war, but rather of watching Germany's every gesture and of refusing to have the slightest meaningful diplomatic contact with it. The problem was, as Ruyssen now realised, that Hitlerian Germany no longer had the same concept of international law as the rest of the world. For it, the only valid law was now national law, and that emanated not from evolving juridical concepts, but rather from the person of the Fuehrer himself. $\mathrm{He}$ realised that on this basis it had become impossible to have meaningful conversations with the German government because the two systems of legal thought now represented completely distinct and non-interlocking sets. ${ }^{253}$ Ruyssen's conclusions about what to do in response to the Rhineland crisis were simply the following:

\begin{abstract}
Neither repression, nor concessions; let us avoid war, but let us not offer to a partner from whom everything separates us the guarantees of a negotiated peace; no economic blockade, which would only cause the innocent to suffer, but a sort of moral quarantine, that it would be most profitable to organise within the framework of the League of Nations - the reaction of nations resolved to maintain the peace against any positive aggression by Hitlerian Germany. ${ }^{254}$
\end{abstract}

Prudhommeaux once again took a much softer line than Ruyssen. He 'begged' the French government not to take an irreparable step, and he called on Britain to make its voice of moderation heard. Clearly for Prudhommeaux, the time to stop negotiating with Hitler had not yet come. He admitted that there was much in the Nazi system that was repulsive but he urged an examination of the German position to see what constructive policies for general European peace might emerge from it. 255

Charles Rousseau, too, rejected the arguments of some parts of public opinion and of some pacifists, that Hitler was after all merely demanding equality for Germany in the international sphere. This was a very simplistic and therefore very dangerous view of the situation. He asked rhetorically whether 'the existence of a demilitarised zone has therefore become a dishonour?'256 'Like Ruyssen, Rousseau centred the problem on the completely different conception of international law held by the Nazis. Locarno had been a glimmer of hope in the regulation of European affairs, but now he foresaw Nazi aggression in the East as a result of its abrogation. The blame for the Rhineland disaster had to be laid at the feet of the French nationalists who were complaining now about the lukewarm English reaction, while only six months previously they had been unwilling to support British action in Ethiopia. The man on the street was incapable of an objective

253 Ibid., pp.141-142.

254 Ibid., p.142.

255 Jules Prudhommeaux, 'France et Allemagne. Le Péril', PD 46, 3 (March 1936), pp.143-145.

256 Charles Rousseau, 'La dénonciation des Traités de Locarno devant le Droit International', PD 46, 4 (April 1936), p.196. 
view of the situation and completely uninterested in collective security, and the government did not have the courage or the intelligence to seek to convince him otherwise. 257 He underlined, too, the differences between the Hitlerian and Geneva conceptions of peace. The former put the 'vital rights' of the German people above everything, and Rousseau found it difficult to see how this could be reconciled with the ideas of the League. He concluded by reiterating his belief that peace and justice must be linked:

For us - and despite the fact that one French journalist has gone so far as to write that peace took precedence over justice 258 - we believe that to refuse today to base peace upon the force of law is to resign oneself tomorrow to suffering a peace imposed by the law of force. $^{259}$

The rise of pessimism was capped in 1936 by the outbreak of the Spanish Civil War. The first comment in the review came from the pen of Charles Rousseau who argued in the early autumn of 1936 for strict non-intervention and neutrality in the Spanish conflict. 'In this powder-keg which is the Europe of 1936', he wrote, 'the hour has not come for proselytism but for prudence'. 260 The desire of some extreme left-wing circles and indeed of some 'pacifists' for intervention in Spain had created an 'intervention mystique'. ${ }^{261}$ In his view the over-riding concern had to be that the general European situation was highly inflammable, no matter what one's sympathies were for the Popular Front or the fears one might have at the thought of a third Fascist state on France's borders. The only sane policy was strict non-intervention and he reminded Frenchmen that the war of 1870 had also begun in Spain. 262

There is no doubting where the APD's sympathies lay in the Spanish Civil War. For the good republicans of the association the Spanish dilemma was nothing short of tragic, but the general consensus seemed to be that Spain was not worth fighting for, that the ostensibly civil nature of the conflict had to be respected and that, above all else, Spain's trauma must be prevented from becoming a generalised European conflict. The latter point especially was the essential concern. Very early on, however, the writers of the review knew full well that the democracies' attempts at non-intervention were being made a mockery of by the Axis powers. Even in Rousseau's early article cited above, fears were

257 Ibid., p.197.

258 Henri Jeanson, 'La Paix prime le Droit', La Fleche, 21 March 1936 cited in ibid., p.198.

259 Ibid., p.198.

260 Charles Rousseau, 'Les événements d'Espagne', PD 46, 8/9 (August-September 1936), p.355.

261 Ibid., P.357.

262 Ibid., p.358. 
voiced at the 'one-way abstention' in the provision of arms to the combatants. ${ }^{263}$ There was thus no illusion about the possibility of isolating the Spanish conflict from the rest of European society. The decision that had to be taken was whether or not to support the Spanish government knowing that it might lead to an escalation of the conflict. This the APD decided it could not do.

The Association debated the Spanish question at its Congress held in Clermont-Ferrand in late December 1936. Henri Guernut, honorary Secretary-General of the Ligue des Droits de l'Homme presented a report and resolution on Spain, which was supplemented by two further resolutions from Ruyssen and J. Lahargue. Guernut said that France had bravely led the way in non-intervention, but it had not been followed. In the face of Italian and German duplicity, the question of intervention raised itself once again. It was heartily supported by the CGT and the Communists, but Guernut argued against it because to go back on her word would only serve to alienate France's ally Britain. The British, he reminded his listeners, had sympathy for neither one side nor the other in the Spanish Civil War. ${ }^{264}$ Guernut's resolution which was passed unanimously by the Congress did not have the courage of its convictions however. It admitted that the French government had subordinated 'its concern for the law, international usages, political friendship and military advantage' to the higher goal of Peace.265 It had asked other nations to do the same, but had not been followed by the fascist powers. Rather than draw the obvious conclusions from this sorry state of events, however, Guernut went on to recommend that Italy and Germany be given one more chance to come round to the French view. The policy of non-intervention, organised internationally, was to be attempted yet again, and then, and only then, if Germany and Italy refused to play according to the rules, sanctions might be applied. But that was some way down the road, and in the meantime, the APD (along with many other Frenchmen) hoped against hope that the Axis would see the light and cooperate. ${ }^{266}$ Ruyssen's resolution called for an armistice to be arranged under the aegis of the League, and followed by a popular consultation in Spain. 267 The third resolution, that by J. Lahargue, reflected again the concerns for the economic arguments justifying fascist aggression which have already been noted in connection with the Ethiopian conflict. It spoke of taking the legitimate economic needs of these powers into consideration and reaching an economic arrangement which would 'relieve the economic distress of the less

263 Ibid., p.356.

264 Guernut in J. Lahargue and Jules Prudhommeaux, 'Le Congres de la Paix par le Droit, Clermont-Ferrand, (Suite et Fin)', PD 47, 4/5 (April-May 1937), p.150.

265 Ibid., p.152.

266 Ibid.

267 Ibid., p.153. 
well-favoured peoples'.268 This sort of attitude on the part of the APD implied an unfortunate and unconscious acceptance of the attempts at rationalisation employed by the Nazi and Fascist regimes in order to justify their expansionist and aggressive policies. Ruyssen had already pressed this idea in a letter to Yvon Delbos, the Minister of Foreign Affairs, together with the idea of creating areas of sanctuary in Spain for the disarmed and innocent population. ${ }^{269}$

1936 was not a good year for the pacifists of the APD. The international situation seemed to be cracking apart at the seams and no one seemed quite sure what to do about it. As Ruyssen lamented at the end of the year, 'We have not changed, despite the treason of men and of events'.270 In early 1937 he issued an invitation to the association's members to join in celebrations of the APD's fiftieth anniversary. This provided him with the opportunity to reflect on the changes pacifism had undergone in the last half-centry. First, it had grown enormously. There were far more pacifists in 1937 than there had been in 1887. But in growing, it had also suffered from increasing diversity, not to say increasingly strange 'incoherences'. 271 The end remained the same for all pacifists, but the inspirations behind pacifism and the methods envisaged for achieving peace were so different that the various tendencies were often mutually antagonistic. He saw the basic division as that between two opposing poles. At one extreme was 'a pacifism which is primarily sentimental in its motives and negative in its conclusions'; opposing this was a pacifism 'above all rational in its principles and active and constructive in its methods'. ${ }^{272}$ This latter pacifism, which he called the 'most constant tradition' of the APD was one which

recognised in war an historical reality which one could not stamp out simply by means of imprecations, meetings and verbal resolutions, and which could only be overcome if one integrated the life of nations into a general system of law, of complete law, implying an international law, institutions and judicial procedures, and if necessary, sanctions - because peace has its price which must be paid. ${ }^{273}$

That was the pacifism of the APD, but Ruyssen recognised that there were many people within the association who held views better typified as sentimental pacifism. It is clear from this that although the lid had been kept on the theoretical debates of the

268 Mentioned in Jules Prudhommeaux, 'Notre Assemblée Générale', PD 47, 2 (February 1937), p.64.

269 Lahargue, Prudhommeaux, 'Le Congrès de la Paix par le Droit, Clermont-Ferrand...', p.153.

270 Ruyssen cited in Jules Prudhommeaux, 'Le Congrès de la Paix par le Droit, ClermontFerrand, 26-27 Décembre 1936', PD 47, 3 (March 1937), p.105.

271 Théodore Ruyssen, 'Le Cinquantenaire de la Paix par le Droit', PD 47, 2 (February 1937), p.50.

272 Ibid., p.51.

273 Ibid. 
early thirties, the issues were still very much alive for the APD. If the pacifism of the association had been discussed and 'defined' like so many articles of faith at the 1933 AGM, the faith had not really been completely internalised by all of its members. As Ruyssen said, the treason (if treason there had been) was most certainly that of men and events. The ideological attacks on the APD's conception of pacifism came at a time when the international situation and France's place in it were both worsening by leaps and bounds. As will become clear in Part II of this thesis, the new-style pacifism was providing a strident alternative which became more and more attractive to some pacifists as the ultima ratio of the old-style juridical pacifism increasingly appeared hide-bound, dusty and incapable of resolving the problem of peace without resort to force. As in the case of the LIFPL, whose commitment to freedom gradually took pre-eminence over the fight for peace, so for the APD the attachment to the cause of justice gradually assumed over-riding importance over the question of peace. The final divorce between justice and peace occurred in the period from 1938 to the outbreak of war in September 1939, and it is to that final period that we turn now. 


\section{I.7. The Paradigm Reaffirmed (1938-1940).}

The age of the Association's leadership, if not of its membership, combined with the disappointments of the thirties seem to have produced a period of sharp introspection for the APD in 1937 as it considered its future within French pacifism. In 1934 the executive committee of the association had examined and rejected a proposal for union of most of the groups belonging to the Fédération Française pour la SDN. It was felt that the APD represented an old, established and central position within French pacifism which surpassed the johnny-come-lately groups whose sole purpose was support of the League of Nations. The Nantes group defined the association's role in French pacifism as a 'central position ... between the extreme-left, pacifist at any price, and a Right too ready to see in the League of Nations as it was, the ultimate stage of pacifism'. ${ }^{274}$ By contrast the APD had been only too willing to participate extensively in the Rassemblement Universel pour la Paix organised by Lord Cecil and Pierre Cot; indeed Prudhommeaux served as a committee member of this organisation. 275 The mid-thirties were marked, then, by the continuing concern at the dispersion of pacifist efforts, and a willingness to participate as fully as possible in combined efforts for peace which did not infringe on what the association considered to be its independence, and its central place in French pacifism.

But to return to 1937, the APD seems to have undertaken in this year a quiet stocktaking and actually briefly considered merger with another association or else the

274 Jules Prudhommeaux, 'L'Association de la Paix par le Droit. Séance du Conseil de Direction', PD 44, 6 June 1934), pp.250-251.

275 For the APD's comments on, and participation in, the RUP see Ch. Rousseau, Jules Prudhommeaux, 'La grande pitie du pacifisme international: le "Rassemblement Universel pour la Paix"', PD 46,1 (January 1936), pp.43-46; Jules Prudhommeaux, 'Le Rassemblement Universel pour la Paix - La Conférence de Londres', PD 46, 4 (April 1936), pp.206-208; Théodore Ruyssen, 'Les Voies de la Paix. A propos du Rassemblement Mondial', PD 46, 8/9 (August-September 1936), pp.329-332; Odette Laguerre, 'Le Congrès du Rassemblement Universel pour la Paix à Bruxelles', $P D$ 46, 10 (October 1936), PP.397-400; Ch. Rousseau, Jules Prudhommeaux, 'Le Conseil général du RUP à Genève; le discours de Lord Robert Cecil; les Résolutions', PD 47, 4/5 (April-March 1937), pp.184-187; Odette Laguerre and Jules Prudhommeaux, 'Le Congrès Français du Rassemblement Universel pour la Paix, Paris, 25-27 Septembre 1937', PD 47, 11/12 (November-December 1937), pp.393-399. Ch. Rousseau and Jules Prudhommeaux, 'Lord Robert Cecil, Prix Nobel de la Paix pour 1937', PD 47, 11/12 (November-December 1937), p.417. Prudhommeaux and Ruyssen were members of the international committee of the RUP. 
cessation of its activities. There are subtle indications that something serious was happening at the top. For the first time since 1920, the association did not hold an AGM or congress in 1937. To be sure, many of its members were active in the French Congress of the RUP and other activities, the review continued to be published and so on, but the announcement in the review that the Fiftieth Anniversary Celebrations in Nimes, no less, were being postponed has a faint air of implausibility about it. ${ }^{276}$ This impression is reinforced by the 'pressing appeal' addressed by Ruyssen to the members of the association and the readers of the review in late 1937 . He described the executive committee meeting in Paris on 24 November at which the first question discussed was precisely whether or not the Association should disappear or perhaps merge with another pacifist body. The violent reaction against this idea of those members consulted by the Committee convinced it to go ahead with the Fiftieth Anniversary congress in the conviction that the Association de la Paix par le Droit would continue. 277 Secondly, it was very apparent that the APD was suffering a 'crisis of age', as Ruyssen called it. Several of its most prominent militants had either been present at its birth in Nimes in 1887, or else were of the same generation. It was time for young men and women to step forward and take the torch from the old and increasingly tired hands which had held it for so long. Many local groups also seemed to be faltering and Ruyssen appealed to the young to take over. 278

1937 was thus a pivotal year. It marked the beginning of the prise de conscience of most of the leadership of the APD, a sudden realisation that no more could be conceded to the fascist powers. The two crucial events of 1938 were undoubtedly the Anschluss and the Munich crisis. Sandwiched between them was the association's Fiftieth Anniversary Congress in Nimes. But as we have argued above, the realisation that war might not be avoidable began to penetrate the pages of the review as early as January 1938. In the first number of that year, Georges Scelle published an article in which he separated the two ideals contained in the association's device, and spoke of peace and of justice as two distinct entities. It seemed clear to Scelle that the democracies had searched for peace outside of justice and had not found it because the dictators had cynically violated every legal

276 See 'Le Cinquantenaire de l'Association. A nos Amis', PD 47, 8/9 (August-September 1937), pp.297-298.

277 Théodore Ruyssen, 'Pressant Appel aux Membres de l'Association et aux lecteurs de la Revue', PD 47, 11/12 (November -December 1937), pp.385-386.

278 Ibid., pp. 386-387. Mme Prudhommeaux in her rapport moral, given in the absence of her husband, at the AGM held in Paris on 23 January 1938, described the active groups within the APD as: Marseille, Saint-Etienne, Montpellier, Nantes, Chatellerault, Nîmes, Bordeaux, Saint-Foy-laGrande. Those which were lethargic were: Nancy, Boulogne-sur-Mer, Paris, the Federations of the Languedoc, the Vienne, the Pyrénees, and Versailles. Those groups which seemed to have disappeared completely were: Rouen, Lyon, La Rochelle, Limoges, Saintes, Ivry-sur-Seine, the Landes, Montpezat-du-Quercy, and the Federations of the Cevennes, the Charente and Poitou. See 'Rapport Moral' in M.-L. Puech, 'Notre Assemblée Générale, Paris, 23 Janvier 1938', PD 48, 3 (February 1938), p.66. 
precept and had prepared and waged war. The abdication of the democracies could be clearly seen in successive stages: the Japanese incursion into Manchuria in 1931 began the dismantling of collective security; the problem of unanimity demanded by article XI of the Covenant of the League created the hole through which demands for collective action went unfulfilled; the third stage was the continuance of Japanese aggression in China which went essentially unchecked; the fourth was the failure of sanctions against Japan, and the fifth was the Italo-Abyssinian conflict. All of these, he wrote, were 'the result of the $a$ juridical policies of M. Laval and several of his successors'. 279 He condemned public opinion for lethargically accepting the remilitarisation of the Rhineland. Spain however was the big crisis and still no action had been forthcoming from either the British or the French governments. Important fractions of French public opinion, he wrote, were blinded to the real issues of legality, freedom, civilisation and pacification - all of which remained very much in the background - because of the ideological divisions caused by the Spanish Civil War. The whole policy of non-intervention was wrong-headed, he believed, based as it was upon a misconception of what law and justice were really about. He remained 'profoundly convinced that if the governments of Paris and London had had the energy to oppose a categorical veto to the intrigues of the totalitarian governments while there was still time, these governments would have withdrawn...280 The governments hid behind what they claimed to be public opinion, an opinion which refused to envisage the slightest risk. This 'infantile' public opinion, he wrote, now needed to be guided towards accepting the fact that no more could possibly be conceded to totalitarian threats. The line had to be drawn, and for Scelle it had become necessary to affirm a slogan which he had hoped as a pacifist to see banished forever from human political discourse: Si vis pacem, para bellum. 281

Scelle returned to the attack in an article written just before the Anschluss in which he castigated the 'defeat of the democracies', a defeat which 'annihilated almost completely the results so dearly bought in the war of 1914-1918.282 This defeat existed on three levels. First, there had been a juridical defeat. The League of Nations was dead because it had lost what Scelle considered to be the three essential components of the Covenant: 'the guarantee of the governmental and territorial competence of its members (Art. X), the principle of respect due the treaties and rules of international law; and finally, the principle of the abrogation of the right to wage war, and the obligatory recourse to pacific

279 Georges Scelle, 'La Paix...et le Droit', PD 48, 1 (15 January 1938), pp.4-7. Earlier in 1937 he had already commented on the end of collective security in Georges Scelle, 'La Fin d'un Système', PD 47, 4/5 (April-May 1937), pp.169-172.

280 Scelle, 'La Paix et le Droit', p.10.

281 Ibid., pp.10-12.

282 Georges Scelle, 'La Défaite des Démocracies', PD 48, 4 (March 1938), p.129. 
procedures'. ${ }^{283}$ Flowing out of the juridical defeat, was the diplomatic defeat, essentially the failure of collective security. Finally, there was the 'moral defeat, and the prime example of this was the policy of non-intervention in Spain. 284 The big question was whether or not it was too late to limit the damage done and save the situation. The choice seemed to lie between the policies of Eden or Chamberlain, firmness or continued pliability in the face of threats. For Scelle, the choice was clear, but he feared that it would not be taken:

The virile choice would be the choice of the immediate danger, compensated by an energetic attitude and feverish effort at armament. We persist in believing that this would be the lesser risk.

But we are under no illusions. The democracies will choose the long-term peril, even if it be the peril of death. 285

When the Anschluss finally did occur in March 1938, Charles Rousseau wrote that it had proved easier to accomplish than the formation of a French cabinet. ${ }^{286}$ Perhaps the worst aspect of the crisis was the incredible extent of French disunity which it showed up; the intransigence of the so-called 'national' parties was most to blame in his view, and he darkly concluded that 'a 1938 Sadowa has occurred. Between Sadowa and Sedan there were but four years'. 287

The Fiftieth Anniversary Congress held in Nîmes from 19-21 April 1938 was thus a time of reflection on a glorious past combined with debate on a depressing present. 288 The question of colonialism and the economic bases of peace continued to figure largely in the association's deliberations, the former topic being covered in a report by $M$ Hubert de Monbrison, and the latter by Edgard Milhaud, Professor of Political Economy at the University of Geneva. ${ }^{289}$ But undoubtedly the core of the Congress was a discussion of the 'present tasks of pacifism'. This essential topic was covered in a report by Jacques Lambert, a professeur agrégé and the holder of the Chair of Peace at the University of Lyon, and in Ruyssen's report on 'Peace through Justice'. 290 The tone of both reports and indeed of the

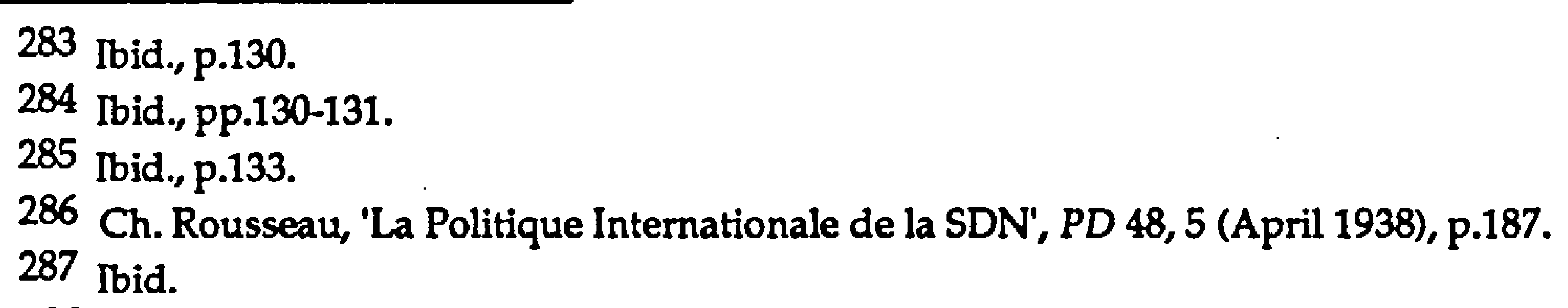

288 See Jules Prudhommeaux, J. Lahargue, 'L'Assemblée Générale et le Congrès du Cinquantenaire, Nîmes, 19-21 Avril 1938', PD 48, 6/7/8 (May-June-July 1938), pp.209-299.

289 See 'Les Colonies, terrain de lutte ou de collaboration entre les Peuples (Rapport présenté par M. Hubert de Monbrison)' and 'Sur la Réorganisation Economique du Monde, condition de la Paix future (rapport présenté par M. Edgard Milhaud)' in ibid, pp.278-289 and 293-297.

290 See Lambert's report, the ensuing debate and the two resolutions, by Lambert and Ruyssen, in ibid. pp.230-239. For Ruyssen's report on 'La Paix par le Droit', see ibid., pp.256-268. 
resolutions springing from them was the bitter-sweet mixture of pessimism and optimism pessimism for the immediate future, but clearly optimism in the long-term success of the APD's goals for building a better world.

Lambert emphasised in his report that it was not the League of Nations which had failed as such, but rather the governments which had broken with the Geneva institution and the moral obligations which it represented. The doctrine of collective security remained a sound idea, but its implementation had failed. He insisted that the famous trilogy - arbitration, security, disarmament - was still valid and the day would come when it would impose itself on international politics. ${ }^{291}$ The extent to which the pacifist debate had subconsciously accepted many of the Nazi/Fascist arguments about the nature of postVersailles Europe, was once again demonstrated by Lambert's musings on the need for conciliation even in 1938. Sadly he chose Czechoslovakia as his example and argued that while it would be 'odious' to abandon it, nevertheless the Czechs themselves had to admit that their state contained many internal contradictions which required the moral disarmament of its ethnic minorities. 292 This was the Achilles heel in an otherwise excellent report. Lambert's resolution spoke of preparing the public for the acceptance of the necessity of a temporary policy of re-armament. ${ }^{293}$ Ruyssen's resolution remained firmly attached to the League and collective security and declared itself willing to defend these principles by force if necessary. 294 Needless to say, there was tremendous debate both on the reports and the resolutions which arose from them. One speaker declared that fear was at the basis of French pacifism, but saw the greatest danger of the present hour in the continued bloodletting in Spain, rather than in the danger posed by Italy and Germany. Another speaker, Emile Giraud, condemned French pacifism's 'incoercible terror' of war, but Mme Prudhommeaux sharply defended the principle of not accepting any war until it was actually upon the nation:

Let us remain loyal to our past; let us refuse today any declaration implying acquiescence, even conditional, to war. The day on which the methods of law will have failed, the war will be inevitable, and may each one of us act according to his conscience. But until then, let us not proclaim that the next 'last' will be a 'war of justice'. We thought so, we said so for four years, from 1914 to 1918. And we received, in recompense, these nefarious Treaties of 1919 which created more injustices than they repaired. And since we are speaking of 'fear', she concluded with emotion, the mother that I am rebels against the ignoble realities of today's aerial warfare:

291 Ibid., p.230.

292 Ibid., p.231.

293 Ibid., p.239.

294 Ibid., p.238. 
yes, I have the right, I would say even that I have the duty, to be afraid for my children! 295

P. M. Masson, a professor at the Sorbonne, proposed an amendment to the resolution which would have seen an active preparation undertaken in French schools against the eventuality of war. This provoked in the audience what was 'discreetly called in parliament "des mouvements divers"', and the idea was quickly rejected. ${ }^{296}$ It is clear from all of the above, then, that the last pre-war congress of the APD was rent with the same divisions as usual when faced with the the question of pacifist tactics. Undoubtedly, the majority of the members present remained true to the Ruyssen conception of the association's task, that is to say, of the necessity of peace being laboriously constructed in justice, and if that proved impossible, the necessity of fighting to defend it. But it is also clear that many members - the Prudhommeaux' foremost amongst them - were terribly unwilling to grasp the nettle before them. No doubt they would have been horrified at the idea of 'peace at any price', but in their unwillingness to see that the Europe of Versailles was dead and even the cadaver threatened by Hitler, they unwittingly came close to the intégralité they professed to combat. It is clear from the account of the congress that there were other subtle currents representing variations on these two main themes as well, but the majority sense of the deliberations and vote was certainly in favour of the national defence against any further affronts by the fascist states.

There remained but one more major crisis in European affairs before the outbreak of war: the two-step dismemberment of Czechoslovakia. The APD's response to the Czech crisis can hardly be characterised as wholeheartedly munichois. Once again, the association seemed to revolve around two fixed reference points: Ruyssen's hardline anti-Munichois attitude and Prudhommeaux' softer approach. The official pronouncements made by the association condemned outright the attack on Czech territorial sovereignty. A press communique congratulated the initiative taken by Paris and London to resolve the problem peacefully, but bitterly attacked these same governments for 'imperiously' putting aside the attempt made by the Czech government to arbitrate the situation according to the 1926 Germano-Czech treaty. It nevertheless congratulated the Czech government for its 'sagacity' and sense of sacrifice in putting the European good before the Czech. ${ }^{297}$ The title of Ruyssen's article on the crisis, 'Peace outside the Law', said it all - he saw nothing but further trouble coming out of the Munich débâcle. 298 Prudhommeaux took the opposite view, however. He defended the government's actions at the Ligue des Droits de l'Homme

\footnotetext{
295 Ibid., p.234.

296 Ibid., p.236.

297 Théodore Ruyssen, 'Notre Effort pour la Paix,' PD 48, 11 (October 1938), pp.338-339.

298 Théodore Ruyssen, 'La Paix hors du Droit', PD 48, 11 (October 1938), pp.341-350.
} 
and in the pages of the PD.299 The divisions within the APD were further underscored by the publication of two essentially munichois articles by Maurice Lacroix and Henri de Man in the review. 300

The end was definitely now in sight. The January number of the review contained three articles all of which presaged the war which was only eight months away. P. Teissonnière enumerated the failures of collective security over the past twenty years and argued that justice had to have force on its side. ${ }^{301}$ Ruyssen was already addressing an article to 'our friends of tomorrow', in which he rejected categorically the four main political developments pacifism had made in the interwar period: conscientious objection which while to be respected on the genuine, and individual level, in no way resolved the social problem of war; non-resistance to war; the purely negative and sentimental pacifism based merely upon a horror of war; and finally, unilateral disarmament. 302 The most important of the three pieces, though, was that by $\mathrm{A}$ Bloch, on the 'necessary adaptations pacifism must make' in the wake of Munich and the ideological upheavals it had suffered. ${ }^{303}$ Since 1933 events in Europe had succeeded in turning the world of ideologies and politics upside down. Right and left seemed to have lost their traditional meanings as French nationalists supported Munich and refused to fight, while what he called the 'pacifists of the resistance' found themsilves in general agreement with the Communists (who had always castigated pacifism as a 'petit bourgeois' ideal), and some renegades from the Right. 304 $\mathrm{He}$, too, examined the mistakes of the past twenty years, but insisted that the time was not for recriminations, but rather for new ideas. Disarmament and even the League of Nations were now mere cadavers. What had to be recognised was that the league had always been an instrument, a means to an end, and not the end in itself. In this sense, the APD was undoubtedly in a stronger position morally than the groups which had the support of the league as their sole reason for being. For the APD the ideal could and would live on. For the moment, he argued in favour of energetic rearmament as a first measure, followed by an attempt at a European agreement, disarmament and a return to the principles of collective security if possible as long term goals. 305

299 Jules Prudhommeaux, 'La Ligue des Droits de l'Homme et la Paix en péril', PD 48, 11 (October 1938), pp.359-363.

${ }^{300}$ Maurice Lacroix, Henri de Man, 'Les lendemains de Munich: faisons la Paix!', PD 48, 13 (December 1938), pp.404-410.

301 P. Teissonnière, 'Faut-il résister aux violents?', PD 49, 1 (January 1939), pp.12-14.

302 Theodore Ruyssen, 'A nos amis de demain', PD 49, 1 (January 1939), pp.1-3.

303 A. Bloch, 'Adaptations nécessaires de la Doctrine Pacifiste', PD 49, 1 (January 1939), pp.4-7. See also the suggestive essay on the ideological changes occurring within pacifism: Joseph Folliet, Pacifisme de droite? Bellicisme de gauche? (Paris: Editions du Cerf, 1938).

304 Ibid., p.4.

305 Ibid., p.7. Cf. Georges Scelle, 'Péril de mort', PD 49, 3/4 (March-April 1939), pp.81-86 in which the author described the European situation in terms similar to those of Bloch. Scelle's article also contains the seeds of the epuration mentality in its search for someone to blame for the mess France 
The final dismemberment of Cechoslovakia in March 1939 put the last nail in the lid of the APD's remaining optimism. Georges Scelle informed readers that from a purely logical point of view, no one could now say that war was not inevitable. The final capitulation of the Czechoslovakian republic meant war in the long or short term. The only hope was that the coming of war would in the long run bring about the downfall of the dictatorships. 306

found herself in. He said that Munich ought never to have taken place (p.82), and blamed a 'certain pacifisme idéologique et passif qui nous a menés où nous sommes' (p.81).

306 Scelle, 'Péril de Mort'. 


\section{I.8. Conclusions.}

This first section of the thesis has attempted to show the nature of the old-style pacifism in France. The pacifisme ancien style of the Association de la Paix par le Droit represents better than any other competing organisation, the type of pacifism from which the new-style integral pacifism of the late twenties and thirties was to evolve. The APD was important because of its relative size within the French peace movement, the quality of its membership and leadership, and the consistently high level of political comment it was able to make in the period under discussion. Because it antedated by some twenty-five years the associations and societies which sprang up in the immediate post-World War One period to support the idea of a League of Nations, it had obvious claims to preeminence within French pacifism. It was also a society which embraced a surprising spectrum of dissent and variance of views on the nature of pacifism. This spectrum was not apparent in the immediate post-war era, but it began to become an issue by the late twenties with the rise of challenges to the hegemony of political thought enjoyed within French pacifism up until then by the APD.

The APD's raison d'etre was not bound up inextricably with the fate of the League of Nations. To be sure, the League represented the highest attainment so far in the realm of international political and juridical development, but unlike the societies which were wedded intellectually to the League, the Association had existed before the League and it would exist after it. This is not to say that the APD was not terribly disheartened by the apparent failure of the League idea in the late 1930s. It was. But as Bloch pointed out in the article cited above, the League was above all an instrument in the implementation of an idea, and if the instrument failed, or rather if men and events failed it, then another one could always be constructed: the important thing was the essential truth contained in the idea. 307

At the 1938 AGM, en pleine crise between Anschluss and Munich, Ruyssen had meditated on the essence of the APD's work in his report to the Congress. As we have seen many times, the APD considered its pacifism above all else to be positive and constuctive in

307 Bloch, 'Adaptations...', p.6. 
its prescriptions for peace. Flowing from this general philosophical position was its commitment to social, collective action as opposed to individual gestures which, while often deserving of respect, were essentially negative in their practical effect. These positive, constructive measures for peace could be divided, broadly speaking into two areas: the political and the pedagogical. On the political level, the APD acted as a pressure group, a think tank, speaking out during times of decision and crisis and trying by means of article, propaganda, public meetings, and letters to appropriate political figures, to further the idea of internationally organised peace. The effect of this programme of action on the political level is impossible to measure accurately. $308 \mathrm{So}$, too, is the effect of the second plank in the APD's platform, the pedagogy of peace. It was only natural that in an Association comprised of so many people in the teaching profession, the teaching of peace should occupy such a major part. With its summer schools, its contributions to international symposia on history, education, textbook reform, and its propaganda efforts once again, the APD undoubtedly left its mark on French and European society. How deep a mark it is impossible to say. There is much truth, though, in Ruyssen's comment to the 1938 congress that it was not inconsiderable:

I spoke above of the first of our tasks: the psychological preparation of peace, the education of minds. How to contest that in this respect we have realised a considerable work in collaboration with the other Peace Societies? If the French people whose armies have ploughed through Europe over the course of centuries, are today hostile to adventures and desirous of living in peace with all its neighbours, we have the conviction of having contributed to that. We have also certainly played a role in the penetration of the spirit of peace, equity and respect for other nations into public education in which we are proud to count so many friends. 309

1939 closed the circle for the APD, bringing it back to the unflinching affirmation of the primacy of justice and law over peace in its device, which had been its position during the Great War. The APD's thought evolved from initial suspicion of Germany in the early twenties to a gradual conviction of the need for Franco-German rapprochement. Along the way, the association was forced to debate and deal with the demands of the new, 'negative' pacifism which made its appearance in France in the late twenties. While often

308 Ruyssen, in his report 'La Paix par le Droit', to the 1938 Fiftieth Anniversary Congress in Nîmes, said as much: 'Or, en face de ce fléau de violence collective qu'est la guerre, les pacifistes peuvent bien jouer le rôle de l'ingénieur, de l'hygiéniste; ils peuvent proposer les plans d'une meilleure société humaine; mais après tout, ce n'est pas d'eux que dépend directement l'élimination de la querre: les artisans, en l'espèce, ce sont les Gouvernements. Tout notre rôle, en face de la catastrophe imminente, se borne à offrir nos plans aux Gouvernements et a les adjurer de faire leur devoir'. Cited in Prudhommeaux, Lahargue, 'L'Assemblée Générale et le Congrès du Cinquantenaire, Nîmes, 19-21 Avril 1938', PD 48, 6/7/8 (May-June-July 1938), p.263.

309 Ibid., pp.267-268. 
showing tremendous sympathy for the individual cases which the new pacifism produced, or even sometimes for the ideas behind it, the association nevertheless consistently affirmed its attachment to the positive ideal of peace through law. One senses that it came close at times to being seduced by the charms of the new-style pacifism, but always at the last minute held back. The arrival of Hitler to power in 1933 changed the political map of Europe and with it the mental universe of the APD which was quicker than many pacifist groups to understand the meaning and the threat of Nazism, although even here there was dissent within the association.

The APD represents the dashing of the reasonable hopes of reasonable men in a most unreasonable world. But the inherent optimism behind the view of moral and political progress held by the men and women of the APD precluded anything other than temporary pessimism about the final victory of their ideals. As Ruyssen, once again, said in closing his remarks to the 1938 congress:

As to the future.... I don't know what it will be. Will peace be saved? The League of Nations, after a passing crisis, will it regain confidence in itself? I do not know. Only one thing is certain: that is that peace will not be achieved if in the tempest pacifists themselves deny their ideal or despair. In order that the work of peace may be achieved little by little, the desires for peace must remain alive. For a half-century La Paix par le Droit has affirmed this desire. It cannot, far from it, claim to have realised all its dreams; but it is proud to have portended, and in a certain sense, marked, beaten, levelled the track on which humanity, weary of so many horrors and acquainted with so many sufferings, can finally wend its way towards a better destiny. 310

310 Ibid., p.268. 
PART II

PACIFISME NOUVEAU STYLE, OR THE POLITICS OF DISSENT 


\section{II.1. Introduction: The Origins of the New Pacifism.}

Part I showed how traditional pacifism developed within French political society from the end of the Great War onwards. This evolution followed an ascending curve in terms of pacifist commitment, culminating in the early thirties with the debate between Ruyssen and Challaye on the latter's contentious thesis in favour of 'peace without reservations'. Having reached this high-water mark, pacifisme ancien style began a retreat into a defence of justice and law as opposed to peace - a retreat which coincided with, and indeed was largely shaped by, the Nazi seizure of power and the succession of European crises which followed it down the decade to September 1939. The new pacifism which superseded it was integral or absolute, one which rejected and condemned all foreign wars. It was not synonymous with conscientious objection, nor with absolute non-violence, although these elements were certainly prominent within it. On the contrary, it occasionally espoused violence, or at least accepted it in cases of civil as opposed to international conflict. The new pacifism did not pretend to homogeneity either, but rather sought to group together all those who were opposed absolutely to any external war, and who were prepared to fight against such wars with a variety of means. In broad terms, it emerged from three types of dissent: historical dissent about the origins and nature of the First World War, a deepening divorce from French political society, and finally a growing conviction that modern warfare had become untenable by virtue of the magnitude of the destruction it could wreak upon society.

\section{Historical Dissent}

Mathias Morhardt, in a letter to Georges Demartial in the spring of 1936, wrote that

For the past twenty-two years, you and I have suffered an unspeakable moral and intellectual martyrdom. The atmosphere of imposture in which we live has poisoned all our joys. And we no longer have before us the hope of seeing the fog of hatreds dissipate, in which minds and spirits are so furiously agitating. This is because we are expiating the honour of belonging to a class of Frenchmen that is far too small. We are those, in effect, who 
suffer more from an injustice committed by France than from an injustice committed against her. ${ }^{1}$

This 'moral and intellectual martyrdom' of which Morhardt wrote was the fons et origo of the new pacifism. While the pacifists of the Association de la Paix par le Droit had accepted the need to fight the Great War, held it to be a just war which had been forced upon an unwilling France, and saw much good in the Versailles Treaty and the new Europe which it founded, the fundamental tenet of the new pacifism was a complete rejection of post-Versailles Europe and of all the premisses upon which it was built.

Fifteen years before pacifisme nouveau style finally emerged in the French body politic as a corpus of coherent and developed ideas, its foundations were laid in what was perceived by a small group of intellectuals to be the lies of the Great War. The primary critique was a rejection of Article 231 of the Versailles Treaty and the thesis of unique war guilt. This was followed closely by a rejection of the political and demographic nature of post-war Europe. In the minds of the new pacifists, the second flowed logically out of the first. If Europe continued to seethe with political problems which might lead to war, this .was precisely because of Versailles and the war-guilt 'lie'. As René Gerin wrote in the introduction to a brochure he published in 1933: 'The question of responsibilities for the war has not ceased to be current since the end of hostilities; it is becoming even more so because it is on this question which are hung all of the problems of world politics of our times'. 2

The foundations of historical dissent were laid in Paris in January 1916 when a small group of men met together to discuss the origins of the War as they could then be known. This group, known as the Société d'Etudes Documentaires et Critiques sur les Origines de la Guerre, quickly discovered discrepancies in the French government's case against the Central Powers as the breakers of the peace. ${ }^{3}$. The Society included in its number eminent men such as the economist Charles Gide, professor at the Collège de France, Mathias Morhardt, formerly secretary general of the Ligue des Droits de l'Homme, and Georges Demartial, a former under-secretary of state in the colonial office. None of these men was a political extremist, but they all shared a passionate desire for truth and justice, and they were appalled at what they saw happening around them in France as men and women of

1 M. Morhardt, 'Le respect des traités' (letter to Demartial dated Capbreton, 19 March 1936), Le Barrage 91 (26 March 1936), p.3.

2 René Gerin, Les Responsabilités de la Guerre de 1914 (Paris: Editions de la LICP, 1933), p.3. See also Georges Demartial, 'Les responsabilités de la guerre. Une réponse de G. Demartial à M. Camille Bloch', PH 105 (2 March 1934), p.2. See also Félicien Challaye, 'Raymond Poincaré, René Gerin, et les responsabilités de la guerre', Le Barrage I, 26 (8 November 1934),pp. 1-2. In late 1934 Challaye also published a series of articles in Le Barrage on 'Les responsabilités russes et françaises', and beginning in No.36 of Le Barrage, General de Montgelas began a series on 'L'explosion de la Guerre de 1914'.

3 See the account in Félicien Challaye, Georges Demartial. Sa Vie, Son CEuore (Paris: A. Lahure, n.d. (1950]), pp. 6-7. 
all political hues threw themselves into the Union Sacrée. With the war over, the group continued to publish harsh criticism of the Versailles Treaty and French foreign policy, especially with regard to their insistence on the total guilt of the Central powers. 4

In 1925 Georges Demartial published an article in the American journal, Current Affairs, contesting the Poincaré version of events in 1914. For his pains, he was expelled for five years from the Légion d'Honneur for having brought the French nation into disrepute. 5 He joined Victor Margueritte in the ranks of the victims of the Legion's purges. Rene Gerin, a former normalien, an infantry captain mentioned in despatches in the Great War and decorated with the ribbon of the Légion d'Honneur himself, was scandalised by the treatment meted out to Demartial and began his own investigations into the origins of the war. As an agrégé des lettres, he was eminently well-qualified to pursue these researches, which culminated in a book published in 1930 containing fourteen questions by René Gerin together with fourteen answers by Raymond Poincaré. This, together with his subsequent pacifist activities, earned Gerin, too, an expulsion from the Légion d'Honneur. 6

In 1926, Victor Margueritte, together with Armand Charpentier, founded the journal Evolution, whose contents and subtitle ('reoue mensuelle des questions intéressant l'apaisement international et le rapprochement des peuples') really underscored the developing nexus between new pacifism and the question of war guilt and war origins. Evolution was one of the primary journals of comment in France on the question of war origins, and attracted not only French commentators, but also German and American scholars and journalists as well.

By 1930, it was thus a well-established fact in the mental universe of integral pacifists that the Great War had been an unjust war, fought under false pretences, and that the peace which had resulted from it contained the seeds of a future conflict. It was the duty of pacifists to enlighten the public about these matters and in so doing put pressure on the French government to adopt different policies, primarily towards Germany. For right or wrong, this historical Weltanschauung provided the new pacifism with an antiestablishment political orientation which would last well into the Second World War. ${ }^{7}$

4 For a bibliography of Demartial's articles and books, see ibid., Pp. 28-54.

5 For Challaye's account of the affair, see ibid., pp. 14-15. For an account of the inquest and expulsion, see 'Le Dossier Demartial (Défense, Témoignages et plaidoirie)' in Evolution 30 June 1928), pp. 34-50.

6 René Gerin, Les responsabilités de la Guerre. Quatorze questions par René Gerin, Ancien Eleve de l'Ecole Normale Superieure, Agrégé des Lettres. Quatorze Réponses par Raymond Poincaré de l'Académie Française (Paris: Payot, 1930). On Gerin's expulsion from the Légion d'Honneur, see René Gerin, Honneur et Patrie ou Comment j'ai été exclu de la Légion d'Honneur (Paris: Editions de la LICP., 1934).

7 See for example, Georges Demartial, La Légende des démocraties pacifiques (Paris: Rieder/Presses Universitaires de France, 1939); and 1939. La Guerre de l'Imposture (Paris: Editions Jean Flory, 1941). 
The historical dissent over the question of war guilt and the origins of the Great War quite naturally manifested itself in the growing sense of estrangement which the nascent integral pacifists felt with regard to French political society. With the signing of the Kellogg-Briand Pact in 1928, integral pacifists tried to take governments at their word in their claim to have made war a crime. Conscientious objectors began to use this argument as one of the planks in their defence after 1928. By 1932, however, it had begun to become apparent that nothing much had really changed. The Geneva Disarmament Conference which opened in February of that year had been hailed by many pacifists as the one last chance they had of imposing their wills upon governments and of bringing national policies into line with the provisions of the Kellogg-Briand Pact.

It soon became clear, however, that nothing of the sort was happening in Geneva. In the four years from Kellogg-Briand to Geneva, the world situation for pacifists had swung sharply from one of optimism to one of pessimism. The deepening world depression combined with increased political turmoil in Europe conspired to wreck the hopes of many pacifists who began a retreat from participation in political society, and began to speak in extra-parliamentary, if not anarchist, terms of peace being an issue which the peoples had to impose upon their governments. All hope seemed to be lost in governments which were increasingly viewed as corrupt, unrepresentative, and completely in the hands of the capitalist class.

There was thus very much a socialist analysis of peace in the new integral pacifism, but it was coupled with a political anarchism which waxed and waned according to circumstances. In the 1933-1934 period, French integral pacifists became convinced that the greatest danger to peace was an internal one, in the form of French fascism. The conviction that Frenchmen had to 'sweep before their own doors' grew and provided a mirror image in the domestic sphere of the ideas held with regard to the question of responsibility for the Great War.

The enemy was within. As Michel Winock commented recently, 'the French expended much talent and energy during the thirties in a cold civil war'; this produced a 'francocentric myopia' which permitted the temporary reconciliation of the irreconcilable: antifascism and pacifism. 8 But the antifascism was directed at anternal danger and not so much at the outward manifestations of fascism in Italy or Germany. From the pacifist perspective, there were, initially at least, good reasons to be primarily concerned about the internal danger. Pacifist meetings were regularly the target for the excesses of right-wing

8 See Michel Winock, 'Le Fascisme passera... Pourquoi?', Le Monde Aujourd'hui (Supplément du numéro 12852 du Monde [Sunday 25-Monday 26 May 1986]), p.V. 
thugs, especially in the period up to 1934 and integral pacifism was the subject of continual vilification by the organs of the right-wing press.

Integral pacifism was also squeezed from the extreme-left. In the early years of the Ligue Internationale des Combattants de la Paix, Victor Méric, the League's founder, often complained in the columns of the Patrie Humaine of attacks by the Communists. The split became even more pronounced after the Laval-Stalin pact of 1935 which once again made Communists patriotic Frenchmen by rehabilitating military service for them. Integral pacifism in France was, then, subjected to a pincer movement between an extreme-left and a virulent proto-fascist Right which is probably unparalleled in the history of other modern peace movements. This was partially due to the extreme polarisation of Third Republic political society, but also to the political nature of much of French pacifism. Thus, paradoxically, while appearing to reject French political society, French integral pacifists were actually intimately bound up in it in an antipolitical movement which expressed itself in uniquely political terms. The result was that, shunned by the bien pensant middle, attacked by the extreme right and vilified by the extreme-left, French integral pacifism had nowhere to go. By 1939, the politics of marginality had become in France the politics of No-Man's Land.

\section{'Fraîche et Gazeuse - Fears of a Coming War}

The third strand in the origins of the new pacifism was the increasing sense that another war could destroy civilisation because of the progress made by science and technology since the end of the Great War. The 'bombing aeroplane' and gas warfare constituted the atomic weapons of the 1920s and 1930s. Writers were convinced that they spelled the end of civilisation if ever they should be released upon an unsuspecting humanity. Professor Paul Langevin provided the Ligue Internationale des Femmes pour la Paix et la Liberté with his considered scientific opinion that another war would be the last, given the progress made in the delivery of death by science and technology since 1918.9

In Paris, Victor Méric, a journalist on Le Soir conducted an enquête on aero-chemical warfare in 1930 which led to the foundation of the Ligue Internationale des Combattants de la Paix. He published a book on his findings the following year with the evocative and darkly amusing title Fraiche et Gazeuse. ${ }^{10}$ The theme of terrible destruction was a common one in the editorials of Méric and others in his newspaper La Patrie Humaine. It is also to be found in the league's more official newspaper, Le Barrage, from 1934 onwards. In fact, Le

9 Langevin's 'Déclaration', together with the accompanying petition organised by the LIFPL and a list of the original signatories are to be found in BDIC/DD/ FARés. 235/4/3.

10 Victor Méric, Fraiche et Gazeuse! La guerre qui revient (Paris: Editions 'Sirius',1932). 
Barrage carried a citation from Bertrand Russell on its masthead which gave utterance to the deep belief of pacifists that war could never be justified because of the destructive forces it would unleash: 'Not a single evil that one should like to avoid by war, is greater than the evil of war itself'. This is what Martin Ceadel has called the single important moral or philosophical advance of interwar pacifism: the enunciation of an apparently value-free rejection of war based purely on humanitarian or utilitarian grounds. ${ }^{11}$

It is difficult to say whether the impetus for this development in France came from abroad or not. It seems likely that the same train of thought was being followed by pacifists in several European countries at the same time. Whatever the case, fears of the next war allowed the integral pacifism of some intellectuals to be broadened into a pacifist campaign attracting mass support. If people were sometmes unwilling or unable to understand the complexities of the historical arguments about war origins, or to take sides in the politics of dissent with regard to late Third Republic political society, they most certainly were able to understand the inflammatory rhetoric of the propagandists of the LICP who fanned out across the length and breadth of France beginning in the winter of 1930-31. This croisade de la paix, as it was called, brought home to hundreds of French towns and villages the pacifist message that the next war would be the last. "It is probably true to say that it was this fear which contributed largely to the initial successes of integral pacifism at a time when it was manifestly clear that not much could be expected of governments at the Geneva Disarmament Conference. 12

To summarise this brief introduction to the new pacifism, it was based upon three lines of thinking which began to converge around 1928 and were united in a fairly coherent way by about 1931. 'The first was the continuing sense that the Great War had been fought under false pretences in France, and that the peace which flowed out of it was iniquitous and furthermore based on the lie of the unique war guilt of the Central Powers. Secondly, there

11 Martin Ceadel, Pacifism in Britain, 1914-1945: The Defining of a Faith (Oxford: Clarendon Press, 1980), pp. 13-15. Ceadel cites Bertrand Russell's adage in slightly different and later form: 'Modern war is practically certain to have worse consequences than even the most unjust peace'. This version is taken from Russell's 1936 book Which way to Peace?, cited in ibid., p. 216.

12 The government was particularly concerned at the spread of ideas relating to conscientious objection. The LICP was singled out as the organisation having the most impact across France in the spread of integral pacifist ideas. A report dated 19 April 1933 in the files of the Ministry of the Interior reads: 'La propagande pour la reconnaissance légale de l'objection de conscience et pour la libération des objecteurs de conscience emprisonnés a pris en France un grand développement depuis quelques mois, sous l'impulsion des associations pacifistes, en particulier de la Ligue Internationale des Combattants de la Paix. Non seulement les manifestations pacifistes se multiplient mais encore elles réunissent des auditoires de plus en plus nombreux. Elles attirent courament plusiers centaines de personnes et il n'est pas de ville de quelque importance qui n'ait été le siège d'une de ces manifestations'. See report entitled 'La propagande pacifiste et le mouvement en faveur de l'objection de conscience en France' in AN F7/13352. See also Appendix I of this thesis. 
was a growing feeling of divorce from French political society; the new pacifism embodied a belief in the efficacy of direct action by the masses upon corrupt parliamentary governments. Finally, the realisation by the end of the twenties of the terrible destruction the next war would bring, acted as the humanitrarian/utilitarian catalyst necessary, in company with the other two factors, to give birth to a new type of pacifism. This section of the thesis will examine the growth and development of this new type of pacifism in France from 1928 to the outbreak of war.

\section{Precursors of Integral Pacifism}

Integral pacifism emerged as a coherent, developed movement in the period from 1928 to 1930 , but its origins go back much further than that. Isolated individuals and numerically insignificant groups were precursors, voices crying in the wilderness, proclaiming the advent of a new pacifism which would respond to the growing aspirations of many people for a categorical rejection of war.

Probably the most important precursor in the French context was Romain Rolland, who in the dark days of the Great War defined almost single-handedly the nature of the new French pacifism already gestating in the minds of a generation marked in the trenches of northern France. Because of his courageous, albeit essentially elitist, stand during the war, Rolland was viewed as the grand old man of French, if not European, pacifism in the twenties. But his political evolution away from absolute non-violence, his flirtation with and then gradual embracing of a Soviet-oriented view of peace and pacifism, gradually left behind many of the people who had seen in him the John the Baptist of the new pacifism. ${ }^{13}$ For all that, his influence remained strong through-out most of the period under discussion, and it was with sorrow that French integral pacifists in the mid-thirties felt themselves obliged to leave behind the man who had been their spiritual guide for much of the pacifist pilgrimage.

There were, of course, other precursors to the new pacifism. One such was Marianne Rauze who published a number of small books and brochures on pacifism in the twenties. In one of these she defined the essence of the new pacifism as follows:

Antimilitarism - real antimilitarism - can only be achieved through absolute pacifism. It is in order to cause war to disappear immediately and definitively that the antiwarrior is

13 See Norman Ingram, 'Romain Rolland, Interwar Pacifism and the Problem of Peace' in Charles Chatfield and Peter van den Dungen, eds., Peace Modements and Political Cultures (Knoxville: University of Tennessee Press, in press). A copy of this chapter may be found in Appendix II of this thesis. It is largely based on the author's M.A. major research essay at the University of Toronto, and was read as an invited paper at the American-European Consultation on Peace Research in History, held 24-29 August 1986 at Stadtschlaining, Austria. 
antimilitarist. To be an antimilitarist is to work towards the total suppression of all the institutions that are instruments of death. ${ }^{14}$

Rauze prefigured many of the concerns of pacifists in the thirties. She underlined, for example, that antimilitarism must be collective and active. 'Emotions and feelings are nothing', she wrote, 'action is everything' ${ }^{15}$ Isolated, individual gestures were of little value; but they could become effective if they were organised into a mass movement. This concern for collective action was a predominant theme in all of French interwar pacifism. The individual gesture was usually respected but not recommended if it could not play a part in a larger collective movement. ${ }^{16}$ Finally, Rauze argued that in order for antimilitarism to be effective, it had to be international. Antimilitarism on the national level would be 'foolishness' because, far from being an obstacle to war, it would encourage the covetousness of neighbouring nations which had not disarmed. 17 This latter insistence on international action gradually gave way in the thirties to an emphasis on unilateral national pacifism, even in the face of Nazism.

Another theme in Rauze's book which was to become a commonplace of integral pacifism was her view of the League of Nations. She had nothing but scom for people who expected general disarmament from this 'powerless' body. She also attacked the old-style pacifists who continued to believe in defensive wars; and interestingly, she condemned the new 'revolutionary' pacifism which sought to justify a war fought for revolutionary reasons. The only real pacifism, she proclaimed, was that which refused all wars. ${ }^{18}$

Conscientious objection, which was a sub-set within interwar French pacifism, also began to attract its exponents and defenders in the twenties. Paul Bergeron founded a Ligue pour la reconnaissance légale de l'objection de conscience in Lyon in 1924, which after publishing a few tracts, seemed to lapse into lethargy. The twenties also saw the first of the rather spectacular trials of objectors in France which sent men of varying religious or political persuasions to prison for terms of six months to a year. Conscientious objection in France initially drew much inspiration from the example set in Britain during the First World War. Only in the thirties did it begin to find its own theoreticians in France, such as René Gerin. The connections between anarchism, libertarianism, and conscientious objection were always strong. For example, Le Semeur, a libertarian newspaper published in the Calvados, supported COs from at least 1924 onwards. 19

14 Marianne Rauze, L'Anti-guerre. Essai d'une doctrine et d'une Philosophie de l'antimilitarisme en 1923. Suivi d'une post-face de Romain Rolland. Préfaces de W. Wellock et Dr. Stoecker. (Niort: Imprimerie du progres, 1923), p.3.

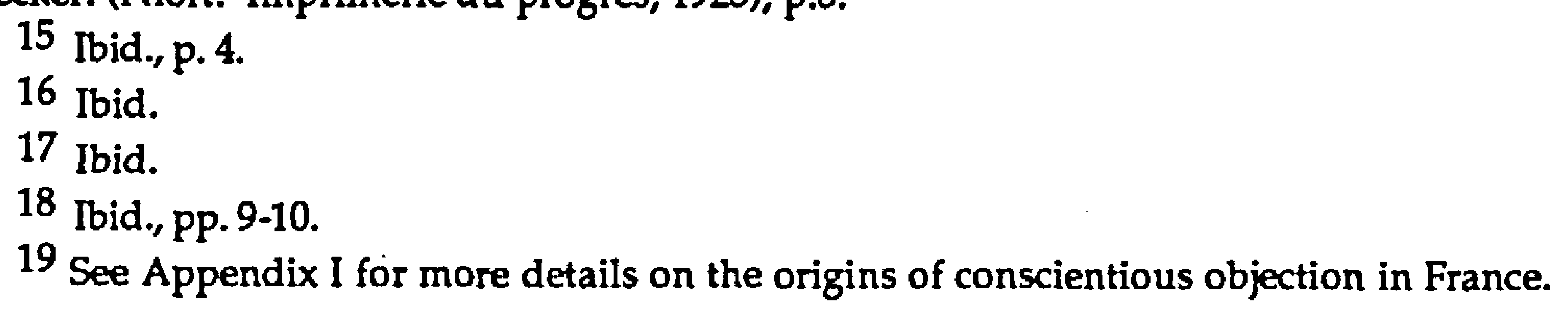


Integral pacifism also had its Christian voice in France in the 1920 s. The French branch of the International Fellowship of Reconciliation began publishing its Cahiers de la Réconciliation in the mid-twenties. Some of the most famous C.O.'s of the period, including Philippe Vernier and Jacques Martin, came from its ranks. 20

The Kellogg-Briand Pact provided much of the impetus to the development of pacifisme nouveau style. Many pacifists, and certainly not only the least educated amongst them, wanted to take the pact at its word and declare war a crime. Thus, for example, Francis Delaisi could declare at the annual general meeting of the rather staid APD in 1928, that forced to choose between his mobilisation papers and the Kellogg-Briand Pact which made war a crime, he would not hesitate to choose the latter. It was this kind of independent thinking which worried the authorities. 21

La Volonté de Paix, the organ of the peace movement of the same name, started by Madeleine Vernet in 1928, took much the same view. In its Manifesto it demanded that war be declared a crime, that immediate and total disarmament take place, and that all war matériel be destroyed and the public or private production of arms abolished. This manifesto gathered 10,000 signatures in France and 3,000 in Belgium by the late summer of 1928, but these numbers paled into insignificance beside the results obtained by similar petitions in England and Germany. By early 1931, the Volonté de Paix was claiming 30,000 signatures for this petition - still not an impressive number over a three-year period. ${ }^{22}$ Madeleine Vernet and the Volonté de Paix are important as examples of the nascent integral pacifism, but the movement never really became very large and its influence was limited accordingly. The group's organ appeared regularly at first, and then more and more intermittently, until finally, in 1936, the Volonte de Paix folded up and merged with the larger and more influential Ligue Internationale des Combattants de la Paix. ${ }^{23}$

But that is in the future. What is important is the fact that the Volonte de Paix was one of the first examples in France of the new style pacifism, albeit in rather limited and sentimental form. Probably its most important act over the course of its existence was the organisation in Paris in 1932 of two Conférences Libres du Désarmement, which brought together people who despaired of ever seeing anything significant come of the Geneva process. 24 The VdP's pacifist experience was, in effect, bounded by the two formative

20 See for example, Process de Jacques Martin (Aubervilliers: 'La Réconciliation', 1932); and Procès de Philippe Vernier (Aubervilliers: 'La Réconciliation', 1933),

21 See note 92 of Part 1.

22 See 'Manifeste de la Volonté de Paix', La Volonté de Paix (August-September 1928), p.4. See also 'Lettre ouverte aux 30.000 Signataires de notre Manifeste', La Volonte de Paix January -February 1931), p.l.

23 'Volonté de Paix et L.I.C.P.', Le Barrage 99 (28 May 1936), p.1.

24 There is some material on the two Conférences Libres du Désarmement in BDIC/DD/F $\Delta$ Rés 273/8. For the report on the first one, see Pour un désarmement Réel. Compte- 
experiences of Kellogg-Briand and the Geneva Disarmament Conference. In 1928, the Pact had given it the tremendous boost of optimism it needed to proclaim an end to all wars. By 1932, however, it was clear how little had really changed in the world situation and the VdP sank into lethargy after one last burst of pessimistic activity in organising the independent disarmament conference.

By the beginning of the thirties, the hope expressed by the German pacifist Kurt Hiller to Edmond Vermeil at the 1925 Universal Peace Congress in Berlin, that the two 'tendencies' within pacifism might continue to work together towards their common goal, was becoming manifestly impossible to sustain. ${ }^{25}$ The means began in essence to define the end - the type of peace envisaged by the different strands of pacifism. Thus, for the oldstyle pacifists, peace and pacifism were functions of law and justice. Later on in the thirties, the integral pacifists would also have to refute the arguments of those who sought to make peace a function of the social revolution. What was new and exciting in integral pacifism was its insistence on peace as the ultimate end. This ultimate end was to be achieved either through an individual rejection of war - conscientious objection in one form or another - or through concerted collective action which might involve the use of civil violence. The clearest nexus for the multifarious strands of thinking which defined it, and the most important new-style pacifist group in interwar France, in terms of numbers, intellectual depth, and certainly of radical commitment, was the Ligue Internationale des Combattants de la Paix, to whose examination we now turn.

rendu de la Conférence Libre du Désarmement tenue d Paris les 23 et 24 avril 1932 (Levallois-Perret: Edité par la Commission de la Conférence, 1932).

25 See Part I, note 55. 


\section{II.2. Years of Growth (1930-1934)}

The Ligue Internationale des Combattants de la Paix was the most important and influential of the new style pacifist groups in interwar France. This significance was based upon a variety of factors. First, the LICP was a numerically large pacifist group by French standards. Two and half years after its creation, Victor Méric claimed that it had almost 20,000 members. 26 Secondly, the LICP was important because it provided a consistently high standard of comment on French political affairs for the nine years immediately preceding the Second World War. Thirdly, it was a remarkably heterogeneous group composed of people from varying political, philosophical, and religious traditions, although the anarchist and socialist elements were always strongest within it.

Méric was the Dick Sheppard of French pacifism. The LICP was his creation, the response to his series of articles on the dangers posed by aero-chemical warfare. He almost single-handedly founded the Ligue in October 1930,27 and some four months later, the Patrie Humaine, which was the league's semi-official newspaper until 1933. Like Dick Sheppard and the Peace Pledge Union, Victor Méric and the LICP relied initially on an emotional response from a population pre-occupied by the rising political unrest in Central Europe and the fear of a coming war. The LICP sought to group together all those people who were resolutely prepared to fight against the fatality of war. But there the similarities end because Méric's league was essentially secular in character and was not explicitly non-violent in nature.

In his book Fraiche et Gazeuse, written between November 1930 and February 1932, Méric described the formation of the LICP. He elaborated the reasons behind the creation of yet another pacifist league in France. There was certainly no lack of pacifists, he wrote. There were those who remembered the horrors of the Great War; there were others who condemned war through a sort of sentimentality, still others based their rejection of war on a 'cold' rationality which detested the periodic and criminal massacres which humanity inflicted on itself. His purpose, he wrote, was to 'gather together all of these scattered

26 Figure cited in Victor Méric, 'Pour tuer la guerre', $P H 54$ (4-11 February 1933), p.1.

27 See Victor Méric, 'Rapport Moral', PH 59(11-18 March 1933), p.5. 
energies, to assemble them in a solid bundle and throw them irresistably against war....28 There were certainly many other pacifist groups in France: But they acted in isolation one from another, and 'the battle is carried out in dispersion'. ${ }^{29}$ What he wanted to create was a 'vast movement, a powerful association, brimming over onto the international level, capable of imposing its will on politicians and diplomats'; this organisation remained still to be created. ${ }^{30}$ Méric's desire in creating the LICP had been to found a group which would draw together pacifists of all origins, inspirations, backgrounds and political persuasions. The league's first appeal called for the union of

all energies, with no concern whatsoever for political, philosophical, or religious creeds. Believers or atheists, socialists or bourgeois, revolutionaries or conservatives, whosoever is decided to fight for peace is one of ours. No distinctions of class or of caste..... Only one thing counts: Peace. ${ }^{31}$

The LICP sought therefore to group together pacifists from all backgrounds. But Méric laid down one condition which he viewed as essential to the new group. The LICP was only interested in absolute pacifists, integral pacifists. Méric recognised that 'pacifism can be a vague aspiration towards peace' and in this sense, 'everyone is pacifist and it is the eminent Clément Vautel who is right'. ${ }^{32}$ But Méric rejected out of hand this vague pacifism which at the first call to arms would collapse in the heat of nationalist fervour. In contradistinction to an insipid pacifism, Méric defined integral pacifim as follows:

One is really, thoroughly, pacifist only on condition of having rejected, once and for all, the extravagant nonsense with which we have been brainwashed. I suggest in principle that for the true pacifist: 1. there is no national defence and 2. peace is only possible and lasting by total and rapid disarmament, without concerning oneself about the neighbour. ${ }^{33}$

Méric underlined the disaffection from the official diplomatic and political worlds of Paris and Geneva felt by the new pacifists. The tone of pessimism in his conclusion was paramount. Asking rhetorically what tomorrow would bring, he wrote that despite all the pacific palaver and talk of 'Guerre hors la loi', war still went on around the world. His view of political society was scathing in its denunciation of the abdication of leadership in France and elsewhere. 'Our leaders are mediocrities', he wrote, 'and the leaders of all nations are mediocrities'. ${ }^{34}$ But he provided no concrete answers to the problems he raised.

28 Victor Méric, Fraîche et Gazeuse, pp.239-241.

29 Ibid., p.241.

30 Ibid.

31 Ibid., p. 246.

32 Ibid., p. 247.

33 Ibid., p.249.

34 Ibid., p. 254. 
The pessimism of his approach to peace and politics was overwhelming. The vague calls to undefined action, the continual anathemas pronounced against war, gave voice to a pacifist nihilism of despair. In the early years of the LICP this cry was sufficient to rally thousands of people across France to the pacifist cause, but under the cold douche of postMachtergreifung reality, the angry rhetoric began to appear slightly sterile and empty. Practical, well thought-out approaches to integral pacifism became necessary and were increasingly formulated within the LICP from about 1934 onwards. But in this chapter we shall be primarily concerned with the House that Méric built, the LICP in the years of growth from1930 to 1934.

The LICP's first appeal spoke in apocalyptic terms of the approaching catastrophe hovering over everything, of 'cities destined to incendiary bombs, assassinating gases, and annihilation', in which the population would succumb to 'mortal panic, terror and misery'.35 The choice open to people was that between 'Devastation, Ruin and Madness' on the one hand, and Life on the other - all capitalised in shades of the religious tract. In political terms, the Appeal called for an individual response couched in antipolitical terms: 'We must rise up against the Masters and those Responsible, against the bellicist Insanity, against the Hatreds which throw the Peoples against one another'. ${ }^{36}$ Méric ended with a call to pacifist militant action. Peace had to imposed, and readers were invited to join the 'combat formation' of the LICP. A complete break was needed from sterile political debates, from the games that egos played, from the 'human intelligence which is spinning aimlessly, and applying itself desperately to a masturbation as conscientious as it is infinite. .37

Méric's appeal seems to have struck a responsive chord in France. The LICP grew quickly, as did the readership of La Patrie Humaine. A financial statement for the year 1 December 1930 to 31 December 1931 showed a total income for the league of 135,199 francs, of which some 61,000 francs had come from memberships, a further 18,000 from a voluntary subscription, and 39,500 francs which were raised at meetings across France ${ }^{38}$ - these are impressive sums for so young an organisation. By issue number eleven, the Patrie Humaine had become a weekly, and in early 1932 it was reported that 6,200 membership cards for the league had already been distributed for that year. ${ }^{39}$ A report about the LICP's first congress in Angers later in 1932 claimed that 200 delegates took part in the debates. This

\footnotetext{
35 Méric, Fraîche et Gazeuse, p.244.

36 Ibid., p.245.

37 Ibid., pp. 245 and 255.

38 'Comité Central de la Ligue', $P H 10$ (30 January - 14 February 1932), p.8.

39 A note on p.4. of $P H 12$ (20-26 February 1932), gives this information.
} 
included representatives of sixty-five sections numbering 7,000 league members, as well as the mandated representatives of a further 5,000 individual leaguers. 40

The local sections grew rapidly, too - especially those in the provinces. In February 1932 the Avallon section reported that it had 200 members, and at Limoges during a demonstration for peace, the section seemed disappointed to have collected only fifty new members. ${ }^{41}$ Two months later, the Saintes section numbered 200 members, and at a meeting held on 2 April at which Marcelle Capy, Rudholf Leonhard and Roger Monclin spoke, there were 400 people present. This was exceeded at St. Jean d'Angely, where 1200 people heard the league's propagandists speak in a converted hangar. 42 These meetings were not without their troubles. At Poitiers, the Camelots du Roi tried to prevent Leonhard from speaking but were given a thrashing instead by the pacifists and had to retreat to a local pharmacy to plaster their wounds. ${ }^{43}$

By the time he wrote his New Year's editorial in 1933, Méric was claiming that the LIPC had almost 16,000 members. The Patrie Humaine had a readership of about 20,000 , of whom 6,000 were subscribers. 44 A year later, after the trauma of the schisms between the LICP and the Patrie Humaine, further exacerbated by Méric's death in October 1933, Robert Tourly noted with satisfaction that all of that notwithstanding, the paper had infreased its print run from 18,000 in January 1933 to 22,000 copies in 1934.45 And a year after the schism, the LICP still claimed a membership of $12,000.46$ As has already been noted, Méric had claimed in early 1933 a membership of just under $20,000.47$

Clearly the numbers game is a dangerous one, but the LICP was indubitably a numerically important group in the first four years of its existence at least. As a rather alarming report in the files of the Ministry of the Interior put it in May 1933: the LICP 'estimates at 300,000 the number of mobilisable men who, touched by the propaganda of this organisation in France, are liable to return their mobilisation papers or destroy them in the event of a direct threat of armed conflict'. 48 Another, slightly earlier, report from an informer who appears to have been present at the LICP congress in early March 1933, reported that the LICP estimated its membership at 40,000 across France, although the

40 '200 délégués participent aux débats', PH II, 31 (2-9 July 1932), p.1.

41 'La Vie de la Ligue', PH 12 (20-26 February 1932), p.4.

42 'La Vie de la Ligue', PH 19 (9-16 April 1931), p.4.

43 Reported in ibid.

44 VictorMéric, 'Nos Souhaits', PH 49 (31 December 1932 - 7 January 1933), p.l.

45 R. Tourly, 'Bilan et Souhaits', PH 97 (5 January 1934), p.l.

46 'Précisions nécessaires', Le Barrage I,13 (9 August 1934), p.l.

47 See Part II, n.23.

48 'D'un correspondent', Paris, 2 May 1933. P.J./5 A-3870 in AN. F7/13352. See pp. 19-20 of Appendix 1 (n.35). 
money for only 5,000 memberships had so far been received by the Paris office. ${ }^{49}$ The latter point highlights the organisational confusion which attended the LICP's early development. Perhaps because of lack of staff, but more likely because of Méric's inherent distaste for organisations and centralised control, the LICP in its early years showed astonishing growth and an equally amazing capacity for self-immolation and disintegration which came to a head at this same 1933 congress. More will be said about that in due course. Suffice it here to say that the LICP was a major pacifist organisation by French standards in terms of the size of its membership. It had grown very rapidly and spawned a newspaper which had quickly become a weekly and was being distributed across France by Messageries Hachette.

For all that the LICP began life as a Paris-based organisation in which Parisian intellectuals played a preponderant role, it quickly developed a large base of support in the provinces. As the Interior Ministry report mentioned above made clear, by 1933 there was hardly a village of any importance in France which had not been the site of a pacifist meeting for which the LICP was held largely responsible. 50 The provinces began to outstrip Paris in importance, and this was likely one of the factors which led to the effective seizure of power by a group of provincial pacifists at the 1933 congress. The most important regional federations were undoubtedly those of the Calvados, Angers, and Algeria. All three of these regional federations were strong numerically, and their leaders - Emile Bauchet, Marcel Fouski, and Edouard Lemédioni respectively - played important roles in the development of the League after 1933. But that is to jump ahead somewhat.

The organisational weakness of Paris became apparent in the communiqués from the Paris sections in 1932. Parisians could be depended on to turn out for a mass meeting at the Salle Wagram or the Palais de la Mutualité, but the week to week work in the sections seemed difficult to sustain. Perhaps as Drevet remarked in 1938, the rural masses were more easily organised than the highly politicised urban populations. 51 For whatever reason, Paris seemed to provide the head to the organisation (although even this was disputed), and the rest of France the body. Thus, for example, the section in the 11th and 12th arrondissements in Paris somewhat bitterly complained in the autumn of 1932 that 'for almost a year now, we have tried to unite all of the Leaguers in our arrondissement into a section, ... Unfortunately, our efforts have not been a great success, since at our meetings we scarcely gather forty comrades, even though some 250 are on the books'. 52 The reporter from

49 'D'un corrspondent', 25 April 1933. A/3624 GB5 in AN F7/13352.

50 See note 12 above.

51 See Camille Drevet, 'Rapport Moral', Le Barrage 125 (17 March 1938), p.3.

52 'La Vie de la Ligue: 11e et 12e arrdt.', PH 40 (29 October-5 November 1932),p.4. 
the section in the 7th and 8th arrondissement echoed this criticism when he wrote that there was too much 'carelessness' in the section. 53

What is clear is that the LICP organised a very effective propaganda campaign across France in the winters of 1931-32 and 1932-33. It is impossible to ascertain the aggregate number of Frenchmen who heard the League's speakers, but the number must run into the tens, if not hundreds of thousands. For example, in June 1932, the Patrie Humaine reported that more than 3,000 people attended a public meeting in St. Etienne at which Pierre Scize, Méric, and Georges Pioch spoke on behalf of the League. Henri Jeanson, 'toujours fantaisiste', was also supposed to speak but missed his train and arrived at midnight. At Morlaix, in the Finistère, 1,000 people turned out to hear Méric, Leonhard and Robert Tourly on 4 June. 54 . In early 1932, Marcelle Capy spoke for the League at meetings in Hamburg, Munich, Berlin and elsewhere in Germany and Switzerland, and the Patrie Humaine reported that 'despite the Hitlerians' all of these meetings were successful demonstrations of fraternity between the two peoples. 55 Georges Pioch spoke before 30,000 people at the Palais des Projections in Barcelona, and later before an audience of 5000 people in the small city of Geronne. As a result of his Spanish tour, a Spanish section of the LICP was formed. 56 In Angers, Méric, Maurice Gilles and Louis Loréal spoke before 3,000 people in the CirqueThéâtre. Méric was clearly elated at the growth in the Angevin region; two months before, Angers had been completely ignorant of the league's existence, but now there was a section of 400 members active in the city. .7 In Brest on 19 February 1932, Marcelle Capy addressed 1500 people in the Salle Peloutier of the Maison du Peuple; the same edition of the Patrie Humaine reported meetings of eighty people in the small village of Sainte-Lazaigne (Indre), 250 people at a meeting held by Roger Monloin at Meudon, 600 present for a meeting at Quimper, and 1700 attending a meeting at Lorient. 58

Clearly something extraordinary was happening. Sections and federations were springing up across France and growing rapidly. One of the fastest areas of growth seems to have been the Calvados. A report on the Patrie Humaine in March 1932 on the Grande Semaine de manifestations pacifistes internationales outlined how quickly the Calvados federation had grown. The first LICP section in the department was formed on 3 January 1932. Twenty-four members contributed forty-five francs for a propaganda campaign. With this small sum as seed money, 400 posters and 20,000 prospectuses were printed and distributed across the department. The League's speakers were shuttled around in one of

53 'La Vie de la Ligue', PH 38 (1-15 October 1932), p.4.

54 'Notre Agitation', PH 28 (11-18 June 1932), p.4.

55 'Marcelle Capy en Allemagne et en Suisse', PH 10 (30 January-14 February 1932), p.2.

56 See short report in PH 10 (30 January -14 FEbruary 1932).

57 Victor Méric, 'La Paix est en Marche', PH 10 (30 January -14 February 1932), p.2.

58 Figures given in 'La Vie de la Ligue', PH 13 (27 February-4 March 1932), p.4. 
Bauchet's motor coaches, and although the whole campaign cost some 3,000 francs, the outlay was recovered by voluntary collections at the meetings. The result was that from being a section of forty-seven leaguers in January, the Calvados had grown to over 1000 members by March. 59

The Algerian federation also recorded spectacular growth. By late 1932, after a speaking tour by Pioch, Capy and Lemédioni during which a profit of 2,000 francs was made, the Federation reported that it now numbered fifteen sections. The speaking tour had seen fifty-three public meetings held, and the writer claimed that the LICP's propaganda had reached more than 200,000 people in Algeria. This might well be one of the reasons for which Gerin later in 1933 was forbidden by the authorities in Algiers from preaching the pacifist message to the indigenous population there. 60

Normally one might well be rather sceptical about the strict veracity of these figures, but they seem to represent a realistic assessment of the LICP's initial development. It will be remembered that the police and Interior Ministry reports cited above all came to the conclusion that the new pacifism, and especially the LICP, was making tremendous headway in towns and villages all across the Hexagon.61 The period 1930-1934 was one of growth for the LICP, but its flowering was to be short-lived. It remained an important organisation right down to 1939, but it began to shrink in size from about 1934 onwards.

At the time of the schism at the 1933 AGM, Méric claimed that the League had 18,000 members and the Patrie Humaine about 6,000 subscribers; this he contrasted to the League's first winter (1930-1931) just a little over two years previously, during which the organisation had grown from nothing to about 2,000 members. 62 Of these numbers only 10,056 league members were represented at the congress by 253 mandates. ${ }^{63}$ By the following year at the Montargis Congress, Rene Gerin reported that the number of leaguers was only about 11,000 - although it was difficult to be more precise because of some sections' unreliability in reporting their membership figures to the office in Paris. In any case, it was a far cry from the figure of 18,000 quoted the previous year at the Paris Congress. 64

These figures were called into question by the League itself only two years later at its 1936 Congress when Emile Bauchet revealed in his Rapport Moral that in 1933 the LICP had had 7,868 members, 7,617 in 1934 and 7,481 in 1935. He had arrived at these figures by

59 R. Henry, 'Un bel exemple à suivre', PH 16 (19-26 March 1932)

60 See 'La Vie de la Ligue: Alger', PH 47 (17-24 December 1932), p.4. See also Appendix I on Gerin's adventures in Algeria.

61 See Appendix 1 for further corroboration of the size of LICP meetings.

62 Victor Méric, Rapport Moral', PH 59 (11-18 March 1933), p.5. Robert Tourly, in his report on L'Activite de la Ligue' in ibid. claimed 'almost 20,000 members' and 'hundreds of thousands of sympathizers' in France.

63 'Congrès National de la LICP, 16-17 avril 1933', Le Combat pour la Paix 1 (May 1933), p.5.

64 René Gerin, 'Rapport moral sur l'activité de la Ligue de Pâques 1933 à Pâques 1934 qui sera présenté au Congrès de Montargis', Le Combat pour la Paix 10 (March 1934), pp. 4-5. 
the only effective means, that of counting the francs which arrived at the Paris office as the percentage of the membership subscription that was its due.65 While these figures are doubtless accurate, they probably do not reflect the total number of LICP members across France. It is clear from the reports published in Le Barrage and elsewhere that one of the perennial problems faced by the organisation was the unreliability of its local sections in the matter of sending the Paris headquarters the requisite percentage of the membership subscriptions they received. The 1938 Congress did not provide global membership figures, but only fifty-eight sections containing 2,560 members were actually represented when the meeting opened in Arras. ${ }^{66}$ To give some idea of the magnitude of the decline, at least in terms of the numbers of league members and sections represented at the Congresses, it is worth noting that in 1936 at the Congrès de Bernay, 107 sections comprising 5,728 league members had been represented. 67

If not an entirely accurate representation of the League's size, these figures nevertheless give some indication of the downward trend it was experiencing. Given the political situation, the 1939 reports on the League's health are surprisingly optimistic. Camille Drevet reported that there had been a surge in membership following the Munich crisis and most of the new members had remained loyal to the League. She believed that the number of members would exceed that for 1938, but unfortunately gave no precise figures. 68 In the report on the 1939 Congress, however, it was reported that only forty-three sections or federations were represented, and these contained a total membership of only 2,023 leaguers. ${ }^{69}$ Once again, it is clear that these numbers do not indicate the full extent of the LICP's membership because not all sections or individual members would be represented at any one congress. But it is equally apparent that the general trend in terms of membership was downwards from about 1934 on.

Further indications about the size of the League can be gained from an analysis of the number of sections, public meetings held, and subscribers to the Barrage reported every year. In 1933, Roger Monclin claimed that more than 600 meetings had been held across France, Algeria and Morocco since the previous congress. In the process some 500 cities or towns had been visited, and 200 LICP sections created. 70 In 1934, Gerin noted that there were 180 active sections with a further twenty or so which had fallen dormant. Six sections had been dissolved for a variety of reasons. There were also approximately 120 localities in which small groups of leaguers existed which had not yet been able to consolidate themselves into

\footnotetext{
65 Emile Bauchet, 'Rapport Moral', Le Barrage 87 (5 March 1936), p.4.

66 Cited in 'Les Travaux du Congrès d'Arras', Le Barrage 127 (28 April 1938), p.4.

67 Reported in 'Les Travaux du Congrès de Bernay', Le Barrage 94 (23 April 1936), pp. 3-4.

68 Camille Drevet, 'Rapport Moral', Le Barrage 145 (16 March 1939),p.4.

69 'Les Travaux du Congrès de Marseille', Le Barrage 147 (20 April 1939), p.4.

70 Roger Monclin, 'L'activité de la Ligue', PH 59 (11-18 March 1933), p.5.
} 
proper sections. ${ }^{71}$ The following year showed a slight increase in the apparent level of activity with 191 active sections, and a further hundred in the process of formation. The year ending in February 1935 had also been a good one for the League's propaganda; Bauchet reported that some 300 public meetings had been held. In this same period the LICP had alsoldistri buted some 100,000 copies of its Tract/Programme, 3,000 copies of its brochure, Programme, Tactique et Moyens d'action, 30,000 copies of the tract 'Enfants, ne jouez pas à la guerre', 20,000 copies of the tract 'Aux Travailleurs', and a large number of propaganda posters and post cards. In addition Bauchet estimated that about 400,000 copies of theBarrage were circulating in the country. ${ }^{72}$

1936 produced another strong showing on the propaganda front with about 180 lectures or meetings held over a five month period in forty or forty-five departments. 150,000 copies of the League's tract 'Nos principes' were distributed. The number of sections seemed to have fallen, though. It will be remembered that 1936 marked the beginning of a slump in the membership figures. It also saw the number of sections decrease to 158 with an additional twenty-nine in either dormant or embryonic stage. In 1938 no global figures are given, but apparently the League had lost five sections, while gaining seven. Having said that, Camille Drevet acknowledged that the work was more difficult in the highly politicised urban areas than in the countryside. The Paris office had organised more than 200 lectures or meetings, though, in the period ending March 1938. The number of subscribers to the Barrage was slipping however; in 1937-1938, only 2,300 league members held subscriptions, along with about 300 non-leaguers. ${ }^{73}$

Because of the Munich effect, the 1939 Marseille Congress was vaguely optimistic about the League's future. Although only forty-three sections comprising 2,023 league members were represented at the Congress, Gerin reported that Munich had created a great upsurge in subscriptions to the journal which now stood at approximately 3,000 league members, and a further 350 non-league members. If nothing else, the last figures show that the number of sections represented at the Congresses had little bearing on the aggregate number of league members, at least not in the latter half of the decade. ${ }^{74}$

The above figures give some impression of the numerical size of the LICP and the extent of its propaganda. The growth of its financial side was also rapid. In the financial year

71 Gerin, loc.cit. 'Rapport Moral', Le Combat pour la Paix 10 (March 1934), p.4.

72 Emile Bauchet, 'Rapport Moral', Le Barrage 43 (7 March 1935), p.4. Bauchet listed the departments which were 'relatively untouched' by the LICP's propaganda as: Manche, Morbihan, Vendée, Eure-et-Loir, Oise, Ardennes, Meuse, Seine-et-Marne, Aube, Cher, Nièvre, Sãone-et-Loire, Creuse, Allier, Cantal, Aveyron, Pyrénées Orientales, Var, Basses-Alpes, Hautes-Alpes. All other departments had been reached.

73 Camille Drevet, 'Rapport Moral', Le Barrage 125 (17 March 1938), p.3. See also René Gerin, 'Repport sur le "Barrage"', Le Barrage 125 (17 March 1938), p.4.

74 Figures cited in 'Les Travaux du Congrès de Marseille', Le Barrage 147 (20 April 1939), p.4.; and René Gerin, 'Rapport sur le "Barrage"', Le Barrage 145 (16 March 1939), p.4. 
ending 28 February 1934, the LICP had receipts totalling 137,132 francs. ${ }^{75}$ The following year at the Agen Congress, the League itself had receipts totalling 117,127 francs; the separate Barrage account had an income that year of 106,525 francs. ${ }^{76}$ By 1936, the LICP's financial outlook was once again improving. The league account showed a surplus of 25,000 francs on an income of 151,214 francs. The Barrage took in some 110,000 francs but had an outlay of 118,000; the situation for the Barrage was actually much worse because it was carrying a deficit of about 106,000 francs. ${ }^{77}$ The 1938 financial report does not distinguish between league and newspaper; total receipts of 166,063 francs are recorded. ${ }^{78}$ The 1939 Congress reports gave no financial details whatsoever aside from the impressionistic claims mentioned above about the league's membership rising substantially after Munich. ${ }^{79}$

The composite picture, then, is one of an organisation which experienced enormous initial growth, in terms of membership, subscribers, financial returns, and in the extent to which its ideas were spread across France. This was followed by a levelling off from about 1934 to 1936, followed by a gradual downward spiral thereafter, only partially off-set by the Munich effect in late 1938 and early 1939. Even at the end, though, the LICP probably had claims to being the largest and most influential pacifist group in France - either oldstyle, or new.

\section{The Nature of the LICP's Pacifism.}

The preceding pages have given some idea of the extent of the LICP's propaganda campaigns during the thirties in France. But what of the intellectual content of these campaigns? What sort of pacifism was the LICP propounding, and what sort of tactics did it envisage in its fight against war?

The answers to these questions are complex, especially for the initial period (19301934) under discussion here. In the general intellectual effervescence in which the league appeared there were many apparently contradictory approaches to integral pacifism, for all of which the LICP tried to provide a home. The spectrum spanned everything from absolute non-violence to a revolutionary pacifism which, while eschewing external war, was not all averse to a little civilian blood-letting now and again. The predominant elements within the LICP were those of socialism and anarchism. There was also a minority of Communists, but they were discouraged by their party from having too much to do with petit-bourgeois pacifism like that of the LICP. As far as the Christian community

75 Emile Bauchet, 'Rapport Financier', Le Combat pour la Paix 10 (March 1934), pp. 5-6.

76 Louis Léger, 'Rapport Financier', Le Barrage 43 (7March 1935), p.4.

77 Emile Bauchet, 'Rapport financier', Le Barrage 87 (5 March 1936), p.4.

78 Y. Dandieu, 'Compte-rendu financier', Le Barrage 126 (31 March 1938), p.4.

79 See Camille Drevet, 'Rapport Moral', Le Barrage 145 (16 March 1939), p.4. 
is concerned, the LICP did attract a variety of Catholic and Protestant members, but the marriage between the political avant-garde and the churches was always rather uneasy.

Méric had originally envisaged the League as a haven for all forms of absolute pacifism. In his mind, the sole qualifying characteristics of the integral pacifist were a complete rejection of the idea of the national defence, and a commitment to working towards total, rapid, and if need be, unilateral disarmament. ${ }^{80}$ Within this very broad framework, anything was possible. There were thus LICP members who advocated absolute nonviolence, those who believed in armed insurrection, advocates and opponents of civil war, proponents of judiciously planned assassinations of those 'responsible', and the list goes on.

By early 1932, Méric had expanded the two first principles of the LICP into four: 1) negation of the idea of the national defence, 2) struggle against war by all means; 3 ) pacifism to be placed above the political parties and governments, and 4) the struggle for the union of the Peoples. ${ }^{81}$ The Appeal disclaimed any interest in creating an organisation of 'followers' - LICP members were to be free individuals making a collective statement against war. It also underlined the eclectic nature of the LICP and its willingness to consider a very broad spectrum of tactics under the general rubric of pacifism:

If, taking no account whatsoever of the popular desires for peace, some lunatics were to let loose the massacre, the peoples thus placed before the fact of war would have to resist by all possible means: general strike, individual or collective revolt, passive or violent, according to the individual decision, freely taken, of each man placed before his duty and his responsibilities... We must teach men to be MEN. 82

The propensity to consider anarchist tactics and revolutionary violence as legitimate pacifist methods is one of the distinguishing characteristics of French absolute pacifism which sets it apart from the primarily ethically inspired pacifism of the Anglo-Saxon world. There were certainly those pacifists in France who were integrally pacifist in the British sense of the word (the members of the small Mouvement International de la Réconciliation spring to mind). These pacifists existed within the LICP as well. But what is interesting is the juxtaposition of non-violent and violent pacifism in mainstream French integral pacifism.

Largely under the influence of Méric, the LICP in its first few years of activity embodied this eclectic approach to the politics of peace. Under the effects of the pincer movement from Left and Right discussed briefly above, the LICP developed a 'rhetoric of

\footnotetext{
80 See note 28.

81 'Appel', PH 20 (16-23 April 1932), p.6.

82 Ibid.
} 
violence' in its discussion of pacifist tactics and political problems. In so doing, it created a semantic reflection of the violent abuse of which it was itself the object - primarily at the hands of the extreme-right-wing press. No doubt some of this rhetoric of violence was due to the anarchist analyses underpinning much of the LICP's world view, but equally one could argue that it is yet another example of the extent to which the fabric of late Third Republic political society was frayed, and the political temperature rising. The vitriol which was so liberally splashed about in the course of the pacifist debate was in some respects a warm-up to the épuration mentality.

Examples of this rhetoric of violence abound in the LICP's language of political discourse. In early 1932 the LICP held a large rally at the Salle Wagram in Paris at which Pioch, back from his Spanish tour, and Marcelle Capy, back from Germany, were the featured speakers. Pacifist meetings in the Paris area especially, had been the target of attacks by right-wing extremists 83 and at this meeting at Wagram all of the leaguers who had been wounded in clashes with the Camelots du Roi and their ilk were collectively made the honorary chairmen. Maurice Gilles, who chaired the meeting, warned the .'gigolos du Roy', 'Taittinger's little boys', and the 'Croix de Feu in the pay of Coty' that interruptions and an uproar would not be tolerated. Méric was more explicit, warning that 'we are determined, if need be, to get rid of those responsible'.84 Demonstrating his essentially non-conformist, anti-political stance, Méric wrote in the same number of the $P H$, that honest, ordinary people were in a state of legitimate self-defence vis-à-vis the government:

We shall draw up a list - the red list. We will give their names, their professions, their biographies. It is necessary to know against whom one is fighting, the day on which by their filthy provocations they succeed in precipitating the catastrophe.

We, too, will have our 'Carnet B' ... we will take our precautions and pillory them, ... while waiting to line them up against the wall.. 85

A few weeks later, Méric urged LICP members to examine their consciences and prepare themselves for any eventuality. He said it was absolutely essential to know where the embassies of the imperialist powers were located, so that action could be taken in an emergency. The implication was clear enough. 86

83 See some of the examples given from 1933 in Appendix I. See also a note on p.2 of PH 12 (2026 February 1932) in which is described the setting up of a 'Caisse de Solidarité for Leaguers wounded or hospitalised in fights with right-wing thugs. To date 1570 francs had been raised, of which 891 had been dispersed.

84 'Notre Meeting à Wagram', PH 12 (20-26 February 1932), p.1.

85 Victor Méric, 'Du Bon Travail', PH 12 (20-26 February 1932), p.1.

86 'Pacifistes, tenez-vous prêts!', PH 21 (23-30 April 1932), p.1. 
The direct link in rhetorical style between Méric's editorials and those of some of the right-wing papers, was made startlingly clear in June 1932 in a review of the press in the Patrie Humaine. Commenting on an article in L'Ami du Peuple in which François Coty fulminated against the 'financiers who run the world', and darkly threatened that names and addresses were known and thus would be called to account, the $P H$ responded that 'this time... the masses know where to find those responsible. We know their names, where they live... The 'red list' has been drawn up and on it is the name of the Coty of Cotys' ${ }^{87}$ In January 1933 when the conscientious objector Gérard Leretour lay dying in a hunger strike in prison in Paris, Méric threatened that 'we will not let one of ours be assassinated with impunity. If, through inertia, cowardice, even through ignorance, they let Leretour die, pacifists will know how to establish responsibilities. And they will move on to other options. 88

The above examples indicate how the LICP rather carefully and ambiguously raised the possibility of reprisals against those whom it considered responsible for the problem of war. In a broad sense, this meant envisaging attacks on those members of the capitalist, governing political class who might embroil France in a war. It also meant, in a more immediate way, responding by threat of violence, or even violence itself, to the provocations and attacks of right-wing zealots. To this end, the LICP established what it called the 'Young Pacifist Guard' in early 1932 which was termed a 'combat group par excellence', designed to protect LICP meetings and 'if necessary to pass to the offensive'.89 The Camelots du Roi and 'Taittinger's boys' had thus found their pacifist equivalent.

The fact that the latent violence of the LICP remained ambiguously camouflaged most of the time, in no way lessened its importance as an undercurrent of values in the new pacifism. Occasionally, however, the 'rhetoric of violence' became abundantly transparent. This occurred just before the fractious 1933 Congress in an editorial in which Méric enjoined pacifists to 'remember the days when dynamite brought fear to bourgeois stomachs and sowed the "green terror". Science in the service of the powerful sets itself against the individual. It is up to the individual to use science against the masters and the assassins. ${ }^{90}$ On a motion from the Algerian federation, the Congress of the LICP unanimously underlined that this article represented Méric's personal views and not those of the whole league. 91

87 'Ce que disent les Autres', $P H 28$ (11-18 June 1932), p.3.

88 Victor Méric, 'On Assassine un Homme!'. PH 52 (21-28 January 1933), p.1.

89 'Une Jeune Garde Pacifiste', PH 10 (30 January -14 February 1932). p.8.

90 Cited in 'Congrès National de la LICP, 16-17 avril 1933', Le Combat pour la Paix 1 (May 1933),

91 Ibid. See also Roger Monclin, 'Violence ... ou soumission?', PH 21 (23-30 April 1932), p.3. Monclin raised the question of violence as a means of legitimately reacting to the violences of society and the attacks of the nationalist camp. He listed three cases of pacifists either beaten up by the 
Méric's pacifism was essentially negative. It did not attempt to provide positive answers to the problems of peace, but contented itself instead with increasingly sterile anathemas hurled at French political society. He balanced on the fine line between total despair - announcing that war was imminent and inevitable - and calling the French to resist its fatality. Méric's negative pacifism was incapable of envisaging action in the event of war, however. He called for resistance to war in the peaceful hic et nunc-once war began it would be too late, and he did not have a coherent plan to offer his followers. As he wrote in August 1932:

How many times will it be necessary to repeat that what matters, is to fight war - while it is not upon us - by every means: the spoken word, the written word, demonstrations, education, violence... and to create a coalition of people across borders, across the nations. Afterwards, it will be too late. When war is upon us, it will become vain to seek the best way of avoiding it... The day that war falls upon us, despite all our exhortations, our bleatings and our bellowings, knowing that we can do nothing and that we are irredeemably condemned, we will suffer our fate. 92

But, he added menacingly, 'before falling victim to human stupidity and bloody covetousness, we will settle a few scores'. 93

Méric seemed to see no contradiction between the veiled anarchism of these statements and his position against all wars, including civil wars. Discussing the Einstein Declaration in April 1932 and the fact that too many people were trying to water down the intégralité of their pacifism, he declared that it was 'absolutely essential to define pacifism as we understand it'.

For the convinced pacifist, there can be no pretext, no excuse for war, whatever form it might take, even if its apostles baptise it 'civil'. War is the enemy which must be killed. War must not only be outside the law, but be vomited by real pacifists. ${ }^{94}$

This pacifist prise de conscience had to be achieved by a complete re-thinking of how society operated. Pacifists had to see that there were occult forces as well as human

police or harrassed, and concluded: 'Devant la répression fasciste qui s'abat sur les meilleurs militants, nous n'avons plus le droit de rester inactifs. Nous comprenons très bien que nombre de nos amis, tolstoiens, gandhistes, objecteurs de conscience (encore que tous les objecteurs ne soient pas des non-violents), des chrétiens, entendent lutter par les moyens qui leur semblent les meilleurs. Mais nous leur demandons de ne pas considérer tous ceux qui n'ont pas exclu la violence de leurs moyens commes des fanatiques de la bagarre. Il est des moments où il est nécessaire, il est des iniquités scandaleuses qui nous tracent notre devoir: il est normal qu'à la violence on oppose la violence'.

92 Victor Méric, 'Celle d'hier, celle de demain', PH 23 (6-19 August 1932), pp.1-2.

93 Ibid.

94 Victor Méric, 'Le Véritable Pacifisme. Le Postulat d'Einstein', PH 19 (9-16 April 1932), p.1. 
weaknesses at play in the creation of wars, but once rid of their old 'prejudices', pacifists could begin to see clearly. ${ }^{95}$ Having just rejected the idea of civil war, however, Méric concluded,

Against war, first of all, and by all methods, including, if events permit it and if our skin is in danger, violence and reprisals, exercised against the assassins. Against war, whatever one may say, whatever one may imagine, whatever may happen. 96

A few months later, he had arrived at the point of admitting that for the integral pacifist either his life or his liberty might have to be lost in a war. ${ }^{97}$ This reflected the position already taken by Félicien Challaye that a foreign occupation of France was more desirable than war. 98

Fortunately, there were more nuanced analyses of what constituted integral pacifism in the pages of the Patrie Humaine. Pierre Cuenat discussed the problem in an article in late 1932, taking as his point of departure the postulate that everyone in France was a pacifist. 99 He distinguished two broad categories of inspiration for pacifism: fear, and philosophical or political conviction. There was nothing the matter with fear, but a constructive pacifism needed to be based on more than that. He thought that one could divide the population up into three categories on the question of peace. First, there were those who found war exalting and beneficial - these people were mercifully getting rarer. Secondly, there were those who accepted war through 'amorphism', naivety and fatalism. Cuenat believed this category to be the most ripe for pacifist propaganda. Thirdly, there were the pseudo-pacifists, those who accepted the idea of defensive wars. Recognising the difference between the LICP's brand of pacifism and this latter form of pseudo-pacifism, Cuenat wrote that 'the only pacifism is a total pacifism:. ${ }^{100}$ As far as methods and tactics were concerned, he distinguished two tendencies. The first was the 'democratic' tendency which believed people had a duty to elect pacifist governments, support the League of Nations, and so on. Their method of propaganda was education. Secondly, there were the revolutionary pacifists who offered a 'little more variety', but who shared a belief in the total rejection of war. Revolutionary pacifism could be further broken down into two strands: on the one hand, there was 'individual revolt' or conscientious objection which had tremendous propaganda value, but which was weakened and strengthened paradoxically

\footnotetext{
95 Ibid.

96 Ibid.

97 Victor Méric, 'Pour tuer la guerre', PH 54 (4-11 February 1933), p.1.

98 See the discussion of Challaye's thesis in favour of peace without reservations in Part $\mathrm{I}$.

99 Pierre Cuenat, 'Du Pacifisme à la Paix', PH 46 (10-17 December 1932), p.2.

100 Ibid.
} 
by its very individuality. Finally, there was revolutionary pacifism based upon the belief that peace was a function of economic and social considerations. 101

There were certainly also those who saw the need to elaborate specific tactics for avoiding war. Sébastien Faure, to take one example, subscribed to the Einstein declaration but argued that pacifism needed to go beyond it to the prevention of war by all suitable means. The most efficacious of these he believed to be total and unilateral disarmament. 102 The Geneva process represented the opposite of this unilateral disarmament, and was viewed with a jaundiced eye by the LICP. The desire for general disarmament was certainly not strong enough in the men charged with representing France in Geneva; moreover, general disarmament was well-nigh impossible in the European situation created by the Versailles Treaty. In a review of an article by Professor Edouard Guyot in which it demonstrated that Europe could only be genuinely pacified if the treaties were revised, the Patrie Humaine concluded that it is perfectly clear that the road to Geneva must pass through Versailles. For the moment, it passes through Le Creusot'.103 Another writer in the $P H$ declared that the world situation was like that of 1912 all over again. $\mathrm{He}$ demonstrated the militaristic character of the French government and said that Michelet's dictum about France declaring peace to the world was a sham.

When our officials perorate, they never fail to speak about the true face of France; they give us credit for intentions which the facts put the lie to. We are wasting our resources in armaments, we are provoking war through our attitude and we justify to our neighbours the armaments to which we give the example. As Delaisi says, we give 'the strange spectacle of peoples who arm because they scare themselves, and who scare themselves because they are armed.' The true face of France does not appear crowned with the laurel wreath on which the symbolic dove comes to rest; our features are those of the old trooper, our face has the sinister mouth of Militarism. ${ }^{104}$

The LICP's integral pacifism thus embraced a broad spectrum of ideas about what constituted pacifism. In terms of the league's orientation towards French society, one can only term it non-conformist, anti-establishment, antipolitical. The LICP incarnated the politics of dissent in the pacifist debates of the thirties. As opposed to the old-style pacifists of the Paix par le Droit, those of the LICP had no faith whatsoever in the slow march of juridical and social progress. As one commentator in the Patrie Humaine put it in early 1932, with regard to the Kellogg-Briand Pact and the League of Nations:

101 Ibid.

102 S. Faure, 'Avant tout et à tout prix il faut empêcher la guerre', PH 20 (16-23 April 1932).

103 'Ce que disent les Autres', PH 12 (20-26 February 1932).

104 Bernard André, 'Désarmement', PH 10 (30 January - 14 February 1932), p.7. 
They promise us a juridical organisation of the peace; but we don't want scholarly texts, we want facts. It is vain to dream of legislating Peace - before having created peace in fact and having sculpted it in social reality, before having disorganised the administrative, economic and military apparatus of war and having eliminated its essential and fundamental causes.

Facts always precede the law... We have a Bastille to storm and to destroy: it is : Capitalism which creates wars. Afterwards we will legislate... 105

Gabriel Gobron was even more caustic in his attack on the old conceptions of pacifism and by clear implication, on the APD later in 1932. He referred to the 'good untroubled bourgeois, official and decorated,' whose organisation is 'reconnue d'utilité publique' and who enjoins his fellow countrymen to reject wars of aggression. Such a suggestion in 1932 was enough to make one laugh. Those who advocated such beliefs were 'intellectual crustaceans'.106

The LICP's pacifism in this initial period from 1930 to 1934 was thus largely a negative one. It contented itself with verbal polemics against war which contained an implicit critique of capitalist society, but little in the way of concrete prescriptions for peace. There were some exceptions to this rule; the advocacy of unilateral disarmament is one. Generally speaking, one can say that the LICP was initially an organisation incarnating an unstructured, sentimental revolt against the threat of a coming war. It balanced on the knife edge between total despair which could produce no effective results, and calls to resistance against the fatality which it came close to proclaiming itself. To the extent that tactics and methods were envisaged in this initial period, the spectrum of the possible embraced everything from the most violent attack on those held to be responsible, to complete non-violence. Only with the passage of time, as the rhetoric began to appear a little empty and worn, did the league begin to evolve specific policies for action. It did this largely as a result of challenges to its view of pacifism and as it became necessary to respond to specific political issues.

The first of these challenges to the LICP's world view came in the form of the Amsterdam Congress against Imperialist War which convened in August 1932 on the initiative of Romain Rolland and Henri Barbusse. In an appeal to the LICP, Romain Rolland laid out three steps to peace as he saw them: individual refusal of war, collective refusal, and finally collective action. Collective action meant 'taking Bastilles' and he recommended to the LICP the forthcoming world congress. ${ }^{107}$ The question of whether or not

105 Jean Tempête, 'Propos Incisifs: Législation', PH 15 (12-18 March 1932).

106 Gabriel Gobron, 'Les Crustacés Intellectuels', PH 44 (26 November - 3 December 1932), p.3.

107 Romain Rolland, 'Appel de Romain Rolland aux Combattants de la Paix', PH 31 (2-9 July 1932), pp.1-2. This appeal is also reprinted in Romain Rolland, 'Appel à la Ligue des Combattants de la Paix' in Par la Réoolution, la Paix (Paris: Editions Sociales Internationales, 1935), pp.31-36. Rolland's 
to attend the Amsterdam congress greatly divided the League, although Méric's negative view eventually prevailed at the LICP's first congress in Angers in late June 1932.108

Méric's primary reason for wanting the LICP to steer clear of the Amsterdam congress was that the latter seemed to have been taken over entirely by the Communists:

... it is not just a question of Barbusse and Rolland. There are also our old friends the Communists ... In reading $l^{\prime}$ Humanité we note that it is all a question of defending Soviet Russia against imperialist aggression, and also that they are preparing to debunk the false pacifists. 109

He took great exception to the notion that the LICP was comprised of false pacifists. $\mathrm{He}$ reminded league members of the nefarious campaign conducted against the LICP by l'Humanité when the league was still struggling to establish itself. In three or four 'copious articles', it had been explained that the LICP was composed of 'bourgeois pacifists, sold to the government and playing the game of fascism, duping the masses. 110 The League could not forget that Communist speakers would arrive at its meetings to spread these lies, causing an uproar and fights. All of that could perhaps be forgiven, but Méric underlined that an even greater obstacle remained. The LICP had been founded on very strict principles: 'negation of the national defence, repudiation of all ideas of fatherland, and war against all wars'. But the upcoming congress was trying to establish the idea of a necessary defence of the 'patrie socialiste'. This was a dangerous illusion which would lead straight to the Just War, War-to-end-all-Wars mentality of 1914 . There was thus a definitional problem involved in the League's repudiation of the Amsterdam movement. The LICP was against all wars, and not just against imperialist wars. Furthermore there was a fundamental question of tactics to be considered. Méric wrote that the methods

original appeal for the Amsterdam congress, dated 1 June 1932, is also in this collection. See Rolland, 'Contre la Guerre. Rassemblement!' in ibid., pp.29-30.

108 See reports on the Angers Congress of the LICP in PH 31 (2-9 July 1932), p.1. The LICP congress decided after a long discussion that the League would send a message to the Amsterdam Congress expressing its point of view, principles, and methods and that members would be free to participate on an individual basis. In the wake of the Angers congress, there was much discussion however in the pages of the Patrie Humaine about the LICP's decision not to attend. See PH 32 (9-23 July 1932) and 33 (23 July - 6 August 1932).

109 Victor Méric, 'Nous n'irons plus au Bois...', PH 30 (25 June - 2 July 1932), pp.1-2.

110 Ibid. See also PH 33 (23 July - 6 August 1932), p.4 on which is reprinted an article from l'Humanité which attacked 'le verbalisme stérile des pacifistes à la Victor Méric et Georges Pioch' as well as 'l'action paralysante des individualistes et anarchistes qui croient lutter contre la guerre par "l'objection de conscience" et autres fadaises impuissantes.' The $P H$ pointedly asked what Romain Rolland thought of these 'autres fadaises impuissantes' of which conscientious objection formed a part, and it concluded emphatically that 'on ne peut collaborer avec des gens qui non contents de nous insulter, tentent de jeter le discrédit sur des actes qui prouvent, tout de même, la conscience des hommes qui les accomplissent'. 
envisaged by the Communists for fighting against war are really completely fantastic. These pacifists, who are not petit-bourgeois, invite their militants in times of peace to go to the barracks and take up their rifles. It seems that in the barracks, under the sympathetic eye of Adjutant Flic, they will do some excellent propagandising. In time of war, they will ask their militants to join their regiments. There, they will wait patiently for the hour to arrive when the foreign war can be transformed into a civil war. And, in waiting for that to happen, they will fire their rifles, shoot their canons, and use their machine-guns against other partisans of the same civil war. ${ }^{111}$

Romain Rolland finally intervened directly in the debate within the LICP in his role as Honorary President. In a letter of 12 July 1932 to Méric, he wrote that it was agreed that he and the LICP sought the same goal: the achievement of peace by efficacious means. Having said that, there remained three questions which required further clarification. First, he wanted to know what Méric would do if asked to contribute, either directly or indirectly, to war. Would he refuse absolutely, even to the point of facing the firing squad? Romain Rolland was prepared for this possibility, but was Méric? Secondly, Rolland argued that it was all well and good for intellectuals to refuse to fight because they had little to lose in so doing. But what about the working class? In Rolland's view, it was only the working class that was capable of stopping the outbreak of war. But if the working class revolted or refused service, it could instantly be declared part of the national defence structure and therefore in mutiny. Romain Rolland called that civil war. What did Méric call it? Finally, Romain Rolland wrote that war had become internationalised to the point that it might well not occur in Europe in future, but rather be fought by proxies hundreds of miles away. What did Méric plan to do to prevent such transplantation away from French foyers? What did the LICP say to its members who were part of the 'infernal machine'? Rolland saw civil war at the end of every path. The origins of the debates later in the thirties over collective security and the idea of an indivisible peace are clearly to be seen in this letter. Rolland concluded that he was horrified by the idea of civil war, but saw no other hope in the West:

I know of only one great tactic of non-violence which might be capable, maybe, of bringing war to its knees. It is that of Gandhi and of his people in India. But we still don't know how that experiment will end.

I should be ready to use it in the West. But who is interested in it here? Who is concerned about any tactic at ... all? Words, words... What will remain on the day of battle?... We must achieve social

111 ibid. (Nous n'irons plus au Bois') 
In his response to Rolland's questions, Méric replied that he was personally willing to face execution for his beliefs. As far as conscientious objection was concerned, he agreed with Rolland that in itself it was not enough, despite its great moral value. The coming war would make no distinction anyway between combatants and non-combatants, so in some respects the question was irrelevant. He agreed that the people who had to be reached were the working class, those who produced the chemicals and armaments necessary for modern warfare. The working class needed to be ready to prevent war by sabotaging equipment, going on strike and refusing to participate in the crime. Hundreds of thousands of workers needed to be committed to this action, but that would mean civil war or insurrectional violence. Méric thought Rolland was in contradiction with himself on the possibility of violence having to be used, but this merely indicated the direction Rolland's thought was travelling away from absolute non-violence. As far as the massacre of distant peoples in surrogate wars was concerned, Méric was as opposed to this as Rolland. But he categorically rejected the Communist tactic of preparing civil war by sending young Communists to the barracks to do their military service:

Romain Rolland accepts civil war with a sort of fatality. He goes
so far as to doubt the efficacy of the Gandhian movement. And he
proclaims his dislike for the aforementioned civil war which, as
Georges Pioch has rightly commented, exists already in fact. If it
is a question, as the Communists demand, of joining the army,
taking up a rifle, fighting, while waiting for the right moment, we
will not march. Our entire difference is there. A civil war with
canons, machine guns, tanks, airplanes, bombs, gas, officers and
soldiers? No. It would be too like the other. ${ }^{113}$

Returning to his anarchist theme, Méric asked what Rolland for his part thought of the individual violent gesture, that is to say of the violent act of doing away with one of those responsible for war should it ever break out? And on a larger scale, what did Rolland think of the idea of organising pacifists to commit reprisals in self-defence against the criminals who caused wars? 114

Georges Pioch, who had decided to attend the Amsterdam Congress, took pains to explain why he did so and how his conception of pacifism differed fundamentally from the crude Leninist view that an imperialist war could be turned into a civil war and hence lead to the Revolution. Pioch ridiculed those old-style pacifists who still believed that a

112 Romain Rolland, 'Le Combat pour la Paix. Romain Rolland intervient dans le débat', $P H 33$ (23 July - 6 August 1932), p.1.

113 Victor Méric, 'Le Combat pour la Paix. Réponse de Victor Méric', PH 33 (23 July - 6 August 1932), p.1.

114 Ibid. 
coherent pacifist doctrine could be erected on shifting national ideas of what constituted justice. He believed that capitalism could cause wars, but equally that war was the result of the 'lies and megalomania of certain men', the 'apathy, obedience and submission of the peoples' and that 'cupidity was not the monopoly of one social regime only'. There existed therefore the possibility of wars other than of capitalist origin. And in this sense, he attacked the Communist notion of turning imperialist wars into civil wars. He accused the Leninists of attempting a social experiment; pacifists on the other hand just wanted to live. He revolted against the idea that war could be inevitable; the whole core of his pacifist belief was incarnated in an 'intelligent and certain ... Non-Acceptance'.115

The debate dragged on into 1933 and beyond. Romain Rolland resigned his position as Honorary President of the LICP at the League's Easter Congress in 1933.116 In the meantime, the Amsterdam Congress came and went. Its final Manifesto condemned conscientious objection among other things, and provoked even a negative response from Romain Rolland himself who had been prevented from travelling to Amsterdam because of illness. 117 Gustave Dupin, writing in the Patrie Humaine shortly thereafter, attacked the étatisme and the negation of individual values and action contained in the Amsterdam manifesto which he called a phantasme verbal. 118 Méric for his part had already rejected out of hand the accusation that the LICP was composed almost entirely of anarchist elements:

We are not followers. And don't let anyone say that the anarchist spirit reigns in the League. Lies! There were many anarchists who wanted to participate in the Communist practical joke in Geneva [the originally intended site of the Amsterdam Congress]. Those who understood were the 'Party-less', the 'outsiders', professors, teachers, intellectuals, petits bourgeois, civil servants, all opposed to war - against all wars - and who have put their trust in us to lead the battle. ${ }^{119}$

In his message to the LICP's 1933 Congress, Rolland rejected the notion contained in the league's statutes that pacifism was to be placed above all other considerations and that league members should commit themselves to working towards the unique goal of peace. He also attacked Méric's strange affirmation that the LICP's statutes were intangible; more

115 Georges Pioch, 'Paix dans notre Ligue, d'abord!' PH 33 (23 July - 6 August 1932), pp.1-2.

116 His resignation speech is contained in Romain Rolland, 'Le Pacifisme et la Révolution (Adresse du 15 mars 1933 au Congrès National de Pâques de la Ligue Internationale des Combattants de la Paix)' in Par la Récolution, la Paix (Paris: Editions Sociales Internationales, 1935), pp.119-123.

117 Romain Rolland, 'Lettre à Henri Barbusse sur la place qui doit être faite aux Objecteurs de Conscience et aux Gandhistes, dans le mouvement révolutionnaire, issu du Congrès d'Amsterdam' in Par la Réoolution, la Paix (Paris: Editions Sociales Internationales, 1935), pp.61-64.

118 Gustave Dupin, 'L'Individu et l'Etat', PH 47 (17-24 December 1932), p.2.

119 Victor Méric, 'Précisions', PH 32 (9-23 July 1932), p.1. 
will be said about that in due course. The thrust of Rolland's message was that revolutionary concerns and the righting of injustices were just as important as pacifism, and indeed defined the essence of the longed for goal of peace. Pacifism in Rolland's view had to be social and not exclusively individual and introspective. He wrote,

I will not admit that the League should limit its preoccupations to the salvation of the individual, under whatever form it may be conceived, whether it be in the most noble form of Conscientious objection for moral or religious reasons, or whether it be in the lowest form of the save-your-own-skin egoist. I find it natural that these preoccupations exist and that account should be taken of them. But if they claim to be exclusive and divorce themselves from the social salvation, from the protection of the human' community, they would be shamefully insufficient and I should tax them with indignity. ${ }^{120}$

But the LICP declined to follow Rolland in his evolution away from his former pacifism as an ethic of ultimate ends. In a Manifesto published after the congress, the LICP rejected Rolland's questions as outside the League's competence. It reaffirmed that the LICP had been formed 'outside and above the political parties, to fight against war by all means, and to struggle for peace with no reservations'. ${ }^{121}$ The questions posed by Rolland and the connections he made between peace and the struggle for political and economic social justice were the province of political parties, labour unions, and philosophical or revolutionary groups, but not of the League. The LICP did go some way to answering his criticism, however. It changed its statutes to eliminate the old formula of 'Pacifism above all else' and 'against all wars' to read 'Against wars imposed by governments on the peoples, in the name of a so-called National Interest'.122 This was done in order to realise a greater unity between those pacifists who rejected the notion of the national defence, and those elements which considered themselves revolutionary within the League. ${ }^{123}$

Méric contributed his views to the debate in an article published in late April 1933 in which he sought also to defend his own conceptions of the pacifist struggle which had been partially censured by the Congress. Responding to what he called Rolland's 'sort of message' to the Congress, Méric wrote that Rolland was 'bolshevising' himself more and more.

This is his right. It is also ours not to follow him. And if he wants to drag us into what he calls a 'civil war' (one needs to define one's

120 Rolland, loc. cit. 'Le Pacifisme et la Révolution', p.121. For an analysis of Rolland's changing conception of pacifism see Norman Ingram, 'Romain Rolland, Interwar Pacifism and the Problem of Peace' in Charles Chatfield and Peter van den Dungen, eds, Peace Moovements and Political Cultures (Knoxville: University of Tennessee Press, in press). This is reprinted in Appendix II of this thesis.

121 'Manifeste du Congrès', Le Combat pour la Paix 1 (May 1933), p.3.

122 Ibid.

123 Ibid. 
terms) and the defence of the oppressed, it is understandable that we should hesitate.

In this paper we have always said that we are against all wars, by whatever means, and we accept no excuse for them. We shall no more march in a war against Hitlerism or Mussolini than in the social war of the proletariat. All of these wars are prepared by the profiteers of canons and munitions who leave it to their bought press to create and develop the indispensable psychosis and to agitate one people against another. ${ }^{124}$

In terms of pacifist methods in peacetime, Méric recognised the most passive to the most violent. But what about in time of war? He responded to the criticism he had faced at the Congress in the form of the motion from the Algerian section condemning an overtly anarchist leader he had written a few weeks previously. The pacifist despair of his position came through clearly. For Méric there were no effective means of fighting against a war once it had started - and he included the whole spectrum of pacifist tactics from conscientious objection to insurrection. Nothing would be effective. And so, in the last resort, in the event of war, the only course open to the pacifist was that of individual action, carefully left undefined. ${ }^{125}$

There to all intents and purposes the debate ended. Romain Rolland returned, as he put it, to his place amongst the rank and file, although to 'the extreme left of action', and the League went its separate way. The friendly divorce between the LICP and its former Honorary President marked the first of the significant challenges to the integral pacifist position which the League was to fight off before 1939. Rolland, and to an even greater extent the Amsterdam movement, had tried to make pacifism and the achievement of peace a strict function of other social goals - economic change, social revolution, and one specific sort of political outlook. Despite all protestations to the contrary, it is clear that the type of pacifism espoused by the Amsterdam movement was a very limited one whose parameters were defined by the exigencies of the Soviet world view. The LICP rejected this consequentialist definition of pacifism and clung tenaciously to the view that the achievement of peace was an end in itself.

Having said that, it is clear from the discussions within the LICP that its conception of pacifism was far from an exclusively non-violent one. At one end of the spectrum there existed within the League men who were quite prepared to envisage the most violent tactics as methods of preventing war. Even in the case of its libertarian elements, the definition of pacifism within the LICP seemed to take on overwhelmingly political overtones which masked the ethical point of departure for many of these pacifists. This is probably one of the major differences between Anglo-Saxon and French absolute pacifism. It is perhaps an

124 Victor Méric, 'Nos moyens de lutte', PH 66 (29 April 1933), p.1.

125 Ibid. 
extension of the dichotomy already noted by Pierre Cot in part I with reference to old-style pacifism. The distinction between the British old-style pacifist's Bible and the Code Napoléon of his French counterpart was mirrored in the new pacifism of the thirties by the continued insistence of the French integral pacifists on the political aspect of pacifism. Once again, it is probably a comment on the deeply divided nature of French political society in the thirties that the question of peace should take on such fiercely political colours in an antipolitical movement which expressed such deep-seated resentments against the recent course of French political history.

The paradoxes within the LICP's integral pacifism abound. The extent to which the League sought to provide a refuge for both non-violent and violent pacifists has already been observed, as has its propensity to define itself as an antipolitical movement in uniquely political terms. Its rejection of Amsterdam-Pleyel was largely based upon its refusal to define pacifism in purely collective terms according to just one view of political society. But the opposite position was not necessarily true within the LICP; it did not embrace conscientious objection wholeheartedly as a means of resisting war. Officially, the LICP supported COs and applauded their moral courage but did not see in objection an effective way of preventing war.

1932 and 1933 saw a great upsurge in conscientious objection in France which elicited both a governmental response ${ }^{126}$ and a tactical response from the LICP. Within the League could be distinguished three currents of opinion on objection. The first, represented by Méric, was that objection was inefficacious as a means of fighting war but that objectors should be honoured for their moral courage. The second, epitomised by René Gerin, was that objection was a personal decision made by the individual pacifist; because of the nature of the penalties for conscientious objection by young recruits, Gerin would only go so far as to advise older men like himself, who had fought in the war, to return their mobilisation papers, thus incurring merely short disciplinary sentences in the local gaol. The hard line position was that taken by Eugène Lagot and Gérard Leretour who wanted the LICP to organise a massive return of deserters and objectors from abroad and the concerted return of mobilisation papers to the Ministry.

Thus, for example, Victor Méric in late 1932 saw repression coming for pacifists because of the great increase in conscientious objection. As long as pacifism had remained 'bleating', governments had had little to fear, but it was now becoming active. Men were showing their resolve to reject war by a variety of means and this brought disquiet to the authorities. Conscientious objection was one of these means and Méric wrote that,

We accord a high moral value to these acts. We do not believe they have any practical value, given the form the next war will take against civilian populations. ... we do not believe we have the

126 See Appendix I. 
right to give advice to our younger brothers which will put them gravely at risk... 127

There was thus much respect for objection in the League, but little belief in its practical effects. In view of the coming debate with Leretour over generalised conscientious objection, it is important to note that Méric was against advising young men to become objectors because of the much severer penalties imposed on those who had not yet fought in a war.

Armand Charpentier expressed this duality explicitly in an article on Leretour in early 1933. He had met Leretour just before he turned himself in to the authorities and had been most impressed. But he thought that despite the moral grandeur of the objector's act, it would remain essentially sterile because of the complete indifference of the press and the more important fact that modern warfare meant that both civilians and military would be attacked and annihilated in a few short hours:

This means that the conscientious objectors will not even have the time to show themselves. They will be asphyxiated and roasted with the rest of the citizens. In these conditions, I believe that the struggle for peace must pass from the individual level of conscientious objection to the collective level of non-resistance. I take that to mean that our propaganda must evolve more and more in the direction of making the unsuspecting masses understand that with aero-chemical warfare all of the armaments and all of the armies are completely useless. As a consequence, the only means whereby a people can save itself, its property, its patrie, is to disarm totally, to thereby refuse all war. That is the true propaganda position on which pacifists must stand. 128

René Gerin was the most visible exponent of conscientious objection in the higher echelons of the LICP. He paid for his commitment to this form of pacifism in several disciplinary sentences of short duration and one long sentence passed on him by virtue of the newly strengthened law of July 1934 on conscientious objection. Gerin was careful, however, to emphasise to his audiences that he advised no one to become a CO. Rather, he placed before them the various options open to pacifists and left them to make up their own minds. As he pointed out in a 1934 editorial, the Comite Directeur of the League refused to counsel conscientious objection to young men of twenty years because they believed it to be an individual question eliciting a very personal answer. Perhaps more to the point, they believed along with Gerin that those who advised objection should be the ones to pay for it. ${ }^{129}$ Having said that, Gerin was a very successful propagandist with the anciens combattants and it was to this group that he held up the example of his own successful

127 Victor Méric, 'Vers la répression', PH 40 (29 October - 5 November 1932), p.1.

128 Armand Charpentier, 'Un Héros de la Paix: Gérard Leretour', PH 53 (28 January - 4 February 1933), p.1.

129 René Gerin, 'Une nouvelle loi scélérate', Le Barrage 8 (5 July 1934), p.1. 
objection at least until the change in the law in 1934. To these men who had shared the trench experience with him, Gerin showed the possibility of making a pacifist statement at relatively little personal cost. In an open letter to Edouard Daladier in April 1933, Gerin reckoned about one hundred men had so far followed his example; just over a year later, he put the number in the hundreds if not thousands. To the veterans he said,

To begin with, we want the legal recognition of conscientious objection, and we believe that it is above all the veterans who should be fighting for the realisation of this first point in our programme. 130

In the summer of 1933 Gerin also recommended a way around the problem of the long prison term for young men who nevertheless wanted to affirm their integral pacifist beliefs. Rather than becoming one of the 130,000 Frenchmen who had either left France or assumed a false identity in order to avoid military service, Gerin suggested a third alternative. He advised young men to do their military duty in time of peace, but before joining their regiment for the first time, to send a letter to their regimental commander and to the Minister of War outlining their conscientious objection and making it clear that they would not serve in time of war. ${ }^{131}$ But this tactic raised the ire of Alphonse Barbe, sometime editor of the libertarian newspaper Le Semeur in the Calvados, who protested that Gerin as an ex-officer could not imagine what a young recruit 'deuxième classe' writing such a letter would be put through. Gerin completely underestimated the brutal stupidity and sadism of the non-commissioned officers if he thought such a plan would work. For Barbe it was better to affirm an all-or-nothing stance; either declare oneself an objector and take the consequences or else do one's military service as quietly as possible. In Barbe's view, the more honest and effective approach was that taken by Leretour: the organisation of a massive return of deserters, objectors and insoumis from abroad and from internal exile in an attempt to paralyse completely the Army's judicial system. ${ }^{132}$

Leretour and Lagot advocated the creation of a vast collective movement of conscientious objection which would force the French government to change the law on conscription. The publication of the Chautemps circular in the press in early May 1933 had convinced them that the government was weakened and the time had come to strike while the iron was hot. They attempted to persuade the LICP to back them in this campaign, but the League's Comité Directeur refused, prompting Lagot to respond in his article ' Sous le signe de la Peur' that the LICP did not have the courage of its pacifist convictions. ${ }^{133}$

130 René Gerin, 'Lettre ouverte à M Daladier', PH 63 (8 April 1933), pp.1-2.

131 René Gerin, 'A ceux qui doivent bientôt "partir"', Le Combat pour la Paix 4 (August September 1933), pp.5-6.

132 A. Barbe, 'A ceux qui doivent bientôt "partir"', PH 83 (15 September 1933), p.4.

133 Eugène Lagot, 'Sous le Signe de la Peur', Le Semeur 232 (22 July 1933), p.1. 
Instead, Lagot and Leretour created a Ligue des Objecteurs de Conscience and appealed for COs, deserters and insoumis to come forward in droves, go to prison and begin a hunger strike. ${ }^{134}$ Later that summer, Leretour wrote that the main reason for its creation had been the almost total incomprehension faced by $\mathrm{CO}$ sithin the wider pacifist movement in France. He underlined that he wanted to create a collective movement of objection and was tired to death of hearing that objection had no practical impact - one had only to look at the Chautemps circular to see that it did. ${ }^{135}$ But in the generally received opinion of the LICP that would be to assume a collective responsibility of conscience which by definition had to remain the decision of each man. What the League did promise was to remain faithful to those who rebelled and this it did. 136

The first three years of the LICP's life saw, therefore, major definitional debates on the nature of the new pacifism. Méric had sought to create an organisation which would be as broad as possible in its intake; political, social and religious preferences were to be left in the vestibule as he liked to say. Thus began an uneasy marrige of different strands of absolute pacifism. The most difficult dichotomy to be bridged was undoubtedly that between the partisans of non-violence and violence. Amsterdam-Pleyel highlighted some of these contradictions but the League was able to maintain its organisational independence by insisting on the purity of its pacifism and its application to all wars. Conscientious objection provided the next challenge to the League's position but was easily accommodated within the LICP's world view. The third and final crise de croissance came at the League's second national congress in 1933.

By 1933 it was clear that more was needed than sterile anathemas hurled at the spectre of a war which Méric proclaimed imminent, almost inevitable, and impossible to resist once it had arrived. Pacifist despair undoubtedly succeeded in grouping together the thousands of men and women who joined the LICP in its first three years, but increasingly it became necessary to offer these leaguers specific policies for fighting war. A further problem was the deepening perception within the league, especially in the provincial sections, that the LICP was being run like a tin-pot dictatorship by Méric and a few friends in Paris. The League's accounts were mixed up with those of the Patrie Humaine, and were in a state of considerable chaos. There was also the question of the Patrie Humaine. Many people thought that an organisation like the LICP ought to have its own independent organ. The

134 Gérard Leretour, 'Debout, les Objecteurs!', PH 71 (2 June 1933), p.2.

135 Gérard Leretour, 'Pourquoi le Manifeste?', PH 81 (18 August 1933), p.4.

136 Robert Jospin, 'Précisions nouvelles', Le Combat pour la Paix 4 (August -September 1933), p.2. The League's position was supported by Professor Pierre Doyen, the president of the French section of the War Resisters' International. See Pierre Doyen, 'Deux lettres du Professeur Doyen', in ibid., p.4. 
question had been raised at the Angers congress in 1932 and Méric had explained that the 'PH is completely at the disposition of the League but does not belong to it'. 137

All of these issues came to the boil in the Congress which convened at Easter 1933 in Paris. It is clear that Méric felt control of the League slipping from his grasp; there was a violent altercation between him and Emile Bauchet, President of the Calvados Federation and chairman of the commission charged with organising the congress, over what would and would not be published in the Patrie Humaine concerning the congress. ${ }^{138}$ As the writer of a report on the Congress quite rightly pointed out, Méric's Rapport Moral was more an exercise in self-exculpation and justification of past errors than a report as such. ${ }^{139}$ Méric spoke at length about the origins of the LICP and about the complete intangibility both of the League's structure and its statutes. The League under Méric had a committee of patronage at the top, composed of eminent writers, professors and intellectuals. This committee designated a president and a secretary general. Méric also outlined the League's principles - and it was these, or rather their wording, which prompted Romain Rolland's intervention as we have seen. What is clear is that Méric viewed the LICP as akin to the law of the Medes and the Persians. This dogmatism asserted itself even down to the section and federation level where no dissent would be brooked: 'It has never been a question of the sections and federations intervening in the general propaganda of the League or of claiming to modify in the slightest its directives'. ${ }^{140}$ It is unclear from all this exactly what the members, sections and federations of the League were supposed to do if they were barred from any active role either in policy formation or in spreading the good word. In a man of such obvious anarchist inclinations as Méric, there was a surprising degree of étatisme when it came to the running of 'his' league. Undoubtedly, part of the reason for the grass-roots revolt in 1933 was due to financial mismanagement. Méric referred in his report to the Odéon Incident; Pierre Odéon had been taken on to help run the league after his release from prison for conscientious objection. Without going into the sordid details and defending Odéon's probity, Méric nevertheless acknowledged that a debt of some 70,000 francs had been run up before Odéon had finally been let go. Méric ascribed the subsequent 'malaise' in the League to this incident. 141

With regard to the Patrie Humaine, Méric refused to give it up, ostensibly to protect it from becoming the journal of just one tendency within pacifism. He was also afraid that it would quickly collapse if not run by professional journalists like himself. All of this was

137 See the account of the Angers Congress in PH 31 (2-9 July 1932), p.2.

138 See 'Bulletin Officiel de la LICP. Autour du Congrès de Pâques', PH 61 (25 March 1933), p.5.

139 See Bauchet's comments in 'Congrès National de la LICP, 16-17 Avril 1933', in Le Combat pour la Paix 1 (May 1933), p.4.

140 Victor Méric, 'Rapport Moral', PH 59 (11-18 March 1933), p.5.

141 Ibid. See also 'Congrès National...', loc. cit., p.5. 
probably just a smokescreen for Méric's real desire to hold on to a paper which despite its debts was increasingly widely read in France. It also guaranteed him a continued voice in French pacifism. 142

Finally, Méric argued vehemently against the idea of declaring the LICP at the Préfecture de Police, a move which would have the advantage of giving the League legal status. He foresaw problems because of the League's potential advocacy of illegal means in the fight against war. ${ }^{143}$ Marcel Fouski of the Angers section, who had written the report in favour of declaring the League, said that such fears were groundless. Instead, declaration would protect the League financially, permit it to sue those who defamed it, and protect individual members from the effects of a lawsuit. 144

René Gerin read a report on the League's propaganda which sought to define the LICP's position within the peace movement and in relation to the political parties. The LICP had no doctrine as such, and was neither a movement (like Amsterdam), nor a political party. Gerin defined it rather as simply a league - a society of study, propaganda and information. Having said that, it was necessary to delimit those parts of the political spectrum with which the LICP could have nothing to do. On the right, this meant rejecting all persons or groups who accepted the idea of a national defence through arms. On the left, he admitted that definition was much more difficult because the League's formula 'Against war by all means' implied an acceptance of revolutionary tactics. Given the problems the league would face at the time of Munich over the question of the neo-pacifism of the Munichois extreme-right, it is worth noting that as early as the 1933 Congress, the LICP seemed unprepared to share its political bed with just anybody. 145

When the Congress closed, it was clear that the House that Méric built had been redecorated, if not redesigned, from top to bottom. He had been censured in a resolution from the Algerian section for advocating violent anarchist tactics, the League had decided to declare itself officially at the Préfecture de Police, a paid treasurer (Bauchet) had been designated, the Comite Directeur was henceforth to be elected and the old committee had been turned into a Comité d'Honneur. Individual leaguers were to be attached obligatorily to a local section. The $P H$ remained Méric's property. The League's statutes were also changed to reflect a more nuanced definition of the type of pacifism espoused; henceforth

142 Ibid. (Rapport Moral). See also André Dumas, 'Ligue, "Patrie Humaine" et Librairie', PH 58 (4-11 March 1933), p.4. See also 'Congrès National ...', loc. cit., p.7.

143 Ibid. (Rapport Moral). See also 'Congrès National...', loc. cit., p.5.

144 Marcel Fouski, 'Rapport sur la déclaration de la Ligue', PH 58 (4-11 March 1933), p.3. See also 'Congrès National...', loc. cit., p.5.

145 René Gerin, 'Rapport provisoire sur la déclaration de la Ligue', PH 58 (4-11 March 1933), pp.3-4. See also discussion of this report in 'Congrès National...', loc. cit., pp.6-7. 
the LICP was to fight against wars 'imposed by governments on peoples in the name of a socalled national interest'. 146

In the debate on Romain Rolland's message to the congress and in the continuing discussion on adherence to the Amsterdam movement, the amazing spectrum of pacifist values within the LICP was once again evident. Méric was censured, as has been seen, for his overtly anarchist prescriptions for a violent approach to peace. But Pioch agreed with Rolland that in the coming struggle 'conscientious objectors, organised non-violents and the armed proletariat' should coalesce in the LICP. In almost the next breath, however, Victor Margueritte announced that the League agreed with Romain Rolland but was in favour of non-violence. Han Ryner and Armand Charpentier both thought that no distinction should be made between civil and foreign wars. Sébastien Faure was against the Gandhian method and announced himself a partisan of violence every time one was a victim of it. The Toulouse group wanted to draw up lists of those responsible for wars as future 'hostages for peace' and was in favour of armed resistance to any war. The Toulouse resolution was approved by a majority of the Congress. Gerin continued to believe that if the masses knew what the LICP knew about the origins of the Great War, they would flock to pacifism - an indication that the question of war responsibilities continued to be important in the pacifist debate. Even on the question of conscientious objection there was incoherence. A motion from the St-Denis section demanding that the Comite Directeur officially support the 'movement of collective conscientious objection proposed by comrade Leretour' was adopted; but strangely a resolution from the section in the fourteenth arrondissement demanding a collective return of mobilisation papers was rejected. 147

The 1933 Congress was important, therefore, bcause it marked a break from the Méricdominated past of the League, which while fecund in membership growth, had increasingly come to be seen as undemocratic and imbued with a sterile nihilism incapable of developing specific policies for pacifists. 1933 also re-affirmed the League's position on the Amsterdam movement and began a debate on conscientious objection which would broaden into a discussion on pacifist tactics generally. That said, the Congress continued to show up the divisive nature of the League and the uneasy alliance which existed between its disparate constituent parts. A police report on the congress underlined the 'great doctrinal confusion' as well as the 'strong personal rivalries' which existed within the League, mostly between Méric and Pioch, and concluded,

146 'Chez les Combattants de la Paix. Le Congrès de Pâques', PH 66 (29 April 1933), p.4. See also 'Congrès National de la LICP, 16-17 Avril 1933', Le Combat pour la Paix 1 (May 1933), pp.4-10. See also 'Réunion du Comité Directeur', Le Combat pour la Paix 1 (May 1933), pp.10-11.

147 See 'Congrès National...', loc. cit., Pp.8-12. 
To sum up, no precise policy directives given, no political line laid down. Each section and each member of a section is left free to act as he pleases. This is anarchy. 148

The anarchy evident in the League as a whole was apparently even more extreme in the Paris federation. It led finally to the resignation of three early members, J. Bardin, A. Dumas and O. R. Monod. These three published a manifesto explaining their decision to leave the League in November 1933. It castigated the LICP's inability to put its house in order. They thought that the Easter congress had succeeded finally in clarifying the League's principles and providing it with a sound and democratic administration. But the situation in Paris was even worse:

At the Easter Congress, the vast majority of the Paris sections, under the direct influence of anarchist elements, declared themselves against the majority of the League, represented by the provinces and for the continuation of the 'methods' and the fantasies of the old administration. 149

The manifesto writers criticised the sterile gesture of Leretour and Daunay in decapitating the statue of Déroulede, and the folly of the armed attack made on a meeting of the Amis de la Patrie Humaine. In response to these criticisms, Gerin had apparently said that the Paris region was of little interest to the League because of the minimal possibilities for action there. Part of the problem for the League as a whole was its attempt to be all things to all men:

We know now that it is vain and sterile to gather together in the same pacifist league, for action, Tolstoyans and revolutionaries, individualists and socialists, religious pacifists and Marxists. In order for such a unity, based on confusion to continue, it is necessary for each tendency to renounce the enunciation of its own points of view, it is necessary for the most active elements to take a vow of immobility. ${ }^{150}$

This the minority refused to do. Since action within the LICP was proving impossible, they had decided to leave. They rejected the sterile, inflammatory rhetoric of the League and opted instead for a 'methodical documentation and systematic education of the masses' on the causes of war and how to fight it. They insisted on the need to maintain a close unity between study and action. The Paris federation seemed to be interested in nothing more

148 See the Report 'D'un correspondent', 25 April 1933. A/3624 GB5 in AN F7/13352. The chronology in this report is a bit ambiguous. It refers to a 'congrès féderal' taking place in the first fortnight of March in Paris. The dates of the national congress were 16-17 April. However, from the context of the report, it is clear that the informant or the person taking down the report was confused about the dates, and it must refer to the National Congress, rather than a meeting of the Paris Federation.

149 J. Bardin, A. Dumas, O. R. Monod, 'Pourquoi nous quittons la Ligue Internationale des Combattants de la Paix'. Copy in BDIC/DD/FARés. 235/4/7.

150 Ibid. 
than the 'action' of 'the demagogues of the "green terror", the fanatical monument attackers and the professional hunger strikers'. ${ }^{151}$

Thus ended 1933 for the LICP. Méric died of a stomach cancer in early October, leaving the running of the Patrie Humaine to Robert Tourly and Roger Monclin. ${ }^{152}$ With Méric gone, French integral pacifism had undoubtedly lost one its greatest visionaries and leaders, a man who had almost single-handedly created the largest French integral pacifist group whose influence was being felt by the government. Méric represented the politics of dissent to his core, but his vision and work were tragically flawed by an unwillingness or inability to see beyond the increasingly sterile polemics which had caused thousands to flock to him initially, but which were incapable of keeping them at his side without the inducement of sound pacifist policies. Méric the anarchist finally triumphed over Méric the pacifist to the detriment of the LICP. 1933 marked the revolt of clear-thinking, democratic forces imbued with just as much vision as Méric, but with organisational sense as well.

151 Ibid.

152 See Robert Tourly, 'L'homme qui s'en va...', PH 86 (13 October 1933), p..; Robert Tourly, 'Sa Vie, Son CEuvre', PH 86 (13 October 1933), pp. 1-2; Roger Monclin, 'Adieu', pH 86 (13 October 1933), p.1.; and Robert Tourly, 'Les Obsèques de Victor Méric', PH 87 (20 October 1933), p.l. 


\section{II.3. Challenges to Intégralité (1934-1938)}

The LICP's pacifism in the period 1930-1933 was largely negative. Its rejection of war owed more to sterile anathema than to sound and practical policies. In the period from 1934 to Munich it began, however, to develop an intelligent approach to pacifism which was reflected in a deeper analysis of internal and external political problems, and in the discussion of pacifist tactics.

If the LICP under Méric had been slow to come to grips with concrete political reality, this was not the case in the post-schism League. In May 1933, immediately after the tumultuous Easter Congress, the League created its own journal, Le Combat pour la Paix which was published monthly until April 1934, after which it was replaced by the weekly and then bi-weekly newspaper, Le Barrage. Both of these publications contained more in the way of political analysis than had the Patrie Humaine under Méric.

\section{Germany}

The primary political problem of the thirties was undoubtedly that of Germany. The LICP was consistently in favour of a revision of the Versailles Treaty in order to arrive at a more equitable European situation. Before the Nazi Machtergreifung the League's propagandists defined the danger posed by Hitler purely in terms of internal German politics. Thus, for example, Rudolf Leonhard, a German émigré and a member of the Gruppe Revolutionärer Pazifisten, propagandised tirelessly in 1932 and 1933 for the LICP to which his organisation was twinned in an amicable accord. Leonhard had this to say about Hitler:

It is not you who have to fear this imbecile Hitler, but I. Hitler isn't war, he is civil war. He is the white terror. If he comes to power - and this may well come to pass and the other States will tolerate him there - Germany's foreign policy will not change. ${ }^{153}$

${ }^{153}$ Rudolf Leonhard, L'Allemagne et la Paix (Paris: Editions de la LICP, 1932), p.12. 
This analysis found its echo in that other indefatigable propagandist of the first hour, Marcelle Capy, who along with Pioch and Leonhard traversed France in two successive peace crusades in the winters of 1931-32 and 1932-33. Capy, who knew Germany well but apparently spoke little German, shared Leonhard's prognosis on the political situation there and what it might mean for France:

\begin{abstract}
Hitlerian nationalism is a fact - moreover an imposing and grave one. It is the arm that heavy industry uses to flatten German democracy and to tear from the working class the union freedoms which were so dearly bought.

Hitler's troops form the counter-revolutionary army of the interior...

Hitler is in truth not an exasperated chauvinistic Germany showing its teeth to France, but instead big German capitalism and behind it big international capitalism - showing its teeth to working people and to German republicans. ${ }^{154}$
\end{abstract}

Before 1933 there were also those within the LICP who did not believe that Hitler would be successful in his bid for power; and if he was, that he would be able to retain it. Robert Tourly, writing in March 1932, thought that it 'was not possible, despite the crazy excitations of the passions, so strangely helped until now by events, to believe in the decisive and durable victory of a party, or rather a movement, whose ideology is nothing but a bric-a-brac of pusrile demagogies. 155

Méric, writing a few weeks later, saw nothing surprising in the Nazi election gains; they were almost inevitable given Hitler's financial backing. He seemed unconcerned at the thought that the Nazis might succeed in taking power, and in a ghastly miscalculation of the nature of Nazism, wrote that 'Hitler in power, will do neither worse nor better than the others'. Méric not only underestimated Hitler, but also showed no small amount of political naivety in equating Nazism with other political systems. He placed his hope in the 'other Germany' which was pacifist and wanted neither Hitler nor war. Méric thought that this other Germany would succeed in keeping Hitler in his place. The bottom line was that Hitler represented no more than a passing crisis on the lines of the Boulanger or Dreyfus affairs, crises 'which bring Democracy within a hair's breadth of disaster'. But he insisted that the trouble would pass and the German people would return to calm reason. 156

Obsessed as they were with the perceived threat from an internal fascist foe in France, the pacifists of the LICP seemed unable to conceive of the danger posed by Nazism in any other terms. This view seemed to prevail within the League from top to bottom. A grassroots pacifist, one comrade Dumont, retumed from a trip to Germany in 1935 to announce to

154 Marcelle Capy, 'Retour d'Allemagne', PH 13 (27 February - 4 March 1932), p.1.

155 Robert Tourly, 'Le Programme de Hitler', PH 17 (26 March - 2 April 1932), p.3.

156 Victor Méric, 'L'aventure hitlérienne', $P H 22$ (30 April - 7 May 1932), p.1. 
his local section that Germans, like people anywhere, were pacifist. He concluded that while the Hitler regime was a danger to the internal situation in Germany, it posed no threat to the outside world. Those who argued otherwise were playing the game of French chauvinists and should be denounced. 157

A note of antisemitism crept into some of these analyses of the new Germany. Gustave Dupin attacked the 'Jewish press' for contributing to the war psychosis which was being fostered by the French General Staff after the Nazi seizure of power. He likened the horror stories coming out of Germany to the atrocity propaganda of all belligerents during the Great War, and rejected the fears being whipped up through 'the exploitation of Dictatorship (in other nations), Fascism and the bluff of antisemitism'. ${ }^{158}$

Pierre Cuenat addressed the question directly in October 1933 when he asked whether in fact Hitler had changed anything. French public opinion seemed to have swung round dramatically to acceptance of the potential for another war. Cuenat wrote that he was under no illusions about the dangers to peace represented by Hitler - he, unlike some subsequent writers in the Barrage, did not believe in Hitler's pacific disposition, - but he posed the essential question, 'has anything changed for the integral pacifist?' His answer was that for integral pacifism any notion of legitimate wars of defence had to be rejected. Frenchmen would perhaps have hesitated to give their lives for the post-Versailles system, but Hitler seemed to be providing a casus belli. It was now once again possible to speak in terms of a war to defend liberty and democracy against barbarism and fascism. But this was a false trap:

Frenchmen need these metaphysical hoists in order to accept a war.
Hitler has allowed war to be disguised under this mask. Against
this brainwashing, our duty is to proclaim loudly that nothing has
changed; French imperialism against German imperialism doesn't
interest us. We will not defend this cause no matter what label is
attached to it. ... We denounce those who identify French
hegemony with peace and proclaim the French army the only
guarantor of peace, those who (Reoue des Deux Mondes, etc) make
of internationalism a treason against peace, and of French
nationalism the only internationalism.159

The position taken by most writers in the LICP's newspaper in 1933 and 1934 was that Hitler was an unsavoury character but that for the good of world peace one had to do business with him. The idea was also prevalent that Nazism and Hitler were not really that much different from the capitalist ruling classes in the democracies. Thus, for example, Gérard de Lacaze-Duthiers, reviewing Challaye's brochure Pour la Paix

157 See anonymous report in 'Lactivité de la Ligue. Montargis', Le Barrage 40 (14 February 1935), p.4.

158 Gustave Dupin, 'La revanche de la Caste', PH 79 (28 July 1933), p.1.

159 Pierre Cuenat, 'Depuis qu'Hitler est là... qu'y a-t-il de changé?', PH 88 (27 October 1933), p.1. 
désarmée même en face de Hitler was of the opinion that Hitler should be taken at his word in his stated desire for peace:

...Whatever may be the atrocities committed by the Hitlerian regime in its first state - and anyone with a little humanity in them could not but disapprove of the anti-Jewish massacres, the hatred of intellectuals, the auto-da-fés of works which are the honour of our species - this medieval night which has rung the knell of a complete civilisation - one must agree that we must have confidence in such a language [of Peace] and try to respond with something other than a complete rejection. 160

The idea that there was little to choose from between Hitler and some representatives of the western liberal democracies was evident in an article written later that year by Gerin. He compared a speech made by Churchill demanding more armaments for Britain and denouncing the Nazi menace with an interview with Hitler published in Le Matin of 18 November 1934. Hitler came off much the better of the two:

...even if Hitler is not sincere, it remains a fact that each time he has been plebiscited, it has been on the question of peace. He could not have imposed himself without this policy of renunciation of war; he is only obeyed because he declares that he has rejected a bloody settling of accounts... 161

Thus, although Gerin recognised that Hitler's regime was odious and that Germany was rearming, he refused to believe that Nazism was any more dangerous than Italy, France or Britain. 162

Sylvain Broussaudier, a member of the League's Comité Directeur, former normalien, and a professor at the Lyceee in Oran wrote in 1935 that he did not understand why it was no longer possible or correct to seek a rapprochement with Germany. Paul Faure had recently criticised in the pages of the Populaire, the creation of a Franco-German society under the patronage of important Nazis and the French ambassador in Berlin. Yet, just a few years previously, Faure had been the first to castigate the French government for its consistently anti-German policies. For Broussaudier, whatever repugnance one might feel for Nazi Germany, he though it 'infinitely preferable' to make peace with Hitler rather than war with Germany. And this was not just because 'peace is infinitely preferable to war, but also because all danger of war reinforces at one and the same time both German and French fascism: 163

160 Gérard de Lacaze-Duthiers, 'Livres, Revues, Journaux' (Review of Félicien Challaye, Pour la Paix désarmée, méme en face de Hitler), Le Barrage 1 (17 May 1934), p.3.

161 René Gerin, 'Un Discours et un entretien', Le Barrage 28 (22 November 1934), p.1.

162 Ibid.

163 Sylvain Broussaudier, 'Nous demandons à comprendre', Le Barrage 72 (21 November 1935), p.3. 
At its most basic, then, the LICP's general position on the danger posed by Nazism and Fascism was that these were internal problems which needed to be resolved by the countries concerned, however much one might sympathise - and there was much sympathy - with the victims of atrocities and oppression in Germany and Italy. Hitler was a political fact and the LICP argued that France needed to do business with him. The desire for peace with Hitler, rather than war with Germany, was an overriding concern. This did not mean that the League was oblivious to the external dangers posed by Nazism. On the contrary, it was very aware that Hitler could spell war. But what it sought to do was underline the need for a modus vivendi with Hitler, a defusing of potential conflicts. And because in the integral pacifist Weltanschauung France and the Allied powers bore a share of unexpiated and unconfessed guilt for the present European situation, that meant agreeing to many of the revisions of the European political map first demanded and then taken by Hitler. There was no question of sympathy for the ideas and methods of Nazism in the LICP. It is true that a rhetoric of violence did insinuate itself into the League in the period from 1930-1934. It is also true, as we shall see, that the League at times spoke an antiparliamentary language in its analysis of French politics. It is also true that it saw rapprochement with Nazi Germany in the foreign sphere as the best policy for France to follow. But it is completely false to suggest that the LICP was in any way 'soft' on Nazism. The League consistently condemned without reservation the atrocities committed by the German regime. What it can be accused of is political naivety, myopia, and a distorted historical vision. But for all the world-weariness with which the LICP viewed the decay of Third Republic society, it never separated the struggle against fascism from that against war. It is the tragedy of its vision that all of this good will directed against a perceived fascist threat found its expression almost solely in the internal political domain.

Thus, Pierre Cuenat, writing soon after the Nazi seizure of power, condemned utterly the idea that war was inevitable, and that responsibilities for this situation lay unilaterally with the Nazis. It was too easy to say simply that Hitler was responsible for everything. That allowed Frenchmen to forget 'the unjust Versailles system, France's policy of hegemony after the war, to say nothing of the economic system which had caused the present collapse which gave rise to conflicts and fascism. ${ }^{164}$ Harking back to 1914, Cuenat asked whether the responsibilities were in fact one-sided. He believed that Hitler had come to power essentially on a platform of bastard socialism; the nationalism in his programme was still in the larva stage, but would certainly emerge if the policy of encirclement of Germany did not stop. Peace with Hitler did not mean, therefore, remaining silent about fascism, but it did mean realising that any foreign intervention would only strengthen the Nazi regime. Cuenat defined instead the task for French pacifists as

164 Pierre Cuenat, '1914, deuxième édition?', PH 71 (2 June 1933), p.3. 
follows: 'For us, the task which is incumbent on us, is to struggle against our own fascism, against our own nationalism. "Sweep before our own door". No union sacrée, even against Hitler, if we wish to spare ourselves another $1914{ }^{\prime} .165$

\section{Pacifism and Antifascism}

All of this points back to the idea that the enemy was 'within'. French pacifists were antifascist, opposed to the Hitler regime, but they clung firmly to their belief that for the overriding good of international peace they had to concentrate on fighting the perceived fascist menace in France and leave Nazism to the German antifascists. The enemy in France was at various times described as the capitalist governing class, the military caste, or simply as the politicians of the Third Republic. In its latter form, the idea carried with it definite antiparliamentarian connotations. Gerin, for example, writing in December 1934 about what he perceived to be an improved international situation, wrote that the real enemies of peace were inside France. They were the parliamentarians:

Our real enemies who are here in France are neither the Pétains, nor the Babrys, nor the La Rocques, nor the Maurras' and the other vociferous Doumergue types, who are more or less sincere and maladroit. Our real enemies are the pikes and swindlers of the present ministerial team. They aren't politicians. They are making money. And we are the ones who are paying. They are ready to do anything, even to declare themselves men of the 'left' and even to dishonour fascism, in order that their plots succeed. 166

The notion that there was something rotten at the very core of Third Republic democracy is a resonant chord in much of the LICP's political analysis during the thirties. In general - and there were exceptions - the League's position was not so much antidemocratic as one of dissent, opposed to what it viewed as the machinations and corruption of the Third Republic. Thus, for example when plans were mooted in 1934 for a reform of the constitution, Gerin wrote,

It is not we who will sing the praises of a Parliament which for a long time has been in disrepute. Its cowardice, particularly since the 6th of February, has shocked those citizens most attached to 'democratic' institutions. The parliamentary regime is worth what it is worth, that is to say, little. Such as it is, sold as it is to the economic and financial powers, it allows, nevertheless, an opposition to make itself heard, if not to be victorious. It justifies, in any case, the great word 'republic'. ${ }^{167}$

165 Ibid.

166 René Gerin, 'Détente?', Le Barrage 31 (13 December 1934), p.1.

167 René Gerin, 'Un Dictateur?', Le Barrage 24 (25 October 1934), p.1. 
He said that men of the 'left', revolutionaries and pacifists, were indiscriminately accused of working towards disorder. 'Order' must not be confounded with subjection or servitude, though. Gerin believed that it was not the product of tyranny or the complementary resignation in the governed that this required. Rather, he thought, it was liberty and a search for progress on the part of both governments and governed. ${ }^{168}$

The LICP nevertheless enjoined its members to put the pacifist case before the public at the time of elections. In 1935, Gerin wrote that pacifists and Frenchmen generally, had been terribly disappointed at the lack of progress made towards peace in the Chamber elected under the 'sign of peace' with Briand at the helm in 1932. In the upcoming elections, candidates had to be forced to take positions on the question of peace, and if possible straw candidacies should be run in order to give the League access to the French electoral billboards. Having said that, Gerin held no illusions about the success of pacifist propaganda in the present state of French democracy: 'In the LICP we do not have great confidence in the elected to maintain the peace. We count much more on the governed rather than the governors to kill war'.169

In 1937, just before the Congress of the Ligue des Droits de l'Homme which had as its theme 'how to defend both democracy and peace', Gerin addressed the question directly in Le Barrage. He began by emphasising that not all members of the League were democrats in the 'present, unfortunately precise meaning' of the word. But, if one were to restore 'to the word democracy its broader sense, which is the liberation of individuals, equality of rights, justice, etc... there is no doubt that we all aspire to the same idea, because this means to aspire at the same time to peace'. ${ }^{170}$ It seemed to be increasingly the case that friendship between nations was a function of similarity of their regime, a fact which made it difficult for pacifists to urge peace with all peoples. The LICP did not condone dictatorship, but it did seek peace with the dictatorships, believing that nations must have the right to manage their own affairs. With regard to France and the other democracies, the LICP did not confuse their pale reflections with the higherideal of true democracy. Nor did it confuse the totalitarian regimes with the democracies. In this sense, Gerin wrote that it would be preferable for the world political situation, if all nations were 'democratic'. At least in the democracies a sufficient level of freedom existed for people to express themselves. $\mathrm{He}$ envisaged the possibility of war between democracies and the fascist states. Hitler had said on 30 January that no further disputes between Germany and France were 'humanly' possible. For Gerin,

This word 'humanly' says too much. It is because the Germans and the French are men who are equally pacific, but unequally free,

168 René Gerin, 'Les "mentalités obstinées"', Le Barrage 21 (4 October 1934), p.1.

169 René Gerin, 'Bientôt, des élections', Le Barrage 47 (4 April 1935), p.1.

170 René Gerin, 'La Démocratie et la Paix', Le Barrage 113 (24 June 1937), p.1. 
above all unequally concerned about freedoms, in a word unequally democratic, that there will perhaps continue to be disputes between them. 171

But the distinction which Gerin admitted existed between democracies and the fascist states in no way implied an acceptance of war as the means to resolve these differences. To defend peace, it was necessary to defend democracy such as it existed in France after centuries of struggles, but it had to be done by example and not by force. 172

It has already been noted that the LICP was convinced from the outset of the danger posed by fascism in France. In the first years of its existence, this was often the result of personal experience since LICP meetings were frequently the target for the excesses of right-wing thugs. The crisis of 6 February 1934 in France, however, served to convince the League even more of the danger posed by indigenous fascism. It strengthened its belief both that France's sickly parliamentary democracy had to be defended and that the first duty of integral pacifists was to fight the war psychosis by fighting French fascism.

In a press communique of 10 February 1934, the LICP called for unity against French fascism: 'More than ever, an end to political discussions. Accept, and even advocate the organisation of a common struggle of all of the popular masses against the fascist hordes!'173 Edouard Lemédioni, a barrister at the Court of Appeal in Algiers, wrote shortly thereafter that 'peace is less threatened today than is liberty'. He said that the present situation in France 'resembles, alas, only too much that of Italy and Germany a little before the advent of fascism and Nazism.'174 He laid a large part of the blame for the crisis precisely at the feet of the democrats, socialists, pacifists, communists, syndicalists and libertarians, none of whom had reacted early enough to the situation. The problem with the parties of the left was that they spent too much time tearing one another apart and too little time fighting the real foe. Lemédioni could not overstate the seriousness of the situation:

We must not hide from ourselves the importance of the present events. The proletariat and with it the democrats and pacifists, has just suffered a redoubtable setback. The so-called Ministry of National Union or of the party truce is making a bed for the fascists if we do not know how to react. 175

171 Ibid.

172 Ibid.

173 'Notre Mot d'Ordre', Le Combat pour la Paix 9 (February 1934), p.4.

174 Edouard Lemédioni, 'Rapport sur la tactique que la Ligue doit adopter afin de rendre efficace l'action qu'elle mène contre la guerre', Le Combat pour la Paix 9 (February 1934), p.4 .

175 Ibid. 
He called for the creation of local antifascist committees across France and with them the establishment of militias designed to defend Republican France by force of arms. 176

In the wake of the events of 6 February, the LICP reviewed its statutes and revised its goal to include the fight aganst fascism as well as war. A Manifesto read to the League's 1934 Montargis congress and passed unanimously condemned fascism and war in equal terms, but suggested that the more immediate danger came from fascism. In the LICP's view, fascism in France, which was defined as the triumph of capitalist, military, clerical and police reaction, greatly aggravated the dangers of war. The signatories of the manifesto were careful, however, to define the League's struggle as against internal fascism and external wars, the conjunction of these two phenomena being the paramount danger. ${ }^{177}$ The position taken by the Manifesto writers was enshrined in a rewording of the League's goal so that it now read:

[The League] will use all means of action (lectures, publications, demonstrations) against wars imposed by governments on the Peoples in the name of a so-called national interest, and against fascism which, destroying our liberties, leads inevitably to war. Against fascism and against war by all means, that is our motto. ${ }^{178}$

Six months later, Gerin declared, however, that fascism had failed in France, and was in retreat in the rest of Europe. In his view, France had never really known fascism; instead there were only the usual reactionaries who sought to exploit social problems in an attempt to create a 'renovating' regime on foreign lines. The two forces which had coalesced in creating Italian and German fascism had been a strong need for national unity and the misery created by economic collapse. With regard to the first, it had proved impossible to resuscitate the nationalist passions in France necessary for the creation of an indigenous fascism. As for the second, France had mercifully been spared the full effects of the Depression. In Gerin's view, the events of 6 February had in the final analysis merely shown the impotence of French fascism. 179

The LICP remained committed to this policy of internal antifascism right up to 1939. It also continued to condemn the atrocities of the Nazi regime but increasingly as the thirties drew to a close, the LICP became concerned that antifascism 'for external use' might lead to war. The League's insistence on the somewhat paradoxical need to take a moral position on Nazism - and at the same time to eschew any unnecessary stirring of troubled waters with the Nazis - is the hallmark of the LICP's approach to the problem posed by the external

176 Ibid.

177 'Paix et Liberté (Manifeste adopté au Congrès de Montargis)', Le Combat pour la Paix 11 (April 1934), pp.1-2.

178 'Compte-rendu du Congrès de Montargis', Le Combat pour la Paix 11 (April 1934), p.4.

179 René Gerin, 'Le "Fascisme" a fait faillite', Le Barrage 17 (6 September 1934), p.1. 
threat of fascism. In this sense, the LICP drew its historical inspiration from Robespierre. 180 Georges Michon, for example, writing about Robespierre's position on the external, essentially imperialist wars of the French revolution, compared Robespierre's opponents with their latter-day equivalents:

May our little politicians draw inspiration from this great
example of civic virtue. But they do not like the Incorruptible who
would have nothing to do with a République des camarades. They
prefer Danton. One understands how M. Herriot not long ago
sharply criticised the idea of erecting a statue to Maximilien, and
that he afterwards figured at the head of an honorary committee
constituted to commemorate the centenary of Napoleon I (1921). Do
we not also see the Communist party celebrating the centenary of
Rouget de l'Isle, and waxing lyrical on posters about Danton -
whose venality was proven many times - without even mentioning
Robespierre or Babeuf. 181

Félicien Challaye expanded this view eighteen months later in a review of Michon's book, Robespierre et la Guerre Révolutionnaire (1791-1792), arguing with Michon and Robespierre that war does not serve the interests of the masses. He denounced the 'criminal and anti-revolutionary character' of war and wrote that 'we shall repeat that war is incapable of sowing a love of liberty; because "no one likes an armed missionary"'.182

This historical position easily translated itself into a justification of the league's oppositon to external antifascism and its views on German refugees in France. In early 1936 Challaye expressed concern at the actions of 'certain refugees' in France who seemed to be pushing towards a war with Germany. He had all the sympathy in the world for the vicitims of Nazism who were in France - the Jews, Communists, Socialists and democrats but he was alarmed at the anti-German, or pro-war propaganda bing spread by these people. It was essential in his view that the ire of these refugees not be allowed to be added to the traditional hostility already existing between the French and German peoples. The refugees must not be allowed to foment a war that would enable them to return victorious to Germany on the backs of the French army. Connecting present events with historical antecedent, Challaye drew his conclusion: 'the action of the German refugees of 1935 calls strangely to mind that of the foreign refugees of 1792, pushing France into a so-

180 It is interesting to note that Albert Mathiez, the historian of Robespierre, was one of the first members of the old Comite Directeur of the LICP under Méric. See James Friguglietti, Albert Mathiez, Historien reoolutionnaire (1874-1932), translated from the English by Marie-Françoise Pernot (Paris: Société d'Etudes Robespierristes, 1974), pp.226-227.

181 Georges Michon, 'Robespierre et la Guerre Révolutionnaire', Le Barrage 80 (16 January 1936), p.1.

182 Félicien Challaye, 'Robespierre et l'actualité', Le Barrage 116 (30 September 1937), p.1. 
called war of liberation of the nations'. ${ }^{183}$ This general position on the dangers of an antifascism directed exclusively at external threats was echoed by Gerin, who at the same time recognised the tactical discomfiture felt by integral pacifists in defending a political position shared only with the right in France:

We must warn our comrades against the possible excesses of antifascism, however legitimate it might be; we remind them forcefully that our hatred is directed against the tyrants and not against the people, and we regret that it should be only the French Right today which is favourable to ideas of Franco-German rapprochement. 184

The LICP thus trod a very narrow line at times between an ethically acceptable, leftwing pacifism and ideas which seemed on the surface to be more at home on the extremeright in France. The League was consistently antifascist within France but tended to limit its external antifascism to condemnations of Nazi racial attacks in Germany. As far as the claims of the Nazi regime to a complete restructuring of the European political map were concerned, the LICP was often acquiescent, believing these claims to be justified by the 'mistakes' made at Versailles. The LICP condemned antisemitism both in France and in Germany, but equally attacked those Jews it felt were pushing France towards another guerre $d u$ droit. The fundamental tenet of its belief was that one could be both a convinced antifascist and a pacifist at the same time.

Thus, for example, Victor Méric in April 1933 wrote that there were 'Jews and Jews'. He condemned those who sought to embroil France in a war with Germany by rushing to the aid of German Jews. He warned them not to 'be more royalist than the King himself; instead he called them to align themselves with their natural friends, the socialists, revolutionaries and pacifists. Together they would defeat the enemy within France. 185

In 1934 an anonymous writer warned readers of Le Barrage against what it considered the extremist position of the Ligue internationale contre l'antisémitisme (LICA). There was a great danger that the heightened campaign against antisemitism would only serve to increase the chauvinism and Germanophobia which the writer thought the French government was trying to encourage. 186

Having said that, the LICP consistently condemned the attacks on Jews both in France and in Germany. Gerin, writing in the wake of the assassination of the German diplomat Von Rath in Paris in 1938, said that the League and the Barrage 'condemned with the

183 Félicien Challaye, 'La Préparation de la Guerre et l'action de certains réfugiés allemands', Le Barrage 78 (2 January 1936), p.1. See also Félicien Challaye, 'Antifascisme et Pacifisme intégral. Réponse à Bernard Lecache', Le Barrage 81 (23 January 1936), p.1.

184 René Gerin, 'Bilan 1935', Le Barrage 78 (2 January 1936), p.1.

185 Victor Méric, 'Lettre ouverte aux Juifs de France', PH 64 (15 April 1933), p.1.

186 'Prenons garde!', Le Barrage 20 (27 September 1934), p.1. 
greatest indignation the persecutions and diverse acts of antisemitism in which the German government is indulging, in the wake of the assassination, odious in itself, of Counselor Von Rath. ${ }^{187}$

The LICP's insistence on a division between its internal and external antifascism, coupled with its essentially non-interventionist view of European politics based on Robespierrist principles and a conviction that many of the political claims of Nazism in the European sphere were either justified or understandable, led in 1936 to the final break with Romain Rolland. In the period from the Amsterdam congress to 1936 Rolland had become increasingly convinced of the need for what he called an 'indivisible peace' which basically meant collective security. 188 This was rejected categorically by the ideologues of the League. Rolland had argued that the most pressing danger was that from without; he had called for a moral and material resistance to Nazism. Georges Pioch agreed with the idea of a moral resistance but wondered whether material resistance did not mean war. Nations, like people, could no more be forced to be free than to be happy. Italy and Germany had to free themselves from the tyranny of fascism. He did not personally believe that a Franco-German rapprochement was likely but if one were possible he believed that for the cause of peace pacifists would have to swallow their disgust of the Nazi regime. 189

The differences in approach to the problem of external fascism were largely due to the different perspectives held about Nazi Germany and Hitler's intentions. Félicien Challaye protested that Romain Rolland could not possibly know what Hitler's future plans were or that he was lying - to claim the contrary was simply not logical. Much of the dispute seemed to centre around the anti-French passages in Mein Kampf and whether a book written during the Ruhr Crisis should be taken seriously in 1936. Challaye argued that it should not. It was understandable that it was widely distributed in Germany where it helped to 'create a maximum of national cohesion' and also that it was not freely available in the West where in Challaye's view it would merely risk increasing the hostile incomprehension of which Germany is the victim'. 190 Instead of a 'material resistance' to Nazism, Challaye proposed general disarmament. If that failed and war broke out between Germany and the Soviet Union, then France should attempt to localise it and not get involved. If Germany should attack France, then the true interests of the French people lay in avoiding participation in such a war. The only sane strategy, according to

187 René Gerin, 'Décrets-Lois', Le Barrage 137 (17 November 1938), p.1. Similar views were expressed by Nadia Gukowski in 'Racisme et nationalisme', Le Barrage 138 (1 December 1938), p.1.

188 Romain Rolland, 'Pour l'Indivisible Paix', Le Barrage 83 (6 February 1936), p.2. This article was reprinted from Vendredi of 24 January 1936. See also Appendix II of this thesis for a more complete description of Rolland's evolution.

189 Georges Pioch, 'Questions à Romain Rolland', Le Barrage 82 (30 January 1936), p.1.

190 Félicien Challaye, 'A propos de "l'indivisible paix". Réponse à Romain Rolland', Le Barrage 83 (6 February 1936), p.1. 
Challaye, was to avoid the destruction of war at all costs and wait for the internal revolt against Nazi rule to begin. 191

In a further analysis of Rolland's evolution away from integral pacifism, Challaye wrote that the author of Liluli and Stalin's friend were fighting within Rolland, 'just as Jesus and Dionysos fought within the soul of Nietzsche'. 192 The ambiguity of Rolland's position was obvious to Challaye. He was clearly no longer in agreement with Bertrand Russell that war was the ultimate evil. Instead, the worst evil had become the debasement of a people. Challaye disagreed, arguing that social justice is a necessary goal but that it could not emerge from a war. Secondly, Challaye challenged the assumption that Nazism was, in fact, the ultimate evil. He pointed out that concentration camps existed in Italy, and indeed that France used them in Tunisia and Indochina. And what about the Soviet Union under Stalin? His third point was that Rolland's desire to see treaty revision negotiated from a position of strength for the western democracies was ridiculous; for fifteen years after the Great War the West had enjoyed this superiority and had not used it wisely. Germany would never agree to negotiating on such a basis. Finally, Challaye distinguished yet again between external and internal antifascism:

The struggle against internal and external fascism presents, despite everything, very different characteristics. The struggle against internal fascism is the civil battle which we accept. Idea against idea, truncheon against truncheon. The fight against Hitler and Mussolini is, for a Frenchman, the fight against the Colonel-Count de la Rocque and against Charles Maurras. This is the national front which we must occupy in the international struggle against fascism. But the struggle against external fascism takes on necessarily the aspect of a war. We want nothing to do with war, even that which is baptised antifascist and revolutionary. We are convinced, moreover, that one does not bring freedom on the tip of a sword, nor democracy in foreign troop carriers [fourgons de l'étranger]. 193

\section{Pacifist Tactics}

The preceding pages have attempted to define the diversity of the LICP's approach to pacifism, and to describe the League's position on violence, antifascism, antisemitism, and French parliamentary democracy. We have also shown how the League developed an approach to the problem posed by the Nazi seizure of power. As will no doubt be clear from the above, the LICP was an intellectually amorphous organisation comprising many

191 Ibid.

192 Félicien Challaye, 'Seconde réponse à Romain Rolland', Le Barrage 90 (19 March 1936), p.2.

193 Ibid. 
different strands of thought on pacifist definitions and tactics. The one underlying theme common to all of these different orientations within the League was a complete rejection of foreign wars.

At its yearly congresses from 1934 to 1939, the LICP debated a series of reports which defined its views on the nature of pacifism, the causes of war, its political orientation within French society, and the ever-present dilemma for pacifists of effective tactical responses to the problem of war.

At its third annual congress in 1934, and the first since the schism with the Patrie Humaine, Edouard Lemédioni prepared a lengthy report on the tactics which the LICP should adopt in its fight against war. The time had come to elaborate specific policies and to attempt to create a truly mass organisation drawing members from both the working class and the middle class. Lemédioni, perhaps referring to Méric's style, wrote that demagogy was worthless; what was needed was propaganda and education. In his view there were three essential points which had to be made to the public. First, the League had to demonstrate to its audiences the shameful reality of the munitions trade, before, during and after the Great War, a question 'which engages the crowds' and which Lemedioni considered essential. Secondly, the LICP must emphasise the horrors that another war would bring with the advances since 1919 in military science. And finally, it was important to remind audiences of the responsibilities for the war of 1914, thus proving to the masses 'that the peoples are always fooled by the governments which are dominated by the powers of money, and that it is impossible to designate an aggressor when a conflict breaks out'.194 With regard to the League of Nations and a 'certain pacifism' which sought to establish peace through purely juridical means, Lemédioni believed that the LICP had to put the masses on their guard; the League of Nations was nothing more than an association of imperialist governments, some of them under the thumb of heavy industry. On conscientious objection Lemédioni believed strongly that the LICP could not recommend it as a tactic because it was an individual act with such personal consequences; however, the League had an obligation towards COs to aid them materially and morally. Fascism had to be opposed, but he underlined that it was not the only regime which practised a policy of expansionism; he believed that imperialism could be just as great a danger to peace as fascism or Nazism. In any case, the League had to reject any notion of a preventive war of the democracies against Germany. With regard to economic sanctions against German goods, he argued, together with the minority group on the Central Committee of the Ligue des Droits de l'Homme, that these sanctions were ineffective and would only accentuate the

194 Edouard Lemédioni, 'Rapport sur la tactique que la Ligue doit adopter afin de rendre efficace l'action qu'elle mène contre la guerre', Le Combat pour la Paix 9 (February 1934), pp.1-2. 
hatred between the peoples and 'weld the German people more closely to its government'. 195

Having outlined his position on the above matter, Lemédioni proceeded to elaborate a series of steps towards what he called a positive pacifism. This positive pacifism had to be supple and capable of responding even to half measures in the political sphere. As a first measure, he suggested demanding clarification of positions from politicians at election time and support for a bill giving freedom of conscience to conscientious objectors. Secondly, he pressed for the nationalisation of the armaments industry. Thirdly he demanded the abrogation of the 'lois scélérates' of 1893 and 1894. Finally, he thought the league should press for the abrogation of the law of 31 July 1920 which punished anticonceptional propaganda - a law of which several of the LICP's speakers had fallen afoul already. In the wake of the crisis of 6 February, he also went on to prescribe a series of measures to respond to the perceived fascist threat which has already been discussed above. 196

Lemédioni's report was passed almost unanimously by the Montargis Congress, and the Comite Directeur of the League was charged with drafting a programme which would reflect concrete policies for pacifists. It should be stressed, though, that in the wake of the events of 6 February, the Congress took the position that the most pressing danger was that posed by fascism which had to be fought on the domestic level. 197

The 1935 Agen Congress was another fractious one for the LICP. Lemédioni, Marcelle Capy (who was President of the League in 1934-5), and Henri Guilbeaux all left the League for reasons which are not entirely clear. Guilbeaux had been writing a weekly column for some time on international affairs and had been charged with the drafting of the first edition of the League's brochure, Programme, Tactiques et Moyens d'Action. He also prepared a report for the 1935 congress on the idea of a Franco-German-Soviet union and the struggle against fascism. This report was printed in the Barrage, but strangely appears never to have been presented or discussed at the Congress; Guilbeaux resigned from the League in an apparently discourteous letter before the congress opened. 198 From the Congress proceedings it appears that part of the reason for these multiple departures was the League's consideration of a report by Sébastien Faure on unilateral disarmament. Lemédioni attacked it as a 'chimerical idea', 'inoperative' and liable to 'upset public

195 Ibid., pp.2-3.

196 Ibid., pp.3-4.

197 'Compte-rendu du Congrès de Montargis', Le Combat pour la Paix 11 (April 1934), p.4. See also 'Paix et Liberté (Manifeste adopté au Congrès de Montargis)', Le Combat pour la Paix 11 (April 1934), pp.1-2.

198 See 'Les Travaux du Congrès d'Agen', Le Barrage 50 (2 May 1935), p.4. 
opinion': He accused Faure of making an 'anarchist profession of faith' in arguing for unilateral disarmament. 199

Guilbeaux' report, which was never voted on, was a logical continuation of his column in the pages of the Barrage. He argued against any policy of encirclement of Germany which could only lead to war. He was opposed to the League of Nations because it was an association of imperialist powers which 'by definition' could only foster wars. On the other hand, he was in favour of the nationalisation of war industries as a useful first step towards eliminating war. Undoubtedly, Guilbeaux' favourite project, though, was the idea of a Franco-Soviet-German union. He declined to call this an alliance or a bloc, because these all led inevitably to war, and denied that the idea had an anti-British flavour to it. The logic behind his thinking, difficult though it is to conceive, was that the three powers that mattered in continental Europe were France, Germany and the Soviet Union. Any other constellation was likely to be dangerous because the ideological dimension might create friction; but in the arrangement proposed by him, liberal democracy, fascism, and communism would, supposedly, harmoniously cancel one another out. He also wanted the League to differentiate between imperialism and fascism which were both dangerous for peace, but in different ways. 200

Lemédioni's report on an obligatory popular referendum before any declaration of war was not presented to the Congress. A report by Robert Jospin on the nationalisation of the armaments industry was passed by the Congress. It seemed to contradict the conclusions reached the year before which had been favourable to such a move. Jospin argued that while nationalising weapons manufacture could perhaps be interpreted as a first step, in reality such a move would change little or nothing for the integral pacifist. A nationalised arms industry was no guarantee of peace, although it would undoubtedly cut off a source of funding for the 'bought' press. Nevertheless, the weapons would remain instruments of death. A further problem was the incompleteness of such a proposal. To be truly effective, nationalisation would have to include all of the raw materials industries - the iron, potash, petroleum, and colonial markets - which contributed to the manufacture of arms. But perhaps more importantly, Jospin saw a potential trap for integral pacifists in this proposal. Pierre Cot had already suggested in the Chamber that if nationalisation occurred it would remove one of the biggest arguments for pacifism. Jospin concluded: 'We have been fairly warned. Our total submission would be the ransom, the payment in a sense, for the nationalisation of arms'.201

199 Ibid.

200 Henri Guilbeaux, 'Rapport sur le programme, l'Union France-Allemagne-URSS, et la lutte contre le fascisme', Le Barrage 43 (7 March 1935), pp.4-5.

201 See Edouard Lemédioni, 'Rapport sur le référendum populaire', Le Barrage 44 (14 March 1935), p.4. Lemédioni's report was not presented to the Congress or voted on. See 'Les Travaux du 
The Congress also passed by a large majority the report by Sébastien Faure in favour of unilateral disarmament; this report really summarised Faure's thinking on a subject on which he had already published. 202 Maurice Weber's report on nationalist ideologies was also passed but it implied nothing for the League's tactics and was more a critique than a call to action. ${ }^{203}$ In another report, though, Robert Jospin addressed the question of what to do if war actually broke out. He wove a narrow line between laying down specific recommendations and avoiding the entrapment of the 'lois scélérates' by saying little that was precise. His emphasis, though, was on the hic et nunc. War had to be opposed before it erupted and this meant education and having the courage to take individual positions. 'We will reap what we have sown', he said, '... let us promise ourselves, and that will suffice'. His report was passed by the largest majority, thus giving it claim to being the method of fighting war most favoured by the LICP. 204 The Comite Directeur had wanted to establish a sort of hierarchy of pacifist tactics at the Agen Congress. At the same time, it was careful not to exclude any and to leave the choice of tactics up to the individual sections. In order of preference, the LICP had therefore pronounced itself in favour of Jospin's educative approach with the latent suggestion that individual acts of resistance would be called for in the event of war; secondly for the idea of unilateral disarmament; and thirdly against the idea of a simple nationalisation of the armaments industry only. The popular referendum and Guilbeaux' political report were never discussed.

The following year at the Bernay congress, the league continued its examination of pacifist tactics; Bauchet said in his Rapport Moral that while all methods were acceptable, the League needed to continue its attempt to establish a hierarchy of values. ${ }^{205}$ Aside from the theoretical questions, there were also practical issues to be considered. In the previous Congress, at Agen, Bauchet had presented a report on the practical organisation of the League, especially as it pertained to propaganda. ${ }^{206}$ The following year at Bernay, Gerin ran through the many excellent suggestions made by Bauchet and

Congrès d'Agen' loc. cit. See also Robert Jospin, 'Rapport sur la nationalisation des armements', Le Barrage 44 (14 March 1935), p.4.

202 S. Faure, 'Rapport sur le désarmement unilatéral', Le Barrage 44 (14 March 1935), pp.5-6. See also 'Les Travaux du Congrès d'Agen' loc. cit. See also S. Faure, Nous voulons la Paix (Paris: chez l'auteur, 1932), in which Faure argued the case for unilateral disarmament.

203 Maurice Weber, 'Rapport-critique sur les ideologies nationalistes', Le Barrage 44 (14 March 1935), pp.4-5.

204 Robert Jospin, 'Rapport sur la question: Si la guerre éclatait?', Le Barrage 44 (14 March 1935), p.6. See also 'Les Travaux du Congrès d'Ágen' loc. cit.

205 Emile Bauchet, 'Rapport Moral', Le Barrage 87 (5 March 1936), p.4.

206 See Emile Bauchet, 'Rapport sur l'organisation pratique', Le Barrage 44 (14 March 1935), p.2. 
found that hardly any of them were being followed. The league was in danger of failing in its mission because of lack of organisation. 207

The 1936 congress saw two main doctrinal reports presented and discussed. The first of these, by Jeanne Humbert, dealt with over-population as a cause of war. Humbert argued an essentially Malthusian case, saying that there were natural or biological reasons for war as well as social and psychological ones. Overpopulation and the scarcity of food and raw materials caused wars, and she demanded in conclusion an end to the restrictive laws on anticonceptional propaganda and sex education. Humbert's report was adopted with near unanimity, although Challaye reacted strongly against the suggestion that overpopulation led inevitably to war. 208

\section{Political Parties, the Popular Front and Pacifism.}

The 1936 Congress also discussed a substantial report on 'The Political Parties, the Popular Front and Peace', drawn up by Robert Jospin and Maurice Weber. ${ }^{209}$ They underlined the differences between the LICP's viewpoint and those of all political parties. Their distinction between political party and pacifist movement is important to our definition of what is under discussion in this thesis. For Jospin and Weber, the essential characteristic of political parties was a preoccupation with the organisation of society and the state. 'All parties, however excellent may be their intentions, claim to create man's happiness in spite of him if necessary: they resign themselves sometimes to sacrificing a great number of men in order to guarantee the salvation of those who are left'. 210 Thus, in the authors' view, the masses were but the instruments which the parties used to further their own external and internal political views. The LICP on the other hand, had a completely different conception of the role of the State; it placed the 'interests of the governed, not those of the governors' first. 211 The distinction reduced itself fundamentally to one between an individualist versus a collectivist view of the state. The LICP believed fervently that the individual was the most important social unit, while still taking account of the needs of the larger social group. The problem in France was that the needs of society had begun to take precedence over those of its units, with the unfortunate result that society had become an oppressive creature periodically demanding the sacrifice of the individual to its 'higher' needs. The LICP was not arguing for unbridled individualism;

207 René Gerin, 'Rapport sur l'organisation de la propagande', Le Barrage 87 (5 March 1936), p.4.

208 Jeanne Humbert, 'La surpopulation et la guerre', Le Barrage 87 (5 March 1936), p.5. See also 'Les Travaux du Congrès de Bernay', Le Barrage 94 (23 April 1936), p.3.

209 Maurice Weber and Robert Jospin, 'Rapport sur les Partis Politiques, le Front Populaire et la Paix', Le Barrage 87 (5 March 1936), Pp.5-6; and Le Barrage 88 (12 March 1936), p.4.

210 Weber, Jospin, '... les Partis Politiques...', Le Barrage 87 (5 March 1936), p.5.

211 Ibid. 
Weber and Jospin believed that individualism must be limited in its expression, but that equally society had to attempt to assure the maximum amount of happiness and prosperity for the greatest number in the greatest liberty. In France it seemed that there was an inevitable drift towards forgeting this principle; that was why the slide towards absolutism had to be constantly checked by, to borrow Alain's expression, 'the citizen against the authorities. 212 The important concept in the report was that all political parties in France were infected with varying degress of the same mentality.

With regard to the parties of the Right in France, Weber and Jospin demonstrated that they were torn between conflicting ideas and tendencies. The political situation had become even more complicated with the Nazi accession to power because the Right was now split between those who favoured a pact with Hitler and those who advocated the LavalStalin pact because they continued to conceive of Germany as the principal and traditional enemy. A pseudo-pacifism had thus insinuated itself into the Right, a pacifism based not on conviction but on political opportunism. Weber and Jospin thought that the LICP should be encouraged in its work without being under any illusions about the temporary nature of the conversion of these 'unexpected neophytes'; the Right remained camouflaged bellicists, interested only in the maintenance of France's conquests and colonial domains. ${ }^{213}$

As far as the Radicals were concerned, the report concluded that they had always been infected with nationalist and patriotic ideas. Some radicals it was true, professed a vague pacifism based purely on juridical principles - 'genre "Paix par le Droit" - but their pacifism was based on too many mistakes from the past. The idea that peace could be achieved through the League of Nations or an armed international force was 'the policy of sanctions pushed to the point where it could provoke a war'.214 The LICP rejected a repetition of this tragic vision from recent history.

The position of the Communist party created special problems for the League. Weber and Jospin wrote that they were 'profoundly convinced of the need to defend the USSR', but the 'essential question' was precisely to know by what means this could be achieved. As far as the LICP was concerned, methods of force and violence were not the way to go about this. The Stalin declaration had turned the world of pacifism upside down. Part of the blame for the situation lay with the Allies' failure to disarm according to the provisions of the Versailles Treaty. This had helped to prepare the way for Hitler. But they rejected out of hand any notion of a Communist-inspired crusade against the fascist dictatorships. For real pacifists the challenge and the duty were clear:

212 Ibid.

213 Ibid. Cf. Joseph Folliet, Pacifisme de droite? Bellicisme de gauche? (Paris: Editions du Cerf, 1938), which examines the pseudo-pacifism of the Right at the time of Munich.

214 Ibid., p.6. 
It is up to pacifists to affirm, despite all individual weaknesses, the convictions that are theirs, and to resist with all their force the bellicist contagion. They must maintain the distinctions which are necessary, and not permit the confusion of the necessary fight against the fascist regimes with a crusade which would be transformed into a holy war... The danger is so great that one can perhaps after all consider the existence of a part of French public opinion favourable to Hitlerism - as long as it remains a sufficiently weak minority - as a useful counter-weight. For it is good that a government does not have behind it an overly unanimous public opinion; that helps to make it more prudent and wise. 215

Because of this view of international politics, Weber and Jospin could only warn League members to stay away from the Rassemblement Universel pour la Paix, as well as Soviet front organisations like the Amsterdam-Pleyel movement. 216

Unlike the situation within the PCF, the Socialist party was completely divided on the question of peace and how best to attain it. The party contained a number of different individual attitudes which did not concern the LICP as much as those of other parties. This was not to say that they all gave complete satisfaction - far from it. The writers singled out Zyromski and his faction, in particular, for attack. They praised the SFIO for always having refused to condone the Versailles treaty and for its condemnation of the Ruhr occupation. Léon Blum was lauded for his personal stand against war and for unilateral disarmament, but he was too constrained by his position as party leader. Paul Faure was praised, There was also support for Marceau Pivert's Gauche Révolutionnaire which seemed to be evolving towards the sort of pacifism espoused by the LICP. ${ }^{217}$

The programme of the Front Populaire came in for serious criticism as much for what it did not say, as for what it said. Weber and Jospin provided a critique of the seven points of the programme of the Popular Front which related to the defence of peace. The first of these was an appeal for the collaboration of the masses in the work of the organisation of the peace. But as the writers acerbically remarked, if peace was indeed so threatened and in such a precarious state, it was certainly not the fault of the masses, but rather of governments. It was these same governments which had created the Versailles system which was the origin of so many of Europe's troubles. 218

The second point of the programme demanded national collaboration within the context of the League of Nations, and collective security through the definition of the aggressor and the automatic application of sanctions. The LICP rejected this idea almost in its entirety. Its confidence in the League was very limited anyway, and the notion that military

215 Ibid.

216 Ibid.

217 Weber, Jospin, '... les Partis politiques...', Le Barrage 88 (12 March 1936), p.4.

218 Ibid. 
sanctions could be called for under article sixteen of the Covenant was completely unacceptable. 219

The third point spoke of an 'incessant effort to move from a state of armed peace to one of disarmed peace', through the negotiation of an accord first on the limitation, and then on the reduction, of armaments through gradual, controlled and simultaneous disarmament. The LICP praised the good intentions, but criticised the method. Governments did not have the courage to set an example through unilateral disarmament. 220 .

Fourthly, the programme called for the nationalisation of the armaments industry and the suppression of free trade in arms. The LICP report saw this as a positive demand but one which was far from capable of assuring peace. Jospin and Weber wrote, 'to say that war is due to the will of the arms merchants is really to minimise and make puerile a terribly complex question:.221 But it would not do away with the problem of war and pacifists should not be lulled into thinking that it would.

The Popular Front's fifth point was a 'repudiation of secret diplomacy', coupled with an attempt to reintegrate into the League of Nations those countries which had left it, whilst at the same time reaffirming the ideas of collective security and an indivisible peace. Weber and Jospin rejected the notions of collective security and indivisible peace and stressed that the programme did not mention the denunciation of the secret treaties already in force. This had to be done in order to clean up international affairs. 222

The sixth point dealt with the 'peaceful adjustment of those treaties which were dangerous for the peace of the world'. It is interesting to note that the LICP view of what constituted a dangerous treaty was any treaty which 'was not in accord with the political, economic, and moral realities of the moment, and which were dictated to the vanquished by force, instead of being freely negotiated between equals'.223

Finally, Weber and Jospin criticised the seventh point of the programme which pressed for an extension of the open pact system in central and eastern Europe along the lines of the Franco-Soviet Pact. They rejected the idea that these pacts were in fact open to everybody; they could not be because they were based upon a vision of Europe which had its origin in the Versailles Treaty and was therefore inimical to the desires and view of the defeated nations of 1918. The Franco-Soviet Pact was in danger of becoming anything but 'an instrument of pacification' in their view. If further pacts were to be signed, it was essential

\footnotetext{
219 Ibid.

220 Ibid.

221 Ibid.

222 Ibid.

223 Ibid.
} 
that they contain no military clauses, but the reticences of the programme on the specific point of secret treaties caused Weber and Jospin great concern. 224

These specific concerns were relatively minor alongside Jospin and Weber's main worry about what the Popular Front programme did not say. There was nothing in it about imperialism which the authors called the idea that nations enjoyed an absolute sovereignty in their own affairs. This was the real cause of wars. Harking back to 1918, Jospin and Weber strongly criticised the programme for remaining frozen in the past and refusing to embrace the still untried ideas of Wilson, 'the only ones which can lead to a real peace'.225 The indispensable revision of the treaties could never occur in a moral and political climate so opposed to it. They concluded:

This peace programme is insufficient for the creation of Peace. It is liable, if not of leading into a war, at least of being impotent to preserve us from one, despite the good will of its authors. 226

Having criticised at great length the policies of both the Popular Front and of the main political parties in France, the authors passed to an examination of what they considered the fundamental question, the conditions of a genuine Franco-German rapprochement. With regard to recent events, such as the remilitarisation of the Rhineland and the abrogation of the Locarno treaty, Jospin and Weber 'dared' to write that they found the new situation 'more encouraging' because clearer. They cited Paul Faure in an article of 8 March in the Populaire, who wrote that 'everything remains to be done, everything remains to be rebegun, or rather everything must now begin.' As far as the internal atrocities of the Nazi regime were concerned, these undoubtedly constituted a 'difficult psychological obstacle to be overcome'. In a biting criticism of what they perceived to be the essentially antiGerman, rather than specifically anti-Nazi orientation of recent French foreign policy, they wrote,

In reality, the argument about the internal regime is really just a bad pretext; those who would move against it confound the necessary struggle against fascism within each country with an anti-German crusade. These are not real pacifists. These people did not seriously protest against the formation of the 'Stresa Front', and they continued to view Mussolini's Italy as a pacifist nation right up to the outbreak of war in Ethiopia. They also find it completely normal to have military alliances with the little fascist countries of the Balkans. ${ }^{227}$

224 Ibid.

225 Ibid.

226 Ibid.

227 Ibid. 
Thus, while reserving the legal and moral right to criticise, Jospin and Weber argued that the only logical and sane approach to the dilemmas posed by Nazism was to follow religiously the old diplomatic rule of 'taking no account of our preferences or repugnances for any particular regime'.228 To do otherwise required a constantly high level of military preparedness and constituted what the authors called 'the revolutionary deviation of 1792' which led 'us to foreign wars, militarisation and Bonapartism'. ${ }^{229}$ They rejected the idea that by refusing an alliance with the USSR, France would be opening herself up to the possibility of an aggression which would finally rebound onto her. They supported Guilbeaux's idea of a Franco-German-Soviet union which had not actually been discussed at the previous year's congress.

Weber and Jospin concluded their report with a plea for a measure of historical transcendence; Europe urgently needed to forget the History of which she was the victim, and to unite. If this did not occur, they foresaw instead a new war of religion between the latter-day faiths of fascism and communism. They accepted Hitler's principal prescriptions for a peace with Germany: equality of rights, bilateral and reciprocal treaties, simultaneous demilitarisation of two zones on both sides of the border, the return of all European nations to the League of Nations, this time on an equal footing, and a thorough revision of the Treaty of Versailles. In order for much of this to be accomplished, the League's covenant would have to be separated from the Treaty, and a rapid and total disarmament would have to occur. 230

In the discussion of the report at the Bernay Congress, it was stressed that while the League disagreed with many aspects of its programme, it did not want to do anything to harm the Front Populaire in terms of domestic politics. Jospin indicated the point of disagreement with most socialists on the question of peace: the pacifists of the LICP could not support the reservation 'in a capitalist regime' inherent in the traditional socialist rejection of war. As he said, 'our refusal of war is absolute', and that was what distinguished integral pacifism from all other shades of antiwar feeling. The Congress also decided not to mount a public campaign against the policies of the PCF, but merely to continue its comments in the pages of Le Barrage. The Weber-Jospin report was passed unanimously. 231

The Bernay Congress came at the mid-point of the LICP's trajectory vis-a-vis the Popular Front. The League had originally supported the idea of a Popular Front, not so much as an organisation of parties, but as a powerful manifestation of popular feeling on a

228 Ibid.

229 Ibid.

230 Ibid.

231 'Les Travaux du Congrès de Bernay', Le Barrage 94 (23 April 1936), p.4. 
range of issues, including peace. ${ }^{232}$ By early 1936 many of the reservations discussed above had already begun to make their appearance. Jospin attacked the insufficiencies more than the defects of the Front's programme. It had nothing to say about the two-year military service law, the swollen war-budget, repealing the Daladier-Forcinal law on conscientious objection, or about creating a statute for COs. ${ }^{233}$ After the election victory of the Popular Front, however, Gerin expressed the optimistic euphoria of the League in what he hoped would be the pacifist orientation of the new government. He declared that the victory of the Front meant the defeat of fascism in France, and the creation of a left-wing government a sign of hope for pacifism because 'it is always on the left, among the exploited that world peace is wished for most ardently and prepared the best'. ${ }^{234}$ The hopes he placed in the Popular Front - especially as regards the liberation of conscientious objectors and a separate statute for them - were almost bound to be dashed. He spoke of the 'guaranteed vote' of an amnesty of COs, and the failure of fascism in France. In the longer term, Gerin demanded a real disarmament, 'supported by a policy of sincere rapprochement with all peoples'. ${ }^{235}$ These hopes invested in the Popular Front were great, and it is easy to see how disappointments followed. Gerin had in fact put his finger on one of the reasons for this. He wrote of the opportunistic hypocrisy of the Communists who, in order to attract middleclass votes, had 'noisily accepted the need to guarantee the national defence and the defence of "democratic" liberties'.236 He thought that this sudden conversion had undoubtedly profitted them in parliamentary terms, but would have little impact on the Revolution. The world of French politics was rapidly changing in the face of threats from within and without; and as integral pacifists were to learn in the next few years, the presence of a left-wing government in the Palais Bourbon was no guarantee of the implementation of pacifist policies.

There was no lack of warnings in the pages of the Barrage of the disappointments likely to be in store for pacifists who put too much faith in the political process. Armand Charpentier welcomed the Popular Front, but warned that pacifists ought not to have the 'naivety' to believe that much would change. Relatively few members of the Popular Front

232 Initial positive reactions to the Popular Front idea can be found in René Gerin, 'L'espoir, enfin, change de camp', Le Barrage 52 (16 May 1935), p.1; Le Barrage, '14 Juillet 1935', Le Barrage 60 (18 July 1935), p.1; 'A propos du front populaire', Le Barrage 67 (17 October 1935), p.4.

233 Robert Jospin, 'Le Rassemblement Populaire et la Paix. A propos d'un programme', Le Barrage 84 (13 February 1936), p.2. Cf. Charles Boussinot, 'Le Salut n'est qu'en nous-mêmes', Le Barrage 86 (27 February 1936), p.1.; Edouard Rothen, 'Avec la Peau des autres', Le Barrage 92 (2 April 1936), p.1; Maurice Weber, 'Fermeté et Vigilance', Le Barrage 86 (27.February 1936), p.1.

234 René Gerin, 'Les Elections et la Paix', Le Barrage 95 (30 April 1936), p.1.

235 Ibid.

236 Ibid. 
parties were in any sense integral pacifists. ${ }^{237}$ Sébastien Faure echoed these fears in even more precise form. He predicted that the Blum government would very quickly make concessions on two capital points: the League of Nations, and support for the national defence. He claimed that Blum had never considered disarmament outside the bounds of the League of Nations, and in order to retain power it would be necessary to arrive at a modus vivendi with the military establishment. He wagered that the Popular Front would not change to any appreciable extent the foreign policy of France, that the length of military service would not be diminished, the size of the Army and its budget would not decrease, and if they persisted in talking about disarmament, it would be a very official and gradual one.238

Disenchantment was not long in making its voice heard, quietly at first and then in increasingly strident tones. At the end of May 1936 Gerin urged the Popular Front to embrace a real antimilitarism which would move beyond the anodyne nationalisation of the arms industries to real disarmament. He criticised the Socialists for following the evolution of the Communists towards the idea of defence of the Soviet fatherland as well as of France. This was all a result of the Franco-Soviet pact, and he noted that the closer a party got to the reins of power, 'the more it is willing to compromise with the militarism which will be its protector. 239 This was why the Socialist party had sworn in the recent elections to support the necessary credits for the War Ministry. Léon Blum wanted disarmament, but he was now constrained by the realities of holding power. Gerin hoped fervently that at least the minimum programme of controlled, simultaneous and progressive disarmament would be achieved. 240 .

The wave of strikes in June 1936 provided an object lesson for pacifists. Gerin wrote that they proved that if the people had the courage to follow Mirabeau's dictum - 'the people would be powerful if they knew how to remain immobile' - they ought to be able to prevent any war from breaking out. No mobilisation was possible without the active consent of the mobilisable. This was the antithesis of the Communist approach which preached the creation of the revolution from within the army in time of war. The militarism and uncertainty of this method were reason enough to reject it. Instead, Gerin enjoined his Communist comrades to 'meditate instead on the lesson of these past days; and for the maintenance of peace, as well moreover for the triumph of the revolution, to draw the necessary conclusions'. 241

237 Armand Charpentier, 'Heureuses Victoires et Joyeux Echecs', Le Barrage 96 (7 May 1936), p.1.

238 Sébastien Faure, 'La sauvegarde de la Paix', Le Barrage 98 (21 May 1936), p.2.

239 René Gerin, 'Antimilitarisme d'abord!', Le Barrage 99 (28 May 1936), p.1.

240 Ibid.

241 René Gerin, 'Une leçon à méditer', Le Barrage 100 (11 June 1936), p.1. 
There was tremendous initial goodwill towards Léon Blum within the LICP. At the outset of the Popular Front, the League often criticised its failures and shortcomings while at the same time making clear that it believed in Blum's commitment to peace. Thus, Georges Pioch announced in June 1936 that he was 'playing the Léon Blum card'.242 At the same time Challaye addressed an open letter to Blum which was full of affection and faith in what Blum was trying to achieve. He clearly considered Blum to be 'one of us', but he was most concerned that Blum's government break with the past and with those advisors who were urging continuity in French foreign policy. Blum also had to contend with those within his own coalition who were partisans of revolutionary wars. Challaye enjoined him to remain true to his convictions. There were serious lacunae and ambiguities in the government's programme, but Challaye demanded that these be transcended and that France declare 'peace to the world' through moral disarmament, revise the treaties of 1919 , and proceed to a material disarmament as well. The latter point Challaye recognised would be difficult, if not impossible, for the Popular Front government even to achieve, so as a first measure of good faith, he advocated the reduction of military service to one year. 243

By July 1936, the LICP's disillusionment with the Popular Front was palpable. In a second letter to Blum, sent on behalf of the League's office-bearers, Challaye expressed his disappointment that there was no mention of conscientious objectors in the bill being prepared on an amnesty. 244 Georges Michon was far more caustic. He wrote that the first sitting of the new Chamber exclusively devoted to questions of foreign affairs, had been a 'demonstration of an anti-German union sacrée'. 245 The ministerial statement had 'affirmed... the continuity of French policy', making no mention at all of the rather 'timid' hints of a complete revision of the unjust treaties which had been contained in the Front's programme. Instead, there had been the familiar insistence on the need for a strong defence and the prevailing length of the military service had been reaffirmed. From Right to Left there seemed to be unanimity on the fact that Hitler was the great danger to peace. Rather than revise the treaties, the government was preparing to follow the Moscow line and recommend regional treaties within the context of the League of Nations. Michon concluded:

These are the consequences of the Blum speech. In truth, Poincare and Tardieu could not have done better. Did the electors of the Popular Front want that? On top of this, there are the stupefying reversals of the Communists, and the apotheosis by the extremeleft of the Marseillaise, the flag, Joan of Arc(who will remain the symbol of religious mysticism and monarchical faith), and of the

242 Georges Pioch, 'Je joue la carte Léon Blum', Le Barrage 100 (11 June 1936), Pp.1-2.

243 Félicien Challaye, 'A bas les deux ans! Lettre ouverte à Léon Blum', Le Barrage 101 (25 June 1936), p.1.

244 Félicien Challaye, 'Lettre à Léon Blum', Le Barrage 102 (9 July 1936), p.1.

245 Georges Michón, 'Union Sacrée', Le Barrage 102 (9 July 1936), p.1. 
national union in all its forms. These manifestations create in some a demoralising effect, and in others a nationalistic and pseudorevolutionary state of mind which recalls Boulangism, both of which are essentially favourable to fascism and above all to the acceptance of war. 246

The criticism of the Popular Front continued, even into 1939 with post-mortem comments on why it had all failed to give satisfaction to the great desire for peace. Having lost its political virginity, the Popular Front seemed unable to move beyond quiescence and lack of daring in everything from its foreign policy to what Pioch considered to be its unworthy attitude towards the Moscow Purge trials. 247

We have already noted the affinity felt for Blum within the LICP. There was also initially a tremendous feeling of communion of thought with the Socialist party as a whole. But by 1937, the LICP was becoming very concerned at the evolution the SFIO seemed to be taking on questions of peace. Maurice Weber and Sylvain Broussaudier took opposing views of whether the Socialists could be counted on as a force for pacifism. Weber, who in 1936 had written that he could see no incompatibility between membership of the SFIO and the LICP, 248 wrote the following year that the situation seemed to be changing as the party moved steadily away from its old, admittedly vague, but deep-seated antimilitarism, in the face of German rearmament. Weber concluded that the next party congress would likely see the end of pacifism within the SFIO. 249 Broussaudier disagreed with Weber's conclusions about the direction the Socialists seemed to be taking. Instead, he thought that while the SFIO could not be described as integrally pacifist, it would continue to represent a 'minimum pacifist programme, realisable in the short term, and able to exercise a positive influence on the government'. 250

But it was perhaps left to René Gerin in early 1939 to sum up the feelings of disillusionment experienced by many pacifists, in an article in which he referred to Blum as a simpleton. After the Montrouge congress of the party, it was clear that Blum must henceforth be placed among the LICP's adversaries. He was perhaps not even still a

246 Ibid.

247 For developing disenchantment on the Popular Front, see Maurice Weber, 'Ce n'est pas par la guerre que l'on fera la Paix', Le Barrage 102 (9 July 1936), p.2; Félicien Challaye, 'Un terrible lapsus', Le Barrage 109 (29 April 1937), p. 1; Adrien Duthu, 'Ange ou démon?'; Le Barrage 110 (13 May 1937), pp.1-2; Georges Pioch, 'Rougeur sur le Front Populaire', Le Barrage 111 (27 May 1937), pp.1-2; Madeleine Vernet, 'La Paix et la Politique', Le Barrage 113 (24 June 1937), p.2; Pierre Nézelof, 'Le front populaire ruiné par ses chefs', Le Barrage 150 (8 June 1939), p.2.

248 Maurice Weber, 'Pacifisme et Socialisme', Le Barrage 78 (2 January 1936), p.1.

249 Maurice Weber, 'La Situation des Pacifistes dans le Parti Socialiste', Le Barrage 109 (29 April 1937), p.2.

250 Sylvain Broussaudier, 'Les Pacifistes dans le Parti Socialiste', Le Barrage 110 (13 May 1937), p.2. See also Maurice Weber, 'Les pacifistes et le Parti Socialiste', Le Barrage 111 (27 May 1937), p.3; Régis Messac, 'Lettre à Sylvain Broussaudier', Le Barrage 111 (27 May 1937), p.3; Sylvain Broussaudier, 'Brève réponse à R Messac', Le Barrage 111 (27 May 1937), p.3. 
socialist because he seemed to put little stock in the concerted action of the international proletariat against war:

If one renounced the union of the world working class, in order to participate totally and without reservation in the defence of the fatherland; if, in spite of all denials, one became an imperialist, under the grossly false pretext of pacifism, then one can certainly lay claim still to the title of Statesman, but it would be an imposture to call oneself a socialist. 251

Gerin also asked whether Blum was any longer a democrat, because he had recently expressed support for the 'exaltation of all energies' and the 'effort of national stimulation'. Citing Paul Valéry's bon mot, Gerin charged that since coming to power, Blum had become a petty politician, practising the art of 'preventing people from involving themselves in the things which concern them'. 252 Finally, Gerin asked whether Blum could be considered a pacifist any longer. The answer was a categorical no, because he 'no longer believes in peace'; instead, Blum had become an 'evangelist for the policy of blocs', a man who wanted 'his peace and not the peace'. ${ }^{253}$

\section{Wars and Rumours of Wars.}

The positions taken during the thirties by the LICP on questions of foreign policy were consistent with its general outlook and activity in the domestic sphere. In both domains, the LICP's stance was a reflection of its general dissenting attitude outlined at the beginning of this section. In the period from 1934 to 1938, the League's pacifism was challenged by events outside France. The most important of these were the outbreak of the Italo-Abyssinian War, the Sarr: plebiscite, the remilitarisation of the Rhineland, the Franco-Soviet Pact and the Spanish Civil War.

With regard to the Sarr, Gerin wrote in late 1934 that if Paris was worth a mass, then peace was certainly worth the Saxi He was in favour of negotiations with Hitler, and approved Blum's statement that he was prepared to shake the bloodiest hand for peace. ${ }^{254}$

There was dissension, however, within the League. Rudolf Leonhard, the German propagandist who had been an active member of the LICP's Comite d'Honneur almost from its inception, disagreed entirely with the Gerin analysis. He put his case in a two-part article published in late December 1934 which was printed with the disclaimer that the views expressed therein were those neither of the Barrage, nor of the LICP. Leonhard

251 René Gerin, 'Blum-Gribouille', Le Barrage 140 (5 January 1939), p.1.

252 Ibid.

253 Ibid.

254 René Gerin, 'Si Paris valut une messe...', Le Barrage 30 (6 December 1934), p.1. 
wrote that for some time now, German émigrés had been receiving a bad press in France; it was almost as if they, rather than Hitler, were to blame for preventing an entente with Germany. He attacked a recent article in La Paix par le Droit which sought to minimise the atrocity stories coming out of Germany; on the contrary, Leonhard retorted that he 'could show the pacifist review La Paix par le Droit and Georges Demartial the unhealed wounds which our comrades have brought back from the Hitlerian hell'.255 As to the argument that the émigrés were fomenting war, Leonhard underlined that not only did they not believe in the efficacy of a 'war of liberation', but that each time the opportunity presented itself, they spoke out against any notion of a preventive war as well. Coming finally to the question of the Sarre, he wrote that it was false to assume that Hitler had a united German people behind him. Leonhard claimed to be speaking as a German on the Sarre issue, and as such, it was his considered opinion that the status quo should prevail in the Sarre. Why? 'Because the Sarre is German, without the slightest doubt. We want it to remain German, and not become Nazified.'256 The problem of the Sarre was not so much a Franco-German one as an international one. It ought to be seen in European terms and the Sarre should remain independent until Germany herself became so once again. 257

Georges Demartial responded by insisting that the only course for French pacifists was to respect the internal affairs of Germany and avoid meddling in them. ${ }^{258}$ Henri Guilbeaux took the same line, castigating Leonhard for supporting the point of view of the Sarre Communist Party which received its orders from Moscow. ${ }^{259}$ When the vote finally went in Hitler's favour, Guilbeaux thought it entirely predictable - and not just the fault of the Nazis, but also of the incompetence of the Social Democrats and Communists. He did not want to see the Sarre become a further point of friction in Europe, but argued that it could instead evolve into a sort of bridge between France and Germany, perhaps through an economic and customs accord. 260

Gerin tried to demonstrate that the massive vote in favour of attachment to Germany proved that the war-guilt issue, which transcended party political lines, was one which all Germans wanted to see expunged. The vote in the Sarre was the 'consequence of all of

255 Rudolf Leonhard, 'Le Problème de la Sarre du point de vue allemand', Le Barrage 32 (20 December 1934), p.2. The article in La Paix par le Droit would seem to be 'Lettre a M. Charles Rousseau à propos de "l'Allemagne contre le Droit" - Lettre du 20 novembre 1933 de Mlle Hélène Lhoumeau, Licenciée en droit et fonctionnaire des services de la Société des Nations', PD 44, 10anuary 1934), pp.18-21.

256 Ibid.

257 Rudolf Leonhard, 'Le Problème de la Sarre du point de vue allemand (suite)', Le Barrage 33 (27 December 1934), p.2.

258 Georges Demartial, 'L'hitlérisme et la France', Le Barrage 34 (3 January 1935), p.1.

259 Henri Guilbeaux, 'La Sarre et les rapports franco-allemands', Le Barrage 34 (3 January 1935), p.3.

260 Henri Guilbeaux, 'La Sarre est allemande', Le Barrage 36 (17 January 1935), p.3. 
the stupidly inhumane policies of France in the last fifteen years'. ${ }^{261}$ Hitler had said that there now remained no more territorial problems between France and Germany. Gerin thought that the time had now come to try to resolve the moral issues which continued to fester between these two countries. 262

The LICP also took a very measured view of the remilitarisation of the Rhineland which conformed with the general position it had taken on the Sarre. Gerin wrote that people from the extreme Left to the extreme Right were asking what Hitler really wanted. The answer was simple: 'the suppression of Article 231 of the Versailles Treaty, which gratuitously and stupidly dishonours a great people, [and] equitable revision of the treaties'. ${ }^{263}$ He expressed no surprise at the remilitarisation of the Rhineland:

It was to be expected; Germany has a habit of presenting her adversaries with a fait accompli. And it is to be expected, too, that our rulers, after having for so long refused a policy of open hands, will be forced, one day, to accept the fait accompli. 264

The exculpation of Hitler's moves in the present was thus justified by the LICP's view of the past. As the League officially stated in a front-page communiqué, 'bellicists and bellipacifists obstinately continue to close their eyes to the injustices of the past, and dream of a war to resolve the conflict'; integral pacifists, on the other hand, 'proclaim that it is time to have recourse to a genuine peace policy: a policy that is frank, loyal and courageous. It is time to recognise the errors and the faults of the past which are at the origin of the present conflict: 265 The apparent insouciance with which the LICP viewed the remilitarisation of the Rhineland might well be summed up in the headline of that fount of irony, Le Canard Enchainé, at the time: 'L'Allemagne envahit ... l'Allemagne'.266 In taking such a position, the League seemed to ignore that more was at stake than simply the Versailles Treaty. In remilitarising the Rhineland, Hitler had also torn up the Locarno accords as well - an agreement which had been fairly negotiated with Republican Germany. This point was passed over in silence by the Barrage.

It is interesting to contrast the above two incidents to the reaction of the League to the outbreak of the Italo-Abyssinian conflict. The LICP found it much easier to condemn Italian aggression and atrocities in Ethiopia than to castigate Germany for the Rhineland episode. Undoubtedly there were good reasons for this. Ethiopia was, after all, a real war. But one wonders if the ability to censure more easily in the case of Italy might have been due to the

261 René Gerin, 'Ce que signifie le vote des Sarrois', Le Barrage 37 (24 January 1935), p.1.

262 Ibid.

263 René Gerin, 'Que veut l'Allemagne?', Le Barrage 88 (12 March 1936), p.1.

264 Ibid.

265 'Nous ne marchons pas!', Le Barrage 88 (12 March 1936), p.1.

266 Cited in Michel Winock, 'Le Fascisme passera ... Pouquoi?', Le Monde Aujourd'hui (Supplément du numéro 12852 du Monde, [Sunday 25 - Monday 26 May 1986]),p.V. 
fact that the LICP always saw the German problem as the major difficulty which had to be resolved in French foreign affairs. Its resistance to post-War French policy, its politics of dissent, created an in-built need in its political analysis to criticise French policy towards Germany. Having said that, the League did maintain a pacifist position on the Ethiopian affair while criticising the Italian government very sternly for its aggression.

The received opinion within the LICP was that the developing conflict in Ethiopia was more about colonialism and imperialism, than about Italian fascism per se. Henri Guilbeaux claimed to see the occult hand of British imperialism in the matter, with a supporting role being played by Japan. ${ }^{267}$ Challaye echoed this view, and denounced the spurious Italian argument that they were performing a 'civilising' task in Ethiopia where slavery still existed; better to have black man exploiting black man, than to have the wholesale proletarianisation of the nation under the imperialistic boot of the white man, according to Challaye. 268 Two months later, in September 1935, he analysed what the Italo-Ethiopian conflict meant in terms of the principles of the LICP. People who called themselves pacifists were currently making two sorts of comments on the conflict. There were those who argued that sanctions led to war and should therefore be avoided. And there were others, like the British TUC, who advocated the imposition of all sorts of sanctions, including military ones if necessary. In Challaye's view, the latter positon was not 'pacifist' at all. So, was the choice between doing nothing and going to war? He argued that on the contrary, the Ethiopian people should fight foreign oppression by means other than war, which would have as its only effect the destruction of their country. Challaye suggested Gandhian non-violent resistance, strikes, individual acts of terrorism, insurrections, and so on. As for the other nations of the world, it was incumbent on them not to get involved at almost any price. He rejected the idea of an indivisible peace and argued that wars must be localised, not generalised. The methods to use were a diplomatic, moral, economic and financial boycott, universally applied. Sanctions did not automatically mean war because their application could be limited to one's own national territory. There was no suggestion of using gunboat diplomacy to erect naval blockages around the belligerant countries. 269

Challaye's prescriptions for peace were reiterated by the League as a whole which published a manifesto on the Ethiopian crisis. It condemned fascism and Mussolini's incursion into Ethiopia but advised the Ethiopian people that it 'would defend itself more

267 Henri Guilbeaux, 'Le conflit italo-abyssin', Le Barrage 33 (27 December 1934), p.3.

268 Challaye, 'A propos du conflit Italo-Ethiopien. Guerre et Colonisation', Le Barrage 60 (18 July 1935), p.1.

269 Félicien Challaye, 'Le conflit Italo-Ethiopien et les principes de notre Ligue', Le Barrage 64 (12 September 1935), p.1. 
effectively and bring honour to itself in not having recourse to the means of war. 270 The League also condemned in anticipation any attempt on the part of other powers to get involved in the conflict. The political anarchism of the LICP, or its politics of dissent, came through baldly in its statement that for both the Italian and Ethiopian peoples, their primary enemy was to be found in their own governments. The LICP recommended the breaking-off of diplomatic relations with Italy, a freeze in all arms trade with both countries, and the refusal of all bank credits to the aggressor. The important task was to halt the spread of the conflict. 271

The Ethiopian war had as a further interesting result the significant emergence for the first time of what the LICP chose to call, somewhat incongruously to the Anglo-Saxon ear, the pseudo-pacifism of the French Right. This was to appear in even more evolved and virulent form at the time of Munich. But 1935 gave a foretaste of things to come. The Barrage of 10 October catalogued the anti-interventionist views of a number of right-wing newspapers and the anonymous writer concluded that this 'pacifism' was all well and good. The LICP would remember it the next time when it was no longer a question of fighting 'Uncle Mussolini' but instead of going into battle against 'our German, Russian or Patagonian brothers'. ${ }^{272}$ Gerin denounced Mussolini's aggression and French fascists for supporting him. He also condemned the League of Nations for not doing anything to stop the conflict and Laval for tacitly supporting the Italians. 273

Gerin had nothing but scorn for the 'patriots' who had the 'audacity to cry "down with war", not because they want peace, but becaue they want a victory for external fascism' 274 Challaye tackled head on the issue of what the League viewed as the opportunistic pseudo-pacifism of the Right in an examination of the Manifesto, 'Pour la Défense de l'Occident', drafted by the royalist Henri Massis. He recognised that the intellectuals who had signed it agreed with the LICP on several points. Should the League reject or accept this apparent convergence of views? Challaye recalled La Rochefoucauld's maxim that 'hypocrisy is a praise that vice gives to virtue'. It was clear that this so-called pseudopacifism of the Right was ephemeral. The signatories of the manifesto were not against all wars like the LICP. With no inkling of what lay in store at Munich, Challaye concluded with an attack on the Right in which he assumed its Germanophobia as a constant value: 'If it so happens that a government approved of by the signatories of the manifesto wants

270 'L'Affaire d'Ethiopie et nous', Le Barrage 65 (26 September 1935), p.1.

271 Ibid. These demands were repeated in the following number as well. See 'Honte aux Assassins', Le Barrage 66 (10 October 1935), p.1.

272 'Echos', Le Barrage 66 (10 October 1935), p.2.

273 René Gerin, 'Honte aux assassins!', Le Barrage 66 (10 October 1935), p.1.

274 Ibid. 
one day to throw us into a war against Germany, we shall turn back on these gentlemen the weapon of their own declarations'. 275

Throughout the rest of 1935 and until Addis-Abbaba fell, the LICP continued to press for the application of economic and financial sanctions against Italy, and a complete boycott of war material to both belligerant countries. The LICP did not want to see the Italian people die of hunger, but they were profoundly disappointed that the sanctions which should automatically have come into play under article 16 of the League Covenant, never did. But even with the apparent end of the war, the LICP still expressed its certainty that Mussolini would one day pay for his African adventure. One writer in the Barrage expressed the hope that the atrocities committed by the Italian army would not be simply forgotten. 276

The LICP viewed the Laval-Stalin Pact and the general evolution of the French Communist Party on the question of peace with a very jaundiced eye. It has already been noted above that there was much friction between the early League under Méric and the PCF. This increased in the wake of the Amsterdam Congress with which the LICP would have little to do, at least officially. There was therefore a long tradition of hostility to the opportunistic antimilitarism - not pacifism - of the Communists. The League could never agree with the Communist distinction between just revolutionary wars and unjust imperialist wars, nor with the notion of sending young Frenchmen to the casernes to learn the military art in the hope that some day this knowledge could be used against the bourgeoisie. For the LICP external war was external war and could not be justified.

It is no surprise therefore to learn that the League condemned the Laval-Stain declaration and the nascent anti-Nazi nexus which seemed to be developing between Paris and Moscow. Sacred alliances spelled holy wars, and the LICP wanted to avoid this at all costs. The Franco-Soviet Pact spelled the end of the hopes of integral pacifism in the peaceful outlook of the Soviet Union. 277 . Hubert Gilbert wrote that the pact brought France full circle back to the situation of 1894 and the defensive military alliance with tsarist Russia. 278 Gerin condemned the pact without reservations, but had seen it coming for some time. In the course of the League's speaking tours across France, they had been 'constantly asked to take a position for the defence of the USSR which was confused with the defence of peace'.279 But the League's position had been and remained one of opposition to all

275 Félicien Challaye, 'Un Manifeste d'Intellectuels', Le Barrage 66 (10 October 1935), p.2.

276 René Gerin, 'Sanctions', Le Barrage 73 (28 November 1935), p.1; 'Addis-Abéba est Prise: à Bas Mussolini!', Le Barrage 96 (7 May 1936), p.1; Pierre Nézelof, 'Une Enquête', Le Barrage 100 (11 June 1936), p.1.

277 René Gerin, 'La nouvelle alliance Franco-Russe est-elle une étape vers la paix?', Le Barrage 51 (9 May 1935), p.1.

278 Hubert Gilbert, 'Le pacte Laval-Potemkine', Le Barrage 51 (9 May 1935), p.3.

279 René Gerin, 'Le Coup de Staline', Le Barrage 53 (23 May 1935), p.1. 
alliances. The Franco-Soviet Pact had changed definitively the LICP's view of Soviet Russia. It would continue to support the economic and social work of the revolution, but the Soviet leadership was now to be placed in the same camp as that of other nations. He underscored that the LICP rejected all military alliances, even with the land of the Revolution, and refused all foreign wars. The League also 'rejected all civil wars - which in no way means that we do not accept the revolution; but we want a clean revolution, and if this revolution becomes bloody, it will not be we who have wished it so'. 280 Gerin's rejection of civil war is here more absolute than it was to become at the time of the Spanish Civil War of which more will be said presently.

The Pact occasioned the departure of Challaye from the Cercle de la Russie Neuve, of which he had been one of the founders. ${ }^{281}$ It also created one of the fissures within integral pacifism which would slowly lengthen into the attempt to split antifascism from pacifism in the wake of Munich. But it is instructive for what was to follow that Félicien Challaye rejected in 1935 any suggestion that such a divorce was necessary or desirable from the pacifist point of view. What was good was that people were now being forced to think about political choices that related to peace. As Challaye concluded, 'one might well be tempted to thank Stalin for having, involuntarily, provoked this vast outpouring of pacifist sentiments - just as Leibniz praised God for having allowed the fall of Adam because it occasioned our redemption through Jesus Christ'. ${ }^{282}$

Louis Emery attacked the Pact as a danger to peace because despite its pretentions to being open to Germany, it was in fact directed solely against her. It was a one-way treaty, and destroyed the symmetry of Locarno which envisaged, theoretically at least, an attack by either France or Germany. To say that such a treaty was open to Germany was 'really to abuse the elasticity of the language'. ${ }^{283}$ No one could take this type of formula seriously.

For Gerin, the Franco-Soviet Pact represented a lack of faith in the Revolution and in the ability of the masses to carry it through. The Russians were simply afraid of Nazi Germany; but fear led to massacres as much as did ambition. He had always felt that Communist comrades did not put enough stock, enough faith in the feeling of revolution, the desire for revolution. This desire was only temporarily asleep in Germany - and he begged the Communists not to compromise the world revolution by lowering themselves to the level of reaction, that is to say the battlefields on which it preferred to fight. ${ }^{284}$

280 Ibid.

281 'Au Cercle de la Russie Neuve', Le Barrage 56 (13 June 1935), p.2.

282 Félicien Challaye, 'Pour l'union des adversaires de toute guerre', Le Barrage 58 (27 June 1935), p.1.

283 L. Emery, 'Le Pact Franco-Russe et la Paix europénne', Le Barrage 95 (30 April 1936), p.2. This article is an extract from Emery's article published in the 15 April 1936 number of Europe.

284 René Gerin, 'La Politique extérieure de l'URSS', Le Barrage 96 (7 May 1936), p.1. 
The Sarre, the Rhineland, Ethiopia and the Franco-Soviet Pact were all important stages on the pacifist journey in the thirties. But no event so shook the world of the integral pacifist as the Spanish Civil War. Spain caused French pacifists to reflect deeply on the problems posed by international fascism. Should one resist and if so how, and on what level? These were the issues which Spain raised and which were debated within the LICP. The LICP had certainly never proclaimed itself against civil wars in principle. In August 1934, for example, Gerin had explained that there were many in the League who believed in the necessity of the revolutionary struggle. If this struggle became violent and blood was shed, it would not be the pacifists who would strike the first blow. The nonviolence of the civil struggle was therefore to be the responsibility of capitalist society; if the Rubicon of bloodshed were crossed, it alone would bear the responsibility. 285

It is not surprising, then, to find that with the worsening situation in Spain, Gerin and the LICP took the position that the Spanish conflict must be prevented from becoming an arena for imperialist rivalries - be they black or red - and also that there was nothing preventing an integral pacifist placed in a situation similar to that of Spain from responding to social violence with violence. In an editorial in early August 1936 Gerin reiterated the League's opposition to both civil and foreign wars. 'We are against all wars, including civil wars', he wrote. 'We believe, in effect, that to shed the blood of one's "fellow citizens" is just as abominable as to shed that of "foreigners"'.286 One of the differences, though, between civil and foreign wars, was that in the former one generally knew why and against whom one was fighting. Integral pacifists would never foment a civil war, and they did not confuse civil war with revolution. Having said all that by way of preamble, Gerin nevertheless admitted that if he were Spanish, he would have taken up arms to fight for Azaña and the Republic against the rebels. The reasons for this were threefold. First, Azaña represented democracy (for what it was worth), freedom and some measure of the social revolution. Even the 'anarchists' who fought with him agreed on this. Secondly, the civil war in Spain had been forced upon the Azaña government. The Spanish government, the Popular Front, were thus in a state of legitimate self-defence against their own internal fascism. Finally, Gerin wrote that this internal Spanish fascist enemy was completely comparable to an individual enemy. Only Tolstoyans would refuse to fight such an enemy. The Spanish state had become a collection of internal police forces which were fighting a domestic foe. It was the occasional duty of the citizen to aid his police force. ${ }^{287}$

\footnotetext{
285 René Gerin, 'La Joie mauvaise', Le Barrage 14 (16 August 1934), p.1.

286 René Gerin, 'Guerre étrangère et guerre civile', Le Barrage 104 (6 August 1936), p.1.

287 Ibid.
} 
Gerin's position on the conflict in Spain is interesting. It points out the rather artificial dichotomy which existed in the LICP's view of international versus civil conflicts. The League believed that only in cases of civil conflict could the aggressor be reliably determined. The problem reduced itself to one of the fight against internal fascism and the propensity for fascist reaction inherent in the institution of the Army itself. In Gerin's view, armies served merely as hotbeds of reaction which provided the means for a fascist coup d'état and hence civil war. If one got rid of the army, the potential problem would disappear as well. But the important aspect of Gerin's position on civil war is his insistence on the need for violence only in cases where civil conflict has been imposed upon a pacifist population. In general, he continued to affirm that the revolution could and should occur without recourse to violence, even if only by means of the general strike. 288

It was clear, though, that Gerin's position was far from being the unanimous position of all league members. There must have been a sizeable minority who were opposed to civil war as well as foreign wars, because Gerin and Challaye both responded to criticisms in the next number of the Barrage. For Challaye it was important to point out that the LICP's pacifism extended only to 'wars imposed by governments on the peoples in the name of a socalled national interest'. He argued for mutual indulgence within the League so that revolutionaries and Tołoyans could continue to live and work together. 289

Adrien Duthu was one such leaguer who refused to admit the rectitude of civil wars. He begged to differ with Gerin's and Pioch's statements that if they were Spanish they would be fighting. For Duthu, there was nothing intrinsically different about civil as opposed to international conflicts. The LICP had made much of the idea that any modern war would be so costly in terms of the destruction it would bring that it must be avoided at all costs. Duthu asked why a civil war would be any less destructive. He suggested that the LICP should make disarmament its condition of support for the Left. In no case, however, should the masses consider taking on the Army. Technology would quickly slaughter vast numbers, and that was what was happening in Spain.290

The general impression gained from the Barrage, however, is one of non-interventionist moral support for the Spanish government coupled with the implicit or even explicit warning to reactionary forces within France, that if the Republic were attacked, integral pacifists would be found amongst those who defended it by force of arms. The general principle of separation of internal antifascism from external pacifism found its expression

288 Ibid. For a more complete analysis of the problem posed by civil war, see René Gerin, Pacifisme "intégral" et guerre civile (Paris: Ligue Internationale des Combattants de la Paix, 1937).

289 Félicien Challaye, 'Pacifistes, tolstoiens ou révolutionnaires', Le Barrage 105 (20 August 1936), p.1. See also René Gerin, 'Union Sacrée et lutte de classes', Le Barrage 105 (20 August 1936), p.1.

290 Adrien Duthu, 'Une léçon à tirer des événements d'Espagne', Le Barrage 108 (22 October 1936), p.2. 
clearly in the Spanish Civil War. Régis Messac, for example, wrote of accepting the battle 'on class frontiers, but not on capitalist frontiers'.291 Maurice Weber also thought that the events in Spain were producing a profound reorientation in pacifist thinking. It had long been part of pacifist mythology that it was governments who often caused or declared wars. This had now been shown to be false in Spain, where the legitimate government had been attacked by the rebels, and more recently in France where only the sang froid of the Popular Front had prevented France from becoming embroiled in the Spanish war. Paradoxically, both the Communist party and the CGT advocated this intervention. Weber congratulated Blum and Delbos for having resisted the interventionist temptation. While it was tragic to have to put the Madrid government on the same moral footing as the rebels, imposing sanctions was a necessary step in order to prevent the conflict from spreading. He saw the hand of Moscow behind all of the formerly pacific forces which were trying to get France involved in the Spanish war - the Communists, the CGT, some parts of the Socialist Party and the Amsterdam-Pleyel movement. In 1936, Weber believed the greatest danger came from what he called 'red fascism' as opposed to 'black fascism'.292

In official pronouncements on Spain, the LICP tried to emphasise that it remained an organisation for all types of integral pacifists, while acknowledging that there were some pacifists who would fight in a civil war. The League decined therefore to take a position on the legitimacy of the Spanish Civil War, although its sympathies were with the government. It approved the French government's decision to impose an embargo on Spain, and drew from the Spanish tragedy the justification for one of its standard theses. If Spain had been disarmed, the aggression of the rebels - and hence civil as well as international war - would have been impossible. 293 A year later, the League was still holding to this official position of strict non-interventionism coupled with the belief that if the Spanish situation were to be replicated on French soil, many league members would take up arms. ${ }^{294}$

Guernica seemed to provide another striking proof of the rectitude of the League's longheld position against war. 'Think ... what the effects would be of a war brought over great cities by, not just fifteen or twenty airplanes, but by hundreds and thousands. ${ }^{295}$ In this situation it was a nonsense to speak of passive defence.

291 Régis Messac, 'Que chacun reconnaisse les siens!', Le Barrage 106 (3 September 1936), p.1.

292 Maurice Weber, 'Excitations Guerrières', Le Barrage 106 (3 September 1936), p.3. Armand Charpentier also attacked the Communist support for armed intervention in Spain. He argued that this was one of the effects of the Franco-Soviet Pact. See Armand Charpentier, 'Ce que coûtent les alliances franco-russes', Le Barrage 107 (1 October 1936), p.1.

293 'Résolution sur les événements d'Espagne', Le Barrage 108 (22 October 1936), p.1.

294 'Réunion du Comité Directeur', Le Barrage 113 (24 June 1937), p.3. See also René Gerin, 'A propos d'un incident', Le Barrage 114 (22 July 1937 ), p.1.

295 René Gerin, 'Guernica...', Le Barrage 110 (13 May 1937), p.1. 
Thus, while it is true that the LICP hardly presented a unanimous face to the world regarding the Spanish Civil War, it is nevertheless the case that the majority of League members seem to have taken the line consistently presented by Gerin, namely that civil wars could be justifiably fought by pacifists but only within their own national context. Even in Spain, where the conflict had quickly become internationalised, one could still speak of an essentially civil affair in which the men fighting knew for whom and for what reasons they were laying down their lives. There was thus a fundamental distinction of scale and of orientation between civil and international wars. What integral pacifists outside Spain had to do was ensure that the conflagration did not spill over the Pyrenees to the rest of Europe. As Gerin wrote in 1937, 'the most clear-sighted and effective pacifism in these troubled times is undoubtedly not that which refuses all wars, but rather that which refuses to transform localised civil conflicts into universal butchery'.296

The period from 1934 to the beginning of 1938 ended for the LICP on a worried note. The Sarre, the remilitarisation of the Rhineland, the Italo-Abyssinian conflict, the FrancoSoviet Pact, and the continuing development of Nazism in Germany had all provided in different measures a challenge to the LICP's pacifism. Through it all, the League had remained true to its initial premises that external wars and internal fascism could and must logically be fought together. Spain began the slow process of doubt that perhaps integral pacifism could ill afford to be so absolute in its prescriptions. In the final two years of the interwar period these doubts manifested themselves in two opposing lines of thought. Some pacifists began to express serious reservations about the extent to which pacifism could claim to be absolute, while for still others, it became finally necessary to argue the primacy of pacifism over antifascism. These challenges to the LICP's carefully elaborated world view came in 1938 and 1939, and it is to this final stage that we turn now.

296 René Gerin, 'Défense de libertés et "Défense Nationale"', Le Barrage 111 (27 May 1937), p.1. 


\section{II.4. Munich and all that (1938-1939).}

It is strange that while the events of 1938-1939 seem to have challenged the LICP's view of pacifism, there is nevertheless no single moment which can be selected as the point at which the League's world view changed. No line was drawn that could not be crossed. In terms of the League's comments on the issues raised by the crises of this eighteen month period, there was little apparent dissent over its policies. The debates which did occur seem almost to have taken place in a vacuum. The Anschluss did not produce a crise de foi and neither did Munich. March 1939 and the final agony of Czechoslovakia occasioned no prise de conscience and in August, the League was still most unwilling to die for Danzig. So what happened? There is no doubting that fundamental changes were occurring in the League's thinking. The intégralité of its pacifism was brought into question, and there was an attempt to separate antifascism from pacifism. In other words, major debates took place in the immediate pre-War period, but they did so in some isolation from real political events, on which the LICP maintained a steady pacifist doctrinal outlook.

In the first crisis of 1938, the Anschluss of Austria to the Third Reich, there was little surprise and certainly no breast-beating within the League. Gerin sanguinely commented that the treaties were being revised and it was in that light that the League saw the annexation of Austria. He seemed to take roughly the same position as that of the Canard Enchaine at the time of the remilitarisation of the Rhineland: Germany was invading part of Germany. He stressed that the Anschluss had been effected without war, that it did not seem to affect too many Austrians who had been living under a dictatorship already anyway, and that, citing the expression of La Fourchardière, 'what happens between Austria and the Reich is pure politics'.297 Moving from the particular to the general, Gerin also considered the question of the other Auslandsdeutsche. He thought that as a democratic principle, they should be allowed to join the Third Reich if they wanted to. This begged the question of whether democratic principles were involved at all, but Gerin seems to have passed this problem over. As an interesting backdrop to what was to follow, Gerin attempted to refute the argument that Hitler would turn on the other peoples of

297 René Gerin, ' On revise les traités...', Le Barrage 125 (17 March 1938), p.1. 
Europe once the German minorities had been reintegrated into the Reich. In a stupendous miscalculation of the nature of Hitler's plans, he wrote that if the Sudeten Germans, at least in part, desire to be reattached to Germany, the Czechs, for their part, will never want to submit to the yoke of the Reich. Hitler is not so stupid as to compromise the advantages he has justly won through an attempt at an imbecile conquest'. 298 In any case, the whole problem was the fault of the 1919 treaties and of French policy, and he foresaw that France still had more to pay in penance for the errors of its ways at Versailles:

We have several moral kicks up the backside still to receive unless - better late than never - our rulers decide to substitute the policy of the extended hand ['de la main tendue'] for that of the presented posterior, and understand that peace will only result from an international economic and political negotiation, openly and generously offered to everyone, to the Germans as well. And to the Germans of 1938 since we did not want to deal with those of 1928 who were still in a republic.

All mistakes are paid for. And the longer one waits to pay for them, the more expensive they are. 299

The important thing was to prevent these mistakes being paid with the blood of twentyyear old young men

Henri Jeanson expressed the complete sense of disillusionment and alienation from the Third Republic felt by some pacifists at the time of the Anschluss. For Jeanson, the enemy was within. In response to the cries for an anti-Hitlerian Union Sacrée, he wrote,

So be it.

I want to fight for the Republic.

I want to defend democracy.

I want to sacrifice myself for freedom.

But first, give me a Republic, give me a democracy, and restore my freedoms.

The Republic is a trust, democracy is a business, and freedom is a monopoly.

... Our real enemies are not outside.

They are within. 300

Instead of looking outside France for the battle to come, he invited readers to begin the fight amongst Frenchmen. The old class struggle had been waylaid, but in the interests of defeating fascism once and for all, Jeanson declared that it was necessary to defeat the General Staff, the industrialists and the 'petty politicians'.301

298 Ibid.

299 Ibid.

300 Henri Jeanson, 'A bas l'union sacrée!', Le Barrage 125 (17 March 1938), p.1.

301 Ibid. For further comment in much the same vein on the Anschluss, see Louis Trégaro, 'A la croisée des chemins', Le Barrage 125 (17 March 1938), p.1. Trégaro argued that France must follow 
The LICP's 1938 Congress was held in the city of Arras. Three important reports were debated dealing with the economic and political aspects of the fight against fascism and war, and also with the colonial problem. Probably the most important of the three was Sylvain Broussaudier's report on the political aspects of the fight against fascism and war. Since the Nazi seizure of power, this question had been debated with increasing urgency and frequency. Broussaudier took it as given that everyone within the LICP was as equally committed to antifascism as to pacifism, but many old friends were beginning to renounce their pacifism in favour of antifascism pure and simple. Pacifism was slowly becoming a dirty word and pacifists were accused of doing Hitler's work. This idea was current amongst Communists and a growing number of Socialists. As for the Radicals, 'their jacobinism is strangely allied with the anti-Hitlerism of the extreme-left'.302 The Popular Front had now more or less abandoned its antimilitarism and accepted the preparation of war with either enthusiasm or resignation.

The crux of the question was to determine whether or not fascism inevitably meant war. Broussaudier reminded LICP members that after the events of 6 February, the League had included a line to this effect in its statues. But in 1938, he rejected the fatalism of this view for a number of reasons. First, there had been many wars before fascism appeared, and even the most democratic of countries had many of them on their consciences. Secondly, France bore heavy responsibility for the emergence of German fascism. Thirdly, it was clear that France did not hesitate to ally herself against Germany with regimes which were 'clearly fascist', such as those of Poland, Roumania, and Yougoslavia. Fourthly, and perhaps more importantly, because it revealed the dissenting nature of much of the LICP's thinking on internal versus external politics, Broussaudier wrote that,

Our democracy is often only distinguishable from fascism by differences of degree and not of nature. The administration of the country is over-run with fascists, and our politics are subject to economic forces which have nothing in common with the will of the people, but on the contrary are in solidarity with capitalism and external fascism. 303

Chamberlain in the policy of appeasement, or rather 'accompany him'. Negotiating did not mean capitulating. See also Félicien Challaye, 'Pas de guerre pour l'Autriche!', Le Barrage 126 (31 March 1938), p.2.; A. Duthu, 'Autriche-Tchécoslovaquie', Le Barrage 127 (28 April 1938), p.2; Louis Trégaro, 'Aragon-Autriche', Le Barrage 131 (7 July 1938), p.1; Jean Carrère, 'L'Autriche depuis l'Anschluss', Le Barrage 135 (20 October 1938), p.3.

302 Sylvain Broussaudier, 'Comment lutter à la fois contre la Guerre et contre le Fascisme? Rapport sur l'aspect politique de la question', Le Barrage 124 (24 February 1938), p.3.

303 Ibid. 
Finally, Broussaudier argued that if fascism did, indeed, bring with it an increased danger of war, it did not mean that war was inevitable. In either a democracy or a fascist dictatorship, war was only possible with the active consent of the population. 304

Two possible approaches to the problem of fascism presented themselves. One was the policy of firmness or even of force. This entailed engaging in an arms race with Germany in the belief that the structural weaknesses of the Nazi regime would cause a collapse in its economy thus making war impossible. This was a pernicious argument, though, because it required in the democracies an abdication of all hope for social progress through lack of public funds, and therefore, in reality, a 'progressive fascisation'. It was an illusion to think that the democratic economies were immune for this same sort of dislocation anyway. Secondly, he argued that economic hardship in the fascist countries would not necessarily bring about their internal collapse; it was equally possible that it might exacerbate the political situation to the point where in a moment of desperation, these countries threw themselves into a war as a way out of their difficulties. 305

At the opposite end of the spectrum, there was the policy of peace. Broussaudier argued for a policy of concessions to the dictators so that wounded national feelings could be assuaged, and the psychological reasons for war thereby removed. In the process, the political rug might be pulled from underneath the dictators. If the protestations of peace of Hitler and Mussolini were shown to be false, this hypocrisy would 'explode' in the eyes of their own people. What is important here, though, is the fact that Broussaudier stressed that the LICP did not at all agree with a policy of simple capitulation. Capitulation, instead, had been the hallmark of the policies of French governments. 'The absurdity of the policies followed until now by France in particular, is that they combined imprecatory bravado (verbal energy) and retreats (practical weakness), adding therefore the dangers of the one to the dangers of the other, without drawing any benefit from either'. 306 In Broussaudier's view, the hope for peace lay in a resolution of the economic conflicts in the world. This would remove the primary propaganda weapons from the dictators and at the same time strengthen the democracies morally, politically, and economically. 307

If war should break out anyway, Broussaudier underlined that the course of action to take was an entirely individual decision. But he believed that it was naive to think that one could defend one's liberties by fighting fascism. His report makes clear that even at the eleventh hour in 1938, the LICP still placed its primary emphasis on preventing war and had nothing to say about the tactics to be employed once war had broken out; this decision

304 Ibid.

305 Ibid.

306 Ibid.

307 Ibid. 
was left entirely to the personal appreciation of the individual leaguer. The problem of civil war was necessarily beyond the purview of the LICP, but he believed that it could be prevented from occurring through essentially the same policy of reforms which would weaken fascism. ${ }^{308}$

His conclusions contain the seeds of the debates which would erupt later in the year in the wake of the Munich crisis. He believed that it was possible to reconcile the struggle against war and the fight against fascism 'as long as the catastrophe has not occurred'. But, and here lay the crux of the future dilemma, 'pacifism can only be opposed to antifascism if, all our efforts having failed, we are thrown into a war, that is to say, when all other acceptable solutions are impossible' 309 Broussaudier's report was passed unanimously by the Congress. 310 Later that spring, the League's statutes were also amended so that Article 1 on the League's goals now read that it was 'against fascism which, destroying our liberties, aggravates still more the dangers of war'. This resolved the problem posed by the phrase in the 1934 version of the statues that fascism led 'ineluctably to war'. ${ }^{311}$

Gaston Pauthe's report on the economic aspects of the same question was full of statistics which gave credence to the idea of 'nations repues' and 'nations affamées'. It was a report larded with Leninist citations and analysis, and Pauthe envisaged the use of revolutionary violence in certain situations. The hour was desperate; he believed the current was pulling France ever closer to fascism, the union sacrée and war. The Popular Front had failed, and it needed to be recreated at the grass-roots level. As far as the external danger was concerned, Pauthe thought that the French people had to speak directly to the Germans, over the heads of both sets of rulers. When the Congress debated his report, it passed unanimously the first section dealing with the analysis of the economic situation, but declined to express its views on the conclusions arrived at by Pauthe because of their tendentious support for civil war and revolutionary violence. The League was, after all, supposed to be a home for pacifists of all persuasions, violent and non-violent. 312

Louis Emery's report on colonialism condemned the principle of colonialism, but equally rejected the Communist notion of wars of liberation and armed insurrection. He considered this method to be either utopian or catastrophic in its practical effects. It entailed allying oneself with indigenous nationalist parties, and this led to increased national isolation and not internationalism. Emery rejected nationalism for Frenchmen and also for their colonial

308 Ibid.

309 Ibid.

310 See 'Les Travaux du Congrès d'Arras', Le Barrage 127 (28 April 1938), p.4.

311 'Modifications aux Statuts', Le Barrage 130 (9 June 1938), p.4.

312 Gaston Pauthe, 'Comment lutter à la fois contre la Guerre et contre le Fascisme? Rapport sur l'aspect économique de la question', Le Barrage 124 (24 February 1938), pp.3-4. See also 'Les Travaux du Congrès d'Arras', Le Barrage 127 (28 April 1938), p.4. 
subjects. He criticised the parties of the left for having done preciesely nothing in the colonial field; the Popular Front was too occupied with questions of defence. What did Emery recommend as a solution to the problem posed for peace by the existence of colonies? He argued for an 'internationalisation of the colonial regime' within the context of a peace policy. This meant giving Nazi Germany colonies again. For Emery, justice and peace demanded a new division of colonies:

it is annoying that we have allowed Hitler to be right; in the area of colonial demands, he is right ten times over... You say that we cannot possibly make a negro from the Cameroon a subject of Nazi Germany; start at least by asking him if he prefers that we make of him a cadaver dressed up in horizon-blue..... But naturally, the transfer, pure and simple, of a colony must be considered as the last possible solution, only war being more abominable. What must be tried, is the creation of a system which will provide the greatest amount of international control... the mandate system of the League of Nations was an appreciable progress. We must take inspiration from this system and perfect it. 313

Emery's report was passed unanimously, too. 314

The Arras Congress manifesto, which was written by Challaye, reaffirmed the LICP's implacable opposition to fascism but stressed that fascism could only be fought inside one's own country. The League declared itself against the idea of any foreign war for freedom. 'In the city of Robespierre, we reiterate his formula: "Liberty cannot be found at the tip of a bayonet. The peoples do not like armed missionaries"'.315 On the Anschluss, the Manifesto expressed the disgust of the League at the excesses of militarism which had accompanied it, but underlined that it had long been the desire of the Austrian people to be joined to Germany. Looking ahead to the coming Czech crisis, the LICP 'rejected in advance any idea of war for Czechoslovakia'. Challaye turned around the phrase in vogue, to express the LICP's belief that war would mean the suppression of all liberties in favour of a military dictatorship: we know, he declared, that 'War is Fascism'. ${ }^{316}$

With the worsening international situation and especially, perhaps, with the experience of the Spanish Civil War, some parts of the LICP began to express doubts about the use of the word intégral to describe the League's pacifism. Gerin gave voice to these concerns in two articles in early 1938 in which he argued that it was time to abolish the term 'integral' because it was 'incorrect, inexact, and even pretentious'; it was abstract and evoked the absolute. Gerin thought that it was enough to affirm that 'we are pacifists as much and as well as we can be. That is already not so easy! Let us reject all verbal

313 L. Emery, 'Le Problème colonial et la Paix', Le Barrage 125 (17 March 1938), p.3.

314 'Les Travaux du Congrès d'Arras', Le Barrage 127 (28 April 1938), p.4.

315 'Manifeste du Congrès d'Arras', Le Barrage 127 (28 April 1938), p.1.

316 Ibid. 
outbidding'.317 The LICP contained pacifists of many tendencies but what united them was their opposition to wars between peoples. To imply more in a word such as intégral only gave ammunition to the League's opposition, and confused 'our friends and comrades'. The clinching argument for abolishing the word 'integral' was that it allowed people to assume that the LICP espoused absolute non-violence, according to Gerin. But there was no 'catechism' in the League. He could not come up with a word to replace 'integral' however, nothing seemed to capture fully the essence of the League's pacifism, which he defined in largely dissenting terms:

Our pacifism is antinationalist, antifascist (in a sense which the next congress will define), anticolonialist, antimilitarist... and anti-many other things. But it also wishes to construct peace in a positive way by multiplying efforts towards justice on both the national and international levels. 318

In any case, the Arras Congress declined to follow Gerin in his apparent evolution away from an absolute expression of pacifism, deciding instead to retain the use of the word 'integral' because no other word seemed to come close to expressing the League's position. ${ }^{319}$

If the Spanish Civil War and the generally worsening international situation proved to be major trials for the LICP's pacifist vision, Munich and the two-step dismemberment of Czechoslovkia provided the major crisis of the period under discussion here. Paradoxically, as has already been noted, Munich also occasioned an upsurge in the League's membership.

Beginning in the spring of 1938, writers in the Barrage began to comment on the impending Czech crisis. They rejected the idea of fighting a war for Czechoslovakia in part because they viewed the Czech state as the bastard creation of Versailles. Adrien Duthu, for example, argued that in 1919 when the Czech state was created, Austria advised against including the Sudeten German minority, but it was to satisfy the demands of the Czechs for their 'natural' frontiers and the heavy industry of Bohemia, that the Sudetenland was included. He did not believe that France was in any way compelled to come to the aid of Czechoslovakia in the event of an attack because the Locarno treaty, to which the accord with the Czechs had been linked, had fallen by the wayside. This was a convenient euphemism for France's abdication; strangely, it seemed that Duthu was arguing that one abdication was worth another. Because the German minorities were apparently

317 René Gerin, 'Pas de surenchère verbale!', Le Barrage 122 (20 January 1938), p.1.

318 Ibid. See also René Gerin, 'Pas de surenchère verbale (II) Réponse à Robert Tourly', Le Barrage 123 (3 February 1938), p.1.

319 'Les Travaux du Congres d'Arras', Le Barrage 127 (28 April 1938), p.4. 
oppressed by the Czechs after the war, he believed that they ought to be given selfdetermination. In short, Czechoslovakia was not worth going to war for. 320

Louis Emery was even more radical in his prognosis for the future of Europe, a future which he saw quite naturally dominated by Germany. He attacked the 'pacifists' who would have France defend the territorial integrity of Czechoslovakia. Instead, he proposed a referendum along the lines of those held in Upper Silesia and the Sarre. If this idea were refused, he suggested that Czechoslovakia should be assimilated into the Swiss federation. Whatever happened, the Czechs must renounce their alliances with France and the USSR, and give up all ideas of collective security, which were nothing but a smokescreen for an anti-German coalition. The Czech affair was not about principles in Emery's mind, but about the defence of a political system in which the Czech state played an important role - in other words, the old balance of power. According to this view, then, Europe needed to adjust peacefully to the historically determined rise of a German hegemony:

Any real pacifism presupposes that one believes in the possibility of changes in the organisation of the world, changes which are made inevitable by the play of natural forces which need not entail war. We do not see how it is possible to prevent Germany becoming the economic and demographic power called by virtue of its size and its workforce, to colonise Danubian Europe.

Did not the Versailles Treaty. prepare this victory in the long run? All that we can hope is that this evolution will take place in peace.

The only chance this has of happening is through a global negotiation with Germany, including the Czech problem, in a search for a just equilibrium of the resources and vital needs of everyone. It is necessary for the democracies - and this is their supreme chance to avoid the catastrophe - to take the initiative of this revision of the treaties, in the broadest possible sense, in thus using the last possibility they have to undertake a new and generous policy, that is to say one that offers a new colonial partition capable of leading to a moral detente and to disarmament. May each one take his responsibilties here, and know, in himself, if he really wants peace. ${ }^{321}$

When the September Crisis finally broke, Gerin declared that it was the beginning of peace. War would not break out over Czechoslovakia because neither Hitler nor the German people wanted it. Secondly, no one anywhere else either wanted war, with the possible exception of what he called some 'communistes exaltés'. The French government did not have the nerve to declare war, he thought, and even if it did, it was doubtful whether there would be the required unanimity either in Parliament or in the country as a

320 A. Duthu, 'Tchécoslovaquie', Le Barrage 129 (26 May 1938), p.2.

321 L. Emery, 'Encore la Tchécoslovaquie', Le Barrage 130 (9 June 1938), p.1. 
whole. No one wanted war. He seconded Alain's declaration that the September crisis was in fact the beginning of peace. It was beginning with the wholesale destruction of the iniquitous treaties of 1919. He said that a sort of 'immanent justice' was repairing the damage of Versailles, and if that process went against France it was because France was too proud to have done it herself. 'Am I exaggeratedly optimistic?', he asked,

I am convinced that we have just won the peace: at the hour in which I write these words, English and French are in the process of trying only to save face, in accepting the ineoitable.

Courage, comrades! The treaties are being revised without war! This is indeed what we have been demanding in our propaganda. But we never dared to hope that we would be listened to so soon. ${ }^{322}$

There certainly seem to have been few tears shed in September 1938 in the pages of the Barrage for the truncated Czech state. Armand Charpentier attacked it as a totally artificial creation which should not exist, this 'proscenium arch called Czechoslovakia'. He proclaimed 'eternal glory to Neville Chamberlain'.323

At the beginning of October Gerin reiterated his belief that peace was just beginning. War had been impossible in September because circumstances were not at all comparable to July 1914. None of the diplomatic, military, social, moral or psychological conditions were favourable to the explosion of a war. 'We knew that in 1914 all of the rulers and all of the peoples had to some degree wanted or accepted the massacre; and that in 1938 no people, no government even, envisaged it with a light heart'.324 The 'peace of the peoples' had thus emerged from the Munich crisis. For the first time the masses had shown their pacifism and there had been a collective rejection of war which made a mobilisation impossible. He claimed victory for the pacifist cause. This peace was their peace. It was a peace 'conceived before the war', and a 'revision of the treaties without war'. He went further and called it the 'birth of a ... peace psychosis'. But he warned against complacency. 'Real peace, that which will last, because it is just, has not yet been made. It is only starting to be made. We are at the dawn of a new day, at the first hour. Everyone to work!'325

If the LICP was Munichois, it was so from pacifist conviction and a (perhaps misguided) historical Weltanschauung, not from philo-fascism. In late October 1938, Gerin returned to the question of Munich to underline that there were still at least two dangers to beware of. The first was a misplaced confidence in Hitler. Gerin did not believe that Hitler wanted a war, but equally he stressed that the paix hitlérienne in no way

322 René Gerin, 'Alain a raison: c'est la paix qui commence', Le Barrage 133 (22 September 1938), p.1.

323 Armand Charpentier, 'Similitudes: 1914: Iswolsky - 1938: Bénès', Le Barrage (22 September 1938), p.1.

324 René Gerin, 'Au Travail, pour la Paix des Peuples!', Le Barrage 134 (6 October 1938), p.1.

325 Ibid. 
represented the LICP's ideal. He blamed the European situation on 'French idiocy' which had allowed the gars de Berchtesgaden to reign in Europe. On the doméstic level, it would be criminal to express the slightest admiration for Hitler's man in France, Flandin. If Flandin had served the cause of peace in September, the LICP was only 'moderately thankful' to him. In any case, the League rejected German hegemony in Europe, as indeed it rejected all hegemonies. He warned Leaguers to have nothing to do with what he termed an ideology as dangerous as that of Stalinism, that is to say, the wave of antisemitism which had been sweeping across France in recent months. 326

The second big danger was that of rearmament. Chamberlain had returned to London to announce a major armaments programme and the same thing was happening in France, Germany and the USA. An understanding had to be reached. The peoples had made it very clear three weeks previously that they wanted nothing to do with a war. They must now refuse to pay for the armaments which their governments wanted. For the first time, Gerin laid down a test for Hitler:

Disarmament and negotiations - in the order that one wishes or is
possible - this is, this must be our programme. If, now, Hitler and
his disciples, German and French, accept this programme, may
they say it and prove it. Then - and only then - will we be able to
reach an agreement with them. 327

March 1939 and the annihilation of the rump Czechoslovkia occasioned a partial prise de conscience in Gerin. The scales seem at least partially to have fallen from his eyes. He recognised the odious threat posed by Hitler, but refused obstinately to modify 'one iota' of the League's principles. He rejected the solutions of force proposed by others, and called instead for the immediate convocation of an international conference. He did not specify, however, exactly what this conference should discuss. As far as economic sanctions were concerned, these he rejected 'in principle', at least until such time as all attempts at economic collaboration with the Reich had failed. Instead, he suggested moral sanctions which he thought the Reich feared most. He proposed a propaganda campaign by radio to enlighten the German people to the point of revolt. But even this method was to be used only in the last resort, because it was in essence an attack on the territorial integrity of another country. So, in Gerin's view, the situation, while serious, had not reached the point where this type of moral sanction ought to be imposed. ${ }^{328}$

326 René Gerin, 'Ecueils', Le Barrage 135 (20 October 1938), p.1.

327 Ibid. For further comment on Munich, cf. Madeleine Vernet, 'Protestation', Le Barrage 134 (6 October 1938), p.1; Pierre Nézelof, 'Aux innocents les mains vides', Le Barrage 135 (20 October 1938), p.1; Robert Jospin, 'Maintenant, bâtissons l'Europe', Le Barrage 135 (20 October 1938), p.1; Fernand Gouttenoire de Toury, 'Désarmement, ou catastrophe final', Le Barrage 135 (20 October 1938), p.1; Sylvain Broussaudier, 'Le repli impérial', Le Barrage 142 (2 February 1939), p.1.

328 René Gerin, 'Pour un appel aux peuples', Le Barrage 146 (30 March 1939), p.1. 
Robert Jospin was also in favour of some sort of international conference to sort matters out, although the title of his article - 'force or collaboration' - was an unfortunate semantic example of what was to come. He thought that Hitler had made an enormous mistake in taking the rest of Czechoslovakia, but he also ran through the usual litany of Allied faults running back almost twenty years, as if the sins of the sons were justified by those of the fathers. He could see no way to stop the expansion of Germany into south east Europe. The peoples of the Balkans needed German markets and vice versa. Germany had no choice but to expand. It was either that or disappear. From this (and indeed from many other articles in the Barrage), it is clear that the League had accepted the Nazi arguments about Lebensraum. 'Collaboration' with Nazi Germany was thus the only possibility which did not lead straight to unparalleled slaughter, although to give Jospin his due his article was vague about what he actually meant by this term. 329

By the spring of 1939 it was clear that support for the LICP was falling off as the international situation worsened. In early May the League commented that 'we receive only a very few communiqués from the Sections [and] the requests for speakers are less numerous.... 330 Claude Jamet, writing a fortnight earlier, noted that pacifism was once more in retreat as a minority belief: 'We are alone in a world, in a country, almost unanimously gone crazy. It doesn't matter. Truth is often in the minority'. And referring to the departure of the pseudo-pacifists of the previous September, he said 'here we are once again by ourselves, few but pure'. 331

The moment seemed to have arrived when political pacifism had become virtually untenable. Gerin wrote in May that he considered the annexation of Czechoslovakia 'both a mistake and a crime'. He did not see how anyone could be convinced of the rectitude of Germany's cause by Hitler's speech of 28 April. But the speech did appear to open the way to further negotiations. Hitler's tone was more moderate and diplomatic than previously, and he seemed to be renouncing the ideological demagogy which had been his stock-intrade. His demands were also becoming more precise and his support for Mussolini was on the wane. In the short term, Gerin thought that the pacifist policy of disarmament was dead in the water. What remained was the fight to prevent war from breaking out and that had not yet been lost. He foresaw the policy of 'firmness' towards the dictators continuing for many months or even years. Hitler was fooling himself if he thought he could separate the two western democracies, but France and Britain were deluded if they believed it possible to throttle Germany economically. Gerin believed firmly that only

329 Robert Jospin, 'Force ou collaboration', Le Barrage 146 (30 March 1939), p.1.

330 'L'activité de la Ligue', Le Barrage 148 (4 May 1939), p.4.

331 Claude Jamet, 'La Paix inévitable', Le Barrage 147 (20 April 1939), pp.1-2. 
negotiation could save the day. It had started already, but the road would be long and hard, and pacifist nerves would be truly frayed before its end was reached. ${ }^{332}$

Gerin's moral revulsion at what had finally happened to Czechoslovakia was not echoed by all League members, however. One of the original architects of historical dissent, Georges Demartial, could not see the difference between the German duplicity in overturning the Munich accords, and the history of French and English double-dealing in Egypt and Morocco. Try as he might, he could not attune himself to the 'general diapason', as he put it, he could not 'share the indignation of which Germany was the object'. ${ }^{333}$ If Germany had been able to lay its hands on Austria and Czechoslovakia without firing a shot, without shedding blood, this was 'incontestably because of the anarchy into which these two States had fallen which was leading them to civil war'. 334 He saw the Nazi armies almost as liberators. Both peoples either accepted or desired their inclusion in the Third Reich; the Austrians had ratified it in a plebiscite, and the civil and military authorities in the Czech Republic had quickly put themselves under German protection. 335

\section{Ni droite, ni gauche ?- or Pacifism versus Antifascism}

The extent to which the LICP was prone to equate the failings of the western democracies with those of Nazism and Fascism has already been noted. Because of its peculiar historical vision and dissenting stance with regard to French political society, the League was apt to justify the Nazi re-shaping of the map of Europe for historical, as opposed to moral or present-day political reasons. Even near the end, when Hitler's designs were at last becoming apparent to all and sundry, there was still debate within the LICP about the rectitude of Nazi expansionism.

The League was also concerned with the internal threat posed by Fascism in France. Taking historical inspiration from Robespierre, they were convinced that France must look inward on itself and deal with its own political open sores rather than busying itself with the affairs of others. As the thirties progressed, this political introspection finally succeeded in isolating the League from the rest of political society. It also led in the first months of 1939 to an attempt to separate the fight against fascism from that against war.

The origins of the League's isolation go back well into the mid-thirties. Georges Pioch, for example, as early as 1935 wrote that 'the time has come when the criers of the Union

\footnotetext{
332 René Gerin, 'La négociation aura lieu', Le Barrage 148 (4 May 1939), p.1.

333 Georges Demartial, 'Le Problème tcheque et la Paix', Le Barrage 148 (4 May 1939), p.1.

334 Ibid.

335 Tbid.
} 
sacrée, whether they be of left or right, will soon have only one enemy... the conscious pacifist who desires a complete peace'. .336

Having said this, the LICP had to deal with the gradual emergence in the thirties of an extreme-right-wing pseudo-pacifism which seems to have become confused in the public mind at the time of Munich with the genuine pacifism of groups like the LICP. For example, as early as 1935 once again, at the time of the Italo-Abyssinian War, the Barrage was complaining of what it regarded as the opportunistic conscientious objection of Charles Maurras. With regard to the situation in Ethiopia, Maurras had written,

We do not say: down with war. We say: down with this war. It would be vain, empty, iniquitous and a folly! Down with war against Italy. Down with a war for London and for Geneva. Down with war for the Covenant...337

The sea-changes occurring in the old right-left boundaries on the question of peace left the pacifists of the LICP somewhat confused. In early 1936, one writer said quite simply, 'we do not understand anymore' 338 , and in April of that year the Barrage commented on a piece by Albert Thibaudet in the Nouvelle Reoue Française which had argued that the danger of war now came more from the Left than from the Right. 'The war of religion for or against Moscow is replacing the war of religion for or against Rome'.339

By early 1938 it had become apparent to Gerin that the Union sacrée was rejected only by integral pacifists and some parts of the Right. But he stressed that the motives and ideals of the Right were not at all those of the LICP. The Right rejected the idea of a union sacrée with the Left 'because they wanted to rid themselves of the representatives of the proletariat' and because 'they admire, at the end of the day, both Hitler and Mussolini'.340 The attitude of the right was therefore completely ephemeral and opportunistic. Its rejection of war was based upon internal political antipathies and external political sympathies which transcended national boundaries. Gerin wrote that he rejected the notion of the union sacrée because he was opposed to fascism, dictatorship and nationalist reaction, and because he desired justice and peace. These reasons were very different from those of the right. And he rejected the idea that integral pacifism could find an ally in this passing pacifism of the Vautels, Doriots, Maurras and their ilk:

Let there be no equivocation! We are not two-faced. We reject and will always reject, in all cases, any national union, any sacred union... One would have to be terribly naive not to understand the hypocrisy of the Right. It would be the most vulgar stupidity to

336 Georges Pioch. 'Quand Brid'oison se double de Basile', Le Barrage 61 (1 August 1935), p.2.

337 'Echos. Distinguo', Le Barrage 76 (19 December 1935), p.2.

338 'Une politique maladroite', Le Barrage 87 (5 March 1936), p.3.

339 'Une prédiction d'Albert Thibaudet', Le Barrage 94 (23 April 1936), p.1.

340 René Gerin, 'Pourquoi nous refusons toute Union Sacrée', Le Barrage 126 (31 March 1938), p.1. 
consider as allies, even temporarily, the neo-conscientious objectors of the Journal, Gringoire or the Action Française. They are just as pacifist as the malignant Muscovites. ${ }^{341}$

This was the somewhat confusing backdrop then, to the debate which broke on the League in January 1939. Félicien Challaye published an important article in which he questioned the linkage between pacifism and antifascism which had until then been one of the cardinal tenets of the LICP's system of belief. It was the Spanish Civil War which had caused him to begin to revise his ideas on the acceptability of civil war. He described how the old political divisions of left and right seemed to have become blurred. The warmongering spirit seemed to lie more to the left than to the right now, in the sole interest of Stalinist policies'. ${ }^{342}$ For Challaye, the choice was simple. 'If one had to choose, it would be better to save the peace with the right than to throw oneself into war with the left or extreme-left'. 343 Happily, though he did not think it would be necessary to make this choice. There was a right-wing in France which 'remained true to itself', the right of Tardieu, de Kerillis and Pertinax. The great dividing line had been the events of the past September. Munich, which caused Challaye 'not the slightest humiliation', had occasioned a great political effervescence which had not yet settled. On the question of peace, however, the route to take was clear for Challaye:

Certain of our comrades are not wrong to say that neither Chamberlain, nor Daladier, nor Bonnet is a pacifist in the sense that we give to the word, because we demand a disarmed peace and they are for over-armament. But the "Anti-Munichois" too, the Thorezes, the Léon Blums are in favour of over-armament. Between these over-armers, whose common thesis I reject, I ask permission to prefer those who have wanted and who want peace, to those who have wanted and want war. 344

Challaye argued that his new position did not change one iota his fundamental opposition to fascism. He remained a convinced antifascist, which he defined as the 'will to protect in our country those of the union, political and daily freedoms which still exist', the will to reconquer those which had been lost, the will to liberate the workers in a capitalist society, the immigrants who were the subjects of police harassment, and the peoples suffering under the yoke of colonialism. ${ }^{345} \mathrm{He}$ also called antifascism the struggle against war, because he believed that once war had broken out, it spelled the end of all liberties and the imposition of a form of fascism, through military dictatorship. Here lay the essential distinction in Challaye's mind. He distinguished between what he called an

341 Ibid.

342 Félicien Challaye, 'Pacifisme et Antifascisme', Le Barrage 140 (5 January 1939), p.2.

343 Ibid.

344 Ibid.

345 Ibid. 
'antifascism of peace' and an 'antifascism of war'. Because of recent events, he thought it would be wise to dissociate antifascism from pacifism in the League's propaganda. 346

Gerin replied to Challaye in the next number of the Barrage. He insisted that he, too, supported an 'antifascism of peace', not of war. But he was equally insistent that all League members were resolutely opposed to fascism; Challaye's article contained the seeds of 'grave disagreements' within the League if the issues it raised were not dealt with quickly. For his part, Gerin rejected any idea of separating antifascism and pacifism, for four main reasons. First, he argued that just because certain antifascists deported themselves like 'bellicose imbeciles' was no reason in itself to renounce one's own antifascism. The League was not obliged to follow them in 'their criminal deviations'. In his view, it sufficed to distinguish as they had always done between antifascism for internal use and antifascism for external use. This usage, consecrated by time, was also easier to understand than Challaye's rather nebulous construct 'antifascism of peace'. If antifascism were removed from the League's programme, Gerin said he would resign from it immediately. 347

Secondly, he pointed out that the League had been officially antifascist since its congress at Montargis in 1934, that is to say two years before the arrival of the Popular Front in power. If the Popular Front had subsequently deviated from its original programme, that was of no immense concern to the LICP which ought to remain true to its own ideals. Thirdly, Gerin argued that to accept Challaye's proposition would actually mean taking a step in the direction of a union sacrée with the very political elements that were the natural enemies of pacifism. Le Matin, Le Temps, Gringoire and the Action Française had none of them ever genuinely worked for peace between the peoples; what he called their pseudo-pacifism was opportunistic and ephemeral, and they represented moreover an attack on the same freedoms which the League was trying to protect. If these pseudo-pacifists of September 1938 had rejected war with Germany, this was all well and good, but Gerin was certain that given half a chance they would support a war against Soviet Russia. He urged the League not to be admirers of either Le Matin or L'Humanité, but to remain true to itself. 348

Finally, Gerin recognised that the League had perhaps been wrong in 1934 to call 'fascism' in France what was in reality merely the most recent manifestation of an old, and deeply-rooted, French right-wing reaction. But this reactionary force in French politics was becoming increasingly 'fascist' in the proper sense of the word - in the same way that Stalinism had evolved towards a sort of left-wing fascism. Gerin believed that fascism

346 Ibid.

347 René Gerin, 'Pacifisme et Antifascisme', Le Barrage 141 (19 January 1939), p.2.

348 Ibid. 
could be found on the left or the right, and he declared that it was the thing that the LICP hated the most because it implied nationalism, militarism, racism and totalitarianism. He wondered aloud whether any Combattant de la Paix could be found who could say he was a fascist. 349

Gerin disagreed with Challaye about other things as well, such as the use of the word 'integral' to describe the League's pacifism. He continued to believe that this was meaningless and furthermore dangerous. He also disagreed about the unacceptability of fighting a civil war should it be forced upon one. Unlike Challaye, he thought that to fight back in a civil situation was legitimate. In the troubled days of early 1939, he defined the kernel of pacifist truth to which the LICP as a whole adhered:

We are agreed not to prepare or start a foreign war, or even a civil war, on the pretext of antifascism. Fascism, we have always affirmed, can only be effectively fought inside a country. But we must also be agreed neither to give arms to our own fascists, nor to those outside. Let us condemn fascism wherever it exercises its ravages. Let us sweep first before our own door; but let us retain the right, indeed let us fulfil the duty, of pointing out that the doorstep of our neighbour can be just as dirty, if not more so, than our own. 350

It was necessary to put Tardieu, Kerillis, Pertinax, Péri, Aragon, Le Matin, Gringoire, the Action Francaise, Flandin, Hitler, Mussolini, Franco and even Daladier and Bonnet, all in the same bag, because each one was as much in favour of an arms race as the other. The LICP was not in the business of choosing between surarmeurs.. Gerin concluded that 'we cannot do otherwise. To act differently would be to betray our programme and peace itself'. 351

The problem did not seem to disappear, however. A month later Gerin was writing as if the number of Combattants de la Paix prepared to do business with the French fascists was larger than he had first suspected. 352 Pioch, too, roundly attacked the notion that real peace, 'our peace', 'this peace which makes us not non-resistants, but the only real resistants to war - that this peace could have anything in common avec ça'. ${ }^{353}$ It was an 'impossible promiscuity' 354

The debate bubbled on into late March. Louis Trégaro attacked the tendency of some LICP members to support the extreme-right following Munich. He insisted that in order for pacifism to be viable, it had to be allied to anti-fascism, and also anti-capitalist in

349 Ibid.

350 Ibid.

351 Ibid.

352 René Gerin, 'Union Sacrée? - Non, Jamais!', Le Barrage 143 (16 February 1939), p.1.

353 Georges Pioch, 'L'impossible promiscuité', Le Barrage 144 (2 March 1939), p.1.

354 Ibid. 
orientation. Since Munich, it had been in crisis. Pacifists had been lumped together with Daladier and anyone else supporting the accords, for whatever reasons. He was particularly concerned at the position taken by Challaye, Louis Emery, and the Ligue des Femmes pour la Paix. .355

Louis Emery replied to Trégaro's article in the next number, arguing that pacifism could no longer be assumed to be uniquely a left-wing position. As far as the temporary and 'fortuitous' alliance with the right at the time of Munich was concerned, it had changed nothing in the basic pacifist credo. Recent history seemed to put the lie to the assumption that pacifism was necessarily of the left. Blum was in favour of a policy of armaments, and the Communists had become just as bellicose as the right had ever been. What he called this 'parliamentary and electoral geography' was no longer of the slightest interest to pacifists. The defence of liberty, no more than the defence of peace, was no longer a reliable criterion of political judgement. For twenty years and in twenty different countries, he argued the left had often been just as authoritarian and militaristic as the right. Emery argued that pacifism had to remain above and outside the political parties - it was no longer even nominally a party issue. Instead, it had taken on almost mystical proportions. He rejected the idea that it was the preserve of socialism, or even any particular class. By extension, there was also no reason why pacifism should necessarily be revolutionary or anti-capitalist. If that were the case, and orthodoxy had been important, the LICP would never have been formed, and the fight for peace, such as it was, would have remained the preserve of the political parties. 356

Emery stressed instead the mystical nature of pacifism, and argued that pacifists had to be prepared to place their doctrine above party and political considerations. One could no longer deny that large sections of the working class, for example, now advocated an ideological war against fascism. So, it was a nonsense for pacifists to feel obliged to fight both war and capitalism, and to refrain from choosing, if hard choices for the higher ideal of peace became necessary. He firmly believed that fascism was only aided by the bureaucratic and military demands of war, and that it was as likely to come from the left as from the right. He rejected completely the charge that he and his friends were the dupes of international fascism, however: 'What man of good faith could possibly contest that a programme which goes completely in the individualistic, anti-State direction, is therefore intrinsically anti-fascist?' From all points of view, Emery believed that his pacifism was

355 Louis Trégaro, 'Casse-cou!', Le Barrage 145 (16 March 1939), p.1. See also Part III of this thesis for a brief analysis of the dissensions within the French section of the Ligue Internationale des Femmes pour la Paix et la Liberté which finally led to the creation of the schismatic Ligue des Femmes pour la Paix. p.1.

356 Louis Emery, 'Le pacifisme et la doctrine révolutionnaire', Le Barrage 146 (30 March 1939), 
'diametrically opposed to Nazi doctrine'; in fact, much more so than many of the present manifestations of socialism. The fascist states thrived on international tension and economic competition. Take this away and they would slowly crumble. He concluded that 'the most fecund and certain revolution is the establishment of peace'.$^{357}$

Challaye and Emery seem to have faded into the background after this debate. Given the importance of the issues it raised, it is surprising that it appears not to have been discussed at the League's 1939 Marseille Congress which was, all things considered, a rather tired affair. 358 The only report of note was that by Jospin on economic problems and peace. He argued that the economic aspect of the present discontents was by far the most important. The dangerous ideologies of the hour had been erected on the sub-structure of economic malaise. There was a tremendous disequilibrium between the wealthy and the poor nations. The latter reacted to this situation by creating a powerful military apparatus which they used for territorial gain. Politically, they evolved into fascism, trying to solve their problems internally through economic autarchy. Fascist ideology was therefore not that important according to Jospin; what mattered was the economic side of the question. 'The problem of peace and of war is entirely there'. ${ }^{359}$

\section{Mourir pour Dantzig?}

A spirit of lassitude seemed to descend on the League in the final six months before the outbreak of war. Régis Messac wrote that France had become a small country between two big power blocs: the Anglo-Saxon nations on the one hand, and Germany on the other. Her only hope was to become the trait d'union between them. He thought the fight had gone out of the French, and his description of the France of 1939 is dejected:

France already no longer belongs to the French, and the French are incapable of taking it back. Aside from the fact that they are no longer strong enough, either from the economic or the demographic point of view, their heart is no longer in it. We let things happen, even to us, but we are incapable of action or reaction. 360

357 Ibid. There were of course, opponents within the League of the idea that pacifism had to be placed above all else. In December 1938, for example, Jospin had argued this case, saying that 'la résistance au fascisme demande des mains propres'. (R. Jospin, 'Au dessus de la Paix', Le Barrage 139 [15 December 1938], p.3). But clearly what had changed in early 1939 was the insistence of Emery and Challaye on the potential need to separate antifascism from pacifism. It was this that so shocked Gerin who continued to advocate an antifascism allied to pacifism, both of them conducted with 'clean hands'. In the summer of 1938 he had already embraced the formula of Andre Delmas who wrote 'je me refuse à choisir entre la servitude et la guerre. Je repousse les deux'. (René Gerin, 'La formule d'André Delmas', Le Barrage 132 [11 August 1938], p.1.).

358 'Les Travaux du Congrès de Marseille', Le Barrage 147 (20 April 1939), p.4.

359 Robert Jospin, 'Les problèmes économiques et la Paix', Le Barrage 142 (2 February 1939), p.4.

360 Régis Messac, 'Pour un esprit civique européen', Le Barrage 147 (20 April 1939), p.1. 
Poland was the final item on the European agenda before the shooting began. The LICP had not had much sympathy for Czechoslovakia, although it had certainly castigated the final dismemberment of the country in March 1939; it had even less sympathy for Poland, a country 'least worthy to be called a nation' in Gerin's words. ${ }^{361}$ Poland was a mixture of different ethno-linguistic groups, largely illiterate, not at all liberal, but rather a country under the boot of a domestic fascism. Furthermore, it was a nation in which antisemitism was as rife as in Nazi Germany. It was a 'still more artificial and stupid' creation of the 1919 treaties than Czechoslovakia, and as such Gerin did not believe that France or Britain would be prepared to go to war for it. It was plain to Gerin that Danzig was a German city and the corridor was still probably more German than Polish despite the expulsions. $\mathrm{He}$ agreed that Poland should have access to the Baltic, but this should naturally be the estuary of the Vistula. All of the territorial problems raised by the Polish question could be resolved without war, and Gerin predicted many more 'Munichs' to come. 362

Even in the face of so obvious an external threat, the LICP continued to affirm that the primary foe was an internal one. In early June, Gaston Pauthe attacked a recent speech by Daladier in which he had said that the French belong to a privileged nation and their margin of happiness can only be preserved by an heroic resolution'. ${ }^{363}$ Pauthe rejected categorically the idea that there was one nation of Frenchmen who must defend their privileges against an external foe. For him, the enemy was and would remain a class enemy: 'Yet again, let us state that our enemy is abooe all here at home, and Blum is worth no more than Daladier... 364

The desperate optimism of the League remained right up to the end. In July, echoing the title of a play by Giraudoux, Gerin was proclaiming that the 'war for Danzig will not take place'. 365 He thought it was 'incontestable' that a certain détente seemed to be developing on the international level. He asked whether it was but a truce in the war of nerves, and arrived at the conclusion that there would definitely be no war, at least that summer. The situation had been 'serious' at the end of March after the 'crime' of the Nazis in invading Czechoslovakia. The union sacrée had begun to reestablish itself in France, the Anglo-French alliance became very close, and the encirclement of Germany was obvious. But the situation had improved since then for two reasons. First, the protests against the preparation of war had helped a lot. In particular, Déat's articles had provoked a good

361 René Gerin, 'La Pologne et nous', Le Barrage 149 (18 May 1939), pp.1-2.

362 Ibid.

363 Gaston Pauthe, 'Non! Monsieur Daladier, nous ne sommes pas dupes!', Le Barrage 150 (8 June 1939), p.2.

364 Ibid.

365 René Gerin, 'La guerre de Dantzig n'aura pas lieu', Le Barrage 151 (13 July 1939), p.1. Jean Giraudoux' pacifist play was entitled $L a$ Guerre de Troie n'aura pas lieu and had been enthusiastically reviewed by Georges Pioch in 1935. See Le Barrage 74 (5 December 1935), p.1. 
deal of discussion. Even the right-wing parties now seemed ready to consider negotiations rather than war. Secondly, and more importantly, the Anglo-Franco-Russian alliance did not seem to be coming together. The so-called 'peace front', the coalition of the 'pacific democracies', the organisation of 'collective security' had all failed. This was a happy event for Gerin and the LICP. Tensions remained in the international sphere but pacifists would have to keep their sang-froid as they had done so far. 'The treatment for our nerves through a system of hot-and-cold shower-baths [la douche écossaise] is surely not over'. ${ }^{366}$

Seven weeks later, Europe was at war.

366 Ibid. 


\section{PART III}

THEMES ET VARIATIONS, OR FEMINISM AND PACIFISM IN INTERWAR FRANCE. 


\section{III.1. Introduction.}

James F. McMillan in his book Housewife or Harlot argues quite rightly that the history of feminism in the Third Republic has been neglected. He examines at some length the impact of the Great War on French society, and argues that it had little effect on the status of French women'. On the contrary, he sees continuity rather than change as the key concept in this period - in contradistinction to the views of many contemporary observers. With regard to women's activities during the war, McMillan writes that '... the average French woman accepted the First World War as a cruel and evil necessity. She was prepared to make immense sacrifices, but she did so with her eyes open. She did not attempt to delude herself that here was a crusade to be supported with a kind of mystical patriotic fervour. Without wanting the French government to purchase peace at any price, she was well aware that the war brought misery and privation'. 2

So much for the views of the average woman, but what about those who could rightly claim to be self-conscious feminists, aware of themselves and of their femininity? McMillan writes that the official feminists were stridently patriotic. Propaganda on behalf of the right to vote was dropped in favour of exhortations to serve the patrie... Compared to the enormous amount of patriotic activity, opposition to the war effort among French women was almost negligible'. ${ }^{3}$ Thus, in McMillan's view, the 'most important conclusion that can be drawn from this rapid survey of women's position on the home front during the First World War is that both the 'patriotic' and the 'pacifist' camps were in a distinct minority in the country as a whole'.4

But it is perhaps necessary to look behind this apparent inactivity on the part of feminists in the fight against the militarism of European society in the era of the Great War and afterwards. Jo Vellacott argues in a recent paper that far from being of no

1 James F. McMillan, Housewife or Harlot: The Place of Women in French Society 1870-1940 (Brighton: The Harvester Press, 1981),p.5

$\begin{array}{ll}2 & \text { Ibid., p.105. } \\ 3 & \text { Ibid., p.112. } \\ 4 & \text { Ibid., p.114. }\end{array}$ 
consequence whatsoever, women's peace efforts in the First World War and afterwards were important because by involving themselves in the peace movement, women were stepping outside their assigned social roles and thus making a powerful feminist statement. By implication, what matters according to Vellacott's argument is not so much numbers as the mere essential fact of women's activity within a larger peace and protest movement. She writes:

Women's peace efforts are often dismissed as simply part of the general softness of women's nature, or as part of their motherhood role, with no serious import for the public sphere. This patronising view has not only made it possible to disregard the content of what peace women have said, but at times even succeeds in making peace a suspect cause among feminists. Many first world war feminists, however, believed that pacifism was not only a logical development from feminism, but an integral part of it.

In a culture which strongly enforces gender inequality and the widely differentiated traditional roles of men and women, where women are relegated to the private sphere, and where they are not organised to reclaim equality or push back the frontiers, women do not emerge as forceful opponents of war, demanding to be heard. They fulfil instead their assigned role, in war as in peace, sacrificing their sons and lovers without complaint (mourning yes, but complaining no), keeping the home fires burning, loving soldiers, being sexually available, bearing and nurturing cannon fodder for future war, enduring hardship, taking on extra tasks for the duration and relinquishing them without a murmur when the men come home. 5

Vellacott suggests that simply by stepping outside this traditional role vis-à-vis war, women were taking part in the larger feminist movement and it is in that context that their action must be seen. Although she is primarily concerned with the British example, her analysis is sufficiently broad in its theoretical implications to be interesting and useful here. Her statement that 'in the long run ... making use of certain gender-based advantages, sisterhood made a stronger anti-war showing than brotherhood' is a provocative one. ${ }^{6}$ Leaving aside the British case, one would have to agree with McMillan that the Great War provided many examples of women active in the suffrage and feminist movement who supported the war effort jusqu'au bout.

5 Jo Vellacott, 'Women against Militarism in the First World War: the British Connections'. Paper read at the American-European Consultation on Peace Research in History, 24-29 August 1986, Stadtschlaining, Austria. To be published in Charles Chatfield and Peter van den Dungen, eds, Peace Movements and Political Cultures (Knoxville: University of Tennessee Press, in press).

6 Ibid. 
It is the purpose of this section to examine the putative link between feminism and pacifism in interwar France in the form of its clearest nexus, the French section of the Ligue Internationale des Femmes pour la Paix et la Liberté (LIFPL). There is no doubt that women played an important role in both women's and mixed French pacifist groups in the twenties and thirties. Some women such as Madeleine Vernet and Marcelle Capy saw their role as little different from that of men, and organised and led important nouveau style pacifist groups from about 1928 onwards. ${ }^{7}$ Both of these women were also active as pacifist and feminist journalists. Primarily though it is the French section of the LIFPL and its contribution to the pacifist debate at both the international and national levels which will be the focal point of this section. The LIFPL was founded at the Hague in 1915 and was initially called the Women's International Committee for a Permanent Peace. It grouped together the cream of British, European and North American avant-garde feminist women. 8 In France its leading lights were Gabrielle Duchêne, Camille Drevet, Andrée Jouve, Léo Wanner, and Madeleine Rolland. ${ }^{9}$ These five women served for much of the interwar period as members of the International Executive committee of the LIFPL. Duchene was an international vice-president for a number of years and Treasurer from 1935 to 1937. Camille Drevet was International Secretary during the mid-thirties, and the others were so-called non-voting 'consultative' members of the executive.

A second, more tangential, purpose of this section is to consider the extent to which this nascent French feminist pacifism was challenged by what will be termed the 'misogynist' attack, men who tried to lay the blame for the European Calvary of 1914-1918 at the feet of women.

In a broader sense, though, this section raises questions about the nature of the French feminist pacifist experience in the interwar period. For many feminist pacifists of the time (and indeed still today), 10 it was a self-evident axiom, as Vellacott mentions above, that feminism and pacifism ought to be linked. But it will be argued, unlike Vellacott, that it was not sufficient for women to emerge from their traditional sphere into the post-war political world in order to make a feminist statement for peace. As Vellacott herself admits, the content of women's peace ideas was important, and it was this content which

7 See James Friguglietti, 'Marcelle Capy' in Harold Josephson, ed. Biographical Dictionary of Modern Peace Leaders (Westport, London: Greenwood Press, 1986), pp.141-43. See also Albert S. Hill, 'Madeleine Vernet' in ibid., pp.986-988.

8 For an account of the international work of the LIFPL see Gertrude Bussey and Margaret Tims, Women's International League for Peace and Freedom (London: 1965). For a generalised overview of the French section of the LIFPL see Yvonne Sée, Réaliser l'Espérance (Paris: Section française de la LIFPL, 1983). See also Gabrielle Duchêne 1870-1954 In Memoriam (Paris: Section Française de la LIFPL, n.d. [1954]).

9 See Albert S. Hill, 'Gabrielle Duchêne' in Josephson, Dictionary, Pp. 226-228. See also Yvonne See, 'Andrée Jouve' in Josephson, Dictionary, p.481.

10 See for example Pam McAllister, ed., Reweaving the Web of Life: Feminism and Nonviolence (Philadelphia: New Society Publishers, 1982). 
distinguished women's efforts for peace from 'masculinist' pacifism. What was inherently new, exciting, innovative and unique in the feminist contribution to peace in the immediate post-war world, was lost in France by the thirties. In the process, the French section of the LIFPL became a shadow of what it might have been, its arguments a shell of what they once were, and the only genuinely avant-garde French feminist contribution to the pacifist debate a mirror image of the ideologically divided world of mainstream French pacifism. Paradoxically this is in no way to denigrate the French feminist contribution to peace. Right up until 1939 women such as Gabrielle Duchêne continued to play an extremely important role in the larger French pacifist movenent, but they did this increasingly as pacifists in the male mould, rather than as feminists.

Thus, the feminist contribution to the pacifist debate in interwar France can be situated between the two ext.remes which have been examined in Parts I and II of this thesis. If the first two sections define the opposing paradigms of new and old-style pacifism, then the pacifism of the women of the French section of the LIFPL consfituted a sort of 'theme and variations' on the motif set in the world of 'masculinist' pacifism. The evolution of feminist pacifism in late Third Republic France followed a curve in opposition to the currents of he day. Thus, in the first decade of the predominance of pacifisme ancien style, the women of the LIFPL were representatives of integral pacifism before it became known as such. And by the time the new pacifism had begun to emerge in the early thirties, the LIFPL, or at least its leadership, was beginning to evolve away from absolute pacifism towards a defence of justice and freedom. This led to an interesting communion de pensée between mainline bourgeois pacifists like Ruyssen and the once radical pacifists of the LIFPL.

\section{The Great War and the Misogynist Memory}

Romain Rolland in his war-time journal, quotes a 'modest proposal' taken from a provincial newspaper, with regard to the activities of French women during the great conflagration. The father of a provincial lawyer apparently suggested augmenting the number of combatants and disposing of a 'social problem' at the same time by the following means:

We must mobilise under the standard of the good and saintly Joan of Arc, the multitude of evil women from twenty to forty years of age who exist in France. To the battalions of these sad girls, who corrupt the race, we will join the vile adulterous women. All of these harmful beings must go to the army and [come] under fire like our beloved sons. ${ }^{11}$

11 Cited in René Arcos, Romain Rolland (Paris: Mercure de France, 1950), pp.206-207. 
Interwar writing on the question of women and peace shows similar antipathies. Some male writers created almost a minor literary genre vilifying perfidious women who, they claimed, ought to have prevented men from going to war. Women, whose voice no one wanted to hear in the great days of August 1914, were reproached for having let their men go off to the trenches, for having harangued shirkers into uniform, in short for having done the 'patriotic' thing.

Other fictional, as opposed to polemical, works, such as Raymond Radiguet's Le Diable au Corps created scandal by portraying the young wife of a soldier away doing his duty at the front involved in a steamy love affair with a sixteen year-old boy - a generational as well as a sexual betrayal and treason on the home front. ${ }^{12}$

Finally, there was the feminist retort to all of this, that women are naturally peacemakers and have an in-bred hatred of war.

To take an example in the first category, Fernand Corcos, a barrister in the Court of Appeal in Paris and a member of the Central Committee of the Ligue des Droits de l'Homme, wrote a couple of books in the late twenties examining the question of women and the Great War. In the second of these, entitled La Paix? Oui, si les femmes voulaient! (1929), Corcos wrote that in 1914 he thought that women would somehow find a way to stop the war, would prevent men from the collective folly that seemed to be overtaking them. ${ }^{13}$ But he was 'deeply mistaken. Before, during and since the war, at any bellicist demonstration, there have been, there are as many women as men. At all pacifist demonstrations there have been, there are, more men than women. Women's activity is therefore at the present hour indiscernible from that of men, insofar as war and peace are concerned. 14

But Corcos seemed to be caught in the paradox which still afflicts modern feminists: that between separatist and integrative feminism. 15 For example, he writes:

The feminist says: woman is naturally a pacifist. I respond: in 1914, woman mobilised herself, by her own will... Not a single soldier was wounded or killed, in one army or the other, by a weapon that was not manufactured by the hand of a woman... Woman is just as bellicose as man. ${ }^{16}$

12 See Raymond Radiguet, Le Diable au Corps (Paris: Grasset, 1923)

13 Fernand Corcos, La Paix? Oui, si les femmes voulaientl, (Paris: Editions Montaigne, 1929), p.286.

14 Ibid., Pp.286-287.

15 See for example in this regard Jo Vellacott, 'Separation and Integration: the nature of women only actions for peace'. Unpublished paper provided by the author.

16 Corcos, Pp.216-217. 
He went on to repeat Andreas Latzko's assertion that women had been prepared before the war to break windows and be vilified and attacked in their struggle to attain the vote, but that when their men left for the front not a word was spoken, not a hand lifted. Corcos concluded that women's education needed to be changed, that instead of trying to make them carbon copies of men from the point of view of passions and ideas, new generations of women must be women, with all of the sweetness and invincible resistance that that word carried. 'This is the angle from which I view the utility of feminism', he wrote. 'My feminism is one of complete encouragement. I ask women to serve Peace for their children and fathers, for their husbands and their men. In so doing they will serve the Patrie. So well, in fact, that everyone will be satisfied - the amazons and the simple, true women too'.17

Corcos' at times self-contradictory analysis was greatly exceeded, however, by a review article by Gérard de Lacaze-Duthier ${ }^{18}$ published in 1933 . He examined the role of women in the light of a recent book by Victor Margueritte entitled Les Femmes et $1 e$ Désarmement::

.... Victor Margueritte publishes a work of the highest interest. He demonstrates the role which women are called to play in the disarmament of hatreds, prelude to a disarmament of peoples. If ever woman had a role to fill, it is surely that of mediator between these enemy brothers called men. For too long she has used her charms, her seductions, her power, to sow discord among the representatives of the stronger sex. The weaker sex must get hold of itself and renounce the use of its weakness to play the game of force. Woman has no other mission in this world than to teach her sons not to kill, for whatever pretext. That is true feminism. There is no other. War against War must be the word of the day for all those women who do not consider themselves the vassals of men but rather their equals. There is no better way for them to prove that they are something other than sex-fodder or work-fodder. Faced with this task of regeneration, what weight can the little claims of an inverted feminism possibly have? What interest can the conquest of power possibly hold for the daughters of Eve? They must stop playing the game of militarism first, they must cease falling into ecstasies before stripes or a flag, they must preach the love of peace to their sons, and try to extirpate from the breast of humanity by all the means in their power, this chancre which is war...Afterwards, we'll see...

... [Women's] conduct in the Just War was below everything. Women showed themselves in 1914 in all countries to be more ignoble than men. They had a disastrous influence on the latter. Sowing hatred, encouraging the combatants, denouncing those whose heroism failed them, we saw these modern-day amazons at

17 Corcos, p.217.

18 Gérard de Lacaze-Duthier, 'Les livres' in La Patrie Humaine, no. 50 (7-14 January 1933), p.2. 
work, more ferocious than those of old. These tigresses exulted when the ones they claimed to cherish fell on the field of honour... Since the war, have women tried to repair the damage they did? Victor Margueritte notes with sadness that if women have become emancipated in the past few years, 'they have become drunk on excessive licence. Short hair, short skirts, short ideas'. - their emancipation reduces itself to that. 19

Lacaze-Duthier echoed Margueritte's call to women to join leagues and become active in the pacifist fight, and also 'to have no more children as long as the nations have the right to assassinate them' 20

This is undoubtedly one of the more misogynist diatribes of interwar French pacifism and it is interesting for a number of reasons. The anticonceptional propaganda - what Victor Mérie called 'la grève des ventres' 21 - is a theme which recurs several times in the speeches and writings of major pacifist figures in the 30 s and one for which several of them were hauled before the courts and tried, having contravened the Third Republic's post-war legislation on natality and anticonceptional propaganda. Secondly and more importantly, there is the attempt to shoulder women with the moral and literal responsibility for the First World War and the militarism which pervaded French and European society.

\section{The Feminist Response}

Most French feminists took quite the opposite view of recent history and women's role in it. Henriette Sauret argued in 1930 that,

If anyone can do much for the establishment of peace it is the woman. Until these past few years she has not been able to play a role of real efficaciousness with regard to this great work. But by virtue of her increasing intellectual importance, her increasingly rapid accession to all branches of human activity, her influence which broadens more and more each day...woman has been designated to tear the torch of peace away from the hands which until now have held it in an intermittent or debilitated way....

... In the opinions of men regarding the attitude of women vis-à-vis war and peace, there is a duality of viewpoints which is rather strange and which should be noted. During the period 1914-1918 the public, the press and in general masculine circles found it scandalous that women should become involved wtih pacifism. For the record let us remember the persecutions suffered by Gabrielle Duchêne, Julia Bertrand, Hélène Brion, Marguerite Thévenet, etc. Since the armistice, a change in attitude. Men presently are trying to lumber women - or almost - with the responsibility for the war.

19 Ibid.

20 Ibid.

21 Cited in Joseph Folliet, Pacifisme de Droite? Bellicisme de Gauche (Paris: Editions du Cerf, 1938), p.14. 
Many a writer has given us his reflections on this subject, which can be summarised more or less as follows: 'Women ought to have thrown themselves in front of the trains! Prevented men from leaving! Not one of them protested! Women adjusted themselves to the rhythm of war. They were the valiant nurses, the amazons of the wagons, the lovers of those on leave! Pacifists, women? Away with you! Pitiless Cornelliennes, yes! Chasers of shirkers, yes! ${ }^{22}$

And Sauret cited as examples of this 'literature' as she politely termed it, the works of Andreas Latzko, Corcos, Pierre Mille, etc. Echoing Simone Ratel, she wrote that one does not undo the effects of a thousand years of education and training in one night, an education which taught women to find good and admirable all that men did, and furthermore one which taught obedience as the supreme virtue. ${ }^{23}$

'Man is fleeing from himself, she wrote, 'he is accusing phantoms instead of looking his own infection in the face and admitting that at the bottom of his heart he consented to the war and that his old instincts were contented'.24

In Sauret's view, men were incoherent. While protesting loudly about women's supposed failings in matters of peace, they went blindly on preparing the next war. Women would be fully justified in saying 'Get on with it' and refusing to have anything more to do with men's childishness. But that was not women's way, according to Sauret. Women were above all else generous, and history showed that they had an amazing capacity to sacrifice themselves to great social movements for the sake of mankind, movements in which they personally had little stake - and she cited as examples of this women's contributions to the French Revolution, the fight against slavery, workers emancipation, and so forth. ${ }^{25}$

Marthe Bray of the Ligue d'Action Féminine pour le Suffrage des Femmes also attacked the tendency of what she called 'sceptical or poorly informed minds' to claim that feminists neglected in their programmes the fight for peace, or even that women looked kindly on the 'warrior spirit, as if women had invented the Patrie!'26 On the contrary she claimed that a look at any feminist tract would soon put the lie to this sort of misogynist slander.

The woman who has embraced the feminist doctrine is a woman liberated from all that the past has handed down to her in the form of errors and prejudices. Giver of life, and of a life which she

22 Henriette Sauret, 'Le Rồle de la Femme dans la Pacification des Esprits' (30 November 1930). Typescript in BDIC/DD/FARés. 312/4/92.

23 Ibid.

24 Ibid.

25 Ibid.

26 Marthe Bray, 'Oui, les femmes veulent la paix!', in Le Progres Civique, no. 535 (1931), p.214. See copy in BDIC/DD/FARés 312/1/47. 
desires to be beautiful and healthy, the feminist is resolutely pacifist! 27

27 Ibid. 


\section{III.2. Aims, Political Orientation and the Führerprinzip}

The French section was certainly never the largest of the LIFPL international sections. In the mid-twenties it numbered some 500 members compared with Germany's 5000, 4000 in Britain, some 8000 in the United States and 10,000 in Denmark. ${ }^{28}$ Out of an estimated total League membership of some 35,000 members, it seems insignificant indeed. Likewise the financial contribution of the French Section to the international work of the League was minimal. In a statement of sums received for a six-month period in the mid-twenties, the French contributed the equivalent of $\$ 12.00$ compared with the two largest contributions of $\$ 3,000$ and $\$ 542$ from the American and British sections respectively. 29 However, by 1935 the French section was claiming a membership of about 4500 women. 30 Whether this is an accurate representation of its size it is difficult to say. In 1931 Duchêne had warned her colleagues on the International Executive Committee of the dangers of an international organisation appearing too small numerically. She counselled prudence in whom these figures should be released to. ${ }^{31}$ This might imply a certain elasticity in her approach to the truth in the matter of membership figures, especially given the French section's increasing isolation and its struggle to maintain its influential position internationally within the League in the mid-thirties. It is impossible to be certain about this, but as a point of comparison, it should be noted that the total maximum membership of the fourteen groups present and voting at the 1936 French section national conference was only 1700 members. 32

Whatever the actual size of the French section, there is no doubting its importance at the international level of the league, and also as an influential part of the larger peace

28 Cited in typescript entitled 'Washington Object' in BDIC/DD/FARés 208/5/5.

29 Cited in 'Statement of Sums Received from National Sections within Six Months', Women's Inter ${ }^{\circ}$ ional League for Peace and Freedom, International Office, Geneva. In BDIC/DD/F $\Delta$ Rés $205 / 5 / 4$.

30 Minutes, International Executive Committee Meeting, Geneva, 12-16 September 1935, p.39. In BDIC/DD/FARés 206/ Septembre 1935

31 Minutes, IEC Meeting, Geneva, 4-8 September 1931, p.3. In BDIC/DD/F $\Delta$ Rés 206/ Septembre 1931.

32 Cited in Procès-verbal de la Conférence Nationale de la Section Française de la LIFPL des 27 et 28 juin 1936, p.6. In BDIC/DD/F $\Delta$ Rés.208/17 
movement in France. As has been noted above, at various times in the twenties and thirties the leading women of the French section served in different capacities on the International Executive of the League. Thus, despite its relatively small numbers and lack of financial power, the French played a disproportionately important role within the international councils of the LIFPL. Primarily through Duchêne, the French section developed a specific approach to the problems of peace and the answers which it hoped pacifism would provide. In this endeavour they were often joined by the members of the German section. The community of spirit between the French and German sections became one of the two poles around which the theoretical and practical debates within the League revolved during the interwar period. The other pole was, perhaps not surprisingly, epitomised above all by the ideas of the British section, with the Scandinavian countries and the American section playing increasingly important supporting roles as the shadows lengthened over Europe in the thirties.

It was perhaps inevitable that in such an international organisation disagreements should quickly arise over goals and methods. Hardly had the euphoria of the first postwar congress in Zurich in 1919 subsided than discussions began which gradually became an at times acrimonious debate for the heart and soul of the League. This debate spanned almost the entire interwar period and saw the British and French sections locked in an almost permanent confrontation from about 1924 onwards. If, as John Cairns has put it, the British in the interwar years were ' a nation of shopkeepers in search of a suitable France ${ }^{33}$, the reverse can also certainly be said to be true within the LIFPL (during the thirties especially). The debates centred on three significant areas: the question of aims or goals for the League, the debate over the nature of the League and its Executive - should it be national or international, delegative or leadership-oriented, and finally, the question of policy - whether the League should be politically engaged, or rather pursue a primarily educative role.

The debate over the aims or object of the League is one which highlights the different approaches taken by the various sections to the question of war and peace. As early as 1920, the International Executive Committee was expressing its concern that new associate members should sign a statement of 'our object' in order to effect a kind of pacifist quality control on incoming members. 34 By 1923 at its meeting in Dresden, the question seemed to have become more acute, with the English pacifist Catherine Marshall remarking that the resolutions passed at The Hague in 1915 are not any longer a real guarantee of pacifistic

33 John C. Cairns, 'A Nation of Shopkeepers in Search of a Suitable France, 1919-40', American Historical Reoiew 79, 3 (June 1974), pp. 710-743.

34 Minutes, IEC Meeting, Geneva, 1-4 June 1920, p.14. In BDIC/DD/FARés. 206/juin 1920. 
convictions, especially not in Central and Eastern Europe'.35 She urged that sections ask their members to subscribe to a statement of aims drawn up by the American, Emily Greene Balch, which included the phrase that the members of the LIFPL opposed 'all war'. 36

But it was in 1924 that the debate over the aims of the League began to become acute, and it is from that year that one can date the beginnings of the Anglo-French rivalries within the League which found expression in the differing conceptions of the nature of peace work and the direction the League ought to be taking. For most of the rest of the decade the battle-lines were drawn over the question of the admissibility of 'defensive' wars, with the French taking the more absolutely pacifist stand that they were not to be countenanced. As Andrée Jouve put it in a letter to Kathleen Courtney in December 1924:

We cannot accept partisans of defensive wars in the League. The French Section was formed at the moment when the [German] invasion was in full swing: it is precisely because we were 'opposed to any war, offensive or defensive', that we were at that time in disagreement with almost all French women. They would all be with us today if we declared ourselves only against offensive wars or wars of conquest. And we all know what the distinction between these two types of wars is worth. We certainly have no need of members who are going to resign at the first incursion of an airplane... ${ }^{37}$

The following summer at the International Executive Committee meeting in Innsbruck, the British section attacked the offending re-wording of the Object which had occurred at the League's congress in Washington in 1924. Together with the Polish, Scandinavian, and Czech sections, the British protested that the new wording of the aims made the work of the league in Britain extremely difficult. 38 By February 1926 the American section had decided that it, too, wanted the Washington object altered to remove the reference to defensive wars, and a concerted move began to amend the League's constitution. ${ }^{39}$ As Duchêne pointed out, it appeared a bit illogical that the American section was prepared to accept a condemnation of 'all wars', but not of 'defensive wars'. 40

Some members thought that the League's role should be to educate women about war and peace, and in so doing gradually bring them into the full work of the League. But as Andrée Jouve argued, the League had been founded in wartime and had taken a very unpopular stand which it would be now rather difficult to go back on.

35 Cited in Minutes, IEC Meeting, Dresden, 1-5 September 1923. In BDIC/DD/FARés. 206/ septembre 1923.

36 Ibid.

37 Andrée Jouve to Kathleen Courtney, December 1924, in BDIC/DD/FARés. 208/5.

38 Minutes, IEC Meeting, Innsbruck, 10-15 July 1925, in BDIC/DD/FARés. 206/juillet 1925.

39 See Minutes, IEC Meeting, Paris, 6-10 February 1926 in BDIC/DD/FARés. 206/Février 1926.

40 Ibid., pp.5-6. 
As far as the education of members is concerned, we do not have a pacific association more radical than the French section. We represent therefore integral pacifism. We do not fulfil our goal if we do not hold to the very firm ideal which was set at the beginning. We believe that any formula ought to be the ideal one holds, that is to say pursue it by different paths, by different stages more or less quickly; but what is necessary in any case constantly to maintain is the sense of where one is going. This is a method of working which is different from that of our American and English friends, but what we must do is understand one another and find a common ground. ${ }^{41}$

The divergences of viewpoint may have been due to differences in national temperament. Catherine Marshall ${ }^{42}$ seemed to think that there were fundamental differences in outlook between the English section on the one hand, and the French and German sections on the other. She wrote to Duchêne in 1926

\begin{abstract}
... this much I can say, perhaps: I think there is a rather fundamental difference between the way the British Committee ... regards the task and function of our League, and the way in which the French Section, and again the German Section, regards it. English people in general, and the women who form the greater part of our membership in particular, are inclined to be very much absorbed in the political aspect of things, and to attach less importance to thought and feelings and more importance to action, than is the case with your countrymen and the Germans. We tend to be not very much interested in the processes that prepare and determine events, and to wake up only when the events are actually happening and there is something to be done, here and now. We tend to dislike too much theorising... 43
\end{abstract}

Marshall's analysis of the French section may be applicable to the situation in the midtwenties, but as will become clear later on, it did not apply to the thirties when the French section became avowedly political whilst struggling to maintain its veneer of impartiality vis-à-vis the political parties. Even with regard to the 1920s, Marshall's comments underestimate the broad interests and strengths of the French section. As early as 1921, for example, Duchêne had written in her yearly report to the League's secretariat in Geneva that 'unfortunately, the majority of the women who have joined us through conviction are too busy (emphasis added) with political action to work for the pacifist cause elsewhere other than within their party political groups. Their action is no less useful for that, but

41 Cited, in French version of minutes, p.5, appended to ibid.

42 For a biographical sketch of Marshall, see Jo Vellacott, 'Catherine Marshall' in Josephson, et al, Biographical Dictionary of Modern Peace Leaders, pp.606-607.

43 C. E. Marshall to G. Duchêne, 29 January 1926 in BDIC/DD/FARés. 206/février 1926. 
that of the Section suffers from it'. 44 The French section was always politically conscious and active, but it is true to say that in the 1920s it placed more emphasis on activities like the Summer Schools, the preparation of the Cahiers de la Paix (an activity which was once likened to the intellectual preparation of the Revolution of $1789^{45}$ ), aid to famine-stricken areas of Europe and so on.

The question of the nature of the League had already been raised briefly in Dresden in 1923 in a discussion of the 'Competence of the Executive Committee to take action for the whole league'46. But it was in 1927 at the Executive's September meeting in Geneva that the issue became an important one. The British section desired a change in the method of voting at the International Executive which would see the vote given to the Consultative Members from each of the sections, in addition to the vote already held by the international executive members duly elected by the congresses. Duchêne, on behalf of the French section, was completely opposed to this change. In her view, it would weaken or destroy the international character of the League and leave it changed into a body of national groups:

National representation would have as its inevitable consequence the modification of the spirit in which the members of the executive work. Elected by national sections, it is towards them that they would feel themselves responsible; it would be no longer possible for them to liberate themselves from national points of view. 47

The problem with national representation was that it would give too much power to 'recently enfranchised' nations which had not yet evolved enough in Duchêne's view to be able to work effectively. Sections such as Greece and Bulgaria were still too imbued with a 'nationalisme aigu' and needed careful nurturing up to the level of the more advanced nations. Duchêne considered the debate over the method of representation in the League perhaps even more important than the debate about the Object:

On this change - or on the maintenance of the present rules depends the future orientation [of the League.] We have been asked to act only by unanimous decision. But if unanimity can be achieved on the philosophical level, it cannot be at the level of action. Action is life - life is the multiplicity of actions and reactions, diversity.

44 Extraits du Rapport sur l'action de la section française au cours du dernier exercice, 1920-1921, adressé au Comité Central de la Ligue. In BDIC/DD/FARés. 206/septembre 1923.

45 Duchêne's comment in Minutes, IEC Meeting, Dresden, 1-5 September 1923. BDIC/DD/FARés. 208/2.

46 Ibid.

47 Typescript remarks of Duchêne dated September 1927 in BDIC/DD/FARés. 206/Septembre 1927. Emphasis is Duchêne's. 
Unanimity ceases to be possible in action, it would lead fatally to impotence.

.... If our League wishes to continue to be what it has been until now: a sower of new ideas; if it wishes to introduce new principles into the social, economic, and political domains, it cannot pretend to unanimity. It must choose: action, that is to say struggle and decisions taken by the majority or: unanimity in nothingness. ${ }^{48}$

She felt the issue to be so important that she threatened the secession of the French section if it should come to pass. 49

The problem reared its head again the following year in Geneva with another debate on the constitution, prompting Duchêne to ask what the other sections' conception of the League was. For her it was to be an avant-garde international organisation, but she suspected that for others it might be conceived in more conservative national terms. 50 Madeleine Rolland, one of the French section's consultative members, echoed Duchêne's comments, saying that 'an avant-garde society signifies an absolutely pacifist society, and we must be very clear about what we would do in case of war and if we are opposed to all wars.... the LIF would prefer to be a small group of absolutely pacifist women... a small group of convinced pacifists can have a real influence'. 51

The purity of Duchene's pacifist internationalist principles is exemplified in her suggestions regarding the healing of the divisions within the Czech section which was split into two sometimes opposing groups, one German and the other Czechoslovak. In 1929, she proposed 'the creation of a small group of genuinely pacifist women imbued with an international spirit in which no attention should be paid to the nationality of the president. This would be the core of a future section:.52 Pacifism for Duchêne was no matter of spineless compromise, however. She believed ardently, in Jane Addam s' words, that 'that which unites us is more important and stronger than that which divides us'.53 Pacifism was a stronger, more positive force than mere compromise as she insisted to the International Executive Committee after an unfortunate incident at a public meeting organised under its auspices in Geneva in September 1927. As she said the following day, 'Some things that were said during the speeches gave the impression that one of the speakers, in concluding, identified pacifism with a method of compromise and this was a deep shock. Another speaker seemed to wish to indicate that in action the League should

48 Ibid.

49 Minutes, IEC Meeting, Geneva, 11 September 1927, afternoon session, p.4. In BDIC/DD/FARÉs. 206/septembre 1927.

50 Procès-verbal, Comité Executif International, Geneva, 20-24 March 1928, p.7. In BDIC/DD/FARés. 206/ mars 1928.

51 Ibid., p.8.

52 Procès-verbal, Comité Executif International, Geneva, 16-19 April 1929, p.3. In BDIC/DD/FARés. 206/avril 1929.

53 Cited in Andrée Jouve, 'Jane Addams' En Vigie I, 1 (October 1935), p.1. 
not let itself feel too closely bound by its high principles. These things are equivocal and seem out of place in a meeting organised under the auspices of the League. ${ }^{54}$

The differences between the French and British sections on the question of principles converged on a number of occasions in relation to specific political issues. At the time of the Geneva Disarmament Conference in 1932 this became clear. The League held its bi-annual congress that year in Grenoble and one of the main points on the agenda was the international work in favour of disarmament. Lida Gustava Heymann and Gertrude Baer 55 representing Germany and Duchêne speaking for France demanded a radical manifesto, but were opposed in this by the British. Mrs Corbett-Fisher said

\begin{abstract}
that the difficulty is the same as in the past. The sections have different points of view in different countries. In Great Britain radical pacifist work is done by the No More War Movement, and although we know that the LIF is in favour of total disarmament, its principal role is to be an association of women well informed and ready to demand practical and immediate measures on any pressing question. 56
\end{abstract}

At the League's Dublin Congress in 1926 the first great revisionist debate on the League's aims and its structure occurred. Duchene agreed to accept a modification of the aims, removing the reference to defensive wars and replacing it with the more anodyne phrase that the LIFPL strove to unite 'women in all countries who are opposed to every kind of war, exploitation and oppression, and who work for universal disarmament and for the solution of conflicts by the recognition of human solidarity, by conciliation and arbitration, by world co-operation and by the establishment of social, political and economic justice for all, without distinction of sex, race, class or creed. 57 But she was adamant that the international character of the League be enshrined in a second paragraph which stated that the work of all of the national sections should be based 'upon the Statements adopted and the Resolutions passed by the International Congresses of the League'. 58

By the beginning of the 1930s the situation had thus begun to reverse itself and the French section increasingly found itself on the defensive, having to defend its attitude to the other sections. This was no mere accident but rather the result of a change in the

54 Minutes, IEC Meeting, Geneva, 13 September 1927, afternoon session, p.5. In BDIC/DD/FARÉs. 206/septembre 1927.

55 For biographical sketches of Heymann and Baer, see Amy Hackett, 'Lida Gustava Heymann', in Josephson et al , Biographical Dictionary...pp. 405-407. See also D. v. Westernhagen, 'Gertrud Baer', in Karl Holl and Helmut Donat, eds., Die Friedensbewegung. Organisierter Pazifismus in Deutschland, Österreich und in der Schweiz (Hermes Handlexikon) (Düsseldorf: ECON Taschenbuch Verlag, 1983), p.35.

56 Procès-verbal, Comité Exécutif International, Grenoble, 11-14 May 1932, p.7. In BDIC/DD/FARés. 206/mai 1932.

57 Minutes, Dublin Congress, 8-15 July 1926, p.7. IN BDIC/DD/FARés. 205/5/4.

58 Ibid. 
orientation of the French section, away from an 'integral' pacifist position towards a more ideologically Marxist view of peace and pacifism, at least at the official level. This slow evolution from what Duchêne herself called pacifist idealism towards pacifist realism 59 was accompanied naturally enough perhaps by a gradual softening of the French section's official position on the question of non-violence, civil war and the methods of the Revolution. This gradual process resulted in an estrangement from the rest of the League, with the exception of the German section, which finally saw Duchêne lose her seat as an international Executive Committee member at the last pre-war League congress in Luhacovice, Czechoslovakia in 1937.

The 1934 League Congress in Zurich is the key point at which the changing views of the French section became clear. Indeed it marked a watershed for the League as a whole as well. The world of 1934 was no longer even that of 1932 - the accession to power of the Nazi party in Germany had seen to that. The German pacifist Gertrud Baer remarked in the opening discussion that the League was undergoing an 'intellectual crisis'.60 In a long address, Clara Ragaz, one of the international vice-presidents, spoke of non-violence as the most important question for the League in the time of trouble it faced in the international sphere, but she wondered whether 'this same strong majority' existed with regard to social struggles or the social revolution. She recognised that right became very difficult to distinguish from wrong in this area, and asked what the path of true liberation was. ${ }^{61} 1934$ marked the LIFPL's first hard encounter with the real world of interwar Europe on a domestic as well as international level. In many ways, the 1920 s and the experience of the Great War had presented relatively clear-cut moral decisions for the pacifist women of the League, but the 1930s marked the convergence of two new factors in a startlingly violent way. First, the rise of fascism and then the Nazi seizure of power destroyed the humanitarian, rationalistic approach to peace which had been possible in the post-World War One era. And secondly, the gradual insinuation into the LIFPL of a Marxist conception of peace led inevitably to a confrontation on the social, domestic level between converts to it and the heralds of the old doctrinaire 'idealistic' pacifism.

The French section quite obviously viewed the 1934 congress as an important event for the future course of the League's work because its delegation of twenty voting members, two executive members and two consultative members was its largest during the interwar period.

59 Gabrielle Duchêne, 'Les Deux Conceptions du pacifisme', typescript of report prepared for the 1936 National Conference of the French section. In BDIC/DD/FARés. 208/17.

60 Minutes of Proceedings, Eighth International Congress, Zurich, 3-8 September 1934, p.4. In BDIC/DD/F $\Delta$ Rés. 205/8/8.

61 Clara Ragaz, 'Changements d'ordre politique, social et économique du monde depuis 1918. Problèmes qui en résultent pour le travail et les méthodes de la LIFPL: This was the opening address to the 1934 Zurich Congress. In BDIC/DD/F $\Delta$ Rés. 205/8/5. 
In a total voting body of 135 delegates, the French section was clearly a strong force. ${ }^{62} \mathrm{At}$ the next congress in 1937 it only managed to send three voting delegates, ${ }^{63}$ so it may perhaps be inferred from this that the 1934 congress was viewed as a pivotal event by the French section and that thereafter its commitment to the international work of the League waned. Pivotal the 1934 congress certainly was. Once again the Aims of the League were debated at great length with the usual stand-off between the Franco-German and British positions. The essentially Franco-German statement of aims that was finally voted after long and acrimonious discussion was much longer than the earlier versions and for the first time contained direct references to the need to abolish 'the present system of exploitation, privilege and profit' which caused wars and to 'facilitate and hasten by non-violent methods the social transformation which would permit the inauguration of a new system under which would be realised social, economic and political equality for all'. The women at Zurich saw as their goal 'an economic order on a world-wide basis and under world regulation founded on the needs of the community and not on profit'.64 The British counterproposal, much more general in its political analysis and stronger in its pacifist principles, originally read that the league 'is opposed to all resort to bloodshed and violence whether by States, by Classes, or by individuals, to dictatorship whether from the "right" or from the "left"'.65 The British proposal also contained references to the need for a 'social transformation' required before the aims could be achieved, but they did not wish to go into too much detail. 'By defining we create division' said Kathleen Innes, 'The British Section is not entirely opposed to the Franco-German proposal. They do not, however, believe that any new order would necessarily bring peace nor that social, economic, and political equality alone would mean peace'. 66 Instead, she thought that the acceptance of such a tendentious statement might very well drive members, and even entire Sections, out of the League.

The British were apparently astonished that the French proposal for a statement of aims made no reference to civil conflicts. Mlle Christol from the Marseilles section strongly opposed 'the suggestion that civil conflicts should be settled only by international arbitration'. In her view, the League 'must stand definitely with the workers even if, as a last means, they had to resort to violence' 67 One of the other French delegates, Mlle

62 List of Delegates, 1934 Zurich Congress, in BDIC/DD/FARés. 205/8/7.

63 Roll Call, IXth International Congress of the LIFPL, Luhacovice, Czechoslovakia, 1937. In BDIC/DD/FARés. 205/9/2.

64 See the revised version of the aims and the debate that preceded it at the 1934 Zurich Congress in 'Constitution. Paragraph II. Statement of Aims' in BDIC/DD/FARés. 205/8/6.

65 See 'CI. British Section Proposals for Revision of Constitution as a whole' in BDIC/DD/FARés. 205/8/6.

66 Minutes of Proceedings, Eighth International Congress, Zurich, 3-8 September 1934, p.17. In BDIC/DD/FARés. 205/8/6.

67 Ibid., p.19. 
Paquet, emphasising that she spoke for a whole group of young delegates, urged 'the necessity of a clear definition of violence under present day conditions'. In her view

... it is violence if young strong people are prevented from working. Even the very fact that we enjoy a more or less comfortable life while others are starving is violence. If we stand for peace we must not indulge in passivity but work out practicable methods of nonviolent action. 68

Catherine Marshall saw the essential differences between the French and British sections hinging on two points: the question of international war and class war, and secondly, on the definition of violence. She did not consider a general strike to be violence, nor was she prepared to accept responsibility for the covert violence of the system. She asked the French to define what they understood by violence to which Duchêne replied that

... in her opinion bloodshed is not always the worst form of violence, oppression in all its forms is violence as well. To the question towards which use of violence we ought to be more indulgent she [stated] that we must understand and sympathise with the oppressed even if they resort to arms. The Speaker makes it however quite clear that under no circumstances should the members of the League fight with arms. ${ }^{69}$

The extent to which the demands of a domestic social policy heavily inspired by the Communist party impinged on the French section's ability to relate to the international debate on non-violence and pacifism can be seen in the remarks of Germaine Baurez, one of the French section's Consultative Members, who explained to the Congress

that to accept the workers' violence in social struggles does not mean to advocate violence but only to consider it unavoidable. In France the union effected between Socialists and Communists makes a general strike possible, within a few months and it must be clear that if, as a result of this, Government forces are used against the workers and they are thus compelled to react with violence, our sympathy must definitely be with the workers. She would prefer a non-violent action but thinks that there is no time left now to build up an organisation for such action which it took years to do in India. ${ }^{70}$

It is clear from the above that for the French section support of a social struggle the parameters of which were defined by the Communist party had become more important

68 Ibid.

69 Ibid., p.21.

70 Ibid., p.27. 
than the struggle for international peace. One wonders if the French section would ever have seen the light of day in 1915 if Duchêne and the other women of that first hour had considered the organised violence let loose over European society 'unavoidable'. The attitude here is in sharp contrast to that of the Munich and Jena sections during the days of the German revolution in 1918-19 when women of the LIFPL several times intervened, not always successfully, with the military authorities and the revolutionaries in an attempt to ward off violence. ${ }^{71}$

The Congress nevertheless passed the Franco-German proposal regarding aims, albeit it in slightly amended form, but the French section voted against the clause which repudiated the use of violence under any circumstances. ${ }^{72}$ This occasioned a rather bitter discussion at the International Executive Committee following the congress when the French section's commitment to non-violence was openly called into question. Clara Ragaz, the Swiss pacifist, noted from the chair that there was 'some uneasiness in regard to the presence on the Executive Committee of a representative of the French Section, since the French Delegation in the Congress had voted against the clause in our new Aims which repudiates the use of violence under any circumstances. ${ }^{73}$ Duchêne replied that the French section was 'realist' and saw things as they were. She claimed that the French detested violence as much as any other section but

\begin{abstract}
they do not believe that the social transformation which seems to them indispensable to assure peace and justice in the world can realise itself without any violence. The French Section is in face of a revolutionary situation. The French workers - who are not armed - are almost daily the vicitms of acts of violence on the part of the Government or of reactionary factions. ${ }^{74}$
\end{abstract}

The French section had accepted Madeleine Rolland's amendment to the aims which spoke of achieving the social transformation deemed necessary 'by the methods most calculated to lessen [emphasis added] violence', an amendment which Duchêne said showed neither 'the naiveté nor the absence of sense of reality of the other amendments'. ${ }^{75}$ In any event, the Rolland amendment was defeated three times in the voting on the new constitution. Duchêne said that it was this lack of reality in the other amendments which was the cause of the French abstention, but she added that it should in no way be construed as an

71 See Gertrud Baer's comments on this in ibid., p.22.

72 Minutes, IEC Meeting, Zurich, 10 September 1934, p.12. In BDIC/DD/FARés. 205/8/7. See also Minutes of Proceedings of the 1934 Congress, p.35, paragraph 279 which records the details of the vote on the League's aims. It is unclear from this whether some members of the French delegation abstained or voted negatively.

73 Ibid. (IEC Minutes)

74 Ibid.

75 Ibid., p.13. See also Congress Proceedings, pp.25-26, 29 and 34 for the discussion and voting on the Rolland amendment. 
acceptance of violence, or as an unwillingness to continue to work within the League. She quite rightly pointed out that certain sections had achieved the removal of all condemnations of defensive wars from the aims in the past without it bringing into question a section's continued membership. At the time of the League's campaign for disarmament, the British section refused to accept the phrase 'total disarmament' and yet on Duchêne's suggestion it had been agreed to allow two formulas to exist side by side within the League. ${ }^{76}$

The continued participation of Duchêne and the French Section in the League was in fact in question. Emily Greene Balch said that when Duchêne 'had asked her directly whether she thought the League would be better without the French Section she had replied that she had arrived, with great pain, at the conclusion that G Duchêne was hampered in her work by her connection with the WILPF, and that the WILPF found its work made difficult by G Duchêne'. Duchêne, for her part, supposed 'that her activity in the Amsterdam movement where she has accepted collaboration with personalities and groups which are not non-violent, [had] not been approved'. She however was of the opinion 'that in working successfully to realise unity in France she [had] done more in two years for the cause of peace and liberty than in 20 years of work in the League'.77

The German section represented by Dr Anita Augspurg, Lida Gustava Heymann and Gertrud Baer protested vehemently against the attacks made on Duchêne and the French section. Heymann thought that many of the troubles 'have arisen because there is too much "Quakerism" in our Executive'. Quakerism was simply not up to the task of dealing with political situations outside the social and humanitarian sphere in which it normally operated. ${ }^{78}$ The comment is interesting because it shows the fundamental differences between an essentially political approach to pacifism, which was primarily that of the French and German sections, and the more idealistic, perhaps religiously inspired orientation of the Anglo-American sections. The Dutch section, too, seemed prone to view pacifism in an ethical, moral light rather than as a political problem. Mme WulfftenPalthe, a Dutch consultative member of the Executive, spoke of 'pacifism as a new religion and of the need to be $100 \%$ pacifist'. ${ }^{79}$ None of this discussion, however, really called into question Duchêne's personal commitment to non-violence. Gertrud Baer recounted how in a conversation with Duchêne about the February troubles in Paris, Duchêne had said that 'never in her life would she be found on the barricades'. 80 The meeting ended with Duchêne still on the Executive Committee and the French section still part of the League, but the

\footnotetext{
76 Ibid. (IEC Minutes), p.13.

77 Ibid., pp.13 and 15.

78 Ibid., P.14.

79 Ibid., p.15.

80 Ibid., p.14.
} 
incident serves to highlight the extent to which by 1934 the French section had begun to isolate itself from the rest of the League.

In some respects it is difficult to understand why Duchêne and the French section should have been singled out for this sort of treatment since in many respects Duchêne's views were no more 'radical' than those of the German Section, or for that matter those of Clara Ragaz, the Swiss international vice-president. Ragaz, for example, earlier that year at an executive meeting in Geneva had said that the League's struggle

for peace must be conducted on two fronts, if not three: against militarism pure and simple, against fascism which is but a disguised militarism, and against the present economic system, that is to say against capitalism, which is a supporter of fascism... We have always wanted peace and freedom. But all of these problems are becoming more concrete and insofar as they become more concrete they put us before the necessity of taking some very clear, very precise decisions, while in the past we have perhaps contented ourselves with more or less vague theories... 81

At this same meeting the Executive Committee passed a declaration drafted by Duchêne on the League's position on the current political situation. The document, especially in its final form, is imbued with a starkly Marxist analysis of the causes of the 'present discontents'. Duchêne wrote that the complexity of the problems facing the world was so great that pacifists and intellectuals were falling into increasing confusion about what course to take. She considered the healthiest attitude for the LIFPL to take to be summed up as follows:

Reject all dogmatism - even pacifist - to become conscious of reality; Tear ourselves away from the greyness of formulas which satisfy the mind too easily, in order to enter into positive action. 82

Duchêne saw the civilised world sliding into a barbarism without equal in human history and proclaimed that the 'passive cult of peace no longer suffices', what was needed in this dangerous hour was an 'active, positive, incessant struggle' against war and fascism. And if real peace was desired, one had also to desire the conditions for it. ${ }^{83}$ Without the support of any doctrine, she claimed that the mere objective examination of the facts obliged one to recognise that:

81 Extraits du discours d'ouverture prononcé par Clara Ragaz au Comité Exécutif International'. Geneva, 24-28 March 1934. In BDIC/DD/FARés. 206/mars 1934.

82 Déclaration adoptée à l'Exécutif de la LIFPL (Genève-Mars 1934) in BDIC/DD/FARés. $206 /$ mars 1934. A rough draft of this declaration is in BDIC/DD/F $\Delta$ Rés. 208/15 and is dated February 1934.

83 Ibid. Cf. Romain Rolland's message to La Volonté de Paix on much the same theme some years previously. Romain Rolland, 'La Volonté de Paix', Par la Révolution, la Paix (Paris: Editions Sociales internationales, 1935), pp.100-104. 
1) the capitalist regime is incompatible with real peace, with lasting peace.

2) that fascism is nothing but a manifestation of the self-defence mechanism of a capitalism under threat. 84

She 'knew' that capitalism would disappear - as the regimes which preceded it in turn had disappeared - but she knew too, that it would not merely abdicate, but would fight until the bitter end. She proclaimed that the hour had come to take sides, to affirm the League's position and to work for a 'social transformation' (a transparent euphemism for revolution!) which was to be achieved with a 'minimum of suffering': 85 She warned in the rough draft that for the league, which considered true peace as its ultimate goal, the fear of a little blood spilt today would have as its consequence the future shedding of much more as the political situation worsened. 86 She urged her fellow Leaguers to accept the historical inevitability of this 'social transformation', to abandon neutrality in internal as well as external conflicts and individually and collectively to adopt an objective, realistic attitude. 87

It is interesting to note the differences between the declaration finally adopted at the International executive level, and the rough draft written by Duchêne in February 1934. The draft version contains a much fuller analysis of the French reaction to the rise to power in Germany of the Nazi party and the problem that posed for the League. Duchene underlined the fact that the League had never ceased to denounce the injustice of the 1919 peace treaties, to demand equal treatment between victors and vanquished (but only through disarmament and not rearmament). The French section did not confound the German people with the new German government. Without underestimating the dangers posed by the new situation in Germany, Duchêne did not think it impossible to arrive at some sort of modus vivendi with Hitler. A treaty of non-aggression would be more than possible provided it contained no military clauses and was not directed against any third countries. The French section believed that its position of principle vis-à-vis Germany should not be changed because of the fact of a change in government'. They. also rejected categorically 'the idea of a preventive war' or a 'crusade of the democracies against the fascist countries', and came out solidly against any thought of a boycott against Germany which they considered both dangerous and impossible to effect. 88 Finally, Duchêne wrote that the French section was convinced that the danger of a war with Germany was neither

84 Ibid.

85 Ibid.

86 See the rough draft of this in BDIC/DD/F $\Delta$ Rés. 208/15.

87 'Déclaration adoptée...'

88 See the rough draft of the declaration in BDIC/DD/F $\Delta$ Rés. 208/15. 
the principal nor the most immediate danger, and she warned her members not to become obsessed with the 'German peril', but to keep everything in proportion. 89

The removal of the paragraphs relating specifically to the position to be taken with regard to the new Germany, and the continued insistence in the final published version on the need to support the workers in a potentially violent struggle for historically predetermined power, suggests a preoccupation on the French section's part not merely with a Marxist analysis of contemporary society, but perhaps more important a concentration on the domestic political situation in France in 1934. It is possible, one could argue, to see in the comparison of these two 1934 documents the beginnings of a political introversion within the French section of the League, an introversion which paradoxically was often in the coming years to express itself in international terms. The draft version of Duchêne's declaration is a mixture of domestic Marxist analysis and traditional League internationalism, whereas the manifesto finally adopted by the International Executive Committee is a Marxist political broadsheet and no more.

Despite the constitutional changes effected at Zurich, sectional peace did not descend on the League. In March 1935 at a meeting in London, Kathleen Innes complained that the British Section disapproved of 'any party implication in the aims accepted at Zurich' and served notice that her section wanted a 'more democratic organisation of the WILPF' which they would soon be trying to achieve despite the opposition they encountered.90 The French and German sections expressed their astonishment at the British action which they believed undermined yet again the basis for concerted international work in the League. At this London meeting, Duchêne was appointed Treasurer of the League, a position she held until the Congress in 1937. The appointment came only after a protracted debate in which the English international vice-president, Edith Pye, attacked Duchêne's lack of commitment to non-violence and said that her appointment as Treasurer would upset the delicate political balance amongst the officers of the League. Duchêne was finally appointed on the understanding that she exercise no political role as Treasurer. ${ }^{91}$

The internecine sniping went on for another two years until at the executive meeting in April 1937, Duchêne proposed a 'ladies' agreement' or a 'truce' not to raise constitutional questions 'until the present political crisis is over'. Failing that, she proposed a 'friendly divorce' between the two opposing tendencies within the League. Her proposal for a truce was narrowly accepted with those dissenting reserving the right to propose constitutional amendments at the upcoming IXth International Congress in Czechoslovakia anyway. ${ }^{92}$

\footnotetext{
89 Ibid.

90 Minutes, IEC Meeting, London, 25-30 March 1935, p.16. In BDIC/DD/FARés. 206/1935 mars.

91 Ibid., pp.23-25.

92 Minutes, IEC Meeting, Bruges, 6-10 April 1937, p.42. In BDIC/DD/FARés. 206/avril 1937.
} 
But at that congress Duchêne lost the seat she had held for so many years as a member of the International Executive and returned to the ranks of the nominally non-voting consultative members.

It is tempting to conclude that no one was happy with the constitutional arrangements worked out at Zurich. The British certainly were not and arguably neither were the French. Undoubtedly one of the reasons Duchêne lost her seat in 1937 was the complete lack of French delegates there to support her. Unlike 1934 when the French delegation had numbered 24 women, in 1937 it consisted only of Duchêne and the two consultative members. 93 This is perhaps an indication of Duchêne's lack of interest in the work of the LIFPL by this time, or perhaps more correctly an example of how the strife-ridden French section was no longer the international force it once had been. But that is to take us from the general to the particular. The internal debates of the French section will be examined in due course, but first it is necessary to look at how the political debate over aims, orientation and leadership was translated into concrete political action by the French section in its dealings with the larger league in the 'era of tyrannies'.

93 See Roll Call, IXth International Congress, Luhacovice, Czechoslovakia, in BDIC/DD/F $\Delta$ Rés. $205 / 9 / 2$ 


\section{III.3. Realism and Politics: the French contribution to international action.}

Moving from the level of theory to that of practice, one is struck by the French section's commitment to action. Even in the early 1920 s before the debates on an active, positive pacifism took place, Gabrielle Duchêne and the French women of the League saw their role as feminist pacifists in very active terms. Despite the analysis cited above of Catherine Marshall regarding the alleged propensity within the French section for theorising, there is no doubting the French commitment to political action. Indeed, by 1936, Duchêne was 'astonished that in such a characteristic case as the situation in Spain there [was] so much theoretical discussion' within the rest of the League. 94

That said, it is probably true that the nature of the action changed as the twenties rolled into the thirties. The French section, and indeed, the League as a whole, in the more immediate postwar years was primarily concerned with mediation, revision of the peace treaties, practical help to famine-struck areas of Europe, disarmament, and the dissemination of ideas of international brotherhood by means of summer schools and the like. In the 1930s with the rise of fascism, the deteriorating political and economic situation, and arguably, with the gradual politicisation in a Marxist direction of the French section's views on peace and pacifism, the calls for action became concrete in a way they had not previously been. As examples in the first category, one might note in passing Duchêne's participation in a group of six women delegated by the 1919 Zurich congress of the League to present a series of resolutions to the peace conference of the power in Paris. ${ }^{95}$ The LIFPL seemed to make a speciality of this sort of delegation. Another example including French participation was a delegation composed of Andrée Jouve, Catherine Marshall, Dr A Jacobs and Gertrud Baer which visited the Dutch, German and French governments during the Ruhr crisis in 1923. It is a measure of the esteem in which the

94 Cited in Minutes, IEC Meeting, Geneva, 10-14 September 1936, p.18. In BDIC/DD/FARés. 206/1936 septembre.

95 See 'Resolutions to be Presented to the Peace Conference of the Powers in Paris' in BDIC/DD/F $\Delta$ Rés. 205/1. The other members of this delegation were Jane Addams (USA), Charlotte Despard (Great Britain), Rosa Genoni (Italy), Clara Ragaz (Switzerland), and Chrystal Macmillan (Great Britain). 
League and these women were held that the delegation was received by the German Minister of the Interior who told them 'in a long and very serious interview the opinion of the cabinet that it is the first and most important aim to bring about an agreement between France and Germany appoved by the other Allies'. He complained that this idea had been urged for several years by the German socialist party but had not been taken up by the French government. 96

Further examples of the French section's activity during the 1920 s will be discussed in the following chapter which deals specifically with its internal affairs. It is above all the 1930s however which demonstrate Duchêne's attempts to force concrete political action on the League. Duchêne and the French became increasingly willing to take sides and to choose what they considered to be the moral and political high ground in the political conflicts of the thirties. While other sections of the League gradually settled into a sort of post-Hitlerian pacifist lethargy, the French section demanded action. Neutrality was anathema to them. Politics was the art of choosing, and choices were made within a neoMarxist ideological construct no matter how much Duchêne might talk about arriving at purely objective conclusions. Four instances, among others, deserve mention here as an indication of the French attitude to political action: first, the League's reaction to the SinoJapanese conflict in 1932, secondly the developing Spanish situation, thirdly the official league reaction to the remilitarisation of the Rhineland, and finally, the overriding concern of the French section in the thirties to support the policies of the Soviet Union.

At the 1932 League congress in Grenoble, Edith Pye, the English pacifist, presented a report on her recent trip to the Orient which was not at all well-received by the French section. Pye argued that the League should adopt a position of neutrality in the nascent Sino-Japanese conflict and avoid coming out on the side of one country or the other. Therèse Pottecher, one of the French delegates, argued on the contrary that it was no good trying, as Miss Pye had done, to examine impartially the wrongs committed by both sides. In her view, the 'great powers control business'. She did not have Pye's faith in the League of Nations, but thought rather that the governments of the day were but façades for financial interests. In her view the boycott of Japan by China was completely justified. ${ }^{97}$ Camille Drevet echoed Pottecher's calls for concrete action saying that the fact that Miss Cao, the Chinese representative to the League, felt it impossible to remain a pacifist in the present situation, only served to underline the extent to which the women of the League had failed in their mission. Something more than the mere sending of telegrams was needed. She proposed a move on the League's part to stop the shipment of men and munitions to China,

96 'News letter from Geneva' in BDIC/DD/FAREs. 206/septembre 1923.

97 Cited in the debate on the report of the Commission on China, in Procès-verbal, VIIe Congrès International, Grenoble, 15-19 May 1932, pp.12-15. 
and to that end suggested talks with trades unions. Léo Wanner of the Lyons section must have become quite agitated during this discussion, because Duchêne felt obliged to apologise for the 'vivacité' of her colleague and to term her temperament not 'violent' but 'passionate'. Duchêne emphasised the feeling of impotence and inactivity felt by the members of the French section in this instance.

If the French temperament shocks some delegates, the impassibility of the latter annoys the French. She thought that once blood began to run, one could not simply 'wait' before acting. She regretted very much that amongst the telegrams read to Congress, that of Mme Sun Yat Sen to Romain Rolland had been omitted. If Chinese women can no longer be pacifists, that proves that we have not yet done the work we should have. People of the west are too little interested in the Orient. She proposed the adoption of a strong motion against the attitude of Japan and the great powers to be sent to the League of Nations. 98

The Grenoble congress did not satisfy the desires of the French section; Duchêne complained after its close that it had been a major disappointment for young people particularly, because it had not adopted a radical manifesto. 99

The Nazi re-militarisation of the Rhineland provided another example of an occasion when political action taken by the international vice-presidents, Clara Ragaz and Gertrud Baer, was called into question and then condemned by the British section. In a letter of 16 March 1935 to the President of the Council of the League of Nations, Ragaz and Baer demanded that action be taken against Germany if the moral standing of the League were to be saved. This action must not be military in nature, but they did envisage the application of moral, political and economic pressure collectively applied, and if German troops did not leave the Rhineland, the eventual use of economic and financial sanctions. The British section argued that the letter conflicted with League policy by leaving the door open for a food blockade. It futhermore succumbed to the dangerous temptation of ultimatum which had never worked in the past. 100 Significantly once again Duchêne had supported the sending of the letter when consulted in early March by telephone. 101

Far more significant perhaps than the re-militarisation of the Rhineland was the French section's consistent support for the policies of Soviet Russia. These date back to the mid-twenties when there was considerable support within the League as a whole for the

98 Ibid., p.14.

99 Procès-verbal, Comité Exécutif International, Grenoble, 20-22 May 1932, p.1. In BDIC/DD/FARés. 206/1932 mai.

100 'British Section protests against Chairmen's Letter' in BDIC/DD/FARés. 206/1936 avril-mai.

101 See 'First Replies: telegrams, telephone or short notes received from Executive Members elected by Congress commenting on the draft letter to Mr. Bruce, sent to them on March 12th 1936'. In BDIC/DD/FARés. 206/1936 avril-mai. 
disarmament proposals of the Soviet Foreign Minister, Litvinoff. But by the early 1930s many sections of the League were beginning to become more hesi vant and less fulsome in their support of the Soviet Union, a tendency certainly not reflected in the policies of the French or the German sections.

This became very clear at the September 1935 meeting of the International Executive Committee in Geneva at which Gertrud Baer delivered a long and wide-ranging analysis of the political situation in Europe. Baer viewed the signing of the Franco-Soviet and Czecho-Soviet pacts as treaties of 'mutual assistance' designed to meet the situation created by the formation of 'blocks of countries aggressive and hostile to one another'.102 She furthermore believed these pacts to be in harmony with the League of Nations covenant because they were 'open for the free and sincere collaboration of all the states interested'.103 Her only veiled criticism was that the two pacts contained no references to disarmament, but she thought that this question might be taken up by the LIFPL with the countries concerned. That rider notwithstanding Baer concluded that the two pacts could serve as 'instruments of collective security [emphasis added] and peace'. ${ }^{104}$ Not all of the League's Executive accepted this charitable gloss put on the Franco-Soviet Pact. Cor Ramondt-Hirschmann, the Dutch executive member and sometime vice-president, believed that far from representing a success for peace, the pact was a 'war danger because it enforces the military system'. Treaties of non-aggression were one thing, but a pact of mutual assistance like that signed between France and the Soviet Union was quite another. ${ }^{105}$ This criticism was repeated by the normally left-leaning American pacifist, Dorothy Detzer, who felt that the pacts constituted a danger because it was now in the interest of Russia to have its allies heavily armed. She thought that this would lead the Soviet Union to ask Communists in other countries to support increases of armaments for defence against fascist attack, and that thus the united front of Communists and pacifists would be rent asunder. ${ }^{106}$ This was in fact precisely the price that Laval had exacted from Stalin in the signing of the pact as American State Department documents for the period show. In return for signing the Laval-Stalin pact, Stalin was to call off the French Communist party's opportunistically antimilitarist line. 107

102 Minutes, IEC, Geneva, 12-16 September 1935, pp.5-9. In BDIC/DD/FARés. 206/1935 septembre.

103 Ibid.

104 Ibid.

105 Ibid., p.10.

106 Ibid., pp.10-11.

107 See for example US National Archives, 751.611/76, Ambassador Bullitt to Secretary of State, Moscow, 15 May 1935, in which Bullitt reports a conversation he had with Pierre Laval. Laval said that Stalin had agreed to tell French Communists to stop opposition to the Army budget and the two-year service bill. See also US National Archives, 851.00B/160, 'Strictly Confidential Report of Conversation between Mr. Marcel Cachin and Ambassador Bullitt', Moscow, 6 July 1935. Bullitt reported that 'I 
The extent to which Duchêne may or may not have been briefed in the new line to take by her Communist friends in the Amsterdam-Pleyel movement is open to question. There is no doubt, though, that she argued forcefully for support of the Soviet position. In response to the criticisms of Ramondt and Detzer she

\begin{abstract}
insisted very strongly upon the fact that though pacts of mutual assistance were not the ideal solution, they had been the only way to prevent an alliance between England, France and Germany which would have been a great success for fascism. Since every country is invited to join the Franco-Soviet pact, it can become a general treaty. The pacts were therefore not directed against certain countries. She expressed her surprise that pacifists should have any objection to this system. 108
\end{abstract}

Her further comment that the United Front between Communists and pacifists in France was stronger than ever (and they had never stopped to stand for general disarmament and to oppose all proposals for an increase of armaments)', is inaccurate as should be clear. Not only was there great dissension within her own section as to the wisdom of the FrancoSoviet pact, but within the larger French pacifist movement there were many groups which viewed the entire Laval-Stalin exercise with a great deal of suspicion.

This pro-Soviet policy on the part of the French section was a constant though in its dealings with the rest of the League in the 1930s. As will become clear in the next chapter, it was a policy hotly contested within the French section. Internationally, however, the section managed to portray a face of monolithic support for the Soviet position.

Coupled with this pro-Soviet stance was a remarkable clear-sightedness on the part of the French section with regard to the danger posed by Hitler for which it must surely be praised. By March 1935 in a debate within the International Executive Committee on the political situation, Duchêne was attacking the attitude of 'Great Britain which encourages the audacity of Hitler by its politic (sic) of resignation, about which the French population is very alarmed'. Running throughout the minutes of this meeting is a continual stream of criticism of the British government's position by both the French and German executive members. Lida Gustava Heymann and Dr Anita Augspurg both warned their.colleagues of Hitler's real designs and asked people to read Mein Kampf if further corroboration were

asked Mr Cachin what the French Communist Party would do in case France should become involved in war with Germany. Mr. Cachin replied that unquestionably the French Communists would make no attempt to hinder mobilisation and would march... I asked Mr Cachin if Stalin's statement to Laval, approving French armaments, had not placed the French Communist Party in an extremely embarrassing position. Cachin replied that on the contrary, it had made the position of the French Communists easier as it was now possible for a Communist in France to be both a good communist and a good patriot'.

108 Minutes, IEC Meeting, Geneva, 12-16 September 1935, p.11. In BDIC/DD/F $\Delta$ Rés. 206/1935 septembre. 
needed. Heymann spoke of the 'extremely dangerous' situation and said that the 'various actions we are taking to tranquilise our own conscience are of no real effect'. What was needed was a mass movement of women dedicated to fighting fascism. Duchêne expressed the hope

that the British Section will not support the attitude of their Government towards Hitler. France always was in favour of agreements but there are different kinds of agreements. England is frightened of Russia and prefers fascism to communism. But England also fears Hitler and out of this fear delivers itself to him. The French government by fear might also come to take the same weak attitude... 109

She condemned the conclusions of the British White Paper with regard to the rearmament of Britain, but believed fervently however that the LIFPL could not put its head in the sand and ignore the fact of German rearmament.

Spain, and the problem of civil war, undoubtedly marked the critical juncture in the pacifist debate of the mid-thirties, not only for the LIFPL but also for most other pacifist groups as well. The gradual politicisation of the league, and especially of the French and German sections, blossomed into full flower in 1936 with the eruption of hostilities south of the Pyrenees. As Clara Ragaz, the international vice-chairman said in her opening remarks at the International Executive meeting held in Geneva in September 1936, 'let us frankly admit it, very often also we find ourselves confronted with situations in which we do not yet see our way, where we seek with fumbling and where we recognise the complexity of questions which do not permit of simple, or apparently simple solutions. I allude among other examples to the civil war in Spain.' Civil war was the question of the hour and Ragaz wondered whether the women of the league would be up to the challenge of finding answers to the problem it posed. 110

Kathleen Innes in a report on the situation in England said that the 'peace societies reflect the division of the Government'. There were political societies which had their own outlooks and divisions, and there were on the other hand societies which preached peace on moral grounds and did not seek to apply their principles to political situations. Innes thought that there was a danger in this in that the government might use the latter sort of peace society as an excuse for taking no leading part in continental political affairs. 111 For once agreeing with something said by Mrs Innes, Madame Duchêne in her report declared that the 'situation of the pacifist societies (in France) is identical to that of

109 Minutes, IEC Meeting, London, 25-30 March 1935, pp.7-10. In BDIC/DD/FARés. 206/1935 mars.

110 Minutes, IEC Meeting, Geneva, 10-14 September 1936, pp.1-2. In BDIC/DD/F $\Delta$ Rés. 206/1936 septembre.

111 Ibid., Pp.4-5. 
England... some pacifists see that some principles must be modified in order to meet the immense danger of a near world war, whilst others are sticking to their doctrines' 112

The crisis had come to the League in Gertrud Baer's view. In a resume of the political reports, she concluded that most reports 'reflect that the Liberal element from which our League members are mostly drawn is more and more won over to Fascism. The League has therefore, as stated in Zurich, a responsibility of showing these elements the real tendency of Fascism'.113 And Spain was the critical case which seemed to have paralysed action within the LIFPL. She recounted how she and Ragaz had wanted to issue a statement to members and to the press making it clear that the Spanish civil war had been started by Franco and not by the Bolsheviks as some press accounts would have it, but they had been opposed in this by the third of the international vice-presidents, Cor: RamondtHirschmann of Holland, who 'did not think it right to say that we could not remain neutral in sympathy'.114 Another opportunity for action had been lost said Baer. The League inust have a decisive policy which would permit action between executive meetings. She concluded

it cannot be a violation of principles to state our sympathy with those who are fighting to maintain the principles we are standing for. The outcome of the Spanish war may be fatal for Europe and the whole world, if, at the last moment, the democratic forces in all countries are not uniting to assist those fighting for democracy. She deplored that the message of sympathy drafted at the same time of the Azaña Government could not be sent and urges the Committee to agree on a statement expressing that we cannot remain neutral in this fight for Peace and Freedom, against Fascism. ${ }^{115}$

The ensuing debate revolved around two opposing resolutions, the first a more hardline version by Ragaz and Baer, and the second a more conciliatory resolution by Ramondt and Pye. At issue was the difference between an 'idealistic pacifism' and a more 'realistic' approach to the problem posed by Spain. Some members of the committee thought that the Ragaz/Baer resolution was too aggressive and not becoming to a league which had peace as one of its goals. The issue essentially was that of peace or freedom. The Ragaz/Baer resolution clearly attached blame to the Franco side in the conflict, which led the American Lola Maverick Lloyd to wonder aloud whether the League would ever have been formed in 1915 if questions of blame and guilt had been allowed. She recalled that the first rule then was not to discuss these things, and she urged the members in 1936 to concentrate

\footnotetext{
112 Ibid., pp.5-6.

113 Ibid., pp.12-13.

114 Ibid.

115 Ibid.
} 
instead on what could be done to end the Spanish civil war. Duchene cut through this theoretical discussion by demanding action. 'If we remain neutral we become accomplices of Fascism', she declared.116 In the end the executive passed a compromise resolution bringing the two opposing sides together. However a Message to Spanish Women drafted by Duchêne was rejected on a motion by Kathleen Innes because it was felt to be too partisan, not being directed to all Spanish women, but from the context only to Spanish women fighting against Franco. 117

In 1938 Duchêne pressed the LIFPL to pass a resolution demanding that the Pyrenees frontier with France be opened to the Spanish Republicans, but Ramondt and others spoke against it, arguing that 'it may be alright for political parties to ask for it, but as a peace organisation we cannot advocate it, because it means opening to arms (sic)'.118 In the event the resolution was not passed.

The above instances demonstrate the extent to which the debate over the aims and orientation of the league was mirrored in the debate over the day to day political action of the LIFPL. Once again, it is possible to generalise and say that this debate was largely conducted around an Anglo-French axis. With the deepening crisis in Europe, the French section under the leadership of Gabrielle Duchêne became increasingly strident in its demand for concrete political action. Whilst laudable in itself, the demand for action became a reflection of the policies of the Amsterdam-Pleyel movement and hence of the Third International. In a bicephalous league such as the LIFPL, such a soul-searching debate was inevitable, confronted as these women were with the unique political situation of a Europe rotten to the core. Some sections continued to cling to their immediate post-war conception of peace as women's highest calling. The French section did not. Like the German section and some others, the French gradually placed more and more emphasis on Freedom, and indeed on a Marxist conception of freedom. Only through the 'social transformation' would true freedom be attained, and what began to matter more and more was the daily struggle to maintain what little freedom they saw around them. In so doing the moral, and perhaps feminist, fight for peace became eclipsed. One should not censure the French section for all that. In an age of increasing pacifist paralysis the French fought back, demanded action, worked for peace and freedom as they conceived it. For that they must be lauded. In an age in which women's voice was seldom heard, and even more rarely heard gladly, the French section of the LIFPL made a significant contribution to the debate on peace. If their conclusions are not ours, if their thoughts seem périmées by the passage of

116 Ibid., pp.13-19.

117 Ibid., pp.54-57.

118 Minutes, IEC Meeting, Geneva, 7-11 September 1938, pp.69-70. In BDIC/DD/F $\Delta$ Rés. 206/1938 septembre. 
time, we must not condemn them for it. They acted in a difficult age and in many ways we must say with St Augustine, 'there but for the grace of God go I'. 


\section{III.4. Inside the French Section.}

- It would be wrong to suppose that the face the French section showed to the rest of the League represented the unanimous views of its members. In precisely the same way that the League's primary concerns and aims evolved from the twenties to the thirties, so the preoccupations and activities of the French section, as well as the theoretical debates which determined them, all changed in this period. It is the purpose therefore of the final chapter of this section to examine the nature of these changes within the French section.

As has been noted above, the French section was never one of the LIFPL's largest numerically or in terms of its financial influence. It was nevertheless a very significant one because of the breadth and variety of its programmes and because of its intellectual contribution to the life of the larger league.

Broadly speaking one can say that the 1920 s were marked by two parallel campaigns within the French section: that for disarmament and that for peace education. Certainly it is true that at the beginning of the interwar period, Gabrielle Duchêne and the French saw their role in much less dramatic and revolutionary terms than was the case in the thirties. For example, in her annual report for 1921-22, Duchêne noted that 'it is above all the work of aid to children in which we have been able to act most effectively'.119 At this stage, too, the section was much more closely allied to pacifisme ancien style in the form of the Délégation Permanente des Sociétés Françaises de la Paix, a group which represented the dominant strand of pre-war liberal, internationalist pacifism interested in the juridical approach to the problem of peace. ${ }^{120}$ In 1921 they participated in the IXe Congrès National de la Paix which was held in Paris and one of their members, the feminist journalist Séverine, was asked to close the congress. Duchêne also noted that she and Séverine were both elected to the Délégation Permanente, a move which constituted in hér mind a sort of recognition of the importance of the French section within the larger scheme of French pacifism. ${ }^{121}$ The fact that she placed such value on this recognition is perhaps an

119 Extraits du Rapport sur l'Action de la Section Française au cours du dernier Exercice (19201921) adressé au Comité Central de la Ligue. In BDIC/DD/FARés. 208/2.

120 Cf. Part I above on pacifisme ancien style.

121 Mentioned in 'Extraits du Rapport...1920-1921' in BDIC/DD/FARés. 208/2. 
indication of the rather conventional, bourgeois starting point from which the French section was to evolve under Duchêne's leadership in the years ahead.

But if the Marxist overtones which were to characterise so much of the Section's thinking in the thirties were absent in the immediate post-war period, the integral pacifism of Duchêne was not in question. This is one of the paradoxes of early interwar French pacifism. In the immediate postwar period, the divisions and ideological differences of later years were not yet apparent. Barbusse, Rolland, Duchêne, Ruyssen, and Prudhommeaux still believed that it was sufficient to desire peace. As has been shown in Parts I and II, it was only over the course of the twenties that the question of means began to take precedence over that of the end to be obtained. And, in fact, the very notion of the goal began to be redefined by the mid-twenties as French pacifism began to define itself increasingly in terms of its position on what became integral pacifism. Thus, in the immediate postwar period, the LIFPL represented an integral pacifism larvé - hidden largely because of the unconsciousness of French pacifism generally of the differences which divided it.

Undoubtedly women did have an important role to play in the immediate postwar debates on peace, on the peace, and on how to pull Europe back together again after the cataclysm it had suffered. Not much positive action seemed to be forthcoming from the masculine world of French politics of pacifism; and,as during the days of wartime despair, it was the filling of this void which Duchene saw as the crucial role of the LIFPL. As she wrote in 1922:

The profound trouble of the present situation renders pacifist action very difficult whilst at the same time showing the urgent need of it.

The divisions at the centre of the parties set at odds men whose goals are very often identical, and shows the necessity for pacifist action independent of all partisan questions. This has given birth to a current sympathetic to the independent feminist pacifist movement. ${ }^{122}$

Here lies the kernel of original, independent, feminist pacifist truth. There was nothing blindly idealistic about Duchene's 1921 report but in the passage cited above there is the recognition of the differences between masculine and feminist approaches to peace. Perhaps with the memory of the 1915 founding congress relatively fresh in her mind, Duchêne still adhered to Jane Addam s' dictum that that which divided had to be set aside, and that which united, emphasised.

The French section defined its work in 1922 as two-fold: first to exercise some form of political action to facilitate understanding between governments. Recognising the minor

122 Ibid. 
political part played by French women, the report conceded that 'this action, pursued with zeal everywhere women have a political role, reduces itself in France, alas, to a few platonic demonstrations. ${ }^{123}$ Secondly, the French section strove towards a rapprochement 'of the peoples, giving them the desire and the opportunity to get to know each other better and to help each other; to bring together the elite of all nations in a common struggle against prejudice, ignorance, injustice and universal violence'.124 It was especially this second part of the League's work which the French section considered most fecund from its own perspective. In 1921-22 it had contributed to the 'work of human solidarity par excellence' which was the aid to infants stricken by famine and privation in other European nations. In particular the French section contributed 10.000 Francs to the relief of children in Russia through the Union International de 'Secours aux Enfants' in Geneva. 125

In this same year the French were also active in the pedagogy of peace. Andrée Jouve and Madeleine Rolland spoke at the Summer School organised by the English section in Salzburg in 1921 at which some 300 students took part. Members of the French section also participated in summer schools organised in the English Lake District, at Bremen, and also at Burg-Lauenstein. Not to be outdone, the French in conjunction with the Italian section held a summer school of their own in 1922 at Varese in Italy. 126

Andrée Jouve was also the League's representative to the Comite d'entente des Grandes Associations de coopération intellectuelle, with Camille Drevet as her substitute ${ }^{127}$ from 1927 onwards. In that year the French section also organised a summer school directed by Félicien Challaye at which Dr Schweitzer was one of the lecturers. The school dealt with the question of relations between the races. 128

In a report on Summer Schools delivered to the international executive committee in Lille in April 1931, Andrée Jouve tried to outline her philosophy for those for which she had been responsible. The underlying principle seemed to be one of openness. The League had no desire to preach only to the converted, and accordingly looked for 'young people whom we hope to win for our ideas, through presentation of the facts themselves and clear

123 See the untitled report, date June 1921, in BDIC/DD/FARés. 208/3.

124 Ibid.

125 Ibid.

126 Ibid.

127 See Minutes, IEC Meeting, 13 September 1927, afternoon session, p.2. In BDIC/DD/F $\Delta$ Rés. $206 /$ septembre 1927. For further information on the peace education movement during the interwar period, see Elly Hermon, 'Approches conceptuelles de l'éducation en vue de la compréhension internationale dans l'entre-deux-guerres' Canadian and International Education 15, 2(1986), pp.29-52. See also Elly Hermon, 'The Rise of the International Peace Education Movement: Some Historical Considerations', paper read at the American-European Consultation on Peace Research in History, Stadtschlaining, Austria, 24-29 August 1986; to be published in Charles Chatfield and Peter van den Dungen, eds, Peace Movements and Political Cultures (Knoxville: University of Tennessee Press, in press).

128 Ibid. (Minutes). 
reasoning'. 129 In Jouve's philosophy of education it was 'best to guard against direct and dogmatic preaching of our doctrine, as that is a sure method of turning active and original minds away from us'. 130 The method seemed to produce results because a French section summer school held at Ribeauville in Alsace in 1930 dealing with the question of the Alsatian separatist movement resulted in the creation of League sections at Colmar and Ribeauvillé. ${ }^{131}$

The section was also very active in the campaign for universal disarmament. Its efforts in this area were largely organised by Camille Drevet who, long after disarmament had ceased to be a popular pacifist issue in the mid- to late-thirties, was still campaigning for it both within and without the League. The French section never attained the vast numbers of signatures on its petitions for disarmament that some of the other sections were able to achieve, but the campaigns did find a certain resonance within France. In the early thirties many French cities could boast a local peace cartel, one of whose goals would have been disarmament. The disarmament interest probably reached its apogee in 1932 at the time of the Geneva Disarmament Conference. The Grenoble Peace Cartel, for example, sent 21,918 signatures in favour of universal disarmament to Duchêne in February of that year. ${ }^{132}$

The French Section seemed to change its mind in the space of only five years on the efficacy of the Lord Robert Cecil/Pierre Cot initiatives for peace. In 1931, at the time of their campaign for disarmament, Camille Drevet thought that the whole exercise had been taken over by the French politicians involved, especially Herriot and de Jouvenel. In her view, nothing much would come of such a conference so obviously under the thumb of the French government. ${ }^{133}$ These criticisms were similar to those voiced by Victor Méric at the time. ${ }^{134}$ Only five years later, however, the French section had joined what were essentially the policies of collaboration between the tenants of Soviet-inspired pact politics and the exponents of a more traditional form of bourgeois collective security.

It is important to note the degree to which the leading women of the French section were linked to other pacifist groups. Léo Wanner represented the LIFPL at the 1931 War Resisters' International congress in Lyon. Camille Drevet was involved with the Rassemblenent International contre la Guerre et le Militarisme in the late 1930s. Gabrielle

129 André Jouve, 'Summer Schools', report prepared for the IEC Meeting at Lille, 8-13 April, 1931. In BDIC/DD/FARés. 206/avril 1931.

130 Ibid.

131 Procès-verbal, Comité Exécutif International, Amsterdam et Loenen, 11-15 October 1930. Morning session, 11 October, p.1. In BDIC/DD/FARés. 206/octobre 1930.

132 La Secrétaire du Comité de Désarmement, Secrétaire Adjointe au 'Cartel de la Paix', to Duchêne, Grenoble, 5 February 1932, in BDIC/DD/FARés. 208/24.

133 See Drevet's comments on the 'Disarmament Conference at Paris initiated by Lord Cecil' in Minutes, IEC Meeting, Geneva, 4-8 September 1931, p.25. In BDIC/DD/FARés. 206/septembre 1931.

134 For Méric's negative comments on the Cecil/Cot/de Jouvenel initiative, see V. Méric, 'La Bataille du Trocadéro', PH, new series no. 3 (7-22 December 1931), p.2. 
Duchêne was involved in literally everything: the RUP, the Comite d'Entente des Grandes Associations Internationales, the Amsterdam-Pleyel movement and its subsidiary movement the Comité Mondial des Femmes contre la Guerre et le Fascisme. Marcelle Capy who had been closely involved with the French section during the 1920 s went on in the thirties to become a leading light within the Ligue Internationale des Combattants de la Paix and finally its president. Madeleine Vernet was closely allied to Duchêne and the LIFPL for a time, but then founded her own pacifist group, La Volonte de Paix, in 1928. She maintained close contacts however with Jeanne Challaye, and together with Jeanne Alexandre, they became the integral pacifist thorns in the French section's side in the late thirties. Rudolf Leonhard, the exiled German pacifist, propagandised both for the LICP and the LIFPL. And the list goes on.

One of the French section's more novel methods of propagandising its views in the late 1920s was the use of the French general election campaign. Token candidates were fielded in the 1928 general election campaign, a ploy which gave them access to the ubiquitous French election billboards as well as the right to have their 'candidates' speak at election rallies. ${ }^{135}$ The campaign was centred in Paris where eight candidates ran in eight electoral districts. One of them was General Alexandre Percin ${ }^{136}$ who had experienced a Road-toDamascus pacifist conversion a couple of years before his death and was only too willing to repent of his evil ways by helping the women of the LIFPL in their pacifist campaign. The eight quartiers were chosen with care as being the most likely to bear fruit for the cause of peace. Tracts, posters and speeches at rallies were all used to put the pacifist message across. Teams of women, journalists for the most part, were deployed to distribute the tracts and to speak whenever the occasion presented itself. Marcelle Capy was often greeted with enthusiasm in the meetings in which she spoke. Jouve's comments on the extent to which the League's peace ideas were taken over by other political groups is worth citing:

It is interesting to note, I believe, that almost the whole electoral campaign was conducted around the idea of Peace: internal peace, external peace. It was in camouflaging themselves and in supporting this programme that the majority of the candidates, even those of the Union Nationale, were able to win their votes.

It is also to be noted that for their own electoral campaign the feminist groups borrowed a part of our programme. It was with these arguments, often developed by the women who normally oppose us: 'give the vote to women, women's vote guarantees Peace, all women are against war', that their propaganda was made. ${ }^{137}$

135 Andrée Jouve, 'Rapport sur l'activité de la Section Française relative aux actions décidées par le dernier Comité Exécutif, September 1928. In BDIC/DD/FARés. 206/septembre 1928.

136 See Général Alexandre Percin, Le désarmement moral (Paris: Delpeuch, 1925); Général Alexandre Percin, Guerre a la Guerre (Paris: Editions Montaigne, 1927). See also James Friguglietti, 'Alexandre Percin' in Josephson, et al, Biographical Dictionary of Modern Peace Leaders, pp.740-742. 137 Ibid. (Rapport) 
It is not our purpose here to examine this aspect of French political society, but it would seem possible to suggest that in the 1920s the mainstream of French politics saw fit to paint itself with the pacifist veneer, a veneer which had little to do with the genuine and radical pacifism of groups such as the LIFPL.

The question of the numerical size of the French section has already been dealt with in a preceding chapter of this section, but it would be useful to consider here the extent to which the section grew from the twenties to the thirties. During the 1920s the French section listed its membership officially as around 500 women. By 1935 this was claimed to be somewhere in the neighbourhood of 4500 members, although the fourteen sections voting at the 1936 French Annual General Meeting had a maximum total membership of only 1700 women. ${ }^{138}$ Examining the problem from the grassroots level one can easily conclude that the section experienced substantial growth from about the late-twenties to the midthirties, but it is almost impossible to arrive at aggregate figures because the extant records simply do not support such an analysis.

That notwithstanding some insight can be gained into the size and distribution of the membership of the French section from the occasional comments and figures which exist in the correspondence between the various groups and the secretariat in Paris. Wihout doubt the Paris and Lyon sections were the largest numerically, which makes the purge of the Lyon section in 1934-5 all the more strange. ${ }^{139}$ In 1936 the Lyon section still numbered some 300 members, but Paris was larger with 421 members, and perhaps another 200 at most in the suburbs. At the 1936 Annual General meeting the following groups were present or represented although only fourteen of the sixteen are listed as having voted: DrômeArdêche, Le Havre, Rouen, Arles, Lyon, La Rochelle, Chalon s/Saône, Dijon, Chambéry, Nîmes, Roubaix, Troyes, Seine, Seine et Marne, Seine et Oise, Paris. The reason for the apparent irregularity in the voting procedure was that the meeting decided not to permit voting by proxy. To the above list was added the Montpellier section which voted, but subtracted from it were the Chambery, Le Havre and Nîmes sections which did not vote. In total, then, at the 1936 annual meeting some seventeen groups were represented if not all actually voting. 140

Other indicators give some credence to Duchêne's 1935 claim of 4500 members for the French section. Early numbers of SOS, the organ of the French section from 1930-34, had a

138 See the discussion of membership figures in Part III.2. of this thesis.

139 For the membership figures in 1936, see Procès-verbal de la Conference Nationale de la Section Française de la LIFPL, 27-28 June 1936, p.6 in BDIC/DD/FARés. 208/17. The purge of the Lyon section is discussed more fully later in this chapter.

140 Ibid., pp.1 and 6. 
print run which varied from 2050 to 3000 in 1930 and 1931.141 Unfortunately further figures for subsequent years do not exist. Not all French section members received SOS or its successor EnVigie however. In 1931-32 for example the Grenoble section reported a total of 156 members only 49 of whom took SOS. 142 This figure for Grenoble shows considerable growth in the period since 1926 when the group seems to have been formed. In 1928 it had numbered only 27 members. 143

The Auxerre group was another one which seemed to show remarkable growth in the early 30 s only to die out in 1934. It included members outside the town itself and further afield in the department of the Yonne. In 1930 the group listed 73 members, half of them 'active', the remainder merely adhérent. In a list of members' occupations, one finds six institutrices, one woman school principal, a grammar school teacher (professeur), one hairdresser, a woman farmer, a lawyer, and a voyageur. Jean-Michel Renaitour, the mayor of Auxerre and the local deputy was also a member. 144 Another undated list gave ninetynine members in the department. A list for the year 1931-32 gives some 150 members, and in 1933 the group claimed 220 active members and 70 membres adhérents. The group foundered in 1934 on the same issues which provoked so much dissension within the French section, and which will be discussed here shortly. 145

The Le Havre group had some 55 members in 1934 but in late 1935 it became moribund due to pressures on the time of its local secretary, Mme Noël. A meeting held in January 1936 to revivify the group produced a turnout of only 8 of the 70 members still on the group's books. 146

The Abbéville group reported thirty-five members by 19 November 1932. The Caen group had 21 members in 1933, 27 in 1934 (of whom several were primary school teachers, six were telephonists and one was a parfumeuse), 35 members in February 1934, and 45 members in March of that year. By 1937 the Caen group had forty-four members, five having resigned that year. The membership list for this year seems to be the only one extant which provides some clues as to the origins of the women in a small provincial group. Of the fortyfour women in the Caen group, only eight were unmarried. Not all of the names listed provide information as to occupation, political affiliation or religious belief, but he majority do. The group contained two primary school teachers, one commerçante, one

141 BDIC/DD/FARés. 208/11 contains bills for SOS Nos 4 and 5 from the Association Typographique Lyonnaise.

142 A membership list c. 1931-32 gives these figures in BDIC/DD/FARés. 208/24.

143 In BDIC/D/F $\Delta$ Rés. 208/24 (report c. 1931-32).

144 Membership list, 1930, for the department of the Yonne, in BDIC/DD/FARés. 208/21.

145 The undated list and the lists for 1931-32 and 1933 are to be found in BDIC/D/FARés. 208/21. See also Duchêne to Groupe d'Auxerre, 26 December 1934 in ibid.

146 See 1934 report on the Group's activity in BDIC/DD/FARés. 208/24. See also the letter of Mme. Noël to Duchêne, 25 January 1936, in ibid. 
telephonist, the director of the local Catholic newspaper, L'Eveil Normand, one landowner, one restaurant owner, and five women who worked for the Post Office. In terms of political affiliation, three women belonged to the Marc Sangnier movement, one was the secretary of the local Socialist party, one was Communist, and eight others were listed as gauche or très gauche. The commerçante belonged to the Communist party and was also the Treasurer for the local RUP. The landowner had the additional failings of being bourgeois and Catholic but her saving grace was that she had two sons who were nettement pacifiste. There was one war widow who was described as a 'good pacifist'. Another woman was 'very afraid of war', while still another 'was afraid of her husband'. Mme Lenormand cynically observed that four women had joined the LIFPL 'in order to please me', while a further ten names carried no annotation or were simply described as 'insignificant'. Four of the women had been drawn to the LIFPL through the newspaper articles written by Mme Lenormand. 147 This very schematic overview provides the only insight into the origins and orientations of the membership of a small provincial group of the French section.

The Cannes section was constituted in the spring of 1931 and seems to have had around forty members in 1933-34. By 1938 it had sunk slightly to 36 members. The Chartres section showed a membership of 35 in a report dated 22 April 1931; another undated (perhaps later) membership list gives 120 members. The Chambéry group which was founded in 1931 had nineteen members by November of that year; once again several of them were primary and secondary school teachers. The predominance of the teaching profession in the provincial groups is strong. The Bordeaux group, too, was composed largely of secondary school teachers with a large minority of institutrices. 148 The composite view then is one of groups gradually increasing in size in the early thirties with some fall-off in the mid- to late-thirties. The teaching element was strong in some of the groups while others displayed a more heterogeneous mixture of women from different social classes. In making the above comments one is very much aware of the lack of proper data on which to base a substantive analysis.

With regard to the activity of these local sections, diversity across the length and breadth of France is again the key. Some groups were much more radical and left-wing in their orientation than others. Some were primarily middle-class in their outlook. Others viewed pacifism in a primarily moral, rather than political, light. Many local groups belonged to peace cartels in their cities or towns. Others had links with Marc Sangnier's

147 See 'Adherrentes de la LIFPL - Caen' in BDIC/DD/FARés. 208/22. The date of this list must be 1937 - it is referred to by Jeanne Lenormand, the Caen group secretary, in her letter of 25 January 1939 to Duchêne (also in F $\Delta$ Rés. 208/20) in which she mentions having drawn up such a list giving comments on the group's members two years previously when she had resigned her office.

148 See material on the Abbéville and Bordeaux groups in BDIC/DD/FARés. 208/21. Material on the Caen group is in F $\Delta R E ́ s / 22$, and material on the Cannes, Chartres and Chamberry groups is in FARés. 208/23. 
Jeune République, while still others had close contact with local sections of the Ligue Internationale des Combattants de la Paix.

A common problem for the peace women of the French section in the thirties was the attitude of right-wing elements of the population to their campaigns for peace. Not only internationally, but within France as well, the LIFPL became quite incorrectly associated in some minds with the Communist party. This attracted the attention of the Camelots du Roi and other right-wing militarist groups as much as did the League's pacifism. From about 1930 onwards one begins to see references in the correspondence of the French section to the problems posed for peace women by the intimidation of these groups. Writing to Duchêne in the early thirties, Mme L Daudin of the Bordeaux group underlined two problems her section had faced in its campaign for the petition in favour of disarmament. First, the attitude of a large number of women revolted her, with their haughty, indifferent and egotistical 'that-doesn't-interest-me' point of view. She added that it was hardly necessary to mention the second form of aggravation which consisted in the 'daily incidents' provoked around the group's stand at the local fair by the Camelots du Roi. ${ }^{149}$ The Auxerre group experienced similar difficulties in May 1933 at the local fair at which the LIFPL had a stand, manned by three of the group's women. The women were subjected to a diatribe by a passing officer, one Commandant Krazinski, who accused them of being in the pay of Germany. Apparently, similar incidents had occurred two years previously. The Auxerre women were not prepared to stand for this nonsense however. They sent a report to the president of the local section of the Ligue des Droits de l'Homme demanding redress. 'It is inadmissible', the report read, 'in a country in which one is after all still free, that an officer in uniform should come and accuse women who are campaigning for peace, of being sold to Germany'. The incident only served to attract a sympathetic crowd and the supportive comments of the local Socialist newspaper, the Réveil de l'Yonne. ${ }^{150}$

These are but two instances recorded in French section correspondence of intimidation on the part of right-wing elements. The LIFPL certainly never had to deal with this sort of attack to anywhere near the same extent as the Ligue Internationale des Combattants de la Paix as we have seen in the preceding section. However, it was intimidation such as this coupled with the French domestic political situation during the late twenties and thirties which undoubtedly fuelled Duchene's tendency to see fascism lurking under every bed. As

149 Mme L. Daudin to Duchêne, Bordeaux, undated (dated 30 June and from context early thirties), in BDIC/DD/F $\Delta$ Rés. 208/21.

150 Rapport à Monsieur le Président de la Fédération de l'Yonne de la Ligue des Droits de l'Homme et du Citoyen par A. Pelcot, Présidente du Groupe d'Auxerre de la LIFPL. Auxerre, 26 May 1933. In BDIC/DD/F $\Delta$ Rés. 208/21. See also 'Paix et Désarmement: Glorieux exploit d'un Galonné!', undated clipping from the Reveil dé l'Yonne in BDIC/DD/FARés.208/21. See also the text of the nationalist poster attacking the LIFPL which appeared on the walls of Auxerre during the Fair. It was printed in a local print ship whose manager was the Abbé Oudin. Contained in BDIC/DD/F $\Delta$ Rés. $208 / 21$. 
early as 1930 she told the International Executive Committee of the League that the police reign in France and there is a very clear tendency towards fascism'. ${ }^{151}$ There was also opposition to the LIFPL at the official level. In order to be able to hold a public meeting at the League's 1932 International Congress in Grenoble, Duchêne had been obliged to ask the mayor of Grenoble to preside. It was only by cloaking themselves in the protection of the mayoral mantle that the League could avoid the interdiction of the meeting by the Prefect who was opposed to pacifist ideas. 152

The intimidation felt by members of the French section led some of them to ask whether they should be setting up some sort of self-protection corps for League events. Madame Perrin of the Besançon group proposed at the 1933 annual general meeting the creation of 'anti-fascist phalanxes' to protect meetings, and wondered if the League had the right to organise such self-defence organisations. Perhaps indicating yet again the differences in outlook between the French section and the rest of the Legue, Madame Duchêne responded that on the national level such a plan was possible, but that 'on the international level we could not do it because we would expose ourselves to criticisms and others might say that our method of action was a form of violence'. ${ }^{153}$ This is a rather benign example of the way in which the rhetoric of violence insinuated itself into a pacifist group. In the LICP this tendency took on starker proportions with the creation of the so-called Jeune Garde pacifiste to protect LICP meetings from the ministrations of right-wing thugs. As the political fabric of the Third Republic continued to decay under the onslaught of competing antidemocratic forces (from both left and right) even the politics of marginality, the politics of dissent, were affected.

The events of February 1934 produced another paroxysm of paranoia in Duchêne. She wrote in a circular sent out to the French groups that 'we have barely escaped a coup d'Etat'. 154 The fear did not dissipate. In her next circular she spoke of the preparations then in progress for the Rassemblement Mondial des Femmes contre la Guerre et léfascisme to be held in the summer of 1934, and saw the great danger of the hour coming from the threat of a fascist coup:

Every day incidents and reactionary, arbitrary measures remind us of the efforts made to implant fascism in France. The decree-laws, too easily accepted, are a step towards such a regime. The successes

151 See Duchêne's comments in Procès-verbal de la réunion du Comité Exécutif International, Geneva, 23-26 April 1930, p.3. In BDIC/DD/FARés. 206/avril 1930.

152 See Duchêne's comments in Procès-verbal de la réunion du Comité Exécutif International Grenoble, 11-14 May 1932, p.3. IN BDIC/DD/FARés. 206/mai 1932.

153 Procès-verbal de l'Assemblée Générale de la Section Française, 1933, p.5, in BDIC/DD/FARés. 208/14.

154 'Circulaire no. 10 de la Section Française', p.2. In BDIC/DD/F $\Delta$ Rés. 208/15. Undated (early 1934 from context). 
we have had so far must not make us forget that the 'party truce' serves above all to leave the fascists time to organise, to arm themselves even more, and that we remain under the threat of a new attempted coup d'Etat. ${ }^{155}$

The constantly changing international and domestic political situation demanded the re-thinking of the shibbdeths cherished by French pacifists. Some women such as Léo Wanner jumped on the ideological bandwagon and proclaimed that the place of women was on the side of the dictatorship of the proletariat where true feminist, pacifist freedom was to be found. 156 A more measured analysis of the political situation came from Andrée Jouve in a report prepared for the 1933 annual general meeting of the French section. In it she examined three key political terms which were greatly misunderstood and abused: revolution, fascism and class struggle. She underlined the falsity of the position taken publicly by the parties of the left that fascism and Nazism were the last desperate attempts of capitalism to prevent its fall', and showed how in fact the Hitler and Mussolini regimes were supported by waves of popular support, at least at the outset. If Marxism was the main enemy of fascism it was precisely because it was internationalist, as opposed to nationalist. She rejected, too, the facile descriptions of class warfare which were the province of popular Marxism. She declared that 'bourgeois' and 'capitalist' were not synonymous.

Without distinguishing, and with this habit of putting everything into the same bag for the sake of the cause, our theoreticians and propagandists do the greatest harm to the idea of a veritable revolution and economic reorganisation. We who are of no party within the League, must watch that this confusion does not contaminate us. Thus, as I have already pointed out, the fascist movement is in no way concerned with the divisions of class, and it is not on this ground that we can combat a movement of unity based on the mystique of race and of the nation and pursuing ends in the economic realm which are very close to those of the Marxists. ${ }^{157}$

The error was in trying to delimit the boundaries of these so-called opposing classes in a nation like France. At what point, she asked, did the bourgeois and the proletarian exchange places at the barricade? Was it a question of money or of esprit? She noted that it was supposedly the bourgeoisie which created capitalist wars, but from which social class, she asked, did most conscientious objectors come from? It was a mistake in Jouve's eyes to try to limit the great pacifist experiment to any one class. Not all of the proletariat was

155 'Circulaire no. 11 de la Section Française', (May 1934), p.3. In BDIC/DD/F $\Delta$ Rés. 208/15.

156 See for example Léo Wanner, 'La Femme et les Dictatures', SOS no. 16 (5ème année), 1934, Pp.1-2.

157 See Jouve's report, 'Devons nous réviser quelques unes de nos idées?' attached to the Procès-verbal de l'Assemblée Générale de la Section Française, 1933, in BDIC/DD/FARés. 208/14. 
pacifist by any means despite the claims of Marxist orthodoxy. She had equally measured comments about the word 'revolution' which had become a word without meaning in the political market place. She made it clear that she detested revolutionary injustice and repression in Russia as much as in Italy or Germany. The LIFPL was a league for freedom, Jouve emphasised, but it was also for peace; and it was here that she thought the members of the League would have to revise their ideas. The League's belief that causes of modern war were almost uniquely economic was true from several points of view, but it did not take sufficient note of the impact of ideas on men's actions. In her view the economic crisis the western world was traversing could have led to either more internationalism or to the exacerbated nationalism it did produce. The reasons for the present unhappy political reality were to be found in 'national defeat, the humiliation of the treaties, the vindictive obstinacy of the allied policy which oriented the opposition in this direction'. All of this had produced the predictable result of a profound nationalist revival. For convinced pacifists and internationalists the crisis reduced itself in Jouve's view to an intellectual one:

It seems that the international idea, still lacking in mystique and traditions is not meaty enough, not rough enough, not heated enough to inspire and raise up the masses which abstract ideas and ... reason itself do not raise up......

A new mystique of peace must be born without which we will not be able to hasten its advent other than by our own personal faith. But I hope that it will be neither so blind, nor so demoniacal, nor so lacking in reason and good sense as the nationalist mystique. ${ }^{158}$

This measured and thoughtful tone was not always the norm of the political discussions within the French section. Léo Wanner of Lyon was a particularly hardline representative of the extreme left-wing orthodoxies within the League which Jouve had argued against in her paper. As we have seen already at the international level, the French section presented a more left-wing face than did most other sections. With regard to the increasing duality of the League's purpose - peace and freedom - and the difficulty from the early thirties onwards of reconciling these two ideas, Gabrielle Duchêne prepared an important position paper for the 1936 French section annual general meeting on 'Les Deux conceptions du Pacifisme'. It mapped out her approach to peace for the remainder of the decade. The paper had its origins in her sad observation that at the moment when unity was most needed, pacifists were most divided. She did not believe that pacifists were at odds over the goals to be pursued, but only in tactics, and she. wrote that 'the gravity of the situation imposes a tactic of unity which is as all-embracing as possible - with all of the sacrifices

158 Ibid. 
which this brings'.159 In her view the defenders of the peace could be classified into two distinct categories: 'the pacifists who claimed to be intégraux, that is to say who wish to have recourse only to means which are absolutely pacifist and the realists who do not accept the questioning of the 'Absoluteness' of their desire for peace, but who see the facts as they are and take account of them, in their choice of means for the action to pursue'.160 The best of the former, she wrote, were doctrinaire and dogmatic, and erected systems of values and action. which they expected the real world to conform to. They were the practitioners of a new religion, with all of the mysticism, fanaticism, and exclusivity that the word religion implies. She criticised their indulgence towards Hitler who was both the enemy of peace and of freedom. Perhaps indicating the extent to which the sterile Stalinist debates of the mid-thirties had made inroads into Duchêne's thinking, she stated in a strange paragraph of her report that the 'pacifiste idéologues' were strange bedfellows of the Trotskyists who wanted a permanent revolution. Her claim that both of these groups could be found on the same side of the barricades is a perplexing one. ${ }^{161}$ The pacifist realists had grouped together with other people from many walks of life in the Rassemblement Universel de la Paix. Not all its members were pacifists - that much was certain - but Duchêne asked whether anyone had the right to search hearts and establish a hierarchy of pacifist values. The realists wfe ready to do business with anybody, and in so doing to neutralise adversaries, and hopefully bring groups and individuals into the fight against war, whether from personal interest or out of idealism. The integral pacifists, on the other hand, denounced the RUP in Le Barrage, and in preparing a congress of integral pacifists committed the original sin of creating division. 162

All of the above is interesting in view of Duchene's insistence in the twenties, as we have seen above, on principles. Means became blurred with ends in her mind somewhere along the road in the thirties. In her desire to support the Soviet Union, she, along with large swaths of French pacifism, allowed her previously principled pacifist action to become enmeshed in the concepts of collective security. This collective security was preached with equal vociferousness by both bourgeois, traditional statesmen and the denizens of a rightfully worried and still somewhat politically isolated Soviet Union. In many respects her analysis of the European political situation remained astute. In her evolution from absolute pacifism to pseudo-pacifism, one should not see a lessening of her desire for peace at all. But it is one of the arguments of this thesis that for many French pacifists the political nature of their pacifist experience was all important. What began in

159 See Duchêne, 'Les deux conceptions du Pacifisme'. Paper read at the Assemblée Générale de la Section Française, 1936. In BDIC/DD/FARés. 208/17.

160 Ibid.

161 Ibid.

162 Ibid. 
the Great War and the twenties as an absolute revolt against the militarism of French society has many echoes across a whole spectrum of European pacifist feeling. In the early years of the interwar period, a political pacifist like Duchêne (and indeed many other French pacifists) could mistakenly assume that her convictions sprang from the same source as the more ethically, if not religiously, inspired British pacifism. But by the thirties this unconscious assumption was no longer tenable. The nature of French pacifism was by and large very different from that of the British experience, and by the mid-thirties this had become clear in the rapidly widening rifts between the tenants of the various French pacifisms. Arguably it was only some Christian pacifists and those in secular groups like the Ligue International des Combattants de la Paix in France who remained true to the purity of their pacifist principles. In so doing they divorced themselves from political society, no matter how much they might protest the contrary, and 'defined a faith', to borrow Martin Ceadel's phrase. Not everyone who says, 'Lord, Lord,' shall enter the kingdom of heaven.

By about the beginning of the thirties, the French section had begun to be put on the defensive at the international level of the league, especially following the Amsterdam Congress against Imperialist War in 1932. The same phenomenon can be seen at the national level within France, where the evolution of Duchene and the leaders of the French section away from an absolute pacifism produced a revolt in the ranks. This was in large part due to the close identification of the official level of the French section with the World Committee against Fascism and War - or the Amsterdam-Pleyel movement as it was more popularly known - in the post-1932 period.

On a theoretical level the issues at stake within the French section were non-violence and civil war; but in practical terms they were often expressed in terms relating either to the Amsterdam movement or the policies of support for Soviet Russia.

Gabrielle Duchêne was an important member of the World Committee against Fascism and War. She worked closely with Barbusse and Rolland, and indeed became the instigator and president of the off-shoot organisation, the Women's World Committee against Fascism and War. As the chapter dealing with the French section's international role has shown, the politicisation of the question of peace proved unacceptable for many national sections and the same was true within the French context. The Communist influence on the pacifist debate in France was thus extremely important. Gabrielle Duchêne returned from the Amsterdam Congress convinced that an important step had been taken in the fight against war. She wrote in SOS of the unanimity which characterised the congress and of the efforts made by all of the speakers to put aside inflammatory rhetoric and emphasise only that which united them all. This was due to the absolute desire of the organisers of 
the congress to keep it above all of the parties'.163 Her only, and somewhat veiled, criticism was that the final Manifesto passed by the Congress had been drawn up in too much haste and passed without discussion by the delegates. She and other members of the preparatory commission had made their feelings known to Barbusse but he had gone ahead and drafted the document as he saw fit anyway. Romain Rolland condemned it for its negative view of conscientious objectors and Gandhian pacifism. 164 Duchêne concluded by emphasising that in the work ahead a great deal of mutual respect, tolerance and goodwill would be necessary. Unilateralism had to be avoided, as did discussions of doctrine in order to arrive at the primary goal which was positive, practical action against war. ${ }^{165}$

But it was precisely this openness which seemed to be lacking almost immediately as a hierarchy of neo-Marxist, neo-pacifist values became implanted in the thinking and political discourse of Duchêne and her colleagues within the Amsterdam movement. The new approach to peace was accepted with great difficulty, if at all, by many groups of the French section. On the question of adherence of local LIFPL groups to the Amsterdam committees which were supposed to be forming across France, Duchêne wrote in October 1932 to the Grenoble group that it was possible to abstain from these, but only if this was done without any public displays of hostility. What, however, is more interesting is her comment in a letter to Grenoble that 'no one can refuse to fight against imperialist war, but if one wishes to fight against other wars that is a question of conscience'. ${ }^{166}$ In that short statement can be summarised the problem for the next three or four years for the French section since some local groups continued to cling to the integral pacifist positions which Duchêne condemned in 1936.

Good will and toleration seemed to be lacking as local Amsterdam-Pleyel committees were formed across France. Supposedly coming together in a struggle for the higher cause of peace, local groups found themselves rent by the same bitter political divisions as those of French political society in the latter years of the Third Republic. Because the Amsterdam Congress had been against imperialist war, it was impossible to separate political doctrine and ideology from the problem of peace, for all the good will in the world. As one British pacifist present in Amsterdam remarked, 'Lord, how the word "pacifism" stinks in the nostrils of most delegates'. 167

163 G. Duchêne, 'Congrès Mondial contre la guerre, Amsterdam, 27-28 Aogut 1932', in SOS no. 12 (1932), pp.56.

164 Cf. Romain Rolland, 'Lettre à Henri Barbusse sur la Place qui doit être faite aux Objecteurs de Conscience et aux Gandhistes dans le mouvement révolutionnaire issu du Congrès d'Amsterdam' (20 December 1932) in Par la Réoolution, la Paix, pp.61-64.

165 Duchêne, 'Congrès Mondial' loc. cit. in SOS.

166 Duchêne to Mlle Leleu, Grenoble Group, 21 October 1932, in BDIC/DD/FARés. 208/24.

167 Cited in Martin Ceadel, Pacifism in Britain, 1914-1945. The Defining of a Faith (Oxford: Clarendon Press, 1980), p.114. 
Rosy unanimity about principle and practice certainly did not prevail within the French section. There was much discussion and dissension as to aims and methods in the fight against war; and it was the Amsterdam Congress and the movements flowing out of it which brought these issues to the fore and polarised the factions within the French section. Whilst it was true that the larger League was officially non-partisan and a-political, it quickly became clear that the French section was increasingly dancing to what Romain Rolland called the 'inevitable tempo of history', in the form of a Marxist conception of war and peace. In the 1920s Duchêne had written about the difficulty of getting bourgeois women to join certain sections which were almost entirely working class; but in the thirties it became clear that the middle-class sections resisted - in some cases fiercely - Duchêne's attempts to force them to follow the doctrinaire Amsterdam-Pleyel line which she had laid down.

The Grenoble group provides a typical example of this sort of grass-roots revolt. Mme Rancon, the local secretary, wrote Duchêne in August 1932 that 'the announcement of the world pacifist congress in Amsterdam has created some difficulty here'. The main problem - and this is a recurring theme across the length and breadth of France - was the role of the Communist party in the Amsterdam movement. Rancon wrote that the local party was excluded from the Grenoble Peace Cartel because the latter organisation 'setting itself clearly against war, whether it be imperialist or revolutionary, cannot in principle admit a party of violence'. On a purely practical level, the local PC conducted a campaign against members of the Cartel; and Rancon pointed out that it would therefore be most difficult for all concerned to have the Communists take a seat in its counsels. Later that autumn she wrote again to Duchene to announce that the local LIFPL had decided unanimously to maintain its own freedom and would not be joining the action committee formed in the wake of the Amsterdam congress. These and similar concerns were voiced by sections in Chambéry, Le Havre, Caen, Nîmes and Rouen. 168

168 See V. Rancon to Duchêne, Grenoble, 27 August 1932; V. Rancon to Duchêne, Grenoble, 10 October 1932; and Duchêne to Grenoble Group, 21 October 1932, all in BDIC/DD/FARés. 208/24. See also Margaret E. Dupont to Duchêne, Chambéry, 3 May 1931 in BDIC/DD/FARés. 208/23, in which Dupont expressed her desire to found a centre for 'radical pacifism' in Chambéry after hearing Léo Wanner and Camille Drevet speak. In Mme Nicollet to Duchêne, Chambéry, 27 March 1933, the new local secretary asks what to respond to people who attack the LIFPL as communist inspired. She also mentions the fact that in the Savoie the Ligue des Mères et des Educatrices pour la Paix has some 1800 members whereas the LIFPL has only twenty-eight. Duchêne responds (in Duchêne to Mme Nicollet, Paris, 4 April 1933) that the LIFPL is independent of all parties, but that the public impression mentioned by Nicollet is likely due to the league's adherence to the Amsterdam movement. As far as the Ligue des Mères is concerned, Duchêne stresses that it is not a genuinely radical pacifist group. Both of these letters are contained in BDIC/DD/F $\Delta$ Rés. 208/24. See also 'Rapport du Groupe du Havre', 10 July 1934, in BDIC/DD/FARés. 208/15. See also Mme Noël (Le Havre Group) to Duchêne, 20 August 1935 in BDIC/DD/F $\Delta$ Rés. 208/24. See also J. Lenormand (Caen Group) to Duchêne, 22 April 1933 in BDIC/DD/FARés. 208/22. See also Groupe de Nìmes to Duchêne, undated, in BDIC/DD/FARés.208/16. See also 'Rapport du Groupe de Rouen' by Mlle J. Decroix, Secretary, 13 July 1934 in BDIC/DD/F $\Delta$ Rés.208/15/10. 
One of the clearest statements of principle and of dissent is that of the Colmar group during the spring of 1934 . In a letter of 10 May the section threatened the probable resignation of the entire local committee and of a good portion of the membership if direct answers to direct questions were not forthcoming from Duchêne and headquarters in Paris. The group said that for too long they had been kept in the dark about the policies of the League and that they had received no answers to repeated inquiries. Of primary concern was what the group termed the fundamental principle of non-violence. 'Concessions seem to have been made in this area', they wrote. 'We have looked in vain in SOS and in the latest declarations of the French section for an absolute condemnation of civil war, which like any other war, renounces the solution of conflicts through conciliation and arbitration'. A further source of concern, flowing out of the question of non-violence, was the 'total adherence without restriction' of the French section to the Committees issuing from the Amsterdam congress. In the view of the Colmar group this was a betrayal of principle indeed of the very principle which had attracted the sympathies of many of the members who were now prepared to leave. 169

But the question of non-violence and the place of the League within the larger Amsterdam-Pleyel movement were but the tip of the iceberg. The League's entire political orientation of apparently blind support for Moscow was called into question. Madame Burger, the Colmar group secretary, in a moment of some political insight, wrote plainly that in her view the Soviet regime was as intolerant and unjust as fascism to those who sought liberty of conscience and of thought. She recognised that the Soviet Union had achieved tremendous success in bettering the social and economic side of life in Russia, but insisted that there were spiritual values in life which the regime did not uphold. It was on the immediate, practical level of watching the local Communists in action which had been most revealing to her, however:

I cannot emphasise enough how much the demonstrations of the great majority of the militants of Communism have done, and continue to do, harm. They are a terrifying and disconcerting revelation of the spirit of violence which the 'leaders' induce without scruple in the fanatical masses. 170

The Colmar group felt that it could no longer support the principle of collaboration without conditions with a party which hated and persecuted everything that was near and dear to them. She complained that while Pax Internationale (the international organ of the LIFPL) remained true to the principles of the League, the French section seemd to have gone its own way. For Burger and the Colmar section the crisis which was rocking humanity was

169 M. Burger to Duchêne, Colmar, 10 May 1934 in BDIC/DD/FARés. 208/15.

170 Ibid. 
above all else a moral one, one which political and economic reforms alone would not solve. What was needed was a sort of moral revolution, in Russia as well as elsewhere. She warned Duchêne not to misunderstand the motives behind her comments:

Do not think that all of this is greyness of formulas or dogmatism on our part. The principle of non-violence is a principle of life; if we abandon it in practice it will be the definitive failure of all action and of lasting reform. .... Do not think [either] that these criticisms formulated in our group come from capitalist milieux.. Women who do not belong to the so-called bourgeoisie of our city are setting themselves against the pan-soviet tendencies of the French section. 171

Duchêne's response to this letter seemed to mollify the members of the Colmar group at least temporarily. They adopted a wait-and-see approach in a subsequent letter to Duchêne. Permament damage had already been done however. Madame Burger told Duchêne that she thought the whole incident had served to alienate, probably permanently, the practising Catholic women who had been part of the group. The group had decided to have nothing to do with the Amsterdam movement, which in any case was making very little headway in Colmar due to the lack of support for the Communists. Colmar left the issue open, deciding to wait and see what the outcome of the Zurich congress would be. On her way back to France from Switzerland in the autumn of 1934, Duchêne visited the Colmar group; and what she termed later to be an amicable divorce was decided upon. Some of the Colmar members remained attached directly to the league on an individual basis; but Duchêne thought that the rest of the group would be happier working with another organisation more appropriate to local conditions, such as the Ligue des Mères et des Educatrices pour la Paix. A bloodless and friendly purge was thus effected, removing genuine pacifist elements from the league who no longer viewed the world situation as Duchêne did. 172

The Stalin-Laval pact of 1935 provoked, not surprisingly, a similar crisis within the French section. The sudden-about-face of the French Communist party on the question of military service and support for the army provoked a great deal of consternation within the ranks of feminist pacifism. Camille Drevet, who had been the League's international secretary, wrote to Duchêne that she was

surprised to see that you placed before France only two alternatives: an entente with Hitler or the entente with Stalin. Do you not think that there is a third, that of negotiating with

171 Ibid.

172 M. Burger to Duchêne, Colmar, 28 June 1934, in BDIC/DD/FARés. 208/15. See also Procèsverbal de l'Assemblée Générale de la Section Française, Paris, 7 July 1935, in BDIC/DD/FARés. $208 / 16$. 
everyone, including Germany, finally to begin the work of disarmament? But the question of the Franco-Soviet military entente is superseded today by Stalin's declaration. We couldn't have received a harder blow. To see Marxists justify the national defence of a capitalist country really surpasses everything. ${ }^{173}$

Whilst the Comite Mondial des Femmes was apparently prepared to accept the new directive, some parts of the French section of the LIFPL were not. Mme Jeanne Petit of the Lyon group wrote to Duchêne that 'the present marching orders of the World Committee concerning international politics are accepted with some difficulty here. The vast majority of the group wants to see the League maintain the strictly pacifist position it has always had'. ${ }^{174}$ And Petit promised to raise the matter at the AGM of the French section in July. The Lyon position was supported by the St Etienne group, whose secretary L Leclerc wrote that they had been disappointed by a recent lecture given by Duchêne. This had done nothing to help the local LIFPL section, but had given a great boost to the St Etienne goup of the World Committee. The partiality of the Communist elements in the latter had provoked many negative observions but Leclerc said that her group would sort this problem out itself. More important was Duchêne's support of the USSR's new international policy which Leclerc feared would 'one day force us into taking a position, and we do not want a war at any price, whatever it may be for'. Leclerc's letters made clear the sense of betrayal which the members felt: 'essentially', she wrote, 'we want to hold to the programme which converted us to the cause, and in this sense we share the view of the Lyon section completely'. ${ }^{175}$

Many of these views were summed up rather succinctly by Madeleine Vernet, the founder of the Paris pacifist group and newspaper of the same name, La Volonté de Paix. She wrote to Jeanne Challaye in July 1935 asking her to voice her concern at the AGM of the French section which was to be held on the 7 th. Vernet felt that she had come to the point of resigning from the League, but had refrained from doing so because of her friendships with some members. But, she wrote,

I find that the attitude taken by the French section, reflected in SOS simply does not befit the League. To make the case for dictatorship and civil war cannot be the position of an organisation which has for its name 'League for Peace and Freedom'... Unfortunately divisions and political quafelling have invaded everything. Since 1932 the League has become the reflection of Amsterdam, thus losing all its personality. The fight for disarmament has fallen by the wayside. [Instead] anti-Hitlerian propaganda is pursued. Now this is not for us. We owe it to

173 Camille Drevet to Duchêne, Claret-Toulon, 30 May 1935, in BDIC/DD/FARés. 208/16.

174 Madame J. Petit to Duchêne, Lyon, 4 July 1935, in BDIC/DD/FARés. 208/16.

175 L. Leclerc to Duchêne, St Etienne, 5 July 1935. In BDIC/DD/FARés. 208/16. 
ourselves to seek appeasement first in order to arrive at peace later. I have no sympathy for Hitler, but his victory in Germany is the work of the governments of the allied countries of 1914.176

Not all groups objected to the evolving political orientation of the French section however. The Marseille group was one which Duchêne could count on to exceed even her own political trajectory. Lucienne Leleu, the local secretary, wrote to Duchene in 1934 concerning the approach to take in the face of the rise of domestic and international fascism. In her view there was absolutely no place for neutrality and the League needed desperately to delineate its doctrine. She saw its condemnation of violence during the Great War and after as an idea born of sentiment. She rejected the notion of neutrality in the case of civil war and declared that the League must be with the workers:

The first confusion to clear up ... is above all that of refusing to see that violence is not something found only in war, but is at the base even of the present regime, and that it is not the unique, or even principal result of gunshots. The revolt against war which was the basis of the action of the League, if it is conscious and not merely sentimental, if it is a revolt against violence in all areas... must be a struggle against the present capitalist regime. A conscious pacifist must today be a revolutionary... ${ }^{177}$

She regarded the coming civil, partisan, class-based violence with astonishing equanimity, saying that western Europeans were not saints 'aे la façon de Gandhi'. The refusal of violence 'signified nothing' for Leleu. ${ }^{178}$

The ideological divisions within the French section described above were also manifestations of generational differences in the approach to the problem of peace. In a movement such as pacifism which seemed to be dominated by the pre-war generation (if subjective impressions are anything to go by in describing a movement which left such incomplete records), the French section of the LIFPL stands out as one group which seemed to recruit younger members. This younger membership contributed to the divisions within the French section, and between it and the rest of the League. As early as 1932 for example Duchêne declared that the League Congress had 'disappointed youth because it had not adopted a radical manifesto' 179 Lida Gustava Heymann thought then that youth must

176 Madeleine Vernet to Jeanne Challaye, 5 July 1935, in BDIC/Dd/FARees. 208/16. This letter was read by Mme Challaye to the 1935 Annual General Meeting of the French section. See the Procès-verbal de l'Assemblée Générale de la Section Française, 1935, p.1. In BDIC/DD/FARés. 208/16.

177 Mlle Lucienne Leleu to Duchêne, Marseille, 12 April 1934 in BDIC/DD/FARés. 208/15.

178 L. Leleu to Duchêne, Marseille, 21 June 1934. In BDIC/DD/F $\Delta$ Rés. 208/15.

179 Procès-verbal, Comité Exécutif International, Grenoble, 20-22 May 1932, p.1. In BDIC/DD/FARés. 206/mai 1932. 
trace its own path in life ${ }^{180}$ but three years later she admitted that the League lacked 'young, energetic blood'. 181 There is no doubt that the LIFPL was an aging organisation. Even given the lack of eligible men in post-war France, the French delegation of 18 unmarried and only six married women at the 1934 Zurich congress of the League must have seemed young in comparison with those of other national sections. 182

The equation of youth and radicalism is perhaps a valid one. The youthful French delegation in Zurich was remarkably disappointed by what it heard and saw - to the point that the two representatives of the Marseille group actually walked out of the congress in disgust. ${ }^{183}$ Four other French delegates had already left the congress by that point, disappointed too at their first contact with the International. ${ }^{184}$ One of the delegates who remained, Germaine Baurez of the Ardeche group, wrote that those who stayed behind did so because Madame Duchêne was 'there to preserve the avant-garde spirit in the French section'. She and the other remaining young French delegates left Zurich

with a feeling of disaffection towards the League and little confident in the future of an organisation which no longer knows how to give satisfaction to the young.

The 'young' have noted with sadness that a fraction of the delegates present were opposed to any new ideas and that these delegates could not or would not see things objectively. ${ }^{185}$

In another speech, Mlle Y Paquet condemned the 'fetishism of words' which seemed to afflict the league and its 'sterile formalism'. She said that the young had come to the congress to learn, to receive directives for future actions, and that instead they had heard little to allow them to say 'now we know where we are going'. The question of violence and non-violence was all word play which had no bearing on reality. If youth could be damned for lacking in idealism, it was because it knew that 'real idealism is sometimes the sacrifice of idealism, an effort of living in the present, in reality with the oppressed of all nations' 186

Duchêne recognised the danger inherent in allowing youth to distance itself from the struggle for peace. She told the Zurich congress that organisations grow old more quickly than individuals, especially in a world evolving as rapidly as it was in the 1930s. And if

180 Lida Gustava Heymann in ibid.

181 Lida Gustava Heymann in Minutes, International Executive Committee, London, 25-30 March 1935, p.4. In BDIC/DD/FARés. 206/mars 1935.

182 List of Delegates, Zurich Congress, 1934. In BDIC/DD/FARés. 208/5/7.

183 Mentioned in 'Intervention que voulait faire G. Baurez, déléguée de l'Ardèche (France) à là dernière séance du Congrès, VIIlème Congrès de la LIFPL', Zurich, 3-9 September 1934. In BDIC/DD/FARés. 205/8/5.

184 Ibid.

185 Ibid. See also 'Autour du Congrès de Zurich', EnVigie no. 1 (October 1935), pp.4-5.

186 'Discours de Mlle Paquet, Congrès du Zurich', 1934, in BDIC/DD/FARés. 205/8/5. 
these same organisations became immobilised in outdated formulas, they condemned themselves to a quick death. 'In order that they conserve their vitality;' she wrote, 'in order that they might renew themselves through the support of contact with youth, they must constantly maintain contact with reality and remain supple enough to evolve'. ${ }^{187}$ But as we have already had ample occasion to observe, this suppleness was selective; and evolution tended towards revolution. In this same speech, Duchêne defined the task of the 'true defender of Peace' as the preparation of minds for the acceptance of the 'idea that a

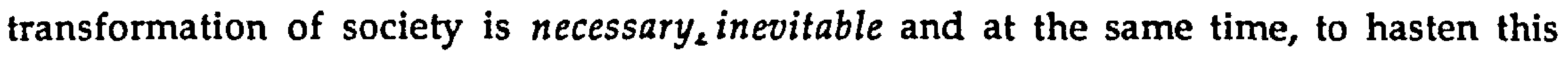
transformation by destroying the evil institutions which block human progress'. ${ }^{188}$ That was the long term goal but in the short term the present situation demanded less a response based on 'orthodox pacifist ideology' than on an 'effective practical, incessant struggle. against war and fascism'. 189

The dissent expressed in letters to Duchêne from across France began to make its appearance at the annual general meeting of the French section in 1934 in a discussion of a dispute between the La Rochelle group and the local Amsterdam committee. 190 But it is in July 1935 that the rifts within the French section became readily apparent at the annual meeting. Gabrielle Duchène protested to the assembled members that she could not understand where the impression had come from that the LIFPL had changed its philosophy or orientation. But changes there certainly were. Duchêne spoke of the 'amicable divorce' which had been effected between the section and the Colmar and Mulhouse groups. Jeanne Challaye read a letter from Madeleine Vernet criticising the present political line of the French section. These criticisms found their echo in a discussion on the Stalin communiqué and a report by Jeanne Alexandre which declared that in her view the Soviet Union had changed its foreign policy from 'one of peace to a policy based rather on force which repudiates disarmament as the Red Army grows, and that renounces revision of the Treaty of Versailles'. 191 The minutes record Alexandre's view that

the declarations of Stalin consecrate the traditional policy of the capitalists which is a policy of armed coalition, the reestablishment of the division of the world into two camps, etc.

She is certain that 'mutual assistance' with Russia is an assistance based on arms and that we have the right to raise doubts about the sincerity of Russia as regards peace. This pact that is supposedly

187 'Intervention de G. Duchêne, Congrès de Zurich', 1934, in BDIC/DD/FARés. 205/8/5.

188 Ibid.

189 Ibid.

190 Procès-verbal de l'Assemblée Générale de la Section Française de la LIFPL, 14 July 1934, p.2. In BDIC/DD/F $\Delta$ Rés. 208/15.

191 Procès-verbal de l'Assemblée Générale de la Section Française de la LIFPL, 7 July 1935, p.5. In BDIC/DD/F $\Delta$ Rés. 208/16. See also Madeleine Vernet to Jeanne Challaye, 5 July 1935, in BDIC/DD/FARés. 208/16. 
open to Germany, do we know on what basis Germany will be asked to join it,...

Given the situation, she believed that the League must take a position with regard to the policy of the USSR, with clarity and precision. If the League wants to remain what it was in 1915 - first and foremost a league for Peace - she demands that it pronounce itself for peace. 192

And she concluded by demanding the redressement of the political line of the French section. This provoked a long and at times acrimonious debate, at the end of which Duchêne asked for a vote on several policy questions. The Assembly passed a resolution (although with some negative votes), expressing its belief in 'the desire of the USSR for peace, as demonstrated by the Pact'. A resolution stating that the 'pacts of mutual assistance [were] a measure for the safeguarding of peace' was apparently also passed although with several abstentions and a motion in favour of unilateral disarmament proposed by Camille Drevet was defeated. 193

The dissent of 1933-35 became a full-fledged rebellion in 1936 and the most explosive challenge to Duchêne's conception of the League's work and her continued leadership of the French section. In an immediate sense the confrontations of 1936 can be linked to the expulsion of the executive committee of the Lyon group and all members sympathising with it. But this incident, unparalleled in the history of the French section, also served to galvanise an entire body of opposition within the section which manifested itself at the 1936 annual meeting.

First, to deal with the purge of the Lyon group. It seems that trouble had been brewing for some time. In 1934 or early 1935 Léo Wanner of the Lyon group stopped production of the section's organ, SOS, for reasons which are unclear and refused to give up her proprietary rights to the title. This resulted in a long hiatus while Duchêne searched for a new title, and also for someone to take over the job of editing and publishing it. The problem was finally resolved in 1935 and En Vigie made its appearance. 194

The immediate origins of the affray lie in what Duchene termed the ironical presentation of, or the attacks on, the actions of the national or international bodies of the LIFPL' in the group's new bulletin, Rassemblement des Femmes pour la Paix et la Liberté.195 The offending lines, ironical perhaps, but only mildly offensive, read:

The French section ... thinks that in putting pressure on our rulers, these gentlemen will end up listening to us and will do something in

192 Ibid. (Procès-verbal).

193 Ibid.

194 Report on the section's journal in ibid., p.3.

195 Procès-verbal de l'Assemblée Générale de la Section Française, 27-28 June 1936, p.17. In BDIC/DD/FARés. 208/17. 
favour of peace. (Our comrades no doubt have not heard of the Rome agreements). In this hope, the leaders [of the League] are using their resources and their time to make representation to more or less important notables, to circulate petitions, etc... Better yet, is it not a question of a forthcoming pilgrimage to the cemeteries of the Nord to protest against the war which is returning?

The results of this action seem to us to go so much against the goal to be attained that we have been dismayed at the thought of such an enterprise... 196

The French executive committee informed the Lyon group that it considered it inadmissible to make such comments in a journal sold to the public. Receiving no undertaking from the Lyon group that it would mend its ways, Duchêne, L. Maréchal, and Gertrud Baer, the international vice-president descended on Lyon for a special general meeting on 26 February. They were 'very badly received', however, and the 'aggressive nervosity of part of the assembled audience did not permit the objective exchange of views that had been hoped for' 197

The real reasons for Duchêne's annoyance become clear in a letter written to her by the Lyon committee in the wake of this meeting. She had apparently accused the Lyon group of being a 'branch of the Trotskyist party' because the group's new secretary, Berthe Joly belonged to a Trotskyist minority group. Mme Joly had only reluctantly accepted the position for fear that this very sort of confrontation might occur, but she had the support of the entire Lyon group. The Lyon committee charged that Duchêne had made a tendentious interpretation of their doctrine, which they claimed was nevertheless in complete harmony with the fundamental principles of the LIFPL. By a large majority the Lyon group had decided to engage itself 'in the revolutionary work which seems to dismay you so much'. They were 'outraged' by Duchêne's 'suffocating tone' at the meeting in Lyon and hoped for better things from the 'proven militant who in other times knew how to lead the fight for peace in complete independence'. They declared that they would continue to work loyally for the goals of the League 'which the national office reminds us of constantly, but from which it deduces methods of action little in harmony with them'. They concluded by accusing Duchêne and the Paris office of 'incoherence', 'sterile polemics', and an unwillingness to tolerate dissent and criticism. 198

Andrée Jouve responded to this letter on the part of the executive, quite rightly condemning the insulting tone of the Lyon group's attack, but leaving untouched the substantive questions it raised. ${ }^{199}$ In a subsequent number of their journal, the Lyon group

196 Rassemblement des Femmes pour la Paix et la Liberte (Lyon), no.1, cited in ibid., p.17.

197 Duchêne in ibid. (Procès-verbal).

198 Le Groupe de Lyon de la LIFPL à Gabrielle Duchêne, secrétaire nationale, 18 March 1936, cited in extensio in ibid., pp.17-19.

199 Jouve's response on behalf of the Executive Committee is given in ibid., p.20. 
protested again against 'the abuse of power at the summit of our organisation' and against the 'intolerable' participation of "'our" presidents and vice-presidents...in the chauvinist campaign which has been unfolding across the country for several weeks, defending the policies of French imperialism in the Franco-German conflict. 200 Extracts from the minutes of the special general meeting published by the Lyon group make clearer though what the dispute was all about. The Lyon group seemed to fear that the Front Populaire was evolving into a Union Sacrée which they would never accept:

This is the reason for which we are fighting against the Popular Front which has no other goal, fundamentally, than to effect a coalition of the workers with a view to having them approve the policies of French imperialism under the cover of the 'defence of the USSR' or of the 'anti-fascist struggle'.201

Mme Joly declared that it was because the action of the Paris office was so sterile that the Lyon group had decided to throw itself into the genuinely revolutionary struggle. The wife of Louis Emery wanted to know why Duchêne had 'done an about-turn' and was now supporting the Franco-Soviet pact. She also wanted to know why the French section supported the Popular Front. Another 'comrade' demanded to know why the League had suddenly stopped its campaign against the two-year military service law after the Stalin declaration. The Lyon group accused both Duchêne and Baer of having no confidence in proletarian sanctions but of putting their faith instead in the bourgeois governments. The group declared that

We remain convinced that the whole of the policies of the Popular Front, such as they are expressed, can only favour the war psychosis to the profit of the capitalists. ${ }^{202}$

This was the straw that broke the camel's back. In a national executive committee meeting on 10 June, it was decided to purge the Lyon executive and all members of that group sympathising with it. Duchêne denied vehemently that she had changed her view on disarmament, or working class sanctions and repeated her by now rather sterile assertion that the LIFPL took orders from no political party. ${ }^{203}$ It seems that she was perhaps reluctant to go through with the purge because the topic was again discussed at the AGM in July and the expulsions did not finally occur until November. To draw the whole affair out

200 Rassemblement des femmes pour la Paix et la Liberté no.4. p.3, cited in ibid., p.21.

201 Cited in ibid. Cf. 'Extraits du Rapport d'Andrée Jouve "Nos tâches dans le Front Populaire", présenté à la Conférence Nationale, 28 Juin 1936' in BDIC/DD/FARés. 208/17.

202 Cited in ibid. (Procès-verbal), p.22.

203 See text of two notes sent to the Executive Committee of the Lyon group by the National Executive Committee following its meeting of 10 June 1936. Both are contained in ibid., pp.22-23. 
even further, it seems to have been raised yet again in a session of the international executive committee in a meeting closed to non-voting consultative members in Bruges in April 1937. No minutes exist for this meeting. ${ }^{204}$

The AGM of the French section in late June 1936 was thus an important one. It saw the most comprehensive attack yet made by the dissenters on the direction the League seemed to be taking. Sixteen groups were represented; 205 and Clara Ragaz, the international vicepresident, was also there. Duchêne knew that the outcome of the meeting would determine the future course of the French section and her control of it. As she wrote in one of a series of letters in late June to people likely to support her view,

We have alas in our League, too, a struggle of opposing tendencies similar to that within the Comite de Vigilance des intellectuels: it is above all in the meetings on Sunday that this will manifest itself and we should be very happy if you could participate in these meetings because it is perhaps the future of the French section which is at stake. 206

Much of the meeting was taken up in a naked power struggle between Duchene and the Paris secretariat on the one hand, and a collection of provincial groups trying to effect changes in the French section's direction. Their efforts bore little fruit; and indeed, the 'coalition' fell apart when the story of the Lyon group's imminent purge was strategically made public on the Sunday afternoon. The combined efforts of the Nîmes, Montpellier, Rouen, Le Havre, La Rochelle, Lyon and Arles groups effectively to disenfranchise the Executive committee fell apart as the Lyon saga was revealed by an astute Duchêne. One after another, groups distanced themselves from the affair, while struggling lamely to insist on the need for changes in the section's management and orientation. 207 There is no doubting the feeling of discontent within the membership of the French section. The minutes make abundantly clear the sense of alienation experienced by most groups. On substantive issues, too, there was hardly unanimity. The Montpellier group criticised the text of the letter sent to the President of the Assembly of the League of Nations; condemning the re-militarisation of the Rhineland, which they did not believe was in conformity with

204 Copies of the form letter of exclusion addressed to members of the Lyon group are in $B D I C / D D / F \Delta R e ́ s .208 / 17$. See the agenda for the closed special session of the International Executive Committee, Bruges, 5 April 1937, in BDIC/DD/FARés. 206. See also Procès-verbal de la Réunion du Comité Exécutif de la Section Française, 10 June 1936, in BDIC/DD/FARés. 208/17.

205 The sixteen groups represented were: Drôme-Ardèche, Le Havre, Rouen, Arles, Lyon, La Rochelle, Châlon-sur-Saône, Dijon, Chambéry, Nîmes, Roubaix, Troyes, Seine, Seine-et-Marne, Seine-et-Oise, Paris.

206 From a collection of copies of letters from Duchêne to unspecified persons in BDIC/DD/FARés. 208/17. Quotation extracted from letter dated 25 June 1936.

207 Procès-verbal de l'Assemblée Générale de la Section Française, 1936, pp.1-3, 6 and 12. In BDIC/DD/F $\Delta$ Rés. 208/17. 
the League's principles. 208 Camille Drevet expressed her belief in the tremendous work of the English women for peace. Both of these statements reveal that the French section's confrontations at the international level of the League did not represent the totality of the views of its membership. 209

This was precisely the point. By 1936 it was apparent that Duchêne had a very rigid idea of what constituted proper action for peace, and her attitude to the French section gradually became one of rule by fiat. As a disenchanted woman in Valence wrote to her later that year, "if I had known that in such a League the orders came "from above" and were given by an international executive committee, I should never have joined'.210 This attitude -was evident in the discussion provoked by Duchêne's paper on 'Les Deux Conceptions $d u$ Pacifisme already mentioned above. She made it clear that she believed that in a political organisation like the league, only the barest minimum of dissent from its policies could be tolerated. She condemned the 'divisionniste' faction which she claimed was ruining the work of the LIFPL by its aggressive and violent opposition. In her opinion if members could not see their way clear to working within the League, they should consider leaving it and joining a more amenable group such as the Ligue Internationale des Combattants de la Paix. As for the others, they were quite welcome to remain in the League as long as they did not hinder its action. The true pacifist, she claimed, must refuse to contribute to division within an organisation which had already given so many proofs of its devotion to peace. She defined the League for perhaps the first time as a body akin to a political party, with a doctrine which had to be imposed on the membership. In this she was both right and wrong, both re-iterating an old League principle and creating a new and dangerous precedent at the same time. The LIFPL had always insisted on genuine pacifist conviction in its members - this principle had been at the heart of the 'aims' debates of the 1920 s as we have seen - but it had equally held itself above the level of party political strife. Duchêne herself had often said at international meetings that if members disagreed on methods, they certainly did not on the goals pursued by the LIFPL. But at some time in the mid-thirties it is obvious that the question of means and ends, of goals and methods fused together in Duchêne's mind and she found it increasingly impossible to brook contradiction. Here in the 1936 annual general meeting one can arguably see signs of the faint Stalinisation of Gabrielle Duchêne and the French section. As Camille Drevet tried

208 This is most likely the letter strongly condemning the League's inaction in the face of Hitler's remilitarisation of the Rhineland mentioned above. Mentioned in ibid., p.4.

209 Ibid., p.4.

210 'LM' to Duchêne, Valence, 12 October 1936. Typescript copy in BDIC/DD/FARés. 208/17. 
in vain to make clear, the real question was not whether there were Trotskyists in the League or not, but simply what policy the League should adopt. 211

The problem of the Lyon group did not disappear after the 1936 annual meeting. Rather it continued to rear its head for some time to come. The French section even went to the lengths of taking legal advice in order to recover section funds held by the Lyon group at the time of the purge. 212

Having scored a somewhat Pyrrhic victory at the 1936 meeting, however, Duchêne could afford to appear to be slightly more indulgent in her dealings with dissent. With the necessary political victory behind her, she reverted to the essentially generous and democratic spirit of former years. For example, in a meeting of the Paris region in November 1936, called to choose representatives to a special general meeting, Duchêne supported the inclusion of Jeanne Alexandre in the group's delegation because she represented the minority tendency. She also attempted to ensure that the French section's executive should contain a member from the 'opposition' and that groups interested in sending delegates to the league's 1937 congress should seek, insofar as was possible, to maintain a balance in their representation. 213

But the spirit of fair play and equity, which Duchêne belatedly tried to reimpose on the French section was not enough or came too late. The factious fronde led by Jeanne Alexandre finally separated from the rest of the League in September 1938, abandoning what they called 'le beau mot libertê and creating simply a Ligue des Femmes pour la Paix. As Duchêne wrote in a special number of En Vigie in March 1939,

This reveals, better than any long commentary, the differences between our two groups...As for us, we are more certain than ever that to abandon the defense of freedom is not to serve the cause of peace, but rather to betray it. This is why, together with the International, our league will continue to put defence_of Freedom and defence of Peace on the same level. 214

211 Procès-verbal de l'Assemblée Générale de la Section Française, 1936, p.7 BDIC/DD/FARés. 208/17.

212 See Compte-rendu de la réunion du Comité Exécutif de la Section Française du 16/7/36 in BDIC/DD/FARés. 208/17. See also Procès-verbal de la Réunion du Comité Exécutif du 13 avril 1937 in BDIC/DD/F $\Delta$ Rés. 208/18. See also 'Activités de la Section Française, Assemblée Générale Annuelle, 15 et 16 mai 1937 in En Vigie, 6/7 (October-November 1937), pp.4-5.

213 See Procès-verbal, Réunion des membres de la région parisienne de la LIFPL du mercredi 4 Novembre 1936, in BDIC/DD/F $\triangle$ Rés. 208/17. See also Circulaire no. 22 (April 1937) in BDIC/DD/FARés. 208/18. See also 'Avis Important' in En Vigie, nos 4/5 (April 1937), p.9. See also 'Activités de la Section Française. Assemblée Générale Annuelle, 15 et 16 Mai 1937' in En Vigie 6/7 (October-Noymber 1937), pp.4-5.

214 'Avis Important', En Vigie nos 10-11-12 (March 1939), p.1. 
Schism had finally come to the French section - schism almost inevitable as the pressure of real political events tore at the bicephalous French section, reducing it finally to impotent schizophrenia.

The schism of the LIFPL French section underlines what Michel Bilis has called with regard to the Socialist Party, the 'untenable dilemma' of French pacifism. 215 The French section's acute sense of political reality finally forced a divorce between the desire for peace and that for freedom and justice. The political and pacifist trajectories had separated, or at any rate were no longer formed of parallel lines. As the Nazi menace became daily more palpable, French political pacifism became increasingly conscious of the need for unity, collective security, and (God forbid) the possibility of having to defend militarily, one's cherished conceptions of liberty. With each succeeding crisis in the thirties, the sands of intégralité poured faster through the pacifist hourglass towards September 1939.

215 The phrase is from the title of Michel Bilis' book Socialistes et pacifistes 1933-1939. Ou l'intenable dilemme des socialistes français (Paris: Syros, 1979). 


\section{III.5. Conclusion}

In examining the political and moral trajectory of the French section of the LIFPL during the interwar years, the ideological evolution of the pacifist debate cannot be overemphasised. What in 1915 had been a tremendous leap of humanitarian, feminist, pacifist courage, became increasingly in the 1920s a politicised debate, and in the 1930s an increasingly sterile, ideologically-determined struggle for one conception of peace for which some French women became increasingly willing to contemplate the shedding of blood. Because the women of the French section were so politically astute, their radical pacifism finally collapsed like a house of cards. The trump card was called Freedom; and it was for freedom that the French section primarily struggled in the latter years of the decade. The widening gap between moral conviction and political reality made the pacifism of the LIFPL untenable until at last it was no longer really pacifism, or at least certainly not 'integral pacifism'.

It is too easy for the historian to look back at the interwar period with the benefit of historical hindsight, and to chastise and to laud d̀ son gré. But until 31 January 1933 nothing seemed inevitable about the rise to power of the Teutonic Teppichfresser across the Rhine threatening yes, but inevitable no. Before the duplicity of the Nazi-Soviet pact of August 1939, little or no suspension of disbief was required for many men and women of good will to believe in the Soviet Union's desire for peace. September 1939 was not a pre-ordained fait accompli, until it had actually happened. In order to understand the brave mixture of optimism and despair of the interwar pacifists, it is necessary to remind oneself constantly of these facts.

The rise of fascism and the Nazi seizure of power transformed the world of politics. Under the pressure of political reality, the French section's early integral pacifism gradually disintegrated as the need to support the fight for freedom became increasingly evident. The gradually increasing ideological content of their pacifist analysis only served to widen further the space between their concern for peace and their fight for liberty.

Thus, women's peace initiatives in interwar France became infected with the same dilemmas, distortions, detours and hard political choices as did more 'masculinist' efforts for peace. In terms of radical feminist pacifism, the 1930 s were a decade of disappointments 
as the women of the LIFPL were gradually forced into a permanent retreat behind the mental Maginot line of collective security and support for the bourgeois democracies. That which had been specifically and originally feminist in the work of the LIFPL in France during the First World War and in the twenties, became diluted and distorted - des idées périmées - as the thirties drew to a close.

While some feminists argue that women are inherently pacifist, in practice this was not necessarily the case. ${ }^{216}$ Women, like men, were susceptible to the drumbeats of their age. As in the working out of Christianity or socialism, there would appear to be no in-built ideological determinism which leads to peace through feminism. Human perversity and individuality usually see to that.

Women in interwar France, individually and sometimes collectively, did make a major contribution to peace. However, they did this more as pacifists than as feminists; and their pacifism gradually became overlaid, diluted, and distorted as a moral creed by the political and ideological demands of their age. 217

In thus returning to the questions posed at the outset of this section, the measured words of the feminist journalist, Marcelle Capy, seem particularly appropriate. Grappling with the same issues dealt with here, Capy concluded:

Many writers - of all countries - have shown themselves extremely severe with regard to women. They have admirably criticised the frivolity, the unconsciousness of some, the exasperated chauvinism of others. They are neither completely wrong, nor completely right.

Is it right to demand that women be pacific heroines? For my part, I believe that men and women have nothing to envy one another, and that they need a reciprocal indulgence in order to judge one another. 218

216 See notes 5 and 10 of Part III for examples of this sort of modern feminist interpretation.

217 Huguette Bouchardeau comes to similar conclusions about the nature of feminist pacifism in interwar France. She writes: 'Ce débat illustre bien ce qui est en train de se passer au niveau de la lutte des femmes pour la paix. D'un côté, des action autonomes des femmes, intéressantes dans leur portée concrète,mais souvent vouées à l'inefficacité et à l'angélisme. De l'autre, des actions qui visent à des rassemblements massifs, s'insèrent dans des luttes politiques d'envergure, mais sont rarement menées à l'initiative même des femmes.' Bouchardeau's point is that the feminist pacifist movement became de-tracked and politicised, and thus less than one hundred per cent feminist or even pacifist in inspiration. 'Les thèmes des droits de la maternité, de la femme pacificatrice, qui avaient été si mobilisateurs, si "productifs" à la fin de la querre et dans les années qui ont suivi, vont devenir clichés, manipulés comme arguments au service d'un discours qui trouve ailleurs ses fondements'. Women became, in Stalin's word, merely 'la grande réserve' of the working class. See Huguette Bouchardeau, Pas d'histoire, les femmes... 50 ans d'histoire des femmes: 1918-1968 (Paris: Editions Syros, 1977), Pp. 110-111.

218 Marcelle Capy, 'Les Femmes et la Paix', Le Progrès Civique 600 (14 February 1931), p.213. 


\section{CONCLUSIONS}


Wars have a nasty habit of ruining the high hopes of pacifists. This was perhaps especially true for those of the 'ideological' variety who in the case of France defined the old-style paradigm from which the new, integral pacifism evolved. Because the ideological pacifists of the APD were collaborative in their orientation to the political society they lived in, the failure of their pacifism was acutely felt. Failure was not interpreted as the end of the struggle, however. As we have seen, if the League of Nations idea had fallen short of the mark, this did not in any way mean that the basic premisses behind the APD's pacifism were wrong. Far from it. Ruyssen, looking back over fifty years of pacifist activity in 1938, could justifiably be proud of the extent to which the theses of the APD had become accepted in political society. As Part I makes clear, if 1939 represented the dashing of the reasonable hopes of reasonable men in an unreasonable world, this did not lessen in any appreciable way the long-term optimism with which the tenants of the old-style pacifism viewed the future. Of the final victory of their ideas they were convinced.

No doubt the political world in which the interwar pacifists moved was very different when it ended from when it had begun. In the immediate post-war years, even the oldstyle pacifism of the APD had been somewhat suspect in the eyes of much of public opinion. We are no longer acquainted today with the species of warmonger who honoured the fact of war and glorified it as a salutary social instrument. But in the early twenties, the memory of the vilification to which the APD had been subjected in the pre-war years was still fresh. The trauma of the Great War did much to alter the political balance in favour of the theses of the old-style pacifists. By the late 1920s it was a common-place for politicians to support the efforts towards international reconciliation of Briand, for example.

For the new-style pacifists of the thirties, the situation was rather different. 1939 represented for them both the complete failure of all that they had striven for, and at the same time a sort of perverse justification of the theses they had propounded. Peace had failed, but it had done so because of the complete rottenness of society. French political 
society was rejected, as we have seen, because of an historical interpretation of the recent past, and an antipolitical, dissenting stance in the present. This, coupled with the fears of the next war, produced a powerful new variant of pacifism. When that war finally arrived, French integral pacifism was already completely isolated from political society. Indeed, one of its problems had nearly always been the fact that it was continuously being squeezed from Left and Right in a political pincer action which finally left it marooned on its own small island of despair. Only in the first few years of the LICP's existence, from roughly 1930-1933, was the League able to make any claims at all to limited public support. But the early thirties were still a time of relative optimism. War clouds were gathering on the horizon and causing people to reflect. Pessimism was around the corner. But in the first years of the League, it was possible for pacifists to make great inroads on public opinion because of the prevailing political climate of relative optimism. The failure of the Geneva disarmament conference, together with international tensions left unresolved by a League of Nations which was increasingly seen as impotent, and above all, the arrival in power of Hitler in Germany, caused this world of public optimism to crumble. The late arriving effects of the world depression only served to exacerbate an already bad political situation. The Popular Front provided a brief respite from the slippery slope of pessimism, but it did not last. This was perhaps the cruellest of the political blows which integral pacifism had to suffer in the thirties. So many high hopes had been vested in the Popular Front, which despite the presence of Communists within it, was initially considered a tremendous guarantor of peace. Because of the idées maittresses which underpinned it, the new pacifism quickly and easily slipped into an antipolitical withdrawal from society. This was an indication of its sectarianism or of the utopianism of its ideas - either model will do. What is interesting, though, is the manner in which this antipolitical movement which was the focus for so much vitriolic dissent from the rest of French political society, continued nevertheless to express itself in purely political terms.

It is important to see the links between all three types of French pacifism discussed in this thesis. Not only can they be classified according to either the Chickering or Ceadel typologies, but they should also be seen as part of a time continuum. Their political evolution is important, and because so many of the major figures of both new-style pacifism and also feminist pacifism began their political trajectories as allies, if not members, of the APD, the only method of explaining these evolutions away from the original pacifist 'faith', seems to be that of paradigmatic change. Historical dissent begat political alienation, which in turn combined with the growing fears of another war, to produce a new type of pacifism which posited a radical departure from the methods of the past. The new pacifism incarnated the negation of politics, the negation of the recent past and the 
affirmation of new political values drawn from, amongst other things, the ethical lessons of the Great War and a vision of French history which owed much to Robespierre.

For the feminist pacifists of the LIFPL, this dissent from political society was more moderately expressed. Women played no significant political role in interwar France, and it was thus easy for the peace women to make an impressive ethical stand against war in the early twenties. As the decades changed, however, this ethical stance became overlaid with many of the political concerns of the male world of politics, and arguably what began as a vibrant vision of feminist pacifism ended up as a shadow of the ideologically divided male version.

The LICP ceased to exist with the coming of war in September 1939. The APD continued to publish its review, however, and only died out in the late forties when all of its leading members were at an advanced age. No younger hands seem to have been willing to take up the torch. But perhaps by then, the task was unnecessary because the post-war years saw the birth of the United Nations which seemed to reincarnate the hopes the APD had originally placed in the League of Nations. The only one of the three organisations which still exists is the LIFPL which seemed to survive the war experience rather well.

For the ideological pacifists of the APD, and indeed for the feminists of the LIFPL as well, the coming of war did not mean the ultimate defeat of their ideas. It is one of the traits of the old-style pacifism and of the feminist pacifism under discussion here, that pessimism and optimism were mixed. Thus, the words of the APD's 1920 Appel-Programme seem to sum up its approach to the temporary failure of its pacifist hopes in 1939:

We are rolling, it seems, the eternal rock of Sisyphus. A bitter observation and one which will discourage some. But we are of those who never despair. Instead, we find even in the avowal of our own disappointment, positive reasons to envisage the future with a reflective confidence. 1

As Appendix II shows, Romain Rolland astutely realised that the problem of peace had become very complicated by the early thirties. As he said, it was no longer enough to desire peace, one also had to desire the means to achieve it. Rolland represents the ideologising of the question of peace which was so rejected both by the old-style pacifists who preferred to think in terms of structures, and less in terms of the larger ideas behind them; and also by the new pacifists for whom peace was an over-riding concern that relegated all else to a secondary position. It was this view of peace as the ultimate goal defining all other political considerations which caused so much friction with the representatives of a Moscow-oriented Communism which sought to define its peace in terms of the social revolution and defence of Soviet Russia. The integral pacifists would have

1 La Paix par le Droit, 'Appel-Programme', PD 30, 1/2 (January-February 1920), p.3. 
none of it, and in their rejection of the Communist view, they affirmed peace as an example of Weber's 'ethic of ultimate ends', an idea which underpins much of Ceadel's analysis of pacifism.

The extent to which a political society can accommodate dissent like that of pacifism is perhaps a comment on its liberality. It is one of the paradoxes of France that a nation so individualistic in its soul should be so intolerant of political and ethical non-conformity. If nothing else, the debates occasioned by pacifism in the thirties represent a struggle for the French historical soul, an attempt to redefine the nature of French politics and the orientation it had towards the nation's revolutionary past. Pacifism struck too near the vitals of the modern French experience to be brooked gladly. The garrison mentality of the interwar years with its 'collective insecurity' was incapable of accommodating the pacifist thesis. In its ideological manifestation, pacifism was tolerated, but the political nonconformity inherent in the individualistic, dissenting new pacifism could not be accepted. Perhaps there is some grain of truth in H.N. Brailsford's rather antipathetic comment that France's

partial eclipse during the last fifty years that followed Sedan has obliterated our recollection of the persistent military tradition of this most nationalist of peoples. ... A nation of small peasant owners and small investors will never be Liberal in the British sense of the word. 2

Whatever the case, it is important to place the French pacifist experience firmly in the context of western European political history. Pacifism was a phenomenon experienced as much by the French in the interwar years as by any of the other western, liberal democracies. If this thesis has succeeded at all in rescuing the interwar French pacifists men and women with different visions of the pathway to a better world, but of good will all of them - from the dustbin of history, then it will have partially attained its goal.

2 From H.N. Brailsford's After the Peace, cited in A.J.P. Taylor, The Troublemakers: Dissent over Foreign Policy, 1792-1939 (London: Hamish Hamilton, 1957), p. 177. 


\section{APPENDICES}




\section{APPENDIX I}

\section{The Circulaire Chautemps, 1933: The Third Republic Discovers Conscientious Objection.1}

Despite the fact that some French dictionaries date the entry of the expression 'conscientious objector' into the French language as 1933, there is little doubt that it was a known quantity both as a political instrument of resistance to war, and as a philosophical, moral or religious position, in the fairly immediate post-World War One period. During the 1920s and early 1930s a number of small books discussing the merits and disadvantages of conscientious objection as an instrument of war resistance were published. Certain newspapers of anarchist tendencies discussed the subject from their own particular perspective from about 1924 onwards. And, in the late 1920s, a bona fide pacifist press appeared and began to include reports on objection in its pages. ${ }^{2}$

Michel Auvray mentions several groups either promoting or supporting objection in the early twenties in France: inter alia the War Resisters' International and the International Fellowship of Reconciliation, known in France as the Mouvement International de la Réconciliation. He has discovered the first French support group for COs in existence as early as 1920, the Conscientious Objection Defence Committee, which counted amongst its

1 Earlier versions of this appendix were read as papers at the University of Toronto and at the University of Edinburgh.

2 For examples of the development of this genre, see: Manuel Devaldès, 'Les Objecteurs de Conscience Anglo-Saxons', in Mercure de France, CLXVI (15 September 1923), pp.642-669; Manuel Devaldès, 'L'Etat mondial de la question de l'objection de conscience', ibid., CXCVIII (15 August 1927), pp.100-122; Marceline Hecquet, L'Objection de Conscience deoant le Seroice Militaire (Paris: Editions du Groupe de Propagande par la Brochure, 1924); René Valfort, L'Objection de Conscience et l'Esprit maçonnique, Préface de Edouard E. Plantagenet (Paris: Collection des Documents maçonniques de La Paix, n.d. [1930]); Madeleine Vernet, De l'objection de conscience au désarmement (Levallois-Perret: Editions de la Volonté de Paix, 1930); see also the newspapers and journals Le Semeur, La Patrie Humaine, Les Cahiers de la Réconciliation, amongst others for a continuing discussion of conscientious objection in the late 1920s and early 1930s in France. 
Committee of Honour writers such as Henri Barbusse and Georges Duhamel. ${ }^{3}$ The earliest trace of C.O. activity in the files of the Ministry of the Interior, however, is the League for the Recognition of Conscientious Objection, founded in Lyon in 1924 by Paul Bergeron. 4 This League, despite a Committee of Patronage counting in its number a great proportion of the future leaders of the French pacifist movement of the late twenties and thirties, seems to have become rapidly moribund. The late 1920 s and early 1930 s also saw the first of the rather pitiful public trials of conscience which sent men of various political, religious and philosophical persuasions to prison for terms of a year or more; in the case of two Protestant theology students, Philippe Vernier and Jacques Martin, these were but the first in a series of sentences they would receive for their convictions until the chaos of June 1940 finally released them into the dangerous world of Vichy. 5 The essential point then is that despite the title of this paper, for those who had ears to hear and eyes to see, conscientious objection was no wildfire malignancy which, in a spasm of bad timing, contrived to make its appearance in the body politic at almost the precise moment that events across the Rhine were riveting French eyes on the spectre of post-Versailles revanche. Far from it. Conscientious objection existed in France throughout the interwar period, although always very much as a minority movement, if one can call it even that. But it was only in January 1933 that the French government suddenly perceived that it had a 'conscientious objection problem'.

The Circular of 26 January 1933 addressed to the Prefects of the French departments by Camille Chautemps, the Minister of the Interior, was the response to this problem. It originated in a letter of 9 January sent on behalf of Chautemps by the Director of the Sưreté Générale to Edouard Daladier, then Minister of War. Chautemps wrote that his attention had 'been particularly drawn to the development of a campaign (italics mine) presently being conducted in France in favour of conscientious objection, that is to say, young people

3 Michel Auvray, Objecteurs, insoumis, déserteurs. Histoire des Réfractaires en France (Paris: Stock/2, 1983), pp.174-175.

4 Archives Nationales, Paris. F7/13352. See report entitled 'Le Mouvement en faveur de l'objection de conscience en France' (Paris, 16 February 1933); see also Tract 1 (Noël 1923) of the Ligue pour la Reconnaissance de l'Objection de Conscience in F7/13352. Tract 3 of the LROC is in Bibliotheque Nationale, Paris, $80 \mathrm{Wz} 3636$.

5 A few examples of men who were condemned in the late twenties and early thirties are: Georges Chevé, sentenced to six months imprisonment on 7 October 1927 [see report on Chevé's case in Le Semeur no. 108, 19 October 1927]; Eugène Guillot, condemned to one year in prison on 10 January 1930 [see 'L'Objection de conscience et l'Affaire Eugène Guillot' in La Volonté de Paix, no. du Printemps 1930. For Romain Rolland's reaction to the affair consult Romain Rolland, 'L'Objection de Conscience doit être, non individualiste et libertaire, mais sociale' in Par la Réoolution, la Paix (Paris: Editions Sociales Internationales, 1935), pp.91-92. See also 'Textes du Comité de Défense Eugène Guillot' in Bibliotheque de Documentation Internationale Contemporaine (BDIC) Fonds Duchène

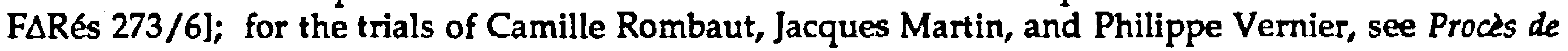
Camille Rombaut, (Aubervilliers: 'la Réconciliation', 1932); Procès de Jacques Martin, (Aubervilliers: 'La Réconciliation', 1932); Procés de Philippe Vernier, (Aubervilliers: 'La Réconciliation', 1933); Martin and Vernier were also interviewed by the author on 16 and 17 September 1983. 
who refuse to submit to the military laws for apparently moral motives'.6 He wrote dismissively of the usual 'propaganda conducted for several years by the Communist Party', thereby recognising, perhaps subconsciously, that conscientious objection differed in style and intent from the more ideologically motivated and politically opportunistic antimilitarism which was part and parcel of the traditional mythical baggage of sizeable portions of pre-War socialist and post-War communist militancy. ${ }^{7}$ In January 1933 the danger seemed to lie elsewhere. Chautemps and the Surreté were particularly concerned at the spread of this moral contagion to other social classes, in short, at its apparent, albeit nascent, generalisation across class barriers.

Three recent events had provoked this worrisome conclusion. Firstly, a Father Ducatillon of the Dominican Order had delivered a series of five public lectures on the theme 'True and False Patriotism' at the Pius XI Institute in November and December 1932. Ducatillon's lecture series, which culminated in a discussion of conscientious objection on 15 December, was part of a larger series of lectures organised by the Institute in the winter of 1932-33 dealing with the teachings of the papal encyclical $C_{j}$ aritate Christi on the world crisis. But more about Ducatillon in a moment.

Secondly, Jacques Martin, a Protestant theology student in Paris, who had been sentenced to a one-year prison term for his refusal to carry out a twenty-one day period of reserve service, had received a letter and petition of support from an impressive group of more than twenty professeurs agrégés, businessmen, a medical doctor, a Polytechnicien and primary school teachers. Nearly all of them were war veterans, some of them had been injured and the group included two Chevaliers of the Legion of Honour, and five Croix de Guerre. Clearly not a group of young people anxious to avoid military duty for apparently moral motives. Nor were these wild-eyed agitators of the Communist Party. Martin must have enjoyed a certain public repute because when the letter arrived at the Cherche-Midi prison, the military censor was scandalised to find that the envelope was covered with the fraternal salutation of five postmen: 'With you with all our hearts! Courage!', and appended below were their signatures.

Finally, Chautemps and the Ministry seem to have been sensitive to charges of softness levelled against them in the right-wing press. He cites an article published in the Action Française of 19 December 1932 attacking the Tribune Vicinale, the organ of the national federation of local road engineers and technical assistants, which had published an article in favour of conscientious objection reading in part:

6 AN F7/13352. 'Le Ministre de l'Intérieur à Monsieur le Président du Conseil, Ministre des Affaires Etrangères, même lettre à Ministre Guerre', Paris, 9 January 1933.

7 Ibid. 
To disarm we must disorganise the military apparatus, refuse to make or to carry arms. 30 conscientious objectors are surreptitiously imprisoned and the whole press, knowingly orchestrated, keeps silent. 300 conscientious objectors would sow confusion in the system. 3000 conscientious objectors would destroy forever any possibility of an army.

The Action Française's pointed question 'What sort of sanctions have been taken against (this group) by the judicial authority?' seems to have struck home. ${ }^{8}$

Ten days passed, and on 19 January Daladier responded to Chautemps' original letter with a set of detailed observations which indicate the extent to which the Ministry of War had already considered the question independently of the police and the Interior Ministry. Moreover, Daladier proposed to do something about the problem, and on the same day he sent a circular to the Military Governors of Paris, Metz, Lyon and Strasbourg as well as to the Commanding Generals of the various military regions, outlining the problem and instructing them to follow it very closely in conjunction with the Prefects. The civil authorities, Daladier assured the Generals, would be issued parallel instructions by the Minister of the Interior. ${ }^{9}$ This effectively forced Chautemps' hand. Daladier had taken action from the military side and he clearly expected the civilians to follow suit - not that Chautemps likely needed much persuading, although in light of future developments it was certainly fortunate for the War Ministry that Chautemps had been obliged to issue his own circular to the Prefects.

What was the view in the Rue St. Dominique of the situation? Daladier's letter is much more detailed in its analysis of the problem, its origins and in its prescriptions for action. He, too, refered to a 'movement' which had touched several social classes and professional groups. Among these were 'libertarian circles which recognise no authority and do not wish to suffer any constraints whatsoever', and 'certain Protestant churches which believe that the Law of Scripture is incompatible with Military Law' - and here Daladier singled out the Society of Friends. More important though in a country such as France was the involvement of certain Catholic groups which disapproved of the potential for war in a nationalism which seemed contrary to the Christian spirit. 'Information from reliable sources' even led the Ministry to conclude that the Pope approved of this sort of activity - what better proof after all could there be than Father Ducatillon's lectures?

8 All of the above cited in ibid. Photograph of Martin's letter contained in 'Objection de Conscience (1924-32). Documents secrets du GMP in AN F7/13352.

9 AN F7/13948. 'Le Ministre de la Guerre à Monsieur le Ministre de l'Intérieur', 19 January 1933; and 'Le Ministre de la Guerre à Monsieur le Président du Conseil', 19 January 1933. See also AN F7/13352, 'Le Ministre de la Guerre à MM les Généraux Gouverneurs Militaires de Paris, Metz, Lyon et Strasbourg, les Généraux Commandant les Régions: Paris 1 à 5, 7 à 13, 15 à 18 et 20, le Général Commandant le $19 \mathrm{e}$ Corps d'Armée, les Généraux Commandants Supérieurs des Troupes du Levant, du Maroc et de Tunisie, le Général Commandant Supérieur des Troupes Coloniales dans la Métropole', 19 January 1933. 
There were also the pacifist associations such as the Ligue Internationale des Combattants de la Paix, the Ligue Internationale des Jeunes contra la Guerre, the Ordre internationale des Bon Templiers, all of which, according to the Ministry 'believe that the refusal to make or carry arms is the most effective means of avoiding war'. Newspapers of various hues were also singled out as being responsible for the spread of this moral disease; la Volonté, la Patrie Humaine, Le Bocage, Voila (all deemed to be pacifist), the Catholic newspaper $L^{\prime} A u b e$ and finally an anarchist newspaper published in the Calvados called Le Semeur had been publishing news of conscientious objectors for almost ten years. Finally, Daladier's memorandum concluded that even the Government and Civil Service were not immune to this contagion. Civil servants belonging to the teaching profession, the Finance Ministry and the Post Office had all apparently openly manifested their sympathies for the recently sentenced objectors. ${ }^{10}$ One can clearly conclude from this list that the War Ministry had been following the development of conscientious objection sympathies for some time and in some detail. But did the Ministry think the problem serious? Apparently, so. Daladier wrote:

The effects of this propaganda have not failed to make themselves felt. Several young soldiers and reservists have refused to carry out their military service or their reserve period, and the reservists have returned their mobilisation papers either to the Minister or to the relevant mobilisation centre.

15 young soldiers or reservists have been sentenced by the Military Tribunals, others are currently incarcerated and will be brought before the Military Tribunal shortly. Finally, several reserve officers have made clear their adherence to the conscientious objection movement. This movement in favour of conscientious objection risks taking a certain extension, if measures are not taken with a view to showing the nation the danger it represents, and to place on their guard against its consequences those who might be tempted to join it, either through conviction, personal interest or simply cowardice. ${ }^{11}$

He prescribed action on three fronts to counter the effects of C.O. propaganda. First, the military and civilian authorities must act so as to present, in the words of the circular to the Generals, ' a complete unity of views in this regard'. Secondly, he suggested that it be made clear to civil servants and state employees that 'conscientious objection constitutes a rebellion against the laws currently in force, and that those who approve of it and defend it risk incurring judicial proceedings'. One should note here that in Daladier's mind it was not even a question of actually being an objector, merely of approving or defending those who were. Finally, he suggested that in order to orchestrate an effective counter-propaganda,

\footnotetext{
10 Ibid.

11 Ibid.
} 
the Government should enroll eminent political and religious personalities such as the Cardinal-Archbishop of Paris, the President of the Consistory of the Reformed Churches of France, and the President of the Ligue des Droits de l'Homme in the public fight against conscientious objection. 12

These were Daladier's suggestions to Chautemps and the Ministry of the Interior in January 1933. But the War Ministry had already taken matters into its own hands and acted independently to curb discussion of conscientious objection in France. Here we return to the Ducatillon lecture series at the Pius XI Institute mentioned above. The Army appears to have taken an interest in Ducatillon's talks from the outset, as well perhaps they should, given the titles of the five lectures: 'What is the Fatherland?', 'True Patriotism', 'Antipatriotism and National Egotism', 'War and Legitimate Defence', and finally, culminating on 15 December 1932, 'Patriotic Duty in the Face of War (Conscientious Objection)'.13 A report by an officer from the General Staff on the third lecture, which took place on 1 December, is instructive. Around 2,000 people were present in the auditorium of the Pius XI Institute on the Faubourg St. Honore to hear Father Ducatillon. The staff officer present wrote that this lecture appeared to be but the exordium of a thesis of vast dimensions, designed to thrust before the world, under the aegis of the Pope, a new conception of individual patriotic duty when confronted with the danger of war. This is, moreover, the title of the lecture on 15 December (which) will examine conscientious objection and must apparently serve as peroration and conclusion to the arguments developed in the lectures of the 1 and 8 December'. ${ }^{14}$

The remaining two reports on Father Ducatillon in the Ministry of the Interior files are unmarked copies. Whatever their origins, however, they make astonishingly clear how well the War Ministry and General Staff were able to bring pressure to bear on someone propounding ideas deemed to be inimical to the interests of the state. The writer of the report on the final lecture noted the presence of several officers from the Military Government of Paris in the very full hall dressed in civilian clothes. The conclusions expected by Father Ducatillon's attentive audience were never drawn. In the words of the report writer:...

at the preceding lecture on 8 December, an officer of the G.M.P. (Military Government of Paris) had come specially on behalf of General G... to draw the attention of Father Ducatillon to the gravity of certain theories developed by him in his lectures of 1 and 8 December - theories which would lead one to admit or excuse

12 Ibid.

13 In an attempt to defuse the controversy these lectures were later published. See (le Père) Joseph-Vincent Ducatillon, Le vrai et le faux patriotisme (Paris: Editions 'Spes', 1933).

14 AN F7/13352. Gouvernement Militaire de Paris, Etat-major, Commissariat Spécial, unsigned typescript dated Paris, 2 December 1932. 
conscientious objectors, if not approve of them. General Niessel, moreover, intervened before the lecture of 15 December in an analagous sense to signal the danger from the military point of view.

Thus, when Father Ducatillon, after having linked his preceding lectures to this one, spoke of the responsibilities of the politician in the face of war, and of the duties of the simple citizen, those in the audience who had followed the previous lectures were not a little astonished to see that the normal conclusion demanded by all of the preceding argumentation was set aside. ${ }^{15}$

Instead, Ducatillon concluded rather lamely by saying that while the Church had never officially pronounced on the subject of conscientious objection, all indications were that it would condemn it. As the report writer noted rather ironically, this statement appeared to contradict the contentions of a book entitled La Papauté et les questions internationales, published by the Institute and on sale in the foyer immediately outside Ducatillon's lecture theatre. In a chapter entitled 'For the suppression of military service' one could read that in the pontifical plan, general disarmament was to be realised by the suppression of military service. ${ }^{16}$

Having achieved its desired ends, the General Staff proceeded to rub salt in the wound, using Ducatillon's 'conclusions' to full effect. In an article in Le Figaro of 31 January 1933, General Niessel responded to charges by a Protestant pastor that the Pope and the Paris Dominicans were preaching conscientious objection by citing the 'correct' conclusions drawn by Ducatillon. 17

These, then, were the immediate antecedents of the Chautemps Circular of 26 January. One week elapsed between the transmission of Daladier's circular to the Generals and Chautemps' parallel circular to the Prefects which is almost a textual duplicate of Daladier's. Chautemps enjoined the Prefects to co-operate fully with the military authorities in the 'struggle against this dangerous propaganda'. Thus, despite the initial letter of 9 January 1933 from the Minister of the Interior, the Chautemps Circular is really something of a misnomer. The War Ministry seemed to be far ahead of the Interior Ministry in its surveillance of and thinking on conscientious objection, and it was largely Daladier's

15 AN F7/13352. '5ème Conférence. Le Devoir Patriotique en Face de la Guerre (Objection de Conscience)', 20 December 1932; and 'Suite à une précédente note sur l'Objection de Conscience', 20 December 1932. Both reports are in a file marked 'Documents Secrets du GMP Objection de Conscience'.

16 Ibid.

17 Le Général A. Niessel, 'Le Patriotisme et l'Objection de Conscience', Le Figaro, 31 January 1933. 
wording over the hapless Chautemps' name which would create the scandal in the Press when the Chautemps version was leaked on 1 May 1933.

But that is to leap ahead somewhat. What fruits did the Chautemps Circular bear? It asked the Prefects to report on the extent of the contagion within their departments. Was the Hexagon loyal or had it been contaminated by an effete Parisian disease? Judging from the initial responses of the Prefects alone, one might safely conclude that not only was France loyal, but also completely oblivious of the very existence of something called 'conscientious objection'. Only six prefects - those of the Indre, Bouches-du-Rhône, BasRhin, Ille-et-Vilaine, the Savoie, and the Calvados - reported any prior knowledge or awareness of C.O. activity in their jurisdictions. Twenty Prefects insisted that no such nefarious propaganda or activity had ever existed in their departments. ${ }^{18}$ Some seemed to take it almost as a question of departmental honour. From Corsica one reads, 'I believe it necessary to inform you right now that no movement of this kind, up to now, has manifested itself in my department. Moreover, Corsica, which furnishes a considerable number of volunteers to the metropolitan and colonial armies, appears to me to be the least likely of all the French departments in which such a campagin would have any success'. The Prefect of the Vendée was even more emphatic: 'Already I think it possible to affirm that the propaganda in favour of conscientious objection will obtain no success amongst the Vendéen population which has always shown the greatest respect for the law as well as an enlightened patriotism'.19 The remaining sixty-odd Prefects merely acknowledged receipt of the Circular, making no mention of any activity at all. Was this then, a tempest in a Parisian teapot, a case of Action Française-induced paranoia chez MM Chautemps et Daladier?

Not wishing to sound unnecessarily ambiguous, the answer is probably both 'yes' and 'no'. Affirmatively for a number of reasons. First, there is little doubt that the view from Paris has often had a curiously magnifying effect on certain aspects of French political history, and it is safe to say that the various permutations and combinations of the French peace movement by and large had their focus in the capital and its environs. Thus, what was true for Paris might not have applied elsewhere in the country. Secondly, the number of bona fide objectors prepared to go to prison for their beliefs was, and would remain, rather small. Finally, the Government and the right-wing press tended to confuse conscientious objection with the larger peace or pacifist movements. People such as Marc Sangnier who did not personally support objection but rather maintained in more general,

18 AN F7/13352. 'Le Ministre de l'Intérieur à Messieurs les Préfets', Paris, 26 January 1933. See this same file for the subsequent Prefectoral responses.

19 AN F7/13352. 'Monsieur le Préfet de la Corse à Monsieur le Ministre de l'Intérieur', Ajaccio, 1 February 1933; 'Monsieur le Préfet de la Vendée à Monsieur le Ministre de l'Intérieur', La Rochesur-Yon, 1 February 1933. 
internationalist terms that 'si vis pacem, para pacem', were painted with the same black brush by the Action Française as the most hardened, libertarian of objectors such as Gérard Leretour. By equating conscientious objection automatically with pacifism, the Government could very easily have taken fright, because the peace movement had been growing steadily since about 1928 in France. But the distinctions between pacifism and conscientious objection were blurred - indeed there was much debate amongst pacifists themselves about the efficacy of objection. Conscientious objection was a sub-set of pacifism and hardly a genuinely independent movement, although there were signs that it could become one.

But in fact, there was cause for concern. Though small in numbers, the fact that men were willing to incur harsh prison sentences for their beliefs in time of peace, with little immediate prospect of war, indicates a groundswell of opposition to military service for whatever reasons. Comparisons with Germany or Britain at this time are really rather meaningless - neither country had mandatory military service. Thus, one could quite cheerfully sign a pledge never to take up arms, or happily support flaccid young Oxford in its resolution 'under no circumstances to fight for King and Country' - because if war clouds were distant and if conscription did not exist, it was almost a non-issue. But in France it did matter. Conscientious and conscious refusal to submit to military law, as opposed to desertion which was widespread, brought upon one the swift and sure wrath of the Third Republic. So conscientious objection was important - as the numbers of objectors increased, the Government might well conclude that traditional support of the Republican Army was being eroded to the Nation's great peril. The Government might have confused conscientious objection with the various forms of pacifism, but the pacifist movement was certainly beginning to make its presence felt. A pacifist press had sprung up, eminent personalities were involved, and 1932 had been a year of great peace crusades centred around the Geneva Disarmament Conference. Some of the campaigns and speaking tours continued into the winter of 1932-1933. This great desire for peace undoubtedly begat some conscientious objectors, how many it is difficult to tell. Finally, though, when a rock is turned over, one usually finds far more activity than on the surface. So it was with the Chautemps Circular.

The Interior Ministry files contain literally scores of subsequent prefectoral reports on conscientious objection from all comers of France for the period February to the end of May 1933. Strangely, the reports seem to cease thereafter - while there continues to be some material on conscientious objection, mostly in the form of internal memoranda or police reports, right up to 1935, the great swell of interest in the subject, at least from the departmental point of view, ceases in late May 1933. No follow-up circular from the Minister of the Interior exists in the file to explain this sudden halt to a programme of surveillance which was turning up a great deal of interesting material. One can only guess 
that word might have gone out from Paris to stop the investigations in the wake of disclosure of the circular in the press in early May 1933. This is hardly likely, however, since a good proportion of the press supported the Government in its campaign against this 'anti-national' sentiment.

What did the Prefects discover when they examined the question more closely? A number of departments continued to report no conscientious objection propaganda or activity within their jurisdictions. However one should note that these reports were sometimes ambiguous, and often contained errors of interpretation or fact. Some police commissaires and sub-prefects were clever enough to distinguish between the existence of pacifist or peace groups within their locales, and groups of individuals committed to the extension of conscientious objection. For example, the Divisional Special Police Commissaire at Lille, in a report to the Prefect of the Nord, wrote that:

There exists no group or isolated personalities in the Lille area openly manifesting any propaganda in favour of conscientious objection. Nevertheless, through excess of pacifism, the refusal of military duty through conscientious objection is admitted in certain Protestant circles which base themselves on the laws of the Church, and by the Ligue des Droits de l'Homme et du Citoyen which considers this refusal inherent in individual liberty and a means of avoiding the return of war.

And here he cited Pastor Henri Roser of the International Fellowship of Reconciliation and F. Corcos of the Court of Appeal in Paris, who had both spoken at meetings in the Lille area. Both Roser and Corcos actually supported conscientious objection, however. In like manner, the sub-prefect of Douai could report on 7 February that there was no C.O. activity in his jurisdiction, but that Pastor André Trocmé, who was actually a proponent of objection, had been speaking publicly merely in favour of peace. The Prefect of the Loire wrote on 11 February that C.O. activity was almost nil but that a plethora of pacifist groups existed in his department. On 21 February, the Prefect of the Mayenne reported no conscientious objectors but noted the existence of a local section of the Ligue Internationale des Combattants de la Paix which had around 200 members. As we shall see shortly, it was the propaganda of some of the leading members of the LICP which was causing much of the concern in Paris. It was, in fact, a rare Department which would boast neither conscientious objection nor the presence of some of the pacifist organisations most likely to induce it as a result of their own propaganda. 20

20 AN F7/13352. 'Le Commissaire Divisionnaire de Police Spéciale à Lille à Monsieur le Préfet du Nord', Lille, 16 March 1933; 'Le Commissaire Spécial Vantomme à Monsieur le Sous-Préfet', Douai, 7 February 1933; 'Le Préfet de la Mayenne à Monsieur le Ministre de l'Intérieur', Laval, 21 February 1933. 
Most Prefects reported some activity or sympathy for conscientious objection. For some, it was an easy case of enumerating those who had refused their reserve mobilisation papers and would therefore be serving short sentences in the local army garrison gaol. Other prefects reported genuine cases of young conscientious objectors, refusing all military service for the first time. For the vast majority, however, it was propaganda in favour of conscientious objection which preoccupied them. One is struck by the scrupulous detail of the reports which made their way to Paris. It seemed that every insignificant primary school teacher, postman, or shoemaker who held seditious views or had merely expressed sympathy for the plight of men and families caught in the trap of conscience, were all carefully noted down and sent to the Ministry. An example of this is a report on a Professor Choski of the Lycée in Oran, Algeria, who had delivered a lecture dealing with conscientious objection in a favourable light to his mathematics class on 29 March. Jaurès, Einstein, and the Oxford Union debate all figure in the notes of a schoolboy's cahier which formed the basis of a report written by the Oran Division Commanding General and passed on to Chautemps through the Governor-General of Algeria in mid-May. ${ }^{21}$

The Ligue International des Combattants de la Paix played a key role in the campaign in support of conscientious objection, despite the fact that it had no official policy on the matter and its membership was divided on its efficacy. That notwithstanding, several of its key speakers and organisers, notably Georges Pioch, René Gerin, Marcelle Capy and Jeanne Humbert, were of great concern to the authorities because of their extreme views on the subject. A lecture by Pioch on conscientious objection, scheduled for February, was cancelled by the Prefect in Strasbourg on the advice of the Interior Ministry which feared, it seems, the spread of this idea in border areas, especially Alsace-Lorraine. Pioch spoke nevertheless, two weeks later, but on a thinly disguised different topic: 'Poets against War'.22

René Gerin was probably the most indefatigable and dangerous of the LICP propagandists, however. This Parisian journalist, Chevalier of the Legion of Honour, an ancien Normalien, and Agrégé en Histoire, covered most of France in the winter and spring of 1933 in his campaign for peace, speaking regularly before crowds of 250 to 1000 people. On March 13th, Gerin and Henri Guilbeaux spoke before an audience of 2500 people at Limoges, and in a circumspect tone, Gerin had this to say about conscientious objection:

21 AN F7/13352. 'Le Général de Division Guedeney, Commandant la Division d'Oran à Monsieur le Général Commandant le 19e CA Alger', Oran, 31 March 1933. Forwarded to the Minister of the Interior only on 12 May 1933 by the Governor General of Algeria.

22AN F7/13352. 'Rapport de l'Inspecteur Principal Léonard sur la Conférence Faite à Strasbourg par M Georges Pioch', Strasbourg, 22 February 1933. See also 'Rapport', Commissariat Spécial, Strasbourg, 22 February 1933. 
There are young people whom I would not advise to refuse to join their regiments, but if they did so, I should support them and take their defence.

\begin{abstract}
Above all I advise men of my age, who like me have already been at war, to refuse all military papers which might come their way. On receipt of their mobilisation papers they have only to follow my example and return them to Monsieur the Minister of War. Having done that, I have suffered no sanction and those would do it will be no more troubled than $\mathrm{I}^{23}$
\end{abstract}

Pioch, too, when asked directly in public whether he counselled conscientious objection would only say that it was a delicate question which had to be answered by each person individually since the consequences were potentially very serious. ${ }^{24}$

Some LICP groups debated collective objection as a means of resistance to war, but seemed chary of actually putting match to tinder. On 4 March the Caen section of the LICP discussed the question after one member suggested a massive, organised return of all members' mobilisation papers. According to the police report, the President of the section replied that 'the number of conscientious objectors' is not yet strong enough for that, and he feared that the result obtained might be the complete opposite of that hoped for. He put his conclusions to the vote; they were adopted unanimously. It was decided to postpone until later the return of mobilisation papers'. 25 Small consolation for the government, though, which could only see that the LICP was organising a most effective and widespread pacifist propaganda campaign which touched all corners of the Hexagon.

Some Prefects took matters into their own hands in an attempt to eradicate the problem. The Prefect of the Vosges, for example, informed the Minister on 10 March that all C.O.s and articles in the press encouraging the military to disobedience were being pursued to the fullest extent of the law. Further, he announced that all active propagandists would have their names inscribed in the Carnet B. If they happened to be of foreign nationality, he would begin expulsion proceedings. Finally, he intended to ban all lectures or meetings called for the purpose of expounding publicly the 'doctrine of conscientious objection'. ${ }^{26}$ The final point is an ambiguous one. Despite the cancellation of Pioch's talk in Strasbourg, the Ministry seemed somewhat reluctant to cancel public meetings outright. The Prefect of the Calvados, whose department seemed to be a veritable hotbed of anarchist/libertarian conscientious objection, asked on several occasions for permission to employ strong-arm

23 AN F7/13352. Report from the Commissariat Spécial de Limoges, 14 March 1933.

24 Loc. cit. Léonard report, Strasbourg, 22 February 1933.

25 AN F7/13352. 'Le Préfet du Calvados à Monsieur le Ministre de l'Intérieur', Caen, 6 March 1933.

26 AN F7/13352. 'Le Préfet des Vosges à Monsieur le Ministre de l'Intérieur', Epinal, 10 March 1933. 
methods such as the banning of meetings at which well-known speakers of the LICP would be present. Finally, on 31 March the Ministry replied that 'the law does not permit the banning which he desires - but that he does have the right to delegate a police commissar to sit on the rostrum and take notes on statements liable to provoke judicial action'.27 Perhaps the situation in Algeria was different, because there in late May, the GovernorGeneral on his own authority banned public lectures by René Gerin before audiences comprising members of the indigenous population, and would permit him to speak only in centres of European settlement and even then only on condition that his talks not be advertised publicly by poster. 28

This apparently vast campaign in favour of conscientious objection was accompanied by a vicious counter-campaign in the nationalist and right-wing press which spilled easily into the streets, especially at public pacifist meetings in the Paris area. If some of the objectors, in particular Gérard Leretour, were guilty of wild and irresponsible rhetoric, the police files make equally clear to what lengths the Camelots du Roi and the Croix de Feu were prepared to go to combat it. As Jean-Baptiste Lhérault, one of the leaders of Gustave Hervé's national socialist militia, wrote with reference to Gérard Leretour in La Victoire on 1 March: 'We have well and truly decided not to let our disciplines be sapped, and if this individual is bent on commercialising his act of cowardice, we shall know, with all Frenchmen who understand the cult of the nation, how to remind [people] with arguments which our conscience will dictate, and with no objection, that we will have respected by all means that which is sacred for us: our patriotism. Lookout Leretour!'.29 Words were put into action on several occasions and the Action Française gloried in its often successful disruptions of pacifist meetings, whilst at the same time slinging barbed attacks at a government which it perceived to be soft on conscientious objectors. Titles such as 'At Charenton: a lesson for M. Daladier, protector of the conscientious objectors"'(19 February, 1933); or 'M. Daladier's police at the service of the traitors and conscientious objectors' - an article of 4 March complaining about what was in fact only a modicum of rather ineffectual police protection for a Leretour meeting in the Salle Bullier; or on 7 March: 'The Camelots $d u$ Roi prevent the meeting of the "objector" Leretour and send his worthy friends packing' ${ }^{30}$ With attacks such as these in the right-wing press, it would be easy for the public to conclude that little was being done about an increasingly visible problem.

27 AN F7/13352. Manuscript note of 30 March 1933 attached to letter of 28 March 1933 (Préfet du Calvados à Monsieur le Ministre de l'Intérieur). Response sent on 31 March 1933.

28 AN F7/13352. See telegrams of 10, 28, 29 and 31 May 1933 from Governor-General of Algeria to Minister of the Interior. See also telegraphed response of 'Intérieur Affaires Algériennes a Gouverneur Général et Securité Générale Alger', 11 May 1933.

29 AN F7/13352. 'Note' ,Préfecture de Police, 1 May 1933.

30 'A Charenton. Une Leçon à M Daladier protecteur des objecteurs de conscience', Action Française, 19 February 1933; 'La Police de M Daladier au service des traitres et des objecteurs de 
The Prefectoral reports are useful in another way in that they provide a look at grassroots objectors and sympathisers. The material is sometimes sketchy, haphazardly collected and certainly not capable of supporting a full-blown quantifiable analysis, but certain admittedly impressionistic conclusions present themselves. Whilst it seems clear that the great propagandists and theoreticians of the movement tended to be Paris-based, well-educated, left-wing and middle-class, this could certainly not be said of the 'movement' as a whole. Indeed, in some areas, notably the Calvados and other parts of Normandy where the anarchist/libertarian strain of objection seemed to be strongest, one could even argue that local leaders were more important and influential than the great men of Paris. But with regard to the names which figure in the reports from across the length and breadth of France, one is struck by the variety of objectors and sympathizers. They vary from well-educated, middle-class businessmen, to liberals belonging to the Ligue des Droits de l'Homme, to simple farmers, to shoemakers, a great many teachers, both primary and secondary, secretaries, bakers, shopkeepers, and the list goes on. In Paris, the Freemasons seemed to play an important role for a time. These indications make it possible to suggest tentatively that Roger Chickering's conclusions about the middle-class basis of the pre-War French peace movement are not applicable to the interwar movement. 31

Given all this information, was the Government really worried about conscientious objection in 1933? There are two position papers in the ministry files on the subject. The first is dated 16 February 1933 and the second 19 April. The first report makes clear that it was not the number of objectors which worried the government; even in the case of war, the writer of the paper did not believe that the number of conscientious objectors would increase significantly. Nevertheless, he wrote, 'the campaign in support of conscientious objection in France has taken a not negligible development over the past few months', and he noted most disapprovingly that it made the citizen 'judge of his own opinions'. But if the danger did not lie in numbers, where did it lie? The report writer saw two great dangers in the C.O. movement. The first was 'the fact that, under the influence of the anarchists and Communists the idea of simple non-resistance, which is that of pure objectors, is being replaced little by little by that of rebellion. Rebellion is, moreover, envisaged differently by the anarchists and the Communists. For the former, it is the individual gesture, for the

conscience', Action Française, 4 March 1933; 'A la Salle Wagram. Les Camelots du Roi interdisent la réunion de 'l'Objecteur' Leretour et dispersent ses dignes amis', Action Française, 7 March 1933.

31 For details of the backgrounds of some objectors and sympathisers see: 'Le Mouvement en Faveur de l'Objection de Conscience en France' (Paris, 16 February 1933) and 'Liste des objecteurs de conscience et des personnes ayant défendu l'objection de conscience ou ayant manifesté de la sympathie pour les objecteurs identifies à la date du 15 avril 1933' both in AN F//13352. These two reports do not contain an exhaustive listing of all objectors or sympathisers known to the ministry. See also Roger Chickering, Imperial Germany and a World Without War. The Peace Movement and German Society 1892-1914 (Princeton: Princeton University Press, 1975), pp.327-383. 
latter, it is the mass movement. But whether it be under one form or another, thoughts of rebellion are winning the world of objection'. The second fear was that of defeatism, the destruction of national morale by a moral disease. 'One cannot say that their efforts have been in vain. Already several reserve officers have given their support to Conscientious Objection. And even in the case where direct action would not be sufficient to create disorder in a mobilisation, the propaganda might not remain without fruit in the aftermath. In essence, this campaign sows doubt in minds poorly placed to see and to understand. Even more, conscientious objection can serve as a cover for cowardice... Thus, this nefarious propaganda could be the source of a defeatism in the first few weeks of a war. And where will this defeatism end if the ravages of war and the hostilities are prolonged? A question which must be asked. There is here a disease capable of destroying the morale of the nation and enervating the force of its resistance' ${ }^{32}$

Two months later, in the report of 19 April, these basic observations were merely strengthened. The writer pointed out that in the interval, the number of objectors and sympathizers identified had doubled from ninety-five to 183 . Still, this was enough to qualify as a 'great development', Much of the credit for the expansion of the movement was given to the LICP which regularly attracted large crowds to its meetings. Not a single city of any importance in France had not been the site of an LICP meeting. The writer detected a growing current of selfishness in the expanding C.O. movement:

... the attitude of the greater part of the pacifists is evolving. As their "public" expands, they become more aggressive, and in their speeches, the "right of not endangering oneself" takes the place of the "duty not to shed blood". They are less attached to exalting a noble ideal than they are to awakening and strengthening sentiments of utility and individual preservation. There is here a danger for the morale of the Nation of a potentially grave nature. 33

Thus, of immediate concern to the Government was the threat of nascent defeatism, incipient rebellion and a growing selfishness which denied national values. Notes such as one dated 2 May 1933 from an informer with good contacts in the LICP could still be a trifle shocking. According to this source, the LICP 'estimates at 300,000 the number of mobilisable men who, touched by the propaganda of this organisation in France, are liable to return their mobilisation papers or destroy them in the event of a direct threat of armed conflict'. 34

The saga of the Chautemps Circular exploded into the public domain on 1 May 1933, when the Echo de Paris, a conservative Paris daily, published the text of the circular under

32 AN F7/13352. See ibid., 'Le Mouvement en Faveur...' (report of 16 February 1933).

33 AN F7/13352, short report dated 19 April 1933 attached to 'Liste des objecteurs...'.

34 AN F7/13352, PJ/5 A-3870, 'D'un Correspondent' Paris, 2 May 1933. 
the title: 'The Sabotage of the National Defence, a confidential circular from the Minister of the Interior to the Prefects'. The disclosure of the circular set off a furore in the press. Whilst almost all newspapers supported the campaign against the conscientious objectors, and indeed against pacifists of almost any hue, there was great discussion as to why it had taken the government so long to discover their existence. The Action Française, unaware of the antecedents of Chautemps' letter to the Prefects, thought it most reassuring that the Sureté Générale appeared not to have known anything about the problem, but rather had been informed of it by the Minister of War. Daladier came in for attack as a man whose right hand did not know what his left hand was doing. On the one hand he was trying to suppress a growing campaign in favour of conscientious objection, and on the other he had given pardons to Gerard Leretour in February and to Jacques Martin in April - both of them conscientious objectors convicted by Military Tribunals. The Catholic newspaper L'Aube demanded and received an apology from Daladier for being painted with the same pacifist black brush as other genuinely pacifist papers. Le Figaro and Ordre both supported the government. L'Humanité condemned both the government and the conscientious objectors, predictably enough. Only Le Quotidien and La République raised important questions about freedom of speech, Albert Bayet suggesting in a measured and thoughtful article in the latter that the debate be removed from the party political plane to the moral and philosophical level for further discussion. ${ }^{35}$

This was expressed in even more forceful terms on 12 May in a resolution of the Central Committee of the Ligue des Droits de l'Homme which condemned the Government's attack on freedom of speech and freedom of conscience and called for the creation of an alternative civil service as a mechanism for dealing with men who for reasons of conscience refused all military service, whilst nevertheless reiterating the Ligue's position that conscientious objecton was inefficacious. 36

35 'Le Sabotage de la Défense Nationale. Une Circulaire confidentielle du ministre de l'intérieur aux préfets'. Echo de Paris, 1 May 1933. For reaction in the press, see: G. Larpent, 'La Politique. I. La circulaire Chautemps. II. Les instructions aux généraux. III. Indignations tardives. IV. Une Circulaire pour rien'; in Action Française, 2 May 1933; Léon Daudet, 'A Propos d'une circulaire', Action Franf̧aise, 2 May 1933; Louis Sauchon, 'Contre les Objecteurs de conscience', Le Figaro, 3 May 1933; Emile Buré, 'Le retour au bon sens', Ordre, 2 May 1933; 'Une Circulaire contre les défaitistes. La propagande des objecteurs deconscience', Le Figaro, 2 May 1933; 'Contre une inqualifiable agression. Une lettre de "l'aube" à M Edouard Daladier', l'Aube, 2 May 1933; Bernard Auffray, 'L'Objection de Conscience est pire qu'un crime, c'est une sottise', Ordre, 2 May 1933; 'Le Sabotage de la Défense Nationale. La Presse et la Circulaire de M Chautemps', Echo de Paris, 3 May 1933; Albert Bayet, 'L'Objection de conscience', La République, 4 May 1933; André Ferrat, 'En guise d'amnistie!', L'Humanite, 4 May 1933; 'A l'Institut Pie XI des Volontaires du Pape devant le RP Gillet les objecteurs de conscience sont hués par les patriotes', Action Française, 5 May 1933; 'Les objecteurs de conscience', Le Quotidien, 6 May 1933; etc. Articles of this sort continued in the Parisian press until at least the middle of May.

36 An F7/13352. 'La Ligue des Droits de l'Homme et l'Objection de Conscience. Projet de résolution sur la Circulaire ministérielle relative à l'Objection de Conscience'. Note of 12 May 1933. 
The debate was quickly picked up by the provincial press and continued into late May. News of the Circular even spread as far afield as the New York Times. ${ }^{37}$ A majority of provincial papers supported the government but there was vigorous discussion of the apparent slur against Catholics in the Circular, and local issues could present interesting variants on the national pattern. For example, on 10 May a Military Tribunal condemned a young man by the name of Armand Rolland to one year in prison for refusal of military service. This provoked a good deal of opposition to the harshness of the government's position and sympathy for Rolland and his family in several newspapers in the Loire Valley. 38

It remains something of a mystery who leaked the Circular to the Echo de Paris. A memorandum in the Interior Ministry files claims that it must have been leaked by someone in the General Staff, or more likely, in the Ministry of War. Several figures at the War Ministry were known to have close contacts at the conservative Echo de Paris. Furthermore, the version of the Circular reproduced in the press carried the marking 'Secret', a classification apparently not in use in the Interior Ministry. Some parts of the press initially thought that Chautemps was trying to embarrass Daladier publicly, but it appears more likely that Daladier (or someone else in the War Ministry?) was goaded into leaking the document by the continual charges of weakness hurled at him by the right-wing press. 39

Whilst the Interior Ministry files fall almost silent on the problem of conscientious objection after May 1933, there continued to be much interest in the subject in the Rue St Dominique. A note of 26 December 1933 indicates that the matter was discussed at a meeting of the Council of Ministers and that subsequently a working party from the Ministries of Justice and War agreed to submit amendments to the law of 31 March 1928 on recruitment to the Army to the next sitting of the Chamber of Deputies. Whereas the old law had only penalised people who were convicted of actually materially impeding a

37 'France combats spread of Conscientious Objection','New York Times, 1 May 1933.

38 See for example: 'Ça devait arriver. Les Catholiques compromis par la folie d'un Francisque Gay et de son "Aube"'. La Province, 23 May 1933; Armand Terrière, 'A propos d'une circulaire ministérielle. Le Patriotisme et le Pacifisme des Catholiques' Le Nouvelliste de Bretagne, 3 May 1933. For the debate in the Loire valley surrounding the trial of Armand Rolland, see: 'Au Tribunal Militaire. L'Objecteur de Conscience Roland (sic) est jugé. Le Procès de M Daladier', Le Petit Orléanais, 14 May 1933; 'Au tribunal militaire. L'objecteur de conscience Armand Rolland explique son refus de porter les armes', La France du Centre, 11 May 1933; 'L'Objecteur de hohscience Armand Rolland devant le tribunal militaire', Le Républicain Orléanais, 11 May 1933; 'Tribunal Militaire d'Orléans. Le procès de l'objecteur de conscience', La France du Centre, 12 May 1933; 'l'Objecteur de conscience', Le Journal du Loiret, 11 May 1933; 'l'Objecteur de conscience', in ibid., 12 May 1933.

39 For the theory that Chautemps was perhaps behind the leaking of the Circular, see 'Les Objecteurs de Conscience', Le Quotidien, 6 May 1933. A reply to this can be read in 'Contre les objecteurs de Conscience', Action Française, 7 May 1933. See also the internal 'Note Confidentielle' of 2 May 1933 probably written in either the Sureté Générale or perhaps in Chautemps' own office - in AN F7/13352. 
mobilisation, the proposed amendment to Article 91 extended the offence to anyone found guilty of 'provoking disobedience or the return of mobilisation papers', whether or not this propaganda or provocation actually led to the act in question - in effect creating a délit d'opinion. The penalities envisaged for recalcitrant reservists were harsher by several degrees of magnitude. Whereas previously purely disciplinary penalties of four or eight days in the local garrison gaol were provided for men who could not produce their reserve or mobilisation papers, the amended version of Article 92 laid down penalties of between six months and three years with a fine varying from 100 to 3000 francs and the potential removal of one's civic rights for five years attached for good measure. 40

Daladier submitted these amendments to the Minister of Justice in early January 1934. The government wanted to slip this bill through the Chamber with as little fuss and debate as possible, 'having as its sole object the stopping of the most dangerous manifestations of the systematic propaganda which appears to have been organised for some time against the fulfilment of their military duties by French citizens.' The harshness of the penalties envisaged was justified by the Ministry's fear that C.O. propaganda could conceivably compromise a mobilisation order. 41

The events of 6 February intervened however, and removed Daladier from office. Not surprisingly, the new War Minister, Marshall Pétain, was equally interested in stamping out the effects of the C.O. 'movement', as a note from him to the President of the Army Commission in the Chamber makes abundantly clear. The Army Commission agreed with the government's analysis of the situation and the proposed amendments in a report dated 21 February. On 2 March the Chamber's Civil and Criminal Legislation Commission recommended that the penalties suggested in the amendments be reduced to between one month and one year. The Government and the Chamber's Army Commission agreed with alacrity, such was the desire to see the amendments become law. Despite the opposition and counter-amendments of the deputies, Chouffet and Planche, both of them pacifist sympathisers, the amendments were finally passed by the Chamber on 30 June, by the Senate on 5 July, becoming law on 8 July, 1934.42

40 Service Historique de l'Armée de Terre (hereafter cited as SHAT), Château de Vincennes, 6N468/Dossier 4. 'Note pour le Secrétariat Général Travaux Législatifs', 26 Décembre 1933.

41 Ibid., 'Le Ministre de la Guerre à Monsieur le Garde des Sceaux, Ministre de la Justice', 8 January 1934.

42 Ibid., 'Philippe Pétain à Monsieur le Président de la Commission de l'Armée de la Chambre des Députés', 16 February 1934; 'Rapport no. 3086 ('Annexe au procès-verbal de la 3e séance de la Chambre des Députés du 21 février 1934) fait au nom de la Commission de l'Armée... par M Albert Forcinal'; 'Avis (no. 3157, Annexe au procès-verbal de la séance de la Chambre des Députés du 2 mars 1934) présenté au nom de la Commission de la Législation Civile et Criminelle par M Georges Pernot'; 'Rapport Supplémentaire (no. 3286, Annexe au procès-verbal de la séance de la Chambre des Députés du 15 mars 1934) au nom de la Commission de l'Armée ... par M Albert Forcinal'; 'Note sur l'amendement de M Chouffet, Député, 29 juin 1934; and M Jean Taurines' (Annexe au Procèsverbal de la séance du Sénat du 3 Juintia34). 
All of this seems to coincide with Pétain's thinking on the nature of French education and military preparedness. The army was concerned about the direction of events in Europe and France's ability to 'enforce respect for a state of peace which she herself would not disturb'. As Pétain wrote in a memorandum of 26 March 1934, 'the education of the race is too much neglected. Youth and children are not educated with a view to their duties: this is what must be remedied first of all, through a better pre-military preparation of youth and by a primary system of education which guarantees health of body and mind to the child. We ought to draw inspiration on these two levels from what is happening in Germany and Italy'. 43

Perhaps the most significant and interesting effect of the disclosure of the Circular, though, was within the pacifist movement itself. Far more than Action Française harassment or police surveillance had ever done, the ideological and tactical rifts opened up by disclosure of the Circular were of enormous import. As has already been mentioned, there had always been debate within the LICP and other pacifist groups about the efficacy of conscientious objection, individual or collective. These now came to a head. Eugène Lagot, the Secretary of the newly-formed Conscientious Objectors' League, tried to convince the officers of the LICP to strike while the iron was hot and government defences down, to mount a campaign to generalise his colleague Leretour's gesture into a nationwide movement in the true sense of the word. Here courage failed the LICP, and with a collective shiver of cold feet, the grand idea died. In a scathing article entitled 'Sous le Signe de la Peur' (Under the Sign of Fear) published in Le Semeur on 22 July, Lagot denounced the failure of nerve of the LICP in the face of obvious government oppression and fear, and the general tendency of the pacifist movement to content itself with meaningless rhetoric and big public meetings. Lagot, Leretour and their Conscientious Objectors' League struggled on by themselves for two more years until they were ordered to cease and desist in a court dissolution order early in 1935.44

The Circulaire Chautemps makes clear that the French government was becoming very concerned by 1933 about the growth of the peace movement and its effects on public opinion. Conscientious objection was but an easily identifiable sub-set of this larger phenomenon which in its virulent anarchist/left-wing forms presented special problems. The observation by the Interior Ministry memorandum writer cited above that the 'movement' was becoming more interested in simple self-preservation and less in high-minded moral valour rings true: then again, in a country whose soil was still damp from the blood of the

43 SHAT 5N577(2). 'Notes du Maréchal Pétain pour le chef de l'Etat-major général de l'armée sur "les idées maîtresses qui doivent inspirer l'organisation de la défense national"', 26 March 1934.

44 Eugène Lagot, 'Sous le Signe de la Peur', Le Semeur, 22 July 1934. See also Notes of 22 December 1934, 2 January and 5 January 1935 on the dissolution of the Ligue des Objecteurs de Conscience from the Préfecture de Police - contained in AN F7/13352. 
Great War, the former position is perhaps understandable if not admirable. The Chautemps Circular seems to point out the dichotomies and contradictions in the interwar French attitude towards the Army, the State, and the Individual. Jean-Jacques Becker's comment that the French perception of the Army had undergone a major change in the period 1870 to 1914 can probably be extended to the interwar period as well. No longer did the French quite as readily accept the burden of service in the glorious Republican Army. But equally as well, French political and military society was not prepared to accept the validity of the Napoleonic dictum, so often cited by the pacifist press, that 'the reign of the Nation ceases where begins the reign of conscience'. It would be another thirty years before the old anarchist Louis Lecoin would in his famous hunger strike of 1963 force General de Gaulle to agree to legislation creating a French statute for conscientious objectors. ${ }^{45}$

45 On changing French attitudes to the Army (and within the Army), see Raoul Girardet, La Sociéte militaire dans la France Contemporaine (1815-1939) (Paris: Plon, 1953). See also Jean-Jacques Becker, Le Carnet B (Paris: Klincksieck, 1973), pp.13-16. On Louis Lecoin and the 1963 Statute for Conscientious Objectors, see Jean-Pierre Cattelain, L'Objection de conscience (Paris: Presses Universitaires de France, 3rd edition, 1982), pp.50-56; and Auvray, op. cit., pp.243-260. 


\section{APPENDIX II}

\section{Romain Rolland, Interwar Pacifism and the Problem of Peace. ${ }^{1}$}

Famous for his stubborn stand au-dessus de la mêlée against the folly of the First World War, for which he earned nothing but the bitter opprobrium of both his native France and of the Germany he loved, Romain Rolland[1866-1944] had become by 1918 France's most renowned pacifist and the 'Conscience of Europe.'2 Winner of the 1915 Nobel Prize in Literature for his ten-volume novel sequence, Jean-Christophe, Rolland had already completed a good portion of his life's work by 1918 . Indeed, in many respects he had become part of the 'older' generation before the war began - neither by inclination nor outlook did he belong to the 'generation of 1914' described in such fascinating detail by Robert Wohl. ${ }^{3}$ Rolland incarnated the intellectuel engagé of the 1920s and 1930s long before Sartre ever popularized the phrase. As Wilhelm Herzog wrote in the 1926 special number of Europe dedicated to Rolland on the occasion of his sixtieth birthday, he was

a man who does not simply want to 'do' literature. Rather, [he is] a man who wishes to help in bettering this miserable world, to transform its anarchy into an order inspired by reason... Certainly not a Marxist. But a man who, nevertheless, adopts the critical conclusions and the categorical imperative of Karl Marx..4

1 This appendix was originally read as an invited paper at the American-European Consultation on Peace Research in History held at Stadtschlaining, Austria from 24-29 August 1986. It is to be published in Charles Chatfield and Peter van den Dungen, ed., Peace Movements and Political Cultures (Knoxville: University of Tennessee Press, in press). It is largely based on the author's M.A: major research essay at the University of Toronto which was supervised by Professor John C. Cairns.

2 Romain Rolland, Le Périple avec une Préface de Maurice Betz (Paris: Editions Emile-Paul Frères, 1946), p. 148 (hereafter cited asPériple). Unless otherwise indicated, all translations in this appendix from the French or German are the work of this author.

3 Robert Wohl, The Generation of 1914 (London: Weidenfeld and Nicolson, 1980), p.15.

4 Wilhelm Herzog, 'Témoignages à Romain Rolland', in Europe (No. spécial consacré à Romain Rolland), 38 (15 February 1926), 165-66. 
Committed to social justice and the principles behind the Russian Revolution, Rolland nevertheless declared in 1927 that 'Bolshevism had destroyed [high ideals] by its narrow sectarianism, its inept intransigence, and its cult of violence. It has engendered fascism which is Bolshevism in reverse. ${ }^{5}$ And yet, by the beginning of the $1930 \mathrm{~s}$, Rolland, to the surprise of many, had 'sudden[ly] and inexplicabl[y] conver[ted] to the communist cause'6. As David Caute says, 'no other idealist writer leapt as abruptly into the arms of Bolshevism as did Rolland.7 Clearly, Rolland, too, was susceptible to the 'rhetoric of his time'. But he was not alone. His remark in the Prologue to Quinze Ans de Combat [published in 1935] that 'the "I" of which I recount the evolution is not me: it is the whole age to which we belong', rings very true. 8

His first post-war fictional hero, Clérambault, in the novel of the same name [1919], became in Rolland's own words, 'the apostle and the martyr of those who refused to bend their spirit to the inevitability of the violence which was being let loose over the whole world... it became the gospel, the rallying point for all French conscientious objectors who were still rather uncertain about their faith'.9 In response to a critique of his interwar novel sequence, L'Ame enchantée [1921-1933], Rolland wrote in 1935 that its theme 'is the negation of war', and he goes on to say that 'this refusal is still, to this very day, the basis of all my social ideas, as well as of those of our Soviet friends'. ${ }^{10}$ The fight against war was not an isolated one for Rolland, however. Intimately and irrevocably allied to it was the categorical imperative of social revolution referred to by Herzog above. As the interwar period progressed this second tenet of Rolland's credo assumed increasingly large proportions. But looking back in 1940 on the early Thirties, as he wrote his spiritual testament ${ }^{11}$. Rolland insisted on the binary nature of what he called his 'extraordinarily perilous task: to lead the opposition to war, which was a fundamental article of my code of social action, and the fight against international oppression'. ${ }^{12}$ In the crepuscular seclusion of Vézelay, with the dust of the Nazi invaders before him, he could write with some

5 Cited in Maurice Nadeau, 'Romain Rolland', Journal of Contemporary History, 2(April, 1967), 216. 6 Ibid.

7 David Caute, Communism and the French Intellectuals 1914-1960 (London: Andre Deutsch, 1964) ,p. 105. Hereafter cited as Caute.

8 Romain Rolland, I will not rest, translated from the French by K.S. Shelvankar (New York: Liveright, n.d,) p. 12. Hereafter cited as IWNR.

9 Ibid., 'Panorama', pp. 22-23.

10 Ibid., p. 43.

11 Périple, pp. 11-23. The words are Maurice Betz': 'Le Testament Spirituel de Romain Rolland Préface par Maurice Betz'.

12 Périple, p.151 
justification that 'I have never separated the struggle against capitalist and militarist imperialism from that for the defence of international peace ${ }^{13}$.

It is the purpose of this appendix to examine this 'perilous task' of Rolland's, to follow the evolution of his political thought on the problems of peace and pacifism, and to see how it was translated into concrete action in his relations with pacifist and war resistance organisations during the interwar years. As will become clear, this evolution was one from Individualism to Collectivism, from one 'above the battle' to one in its very thick, 'du Rêve à l'Action'. This process can be divided into three distinct periods: the first from the Great War to about 1924, the second from then until the early Thirties, and the final period from about 1932 to the outbreak of war in 1939.14

\section{The Rejection of Violence (1914-1924)}

Rolland's individualistic position as the defender of civilization and justice dominates the first period in our narrative. He spent the war years in Switzerland where he happened to be in July 1914, and it was from his Swiss retreat that he issued the periodic articles which earned him the general hatred of all sides in the conflict. The most famous of these was also the first, entitled 'Au-dessus de la mêlée' (Above the Battle) -a title he was to regret in later life. In it, Rolland, the independent man of thought declared that 'for us, the artists and poets, priests and thinkers of all countries, remains another task. Even in time of war, it remains a crime for finer spirits to compromise the integrity of their thought... 15 He laid the blame for the great European bloodletting at the feet of the rulers, and declared that there was no fatality about war: 'The only fatality is what we desire;and more often than not, what we do not desire enough ${ }^{16}$. The war years show us a Rolland committed to individualism, independence of thought, and internationalism, and who rejected categorically the war and all forms of historical determinism. In the famous

13 Ibid., p.152

14 Readers should take note of three articles by David James Fisher which differ from this author's periodisation of Rolland's pacifist activity but which nevertheless provide an interesting analysis of the period up to 1925. See David James Fisher. 'The Rolland-Barbusse Debate' in Suroey. A journal of East and West Studies, Spring/Summer 1974 (20,2/3), 120-159. See also: 'Romain Rolland and the popularization of Gandhi: 1923-1925', Gandhi/Marg, July 1974, Pp.145-180. See also: 'Pacifism and the Intellectual:The Case of Romain Rolland', Peace and Change: A Journal of Peace Research, Winter 1982 (VII,1/2), 85-96.

15 Romain Rolland, Above the Battle, translated by C.K. Ogden (Chicago: The Open Court Publishing Company, 1916), p. 53.

16 Ibid., p. 42. 
interview with the republican German journalist, Hermann Fernau in July 1918, shortly before the close of the war, Rolland stated:

I belong to no political party. Before the war I was invited several times to join pacifist organisations. I was unwilling because this official pacifism seemed childish to me, as long as it did not declare itself revolutionary and republican.- By profession an Historian, I am by nature in every sense an ndependent man of ideas. ${ }^{17}$

Rolland greeted the Russian Revolution gladly as 'the first act of that universal liberation of humanity from the tyranny of the past', which was necessary if mankind was 'to escape a repetition of the sufferings of the First World War'. 18 He was, however, quickly disillusioned by reports of Bolshevik terror and the atrocities committed by both sides in the Civil War. ${ }^{19}$ But whilst Rolland may have entertained doubts about the methods used by the Bolsheviks, he did not for one moment question the need to support this great social experiment, which he saw as the unique effort being made to break away from the bondage of the past. One year previously, he had defined to Marcel Martinet his own, rather different, brand of internationalism as

one of Love and not of Hate. It is doubtless impractical and more religious than realistic. But to each his own role. Mine is necessary, too. 20

With the cessation of hostilities and the advent of peace negotiations in Paris, Rolland remained 'profoundly disturbed'; he thought that it would be the peoples who would continue to suffer, and he feared above all else the hatred which would insinuate itself into the peace treaties and thereby make another future war inevitable. ${ }^{21}$ When the Versailles Treaty was finally signed in June of 1919 , Rolland's feeling of doom was complete. His prophetic reaction is recorded in his journal: 'Sad peace! Ridiculous intermission between two massacres of peoples. But who thinks of tomorrow?'22

Rolland faced the dawn of the post-war world with his idealistic faith in liberty, the individual and the free struggle of intellectuals for social justice intact. In the spring of 1919 he issued his famous Déclaration d'Indépendance de l'Esprit, which by 1921 had provoked Henri Barbusse to attack Rolland's detachment from the real world of political problems

17 Hermann Fernau, 'Romain Rolland und der Weltkrieg. Eine Unterredung', Wissen und Leben, XX (April 1 - September 15, 1918), p.301.

18 Frank Field, Three French Writers and the Great War: Studies in the Rise of Communism and Fascism(Cambridge: at the University Press, 1975), p.57.

19 Ibid.

20 Cited in Marcelle Kempf, Romain Rolland et l'Allemagne (Paris: Debresse, 1962), p. 276. Hereafter cited as Kempf.

21 Ibid., p. 210.

22 Cited in ibid., pp. 221-222. 
where more was needed than 'independence of thought', where the revolution required a commitment to action, and if necessary to violent action. ${ }^{23}$ Rolland took issue with Barbusse's and Clartés tendency, as he called it, 'to assimilate the enigma of human evolution to a problem in Euclidean geometry'. ${ }^{24}$ As he wrote retrospectively in 1934, 'I could not throw away my gods, those who had enabled me to live - the god Humanity, and the god Liberty, in order to serve only the god Revolution'. ${ }^{25} \mathrm{He}$ defended his right to be within the revolution and yet remain a free man. ${ }^{26}$ And he adamantly refused to accept the need for violence: 'Our common enemy', he wrote to Barbusse, 'is the oppressive violence of human society as it exists at present. But against that violence, you arm an adverse violence. In my view .... that method only leads to mutual destruction'.27

The answer lay elsewhere for Rolland and it is here that the first intimations of the development of his thought on the methods of pacifism in the twenties appear

.... there is another weapon, much more powerful and suited for all, to the humblest as well as to the most exalted: it has already proved its efficacy amongst other peoples, and it is astonishing that no one ever speaks of it in France: it is that employed amongst Anglo-Saxons by the thousands of 'conscientious objectors', that by means of which Gandhi is now undermining the domination of the British Empire in India - Civil Disobedience. I do not say passive resistance, for make no mistake, it is the supreme resistance. ${ }^{28}$

The question of Means and Ends, of violence and non-violence, is essential to an understanding of European pacifism and Rolland's development in it during the interwar years. In this initial period under discussion, up to 1924, Rolland's rejection of violence was absolute, and applied to all parties. As he wrote in the epilogue to Marianne Rauze's book, L'Antiguerre, in November 1923, 'you perform a high and humane task in trying to group together all those who are opposed to violence, wherever it may come from, whatever it may be: 29 Betraying already the influence of Gandhi, and pre-figuring his later concerns about the lack of realism amongst pacifists, Rolland wrote that action must be firmly

23 IWNR , pp. 91-94. For George Bernard Shaw's refusal to sign the Declaration see Romain Rolland, Par la Réoolution, la Paix (Paris: Editions sociales internationales, 1935), pp. 11-14. See also Romain Rolland, Textes Politiques, philsophiques, et sociaux choisis, Avec Introduction et Notes par Jean Albertini (Paris: Editions sociales, 1970), for commentary by Albertini, pp. 179-181. In this same collection, see also Henri Barbusse, 'L'autre moitié du devoir. A propos du Rollandisme', p. 193-194. See also Nicole Racine, 'The Clarté Movement in France, 1919-21'; in Journal of Contemporary History, 2, no.2 (April, 1967), Pp. 195-208.

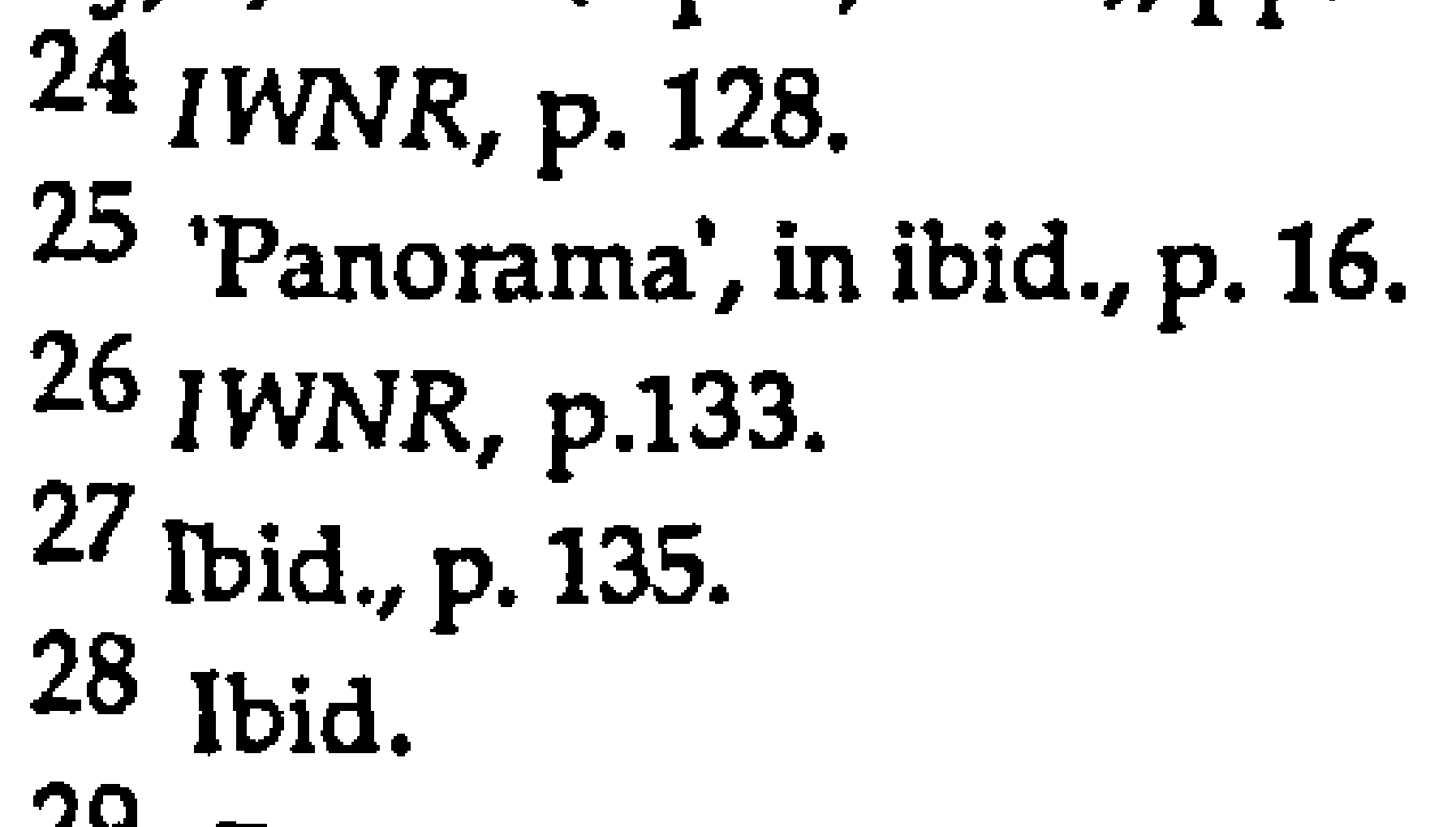

29 Romain Rolland, 'Contre un pacifisme négatif (lettre à Marianne Rauze, 23 novembre 1923), in Par la Réoolution, la Paix, p. 93. 
anchored in faith and in the soul, and must furthermore be prepared for the ultimate sacrifice. The positive task of those opposing la patrie was to oppose a new ideal to the old one, he wrote,

and not to shy away from making it burn brightly in the hearts of the men of today, with all the flames of a new faith... whether the soul exists or not, you will only conquer if you act as if it did exist, as if you were sure of eternity. Because in the fight which is beginning, you are not a majority of numbers or of righteousness against an immoral minority. You are an elite, a moral minority. You mustn't delude yourselves, my friends. A new faith, like that which you represent - human fraternity, the Unity of the living - is never victorious before long trials, sacrifices and martyrdoms. ${ }^{30}$

The summer of 1924 began something of a political prise de conscience in Rolland which forced a re-examination, and then a gradual repudiation of his slide into the Rêve of individualist, idealist independence. In Le Périple, he writes that during that summer, 'away from Paris, sick, alone, and trying to hide from Action, I took up again the happy chains of a new novel cycle. In order to escape better, I had submerged myself into the life of a woman, "une Ame enchantée"t. 31 But escape he could not.

In these summer months of 1924 , a series of stunning events brought me violently back to reality from my dreams in the shadow of the old walnut at Villeneuve. In Italy on the 10th of June 1924, Matteotti was assassinated. On the 6th of April 1926, Amendola succumbed after months of suffering brought on by the most cowardly of attacks. These noble men, these pure consciences, both of them enemies of all violence... were both friends whom I admired. During all of 1925 I was besieged in my retreat by the cries of anguish of the oppressed of the world. ${ }^{32}$

Recognising for better of worse that he was the 'Conscience of Europe', Rolland publicly declared in September 1925 that he was 'with all the oppressed, against all of the oppressors ${ }^{\prime 3}$, thus beginning the slow transition in his political thinking which would see his conversion to Communism in the early 1930s. In the period from 1924 until then, however, he became increasingly involved in the struggle for peace and social justice - a duality which he believed inseparable. 1924 marks the beginning of the end of his cherished 'independence of thought' upon which the demands of action were beginning to impinge. As he himself wrote

...once entered into these seven circles of sorrows, it was no longer possible for me to disengage myself... The more I attached a price to the maintenance of my independence, the more the parties at battle

\footnotetext{
30 Ibid., pp. $95-96$

31 Périple, p. 147.

32 Ibid., pp. 148-149.

33 Ibid., p. 150.
} 
attached a price to conquering it, or if they could not do that, to exploiting it, in availing themselves of my name as of a palladium of moral conscience. ${ }^{34}$

The Struggle for Peace and Social Justice (1924-1932)

From 1924 to the beginning of the Thirties was a time of searching for Rolland during which he attempted to rationalize his intellectual position in politics. And, as he later wrote, 'the great influence which dominated my spirit in those years was that of Gandhi'. ${ }^{35}$ Action, consistent with his idealistic beliefs and non-violent disposition became the key goal. And, as Rolland was wont to say, there could be no more heroic action than that of non-violent resistance.

I could never tolerate that Gandhi's thought [he wrote] should be confused with that of an enervated pacifism which bends its back and acquiesces bleatingly. I have always insisted on the 'fighting character', the word 'sword' which Gandhi repeats constantly opposing it to the steel sword, blade against blade to characterize the heroic weapon of self-sacrifice, individual and collective, in the cause of the Truth... ${ }^{36}$

William Thomas Starr writes that 'Rolland brought to the [peace] movement two concepts: the army of the individual conscience (the rights and the cause of the conscientious objectors), and the army of the collective conscience (Gandhi's Non-Acceptance). ${ }^{37}$ In fact, by 1924 , Rolland had begun to see these two concepts as two sides of the same coin: the collective conscience of Gandhian non-violent resistance would only succeed if it were founded upon a multitude of individual consciences who were strong within themselves. Increasingly, after 1924, the two concepts which Rolland applied to the peace movement and tried to reconcile, were the seeming antitheses of non-violence and social revolution. Whereas Clérambault rejected the 'mechanical perfection of the ant-hill' in favour of the 'individualistic ideal more productive for society',38 Rolland's young interwar hero, Marc, like his creator, wished to reconcile the experiments being conducted in the U.S.S.R. and

34 Ibid., pp. 150, 153.

35 'Panorama', IWNR, p.39.

36 Ibid, P. 40.

37 William T. Starr, Romain Rolland and a World at War(Evanston: Northwestern University Press, 1956), p. 83 [hereafter cited as Starr (l)].

38 Kempf, p. 224. 
India. Society had to be changed and these were the only two hopeful possibilities which presented themselves. As Marcelle Kempf writes:

Historic fatality had made them enemies, and he wanted to reconcile, like his young hero Marc, the Non-Acceptance of India with organized revolutionary violence, the rights of the Individual and the social imperative, le Rêve et l'Action. ${ }^{39}$

It was a task which he later recognized was like trying to wed fire and water. ${ }^{40}$

As Rolland later realized, the world had to will the success of the great experiment in non-violence, and times were not propitious for such a concerted effort of collective self-will. 'Our words must not be equivocal', wrote Rolland to Gandhi on 16 April 1928,

In the coming crisis there must be no doubt about Gandhi's thought....it is necessary to weigh all the consequences of the orders given, to weigh the forces of the men to whom they will be entrusted. The young men of Europe are aware of the trials waiting for them. They don't want to be duped about the imminence of the danger, which too many 'pacifists' are trying not to see and to put out of their minds. They want to look it clearly in the face, and they ask: 'To what extent is it reasonable, to what extent is it human, not to accept? Must the sacrifice be total, absolute, without exception, without any consideration either for ourselves, or for the things which surround us, and depend on us? And in all honesty to ourselves, can we be sure that this total suffering will diminish the sum total of future human suffering - or does it not risk handing over man's destiny to a barbarity without counter-weight?' 11

This long quotation is important for a number of reasons. It shows Rolland's awareness that a disciplined, and well thought-out approach was needed to the problem of nonviolent resistance in Europe. Secondly, the criticism of the lack of realism in pacifist thinking is one which will reappear in the Thirties in increasingly strident tones. Finally, there is in the last phrase of the paragraph an ominous presaging of the trials which awaited European pacifists and non-violent resisters in the years ahead. In a sense, the final phrase is the rock upon which much of European, secular, left-wing pacifism was to founder in the late Thirties.

Bringing together his ideas on peace and social revolution, Rolland told Gandhi in 1931 that 'the only really effective non-resistance would be in the factories and the arsenals, that of the working proletariat'. 42 Accordingly, the 'official' pacifism of governments and the League of Nations did not interest Rolland. Nor could he come to terms with the

39 Ibid. p. 250.

40 'Panorama' in IWNR, p. 40.

41 Romain Rolland and Gandhi Correspondence(New Delhi: Ministry of Information and Broadcasting, 1966). Hereafter cited as Gandhi/Rolland, No.125. Rolland to Gandhi, 16 April 1928, pp. 112-113.

42 Gandhi/Rolland, No.193. Extract from Romain Rolland's Diary, December 1931, p. 169. 
'pacifistic imperialism' of Count Richard Coudenhove-Kalergi and his journal Pan-Europa, whose eurocentricity and avowed hatred of Soviet Russia and the social revolution were the antitheses of Rolland's own beliefs. ${ }^{43}$

Rolland took a much livelier interest, however, in the work of the War Resisters' International (or WRI), a federation of war resisters' organisations which numbered affiliated sections in twenty-one different countries in 1928.44 . Whilst condemning violence, the WRI espoused a positive pacifism which strove for the removal of all the causes of war'. 45 In the words of a 1927 WRI resolution, 'the first object of the War Resisters' International must be to prevent war', by amongst other things, 'working for the suppression of Capitalism and Imperialism by the establishment of a new social order and international order based on the principle of co-operation for the common good'.46 When Gandhi briefly contemplated a European tour early in 1928, it was the WRI which Rolland commended to him as an organisation deserving of his support, containing men of 'limpid faith calmly prepared for every sacrifice. 47

Rolland sent a letter of greeting to the WRI at its conference in July 1928 at Sonntagsberg, Austria. He echoed the appeal of the Roumanian pacifist, Eugen Relgis, for the creation of a Pacifist International: 'Put aside all that separates us, all these little shades of political, social, religious, and philosophical ideas', he wrote. ${ }^{48}$ The only point of disagreement Rolland expressed was the assumption of Relgis and Professor Nicolai of the imminent 'disappearance of war through its own elephantiasis'. 49 This tendency on the part of pacifist groups to view the world through rose-colored spectacles annoyed and worried Rolland - the common theme running through his correspondence with pacifists in the twenties and thirties is the need to look at the world objectively and realistically. War, he proclaimed, 'armed with new and gigantic weapons, threatens not to disappear before it has made humanity disappear... 50

43 The expression is Coudenhove-Kalergi's in 'Das Pan-Europa Programm', Pan-Europa, I, 2 (May 1924), 3. See also Richard Coudenhove-Kalergi, Pazifismus(Vienna/Leipzig: Pan-Europa Verlag, 1924). For Rolland's reaction to a Pan-Europa survey of the attitude taken by selected European intellectuals and politicians to the idea of a United States of Europe, see 'Rundfrage. II. Teil' in PanEuropa, II, 6/7 (1926). For Coudenhove-Kalergi's position on war and the revolution see 'Krieg und Revolution' in Pan-Europa, IV ,9 (November 1928), pp.1-9.

44 War Resisters' International, War Resisters in Many Lands (Enfield: WRI, 1928), republished in Charles Chatfield, ed. International War Resistance Through World War II (New York: Garland Publishing, 1975), pp. 382-448. Hereafter cited as WRI, Many Lands.

45 Ibid,. Pp. 388-389.

46 Idem. International Council Communications, Nos 1-217, Swarthmore College Peace Collection Material, Microfilm, University of Toronto Library. Resolution passed at a meeting of the International Council of the WRI, 21-22 May 1927.

47 Gandhi/Rolland, No.109 Romain Rolland to Madeleine Slade, 7 March 1928, p. 98.

48 Letter of 24 July 1928 contained in WRI, Many Lands, p. 424.

49 Ibid.

50 Ibid. 
But Rolland's views were evolving slowly. In 1928-29, in a protracted correspondence with Relgis over the latter's proposals for a Pacifist International, Rolland advocated not an abstract revolution, but rather one whose potential for violence he defended:

No, I do not condemn the Revolution... I believe revolution, as much as evolution, to be a necessary and fatal form of human development;... Revolution is not necessarily a synonym for cruel brutality. It can be an explosion of enthusiasm and love. Such was, at the beginning, the Revolution of $1789 . .$. revolution is an almost inevitable tempo of the symphony of history. And one must deny neither the grandeur nor the good of it. 51

In a long counter-response, Relgis argued that revolution without recourse to violence was a chimera, throwing back in Rolland's face his earlier statements against violence. 52 Rolland's position here on revolutionary violence shows how far his thought had progressed since the 1922 debate with Barbusse over the ends and the means of the revolution. Clearly, he was moving from a position of undaunted individualism to one of support for an idea regardless of its immediate implications. From this point on, Rolland increasingly beat the drum according to the 'inevitable tempo' of history.

This gradual relinquishing of individual responsibility for the course of history can be seen in another article written by Rolland in 1928 for Madeleine Vernet who published a newspaper entitled La Volonté de Paix which was the organ of a new group of war resisters in Paris of the same name. La Volonté de Paix was an affiliated section of the WRI, had been represented at the 1928 Sonntagsberg conference, and had been active in a peace letter campaign in France and Belgium that year. ${ }^{53}$ In his article Rolland posed the question, 'do we all want the same peace?'. It was not enough to want it, one also had to desire the conditions necessary for peace, and that meant knowing what those conditions were. ${ }^{54}$ Rolland wrote that the great crisis of the age was not so much a political, economic, or social one, as a crisis of conscience. Humanity, he said, found itself at a turning point where it had to choose between an ideal based on the past, and one based on the future. The former had begun to die, and the latter was not yet ripe. Yet it was essential to choose between them. The dying ideal was that of la Patrie nationale, and the one to come was that of la Patrie humaine. 55 Rolland's appeal to the members of La Volonté de Paix contains nothing really new. He re-iterated his call for co-operation between all groups, all peoples, and all nations of the world in the fight for peace, a peace which must include social justice. What is of note, however, is his use of the slogan, 'he who wants the Ends, desires also the

\footnotetext{
51 Rolland in Eugen Relgis, L'Internationale Pacifiste (Paris: André Delpeuch, 1929), pp. 28-29.

52 lbid. pp. 90 and 107-108.

53 WRI, Many Lands, p. 404.

54 'La Volonté de Paix' in Par la Réoolution, la Paix, p. 100.

55 Ibid.p. 101.
} 
Means' ${ }^{56}$ In this article it is not applied directly to a revolutionary situation (although certainly by implication), but it is nevertheless revealing as an indication of the direction of Rolland's thought. It will be remembered that six years previously he had attacked Barbusse for using precisely the same argument!

Through-out 1930 and 1931 Rolland became increasingly concerned that anti-militarist and pacifist groups were beginning to look upon conscientious objection as a simple matter of refusal of military service, without considering either a more positive contribution to society, nor what sort of ultimate self-sacrifice this conscientious objection might entail in time of war, nor even what type of war the next one might be. This fuzzy-mindedness bothered him a great deal. In early January 1930 he wrote a letter to a group of French antimilitarists and libertarians on behalf of Eugène Guillot, an imprisoned conscientious objector. ${ }^{57}$ Rolland supported out of principle Guillot's right to be a conscientious objector, but rejected as a sound reason for this the simple fact that Guillot considered himself a libertarian and merely did not want to sign up for military service. 'I do not accept this consequence or this alternative', he wrote. 'Whether one accepts the idea of the Patrie or not, a man is never alone, and he must take account of the community. His conscientious objection is of value not to him alone, but also to the community, and it is it which he defends in defending his own conscience. ${ }^{58}$ And here Rolland held up the example of the International Civil Service organized by Pierre Cérésole as an example of a positive act of service to the community. Only if there were a social side to conscientious objection could it have any value. ${ }^{59}$

But it was perhaps even more the cowardly, foolish optimism of some leaders of the peace movement which worried Rolland, what he referred to as the 'criminal illusions by which certain leaders of the European non-resistance movement caressed and deluded young people'. 60 Small wonder, then, that he should find himself in complete disagreement with the practical implications of Albert Einstein's famous '2\% speech' before the New History Society in New York City in December 1930. In this speech Einstein made two essential points: firstly, that if only two percent of the world's population refused military service, or any activity related to war, international conflict would become an impossibility. Secondly, he argued for the creation, by international legislation, of an alternative service for those who refused military service. The ' $2 \%$ solution' was immediately taken up by the

56 Ibid.p. 103.

57 'L'Objection de Conscience doit être non individualiste et libertaire, mais sociale' (Lettre pour la libération de l'objecteur de conscience Eugène Guillot - 8 janvier 1930. Réponse à un groupement d'antimilitaristes et de libertaires français), in Par la Réoolution, la Paix, pp. 91-92.

58 Ibid.p. 91.

59 Ibid. p.92

60 'Sür la Résistance Passive'(Lettre du 14 juillet 1930 à un des jeunes organisateurs français du 'septième camp d'amitié internationale' à Chevreuse), in Par la RÉolution, la Paix, Note 1, p. 69. 
War Resisters' International. In response to a WRI questionnaire of very influential people, Rolland maintained that it was for him an obligation of conscience to refuse to participate in war, either directly or indirectly. But if one moved from the level of moral obligation to that of practical utility, Rolland wrote that Einstein's proposal was modest indeed. Warfare had evolved considerably since 1914, he argued, and would continue to do so. $\mathrm{He}$ foresaw the day when small armies of technicians would fight battles of a destructive nature as yet unconceived. 61

It must be said bluntly, without illusions. [There is] no other practical way to abolish war promptly than to abolish the present system of government and society which is the generator of wars! In effect, the revolutionaries are right: a social revolution is necessary. 62

And perhaps the greatest revolutionary tactic, in his view, was the principle of Gandhian non-violent resistance. But war clouds could not be simply wished away. Mere refusal on the part of just $2 \%$ of the population would not stop the modern war machine. Massive organisation was needed, and a realization that self-sacrifice might very well be demanded. Interestingly, just two months before the $2 \%$ speech, Rolland had written to Einstein about the terrible responsibility borne by the leaders of the European anti-war, and about the efficacy of Gandhian non-violent resistance:

You know that this is my conviction as well. I should merely like to
be sure that we never forget, and we never let those who listen to us
forget, that in our violent Europe, on the eve of a new attack of
delirium tremens, this refusal has, or will have, self-sacrifice as a
necessary consequence. Those over whom we have spiritual charge
must not be allowed to form illusions on the strength of our words;
they must realize that we are leading them to almost certain
martyrdom. If they agree to this, then so do we. In our hard human
life, martyrdom is almost always the necessary stage through
which reason must pass in order to progress into the world of
facts....63

Einstein, by stating that such a small proportion of the population could have such a great effect on world politics was contributing to a dangerous illusion. The War Resisters' International simply compounded the error. And so, in Rolland's words,

I clearly separated myself from A. Einstein and the War Resisters' International which had adopted Einstein's declaration; I have condemned their illusions, characterized by a dangerously childish

61 'Correspondance avec Runham Brown au sujet de la déclaration de A. Einstein sur le refus de service de guerre', February 1931, in Par la Révolution, la Paix pp. 65-66.

62 Ibid., pp. 66-67.

63 Gandhi/Rolland, No.381. Romain Rolland to Albert Einstein, 12 October 1930, p. 425. 
optimism about the effectiveness in the abolition of war of simple

individual refusal without any risks. ${ }^{64}$

\section{Pragmatism and Peace (1932-1939)}

The period from about 1932 to the outbreak of war in 1939 is dominated by two major facts: Rolland's sudden conversion to a more doctrinaire support of Soviet Russia, and of course, the Nazi Machtergreifung of January 1933. -To his credit, Rolland never did allow his intellect to become completely submerged in the Third International. With the NaziSoviet Pact in 1939, with his spirited defence of conscientious objectors in the wake of the Amsterdam Congress, amongst other things, Rolland continued to affirm a certain degree of independence. As Caute remarks, there is a difference between faith and blind faith. 65

It was the Amsterdam Congress of August 1932, of which Rolland and Barbusse (what a duo!) were co-chairmen, which showed the path his thoughts on peace were taking in this period. In his opening address to the Congress, read for him in his absence, he proclaimed the need for a common front against war and the system that engenders it. 66 'Action is the end of thought', he declared,

All thought which does not lead to it is an abortion and treason... Future wars are in the hands of the working class. It depends on them to snuff them out. 67

With this last statement, the struggle for peace seemed to become the moral preserve of the working class, although this apparently contradicts Rolland's repeated calls for people of all political hues to join the fight against war. The final manifesto of the Amsterdam Congress condemned conscientious objectors and Gandhian Non-Violent Resistance. As one British pacifist remarked at the time, 'Lord, how the word 'pacifism' stinks in the nostrils of most delegates'.68 In a letter to Barbusse, Rolland vigorously defended the principle of conscientious objection and non-violent resistance, differentiating between them and the 'pusillanimous and only too often hypocritical exploiters of a comfortable and verbal

64 'Panorama', in IWNR, p. 82.

65 Caute, p. 130.

66 'Déclaration lue à la première Séance du Congrès mondial de tous les Partis contre la Guerre', Amsterdam, 27 August 1932, in Par la Réoolution, la Paix , pp. 44-49.

67 Ibid., pp. $48-49$.

68 Martin Ceadel, Pacifism in Britain, 1914-1945. The Defining of a Faith (Oxford: Clarendon Press, 1980), p. 114. 
pacifism without risks'.69 But as a rather disturbing indication of how far Rolland's thought had progressed in the direction of support of violent revolution, he wrote:

Everything can and must serve the common struggle: violence and non-violence (apparent non-violence for energetic Non-Acceptance, vigorously directed is the equivalent of the most violent blockade). Refusal of service disorganizes bourgeois society, to which the violent action of the proletariat gives attack. ${ }^{70}$

Here for the first time, non-violence is defended as a tool - and as a preliminary, subordinate one at that - of violence

During 1932 Rolland was Honorary President of the Ligue Internationale des Combattants de la Paix, a position which he resigned at the Ligue's Easter Congress in 1933 because of its apparent inability to define clearly its position, and perhaps more because of its statement that pacifism had to be placed above all else. As Rolland said in his resignation message,

Pacifism could not conceivably be 'placed above all else' without a demoralizing abdication - above the desperate struggles of the exploited and the oppressed, it could not be neutral - there are no neutrals in the face of oppression. Either one is against it or one is for it, is an accomplice. It is necessary to choose. It is too simple to proclaim oneself 'against all wars'. You cannot put the oppressed and the oppressors in the same bag.... Affirm clearly your line of action. For myself, I affirm mine. I place before all else the defence of the oppressed by the social state, and their efforts to realize a new society - the defence of the social revolution and of the exploited peoples, and I call to their aid the allied forces of the organized non-violent resisters, the conscientious objectors, and the armed proletariat. ${ }^{71}$

Rolland's view of peace and pacifism can perhaps be summed up in the title of the book he published in 1935: Par la Révolution, la Paix.. It is ironic perhaps that he should choose to use 'Par la Révolution, la Paix' as the title of the epilogue article in this book, for in many respects it marks an epilogue to his thought and activity in the period up to around 1935-36. In this article, he wrote that despite his disgust with the bourgeois democracies, despite his implacable opposition to the imperialism of the West, despite all of the things he saw around him with which he did not agree, yet nevertheless, he had no wish to see Europe fall into the trap of war once again. He saw the threat of Hitlerism looming large, believed a war imminent if not quite inevitable, and argued that it is not war, but peace,

69 'Lettre à Henri Barbusse sur la place qui doit être faite aux Objecteurs de Conscience et aux Gandhistes dans le mouvement révolutionnaire issu du Congrès d'Amsterdam', 20 December 1932, in Par la Réoolution, la Paix, pp. 61-62.

70 Ibid., pp. $62-63$.

71 'Le Pacifisme et la Révolution',(Adresse du 15 mars 1933 au Congrès National de Pâques de la Ligue Internationale des Combattants de la Paix), in Par la Révolution, la Paix, pp. 121 and 123. 
which is fatal to Hitlerism (which is) incapable of resolving by ordinary means the social and economic difficulties which are throttling it. ${ }^{72}$ This is the beginning of the final phase of Rolland's political approach to the problem of peace and pacifism, a phase in which he came to terms with the reality of the Nazi threat and the need for some sort of accommodation with the bourgeois democracies in the struggle against the new tyranny.

By 1936 Rolland had rejected Gandhian non-violent resistance as the method which could save Europe from war. He realized that time was running out and that it was impossible to implement such a splendid philosophy in Europe where men had lost the required spiritual faith in a Divinity, and where totalitarian regimes based on violence would have no compunction about slaughtering innocent resisters. ${ }^{73}$ What then to put in its place? In 1936, under the auspices of the World Committee against Fascism and War, Rolland published two essays. The first was his Message to the Brussels Congress, and the second was an essay entitled How to Prevent the War. ${ }^{74}$ Rolland's prescription for peace is reduced in these essays to a practical, immediate level unseen in his earlier articles. Instead of calling for non-violent resistance as a prelude to social revolution, Rolland directed his attention to the problem of what the present bourgeois democracies could do to ensure that war would not break out. Accordingly, he argued that all the nations of Europe including Nazi Germany and Fascist Italy - should be invited to join a collective security pact. In a departure from his earlier position, he declared his support for a revivified League of Nations to confront the present crisis. He continued to see the world situation through Marxist eyes, but he left no doubt in his readers' minds that for the moment the greatest danger by far was the Third Reich - the imperialisms of Britain, France, and even Italy, paled by comparison. ${ }^{75}$ Rolland was convinced that Nazism could not withstand the onslaught of an organized, collective peace offensive. ${ }^{76}$

The end was now in sight, however. Rolland, perhaps in a gesture of solidarity with his country in its hour of need, reversed his action of twenty-five years before, and returned to his native Burgundy from Switzerland, moving into a hillside property at Vézelay. The

72 'Par la Révolution, la Paix', in Par la Réoolution, la Paix, p. 170.

73 Start (1), pp. 84-85.

74 Romain Rolland, Botschaft an den Kongress von Brïssell and Wie kann man den Krieg verhindern? (Paris: Editions du Carrefour, 1936), translated by Rudolf Leonhard, hereafter cited as Botschaft or Wie kann man.

75 Wie kann man, p. 17.

76 Ibid., p.42. 
Nazi-Soviet Pact of August 1939 stunned him - he immediately resigned his membership in the Association Française des Amis de l'U.R.S.S.. On 3 September Rolland wrote to Daladier to express his complete support for the French cause:

In these decisive days in which the French Republic raises itself to block the path against the Hitlerian tyranny over Europe, permit an old fighter for peace who always denounced the barbarism, the perfidy, the frenetic ambition of the Third Reich, to express to you his entire devotion to the cause of the democracies, of France, and of the whole world which is in danger. ${ }^{77}$

Thus, with the coming of war in the Autumn of 1939, ended the interwar period and with it Rolland's active role as a leading light of European pacifism. He remained in the seclusion of his home at Vézelay, unmolested by the occupying German armies, until his death on 30 December 1944.

\section{Conclusion}

I have attempted to show in this appendix the evolution and progression of Rolland's thought on pacifism and the question of peace. Over the course of the interwar period he moved gradually from support of Individualism to Collectivism, from Civilisation to Humanité, from Rêve to Action, a commitment to action which took three successive forms: the primarily Gandhian approach with its emphasis on non-violent resistance on both the individual and collective levels; secondly, the essentially Marxian approach with its emphasis on revolution as a prerequisite to peace; and finally, the pragmatism of the final years with its tacit support of the bourgeois democracies. The common theme through-out the entire interwar period is his insistence on the pressing need for clear thought, foresight, and the necessary definition of tasks, options, and reactions to potential political situations in a minority movement such as pacifism.

Just how far is Romain Rolland representative of interwar French pacifism? The answer is probably to see his pacifism as an eclectic, rather cosmopolitan mixture of ideas and influences coming from a variety of international sources. For example, his early pacifist mysticism is in some ways completely out of step with the political nature of French pacifism, as opposed to the strong undercurrent of religious thinking informing much of Anglo-American pacifism. This early mysticism, traces of which remain right up to the end, was accompanied by an essentially elitist, individualistic and idealistic approach to

77 Cited in Kempf, p. 273. 
the problem of peace. This is the early Romain Rolland who could enthuse to Pierre Cérésole in 1923 that 'I should greatly encourage young people looking for a thesis topic in history to study the origins and development of conscientious objectors'. ${ }^{78}$ At this stage in his development Rolland undoubtedly viewed conscientious objection through glasses very similar to those worn in the Anglo-Saxon world - that liberty of conscience must be protected at all costs. But as the twenties roll into the thirties, this early individualistic ideal became overlaid with the trappings of a more orthodox Marxist view of peace and pacifism. Peace would only be achieved through revolution, and he finally came round to a reluctant acceptance of the potential for violence in the furtherance of that goal. Conscientious objection must therefore have a social side to it, and only certain wars and certain types of violence were to be objected to. Rolland was not alone in his thinking here. The rise to power of the Nazis in Germany, and perhaps even more the case of the Spanish Civil War served to produce a hierarchy of neo-pacifist values in some pacifists' minds. Thus, by at least 1930, Rolland's ambiguous stand on conscientious objection places him neither in the French anarchist/libertarian camp, nor in the majority strand of French pacifism which was always very wary of objection in any case.

Certainly from 1932 onwards, Rolland was increasingly out of step with the main stream of French integral (or absolute) pacifism, typified by the Ligue Internationale des Combattants de la Paix. For French integral pacifists, putting peace first meant incurring the wrath not only of a traditional and also a new proto-fascist Right in France, it also meant fighting a continual rear-guard action against the attacks of L'Humanité and the Parti Communiste. Amsterdam-Pleyel only served to exacerbate this phenomenon; despite the protestations of the French National Committee to the contrary, local AmsterdamPleyel groups continued to be dominated by local communists who in turn made anyone suspected of so-called bourgeois pacifism immediately anathema. Clearly, the major international events of the period, especially the rise of Nazism and the Spanish Civil War, greatly affected and informed the French pacifist debate. But this debate was conducted largely within the confines of a peculiarly French political culture and environment. The attacks of the far-left and the extreme-right acted as an ideological pincer which retarded and deformed the French peace movement. One sees this even today where in France to say that one is a pacifist immediately brings in its wake the assumption that one is also a member of the French Communist party. But the PCF in the twenties and the thirties espoused a bastard form of pacifism, an antimilitarism based not on principle but on political opportunism. The PCF was not and is not a genuinely pacifist party - it, like all political parties, has other more dominant concerns.

78 Gandhi/Rolland,, No. 326, Romain Rolland to Pierre Cérésole, 10 October 1923, p. 381. 
Undoubtedly, the role of a republican conscript army is important in an understanding of French pacifism, too. In a country proud of its revolutionary tradition, the concepts of the 'nation in arms' and the impôt $d u$ sang were particularly difficult to dislodge.

Rolland's slide into Stalinism and then support of collective security gradually left behind the French integral pacifists who had seen in him the father of European pacifism as they, in their turn, became increasingly isolated from the rest of French political society. With the collapse of 1940 , pacifism became equated with defeatism and collaborationism rightly or wrongly, and there are examples on both sides of the coin. Only now, some forty years later is the French political psyche gradually freeing itself from the spectre of Vichy to the point where a reasonable discussion of the French variant of a common international phenomenon called interwar pacifism can finally begin.

Rolland was accused of renouncing his pacifism and urging recourse to violence. This is perhaps to distort his position. In 1931 he protested to Jean Guéhenno that 'he did not and never would approve of violence; but there are many things in this universe that must be accepted without approval - life and its mutual destruction as it has been imposed on us, for example'. ${ }^{79}$ Rolland would undoubtedly have agreed with Bertrand Russell, who wrote retrospectively that 'the doctrine which Tolstoy preached with great persuasive force, that the holders of power could be morally regenerated if met by non-resistance, was obviously untrue in Germany after 1933'.80 As the abyss opened once more before him in 1939, Rolland did not shrink from it. His pacifism was neither absolute nor immutable. With a heart heavy with both resignation and hope for the future, Romain Rolland faced the war he was not to survive. As the epigraph to Mère et Fils, taken from Spinoza, puts it: 'Peace is not the absence of war, it is the virtue born of vigour of the soul'.

79 Cited in William T. Starr, Romain Rolland. One against all. A Biography (The Hague, Paris: Mouton, 1971), p. 236. 275.

80 Bertrand Russell, The Autobiography of Bertrand Russell (New York: Bantam Edition, 1969), p. 


\section{BIBLIOGRAPHY}




\section{Unpublished Primary Sources}

Bibliothèque de documentation internationale contemporaine. (Nanterre) Fonds Duchêne.

(1) Ligue Internationale des Femmes pour la Paix et la Liberté. Section Française.

\begin{tabular}{|c|c|c|}
\hline FARés.208/1 & Textes et correspondence. & 1919-1920. \\
\hline F $\Delta$ Rés.208/2 & Textes et correspondence. & 1921. \\
\hline F $\Delta$ Rés.208/3 & Textes et correspondence. & 1922. \\
\hline FARés.208/4 & Textes et correspondence. & 1923. \\
\hline FARés.208/5 & Textes et correspondence. & 1924. \\
\hline FARés.208/6 & Textes et correspondence. & 1925. \\
\hline F $\Delta$ Rés.208/7 & Textes et correspondence. & 1926. \\
\hline F $\Delta$ Rés.208/8 & Textes et correspondence. & 1927. \\
\hline F $\Delta$ Rés.208/9 & Textes et correspondence. & 1928. \\
\hline F $\Delta$ Rés.208/10 & Textes et correspondence. & 1929. \\
\hline F $\Delta$ Rés.208/11 & Textes et correspondence. & 1930. \\
\hline F $\Delta$ Rés.208/12 & Textes et correspondence. & 1931 \\
\hline F $\Delta$ Rés.208/13 & Textes et correspondence. & 1932. \\
\hline F $\Delta$ Rés.208/14 & Textes et correspondence. & 1933. \\
\hline F $\Delta$ Rés.208/15 & Textes et correspondence. & 1934. \\
\hline F $\Delta$ Rés.208/16 & Textes et correspondence. & 1935. \\
\hline F $\Delta$ Rés.208/17 & Textes et correspondence. & 1936. \\
\hline F $\Delta$ Rés.208/18 & Textes et correspondence. & 1937. \\
\hline F $\Delta$ Rés.208/19 & Textes et correspondence. & 1938. \\
\hline F $\Delta$ Rés.208/20 & Textes et correspondence. & 1939. \\
\hline \multirow[t]{2}{*}{ F $\Delta$ Rés.208/21 } & $\begin{array}{l}\text { Groupes de: l'Ain, Abbéville, } \\
\text { Aix en Othe, Antibes,Autun, } \\
\text { Auxerre,Bar-sur-Seine,Bordeaux, } \\
\text { Digne, Dijon, Région parisienne, }\end{array}$ & \\
\hline & Seine-et-Marne. & $1930-1939$ \\
\hline F $\Delta$ Rés208/22 & Groupe de Caen. & $1931-1938$. \\
\hline \multirow[t]{2}{*}{ F $\Delta$ Rés.208/23 } & $\begin{array}{l}\text { Groupes de: Cannes, Chalons-sur- } \\
\text { Marne, Chambéry, Chartres, }\end{array}$ & \\
\hline & Clermont-Ferrand. & $1926-193$ \\
\hline
\end{tabular}


FARés208/24 Groupes de: Marseille, Lille,

Grenoble, lle de Ré, Le Havre. $\quad$ 1926-1937.

FARés.208/25 Factures 1920-1940.

(2) LIFPL Vie Internationale

F $\Delta$ Rés.207/21 Discussion sur la constitution de 1934. la LIFPL.

(3) LIFPL Comités Executifs Internationaux: FARés.206.

\begin{tabular}{|c|c|}
\hline 1920 & Geneva, 1-4 June \\
\hline 1922 & Fribourg, 6-12 September \\
\hline 1923 & Dresden, 1-5 September \\
\hline 1924 & London, 4-5 February \\
\hline 1925 & Innsbruck, 10-15 July \\
\hline 1926 & Geneva, 7 September, 27 and 28 September \\
\hline 1926 & Paris, 6-10 February \\
\hline 1927 & Liège, 12-17 March \\
\hline 1927 & Geneva, September \\
\hline 1928 & Geneva, 20-24 March \\
\hline 1928 & Lyon, 26-30 September \\
\hline 1929 & Geneva, 16-19 April \\
\hline 1930 & Geneva, 23-26 April \\
\hline 1931 & Lille, 7-13 April \\
\hline 1930 & Amsterdam, 11-15 October \\
\hline 1931 & Geneva, 4-8 September \\
\hline 1932 & Grenoble, 11-14 May, 20-22 May. \\
\hline 1933 & Geneva, 19-25 April \\
\hline 1934 & Geneva, 24-28 March \\
\hline 1934 & Zurich, April, May, August \\
\hline 1935 & London, 25-30 March \\
\hline 1935 & Geneva, 12-16 September \\
\hline 1936 & Prague, 29 April-3 May \\
\hline 1937 & Prague, August. \\
\hline 1936 & Geneva, 9-14 September \\
\hline
\end{tabular}


(4) LIFPL Congrès Internationaux

F $\Delta$ Rés.205/1 1er Congrès International, Zurich, 12-17 Mai 1919 Résolutions.

F $\Delta$ Rés.205/2 Vienne, 10-16 Juillet 1921, Ordre du jour

FARés.205/4 Washington, 1-8 Mai 1924, Procès-verbaux, manifestes.

FARés.205/5 Dublin, 8-15 Juillet 1926, Rapports, résolutions.

FARés.205/6 Prague, 1929, Amendement de la section allemande

FARés.205/7 Grenoble, 14-19 Mai 1932, Rapports, procés-verbaux

FARés.205/8 Zurich, 3-8 Septembre 1934, Rapports, résolutions, procès-verbaux.

FARés.205/9 Luhacovice, 25-31 Juillet 1937, Rapports, résolutions, procès-verbaux.

(5) Pacifism, general dossiers.

FuRés.273/1-22 Pacifisme, 1919-1939. Textes divers, comptesrendus, résolutions, correspondence.

FARés.235/1-6 Pacifisme, 1918-1939. Rapports, textes divers, résolutions, correspondence.

FARés.298 Enseignement de l'histoire/New History. Congrès internationaux pour l'enseignement de l'histoire: La Haye, 1932; Bâle, 1934.

FARés.312/1-4 Pacifisme, organisations diverses, 1920-1940.

FARés.313 Pacifisme, 1923-1930. Congrès national de la paix: Xème (1923); XIème (1927); XIIème (1930).

FARés.317 Comité mondial des femmes contre la guerre et le fascisme, section française. Paris (1932-1938). 
Bibliothèque Nationale, Paris

Fonds Romain Rolland.

Archives Nationales, Paris.

F7/13352 Objection de conscience.

F7/13948

\section{War Resisters' International}

Archives in the private hands of Ms Myrtle Solomon, now transferred to the International Institute for Social History, Amsterdam.

Archives of the United States of America, Washington.

(1) German Foreign Ministry Archives

Microfilm, T-120, Roll 2697

'Viktor Margueritte'

Microfilm, T-120, Roll 5658

'Pazifismus'

(2) U.S. Department of State.

Series 851.00 Political Affairs, France (reports from Paris Embassy).

Series 851.00B Bolshevik Activities in France.

Series 851.20 Military Affairs, France. 
Swarthmore College Peace Collection, Swarthmore, Pennsylvania

$\begin{array}{ll}\text { CDG-B } & \text { France } \\ \text { DG 107/1,4,5. } & \text { André Trocmé Papers. } \\ \text { Autobiographie } & d^{\prime} \text { André Trocmé }\end{array}$

Service Historique de l'Armée de Terre, Château de Vincennes.

\begin{tabular}{|c|c|}
\hline $5 \mathrm{~N} 581(2)$ & Objection de Conscience. \\
\hline $6 \mathrm{~N} 468(4)$ & Objection de Conscience. \\
\hline $5 \mathrm{~N} 601(4)$ & Propagande Révolutionnaire \\
\hline $5 \mathrm{~N} 602(2)$ & Propagande Révolutionnaire \\
\hline $6 \mathrm{~N} 323(4)$ & Propagande Révolutionnaire \\
\hline $7 \mathrm{~N} 2606(2)$ & Pacifisme. \\
\hline $5 N 577(2)$ & $\begin{array}{l}\text { Organisation de la Défense Nationale et du haut } \\
\text { commandement (études et projets de notes). }\end{array}$ \\
\hline
\end{tabular}

Interviews

Monsieur le Pasteur et Madame Philippe Vernier Monsieur le Pasteur et Madame Jacques Martin.

Lord Fenner Brockway. 


\section{Newspapers and Journals}

(1) Systematically examined:

La Paix par le Droit (1918-1940)

En Vigie (1934-1939)

S.O.S. $(1930-1934)$

La Patrie Humaine (1931-1939)

Le Combat pour la Paix (1933-1934)

Le Barrage (1934-1939)

La Volonté de Paix (1928-1936)

(2) Unsystematically examined:

Les Cahiers de la Réconciliation.

Les Cahiers des Droits de l'Homme

Evolution

Le Semeur

Mercure de France. 


\section{Published Primary Sources}

'A Charenton. Une Leçon à M Daladier protecteur des objecteurs de conscience', Action Française, 19 February 1933.

'A l'Institut Pie XI des Volontaires du Pape devant le RP Gillet les objecteurs de conscience sont hués par les patriotes', Action Française, 5 May 1933.

'A la Salle Wagram. Les Camelots du Roi interdisent la réunion de 'l'Objecteur' Leretour et dispersent ses dignes amis', Action Française, 7 March 1933.

'A M. Georges Clémenceau' (Lettre adressée à M. Clémenceau au lendernain de la demande d'armistice formulée par le Empires centraux par le Comité Directeur de "l'Association de la Paix par le Droit", Bordeaux, 8 October 1918), PD 28, 21/22 (November 1918), pp.332-333.

'A propos du front populaire', Le Barrage 67 (17 October 1935), p.4.

'Activités de la Section Française, Assemblée Générale Annuelle, 15 et 16 mai 1937 in En Vigie, 6/7 (October-November 1937), pp.4-5.

'Addis-Abéba est Prise: à Bas Mussolini!', Le Barrage 96 (7 May 1936), p.1.

Allégret, Paul. 'Le Devoir Militaire, et le Scrupule de Conscience. Avant et après la Grande Guerre - Une solution. Rapport presenté a l'Assemblée Générale de la "Paix par le Droit"', PD 36, 4 (April 1926), pp.145-146.

André, Bernard. 'Désarmement', PH 10 (30 January - 14 February 1932), p.7.

Annuaire de la Paix. (Paris: Centre International de Documentation Antiguerrière, 1936).

'Appel', PH 20 (16-23 April 1932), p.6.

'Appel-Programme', PD 30, $1 / 2$ (January-February 1920), pp. 1-5.

Archdeacon, Ernest. 'Pour l'unification des Sociétés pacifistes', PD 41, 7 (July 1931), pp.313314.

'Association de la Paix par le Droit' in Nous Voulons la Paix. (Paris: SRIP, 1932), pp.28-31.

'Au Cercle de la Russie Neuve', Le Barrage 56 (13 June 1935), p.2.

'Au Tribunal Militaire. L'Objecteur de Conscience Roland est jugé. Le Procès de M Daladier', Le Petit Orléanais, 14 May 1933.

'Au tribunal militaire. L'objecteur de conscience Armand Rolland explique son refus de porter les armes', La France du Centre, 11 May 1933. 
Auffray, Bernard. 'L'Objection de Conscience est pire qu'un crime, c'est une sottise', Ordre, 2 May 1933.

Aulard, A. 'La Société des Nations et la Révolution française', $P D 28,17 / 18 / 19 / 20$ (September-October 1918), p.278.

'Autour du Congrès de Zurich', EnVigie 1 (October 1935), pp.4-5.

'Avis Important' in En Vigie 4/5 (April 1937), p.9.

'Avis Important', En Vigie 10-11-12 (March 1939), p.1.

Babut, Henry. 'Les origines de la Paix par le Droit', PD 38, 4/5 (April-May 1928), pp.169175

Babut, Henry. 'Notes brèves sur nos Origines', $P D$ 48, 6/7/8 (May-June-July 1938), pp. 254256

Barbe, A. 'A ceux qui doivent bientôt "partir"', PH 83 (15 September 1933), p.4.

Bauchet, Emile. 'Rapport Financier', Le Combat pour la Paix 10 (March 1934), pp. 5-6.

Bauchet, Emile. 'Rapport financier', Le Barrage 87 (5 March 1936), p.4.

Bauchet, Emile. 'Rapport Moral', Le Barrage 43 (7 March 1935), p.4.

Bauchet, Emile. 'Rapport Moral', Le Barrage 87 (5 March 1936), p.4.

Bauchet, Emile. 'Rapport sur l'organisation pratique', Le Barrage 44 (14 March 1935), p.2.

Bayet, Albert. 'L'Objection de conscience', La République, 4 May 1933.

Belot, Gustave. 'Encore le mot "pacifisme"', PD 28, $7 / 8$ (April 1918), p.109.

Bloch, A. 'Adaptations nécessaires de la Doctrine Pacifiste', PD 49, 1 (January 1939), pp.4-7

Bloch; A. 'Le Pacifisme a-t-il fait faillite?', PD 44, 3 (March 1934), pp.133-134.

Bois, Jacques. 'Enquête sur la Crise du Pacifisme, Réponse de M. Jacques Bois', PD 44, 2 (February 1934), pp.74-77.

Bosse, Louis. 'Quelques Réflexions sur un projet du paradis mécanique', PD 31, 1 (Jan 1921), pp.3-6.

Boussinot, Charles. 'Le Salut n'est qu'en nous-mêmes', Le Barrage 86 (27 February 1936), p.1.

Bray, Marthe. 'Oui, les femmes veulent la paix!', Le Progrès Civique, 535 (1931), p.214.

Broussaudier, Sylvain. 'Brève réponse à R Messac', Le Barrage 111 (27 May 1937), p.3.

Broussaudier, Sylvain. 'Comment lutter à la fois contre la Guerre et contre le Fascisme? Rapport sur l'aspect politique de la question', Le Barrage 124 (24 February 1938), p.3.

Broussaudier, Sylvain. 'Le repli impérial', Le Barrage 142 (2 February 1939), p.1. 
Broussaudier, Sylvain. 'Les Pacifistes dans le Parti Socialiste', Le Barrage 110 (13 May 1937), p.2.

Broussaudier, Sylvain. 'Nous demandons à comprendre', Le Barrage 72 (21 November 1935), p.3.

'Bulletin Officiel de la LICP. Autour du Congrès de Pâques', PH 61 (25 March 1933), p.5.

Buré, Emile. 'Le retour au bon sens', Ordre, 2 May 1933.

Capy, Marcelle. A bas les armes! Discours prononcé à l'occasion de la "Croisade de la paix" de la Ligue internationale des combattants de la paix. (Paris: 'La Patrie Humaine', 1932).

Capy, Marcelle. 'Les Femmes et la Paix', Le Progrès Civique 600 (14 February 1931), p.213.

Capy, Marcelle. 'Retour d'Allemagne', PH 13 (27 February - 4 March 1932), p.1.

Carrère, Jean. 'L'Autriche depuis l'Anschluss', Le Barrage 135 (20 October 1938), p.3.

'Ce que disent les Autres', PH 12 (20-26 February 1932).

'Ce que disent les Autres', PH 28 (11-18 June 1932), p.3.

Challaye, Félicien. 'A bas les deux ans! Lettre ouverte à Léon Blum', Le Barrage 101 (25 June 1936), p.1.

Challaye, Félicien. 'A propos de "l'indivisible paix". Réponse à Romain Rolland', Le Barrage 83 (6 February 1936), p.1.

Challaye, Félicien. 'A propos du conflit Italo-Ethiopien. Guerre et Colonisation', Le Barrage 60 (18 July 1935), p.1.

Challaye, Félicien. 'Antifascisme et Pacifisme intégral. Réponse à Bernard Lecache', Le Barrage 81 (23 January 1936), p.1.

Challaye, Félicien. 'La Préparation de la Guerre et l'action de certains réfugiés allemands', Le Barrage 78 (2 January 1936), p.1.

Challaye, Félicien. 'Le conflit Italo-Ethiopien et les principes de notre Ligue', Le Barrage 64 (12 September 1935), p.1.

Challaye, Félicien. 'Lettre à Léon Blum', Le Barrage 102 (9 July 1936), p.1.

Challaye, Félicien. 'Pacifisme et Antifascisme', Le Barrage 140 (5 January 1939), p.2.

Challaye, Félicien. 'Pacifistes, tolstoiens ou révolutionnaires', Le Barrage 105 (20 August 1936), p.1.

Challaye, Félicien. 'Pas de guerre pour l'Autriche!', Le Barrage 126 (31 March 1938), p.2.

Challaye, Félicien. 'Pour l'union des adversaires de toute guerre', Le Barrage 58 (27 June 1935), p.1.

Challaye, Félicien. 'Pour la Paix sans aucune réserve (Réponse à l'article de M Ruyssen)', PD 42, 4 (April 1932), pp.149-152. 
Challaye, Félicien. 'Pour la Paix sans aucune réserve', PD 41, 11 (November 1931), pp.489497.

Challaye, Félicien. 'Pour la Paix sans aucune réserve', PD 42, 4 (April 1932), p.149-152.

Challaye, Félicien. 'Raymond Poincaré, René Gerin, et les responsabilités de la guerre', Le Barrage I, 26 (8 November 1934),pp. 1-2.

Challaye, Félicien. 'Robespierre et l'actualité', Le Barrage 116 (30 September 1937), p.1.

Challaye, Félicien. 'Seconde réponse à Romain Rolland', Le Barrage 90 (19 March 1936), p.2.

Challaye, Félicien. 'Un Manifeste d'Intellectuels', Le Barrage 66 (10 October 1935), p.2.

Challaye, Félicien. 'Un terrible lapsus', Le Barrage 109 (29 April 1937), p. 1.

Challaye, Félicien. Georges Demartial. Sa Vie, Son CEuvre (Paris: A. Lahure, n.d. [1950]).

Challaye, Félicien. La paix sans aucune réserve. Thèse de Félicien Challaye. Suivie d'une discussion entre Th. Ruyssen, F. Challaye, G. Ganguilhem, Jean le Masaf, et de textes de Bertrand Russell et d'Alain sur: la vraie et la folle résistance. (Nîmes: Imprimerie 'La Laborieuse', 1932).

Challaye, Félicien. La Signification Morale de la Guerre actuelle (Conference faite au Cours d'Instruction Complémentaire pour les sous-officiers du 109e Régiment Territorial d'Infanterie le 29 mars 1916 par le Sergent Félicien Challaye), (Paris: Comité de Propagande Socialiste pour la Defense nationale, 1916.)

Challaye, Félicien. Pour la Paix Désarmée, même en face de Hitler (Le Vésinet: chez l'auteur, n.d. [1933]).

Charpentier, Armand. 'Ce que coatent les alliances franco-russes', Le Barrage 107 (1 October 1936), p.1.

Charpentier, Armand. 'Heureuses Victoires et Joyeux Echecs', Le Barrage 96 (7 May 1936), p.1.

Charpentier, Armand. 'Similitudes: 1914: Iswolsky - 1938: Bénes', Le Barrage (22 September 1938), p.1.

Charpentier, Armand. 'Un Héros de la Paix: Gérard Leretour', PH 53 (28 January - 4 February 1933), p.1.

'Chez les Combattants de la Paix. Le Congrès de Pâques', PH 66 (29 April 1933), p.4.

'Chronique. La révision du traité de Versailles - La Paix par le Droit et la guerre - La paix avec la Russie' (letters from A. H. Fried, A. A. Warden and Louis Guétant, with comments by Ruyssen) PD 30, 3/4 (March-April 1920) p.89-100

'Cinquième Conférence Nationale de la Paix par l'Education', PD 45, 3 (March 1935), pp.116-134 and PD 45, 4 (April 1935), pp.172-192.

'Comité Central de la Ligue', PH 10 (30 January - 14 February 1932), p.8.

'Compte-rendu du Congrès de Montargis', Le Combat pour la Paix 11 (April 1934), p.4. 
'Congrès National de la LICP, 16-17 Avril 1933', Le Combat pour la Paix 1 (May 1933), pp.410.

'Contre les objecteurs de Conscience', Action Française, 7 May 1933.

'Contre une inqualifiable agression. Une lettre de "l'aube" à M Edouard Daladier', l'Aube, 2 May 1933.

Corcos, Fernand. La Paix? Oui, si les femmes voulaient!, (Paris: Editions Montaigne, 1929).

Cot, Pierre. 'La Conception Française de la Lutte contre la Guerre', PD 39, 4/5 (April-May 1929), pp.164-170.

Coudenhove-Kalergi, Richard von. 'Das Pan-Europa Programm', Pan-Europa, I, 2 (May 1924), p.3.

Coudenhove-Kalergi, Richard von. 'Krieg und Revolution' Pan-Europa, IV, 9 (November 1928), pp.1-9.

Coudenhove-Kalergi, Richard von. Pazifismus (Vienna/Leipzig: Pan-Europa Verlag, 1924).

Cuenat, Pierre. '1914, deuxième édition?', PH 71 (2 June 1933), p.3.

Cuenat, Pierre. 'Depuis qu'Hitler est là... qu'y a-t-il de changé?', PH 88 (27 October 1933), p.1.

Cuenat, Pierre. 'Du Pacifisme à la Paix', PH 46 (10-17 December 1932), p.2.

'Ça devait arriver. Les Catholiques compromis par la folie d'un Francisque Gay et de son "Aube"'. La Province, 23 May 1933.

Dandieu, Y. 'Compte-rendu financier', Le Barrage 126 (31 March 1938), p.4.

Daudet, Léon. 'A Propos d'une circulaire', Action Francaise, 2 May 1933.

Déat. Marcel. 'Réponse à l'Enquête sur la Crise du Pacifisme', PD 44, 2 (February 1934), p.78.

Delaisi, Francis. 'Le Problème des populations en surnombre' in J Lahargue, 'Le Congrès de Marseillede la Paix par le Droit (Suite et fin), 28-29 Décembre 1935', PD 46, 4 (April, 1936), pp.170-175.

Delaisi, Francis. 'Les Garanties intérieures de la Paix, conséquence du Pacte Kellogg' in J Prudhommeaux, 'L'Assemblée Générale de la Paix par le Droit, Bordeaux, 2 et 3 Novembre 1929', PD, 39, 12 (December 1929), p.458.

Demartial, Georges. 'L'hitlérisme et la France', Le Barrage 34 (3 January 1935), p.1.

Demartial, Georges. 'Le Problème tchèque et la Paix', Le Barrage 148 (4 May 1939), p.1.

Demartial, Georges. 'Les responsabilités de la guerre. Une réponse de G. Demartial à M. Camille Bloch', PH 105 (2 March 1934), p.2.

Demartial, Georges. La Légende des démocraties pacifiques (Paris: Rieder/Presses Universitaires de France, 1939).

Demartial, Georges. 1939. La Guerre de l'Imposture (Paris: Editions Jean Flory, 1941). 
'200 délégués participent aux débats', PH II, 31 (2-9 July 1932), p.1.

'Deuxième Conférence Nationale de la Paix par l'Education', PD 42, 5 (May 1932), pp.201236.

Devaldès, Manuel. 'L'Etat mondial de la question de l'objection de conscience', Mercure de France CXCVIII (15 August 1927), pp.100-122.

Devaldès, Manuel. 'Les Objecteurs de Conscience Anglo-Saxons', Mercure de France, CLXVI (15 September 1923), pp.642-669.

Doyen, Pierre. 'Deux lettres du Professeur Doyen', Le Combat pour la Paix 4 (August September 1933), p.4.

Drevet, Camille. 'Rapport Moral', Le Barrage 125 (17 March 1938), p.3.

Drevet, Camille. 'Rapport Moral', Le Barrage 145 (16 March 1939), p.4.

Ducatillon, Joseph-Vincent. Le vrai et le faux patriotisme (Paris: Editions 'Spes', 1933).

Duchêne, G. 'Congrès Mondial contre la guerre, Amsterdam, 27-28 Aquat 1932', in SOS no. 12 (1932), pp.5-6.

Dumas, André. 'Ligue, "Patrie Humaine" et Librairie', PH 58 (4-11 March 1933), p.4.

Dumas, Jacques. 'La Société Française pour l'Arbitrage entre Nations', PD 32, 2 (February 1922), pp.59-65.

Dumas, Jacques. 'Les origines de la Paix par le Droit', PD 38, 3(March 1928), pp.105-112

Duméril, Edmond and Prudhommeaux, Jules. 'L'Assemblée Générale de la Paix par le Droit' (Poitiers 31 Octobre et 1 Novembre 1921)', PD 31, 12 (December 1921) pp 401-410.

Duméril, Edmond, Prudhommeaux, Jules, and Ruyssen, Théodore. 'L'Assemblée Générale de la Paix par le Droit', PD 30, 11/12 (November-December 1920), pp.370-380.

Duméril, Edmond. 'L'Allemagne et la Société des Nations. Le Projet de Mathias Erzberger', PD 29, 2/3 (Feb-march 1919) p.65-71.

Dupin, Gustave. 'L'Individu et l'Etat', PH 47 (17-24 December 1932), p.2.

Dupin, Gustave. 'La revanche de la Caste', PH 79 (28 July 1933), p.1.

Duthu, Adrien. 'Ange ou démon?'; Le Barrage 110 (13 May 1937), pp.1-2.

Duthu, Adrien. 'Autriche-Tchécoslovaquie', Le Barrage 127 (28 April 1938), p.2.

Duthu, Adrien. 'Tchécoslovaquie', Le Barrage 129 (26 May 1938), p.2.

Duthu, Adrien. 'Une léçon à tirer des événements d'Espagne', Le Barrage 108 (22 October 1936), p.2.

'Echos', Le Barrage 66 (10 October 1935), p.2.

'Echos. Distinguo', Le Barrage 76 (19 December 1935), p.2. 
Emery, L. 'Encore la Tchécoslovaquie', Le Barrage 130 (9 June 1938), p.1.

Emery, L. 'Le pacifisme et la doctrine révolutionnaire', Le Barrage 146 (30 March 1939), p.1.

Emery, L. 'Le Pact Franco-Russe et la Paix européenne', Le Barrage 95 (30 April 1936), p.2.

Emery, L. 'Le Problème colonial et la Paix', Le Barrage 125 (17 March 1938), p.3.

Emery, L. 'Les Equivoques du Pacifisme', PD 43, 7 (July 1933), pp.239-244.

'Enquête sur l'Objection de Conscience', PD 36, 9/10 (September-October 1926), pp.337-341.

Faure, S. 'Avant tout et à tout prix il faut empêcher la guerre', $P H 20$ (16-23 April 1932).

Faure, S. 'La sauvegarde de la Paix', Le Barrage 98 (21 May 1936), p.2.

Faure, S. 'Rapport sur le désarmement unilatéral', Le Barrage 44 (14 March 1935), pp.5-6.

Faure, S. Nous voulons la Paix (Paris: chez l'auteur, 1932).

Fernau, Hermann. 'De la nécessité d'un rapprochement Franco-Allemand- PD 31, 2 (Feb. 1921), pp.54-57

Fernau, Hermann. 'Romain Rolland und der Weltkrieg. Eine Unterredung', Wissen und Leben, XX (April 1 - September 15, 1918), pp.297-304.

Ferrat, André. 'En guise d'amnistie!', L'Humanité, 4 May 1933.

Foerster, Friedrich Wilhelm. 'Avertissements d'un pacifiste Allemand. Pour un Pacifisme sans Illusions', PD 45, 1 (January 1935), pp.4-14.

Folliet, Joseph. Pacifisme de droite? Bellicisme de gauche? (Paris: Editions du Cerf, 1938).

Fouski, Marcel. 'Rapport sur la déclaration de la Ligue', PH 58 (4-11 March 1933), p.3.

'France combats spread of Conscientious Objection', New York Times, 1 May 1933.

François, Louis. 'Une entente franco-allemande est-elle donc impossible?', $P D$ 45, 3 (March 1935), pp.139-143 and 'Suite' in PD 45, 4 (April 1935), pp.195-204.

Fried, Alfred H. 'Un dernier mot', PD 29, 9/10 (Sept-Oct 1919), pp.401-402.

'Gaston Moch'. PD 45, 9 (September 1935), pp377-378

Gerin, René. 'A ceux qui doivent bientôt "partir", Le Combat pour la Paix 4 (August September 1933), pp.5-6.

Gerin, René. 'A propos d'un incident', Le Barrage 114 (22 July 1937 ), p.1.

Gerin, René. 'Alain a raison: c'est la paix qui commence', Le Barrage 133 (22 September 1938), p.1.

Gerin, René. 'Antimilitarisme d'abord!', Le Barrage 99 (28 May 1936), p.1.

Gerin, René. 'Au Travail, pour la Paix des Peuples!', Le Barrage 134 (6 October 1938), p.1. 
Gerin, René. 'Bientôt, des élections', Le Barrage 47 (4 April 1935), p.1.

Gerin, René. 'Bilan 1935', Le Barrage 78 (2 January 1936), p.1.

Gerin, René. 'Blum-Gribouille', Le Barrage 140 (5 January 1939), p.1.

Gerin, René. 'Ce que signifie le vote des Sarrois', Le Barrage 37 (24 January 1935), p.1.

Gerin, René. 'Décrets-Lois', Le Barrage 137 (17 November 1938), p.1.

Gerin, René. 'Défense de libertés et "Défense Nationale"', Le Barrage 111 (27 May 1937), p.1.

Gerin, René. 'Détente?', Le Barrage 31 (13 December 1934), p.1.

Gerin, René. 'Ecueils, Le Barrage 135 (20 October 1938), p.1.

Gerin, René. 'Guernica...', Le Barrage 110 (13 May 1937), p.1.

Gerin, René. 'Guerre étrangère et guerre civile', Le Barrage 104 (6 August 1936), p.1.

Gerin, René. 'Honte aux assassins!', Le Barrage 66 (10 October 1935), p.1.

Gerin, René. 'L'espoir, enfin, change de camp', Le Barrage 52 (16 May 1935), p.1.

Gerin, René. 'La Démocratie et la Paix', Le Barrage 113 (24 June 1937), p.1.

Gerin, René. 'La formule d'André Delmas', Le Barrage 132 (11 August 1938), p.1.

Gerin, René. 'La guerre de Dantzig n'aura pas lieu', Le Barrage 151 (13 July 1939), p.1.

Gerin, René. 'La Joie mauvaise', Le Barrage 14 (16 August 1934), p.1.

Gerin, René. 'La négociation aura lieu', Le Barrage 148 (4 May 1939), p.1.

Gerin, René. 'La nouvelle alliance Franco-Russe est-elle une étape vers la paix?', Le Barrage 51 (9 May 1935), p.1.

Gerin, René. 'La Politique extérieure de l'URSS', Le Barrage 96 (7 May 1936), p.1.

Gerin, René. 'La Pologne et nous', Le Barrage 149 (18 May 1939), pp.1-2.

Gerin, René. 'Le Coup de Staline', Le Barrage 53 (23 May 1935), p.1.

Gerin, René. 'Le "Fascisme" a fait faillite', Le Barrage 17 (6 September 1934), p.1.

Gerin, René. 'Les Elections et la Paix', Le Barrage 95 (30 April 1936), p.1.

Gerin, René. 'Les "mentalités obstinées"', Le Barrage 21 (4 October 1934), p.1.

Gerin, René. 'Lettre ouverte à M Daladier', PH 63 (8 April 1933), pp.1-2.

Gerin, René. 'On revise les traités...', Le Barrage 125 (17 March 1938), p.1.

Gerin, René. 'Pacifisme et Antifascisme', Le Barrage 141 (19 January 1939), p.2. 
Gerin, René. 'Pas de surenchère verbale (II) Réponse à Robert Tourly', Le Barrage 123 (3 February 1938), p.1.

Gerin, René. 'Pas de surenchère verbale!', Le Barrage 122 (20 January 1938), p.1.

Gerin, René. 'Pour un appel aux peuples', Le Barrage 146 (30 March 1939), p.1.

Gerin, René. 'Pourquoi nous refusons toute Union Sacrée', Le Barrage 126 (31 March 1938), p.1.

Gerin, René. 'Que veut l'Allemagne?', Le Barrage 88 (12 March 1936), p.1.

Gerin, René. 'Rapport moral sur l'activité de la Ligue de Pâques 1933 à Pâques 1934 qui sera présenté au Congrès de Montargis', Le Combat pour la Paix 10 (March 1934), pp. 4-5.

Gerin, René. 'Rapport provisoire sur la déclaration de la Ligue', PH 58 (4-11 March 1933), pp.3-4.

Gerin, René. 'Rapport sur l'organisation de la propagande', Le Barrage 87 (5 March 1936), p.4.

Gerin, René. 'Rapport sur le "Barrage"', Le Barrage 125 (17 March 1938), p.4.

Gerin, René. 'Rapport sur le "Barrage"', Le Barrage 145 (16 March 1939), p.4.

Gerin, René. 'Sanctions', Le Barrage 73 (28 November 1935), p.1.

Gerin, René. 'Si Paris valut une messe...', Le Barrage 30 (6 December 1934), p.1.

Gerin, René. 'Un Dictateur?', Le Barrage 24 (25 October 1934), p.1.

Gerin, René. 'Un Discours et un entretien', Le Barrage 28 (22 November 1934), p.1.

Gerin, René. 'Une leçon à méditer', Le Barrage 100 (11 June 1936), p.1.

Gerin, René. 'Une nouvelle loi scélérate', Le Barrage 8 (5 July 1934), p.1.

Gerin, René. 'Union Sacrée et lutte de classes', Le Barrage 105 (20 August 1936), p.1.

Gerin, René. 'Union Sacrée? - Non, Jamais!', Le Barrage 143 (16 February 1939), p.1.

Gerin, René. Honneur et Patrie ou Comment j'ai été exclu de la Légion d'Honneur (Paris: Editions de la LICP., 1934).

Gerin, René. La Paix anxieuse et obstinée (Paris: Rivière, 1938).

Gerin, René. Les Causes Psychologiques des Guerres (Paris: Ligue Internationale des Combattants de la Paix, 1935).

Gerin, René. Les Responsabilités de la Guerre de 1914. (Paris: Editions de la LICP, 1933),

Gerin, René. Les responsabilités de la Guerre. Quatorze questions par René Gerin, Ancien Elève de l'Ecole Normale Supérieure, Agrégé des Lettres. Quatorze Réponses par Raymond Poincaré de l'Académie Française (Paris: Payot, 1930). 
Gerin, René. Pacifisme "intégral" et guerre civile (Paris: Ligue Internationale des Combattants de la Paix, 1937).

Gerin, René. Si la Guerre éclatait... Que Faire? (Paris: Ligue Internationale des Combattants de la Paix, 1936).

Gerlach, Hellmuth von. 'Guerre Préventive?', PD 43, 6 (June 1933), p.197.

Gilbert, Hubert. 'Le pacte Laval-Potemkine', Le Barrage 51 (9 May 1935), p.3.

Gobron, Gabriel. 'Les Crustacés Intellectuels', PH 44 (26 November - 3 December 1932), p.3.

Gouttenoire de Toury, Fernand. 'Désarmement, ou catastrophe final', Le Barrage 135 (20 October 1938), p.1.

Guétant, Louis and Ruyssen, Théodore. 'Les Responsibilités de la Guerre I et II', PD 30, 10 (October 1920) pp. 328-333.

Guilbeaux, Henri. 'La Sarre est allemande', Le Barrage 36 (17 January 1935), p.3.

Guilbeaux, Henri. 'La Sarre et les rapports franco-allemands', Le Barrage 34 (3 January 1935), p.3.

Guilbeaux, Henri. 'Le conflit italo-abyssin', Le Barrage 33 (27 December 1934), p.3.

Guilbeaux, Henri. 'Rapport sur le programme, l'Union France-Allemagne-URSS, et la lutte contre le fascisme', Le Barrage 43 (7 March 1935), pp.4-5.

Guiton, E. and Ruyssen, Théodore. 'A propos de l'objection de conscience', PD 36, 2 (February 1926), pp. 68-69.

Gukowski, Nadia. 'Racisme et nationalisme', Le Barrage 138 (1 December 1938), p.1.

Hadamard, Jacques. 'Pacifisme Intégral?', PD 41, 2 (February 1931), pp. 57-68.

Hadamard, Jacques. 'Un Nouveau pas à faire dans la Voie de la Paix. Les Manuels Scolaires', PD 40, 1 (January 1930), pp.1-4.

Hecquet, Marceline. L'Objection de Conscience devant le Service Militaire (Paris: Editions du Groupe de Propagande par la Brochure, 1924)

Henry, R. 'Un bel exemple à suivre', $P H 16$ (19-26 March 1932)

Herzog, Wilhelm. 'Témoignages à Romain Rolland', Europe (No. spécial consacré à Romain Rolland), 38 (15 February 1926), 165-68.

'Honte aux Assassins', Le Barrage 66 (10 October 1935), p.1.

Humbert, Jeanne. Contre la Guerre qui vient (Paris: Editions de la LICP, 1933).

Humbert, Jeanne. 'La surpopulation et la guerre', Le Barrage 87 (5 March 1936), p.5.

Jamet, Claude. 'La Paix inévitable', Le Barrage 147 (20 April 1939), pp.1-2.

Jeanson, Henri. 'A bas l'union sacrée!', Le Barrage 125 (17 March 1938), p.1. 
Jospin, Robert. 'Au dessus de la Paix', Le Barrage 139 (15 December 1938), p.3.

Jospin, Robert. 'Force ou collaboration', Le Barrage 146 (30 March 1939), p.1.

Jospin, Robert. 'Le Rassemblement Populaire et la Paix. A propos d'un programme', Le Barrage 84 (13 February 1936), p.2.

Jospin, Robert. 'Les problèmes économiques et la Paix', Le Barrage 142 (2 February 1939), p.4.

Jospin, Robert. 'Maintenant, bâtissons l'Europe', Le Barrage 135 (20 October 1938), p.1.

Jospin, Robert. 'Précisions nouvelles', Le Combat pour la Paix 4 (August -September 1933), p.2.

Jospin, Robert. 'Rapport sur la nationalisation des armements', Le Barrage 44 (14 March 1935), p.4.

Jospin, Robert. 'Rapport sur la question: Si la guerre éclatait?', Le Barrage 44 (14 March 1935), p.6.

Jouve, Andrée. 'Jane Addams' En Vigie I, 1 (October 1935), p.1.

Kawerau, Siegfried. 'Les Livres d'Histoire en Allemagne, notamment depuis 1923', PD 37, 3 (March 1926), pp.104-111.

Kawerau, Siegfried. 'Où en est l'Allemagne dans l'amélioration de ses Livres d'Histoire?, PD 41, 10 (October 1931), pp.449-452.

'L'activité de la Ligue', Le Barrage 148 (4 May 1939), p.4.

'L'activité de la Ligue. Montargis', Le Barrage 40 (14 February 1935), p.4.

'L'Affaire d'Ethiopie et nous', Le Barrage 65 (26 September 1935), p.1.

'L'Objecteur de conscience Armand Rolland devant le tribunal militaire', Le Républicain Orléanais, 11 May 1933.

'L'Objecteur de conscience', Le Journal du Loiret, 12 May 1933.

'L'Objecteur de conscience', Le Journal du Loiret, 11 May 1933.

'La langue de la Société des Nations', PD 29, 4 (April 1919), pp.191-192.

'La Paix sans Réserve?', PD 41, 12 (December 1931), p.561.

'La Police de M. Daladier au service des traitres et des objecteurs de conscience', Action Française, 4 March 1933.

'La Politique Internationale. Deux ordres du jour sur les réparations: la Paix par le Droit et la Ligue de la République', PD 33, 1 (January 1923), pp.29-31.

'La Vie de la Ligue', PH 12 (20-26 February 1932), p.4.

'La Vie de la Ligue', PH 13 (27 February-4 March 1932), p.4.

'La Vie de la Ligue', PH 19 (9-16 April 1931), p.4. 
'La Vie de la Ligue', PH 38 (1-15 October 1932), p.4.

'La Vie de la Ligue: 11 e et 12e arrdt.', PH 40 (29 October-5 November 1932), p.4.

'La Vie de la Ligue: Alger', PH 47 (17-24 December 1932), p.4.

Lacaze-Duthier, Gérard de. 'Les livres' La Patrie Humaine, 50 (7-14 January 1933), p.2.

Lacaze-Duthiers, Gérard de. 'Livres, Revues, Journaux' (Review of Félicien Challaye, Pour la Paix désarmée, même en face de Hitler), Le Barrage 1 (17 May 1934), p.3.

Lacroix, Maurice and Man, Henri de. 'Les lendemains de Munich: faisons la Paix!', PD 48, 13 (December 1938), pp.404-410.

Lagot, Eugène. 'Sous le Signe de la Peur', Le Semeur 232 (22 July 1933), p.1.

Laguerre, Odette and Prudhommeaux, Jules. 'Le Congrès Français du Rassemblement Universel pour la Paix, Paris, 25-27 Septembre 1937', PD 47, 11/12 (NovemberDecember 1937), pp. 393-399

Laguerre, Odette. 'Le Congrès du Rassemblement Universel pour la Paix à Bruxelles', PD 46, 10 (October 1936), pp.397-400.

Lahargue, J. 'Le Congrès de Marseille de la Paix par le Droit, 28-29 Décembre 1935', PD 46, 3 (March 1936), pp.113-123.

Lahargue, J. and Prudhommeaux, Jules. 'Le Congrès de la Paix par le Droit, ClermontFerrand, (Suite et Fin)', PD 47, 4/5 (April-May 1937), pp.145-162.

Lapierre, Georges. 'La Conférence Internationale pour l'Enseignement de l'Histoire', PD 42, 7/8 (July-August 1932), pp.346-349.

Larpent, G. 'La Politique. I. La circulaire Chautemps. II. Les instructions aux généraux. III. Indignations tardives. IV. Une Circulaire pour rien', Action Française, 2 May 1933.

Laskine, Edmond. 'La victoire de Locarno', PD 35, 11 (Nov 1925), pp.429-433.

Lauret, René. 'Pourquoi le Pacifisme est Décrié', PD 32, 2 (Feb. 1922), pp.72-73.

'Le Bureau Internationale de la Paix', PD 29, $7 / 8$ (July-August 1919), p.357-359.

'Le Cinquantenaire de l'Association. A nos Amis', PD 47, 8/9 (August-September 1937), pp.297-298.

'Le Comité Directeur de la Paix par le Droit. 'Pourquoi ces Armements?' PD 37, 6 (June 1927), pp.185-187.

'Le Congrès de Bierville', PD 36, 9/10 (September-October 1926), pp.369-372.

'Le Dossier Demartial (Défense, Témoignages et plaidoirie)', Evolution 30 (June 1928), pp. 34-50.

Le Foyer, Lucien. 'L'Union Populaire pour la paix', in Nous voulons la Paix, (Paris: SRIP, 1932), pp.55-56. 
'Le Journal de Guerre d'Alfred H. Fried'. PD 29, $7 / 8$ (July-August 1919), pp.312-325.

'Le Sabotage de la Défense Nationale. La Presse et la Circulaire de M Chautemps', Echo de Paris, 3 May 1933.

'Le Sabotage de la Défense Nationale. Une Circulaire confidentielle du ministre de l'intérieur aux préfets'. Echo de Paris, 1 May 1933.

Lemédioni, Edouard. 'Rapport sur la tactique que la Ligue doit adopter afin de rendre efficace l'action qu'elle mène contre la guerre', Le Combat pour la Paix 9 (February 1934), pp.1-4.

Lemédioni, Edouard. 'Rapport sur le référendum populaire', Le Barrage 44 (14 March 1935), p.4.

Leonhard, Rudolf. 'Le Problème de la Sarre du point de vue allemand (suite)', Le Barrage 33 (27 December 1934), p.2.

Leonhard, Rudolf. 'Le Problème de la Sarre du point de vue allemand', Le Barrage 32 (20 December 1934), p.2.

Leonhard, Rudolf. L'Allemagne et la Paix (Paris: Editions de la LICP, 1932).

Lepine, F. 'Pacifisme ou défaitisme?', PD 28, 3/4/5/6 (February-March 1918), pp.49-55.

Leretour, Gérard. 'Debout, les Objecteurs!', PH 71 (2 June 1933), p.2.

Leretour, Gérard. 'Pourquoi le Manifeste?', PH 81 (18 August 1933), p.4.

'Les Jeux de Soldats', PD 36, 5 (May 1926), pp.193-213; and PD 36, 6 (June 1926), pp.253-255.

'Les Manuels d'Histoire Allemande et Français. Résolutions adoptées par la commission d'Historiens Allemands et Français, réunis du 25 Novembre au 1er Decembre 1935, pour examen des rectifications qu'il y aurait lieu d'apporter aux Manuels Scolaires des deux Pays', PD 47, 6 (June 1937), pp.209-217 and 47, 7 (July 1937), pp.257-271.

'Les Objecteurs de Conscience', Le Quotidien, 6 May 1933.

'Les responsabilités de la guerre et le professeur Quidde', PD 29, 1 (January 1919), p.56.

'Les Travaux du Congrès d'Agen', Le Barrage 50 (2 May 1935), p.4.

'Les Travaux du Congrès d'Arras', Le Barrage 127 (28 April 1938), p.4.

'Les Travaux du Congrès de Bernay', Le Barrage 94 (23 April 1936), pp. 3-4.

'Les Travaux du Congrès de Marseille', Le Barrage 147 (20 April 1939), p.4.

'Lettre à M Pierre Laval, président du Conseil, ministre des Affaires Etrangères', $P D$ 45, 9 (September 1935), pp.340-341.

'Lettre ouverte aux 30.000 Signataires de notre Manifeste', La Volonté de Paix (January February 1931), p.l.

Léger, Louis. 'Rapport Financier', Le Barrage 43 (7March 1935), p.4. 
Léontin, L. 'Après le Congrès de la Paix de Berlin', PD 34, 12 (Dec 1924), pp.457-458.

Lévy, Roger. 'Société des Nations et Coopération Intellectuelle depuis dix ans', PD 40, 6 (June 1930), pp. 218-225.

Lhoumeau, Hélène. 'Lettre à M Ch Rousseau à propos de "l'Allemagne contre le Droit"', PD 44, 1 (January 1934), pp.18-19.

Ligue Internationale des Combattants de la Paix. Programme, Tactiques et Moyens d'Action (Paris: Editions de la LICP, n.d.).

'Manifeste de la Volonté de Paix', La Volonté de Paix (August-September 1928), p.4.

'Manifeste du Congrès d'Arras', Le Barrage 127 (28 April 1938), p.1.

'Manifeste du Congrès', Le Combat pour la Paix 1 (May 1933), p.3.

'Marcelle Capy en Allemagne et en Suisse', PH 10 (30 January-14 February 1932), p.2.

Maurette, M. 'La Répartition des Matières Premières', in J. Lahargue, 'Le Congrès de Marseille de la Paix par le Droit (Suite et fin), 28-29 Décembre 1935' PD 46,4 (April 1936), pp. $170 \cdot 173$.

Méric, Victor. 'Celle d'hier, celle de demain', PH 23 (6-19 August 1932), pp.1-2.

Méric, Victor. 'Du Bon Travail', PH 12 (20-26 February 1932), p.1.

Méric, Victor. 'L'aventure hitlérienne', PH 22 (30 April - 7 May 1932), p.1.

Méric, Victor. 'La Bataille du Trocadéro', PH, new series no. 3 (7-22 December 1931), p.2.

Méric, Victor. 'La Paix est en Marche', PH 10 (30 January -14 February 1932), p.2.

Méric, Victor. 'Le Combat pour la Paix. Réponse de Victor Méric', PH 33 (23 July - 6 August 1932), p.1.

Méric, Victor. 'Le véritable Briand', PH 17 (26 March - 2 April 1932).

Méric, Victor. 'Le Véritable Pacifisme. Le Postulat d'Einstein', PH 19 (9-16 April 1932), p.1.

Méric, Victor. 'Lettre ouverte aux Juifs de France', PH 64 (15 April 1933), p.1.

Méric, Victor. 'Nos moyens de lutte', PH 66 (29 April 1933), p.1.

Méric, Victor. 'Nos Souhaits', PH 49 (31 December 1932 - 7 January 1933), p.l.

Méric, Victor. 'Nous n'irons plus au Bois...', PH 30 (25 June - 2 July 1932), pp.1-2.

Méric, Victor. 'On Assassine un Homme!'. PH 52 (21-28 January 1933), p.1.

Méric, Victor. 'Pour tuer la guerre', PH 54 (4-11 February 1933), p.1.

Méric, Victor. 'Précisions', PH 32 (9-23 July 1932), p.1.

Méric, Victor. 'Rapport Moral', PH 59 (11-18 March 1933), p.5. 
Méric, Victor. 'Vers la répression', PH 40 (29 October - 5 November 1932), p.1.

Méric, Victor. Fraîche et Gazeuse! La guerre qui revient (Paris: Editions 'Sirius',1932).

Messac, Régis. 'Lettre à Sylvain Broussaudier', Le Barrage 111 (27 May 1937), p.3.

Messac, Régis. 'Pour un esprit civique europén', Le Barrage 147 (20 April 1939), p.1.

Messac, Régis. 'Que chacun reconnaisse les siens!', Le Barrage 106 (3 September 1936), p.1.

'Message adressé au Bureau International de la Paix par la Société Allemande de la Paix au sujet des décisions de la Conférence de Paris', (with response by Ruyssen), in PD 31, $3 / 4$ (March-April 1921), p.118-121.

'Message à la Conférence tenue à Paris le 3 Septembre 1935 pour la défense du Peuple Ethiopien', PD 45, 9 (September 1935), pp.339-340.

Michon, Georges. 'Robespierre et la Guerre Révolutionnaire', Le Barrage 80 (16 January 1936), p.1.

Michon, Georges. 'Union Sacrée', Le Barrage 102 (9 July 1936), p.1.

Milhaud, Edgar. 'Sur la Réorganisation Economique du Monde, condition de la Paix future' in Jules Prudhommeaux and J. Lahargue, 'L'Assemblée Générale et le Congrès du Cinquantenaire, Nîmes, 19-21 Avril 1938', PD 48, 6/7/8 (May-June-July 1938), pp. 293-297.

Moch, Gaston. 'Un réquisitoire nécessaire. Alfred Hermann Fried', PD 29, 4 (April 1919), pp.155-168

'Modifications aux Statuts', Le Barrage 130 (9 June 1938), p.4.

Monbrison, Hubert de. 'Les Colonies, terrain de lutte ou de collaboration entre les Peuples in Jules Prudhommeaux and J. Lahargue, 'L'Assemblée Générale et le Congrès du Cinquantenaire, Nîmes, 19-21 Avril 1938', PD 48, 6/7/8 (May-June-July 1938), pp. 278-289.

Monclin, Roger. 'Adieu', PH 86 (13 October 1933), p.1.

Monclin, Roger. 'L'activité de la Ligue', PH 59 (ll-18 March 1933), p.5.

Monclin, Roger. 'Violence ... ou soumission?', PH 21 (23-30 April 1932), p.3.

Monod, Wilfred. 'L'Antisémitisme et la Notion de Race', PD 43, 6 (June 1933), pp.198-200.

Morhardt, Mathias. 'Le respect des traités', Le Barrage 91 (26 March 1936), p.3.

Nézelof, Pierre. 'Aux innocents les mains vides', Le Barrage 135 (20 October 1938), p.1.

Nézelof, Pierre. 'Le front populaire ruiné par ses chefs', Le Barrage 150 (8 June 1939), p.2.

Nézelof, Pierre. 'Une Enquête', Le Barrage 100 (11 June 1936), p.1.

Niessel, Le Général A. 'Le Patriotisme et l'Objection de Conscience', Le Figaro, 31 January 1933. 
'Notre Agitation', PH 28 (11-18 June 1932), p.4.

'Notre Assemblée Générale, Pau, 29 octobre - 1er novembre 1932', PD 42, 12 (December 1932), pp.513-544.

'Notre Meeting à Wagram', PH 12 (20-26 February 1932), p.1.

'Notre Mot d'Ordre', Le Combat pour la Paix 9 (February 1934), p.4.

'Nous ne marchons pas!', Le Barrage 88 (12 March 1936), p.1.

'Pacifistes, tenez-vous prêts!', PH 21 (23-30 April 1932), p.1.

'Paix et Liberté (Manifeste adopté au Congrès de Montargis)', Le Combat pour la Paix 11 (April 1934), pp.1-2.

Pauthe, Gaston. 'Comment lutter à la fois contre la Guerre et contre le Fascisme? Rapport sur l'aspect économique de la question', Le Barrage 124 (24 February 1938), pp.3-4.

Pauthe, Gaston. 'Non! Monsieur Daladier, nous ne sommes pas dupes!', Le Barrage 150 (8 June 1939), p.2.

Percin, General Alexandre. Guerre d̀ la Guerre (Paris: Editions Montaigne, 1927).

Percin, General Alexandre. Le désarmement moral (Paris: Delpeuch, 1925).

Périé, R. 'Scrupules Pacifistes' , PD 31, 7 (July 1921), pp.237-240.

Pioch, Georges. 'Je joue la carte Léon Blum', Le Barrage 100 (11 June 1936), pp.1-2.

Pioch, Georges. 'L'impossible promiscuité', Le Barrage 144 (2 March 1939), p.1.

Pioch, Georges. 'Paix dans notre Ligue, d'abord!' PH 33 (23 July - 6 August 1932), pp.1-2.

Pioch, Georges. 'Quand Brid'oison se double de Basile', Le Barrage 61 (1 August 1935), p.2.

Pioch, Georges. 'Questions à Romain Rolland', Le Barrage 82 (30 January 1936),p.1.

Pioch, Georges. 'Rougeur sur le Front Populaire', Le Barrage 111 (27 May 1937), pp.1-2.

'Pour la Paix par le Droit. Appel Programme', PD 30, 1/2 (Jan-Feb 1920), pp.1-5.

'Pour la réforme d'une loi inhumaine', PD 46, 2 (February 1936), pp.97-98..

'Pour la Société des Nations', PD 17/18/19/20 (September-October 1918), p.298.

Pour un Désarmement Réel. Compte-rendu de la Conférence Libre du Désarmement tenue à Paris les 23 et 24 avril 1932. (Levallois-Perret: Commission de la Conférence, n.d.[1932]).

'Première Conférence Nationale pour la Paix par l'Education', PD, 41, 3 (March 1931), pp.129-161.

'Prenons garde!', Le Barrage 20 (27 September 1934), p.1.

'Précisions nécessaires', Le Barrage I,13 (9 August 1934), p.l. 
Procès de Camille Rombaut. (Aubervilliers: 'La Réconciliation', 1932).

Procès de Jacques Martin (Aubervilliers: 'La Réconciliation', 1932).

Procès de Philippe Vernier (Aubervilliers: 'La Réconciliation', 1933).

'Projet de Résolution soumis par le Comité Executif de "La Paix par le Droit" à la "Fédération Française des Associations pour la SDN", PD 45, 9 (September 1935), pp.338-339.

Prudhommeaux, Jules and Cadier, Georges. 'L'Assemblée Générale de la Paix par le Droit' PD 34, 7/8 (July-August 1924) p.270-276

Prudhommeaux, Jules and Puech, Jules L. 'L'Assemblée Générale et les Fêtes du XLème Anniversaire', PD 37, 12 (December 1927) p.435-478.

Prudhommeaux, Jules, and Lahargue, J. 'L'Assemblé Générale et le Congrès du Cinquantenaire, Nîmes, 19-21 Avril 1938', PD 48, 6/7/8 (May-June-July 1938), pp.209-299.

Prudhommeaux, Jules. 'A propos du Fascisme français', PD 35, 12 (December 1925), pp.486489.

Prudhommeaux, Jules. 'Conseil Directeur de l'Association de la Paix par le Droit', PD 32, 10 (October 1922), pp.426-429.

Prudhommeaux, Jules. 'Et si l'Allemagne résiste? - les sanctions économiques', PD 43, 11 (November 1933), pp.458-460.

Prudhommeaux, Jules. 'France et Allemagne. Le Péril', PD 46, 3 (March 1936), pp.143-145.

Prudhommeaux, Jules. 'Guillot et Perrin, objecteurs de conscience', PD 40, 4 (April 1930), pp.137-138.

Prudhommeaux, Jules. 'L'Assemblée Générale de Boulogne-sur-Mer (suite)', $P D$ 41, 2 (February 1931), pp.69-84.

Prudhommeaux, Jules. 'L'Assemblée Générale de Boulogne-sur-Mer', PD 41, 1 (January 1931), pp.17-26.

Prudhommeaux, Jules. 'L'Assemblée Générale de la Paix par le Droit' Marseille, 27 December 1935), PD 46, 2 (February 1936) pp. 57-74.

Prudhommeaux, Jules. 'L'Assemblée Générale de la Paix par le Droit', PD 46, 2(February 1936), p.57-74.

Prudhommeaux, Jules. 'L'Assemblée Générale de la Paix par le Droit, Bordeaux, 2 et 3 novembre 1929', PD 39, 12 (December 1929), pp.443-468.

Prudhommeaux, Jules. 'L'Assemblée Générale de Nancy', PD 39, 1 (January1929), pp3-18.

Prudhommeaux, Jules. 'L'Association de la Paix par le Droit. Séance du Conseil de Direction', PD 44, 6 (June 1934), pp.248-252.

Prudhommeaux, Jules. 'L'Objection de conscience: Georges Chevé', PD 38, 3 March 1928), pp 141-142. 
Prudhommeaux, Jules. 'L'Origine, le Developpement et le Fonctionnement de l'Association de la Paix par le Droit', PD 38, 12 (December 1928), p.513-518.

Prudhommeaux, Jules. 'La condemnation de "l'objecteur" Philippe Vernier', PD 43, 10 (October 1933), pp.402-403.

Prudhommeaux, Jules. 'La grande pitié du Pacifisme français - Pour l'Unité et la Coordination des Efforts', PD 45, 10 (October 1935), pp.391-395.

Prudhommeaux, Jules. 'La guerre chimique et l'opinion: un article de $\mathrm{M}$ de Kerillis', PD 40, 11 (November 1930), pp.451-452.

Prudhommeaux, Jules. 'La Ligue des Combattants de la Paix - Le Congrès de Montargis - Les Dissidents', PD 44, 6 (June 1934), pp.244-245.

Prudhommeaux, Jules. 'La Ligue des Droits de l'Homme et la Paix en péril', PD 48, 11 (October 1928), pp.359-363.

Prudhommeaux, Jules. 'La Paix par l'Education, l'Histoire à l'école', PD, 35, 2 (February 1925), pp.61-68 and 35, 3 (March 1925), pp.99-107.

Prudhommeaux, Jules. 'La Politique Internationale et la SDN. La mise hors la loi de la guerre. L'accord est fait.' PD 38, 7/8 (July-Aug 1928), pp.316-318.

Prudhommeaux, Jules. 'La Propagande. Le Monument de la Réconciliation; une Manifestation émouvante au Trocadéro', $P D$ 35, 2 (February 1925), pp.81-83.

Prudhommeaux, Jules. 'Le cartel lyonnais pour la Paix et la SDN', PD 36, 1 (January 1926), pp.39-40.

Prudhommeaux, Jules. 'Le Congrès de la Paix par le Droit, Clermont-Ferrand, 26-27 Décembre 1936, PD 47, 3 (March 1937), pp.101-111.

Prudhommeaux, Jules. 'Le Congrès Mondial contre la Guerre impérialiste', $P D 42,9$ (September 1932), pp.405-411.

Prudhommeaux, Jules. 'Le Pacifisme Oratoire d'Hitler et Cie', PD 43, 11 (November 1933), pp.455-458.

Prudhommeaux, Jules. 'Le Pacte Rhénan et la Conférence de Locarno', PD 35, 10 (Oct 1925), pp.385-387.

Prudhommeaux, Jules. 'Le problème des réparations et la pacifisme international', $P D$ 33, 3 (March 1923), p.119-125.

Prudhommeaux, Jules. 'Le Rassemblement mondial des Femmes contre la Guerre et le Fascisme', PD 44, 9 (September 1934), pp.343-347.

Prudhommeaux, Jules. 'Le Rassemblement Universel pour la Paix - La Conférence de Londres', PD 46, 4 (April 1936), pp.206-208.

Prudhommeaux, Jules. 'Le Tour de France du Musée "Guerre ou Paix"', PD 41, 7 (July 1931), pp.315-320.

Prudhommeaux, Jules. 'Les lendemains du Congrès d'Amsterdam', PD 42, 11 (November 1932), pp.494-495. 
Prudhommeaux, Jules. 'Les paroles et les actes', PD 43, 6 (June 1933), pp.218-219.

Prudhommeaux, Jules. 'Les Rapports du Pacifisme et du Mouvement Ouvrier', PD 15, 11 (November 1905), p.421-433.

Prudhommeaux, Jules. 'Notre Assemblée Générale (Suite)', PD 44, 3 (March 1934), pp.97122.

Prudhommeaux, Jules. 'Notre Assemblée Générale', PD 41, 12 (December 1931), p.573-616

Prudhommeaux, Jules. 'Notre Assemblée Générale', PD 47, 2 (February 1937), pp.52-67.

Prudhommeaux, Jules. 'Notre Assemblée Générale, Paris, 30 et 31 December 1933', PD 44, 2 (February 1934), pp. 49-66.

Prudhommeaux, Jules. 'Notre Assemblée Générale, Suite et fin', PD 44, 3 (March 1934), pp.97-122..

Prudhommeaux, Jules. 'Pacifisme d'avant-garde', PD 38, 3 (March 1928), pp.137-138.

Prudhommeaux, Jules. 'Petite histoire des Cartels de la Paix', PD 42, 4 (April 1932), pp.179182.

Prudhommeaux, Jules. 'Pour la Paix par l'Ecole', PD 38, 7/8 (July-August 1928), pp.293-306; 'Suite' in PD, 38, 9 (September 1928), pp.366-375; and PD, 38, 10 (October 1928), pp.419-431.

Prudhommeaux, Jules. 'Rapport Moral' in Jules Prudhommeaux, Notre Assemblée Générale, Paris 30 et 31 décembre 1933', PD 44, 2 (February 1934), pp.53-58, also p.49.

Prudhommeaux, Jules. 'Rapport Moral' in M. L. Puech, 'Notre Assemblé Générale, Paris, 23 Janvier, 1938,', PD 48, 3 (February 1938), p.65-69.

Prudhommeaux, Jules. 'Un Congrès de la Paix qui s'annonce mal: Genève ou Moscou?', PD 42, 7/8 (July-August 1932), pp.350-351.

Prudhommeaux, Jules. 'Un demi-siècle d'activité de la Revue "La Paix par le Droit", PD 48, 6/7/8 (May-June-July 1938), pp.269-277.

Prudhommeaux, Jules. 'Un récidiviste de l'objection de conscience: Eugène Guillot', PD 41, 2 (February 1931), pp.107-109.

Prudhommeaux, Jules. 'Vers l'union des forces pacifistes: Cartels at Semaines de la Paix', PD 39, 11 (November 1929), pp.425-430.

'PS à l'Enquête sur l'Objection de conscience' PD' 36, 12 (December 1926), p.439-440.

Puech, Jules L. 'A propos des Articles Challaye-Ruyssen', PD 42, 4 (April 1932), pp.153-156.

Puech, Jules L. 'Chronique. La Paix avec l'Allemagne', PD 30, 1/2 (Jan-Feb 1920), pp.26-32.

Puech, Jules L. 'L'Assemblée Générale de la Paix prar le Droit', PD 36, 1 (January 1926), pp.13-19.

Puech, Jules L. 'Le 8ème Congrès Allemand de la Paix', PD 29, 7/8 (July-August 1919), pp.362-364. 
Puech, Jules L. 'Le centenaire de Napoléon', PD 31, 3/4 (March-April 1921), pp.108-111.

Puech, Jules L. 'Notre revue', PD 30, 11/12 (November-December 1920) p.363-369.

Puech, Jules L. 'Notre "Sainte Cause"', PD 34, 4/5 (April-May 1924), p.165-170.

Puech, Jules L.. 'Assemblée Générale de la Paix par le Droit, Nantes, 10 et 11 Février 1923', PD 33, 4 (April 1923), pp.137-145.

Puech, M. L. 'Notre Assemblée Générale, Paris, 23 Janvier 1938', PD 48, 3 (February 1938), pp. 65-76.

Puech, M. L. 'De l'Allemagne', PD 34, 9(Sept 1924), pp.332-335.

'14 Juillet 1935', Le Barrage 60 (18 July 1935), p.1.

'Quatrième Conférence Nationale pour la Paix par l'Education', PD 44, 4/5 (April-May 1934), pp.145-176.

Radiguet, Raymond. Le Diable au Corps (Paris: Grasset, 1923).

Rauze, Marianne. L'Anti-guerre. Essai d'une doctrine et d'une Philosophie de l'antimilitarisme en 1923. Suivi d'une post-face de Romain Rolland. Préfaces de W. Wellock et Dr. Stoecker. (Niort: Imprimerie du progrès, 1923).

Relgis, Eugen. L'Internationale Pacifiste (Paris: André Delpeuch, 1929).

'Résolution sur les événements d'Espagne', Le Barrage 108 (22 October 1936), p.1.

'Réunion du Comité Directeur', Le Barrage 113 (24 June 1937), p.3.

'Réunion du Comité Directeur', Le Combat pour la Paix 1 (May 1933), pp.10-11.

Richet, Charles and Ruyssen, Théodore. 'Fusion de la Société Française pour l'Arbitrage et de l'Association de la Paix par le Droit', PD 32, 2(February 1922), pp.57-58.

Richet, Charles and Ruyssen, Théodore. 'La Fin de la Guerre', $P D$ 28, 21/22 (November 1918), pp. 329-331.

Richet, Charles and Ruyssen, Théodore. 'Pour "La Paix par le Droit"', PD 28, 1/2 (January 1918), p.2.

Richet, Charles. 'La Paix sans réserve est un rêve!'. $P D$ 42, 2/3 (February-March 1932), pp.70-71.

Richet, Charles. 'La vraie figure de la France', $P D$ 42, 7/8 (July -August 1932), pp.321-323.

Richet, Charles. 'La vraie figure de la France', PD 43, 3 (March 1933), p.97.

Richet, Charles. 'Soyons tous les Enfants de la Paix', PD 34, 3 (March 1924), pp.105-107.

Richet, Charles. 'Y-a-t-il des Equivoques du Pacifisme?', PD 43, 8/9 (August-September 1933), pp.285-288.

Rolland, Romain. 'Appel de Romain Rolland aux Combattants de la Paix', PH 31 (2-9 July 1932), pp.1-2. 
Rolland, Romain. 'Le Combat pour la Paix. Romain Rolland intervient dans le débat', PH 33 (23 July - 6 August 1932), p.1.

Rolland, Romain. 'Pour l'Indivisible Paix', Le Barrage 83 (6 February 1936), p.2.

Rolland, Romain. Above the Battle, translated by C.K. Ogden (Chicago: The Open Court Publishing Company, 1916), p. 53.

Rolland, Romain. Botschaft an den Kongress von Brüssell translated by Rudolf Leonhard (Paris: Editions du Carrefour, 1936).

Rolland, Romain. I will not rest, translated from the French by K.S. Shelvankar (New York: Liveright, n.d.)

Rolland, Romain. Le Périple avec une Préface de Maurice Betz (Paris: Editions Emile-Paul Frères, 1946).

Rolland, Romain. Par la Révolution, la Paix (Paris: Editions Sociales Internationales, 1935).

Rolland, Romain. Romain Rolland and Gandhi Correspondence (New Delhi: Ministry of Information and Broadcasting, 1966).

Rolland, Romain. Textes Politiques, philosophiques, et sociaux choisis, Avec Introduction et Notes par Jean Albertini (Paris: Editions sociales, 1970).

Rolland, Romain. Wie kann man den Krieg verhindern? translated by Rudolf Leonhard.(Paris: Editions du Carrefour, 1936).

Romain Rolland and Gandhi Correspondence (New Delhi: Ministry of Information and Broadcasting, 1966).

Roser, Henri. 'L'Objection de Conscience et la Légalité. Lettre ouverte à M le Rédacteur de "La Paix par le Droit"'. PD 44, 1 (January 1934), pp.22-23.

Roser, Henri. 'Réponse à l'Enquête sur la Crise du Pacifisme' in PD 44, 2 (February 1934), pp.71-73

Rothen, Edouard. 'Avec la Peau des autres', Le Barrage 92 (2 April 1936), p.1.

Rotours, Robert des. 'Sur la "VraieFigure de la France"', PD 43, 2 (February 1933), pp.58-61.

Rousseau, Charles and Prudhommeaux, Jules. 'Dans le Gard: à Caveirac', $P D$ 36, 5 (May 1926), p. 234-235.

Rousseau, Charles and Prudhommeaux, Jules. 'La grande pitié du pacifisme international: le "Rassemblement Universel pour la Paix"', PD 46,1 (January 1936), pp.43-46.

Rousseau, Charles and Prudhommeaux, Jules. 'La IIème Conférence Internationale pour l'Enseignement de l'Histoire', PD 44, 10 (October 1934), pp.399-400.

Rousseau, Charles and Prudhommeaux, Jules. 'Le Conseil général du RUP à Genève; le discours de Lord Robert Cecil; les Résolutions', PD 47, 4/5 (April-May 1937), pp.184-187. 
Rousseau, Charles and Prudhommeaux, Jules. 'Lord Robert Cecil, Prix Nobel de la Paix pour 1937', PD 47, 11/12 (November-Dẹcember 1937), p.417.

Rousseau, Charles, and Prudhommeaux, Jules. 'Le Conflit italo-Ethiopien', PD 45, 7/8 (JulyAugust 1935), pp.307-313.

Rousseau, Charles. 'L'Agression Italienne et les Sanctions', PD 45, 11/12 (November December 1935), pp.444-452

Rousseau, Charles. 'La dénonciation des Traités de Locarno devant le Droit International', PD 46, 4 (April 1936), pp.188-198.

Rousseau, Charles. 'La Politique Internationale de la SDN', PD 48, 5 (April 1938), p.184191.

Rousseau, Charles. 'Les données juridiques du Conflit Italo-Ethiopien', PD 45, 9 (September 1935), pp.349-357.

Rousseau, Charles. 'Les événements d'Espagne', PD 46, 8/9 (August-September 1936), pp.354-358.

Roussel, Emest. 'Les Origines de la Paix par le Droit', PD 381 (January 1928), pp.10-15

'Rundfrage. II. Teil' Pan-Europa, II, $6 / 7$ (1926).

Russell, Bertrand. The Autobiography of Bertrand Russell (New York: Bantam Edition, 1969).

Ruyssen, Théodore. 'La Guerre et la morale' (Extrait d'un discours prononcé à l'ouverture du Congrès belge pour le progrès des idées morales), PD 33, 2 (February 1923), pp.49-52.

Ruyssen, Théodore. 'A nos Amis de demain', PD 49, 1 (January 1939), pp.1-3.

Ruyssen, Théodore. 'A propos du 9me Congrès national de la Paix', PD 31, 5/6 (May-June 1921), pp.219-220.

Ruyssen, Théodore. 'Au Travail', PD 30, 11/12 (Nov-Dec 1920), pp.353-355.

Ruyssen, Théodore. 'De quelques polémiques allemandes sur les responsabilités de la guerre', PD 32, 3/4 (March-April 1922), pp.110-114.

Ruyssen, Théodore. 'Désarmement? ou désarmement?', PD 39, 12 (December 1929), pp.441442.

Ruyssen, Théodore. 'Encore l'Article 231!', PD 35, 5(May 1925), pp. 200-203.

Ruyssen, Théodore. 'L'Assemblée Générale de l'Association de la Paix par le Droit', PD 32, 6 (June 1922), pp.237-246.

Ruyssen, Théodore. 'L'Idolâtrie Patriotique', PD 35, 1 (January 1925), pp1-4.

Ruyssen, Théodore. 'L'Internationale des Anciens combattants', PD 30, 6/7 (June-July 1920), p. 204-207.

Ruyssen, Théodore. 'L'Objection de Conscience', PD 36, 9/10 (September-October 1926), pp.331-337. 
Ruyssen, Théodore. 'La Crise du Pacifisme', in Prudhommeaux, Jules, 'Notre Assemblée Générale, Paris 30 et 31 décembre 1933', PD 44,2 (February 1934), pp. 62-66.

Ruyssen, Théodore. 'La Ligue Française des Droits de l'Homme en Allemagne', PD 32, 7/8 (July-Aug 1922), pp.284-291.

Ruyssen, Théodore. 'La nouvelle Crise du désarmement'; PD 44, 4/5 (April-May 1934), pp.180-186.

Ruyssen, Théodore. 'La Paix hors du Droit', PD 48, 11 (October 1938), pp.341-350.

Ruyssen, Théodore. 'La Paix par le Droit. Rapport. Documents de l'Assemblée Générale et du Congrès du Cinquantentire', PD 48, 6/7/8 (May-June-July 1938), pp.256-268.

Ruyssen, Théodore. 'La Paix sans reserves? Non!', PD 42, 1 (January 1932), pp.9-15.

Ruyssen, Théodore. 'La Sarre a voté', PD 45, 1 (January 935, pp.1-2.

Ruyssen, Théodore. 'Le Cinquantenaire de la Paix par le Droit', PD 47, 2 (February 1937), pp.49-51.

Ruyssen, Théodore. 'Le Discours du Fuehrer', PD 45, 5/6 (May-June 1935), pp.244-249.

Ruyssen, Théodore. 'Le double visage de la politique allemande', PD 46, 3 (March 1936), pp.135-142.

Ruyssen, Théodore. 'Le Mouvement pacifiste. Pour et contre la reprise des relations pacifistes internationales', PD 29, 1 (January 1919), pp.47-49.

Ruyssen, Théodore. 'Le renouveau du Pacifisme et le Bureau International de la Paix', PD 29, 9/10 (Sept - Oct 1919), pp.413-416.

Ruyssen, Théodore. 'Le XXIV Congrès Internationale de la Paix', PD 35, 10 (Oct 1925), pp.360-363.

Ruyssen, Théodore. 'Les femmes contre la guerre', PD 31, 3/4 (March-April 1921), pp.140141.

Ruyssen, Théodore. 'Les pacifistes Allemands et le Traité de Versailles', PD 30, 1/2 (JanFeb 1920), p.32-38.

Ruyssen, Théodore. 'Les Voies de la Paix. A propos du Rassemblement Mondial', PD 46, 8/9 (August-September 1936), pp.329-332.

Ruyssen, Théodore. 'Notre Effort pour la Paix,' PD 48, 11 (October 1938), pp.337-340.

Ruyssen, Théodore. 'Où allons-nous?' PD 43, 6 (June 1933), pp.192-194.

Ruyssen, Théodore. 'Polémiques', PD 39, 10 (Oct 1929), p.357-359.

Ruyssen, Théodore. 'Pour le rapprochement Franco-Allemand: La Ligue des Droits de l'Homme et le Bund Neues Vaterland', PD 32, 2 (Feb 1922), pp.90-91.

Ruyssen, Théodore. 'Pressant Appel aux Membres de l'Association et aux Lecteurs de la Revue', PD 47, 11/12 (November -December 1937), pp.385-390. 
Ruyssen, Théodore. 'Réponse à Quelques Objections', PD 30, 5 (May 1920), p.130-135.

Ruyssen, Théodore. 'Un Congrès féminin pour la Paix à La Haye', PD 33, 1 (January 1923), pp.34-35.

Ruyssen, Théodore. 'Veillons!', PD 43, 3 (March 1933), pp.93-96.

Ruyssen, Théodore. 'Y-a-t-il des Equivoques du Pacifisme?', PD 43, 8 /9 (August-September 1935), pp.288-290.

Sauchon, Louis. 'Contre les Objecteurs de conscience', Le Figaro, 3 May 1933.

Scelle, Georges. 'La Défaite des Démocracies', PD 48, 4 (March 1938), pp.129-134.

Scelle, Georges. 'La Fin d'un Système', PD 47, 4/5 (April-May 1937), pp.169-172.

Scelle, Georges. 'La Paix...et le Droit', PD 48, 1 (15 January 1938), pp.4-13

Scelle, Georges. 'Le Pacte Kellogg (fin)', PD 38, 10 (Oct 1928), pp.432-441.

Scelle, Georges. 'Le Pacte Kellogg', PD 38, 9 (Sept 1928) pp.356-365.

Scelle, Georges. 'Péril de mort', PD 49, $3 / 4$ (March-April 1939), pp.81-86

Scelle, Georges. 'Pourquoi doit-on et comment peut-on mettre la constitution française en accord avec le Pacte Briand-Kellogg et les prescriptions de la Société des Nations?', in Jules Prudhommeaux, 'L'Assemblée Générale de Nancy (suite), PD 39, 1 January 1929), pp.7-11.

Scelle, Georges. 'Rétrospective', PD 46, 1 (January 1936), pp.23-31.

'Séverine', PD 39, 6 (June 1929), p.251

Simondet, Henri. 'L'Allemagne dans le gâchis', PD 43, 2 (February 1933), pp.62-67.

Simondet, Henri. 'Les Elections Allemandes', PD 40, 10 (October 1930), pp.376-382.

'Tableau des Cotisations versées en 1926 en Bureau International de la Paix.' Le Mouvement Pacifiste (October 1927), pp. 146-147.

Teissonnière, P. 'Faut-il résister aux violents?', PD 49, 1 (January 1939), pp.12-14.

Tempête, Jean. 'Propos Incisifs: Législation', PH 15 (12-18 March 1932).

Terrière; Armand. 'A propos d'une circulaire ministérielle. Le Patriotisme et le Pacifisme des Catholiques' Le Nouvelliste de Bretagne, 3 May 1933.

Tourly, Robert. 'Bilan et Souhaits', PH 97 (5 January 1934), p.l.

Tourly, Robert. 'L'homme qui s'en va...', PH 86 (13 October 1933), p.l.

Tourly, Robert. 'Le Programme de Hitler', PH 17 (26 March - 2 April 1932), p.3.

Tourly, Robert. 'Les Obsèques de Victor Méric', PH 87 (20 October 1933), p.l.

Tourly, Robert. 'Sa Vie, Son CEuvre', PH 86 (13 October 1933), pp. 1-2. 
Tourly, Robert. 'Sur une tombe', PH 106 (9 March 1934), p.1.

Trégaro, Louis. 'A la croisée des chemins', Le Barrage 125 (17 March 1938), p.1.

Trégaro, Louis. 'Aragon-Autriche', Le Barrage 131 (7 July 1938), p.1.

Trégaro, Louis. 'Casse-cou!', Le Barrage 145 (16 March 1939), p.1.

'Tribunal Militaire d'Orléans. Le procès de l'objecteur de conscience', La France du Centre, 12 May 1933.

'Troisième Conférence Nationale de la Paix par l'Education', PD 43, $4 / 5$ (April-May 1933), pp.125-152.

'Un Appel à l'Opinion Française. Que fera la France:?', PD 45, 10 (October 1935), pp.386390.

'Un manifeste de la Société Allemande de la Paix', PD 29, 1 (Jan 1919) pp.54-46.

'Un manifeste pour l'abolition du service militaire obligatoire', PD 36, 12 (December 1926), p.472.

'Une Circulaire contre les défaitistes. La propagande des objecteurs de conscience', Le Figaro, 2 May 1933.

'Une idée ...turque: Lenine, lauréat du Prix Nobel', PD 28, 1/2 (Jan 1918) p.43.

'Une Jeune Garde Pacifiste', PH 10 (30 January -14 February 1932).

'Une politique maladroite', Le Barrage 87 (5 March 1936), p.3.

'Une prédiction d'Albert Thibaudet', Le Barrage 94 (23 April 1936), p.1.

Valfort, René. L'Objection de Conscience et l'Esprit maçonnique, Préface de Edouard E Plantagenet (Paris: Collection des Documents maçonniques de La Paix, n.d.[1930]).

Vermeil, Edmond. 'Le XXIIIème Congrès Internationale de la Paix de Berlin', PD 34, 12 (Dec 1924), pp.452-456.

Vernet, Madeleine. 'La Paix et la Politique', Le Barrage 113 (24 June 1937), p.2.

Vernet, Madeleine. 'Protestation', Le Barrage 134 (6 October 1938), p.1.

Vernet, Madeleine. De l'objection de conscience au désarmement (Levallois-Perret: Editions de la Volonté de Paix, 1930).

'Volonté de Paix et L.I.C.P.', Le Barrage 99 (28 May 1936), p.1.

Vulliod, A. 'La Valeur du Pacte Kellogg-Briand', PD 39, 6 (June 1929), pp. 214-221.

Wanner, Léo. 'La Femme et les Dictatures', SOS no. 16 (5ème année), 1934, pp.1-2.

War Resisters' International. War Resisters in Many Lands (Enfield: WRI, 1928), republished in Charles Chatfield, ed. International War Resistance Through World War II (New York: Garland Publishing, 1975), pp. 382-448. 
Weber, Maurice, and Jospin, Robert. 'Rapport sur les Partis Politiques, le Front Populaire et la Paix', Le Barrage 87 (5 March 1936), pp.5-6; and Le Barrage 88 (12 March 1936), p.4.

Weber, Maurice. 'Ce n'est pas par la guerre que I'on fera la Paix', Le Barrage 102 (9 July 1936), p.2.

Weber, Maurice. 'Excitations Guerrières', Le Barrage 106 (3 September 1936), p.3.

Weber, Maurice. 'Fermeté et Vigilance', Le Barrage 86 (27 February 1936), p.1.

Weber, Maurice. 'La Situation des Pacifistes dans le Parti Socialiste', Le Barrage 109 (29 April 1937), p.2.

Weber, Maurice. 'Les pacifistes et le Parti Socialiste', Le Barrage 111 (27 May 1937), p.3.

Weber, Maurice. 'Pacifisme et Socialisme', Le Barrage 78 (2 January 1936), p.1.

Weber, Maurice. 'Rapport-critique sur les idéologies nationalistes', Le Barrage 44 (14 March 1935), pp.4-5. 


\section{Secondary Sources}

Arcos, René. Romain Rolland (Paris: Mercure de France, 1950).

Auvray, Michel. Objecteurs, insoumis, déserteurs. Histoire des Réfractaires en France (Paris: Stock/2, 1983).

Barbier,J.B. Le Pacifisme dans l'Histoire de France (De l'An Mille à Nos Jours). (Paris: La Librairie Française, 1966).

Becker, Jean-Jacques. Le Carnet B (Paris: Klincksieck, 1973).

Bilis, Michel. Socialistes et pacifistes 1933-1939. Ou l'intenable dilemme des socialistes français (Paris: Syros, 1979).

Brock, Peter. Twentieth Century Pacifism (New York: Van Nostrand Reinhold Company, 1970).

Bouchardeau, Huguette. Pas d'histoire, les femmes...50 ans d'histoire des femmes: 19181968 (Paris: Editions Syros, 1977).

Boussard, Isabel. 'Le pacifisme paysan' in René Rémond and Janine Bourdin, eds., La France et les Français en 1938-1939 (Paris: Presses de la FNSP, 1978), pp. 59-75.

Bussey. Gertrude, and Tims, Margaret. Women's International League for Peace and Freedom (London: 1965).

Cairns, John C. 'A Nation of Shopkeepers in Search of a Suitable France, 1919-40', American Historical Review 79, 3 (June 1974), pp. 710-743.

Cattelain, Jean-Pierre. L'Objection de conscience (Paris: Presses Universitaires de France, 3rd edition, 1982).

Caute, David. Communism and the French Intellectuals 1914-1960 (London: Andre Deutsch, 1964).

Ceadel, Martin. Pacifism in Britain, 1914-1945: The Defining of a Faith (Oxford: Clarendon Press, 1980).

Chickering, Roger. Imperial Germany and a World Without War. The Peace Movement and German Society, 1892-1914. (Princeton: Princeton University Press, 1975).

Cooper, Sandi. 'Gaston Moch' in Josephson, et al, Biographical Dictionary of Modern Peace Leaders, ,pp. 645-647.

Defrasne, Jean. Le Pacifisme Collection 'Que sais-je? (Paris: Presses Universitaires de France, 1983). 
Delbreil, Jean-Claude. Les catholiques français et les tentatives de rapprochement francoallemand (1920-1933). (Metz: Centre de Recherches Relations Internationales, 1972).

Donat, Helmut and Holl, Karl, eds. Die Friedensbewegung. Organisierter Pazifismus in Deutschland, Osterreich, und in der Schweiz. (Hermes Handlexicon), (Dusseldorf: ECON Taschenbuch Verlag, 1983).

Duroselle, J.B. 'Les précédents historiques: pacifisme des années 30 et neutralisme des années $50^{\prime}$ in Pacifisme et dissuasion. Travaux et recherches de l'Institut Français de Relations Internationales sous la direction de Pierre Lelouche (Paris: IFRI, 1983), pp. 241-252.

Eksteins, Modris. 'All Quiet on the Western Front and the Fate of a War', Journal of Contemporary History 15, 2 (1980), pp.345-366..

Faucier, Nicolas. Pacifisme et Antimilitarisme dans l'entre-deux-guerres (Paris: Spartacus, 1983).

Field, Frank. Three French Writers and the Great War: Studies in the Rise of Communism and Fascism(Cambridge: at the University Press, 1975).

Fisher, David James. 'Pacifism and the Intellectual: The Case of Romain Rolland', Peace and Change: A Journal of Peace Research, Winter 1982 (VII,1/2), pp. 85-96.

Fisher, David James. 'Romain Rolland and the popularization of Gandhi: 1923-1925', Gandhi/Marg, July 1974, pp.145-180.

Fisher, David James. 'The Rolland-Barbusse Debate' Survey. A journal of East and West Studies, Spring/Summer 1974 (20, 2/3), 120-159.

Fitzpatrick, Brian. Catholic Royalism in the Department of the Gard, 1814-1852, (Cambridge: at the University Press, 1983)

Friguglietti, James. 'Alexandre Percin' in Harold Josephson, ed. Biographical Dictionary of Modern Peace Leaders, (Westport, London: Greenwood Press, 1986), pp.740-742.

Friguglietti, James. 'Marcelle Capy' in Harold Josephson, ed. Biographical Dictionary of Modern Peace Leaders (Westport, London: Greenwood Press, 1986), pp.141-43.

Friguglietti, James. Albert Mathiez, Historien révolutionnaire (1874-1932), translated from the English by Marie-Françoise Pernot (Paris: Société d'Etudes Robespierristes, 1974).

Gabrielle Duchêne 1870-1954 In Memoriam (Paris: Section Française de la LIFPL, n.d. [1954]).

Girardet, Raoul. La Société militaire dans la France Contemporaine (1815-1939) (Paris: Plon, 1953).

Gombin, Richards. 'Socialisme et Pacifisme', in René Rémond and Janine Bourdin, eds., La France et les Français en 1938-1939 (Paris: Presses de la FNSP, 1978), pp. 245-260.

Hackett, Amy. 'Lida Gustava Heymann', in Harold Josephson, ed Biographical Dictionary.of Modern Peace Leaders (Westport, London: Greenwood Press, 1986)..pp. 405-407. 
Hermon, Elly. 'Approches conceptuelles de l'éducation en vue de la compréhension internationale dans l'entre-deux-guerres' Canadian and International Education 15, 2(1986), pp.29-52.

Hermon, Elly. 'The Rise of the International Peace Education Movement: Some Historical Considerations', in Charles Chatfield and Peter van den Dungen, eds, Peace Movements and Political Cultures (Knoxville: University of Tennessee Press, in press).

Hill, Albert S. 'Gabrielle Duchêne' in Harold Josephson, ed. Biographical Dictionary of Modern Peace Leaders, (Westport, London: Greenwood Press, 1986), pp. 226-228.

Hill, Albert S. 'Madeleine Vernet' in Harold Josephson, ed. Biographical Dictionary of Modern Peace Leaders (Westport, London: Greenwood Press, 1986), pp.986-988.

Holl, Karl. 'Kurt Hiller', in Helmut Donat and Karl Holl, eds, Die Friedensbewegung (Hermes Handlexicon), (Dusseldorf: ECON Taschenbuch Verlag, 1983), pp.186-188.

Ingram, Norman. 'Romain Rolland, Interwar Pacifism and the Problem of Peace' in Charles Chatfield and Peter van den Dungen, eds., Peace Movements and Political Cultures (Knoxville: University of Tennessee Press, in press).

Kempf, Marcelle. Romain Rolland et l'Allemagne (Paris: Debresse, 1962).

Lütgemeier-Davin, Reinhold. Pazifismus zwischen Kooperation und Konfrontation. Das Deutsche Friedenskartell in der Weimarer Republik. (Köln: Pahl-Rugenstein Verlag, 1982).

McAllister, Pam, ed. Reweaving the Web of Life: Feminism and Nonviolence (Philadelphia: New Society Publishers, 1982).

McMillan, James F. Housewife or Harlot: The Place of Women in French Society 1870-1940 (Brighton: The Harvester Press, 1981).

Merle, Marcel. Pacifisme et Internationalisme XVIIe - XXe siècles. (Paris: Armand Colin, 1966).

Nadeau, Maurice. 'Romain Rolland', Journal of Contemporary History, 2(April, 1967), 209 220.

Prost, Antoine. Les Anciens Combattants et la Société Française. 3 vols. (Paris: Presses de la FNSP, 1977).

Racine-Furlaud, Nicole. 'Le Comité de vigilance des intellectuels antifascistes (1934-1939). Antifascisme et pacifisme', Le Mouvement social 101 (October-December 1977), ppp. 87-113.

Racine, Nicole. 'The Clarté Movement in France, 1919-21', Journal of Contemporary History, 2, no.2 (April, 1967), pp. 195-208.

Robrieux, Philippe. Histoire Intérieure du parti communiste 1920-1945. (Paris: Fayard, 1980).

Schumann, Rosemarie. Amsterdam 1932. Der Weltkongreß gegen den imperialistischen Krieg (East Berlin: Dietz Verlag, 1985). 
Sée, Yvonne Réaliser l'Espérance (Paris: Section française de la LIFPL 1983).

Sée, Yvonne. 'Andrée Jouve' in Harold Josephson, ed. Biographical Dictionary of Modern Peace Leaders (Westport, London: Greenwood Press, 1986),p.481.

Singer, Barnett. 'From Patriots to Pacifists: The French Primary School Teachers, 18801940', Journal of Contemporary History 12 (1977), 413-434.

Sirinelli, Jean-François. 'Khâgneux et normaliens aux années vingt' Thèse de Doctorat d'Etat, Université de Paris-X, Nanterre, 1986, 5 vols.,

Starr, William T. Romain Rolland and a World at War (Evanston: Northwestern University Press, 1956).

Starr,William T. Romain Rolland. One against all. A Biography (The Hague, Paris: Mouton, 1971).

Sternhell, Zeev. Ni droite, ni gauche. L'idéologie fasciste en France. (Paris: Editions du Seuil, 1983).

Taylor, A.J.P. The Troublemakers: Dissent over Foreign Policy, 1792-1939 (London: Hamish Hamilton, 1957).

Vellacott, Jo. 'Catherine Marshall' in Harold Josephson, ed. Biographical Dictionary of Modern Peace Leaders, (Westport, London: Greenwood Press, 1986) pp.606-607.

Vellacott, Jo. 'Separation and Integration: the nature of women only actions for peace'. Unpublished paper provided by the author.

Vellacott, Jo. 'Women against Militarism in the First World War: the British Connections'. in Charles Chatfield and Peter van den Dungen, eds, Peace Movements and Political Cultures (Knoxville: University of Tennessee Press, in press).

Westernhagen, D.v. 'Gertrud Baer', in Karl Holl and Helmut Donat, eds., Die Friedensbewegung. Organisierter Pazifismus in Deutschland, Osterreich und in der Schweiz (Hermes Handlexikon) (Düsseldorf: ECON Taschenbuch Verlag, 1983), p.35.

Winock, Michel. 'Le Fascisme passera... Pourquoi?', Le Monde Aujourd'hui (Supplément du numéro 12852 du Monde [Sunday 25-Monday 26 May 1986]), p.V.

Wohl, Robert. The Generation of 1914 (London: Weidenfeld and Nicolson, 1980).

Wurgart, Lewis D. The Activists. Kurt Hiller and the Politics of Action on the German Left, 1917-1933 (Philadelphia: Transactions of the American Philosophical Society, 1977). 